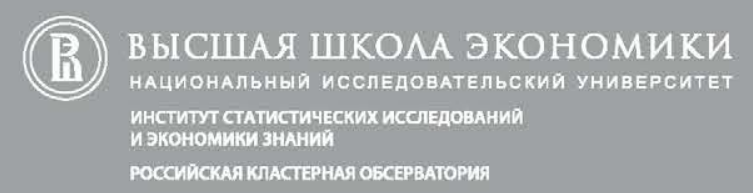

\title{
АТЛАС ЭКОНОМИЧЕСКОЙ СПЕЦИАЛИЗАЦИИ РЕГИОНОВ РОССИИ
}
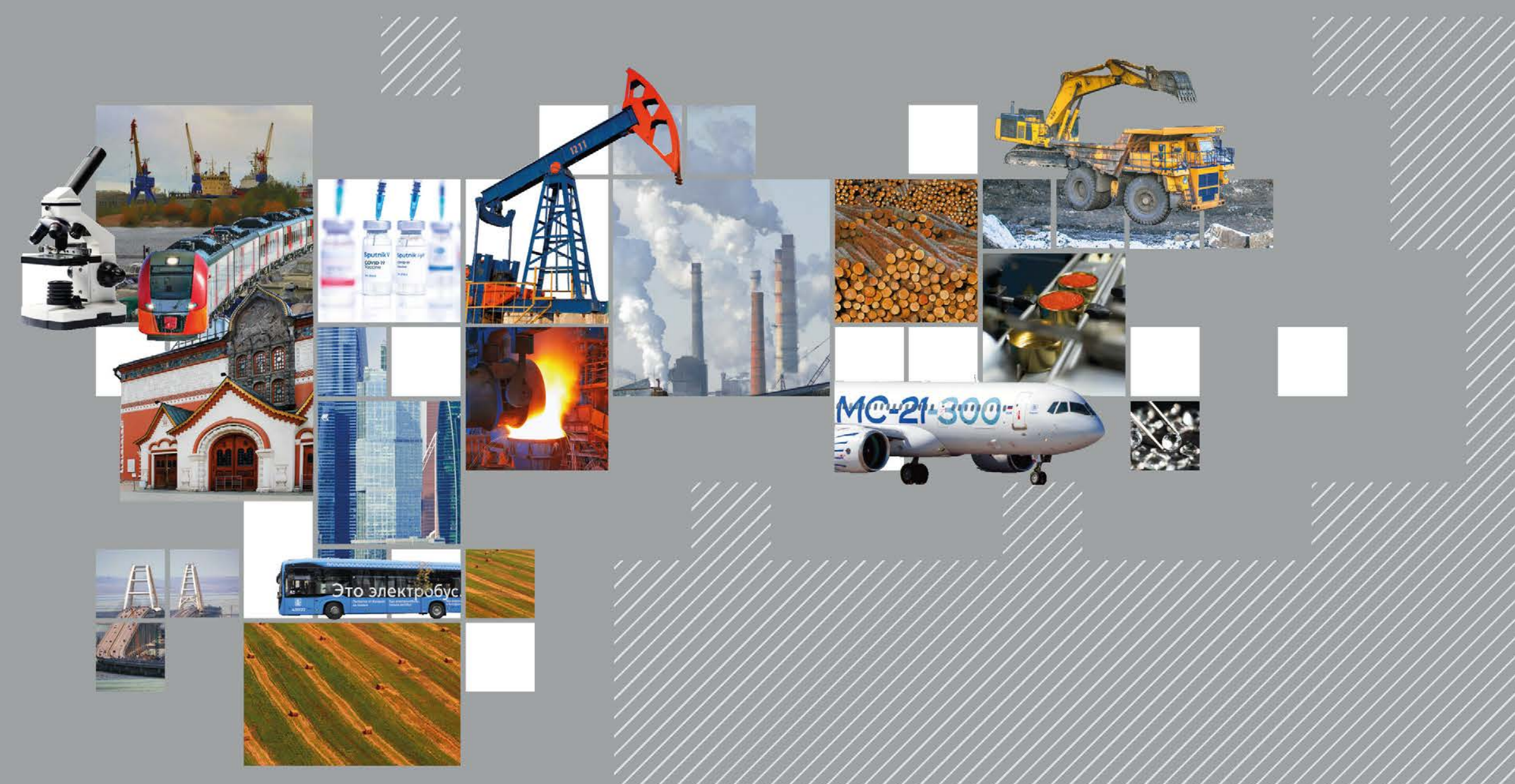
 (.) ВЫСШАЯ ШКОЛА ЭКОНОМИКИ ИНСТИТУТ СТАТИСТИЧЕСКИХ ИССЛЕДОВАНИИ
РОССИЙСКАЯ КЛАСТЕРНАЯ ОБСЕРВАТОРИЯ

\section{АТЛАС ЭКОНОМИЧЕСКОЙ СПЕЦИАЛИЗАЦИИ РЕГИОНОВ РОССИИ}

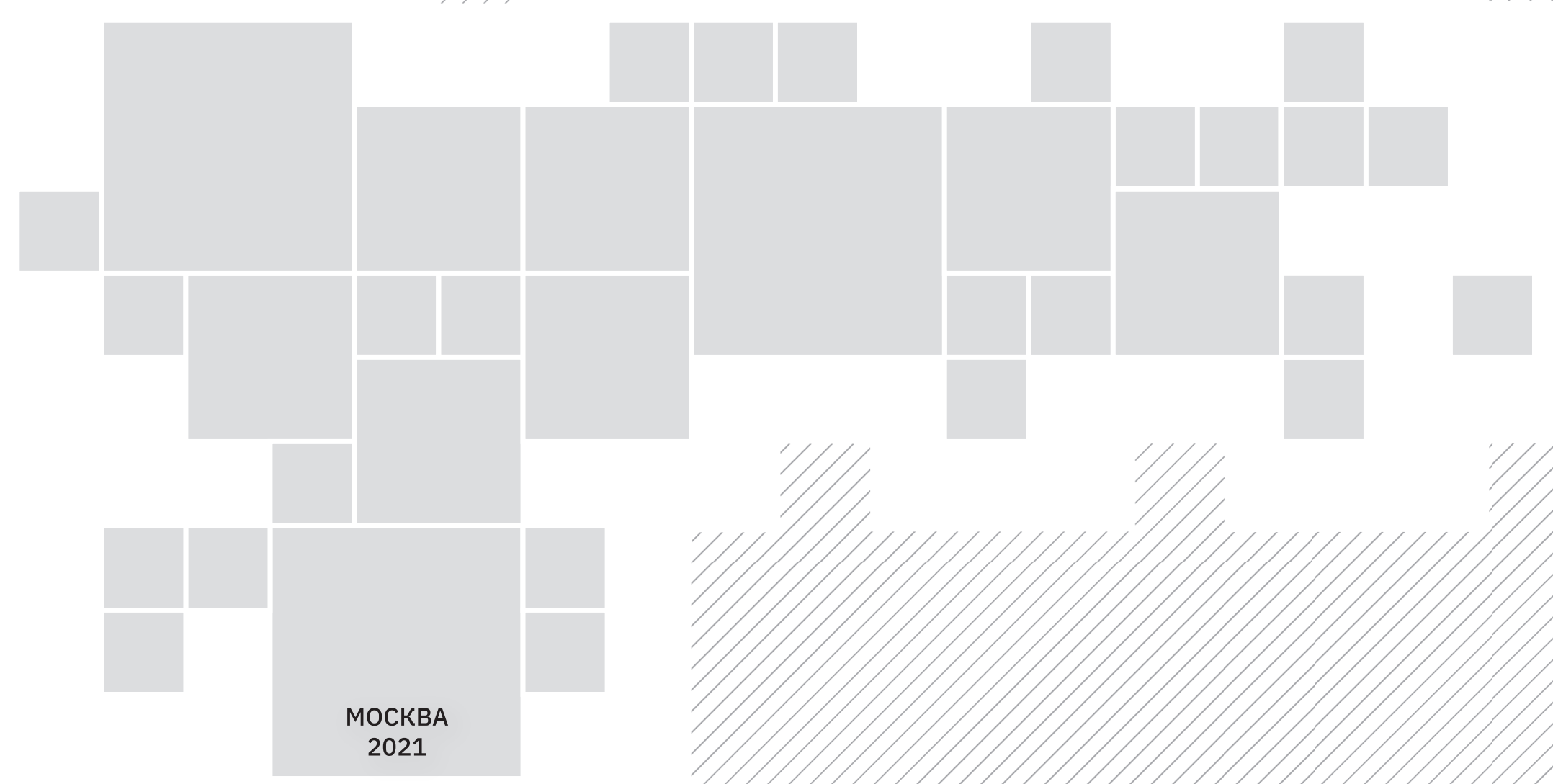




\section{Редакционная коллегия:}

\section{Л. М. Гохберг, Е. С. Куценко}

\section{Авторский коллектив:}

В. Л. Абашкин, Л. М. Гохберг, Я. Ю. Еферин, Е. А. Иванова, Е. С. Куценко, Е. Г. Нечаева, К. С. Тюрчев

Атлас экономической специализации регионов России / В. Л. Абашкин, Л. М. Гохберг, Я. Ю. Еферин и др.; под ред. Л. М. Гохберга, Е. С. Куценко; Нац. исслед. ун-т «Высшая школа экономики». - М.: НИУ ВШЭ, 2021. - 264 с. - 150 экз. - ISBN 978-5-7598-2379-7 (в обл.).

Атлас экономической специализации регионов России, подготовленный Институтом статистических исследований и экономики знаний Национального исследовательского университета «Высшая школа экономики» в рамках деятельности Российской кластерной обсерватории, посвящен изучению экономических профилей субъектов Российской Федерации.

В публикации приведены результаты статистических расчетов, характеризующие развитие торгуемого сектора экономики и входящих в его состав отраслей. Представлена развернутая информация о вкладе различных видов деятельности в занятость, производство и инвестиции в масштабах регионов и страны в целом, включая их специализацию и рейтинги видов деятельности в полиотраслевых субъектах Российской Федерации.

Данные исследования могут послужить основой для выявления перспективных межотраслевых и межрегиональных связей. Издание адресовано представителям бизнеса, научного и образовательного сообществ, практикам, вовлеченным в процессы управления развитием территорий и секторов экономики, включая промышленность, сельское хозяйство, интеллектуальные услуги и креативные индустрии.

УДК 332.122(083.41)(470+571)

ББК 65.049(2Рос)я2

Издание подготовлено при поддержке Программы «Фонд развития прикладных исследований» Национального исследовательского университета «Высшая школа экономики».

\section{Editorial Board:}

Leonid Gokhberg, Evgeniy Kutsenko

\section{Authors:}

Vasily Abashkin, Leonid Gokhberg, Yaroslav Eferin, Ekaterina Ivanova, Evgeniy Kutsenko, Elena Nechaeva, and Kirill Tyurchev

Atlas of Economic Specialisation of Russian Regions / V. Abashkin, L. Gokhberg, Y. Eferin et al.; L. Gokhberg, E. Kutsenko (eds.); National Research University Higher School of Economics. - Moscow: HSE, 2021.

The publication was produced with the support of the Development Fund for Applied Research of the National Research University Higher School of Economics.

doi $10.17323 / 978-5-7598-2379-7$

ISBN 978-5-7598-2379-7 (c) Национальный исследовательский университет «Высшая школа экономики», 2021

При перепечатке ссылка обязательна 


\section{Содержание}

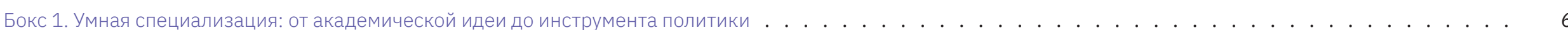

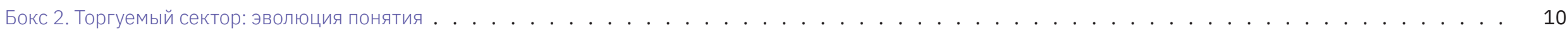

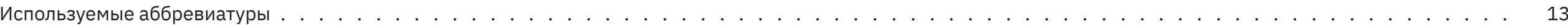

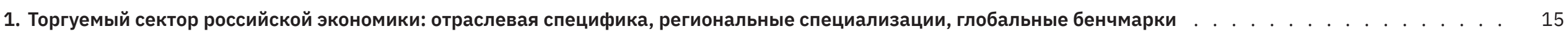

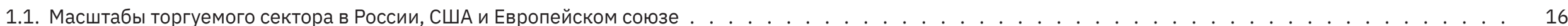

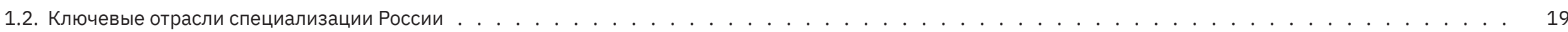

Бокс 3. Производительность труда: кому и зачто больше платят? . . . . . . . . . . . . . . . . . . . . . . . . . . . . . . . . . . . . . . . . . . . . . . . 27

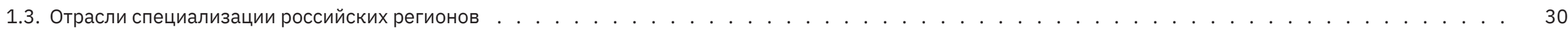

Бокс 4. Специализация или диверсификация: какую стратегию регионального развития выбрать? . . . . . . . . . . . . . . . . . . . . . . . . . . . . . . . . . .

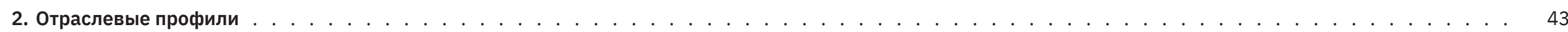

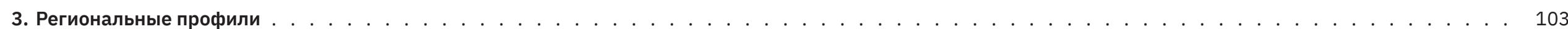

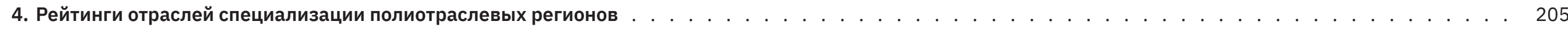

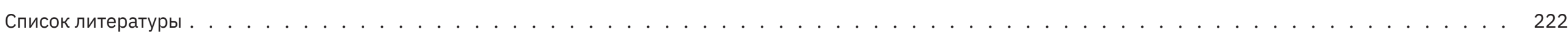

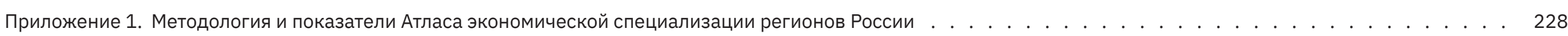

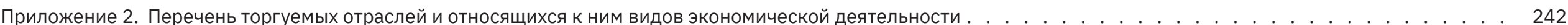




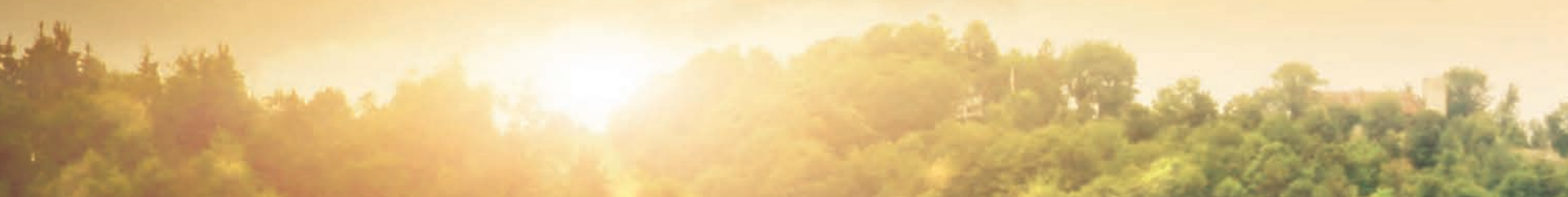


Россия - страна, отличающаяся разнообразием климатических зон и природных ландшафтов, созидательных традиций и культурных практик многих национальностей. Все эти составляющие - географические и социальные уникальным образом переплетались на каждой территории и на протяжении веков формировали ее самобытный экономический облик. Одновременно складывались и определенные стереотипные представления о регионах.

Возникает вопрос: насколько эти стереотипы актуальны сегодня? Можно ли по-прежнему ассоциировать Тульскую область с самоваром и пряниками, а Камчатский край - с крабами и икрой? Верно ли считать ивановский ситец или калининградский янтарь эксклюзивными брендами регионов?

Пространственная организация российской экономики за несколько последних десятилетий серьезно трансформировалась. Этому способствовали возникновение новых технологий, видов деятельности и бизнес-моделей, урбанизация, активная миграция населения, инфраструктурное развитие территорий, перестройка цепочек создания стоимости и торговых маршрутов. Одни регионы лишились динамичных в прошлом отраслей, другие - напротив, адаптировались к современным реалиям экономики знаний и новой промышленной революции и усилили свои позиции либо заняли возникающие ниши.

Цель настоящей работы - составить карту специализации регионов, которая станет информационной основой для принятия управленческих, инвестиционных и карьерных решений. Проведенное нами исследование во многом инспирировано концепцией умной специализации (smart specialisation), paзработанной под эгидой Европейской комиссии. Она предназначена для формирования и оценки стратегий инновационного развития регионов в странах Европейского союза, а в конечном счете - для принятия решений о поддержке выбранных в них траекторий роста (бокс 1)

\section{Бокс 1. Умная специализация: от академической идеи до инструмента политики}

Концепция умной специализации была разработана в 2007-2009 гг. экспертной группой «Знание для роста» (Knowledge for Growth) Директората по исследованиям и инновациям (Directorate General for Research and Innovation) Еврокомиссии. Появление концепции обусловлено необходимостью устранить дублирование компетенций в регионах и фрагментацию средств поддержки инноваций в ЕС [Foray et al., 2009; Foray, van Ark, 2007]. В соответствии с официальным определением Европейского парламента и Совета стратегия умной специализации устанавливает приоритеты для создания конкурентного преимущества региона. Они определяются на основе выявленного соответствия между научно-технологическим потенциалом и потребностями бизнеса, обеспечивая согласованное реагирование на возникающие возможности и рыночные тенденции [European Parliament, 2013].

Рационализм умной специализации заключается в том, что любой регион может найти собственный уникальный и обоснованный путь развития, не копируя приоритеты других территорий. Для этого необходимо фокусировать усилия и ресурсы на ограниченном наборе направлений, существующих либо возникающих на стыке видов экономической деятельности и научно-технологических областей, по которым может быть достигнуто лидерство [McCann, Ortega-Argilés, 2016; Foray, 2013; Giannitsis, 2009]. Уникальность достигается сочетанием внутренних и внешних факторов.

На начальном этапе предстоит оценить локальные ресурсы и выявить «скрытые» знания местных игроков о собственных производственных возможностях, применяемых технологиях и рыночных нишах [Barca, 2009; Frenken et al., 2007]. Этот ключевой для умной специализации принцип получил название «предпринимательский поиск» (entrepreneurial discovery) [Foray et al., 2011; 
Hausmann, Rodrik, 2003]. Он предполагает интерактивный процесс - выявление областей превосходства региона в сфере инноваций с опорой на представления широкого круга стейкхолдеров о новых возможностях экономического использования научного знания и технологий. К заинтересованным лицам относятся не только предприниматели, но и исследователи, специалисты-практики, рядовые потребители [OECD, 2013a]. Многообразие участников, обмен мнениями всех заинтересованных сторон дают возможность синхронизировать усилия государственного и частного секторов. Такой подход позволяет избежать ошибок, возникающих при монополии бюрократии (прежде всего верхнего уровня) на принятие решений о выборе направлений развития и мер их поддержки [Morgan, 2017; McCann, Ortega-Argilés, 2015]. Предпринимательский поиск дает возможность определить не только заслуживающую поддержки отрасль, но и новые, нетривиальные и порой неочевидные возможности ее трансформации. В этом принципиальное отличие умной специализации от традиционной [Foray, Goenaga, 2013; OECD, 2013a].

Не меньшее значение имеет и взгляд извне - сопоставление потенциала отдельного региона с другими территориями и выявление возможного дублирования ключевых стратегических компетенций [Sörvik et al., 2016; Navarro et al., 2014]. Данный подход подразумевает определение нового места региона в глобальных цепочках добавленной стоимости [Brennan, Rakhmatullin, 2015], идентификацию и бенчмаркинг территорий со схожей экономической структурой и научно-технологической повесткой. Полученная информация становится основой для дифференцированного целеполагания [Kroll, 2015; Thissen et al., 2013; Niosi, 2002], развития комплементарных компетенций и интенсификации на их основе межрегиональных связей [Iacobucci, Guzzini, 2016; Iacobucci, 2014; Foray, 2013; OECD, 2013b]. По этой причине важно следовать принципу открытости стратегий умной специализации, который выражается в проведении внешнего рецензирования документов с участием «дружественных критиков» (critical friends) - экспертов из других регионов, обладающих схожей специализацией [Midtkandal, Rakhmatullin, 2014; European Commission, 2012].

Важным атрибутом умной специализации считается многоуровневое управление с отлаженной коммуникацией и четким разделением функций между разными уровнями власти. На национальном уровне задаются общие организационные принципы стратегирования и верификации приоритетов, формиру ются единые базы данных для аналитических сопоставлений; на региональном - определяются приоритеты развития, разрабатываются и реализуются стратегии, создаются соответствующие координационные структуры [НИУ ВшЭ, 2018].

Инструментальной основой для умной специализации в странах ЕС служат:

- единые правила выбора, проверки и синхронизации приоритетов регионального развития;

- карта специализации регионов, задающая общую основу для дальнейшего поиска, обсуждения и согласования отраслевых и технологических фокусов.

Реализация первого механизма регламентируется Методическим руководством по разработке инновационных стратегий умной специализации (Guide on Research and Innovation Strategies for Smart Specialisation - RIS3 Guide) [European Commission, 2012]. Второй механизм опирается на интерактивную платформу по умной специализации (Smart Specialisation Platform), действующую с 2011 г. на базе Объединенного исследовательского центра Европейской комиссии [European Commission, 2020]. 


\section{(окончание)}

Методическое руководство детально описывает инструменты, алгоритмы, шаблоны, содержит «вопросы и ответы», проверенные опытом рекомендации, которые структурированы по этапам разработки стратегии:

- анализ регионального контекста;

- создание управляющих структур;

- формирование общего видения;

- выбор приоритетов;

- реализация мер политики

- мониторинг и оценка.

Платформа по умной специализации обеспечивает информационную, методологическую и организационную поддержку органов власти разных уровней при разработке стратегий. Например, сервис Еуе@RIS3 позволяет визуализировать распределение приоритетов в сфере экономики, исследований и разработок и стратегического развития по регионам. С помощью инструмента RIS3 Assessment Wheel можно контролировать соблюдение методики умной специализации на всех этапах разработки стратегии. На базе платформы регулярно обсуждаются научно-технологические и отраслевые приоритеть регионов, проводятся сессии взаимного рецензирования стратегий умной специализации и их публичные защиты, принимаются решения о согласовании документов.
Концепция умной специализации в течение короткого периода получила широкое распространение за пределами ЕС. Ее принципы нашли отражение в разработках ОЭСР [OECD, 2013a, 2013b] и Всемирного банка [World Bank, 2015], составили методическую основу для стратегий инновационного развития Австралии, Республики Корея, ряда государств Латинской Америки [OECD, 2013b]. Постепенно умная специализация вошла в сферу внимания российских экономистов - вначале как академическая идея, а позднее и как инструмент политики.

В 2018 г. мы впервые попытались оценить, насколько умными в терминах концепции могут считаться стратегии инновационного развития семи субъектов Российской Федерации и выделенные в них приоритеты. Главный вывод невозможно быть умным в отсутствие унифицированного подхода к определению и синхронизации приоритетов, общей аналитической базы данных, инструментов организационной поддержки и экспертизы. Даже регионь с сильной экономикой рискуют ошибиться в выборе специализации, что не позволит сформировать и реализовать уникальные стратегии, полностью соответствующие указанным принципам [Kutsenko et al., 2018].

Следующим шагом стало исследование, в котором мы проанализировали соответствие объективной отраслевой специализации субъектов Российской Федерации приоритетам регионального развития, выраженным в виде кластеров. На примере кластерной политики было показано, что выявленная статистически отраслевая специализация российских регионов часто не учитывается при выборе мер государственной поддержки. Отправной точкой для обсуждения приоритетов регионального развития могла бы стать единая карта отраслей специализации субъектов Российской Федерации [Куценко u дp., 2019]. 
Последующий анализ изменений отраслевой структуры российских регионов за десятилетний период (2005-2015 гг.) показал, что масштаб и интенсивность этих изменений во многом зависят от близости региона к городам-миллионникам. Таким образом, субъекты Российской Федерации отличаются не только по составу отраслей специализации, уровню благосостояния и экономического развития, но и по темпам структурных преобразований. Последний из перечисленных факторов важно учитывать при формировании требований к регионам в выборе новых отраслей специализации и реализации инвестиционной политики, для уточнения мер стимулирования пространственного развития и оценки результативности региональных органов власти [Kutsenko, Eferin, 2019].

При подготовке Атласа экономической специализации регионов России мы исходили из актуальной федеральной повестки, которая постепенно переориентируется на поддержку субъектов Российской Федерации в поиске умной специализации. Целевая установка согласуется с подходом Европейской комиссии - помочь регионам выбрать обоснованные и не пересекающиеся приоритеты развития в перспективных отраслях экономической специализации. Перечень таких секторов установлен в Стратегии пространственного развития Российской Федерации на период до 2025 года (далее - Стратегия), что может рассматриваться как первый шаг на пути формирования умной специализации регионов. Основываясь на Стратегии, федеральные власти намечают механизмы поддержки выбранных сфер специализации в регионах. Среди них - установление особых режимов ведения предпринимательской деятельности, уточнение отраслевых правил предоставления субсидий, совершенствование методики оценки эффективности налоговых льгот и иных мер политики [Правительство Российской Федерации, 2019].
Следующим этапом должен стать поиск субъектами Российской Федерации собственных ниш в экономическом ландшафте страны. Согласно Плану реализации Стратегии региональные органы власти смогут детализировать и при необходимости корректировать выбранную экономическую специализацию. Атлас предоставляет информационную основу для решения данной задачи.

В издании впервые для России предложен инструментарий комплексной оценки развития отраслей региональной специализации, учитывающий практику решения аналогичных задач в США (с 2000 г.) и странах ЕС (с 2005 г.) В его основе - использование статистики занятости и заработной платы за трехлетний период. Учитывается функциональная связанность разных видов деятельности, в частности промышленности и сферы услуг, делается акцент на торгуемых отраслях, что предполагает разграничение торгуемых и локальных видов экономической деятельности (бокс 2).

Наше исследование развивает методологию, применяемую в США и ЕС. Мы расширили состав анализируемых торгуемых отраслей и выделили три их типа:

- отрасли национальной значимости;

- отрасли локальной значимости;

- отрасли национальной и локальной значимости.

Рассмотренный подход позволил сформировать объективные отраслевые профили всех субъектов Российской Федерации, разработанные с учетом неравномерности пространственной концентрации экономической активности как внутри каждого региона, так и между ними (Приложение 1). 


\section{Бокс 2. Торгуемый сектор: эволюция понятия}

Представление о неравном вкладе разных видов хозяйственной деятельности в развитие территорий начало формироваться еще во времена становления классической экономической теории. В середине XVII века Питер де ла Кур выдвинул идею об особом влиянии некоторых отраслей на благосостояние городов. В работе «О процветании города Лейден» (1659) он выделил городские мануфактуры и Лейденский университет в качестве главного подспорья местной экономики, поскольку именно они привлекали в город образованных людей и заграничные капиталы, что позволяло Лейдену конкурировать с другими городами [Wang, Hofe, 2008].

Эта идея получила дальнейшее развитие в XX веке: Вернер Зомбарт сформулировал концепцию «основателей» и «наполнителей» города (от нем.

Stadtegründer und Stadtefüller). Под ними понимались отрасли, развивавшие экономику посредством внешней торговли, и секторы, которые их обслуживали либо удовлетворяли местный спрос. Подобное разделение экономики на два сегмента - базовый (т.е. экспортный) и вспомогательный (т.е. локальный) - легло в основу теории экономической базы (еconomic base theory). Исходя из данных по экспорту и внутреннему потреблению территорий, Зомбарт предложил количественные методы оценки занятости в базовом и вспомогательном секторах [Krumme, 1968].

Позднее Ричард Кан разработал мультипликатор экономической базы, позволявший спрогнозировать рост занятости в экономике региона при ее увеличении в базовых отраслях [Kahn, 1931]. Привнесение количественных методов в теорию дало импульс новым исследованиям, среди которых следует отметить работу Чарльза Тибу «Изучение экономической базы сообщества» [Tiebout, 1962]. Тибу математически обосновал эквивалентность формул мультипликатора экономической базы и мультипликатора Кейнса. Благодаря этому появилась возможность прогнозировать рост экономики на основе осуществленных инвестиций, а теория экономической базы стала элементом экономической науки того времени.

Одновременно развивалась теория международной торговли. Согласно рикардианской модели торговля между странами обусловлена наличием у одной из них сравнительных преимуществ по единственному фактору труду, а в обмен вовлечены два товара. Торговля по принципу «обмена товар на товар» сохранилась и в модели Хекшера-Олина-Самуэльсона, которая пришла на смену рикардианской в XX веке и была дополнена еще одним фактором - капиталом [Heckscher, 1949; Samuelson, 1953]. Новая модель в первую очередь расширяла и уточняла набор факторов, определяющих сравнительные преимущества страны в производстве той или иной продукции, а не ее тип. Таким образом, обе модели не уделяли внимания свойствам обмениваемой продукции (например, ее мобильности).

Впоследствии Рютаро Комия в работе «Неторгуемые товары и чистая теория международной торговли» [Котіуа, 1967] отмечал, что у любой страны часть валового национального продукта формируется отраслями, продукция которых не участвует в международном обмене по причине высоких транспортных издержек или заградительных торговых пошлин. Такие товары он назвал «неторгуемыми» и отнес к ним бо́льшую часть сферы услуг, торговлю свежими овощами и хлебобулочными изделиями, строительство. В этой же работе Комия дополнил модель Хекшера-Олина-Самуэльсона третьим, «неторгуемым», товаром и математически доказал, что данная модификация не противоречит ограничениям и допущениям базовой модели.

Понятия торгуемых и неторгуемых отраслей были перенесены из теорий международной торговли в концепцию «новой экономической географии» НЭГ (new economic geography) Пола Кругмана [Helpman, Krugman, 1985] 
и использовались в разработанной им модели регионального развития. В рамках НЭГ прогресс региона определяется спецификой его торговли с соседней территорией на основе продукции двух отраслей - неторгуемого сельского хозяйства и торгуемой промышленности. Под влиянием нового подхода многие исследователи также стали использовать деление отраслей на торгуемые и неторгуемые, а не на базовые и вспомогательные, несмотря на то, что обе классификации обладают схожими принципами разграничения ${ }^{1}$. Сегодня существуют разные критерии отнесения отраслей к той или иной категории. Так, ряд авторов относят к торгуемым все сферы материального производства, а к неоторгуемым - любые виды работ и услуг. Одним из аргументов в пользу данного подхода выступает ситуация, при которой страна не экспортирует автомобили, однако это вовсе не значит, что автомобилестроение перестает относиться к торгуемым отраслям [Mano, Castillo, 2015]. Другие эксперты предлагают определять торгуемость индустрии по количественным критериям, например, через соотношение ее экспорта и валовой добавленной стоимости, что оставляет возможность для корректировки перечня указанных отраслей [De Gregorio et al., 1994]

Наше исследование основано на подходе Майкла Портера. В качестве критерия торгуемости он использовал неравномерность распределения отраслевой занятости по территории страны [Porter, 2003]. Данный метод позволяет определить отрасли, концентрирующиеся по разным причинам экономического характера (ресурсным, технологическим, кадровым и др.) на определенных территориях. Эти отрасли впоследствии включаются в мировые производственные цепочки, а их продукция реализуется в других регионах и странах. В методологии Портера выделяются 51 торгуемая и 16 локальных отраслей.
В каждую из них входят от 1 до 37 связанных друг с другом видов экономической деятельности, что позволяет одновременно охватить национальный экономический ландшафт и определить уникальные преимущества отдельных территорий [Delgado et al., 2016]. Например, к торгуемому сектору были отнесены такие отрасли, как авиастроение и космос, фармацевтика, ювелирное производство. Локальными считаются сфера коммунального хозяйства, аптеки, деятельность кинотеатров и пр.

В настоящем исследовании специализация российских регионов определяется на базе торгуемых видов экономической деятельности, сгруппированных в 55 отраслей на основе принципа функциональной зависимости между производством и сервисами. В совокупности они составляют торгуемый сектор национальной экономики (Приложение 2).

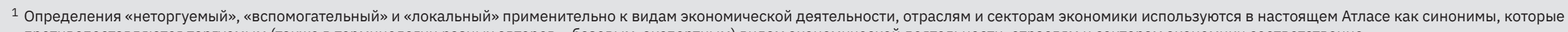
противопоставляются торгуемым (также в терминологии разных авторов - базовым, экспортным) видам экономической деятельности, отраслям и секторам экономики соответственно. 
В первом разделе Атласа рассматривается роль торгуемого сектора в России, в частности дается оценка его доли в экономике страны, приводится анализ динамики развития по показателям занятости и размера заработной платы за десятилетний период, выявляются лидирующие отрасли и регионы.

При возможности проведения межстрановых сопоставлений мы сравнивали параметры торгуемого сектора России с показателями США и государств ЕС.

База данных, сформированная при подготовке Атласа, представляет не только исследовательский интерес. Она позволит органам власти и бизнесу решать

практические задачи. Для этого мы составили два типа профилей: отраслевые и региональные.

Отраслевые профили, представленные во втором разделе Атласа, включают показатели, характеризующие каждую из 55 торгуемых отраслей с позиции ее доли в общей численности занятых, объеме производства и инвестиций, уровня оплаты труда. С помощью этих индикаторов можно сравнивать регионы, для которых рассматриваемая отрасль составляет экономическую специализацию, и ранжировать субъекты Российской Федерации по удельному весу в отраслевой занятости либо оценивать значимость сектора для экономического развития региона или всей страны.

Региональные профили, приведенные в третьем разделе Атласа, отражают число, уровень развития отраслей специализации и связи между ними.
Они позволяют увидеть, какие отрасли наиболее значимы для хозяйства субъекта Российской Федерации, а за счет каких формируется его наибольший вклад в национальную экономику.

В четвертом разделе Атласа собраны специальные рейтинги индустрий, составленные для полиотраслевых регионов. Они сформированы с использованием дополнительных статистических данных - об объемах производимых товаров (работ, услуг), инвестиций, предпринимательской активности. Рейтинги призваны сфокусировать внимание лиц, принимающих решения, на обоснованных приоритетах развития территорий в условиях отраслевого разнообразия, обозначить точки роста и потенциальные кластерные инициативы.

Атлас экономической специализации регионов России послужит ценным источником информации для разных групп пользователей. Органы власти всех уровней смогут уточнить отраслевые приоритеты регионального развития и разработать механизмы их поддержки. Предпринимательское сообщество получит основу для принятия решений о локализации бизнес-проектов. У исследователей появится возможность изучать особенности торгуемого сектора, экономической специализации страны и ее регионов, проводить корректные международные сопоставления. Для граждан Атлас станет навигатором, который поможет выстраивать индивидуальные траектории профессионального роста. 


\section{Используемые аббревиатуры}

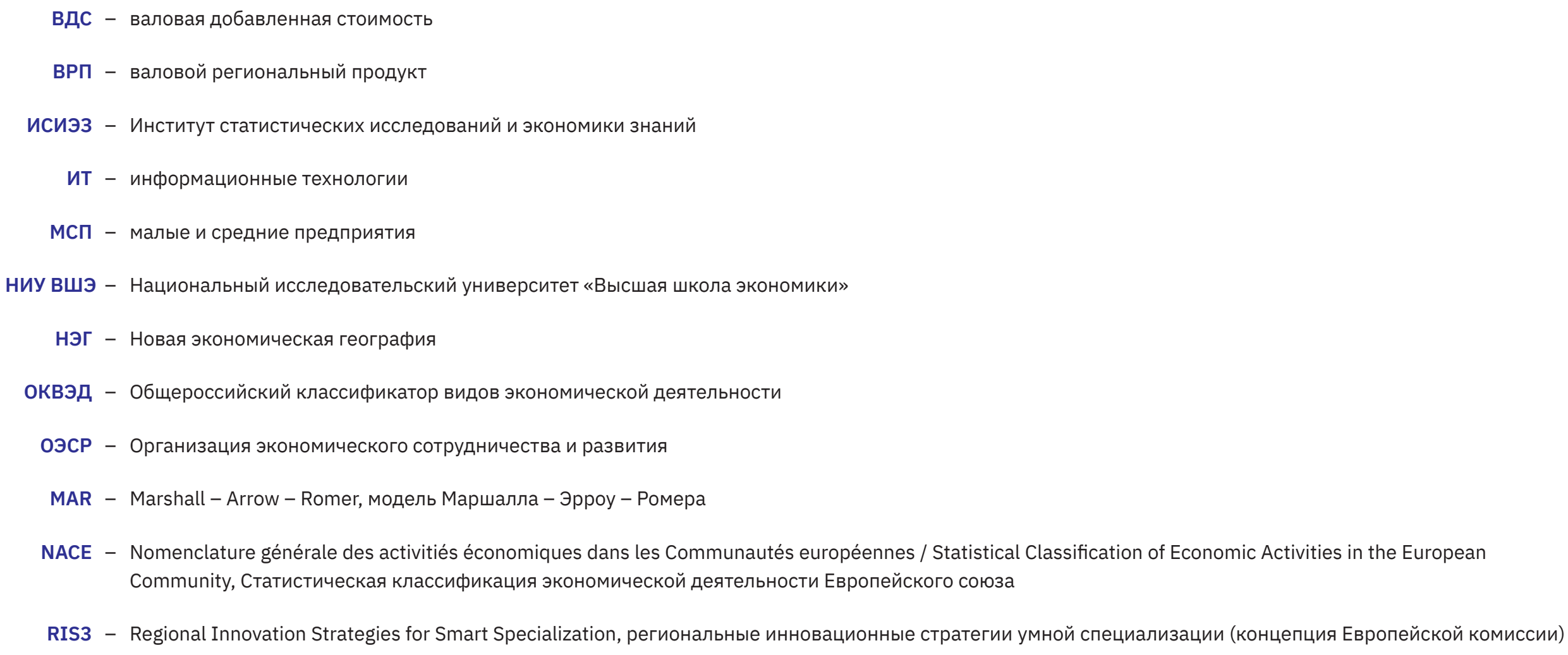



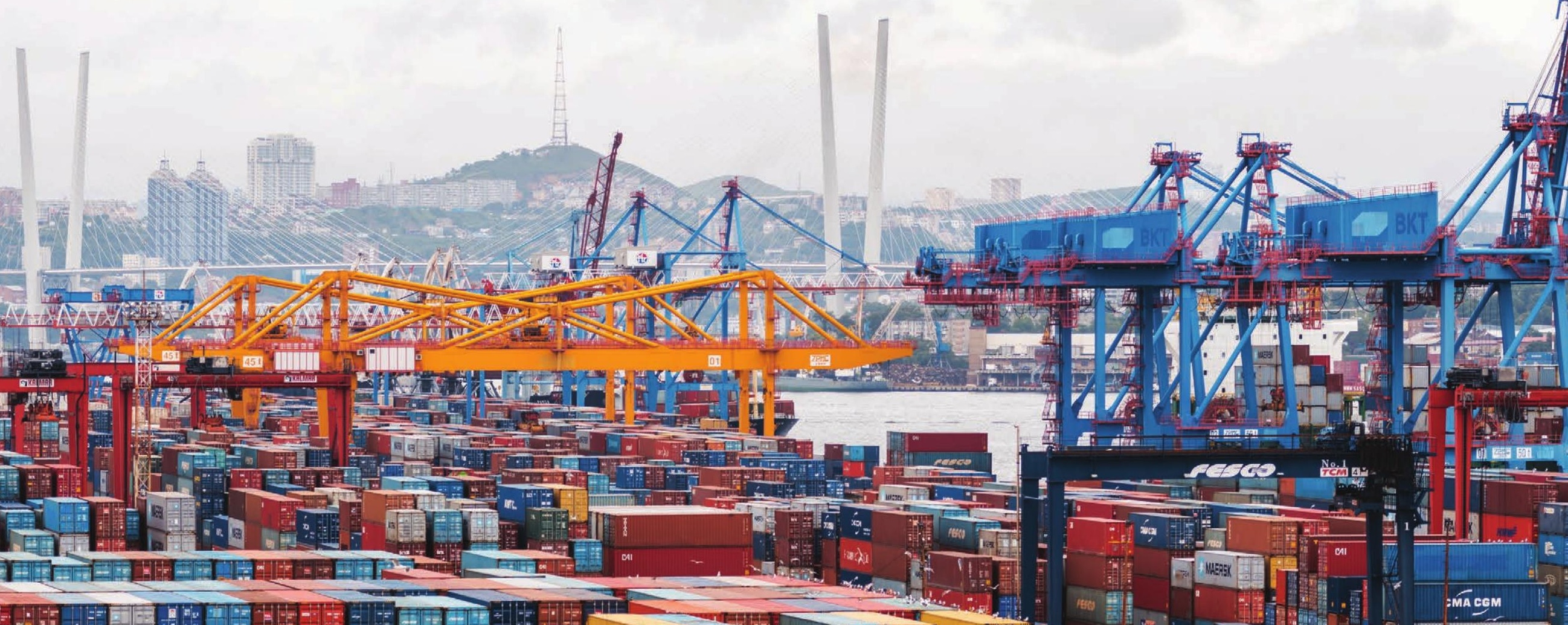

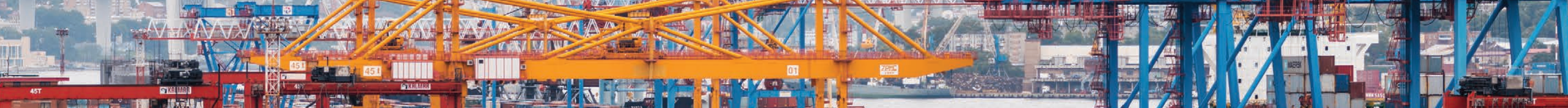
(1) De

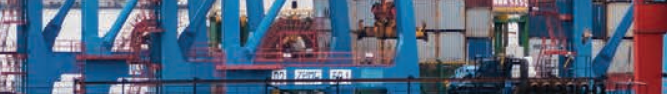
(x) DIf

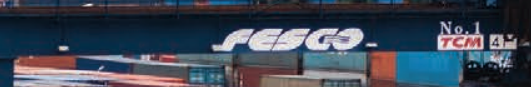

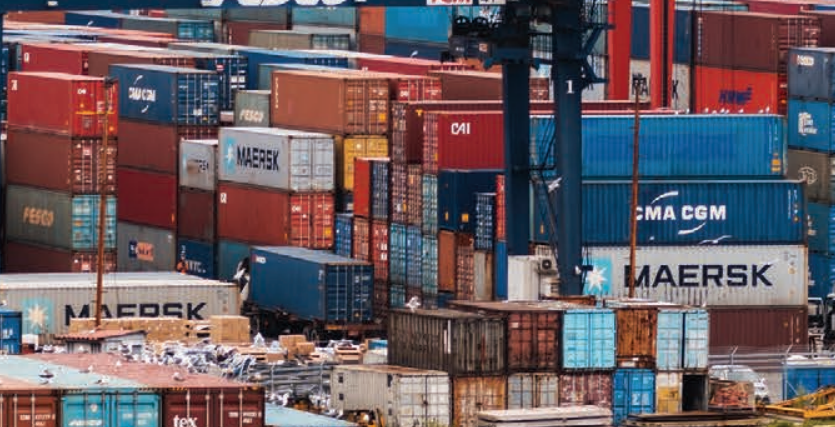

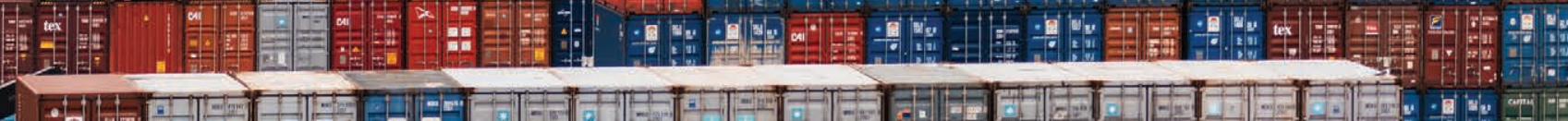

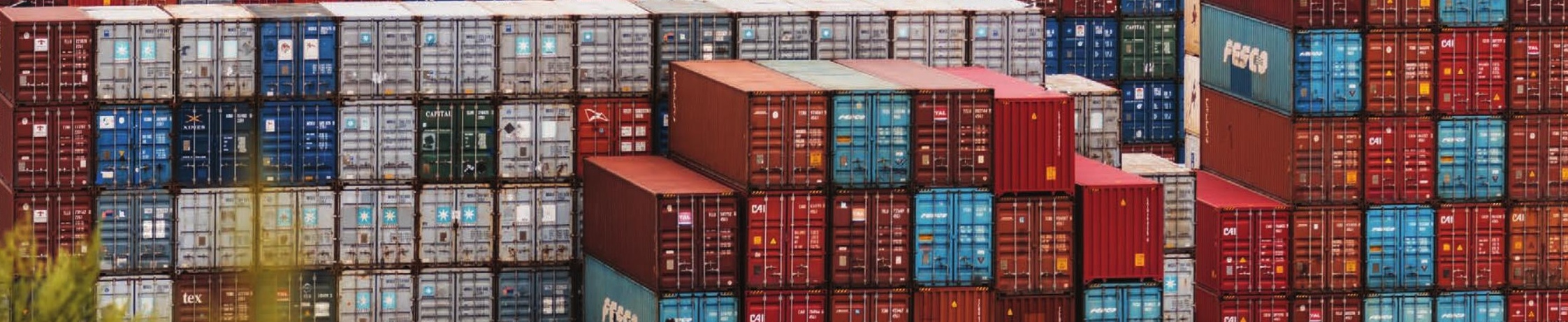
W.

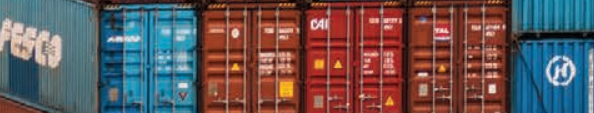

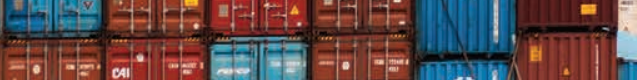

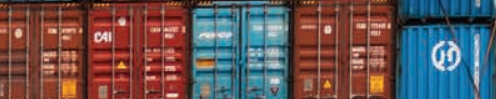

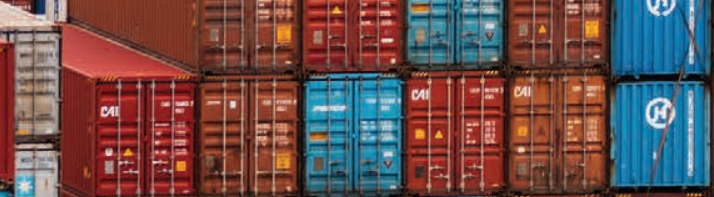

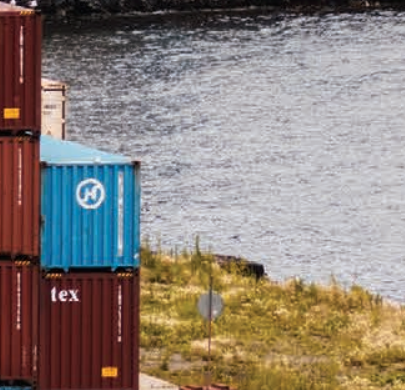




\section{1}

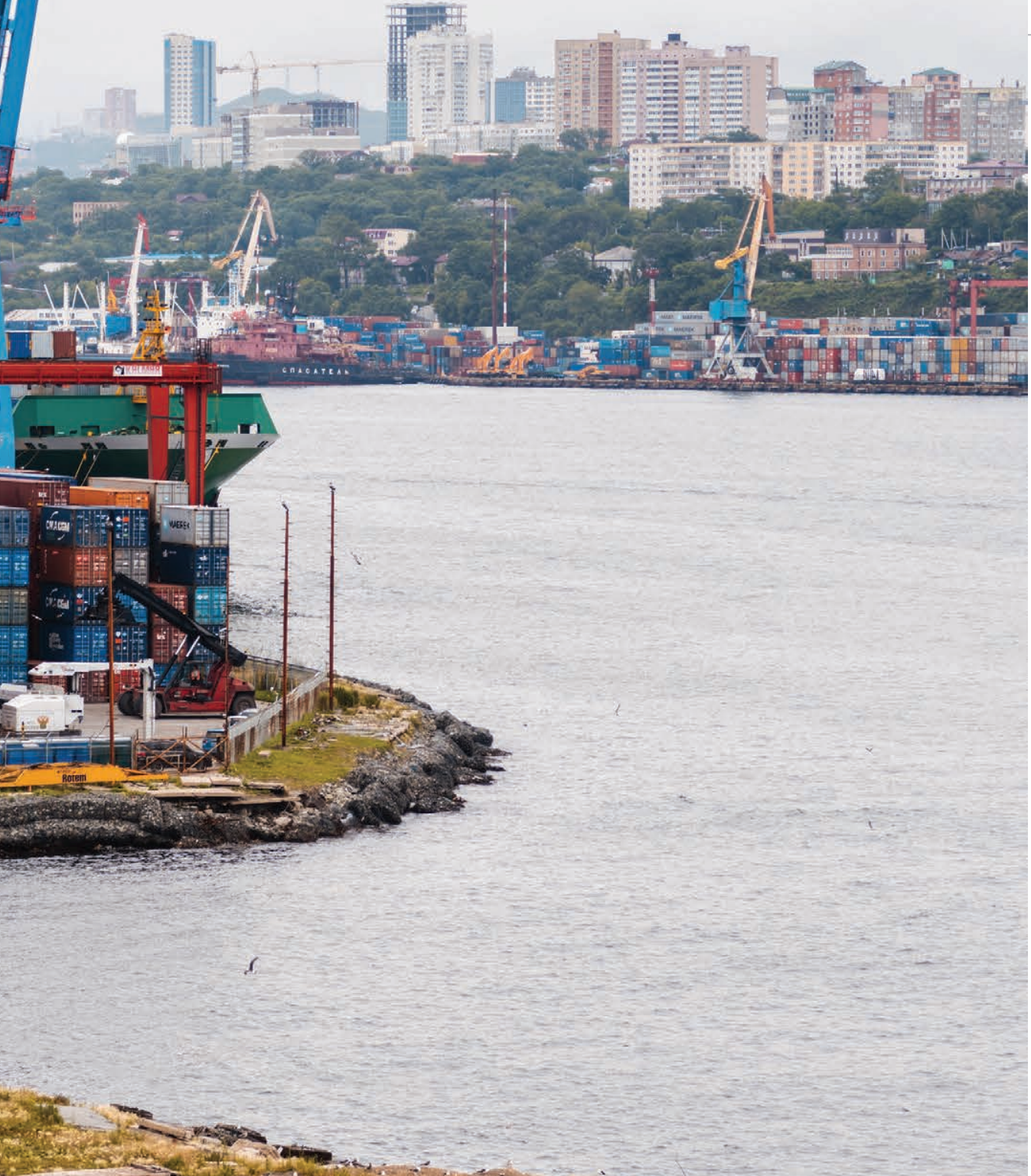

Торгуемый сектор российской экономики: отраслевая специфика, региональные специализации, глобальные бенчмарки 


\section{1. Масштабы торгуемого сектора в России, США и Европейском союзе}

Теоретические аргументы в пользу ведущей роли торгуемых отраслей в экономическом развитии подтверждаются статистическими данными по разным странам. В России, США и государствах ЕС в торгуемом секторе занято от 36 до $47 \%$ работающих (рис. 1.1), но в пересчете на одного работника он оказывается более результативным, чем локальный.

Рис. 1.1. Занятость в торгуемом секторе по странам (\%)

Россия, 2018

44

56

США, 2016

36

64

EC, 2014

47

53
В России на торгуемые отрасли приходится 44\% занятых и 50\% фонда оплаты труда, в них аккумулируется 73\% инвестиций и создается $82 \%$ общего объема товаров, работ и услуг (рис. 1.2). В американской экономике торгуемые виды деятельности обеспечивают 50\% доходов и 97\% патентных заявок, в европейской - свыше половины суммарного фонда оплаты труда.

Рис. 1.2. Торгуемый сектор в экономике России: 2018 (\%)

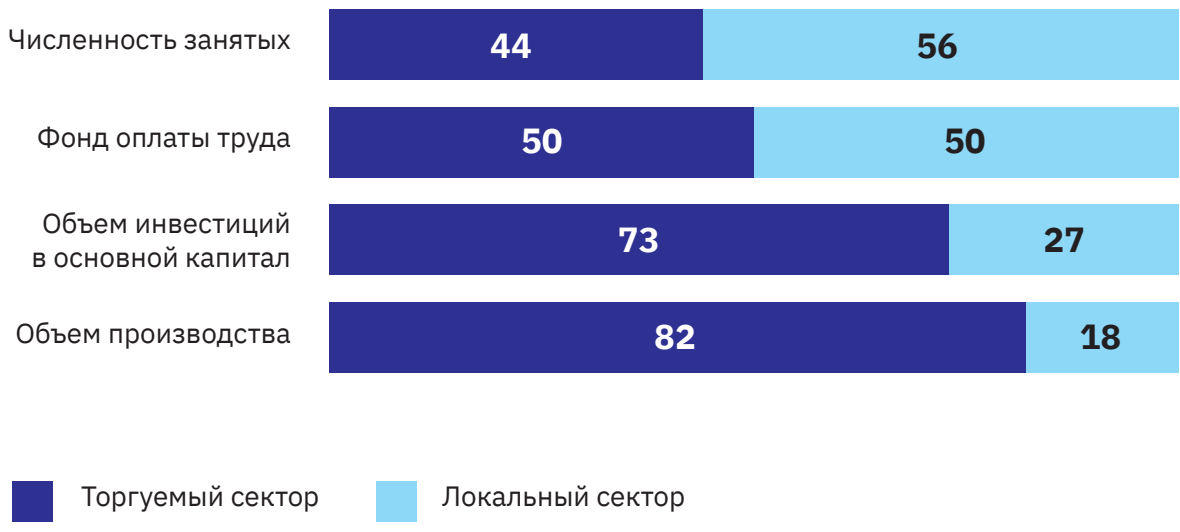

Источник: расчеты ИСИЭЗ НИУ ВШЭ по данным Росстата.

Источники: по России - расчеты ИСИЭЗ НИУ ВШЭ по данным Росстата, по США -

[Harvard Business School, 2020], по странам Европейского союза - [Ketels, Protsiv, 2016].

2 Здесь и далее, если не указано иное, данные по США приводятся на основе информации, представленной в [Harvard Business School, 2020], по странам Eвропейского coюза - в [Ketels, Protsiv, 2016]. 
Заметим, однако, что преимущества российского торгуемого сектора во многом формируются за счет отрасли «Производство и транспортировка нефти и газа». Без учета этой сферы значения показателей оплаты труда, инвестиций и отгрузки снижаются до 45, 44 и 51\% соответственно, а доля торгуемого сектора в занятости уменьшается до $41 \%$.
Именно число рабочих мест, размер заработной платы и динамика этих показателей демонстрируют различия между торгуемыми и локальными отраслями. Помимо высокой результативности при меньшей численности персонала, торгуемый сектор оказывается еще и привлекательнее для работников: в нем уровень оплаты труда выше и растет быстрее, чем в локальных видах деятельности. Последнее десятилетие, на которое пришлись минимум два крупных кризиса в отечественной экономике, подтверждает этот тезис (рис. 1.3).

\title{
Рис. 1.3. Динамика численности занятых и фонда оплаты труда в торгуемом и локальном секторах экономики России (\%)
}

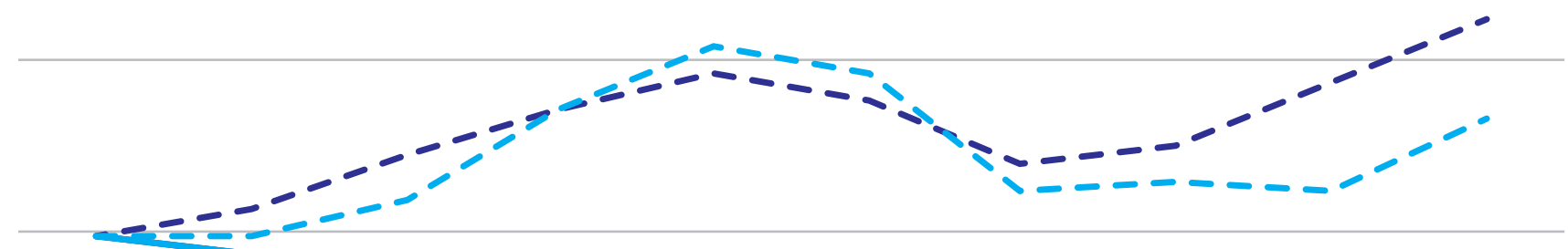

— Торгуемый сектор

100

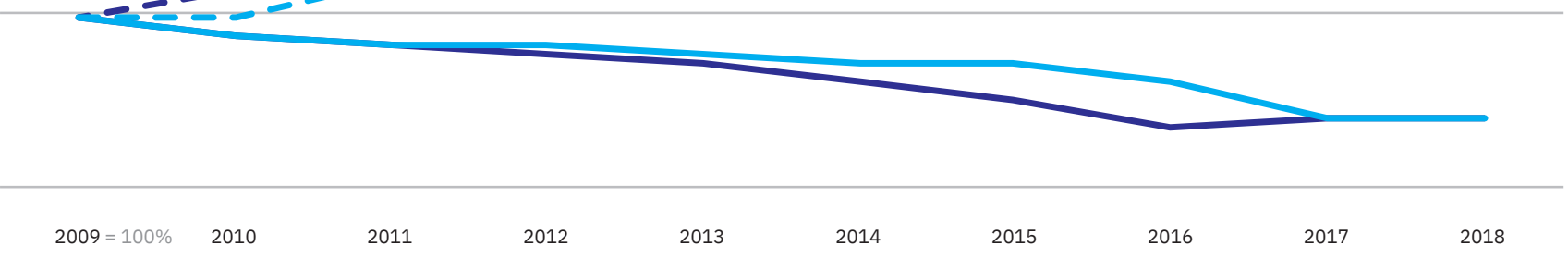

Фонд оплаты труда (в постоянных ценах 2009 г.)

---- Торгуемый сектор

---- Локальный сектор
$2009=100 \% \quad 2010$
2013

(1)

2014

\begin{abstract}
(2015
\end{abstract}

$(2016$

2017


В 2009-2018 гг. статистика зафиксировала сокращение абсолютной занятости по всей экономике России - как в торгуемом, так и в локальном секторе. На фоне общих негативных тенденций на рынке рабочей силы в период с 2015 по 2018 г. фонд оплаты труда в торгуемых видах деятельности рос опережающими темпами - в среднем на 2.5\% в год. Увеличение вознаграждения в компаниях торгуемых отраслей имело значение не только для занятых там работников. Рост их доходов положительно сказался и на зарплатах в локальном секторе благодаря платежеспособному спросу на производимые соответствующими отраслями товары и услуги. Размер оплаты труда здесь повышался, хотя и меньшими темпами: ежегодный прирост в этот период составлял в среднем 1.4\%. Доля торгуемого сектора в общем фонде оплаты труда за последние четыре года увеличилась, при том что доля занятых в его отраслях на десятилетнем отрезке осталась практически неизменной. Можно предположить, что привлекательность карьеры в компаниях торгуемых видов деятельности выросла, а более высокие зарплаты позволили сформировать соответствующие требования к уровню человеческого капитала.

Создание новых рабочих мест в торгуемых отраслях связано с более высокой производительностью труда, инвестиционной активностью, объемами производства и в - конечном счете - с налоговыми отчислениями в бюджеты разных уровней. Поэтому эффективность экономической политики зависит от того, насколько правильно определены границы данного сектора как в национальных, так и в региональных масштабах, его структура и динамика развития. 


\section{2. Ключевые отрасли специализации России}

Торгуемый сектор в России привлекателен для работников. В каких его отраслях занято больше всего жителей страны, а в каких - уровень оплаты труда максимален? Ответы на эти вопросы могут не только раскрыть карьерные траектории населения, но и охарактеризовать современную структуру российской экономики. Полная отраслевая структура занятости в торгуемом секторе экономики России представлена на рисунке 1.4.

В России топ-5 отраслей торгуемого сектора с наибольшей долей занятых составили:

- Образование

- Транспорт и логистика

- Строительство и строительные материаль

- Деловые и ИТ-услуги

- Производство и транспортировка нефти и газа.

Наиболее высокая в масштабах страны занятость сложилась в отрасли «Образование»3. Это связано с наличием в субъектах Российской Федерации обширной сети педагогических, медицинских, аграрных, политехнических и других профильных вузов, создававшихся во времена СССР по территориально-производственному принципу [Кузьминов и др., 2013], филиалов университетов, негосударственных вузов и организаций среднего профессионального образования. Еще один фактор - сложность автоматизации учебного процесса. Образование, особенно в небольших городах и сельской местности, остается исключительно трудоемкой отраслью, требующей вовлечения значительных человеческих ресурсов.

В США и странах ЕС на единую отрасль «Образование и наука» ${ }^{4}$ приходится 7.0 и 4.1\% занятых в торгуемых секторах соответственно. В России отрасли «Образование» и «Наука» суммарно охватывают 14.5\% работников торгуемого сектора, однако в перспективе в них можно ожидать снижения численности занятых. Этому будут способствовать консолидация ресурсного потенциала образовательных и научных организаций, дальнейшая цифровизация академического и исследовательского процессов, исключение дублирующих учебных программ и ликвидация неэффективных организаций.

Лидирующая позиция отрасли «Транспорт и логистика» объясняется высокими издержками на организацию перевозок в стране с самой большой территорией. По протяженности железных дорог Россия находится на третьем месте в мире после США и Китая, автомобильных - на пятом [Аналитический центр при Правительстве Российской Федерации, 2019]. В 2016 г. наша страна занимала седьмое место по пассажирообороту воздушного транспорта, который составил 176.6 млрд пассажиро-км [Росстат, 2018]. Доля занятых в отрасли «Транспорт и логистика» в России (7.3\%) выше, чем в странах ЕС (6.0\%) и США (3.9\%). В то же время, несмотря на масштабы деятельности и высокую численность работников, наша страна проигрывает по срокам и качеству оказания соответствующих услуг. Так, в рейтинге Всемирного Банка Logistics Performance Index 2018, который оценивает 160 стран по легкости осуществления поставок товаров и состоянию торговой логистики на национальном и международном уровнях, Россия занимает 75-е место [World Bank, 2018]. Сокращение

\footnotetext{
${ }^{3}$ В используемой методологии торгуемая отрасль «Образование» охватывает среднее профессиональное образование, высшее образование (включая подготовку кадров высшей квалификации), образование в области культуры, дополнительное профессиональное образование и дополнительное образование детей и взрослых, а также прочее образование, не включенное в другие группировки.

4 Отрасль «Образование и наука» разделена в Атласе экономической специализации регионов России на отрасли «Образование» и «Наука» (см. Приложение 2).
} 
Рис. 1.4. Отраслевая структура занятости в торгуемом секторе экономики России: 2018 (\%)

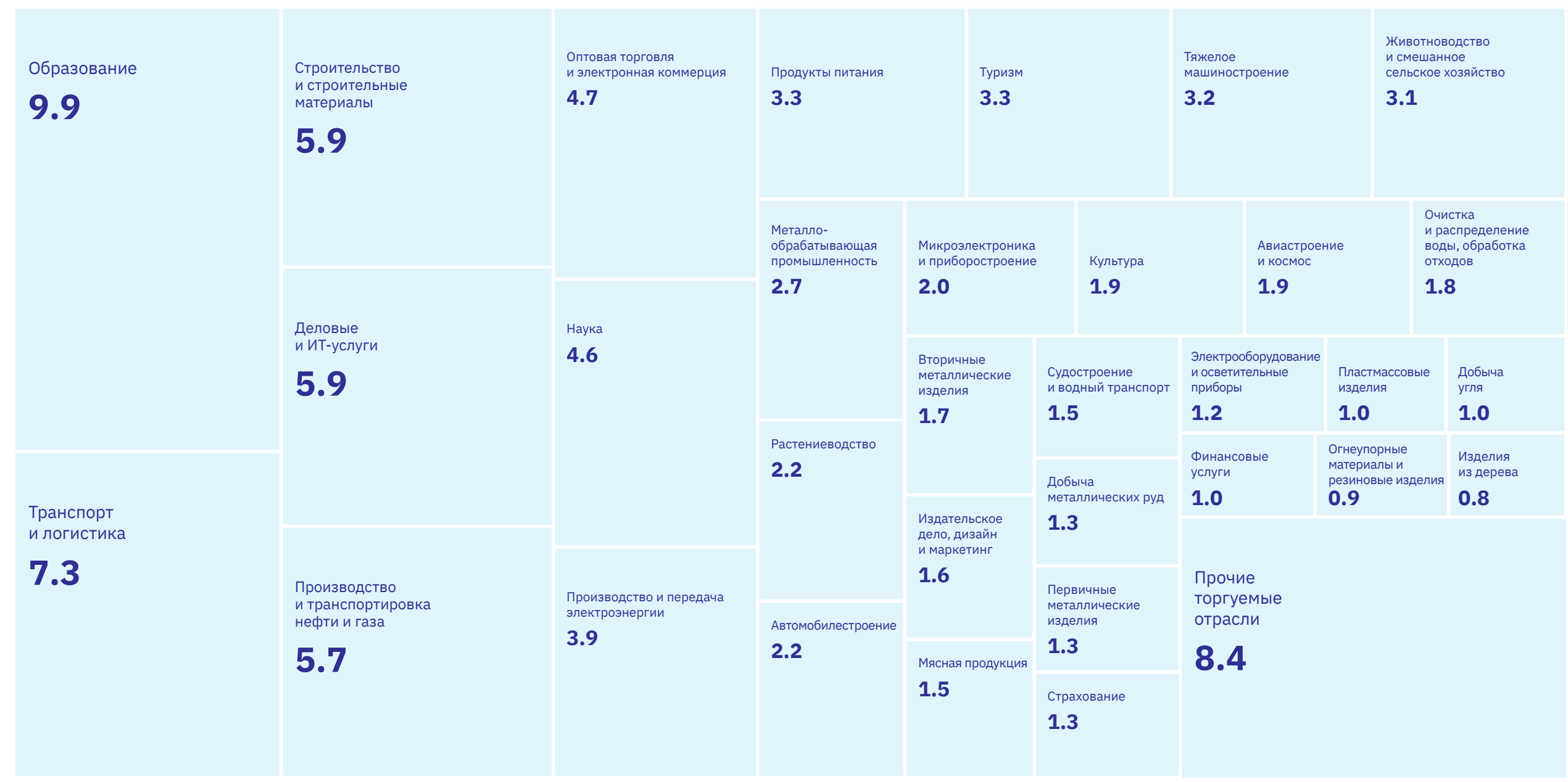


расходов на транспортно-логистические услуги и повышение их качества возможны за счет развития инфраструктуры, распространения практик государственно-частного партнерства, расширения рынка аутсорсинговой логистики, появления в отрасли новых крупных игроков и наращивания кооперационных связей между ними. Учитывая значение транспортнологистического комплекса для экономического развития России, можно предположить, что значительная доля отрасли в ее торгуемом секторе сохранится.

Весомую роль отрасли «Строительство и строительные материалы» в торгуемом секторе можно объяснить массовым девелопментом последних лет от инициатив по созданию комфортной городской среды до инфраструктурных мегапроектов. Доля отраслевой занятости в России - 5.9\%, что существенно выше, чем в странах ЕС (2.9\%) и США (1.8\%). Основным драйвером развития индустрии выступает жилищное строительство. В 2015 г. в нашей стране зафиксирован исторический максимум ввода жилых площадей - 85.4 млн кв. м (в 2018 г. этот показатель снизился до 75.7 млн кв. м) [Министерство строительства и жилищно-коммунального хозяйства Российской Федерации, 2020]. Россия занимает второе место в мире по вводу квартир на тысячу человек населения (7.98 квартир в 2015 г.). Первенство принадлежит Турции (8.6 квартир), Китай (7.3) находится на третьем месте, Франция (5.6) - на четвертом, США (3.2) заняли 10-ю строчку рейтинга [Дом.РФ, 2017]. На показатели ввода строительных объектов и уровень занятости в отрасли повлияла и подготовка к проведению Чемпионата мира по футболу в 2018 г., проходившего в 11 городах России. Предприятия системы централизованного теплоснабжения, к которой подключено 82\% жилищного фонда страны [Дёмина, 2016], обеспечивают 59\% отраслевой занятости. В этом виде деятельности в России занято в 3.7 раза больше сотрудников, чем суммарно в 27 странах EC [Eurostat, 2020]. С учетом нынешних темпов ввода жилья (в том числе в условиях реализации программ реновации в субъектах Российской Федерации) и запуска новых крупных инвестиционных проектов можно ожидать сохранения высокой численности работающих в сфере «Строительство и строительные материалы».

Значимость отрасли «Деловые и ИТ-услуги» для российского торгуемого сектора (5.9\% от общей численности работников) во многом определяется масштабами цифровизации и урбанизации. Первый глобальный тренд поддерживается не только за счет государственных программ развития, но и благодаря появлению российских ИТ-компаний, которые выходят на мировой рынок. Второй тренд связан с расширением в крупнейших российских агломерациях сектора интеллектуальных услуг - консалтинга, аудита, рекрутинга, рекламы и пр. [Кузьминов и др., 2003]. Стоит отметить, что доли отрасли в торгуемом секторе США (26.9\%) и государствах ЕС (10.2\%) превышают российский показатель в пять и два раза соответственно. Подобные структурные различия объясняются рядом причин. Во-первых, динамика отрасли «Деловые и ИТ-услуги» тесно связана с уровнем инновационного развития экономики. Значительный спрос на сервисы сектора интеллектуальных услуг формируют лидирующие на глобальном рынке высокотехнологичные бизнесы США и стран EC [Miles et al., 2018]. Во-вторых, американские и европейские компании данной отрасли уже давно не ограничиваются исключительно внутренними рынками. США и страны ЕС выступают главными мировыми экспортерами интеллектуальных услуг, многократно превосходя по этому показателю остальные государства [Biege et al., 2012]. В России на развитие отрасли оказывают негативное влияние экономические кризисы 2008 и 2014 гг., однако со временем возможен возврат к положительной динамике [Belousova, Chichkanov, 2016]. 
Наконец, значительная доля отрасли «Производство и транспортировка нефти и газа» в структуре отечественного торгуемого сектора (5.7\% от общей численности занятых) обусловлена ее системообразующей ролью для экономики страны. В 2019 г. Россия заняла второе место в мире после США по добыче нефти и газа [Joint Organisations Data Initiative, 2020], а доходы от их продаж сформировали порядка 40\% поступлений в федеральный бюджет [Министерство финансов Российской Федерации, 2020]. Высокая занятость в индустрии связана с необходимостью обслуживания масштабной сети нефте- и газопроводов (второе место по протяженности в мире) и реализацией крупных инвестиционных проектов («Северный поток-2», «Турецкий поток», «Сила Сибири», разработка месторождений на о. Сахалин и в российской Арктике и др.). Вместе с тем воздействие глобальных трендов, таких как развитие возобновляемых источников энергии и децентрализованной генерации, может привести к сокращению занятости в этой сфере.

Сравнение отраслей торгуемого сектора, лидирующих по доле занятых в России, ЕС и США, свидетельствует о низком весе сервисной экономики в нашей стране (рис. 1.5).

На отрасль «Оптовая торговля и электронная коммерция» приходится значительная доля занятых в российском торгуемом секторе (4.7\%), тем не менее она не входит в топ-5 по данному показателю. В Европейском союзе эта индустрия - крупнейшая (13.5\% занятых), а в США - занимает второе место (после сферы «Деловые и ИТ-услуги») с показателем 12.8\%. По уровню развития оптовой торговли и электронной коммерции можно судить о зрелости рынка, поскольку именно оптовая торговля обеспечивает эффективное функционирование ретейлеров, сокращая их транспортные и трансакционные издержки. Многие ведущие торговые компании, расположенные в США, Китае

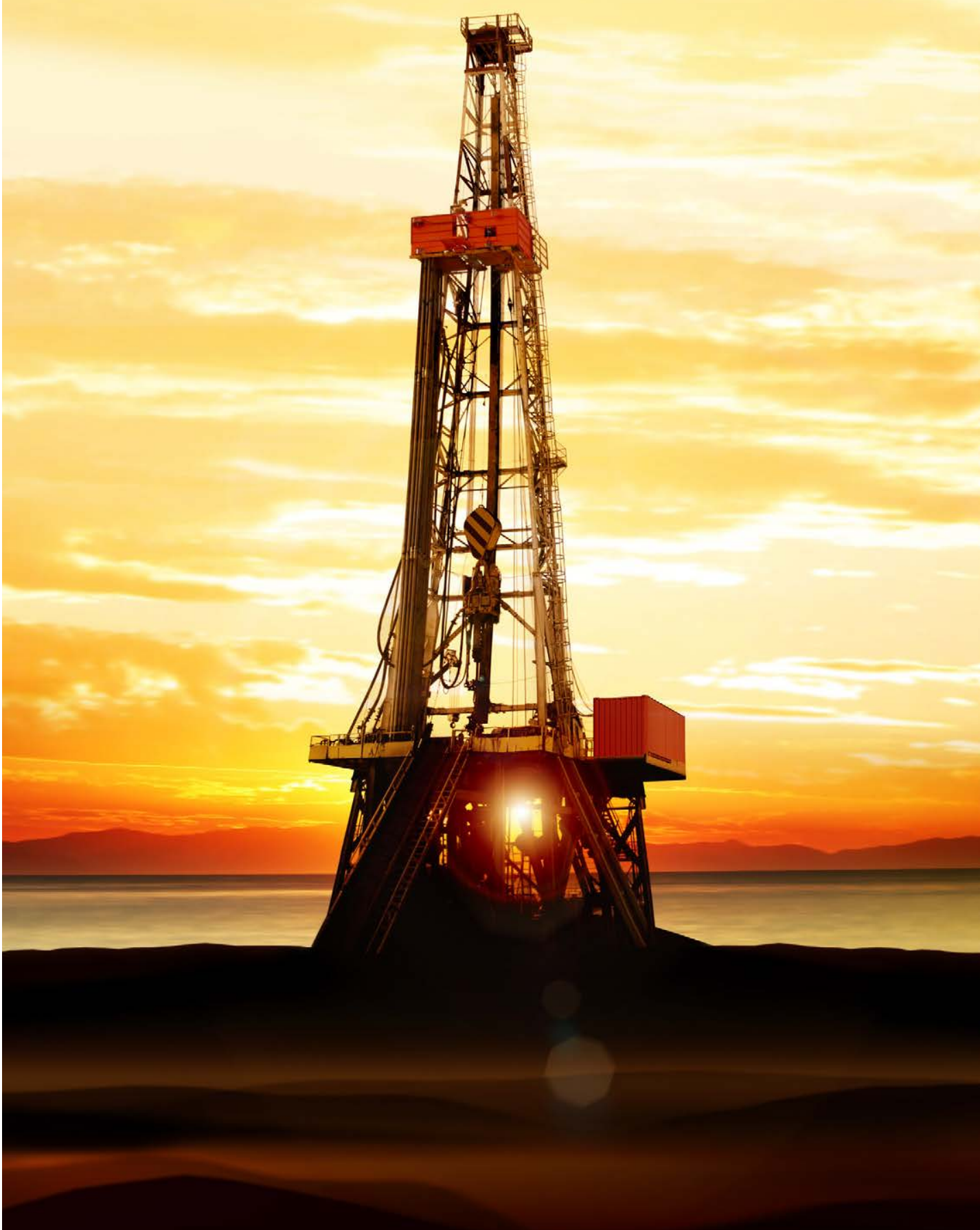


Рис. 1.5. Топ-5 отраслей по удельному весу занятых в торгуемом секторе по странам (\%)

Россия, 2018

\begin{tabular}{ll|l|l|l|l|}
\hline 9.9 & 7.3 & 5.9 & 5.9 & 5.7
\end{tabular}

США, 2016

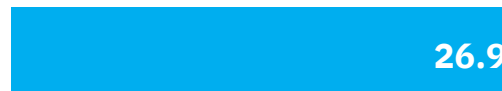

26.9

12.8

7.1

7.0

4.3

EC, 2014

13.5

9.6

10.2

6.7

6.0

Образование

Транспорт и логистика
Деловые и ИТ-услуги

Оптовая торговля

и электронная коммерция
Туризм

Финансовые услуги
Строительство и строительные материаль

Производство и транспортировка нефти и газа

Источник: по России - расчеты ИСИЭз нИУ ВШЭ по данным Росстата, по США - [Harvard Business School, 2020], nо странам Eвропейского союза - [Ketels, Protsiv, 2016]. 
и ряде государств ЕС, появились на волне цифровизации и сформировали новый рынок - электронной коммерции [Fortune, 2020]. Ожидаемое повышение доли отрасли в торгуемом секторе во многом связывается с развитием продаж через интернет: темпы их роста уже сегодня многократно превышают показатели других видов торговли [Российская ассоциация электронных коммуникаций, 2018].

Отрасль «Туризм» также не входит в число лидеров торгуемого сектора России по доле занятых (3.3\%). К 2013 г. интенсивность выездного туризма россиян достигла пика, что обеспечило нашей стране одну из ведущих позиций по данному показателю в мире [Аналитический центр при Правительстве Российской Федерации, 2016]. Последовавшие затем девальвация рубля и ограничения, принятые в отношении популярных направлений отдыха (в первую очередь Египта и Турции), привели к снижению спроса на зарубежные туры и росту востребованности внутреннего туризма [Аналитический центр при Правительстве Российской Федерации, 2017]. Однако предложение отечественного рынка услуг в сферах гостеприимства и впечатлений по-прежнему локализовано в основном в столичных регионах и на Черноморском побережье и, несмотря на повышение качества и разнообразия сервисов, все еще несопоставимо по масштабам со странами-бенчмарками. Для сравнения: в государствах ЕС доля занятых в отрасли (9.6\%) превышает российский показатель почти троекратно, а в США (7.1\%) - более чем вдвое. Высокий спрос на туристические услуги в этих экономиках в значительной степени формируется именно за счет внутреннего туризма. Наибольшее число поездок по стране совершается в Китае, США, Великобритании, Германии и Японии. При этом в первых двух их доля в общем числе путешествий находится на уровне 95\%, тогда как в России - около 50\% [OECD, 2020; Аналитический центр при Правительстве Российской Федерации, 2016].

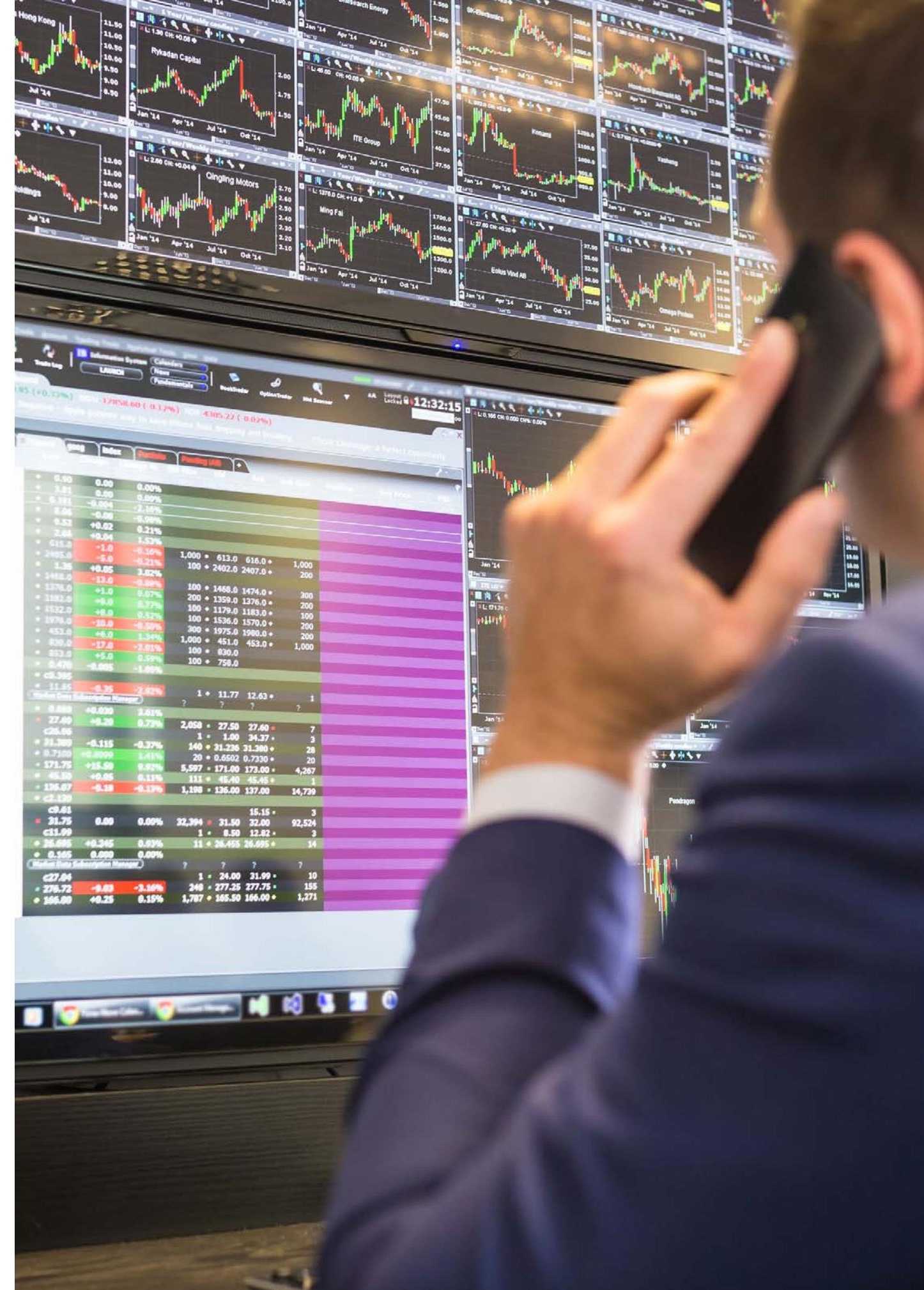


Доля занятых в отрасли «Финансовые услуги» ${ }^{5}$ в России почти в семь раз ниже, чем в странах ЕС, и в четыре раза меньше показателя по США (1.0\% против 6.7 и 4.3\% соответственно). Столь существенную разницу можно объяснить слабым уровнем развития отечественных финансовых институтов. В 2020 г. Москва заняла 71-е место среди 108 городов, оцениваемых в Индексе глобальных финансовых центров, а Санкт-Петербург - 97-е. В первую пятерку рейтинга вошли Нью-Йорк, Лондон, Токио, Шанхай и Сингапур [GFCI, 2020]. Спрос на новых сотрудников со стороны финансового сектора России будет сдерживаться вследствие продолжающейся консолидации банковской системы [Доронкин, Лопатин, 2019], стагнации и негативной динамики в небанковском сегменте [Данилов и др., 2017], интенсивного внедрения ИТ-решений.

Важно отметить, что отрасли, составляющие топ-3 по доле занятых, в американской и европейской экономиках совпадают: это «Деловые и ИТ-услуги», «Оптовая торговля и электронная коммерция» и «Туризм». В США на их долю приходится $46.8 \%$ торгуемого сектора, в ЕС - 33.2\%, а в России - $13.8 \%$. Подобные значения во многом объясняются высоким мировым спросом на продукцию и услуги компаний, работающих в этих индустриях, в странах-бенчмарках. Отрасли «Деловые и ИТ-услуги» и «Оптовая торговля и электронная коммерция» стимулируют появление и развитие других видов экономической деятельности. Наличие между отраслями торгуемого сектора связей (Приложение 1), которые отражают тенденции к их совместной локализации, обмену продукцией и навыками 6 , открывает возможности для структурной трансформации в направлении связанного разнообразия [Delgado et al., 2016]. Исключение из анализа трех ведущих отраслей торгуемого сектора практически выравнивает уровень диверсификации экономик России, США и ЕС. Это подтверждается и обратным расчетом: число отраслей, имеющих в торгуемом секторе долю занятости менее 2\%, практически совпадает (в России - 40, в США - 39, в ЕС - 35). Мы полагаем, что широкая международная интеграция, в частности интенсификация торгово-экономических и научно-образовательных связей, включение в глобальные туристические потоки и процессы трудовой миграции могут повысить конкурентоспособность широкого спектра текущих специализаций Российской Федерации, в том числе в сфере промышленности.

Торгуемые отрасли различаются не только по численности занятых, но и по уровню оплаты труда. Зарплаты в торгуемом секторе в целом выше, чем в локальном. При этом размер вознаграждения в самой привлекательной для работника торгуемой отрасли превышает значение отрасли-аутсайдера в шесть раз. Подобная дифференциация характерна и для стран-бенчмарков. Максимальный размер заработной платы в нашей стране зафиксирован в отраслях «Финансовые услуги» и «Деловые и ИТ-услуги», которые формируют сектор интеллектуальных услуг. В добывающем и обрабатывающем секторах по этому показателю лидируют «Производство и транспортировка нефти и газа», «Табачные изделия», «Рыболовство и производство рыбопродуктов» (рис. 1.6).

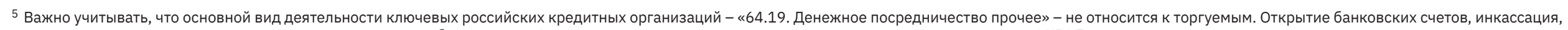

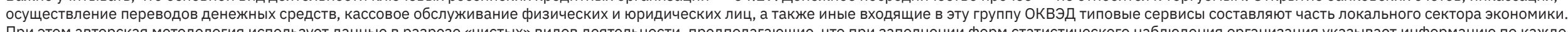

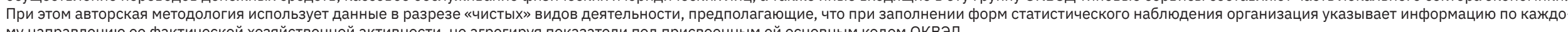
му направлению ее фактической хозяйственной активности, не агрегируя показатели под присвоенным ей основным кодом ОКВЭД.

6 Развитие отрасли «Оптовая торговля и электронная коммерция» будет стимулировать следующие виды деятельности: «Деловые и ИТ-услуги», «Микроэлектроника и приборостроение», «Медоборудование»,

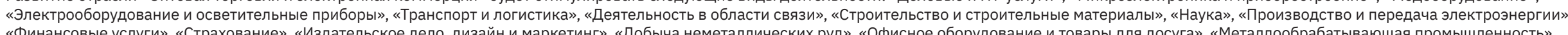

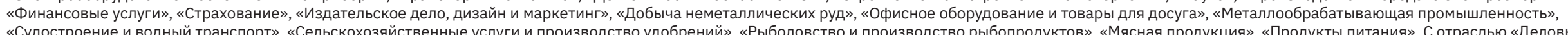

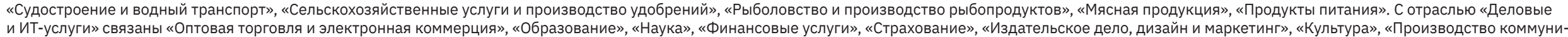
и ИТ-услуги» связаны «Оптовая торговля и электронная коммерция», «Образование», «Наука», «ицинного оборудования», «Фармацевтическая промышленность», «Полиграфия и печать». 


\section{Рис. 1.6. Топ-5 отраслей по среднемесячной начисленной заработной плате в торгуемом секторе по странам (долл. США)}

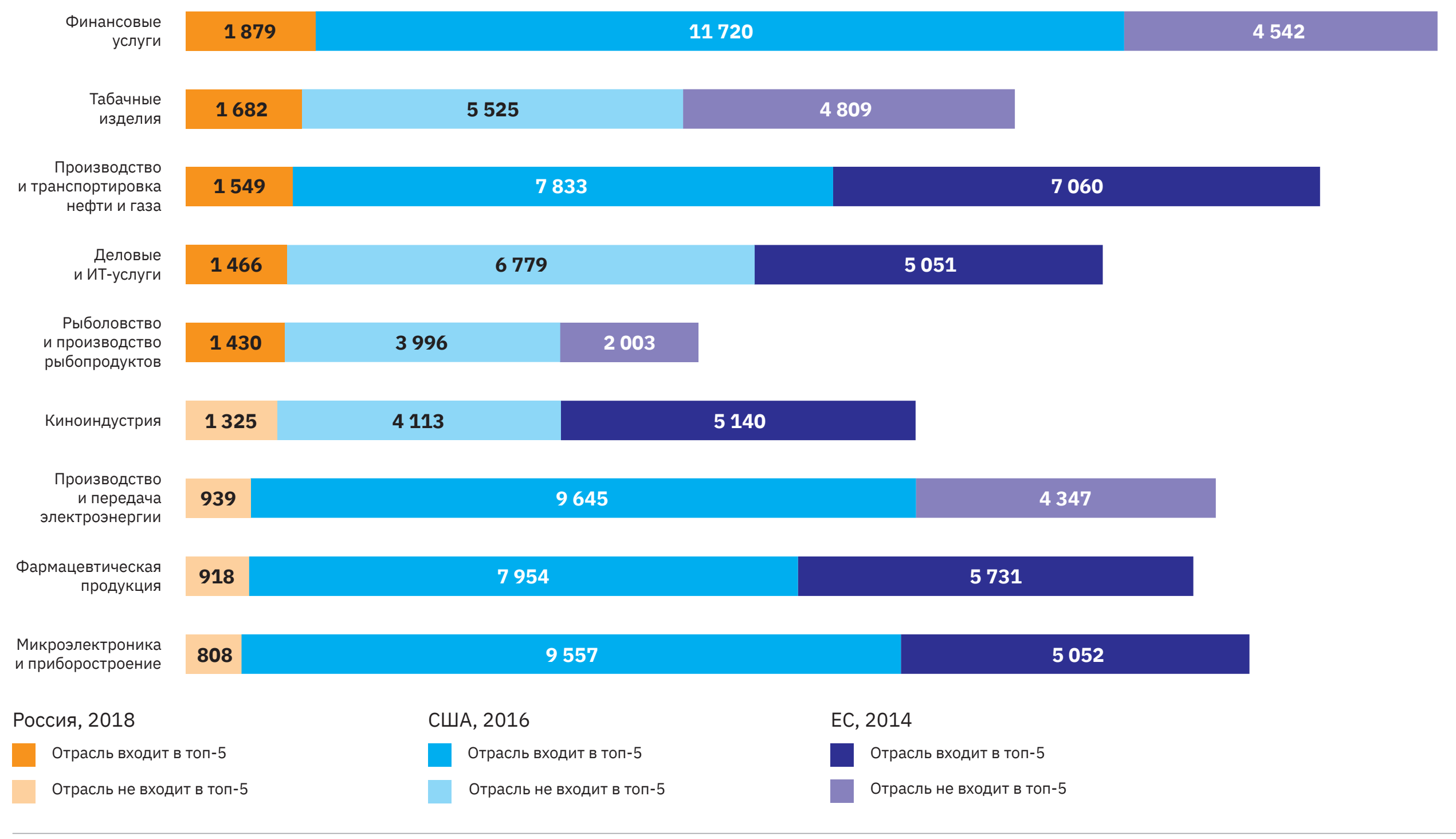

Источник: по России - расчеты ИСИЭз нИУ ВШэ по данным Росстата, по США - [Harvard Business School, 2020], по странам Европейского coюза - [Ketels, Protsiv, 2016]. 
В отличие от России, в США и странах ЕС в пятерку торгуемых отраслей с максимальными зарплатами входят «Фармацевтическая продукция» и «Микроэлектроника и приборостроение». В последнее десятилетие данные направления развивались быстрее, чем национальные экономики в целом [Deutsch, 2019], что стало результатом доминирования компаний этих стран на мировом рынке. Так, фирмы США удовлетворяют глобальный спрос на фармацевтическую продукцию на 45\%, европейские - более чем на $20 \%$ [Wee, 2017]. В сфере информационно-коммуникационных технологий также лидируют разработчики и производители из США и государств ЕС: на их долю приходится 31 и 19\% мирового рынка соответственно [Statista, 2020a].

Следует отметить, что занять лидирующие позиции в этих отраслях США и ЕС также смогли благодаря масштабным вложениям в исследования и разработки. В американской фармацевтике они превосходят средние значения по сектору промышленного производства более чем в 12 раз, в микроэлектронике и приборостроении - в шесть [Statista, 2020b]. Потребность в специалистах, обладающих соответствующей отраслевым требованиям квалификацией, удовлетворяется благодаря высокому уровню оплаты труда.

Примечательно, что и в России, и в США, и в странах ЕС минимальные значения оплаты труда зафиксированы в отрасли «Одежда». В целом среди наименее привлекательных для работников оказались многие отрасли легкой промышленности («Текстильное производство», «Кожаные изделия», «Обувь»), а также виды деятельности, связанные с сельским хозяйством.

Сопоставление численности занятых и размера заработной платы позволяет оценить воздействие той или иной отрасли на производительность труда (бокс 3) в масштабах страны (рис. 1.7).

\section{Бокс 3. Производительность труда: кому и за что больше платят?}

Производительность труда - основной индикатор эффективности использования рабочей силы и важнейшая характеристика развития вида экономической деятельности или отдельной организации. В отраслевом разрезе этот параметр измеряется через соотношение валовой добавленной стоимости (далее ВДС) и затрат труда7 ${ }^{7}$ Однако низкая степень детализации имеющихся данных по ВДС (на уровне страны - по двухзначным кодам ОКВЭД; на уровне субъектов Российской Федерации - по разделам ОКВЭД) ограничивает его использование для анализа торгуемых отраслей. В подобной ситуации наиболее адекватным показателем, отражающим производительность труда, является размер заработной платы [Feldstein, 2008]. Такой подход используется, в частности, при анализе торгуемых отраслей в странах ЕC [Ketels, Protsiv, 2016]. Заработная плата как один из ключевых элементов фонда оплаты труда и, соответственно, ВДС позволяет объективно охарактеризовать отраслевую производительность: рост последней на 1\% ведет к увеличению заработной платы на 0.59\% [Вакуленко, Гурвич, 2015]. В пользу предлагаемого подхода свидетельствует еще и то, что показатель среднемесячной заработной платы работников предприятия служит экономической базой для определения высокопроизводительных рабочих мест ${ }^{8}$.

7 См. Методику расчета показателя «Индекс производительности труда», утв. приказом Росстата от 28 апреля 2018 г. № 274.

См. Методику расчета показателя «Прирост высокопроизводительных рабочих мест, в процентах к предыдущему году», утв. приказом Росстата от 09 октября 2017 г. № 665. 
Рис. 1.7. Распределение отраслей торгуемого сектора экономики России по среднемесячной начисленной заработной плате и численности занятых: 2018*

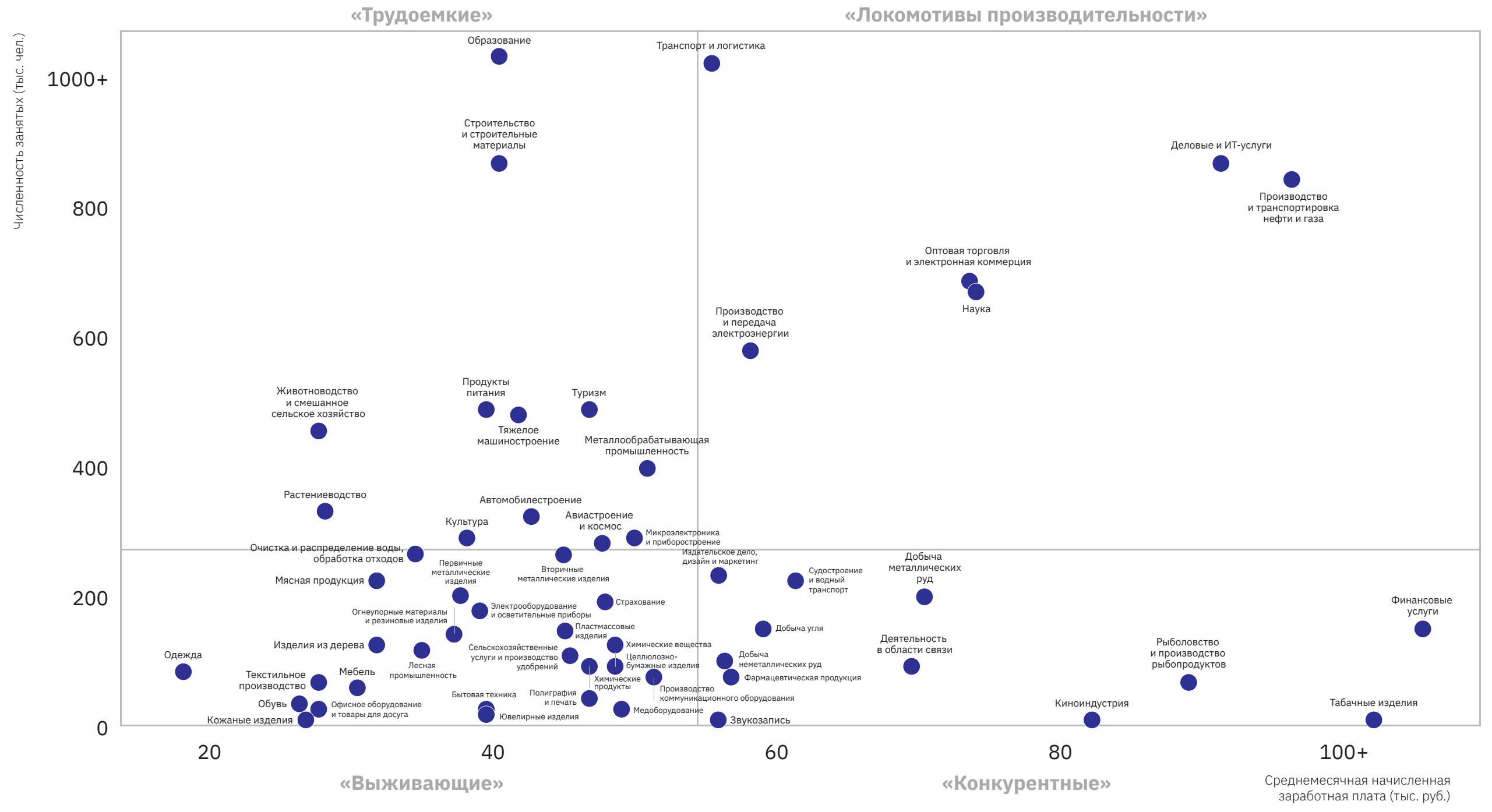

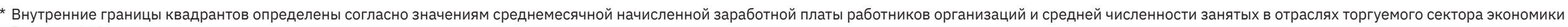
России в 2018 г. соответственно.

Источник: расчеты ИСИЭз ниу ВШЭ по данным Росстата. 
Около трети работников торгуемых видов деятельности в России заняты в шести отраслях - «локомотивах производительности» 9 , отличающихся высоким уровнем оплаты труда. Предположительно, в будущем они сохранят лидерство в торгуемом секторе страны. Факторами их роста могут стать интеграция в глобальные цепочки создания стоимости и стратегическое управление производительностью.

Следующую группу составляют 12 «конкурентных» отраслей ${ }^{10}$. Они характеризуется высоким уровнем заработных плат и низкой численностью занятых. Перспективы их развития связаны, прежде всего, с усилением позиций в торгуемом секторе экономики России. Этому могут способствовать инвестиции в инфраструктуру, активные маркетинговые, инновационные и экспортные стратегии. В результате вырастет спрос, повысится доля рынка, увеличатся обороты производства, сформируется потребность в новых квалифицированных кадрах.

Еще 12 отраслей составляют группу «трудоемких» ${ }^{11}$. При высокой численности работников (около $42 \%$ всего торгуемого сектора) размер оплаты труда здесь ниже конкурентоспособного для России уровня. Положительный сценарий их трансформации предусматривает повышение оплаты труда при сохранении занятости. Решение этой задачи не обойдется без государственных интервенций, поскольку часть «трудоемких» отраслей относятся к стратегическим, системообразующим или социально значимым (например, «Образование», «Культура», «Авиастроение и космос»). Важное направление поддержки - переобучение работников, находящихся под угрозой высвобождения, с целью их дальнейшего трудоустройства. В отраслях, где преобладает частный бизнес («Строительство и строительные материалы», «Продукты питания», «Туризм», «Животноводство и смешанное сельское хозяйство», «Автомобилестроение» и пр.), повышение производительности труда возможно за счет внедрения инструментов автоматизации и использования цифровых технологий.

Ограниченная занятость и недотягивающая до средних значений в торгуемом секторе заработная плата зафиксированы в 25 «выживающих» отраслях ${ }^{12}$, связанных преимущественно с промышленностью. Желательная траектория их развития - создание новых высокопроизводительных рабочих мест. Способствовать достижению этой цели будет поддержка частного бизнеса, включая такие меры, как:

- налоговое стимулирование предприятий, повышающих производительность труда;

- снижение затрат, возникающих в связи с административными барьерами;

- содействие в реализации проектов по техническому перевооружению.

Различия в составе лидирующих отраслей специализации российской и ведущих мировых экономик, равно как и отраслевая дифференциация внутри отечественного торгуемого сектора по показателям занятости и размера заработных плат, во многом формируются на местах - в компаниях, организациях, институтах и органах власти, работающих в субъектах Российской Федерации. Понимание текущего состояния отраслевого ландшафта российских регионов, корректная интерпретация выявленных особенностей и закономерностей необходимы для разработки сценариев дальнейшего развития территорий и видов экономической деятельности.

9 «Транспорт и логистика», «Деловые и ИТ-услуги», «Производство и транспортировка нефти и газа», «Оптовая торговля и электронная коммерция», «Наука», «Производство и передача электроэнергии».

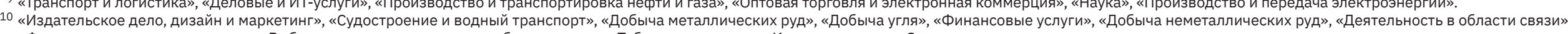
«Фармацевтическая продукция», «Рыболовство и производство рыбопродуктов», «Табачные изделия», «Киноиндустрия», «Звукозапись».

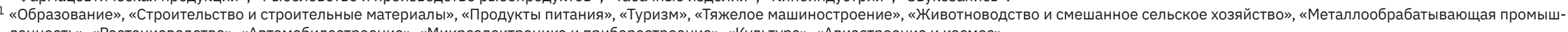
ленность», «Растениеводство», «Автомобилестроение», «Микроэлектроника и приборостроение», «Культура», «Авиастроение и космос».

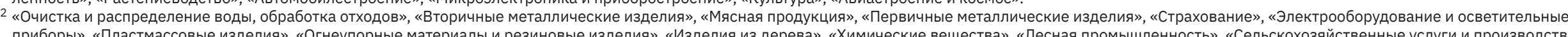

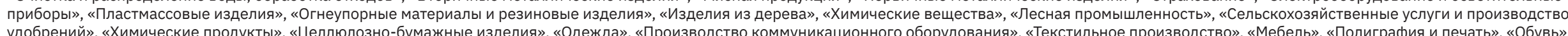

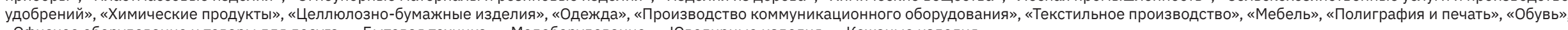
«Офисное оборудование и товары для досуга», «Бытовая техника», «Медоборудование», «Ювелирные изделия», «Кожаные изделия». 


\section{3. Отрасли \\ специализации российских регионов}

Отрасли специализации распределены по территории страны неравномерно. Так, «Культура» выступает профильной отраслью почти половины (42) субъектов Российской Федерации, а «Звукозапись» - лишь трех. Отрасли региональной специализации также различаются по типам значимости (рис. 1.8), которые мы выделяем на основе статистики занятости и заработной платы (Приложение 1):

- Отрасли национальной и локальной значимости - отличаются высокой численностью занятых как в масштабах России, так и в конкретном субъекте Российской Федерации (например, «Автомобилестроение» в Самарской области и Республике Татарстан).

- Отрасли национальной значимости - заметны на уровне страны, поскольку регионы с соответствующей специализацией формируют существенную долю общеотраслевой занятости. Однако доля таких индустрий в региональной занятости может быть сравнительно невелика. Это характерно, например, для отрасли «Фармацевтическая продукция» в Москве и сферы «Строительство и строительные материалы» в Санкт-Петербурге.

- Отрасли локальной значимости - напротив, играют ключевую роль в первую очередь для экономики самого́ субъекта Российской Федерации. Их доля в региональной занятости превышает среднероссийские значения, несмотря на то, что регионы с соответствующей специализацией вносят небольшой вклад в общеотраслевую занятость. Примерами могут служить «Рыболовство и производство рыбопродуктов» в Астраханской области, «Судостроение и водный транспорт» в Камчатском крае.

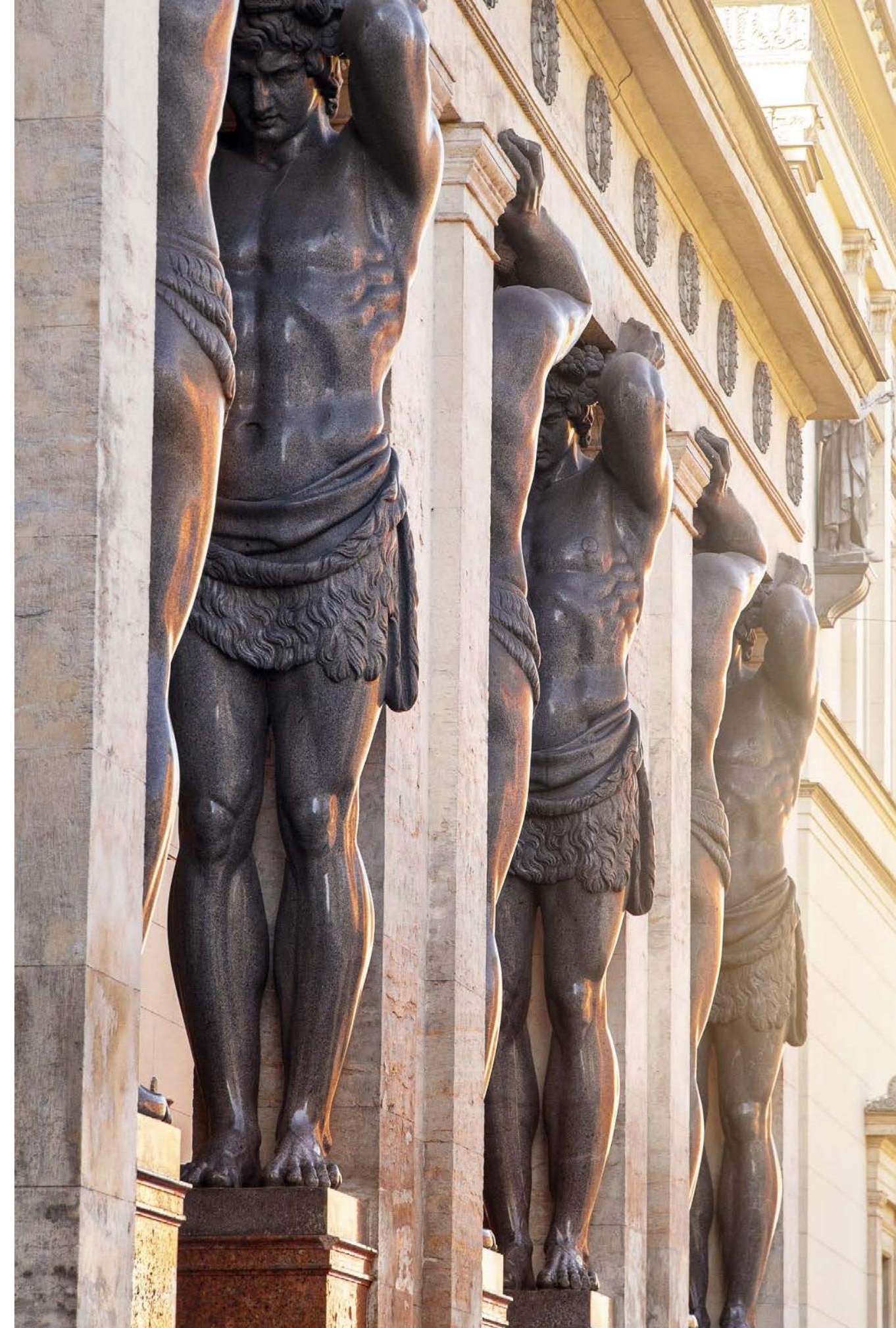




\section{Рис. 1.8. Распределение отраслей специализации по представленности в регионах России и типам значимости: 2018}

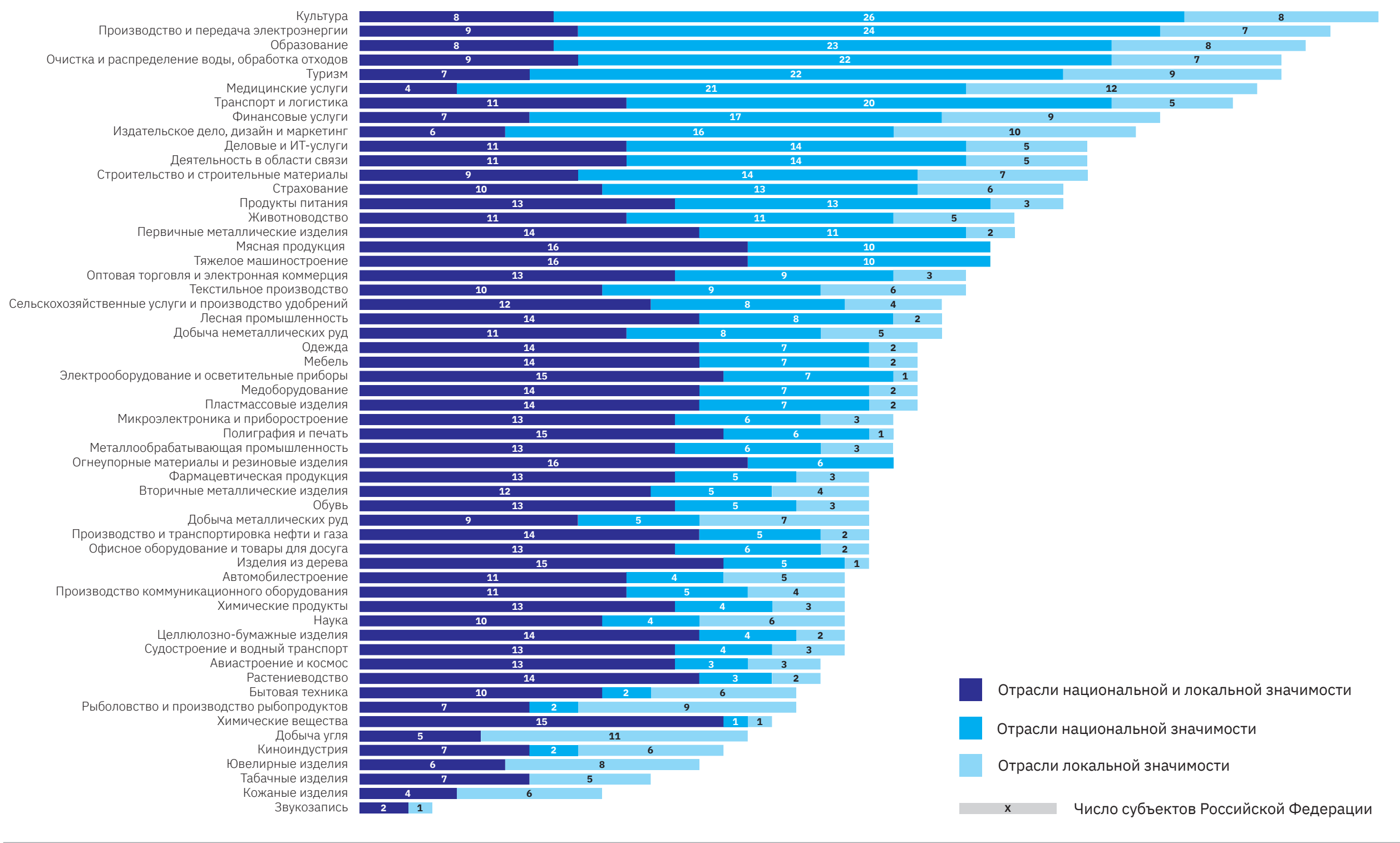


Распределение отраслей специализации по типам значимости и встречаемости в регионах России (рис. 1.9) позволило нам выделить две группы - «Сервисы» и «Промышленность», для которых предложены возможные сценарии развития.

Отрасли, объединенные в группу «Сервисы» ${ }^{13}$, широко распространены на всей территории страны и составляют специализацию многих регионов (от 29 до 42). В то же время отраслями национальной и локальной значимости одновременно они оказываются лишь для некоторых субъектов Российской Федерации, что позволяет сделать вывод о небольшом числе регионов - безусловных лидеров в относящихся к ним видах деятельности. Основой для эволюции отраслей специализации из этой группы может быть стратегия опережающей поддержки точек роста за счет концентрации инвестиционных ресурсов, развития инфраструктуры и усиления компетенций. В ряде отраслей, таких как «Образование», «Культура», «Финансовые услуги», «Деловые и ИТ-услуги», это возможно в том числе за счет укрупнения организаций, слияний и поглощений компаний.

Иное распределение по регионам и типам значимости демонстрируют отрасли, входящие в группу «Промышленность» ${ }^{14}$. Роль отраслей специализации они играют в меньшем числе регионов (от 17 до 26), однако именно там максимально развиты и часто являются отраслями национальной и локальной значимости. Регионы с отраслями специализации из рассматриваемой группы должны продолжать наращивать профильные компетенции. При этом во избежание эффекта колеи (path dependence) в сфере инфраструктурного, технологического и организационного развития рекомендуется искать возможности для формирования связанной диверсификации в существующих отраслях. Одновременно целесообразно начать развивать с нуля отрасли данной группы в новых регионах. Оба сценария предполагают расширение межрегионального сотрудничества.

Для 16 отраслей сформировать группу не удалось. Часть из них, например «Звукозапись», «Кожаные изделия» и «Ювелирные изделия», оказались слабо распространены в регионах России, что может быть связано с их тяготением к территориям с уникальными компетенциями в соответствующих видах деятельности. Другие сферы, такие как «Добыча угля», «Добыча металлических руд» и «Добыча неметаллических руд», редко относятся к отраслям национальной и локальной значимости из-за концентрации отраслевой занятости в ключевых добывающих регионах. Наконец, не удалось обнаружить закономерностей в территориальном распространении отраслей, относящихся к интеллектуальным услугам ${ }^{15}$ и креативным индустриям ${ }^{16}$. Отсутствие единой группы можно объяснить тем, что в России эти отрасли весьма разнородны по уровню внутренней и международной конкурентоспособности, охвату рынка, тяготению к крупным городам и центрам профессиональной экспертизы.

\footnotetext{
13 «Культура», «Медицинские услуги», «Туризм», «Образование», «Производство и передача электроэнергии», «Транспорт и логистика», «Деловые и ИТ-услуги», «Деятельность в области связи», «Строительство и строительные материалы», «Очистка и распределение воды, обработка отходов», «Финансовые услуги», «Издательское дело, дизайн и маркетинг».

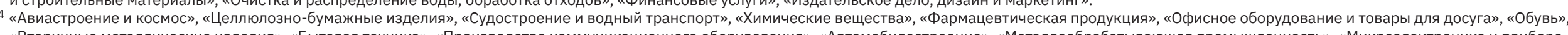

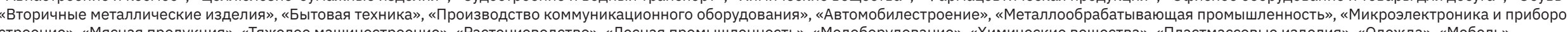
строение», «Мясная продукция», «Тяжелое машиностроение», «Растениеводство», «Лесная промышленность», «Медоборудование», «Химические вещества», «Пластмассовые изделия», «Одежда», «Мебель», 15 «Электрооборудование и осветительные приборы», «Полиграфия и печать», «Производство и транспортировка нефти и газа», «Огнеупорные материалы и резиновые изделия», «Изделия из дерева», 15 «Деловые и ИТ-услуги», «Наука», «Образование», «Страхование», «Финансовые услуги».

16 «Звукозапись», «Издательское дело, дизайн и маркетинг», «Киноиндустрия», «Культура», «Ювелирные изделия», частично «Кожаные изделия», «Обувь», «Одежда» и «Текстильное производство».
} 
Рис. 1.9. Распределение отраслей специализации по встречаемости в регионах России и принадлежности к отраслям национальной и локальной значимости: 2018

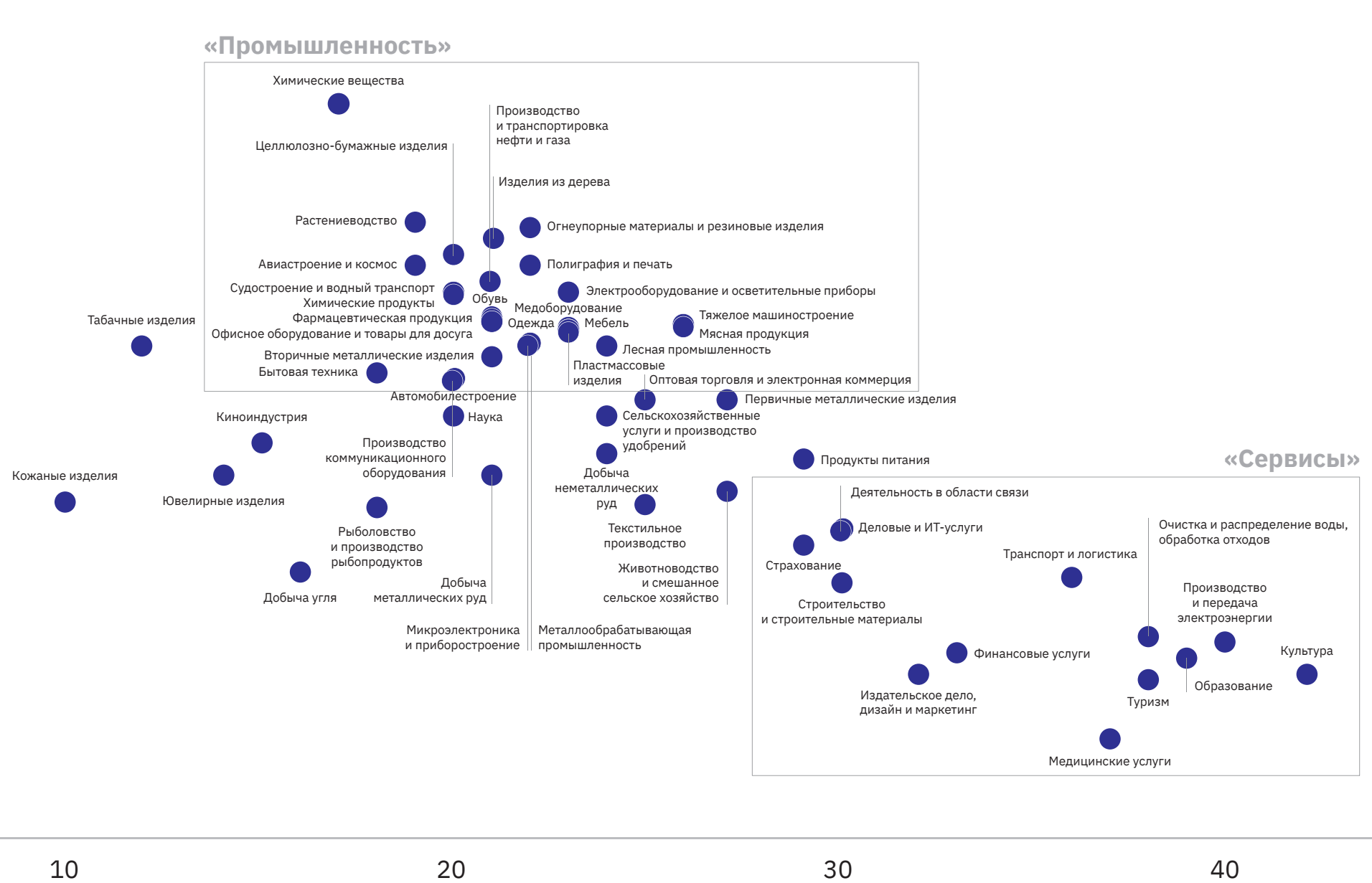

0 
Помимо уровня распространенности разных типов отраслей специализации, субъекты Российской Федерации отличаются по числу таких отраслей и их значимости (рис. 1.10).

Среди всех субъектов Российской Федерации наиболее диверсифицированной оказалась экономика Санкт-Петербурга: в ней выделяются 46 отраслей. В Чеченской Республике структура регионального хозяйства, напротив, максимально однородна - представлена тремя отраслями. В регионах с небольшим числом отраслей специализации в основном развиваются локально значимые виды деятельности. Приоритеты их экономического развития могут быть обоснованы с опорой на региональные профили (раздел 3 Атласа). В полиотраслевых регионах (их специализацию составляют 25 и более отраслей) преобладают значимые на федеральном уровне виды деятельности. В условиях столь широкого отраслевого разнообразия важно сконцентрировать инвестиционные ресурсы и меры поддержки на ограниченном перечне приоритетных направлений. Возможные трудности в решении этой задачи связаны с большими объемами данных и их интерпретацией. В число полиотраслевых регионов в основном вошли субъекты Российской Федерации, на территории которых расположены города-миллионники (включая Московскую и Ленинградскую области). Для всестороннего понимания экономической структуры таких регионов и обоснования приоритетов их развития с учетом всех видов деятельности мы составили рейтинги отраслей специализации, которые представлены в разделе 4 Атласа.

Таким образом, выбор сценария экономического развития для каждого субъекта Российской Федерации индивидуален и может опираться на текущее число отраслей специализации и принадлежность их к определенному типу значимости (национальная, локальная или одновременно национальная и локальная). Эти показатели помогают оценить уровень диверсификации отраслевой структуры, роль каждой отрасли в экономике региона и страны в целом. Однозначного ответа на вопрос, что лучше - развивать имеющиеся отрасли специализации или формировать новые, не существует. В академической среде до сих пор ведется дискуссия о преимуществах и недостатках обоих подходов (бокс 4).

Мы предлагаем несколько сценариев развития отраслей специализации регионов. Для их определения все субъекты Российской Федерации были помещены в матрицу «число отраслей специализации - доля отраслей специализации национальной и локальной значимости в общем числе отраслей специализации региона» (рис. 1.11). Это позволило выделить две группы регионов:

- полиотраслевые - характеризуются наибольшим числом отраслей специализации, среди которых от 25 до 50\% составляют отрасли национальной и локальной значимости;

- специализированные - имеют небольшое число отраслей специализации, уровень развития которых существенно различается. Среди субъектов этой группы мы дополнительно выделили три подгруппы в зависимости от доли отраслей региональной специализации, относящихся к типу «национальная и локальная значимость»: сильноспециализированные (от 80 до 100\%), среднеспециализированные (от 30 до 70\%) и слабоспециализированные (менее 25\%). 
Рис. 1.10. Распределение регионов России по числу и типам значимости отраслей специализации: 2018

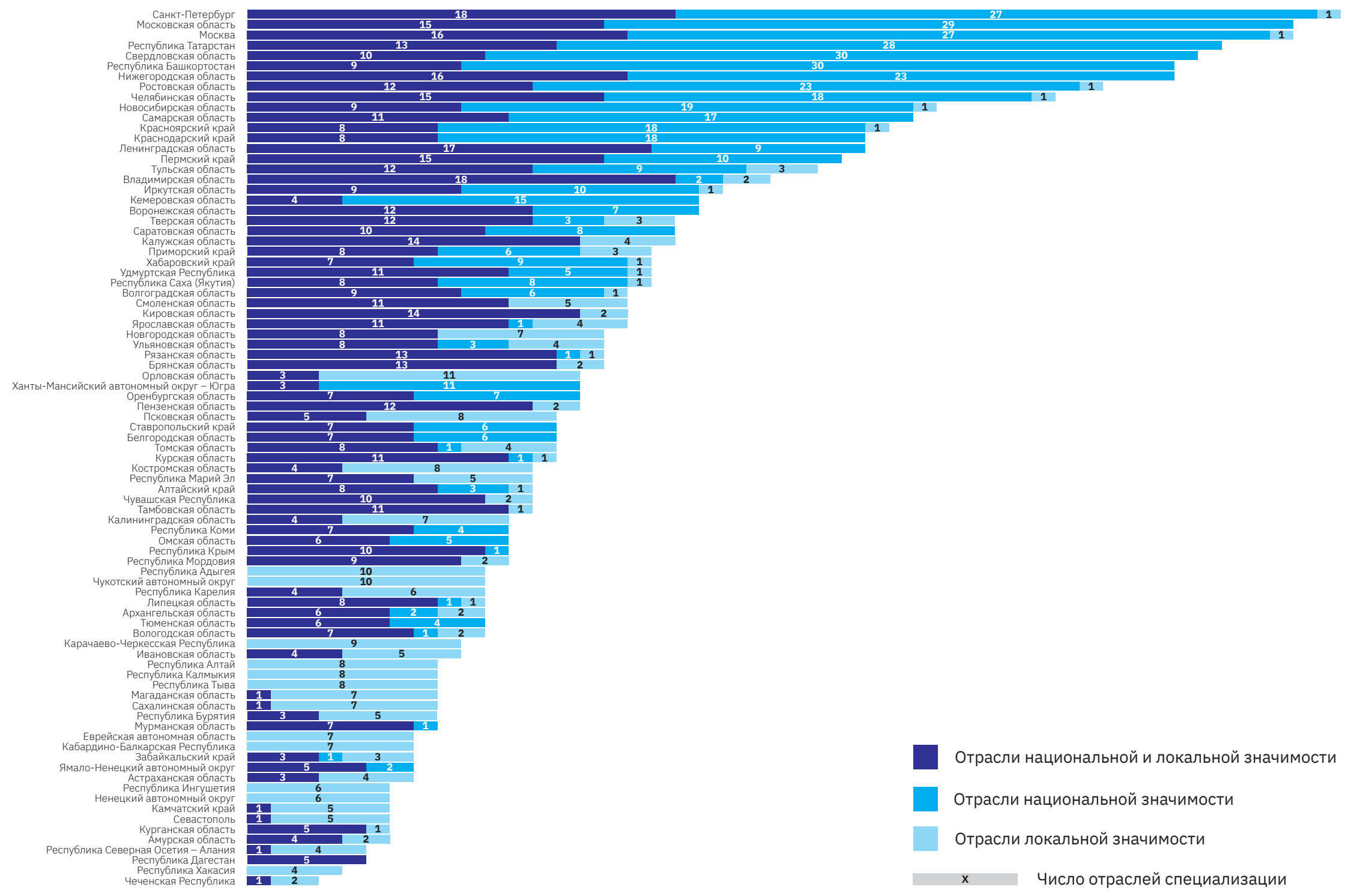




\section{Бокс 4. Специализация или диверсификация:} какую стратегию регионального развития выбрать?

Что определяет благосостояние нации в настоящем и будущем? Одним из первых на этот вопрос ответил Адам Смит в работе «Исследования о природе и причинах богатства народов» (1776), назвав разделение труда (специализацию) ключевым фактором экономического роста. Впоследствии Давид Рикардо (1852) уточнял, что речь идет о торговой специализации страны. Эти работы зародили интерес исследователей к поиску связи между структурой экономики и богатством государства.

Дискуссия о влиянии экономической структуры региона на развитие территорий и инновационную активность расположенных на них организаций ведется с середины XX века [Caragliu et al., 2016; Content, Frenken, 2016; Van der Panne, 2004; Acs, 2003; Feldman, Audretsch, 1999]. Авторы выделяют два основных типа внешних эффектов. Эффект специализации, или MAR-эффект, проявляется в результате пространственной концентрации определенных отраслей, что приводит к формированию профильных рынков труда, генерации и распространению специального знания и профессиональных навыков среди ограниченного пула организаций в определенных видах экономической деятельности [Glaeser et al., 1992]. В частности, эффектами специализации объясняются высокая производительность и инновационная активность компаний, входящих в кластеры [Grashof et al., 2019].

Противоположный результат - эффект диверсификации, или Джейкобсэффект, возникает вследствие отраслевого разнообразия экономики территории. При этом формируются радикально новые отрасли, а существующие

\footnotetext{
17 Подробнее о связи понятий «урбанизация» и «диверсификация» см. в [Lorenzen, Frederiksen, 2008].
}

подвергаются реструктуризации, в том числе на базе межотраслевой кооперации или не практиковавшихся ранее сочетаний видов экономической деятельности и технологий [Jacobs, 1969]. Отмечается, что обмен знаниями и компетенциями между представителями разных отраслевых сообществ приводит к появлению инновационных продуктов и технологий [Essletzbichler, 2015].

К сожалению, в своих работах Джейн Джейкобс не ответила на важный вопрос: связан ли процесс появления новых видов деятельности с существующими отраслями специализации? По мнению Томаса Кемени и Майкла Сторпера, эту проблему помогает решить теория экономической сложности [Kemeny, Storper, 2015], уже длительное время разрабатываемая в рамках НЭГ [Krugman, 1994], но лишь недавно получившая математическую базу благодаря исследованиям Сезара Идальго и Рикардо Хаусмана [Hidalgo, Hausmann, 2009]. Предложенный ими подход позволяет оценить сложность экономической структуры, основываясь на данных об экспорте продукции. Установлено, что развитию экономики страны сопутствует экспорт новых товаров, связанных с существующими специализациями. Например, страна, торгующая преимущественно автомобилями, вскоре начинает экспортировать и другие виды транспортных средств.

Консенсус относительно того, что в большей мере способствует экономическому росту территорий - эффекты специализации или эффекты диверсификации, отсутствует [Greunz, 2004; Duranton, Puga, 2000; Henderson et al., 1995]. Так, в США появление новых товаров имеет значимую положительную связь лишь с эффектами урбанизации, обусловленными разнообразием экономической структуры ${ }^{17}$ [Feldman, Audretsch, 1999]. Для итальянских регионов установлено существенное положительное влияние на патентную активность 
как эффектов специализации, так и диверсификации [Pasi, Usai, 1999].

Что касается регионов Франции, специализация оказывает отрицательный эффект на интенсивность патентования, а влияние диверсификации незначительно [Massard, Riou, 2002].

Горан Линдквист (2009) доказывает, что для экономического развития регионов важны оба внешних эффекта, однако их действие проявляется по-разному. Воздействие эффектов специализации косвенное: в регионах с профилированной структурой экономики отмечается повышенная инновационная активность, что, в свою очередь, способствует росту ВРП на душу населения. Диверсификация выступает драйвером экономического развития территорий, при этом ее связь с инновационной активностью невысока [Lindqvist, 2009].

Кемени и Сторпер (2015) объясняют многообразие получаемых результатов разными трактовками понятий «специализация» и «диверсификация». В исследовании Идальго и Хаусмана (2009) получено доказательство положительной корреляции между экономической сложностью и ростом, что позволяет констатировать преимущества стран с широким набором связанных (related) отраслей специализации.

Таким образом, есть основания полагать, что странам и регионам с диверсифицированной экономикой следует искать свои ниши в глобальных цепочках добавленной стоимости. Для территорий с небольшим числом специализаций оптимальной стратегией может стать межрегиональная кооперация, открывающая новые рынки, возможности развития смежных видов деятельности и повышения отраслевого разнообразия в будущем.
Дальнейшее экономическое развитие регионов, относящихся к разным группам, будет предположительно проходить по сценариям, представленным в табл. 1.1.

Неравномерность в распределении отраслей специализации проявляется и на макрорегиональном уровне - в федеральных округах.

Регионы с самым широким кругом специализаций расположены в Центральном (334 отрасли) и Приволжском (301) федеральных округах. Значительное число отраслей специализации развиваются в субъектах Северо-Западного (166) и Сибирского (151) федеральных округов. Замыкают этот рейтинг регионы Южного (120), Уральского (111), Дальневосточного (111) и СевероКавказского (48) федеральных округов.

По среднему числу отраслей специализации на один регион лидирует Приволжский федеральный округ (22 отрасли), минимальное значение у Северо-Кавказского федерального округа (7).

Максимальная доля отраслей национальной значимости (98\%) зафиксирована в регионах Уральского федерального округа, минимальная (42\%) - в субъектах Северо-Кавказского федерального округа (рис. 1.12).

Полученные результаты отражают многообразие международных и межрегиональных экономических связей субъектов Российской Федерации. Эти связи формировались долгое время под воздействием многих факторов - ресурсных, логистических, политических и др. Их ретроспективный анализ позволяет понять принципы экономического развития отдельных территорий страны, которые сегодня формализованы в границах федеральных округов. Например, мы предполагаем, что отрасли специализации в регионах Уральского и Дальневосточного федеральных округов складывались по совершенно разной логике. 
Рис. 1.11. Распределение регионов России по числу отраслей специализации и распространенности отраслей национальной и локальной значимости: 2018

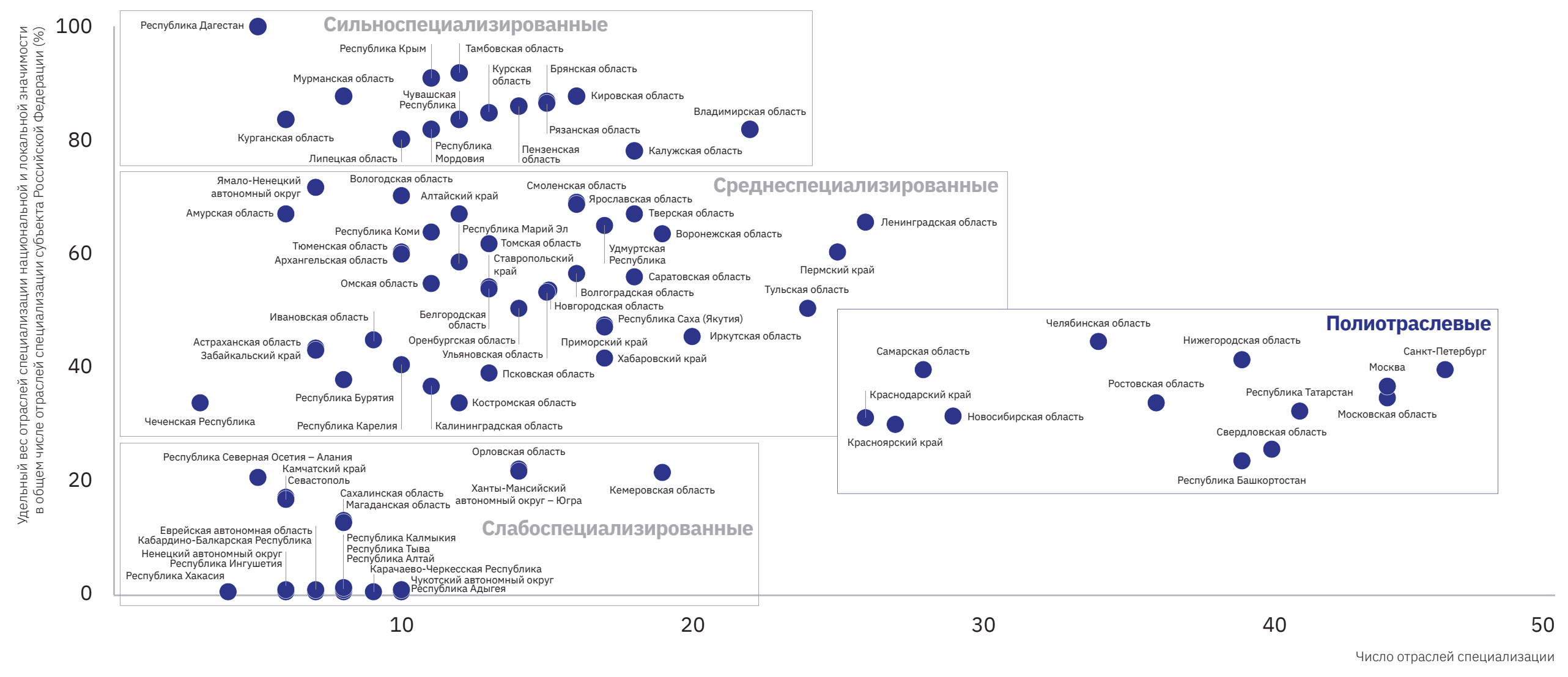




\section{Табл. 1.1. Сценарии развития отраслей специализации для разных групп субъектов Российской Федерации*}

\begin{tabular}{|c|c|c|c|c|}
\hline Группы субъектов Российской Федерации & 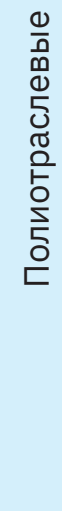 & 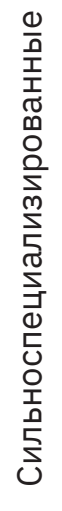 & 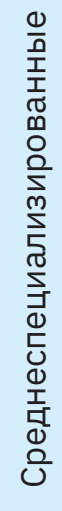 & 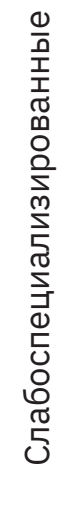 \\
\hline $\begin{array}{l}\text { Развитие существующих отраслей национальной значимости за счет внешнеэкономической интеграции и экспансии, включая увеличение } \\
\text { доли интеллектуальных услуг, привлечение умных инвестиций в торгуемый сектор и расширение присутствия его продукции (работ, услуг) } \\
\text { на экспортных рынках }\end{array}$ & ++ & + & + & - \\
\hline $\begin{array}{l}\text { Модернизация существующих отраслей специализации путем применения технологий общего назначения (большие данные, искусственный } \\
\text { интеллект, новые материалы и передовые производственные технологии, сенсорика и компоненты робототехники, технологии виртуальной } \\
\text { и дополненной реальности, фотоника, нанотехнологии, промышленные биотехнологии и др.) }\end{array}$ & ++ & + & + & - \\
\hline $\begin{array}{l}\text { Формирование новых отраслей специализации посредством усиления межотраслевой кооперации и наращивания цепочек создания } \\
\text { стоимости }\end{array}$ & - & ++ & + & - \\
\hline Трансформация отраслей локальной значимости в отрасли национальной значимости за счет развития межрегиональной кооперации & - & - & + & ++ \\
\hline Создание новых отраслей локальной значимости, в том числе в сфере креативных индустрий & - & - & + & ++ \\
\hline
\end{tabular}

* Обозначения «++», «+» и «-» указывают соответственно на предпочтительную, возможную и нерациональную реализацию сценария в субъекте Российской Федерации, относящемся к рассматриваемой группе. 


\section{Рис. 1.12. Структура отраслей специализации по федеральным округам: 2018 (\%)}

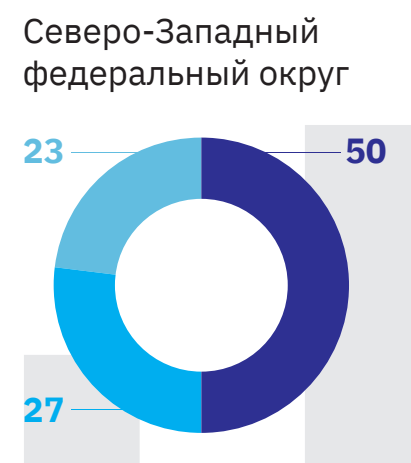

\section{Южный}

федеральный округ

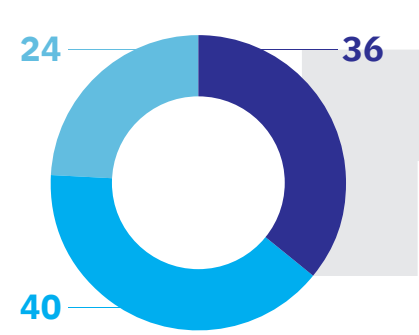

\section{Центральный} федеральный округ

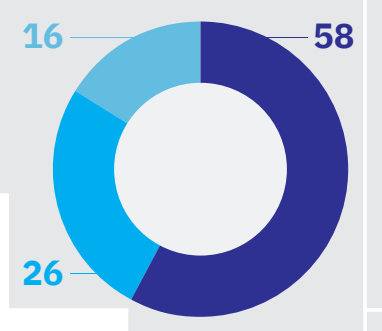

Приволжский федеральный округ

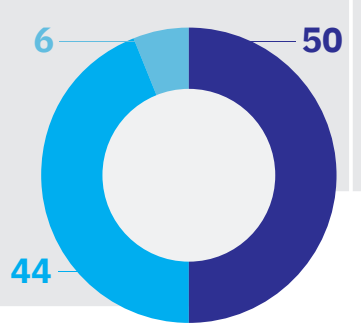

$$
\text { Северо-Кавказский }
$$
федеральный округ

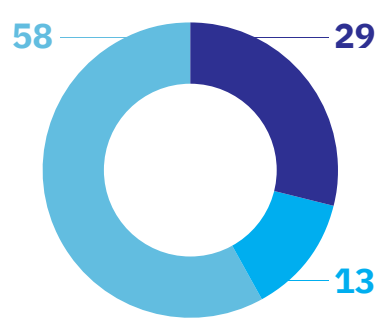

$-40$

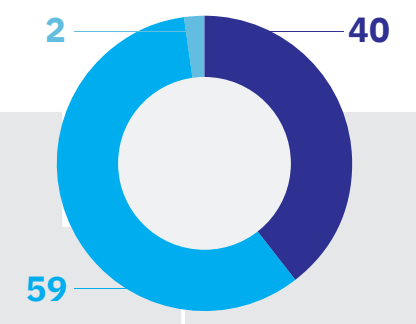

Дальневосточный федеральный округ

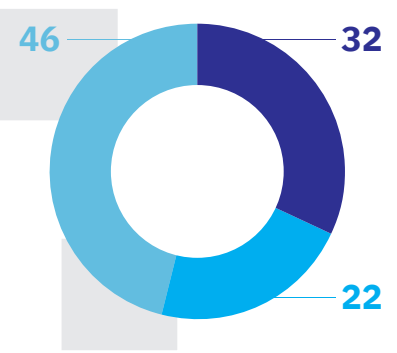

Удельный вес отраслей национальной и локальной значимости

федеральный округ

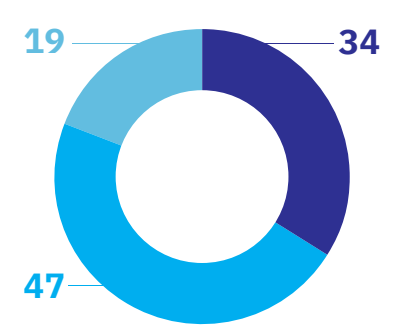


Экономика Урала уже с XVII века была нацелена на развитие торгуемых видов деятельности (добыча металлических и неметаллических руд, металлообрабатывающая промышленность, производство первичных металлических изделий), вывоз произведенной продукции в столицу и соседние области. Дальний Восток, будучи самой удаленной от центра территорией, не имел тесных экономических контактов с другими регионами страны. Для России он долгое время играл роль военного форпоста, а периоды напряженности в отношениях с соседями не позволяли в полной мере развивать торговые связи с приграничными государствами. Как следствие, экономика Дальнего Востока была направлена на обеспечение присутствия российского населения в отдаленном краю империи.

Сегодня регионы Урала имеют обширные торговые связи с другими субъектами Российской Федерации и зарубежными государствами, тогда как экономика Дальнего Востока из-за высокой доли транспортных издержек в бизнеспроцессах по-прежнему оторвана от российского и внешнего рынков. Так, в 2016 г. Уральский федеральный округ опережал Дальневосточный по объему межрегионального товарооборота в 5.9 раза [Единый архив экономических и социологических данных, 2020], а в 2018 г. - по объему внешнеторгового оборота в 1.4 раза [Росстат, 2019]. В субъектах Дальневосточного федерального округа многие отрасли имеют локальную значимость. Полагаем, что поиск возможностей усиления их роли в экономике страны и определение конкурентных ниш, обеспечивающих формирование новых отраслей специализации, станут стимулом для экономического развития. Другая действенная стратегия заключается в более полном использовании потенциала приграничного положения в целях наращивания внешнеэкономического сотрудничества. Для регионов Дальнего Востока это означает, прежде всего, усиление торговой интеграции с экономиками стран Азиатско-Тихоокеанского региона.

Разнообразие отраслевой структуры субъектов Российской Федерации представляет одновременно и вызовы, и возможности для развития национальной экономики, ее выгодного позиционирования в глобальных хозяйственных отношениях. В зависимости от начальных условий легитимными стратегиями могут быть как диверсификация для повышения устойчивости, так и концентрация ресурсов на отдельных видах деятельности, со временем способная привести к усилению позиции региона на мировых рынках. Преимуществом обладают индивидуализированные стратегии трансформации и мерь поддержки, учитывающие сложившиеся экономические профили территорий, которые наглядно представлены на следующих страницах. 


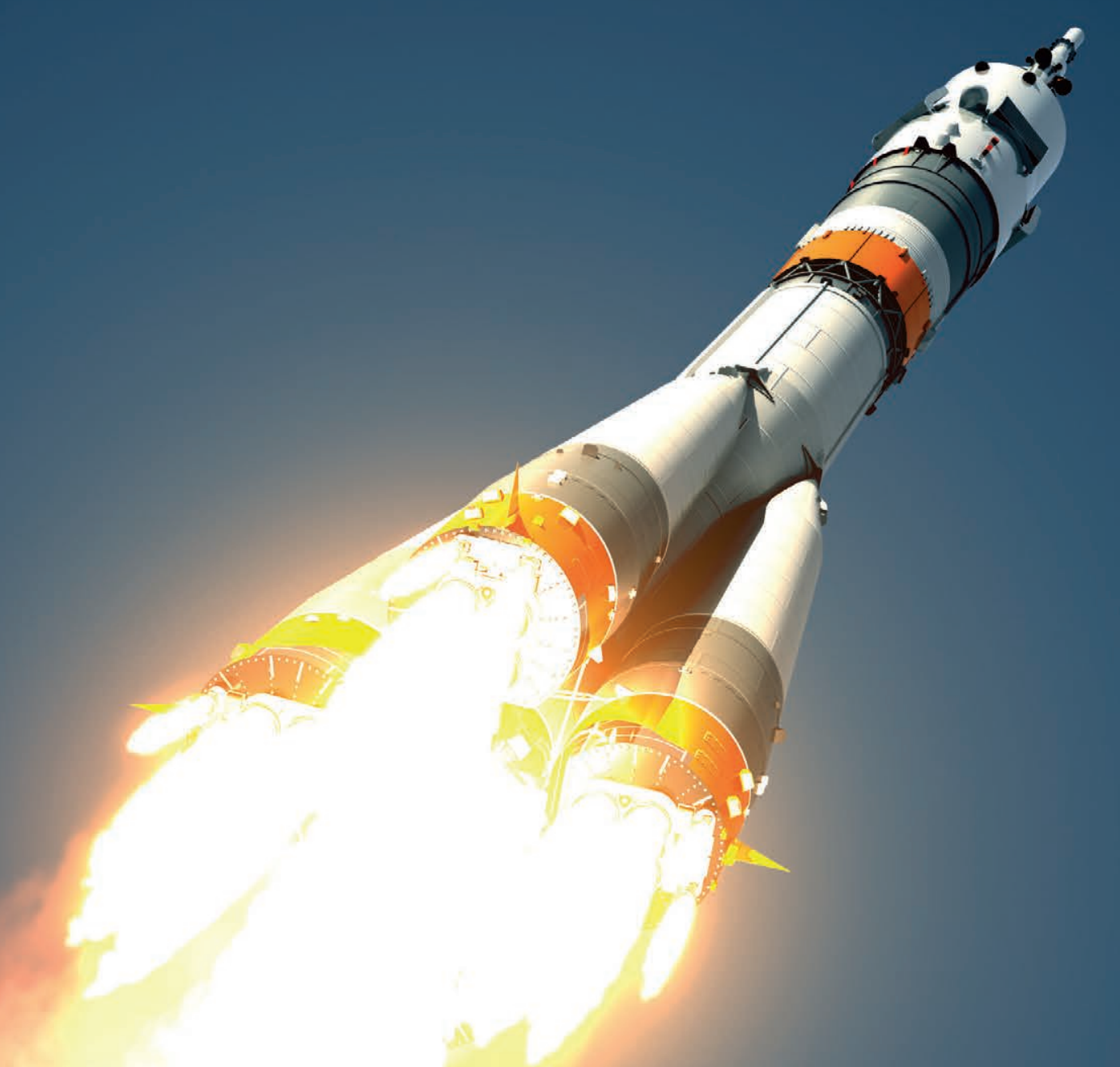


Отраслевые профили 
Удельный вес отрасли в общем объеме

отгруженных товаров выполненных работ и услуг (без НДС и акцизов) в России, 2018, \%
Удельный вес отрасли

в общем объеме инвестиций в основной капитал в России, 2018, \%

Удельный вес работников организаций отрасли

в общей численности

работников организаций в России, 2018, \%

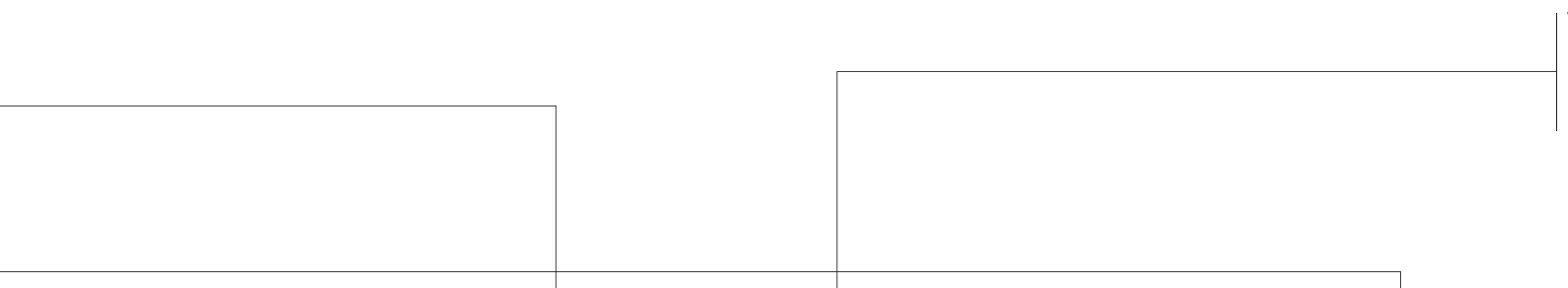

\section{Торгуемая отрасль}

Доля занятых, \% Доля товаров, работ, услуг, \% Доля инвестиций,

0.8

$20 \mid$

$21 \mid 0.7$

\begin{tabular}{|l|l|}
\hline Заработная плата, тыс. руб. \\
\hline 48.6
\end{tabular} заработная плата работников

организаций отрасли

в России, 2018, тыс. руб.

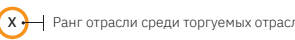

Регионы, специализирующиеся в отрасли
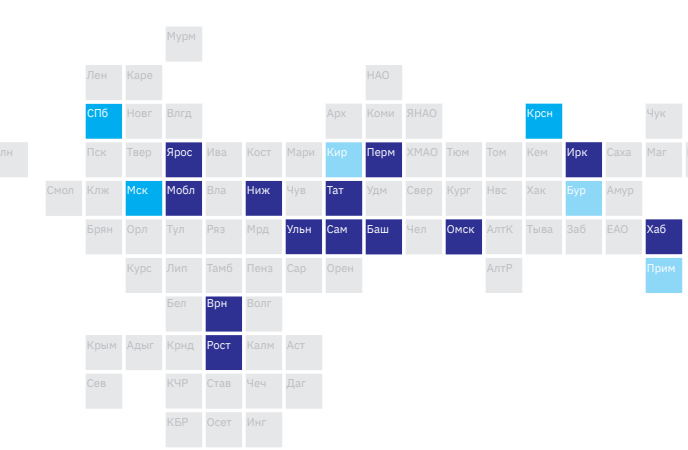

-

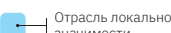

\begin{tabular}{|c|c|c|c|}
\hline & 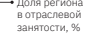 & 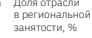 & 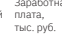 \\
\hline Campactan of ofractio & 12.06 & 4.30 & 39,7 \\
\hline Республика Башкортостан & 9.42 & 3.32 & ${ }_{44.0}$ \\
\hline Московскаa область & 7.35 & 122 & 59.3 \\
\hline 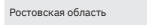 & 5.31 & 186 & 50.2 \\
\hline 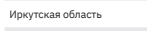 & a.72 & 2.23 & 55.2 \\
\hline 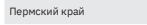 & 4.52 & 206 & 47.0 \\
\hline Нижегорорасскаa обпасть & ${ }_{4.45}$ & 1.50 & 50.0 \\
\hline 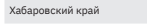 & 4.36 & 3.50 & 57.6 \\
\hline 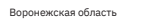 & 3.77 & 214 & 38.1 \\
\hline Pecengmama Tarapcran & 3.42 & 0.98 & ${ }^{44.5}$ \\
\hline 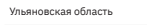 & 3.11 & 3.26 & 34.3 \\
\hline 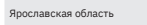 & 3.01 & 258 & 39.7 \\
\hline Oncrean obractro & 2.43 & 1.65 & ${ }^{412}$ \\
\hline Mockea & 10.01 & 0.80 & 66.9 \\
\hline 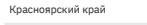 & 3.32 & 1.20 & 523 \\
\hline Camerc-nerepobyer & 2.58 & 0.48 & 59.0 \\
\hline Приморсский кайй & 2.44 & 1.65 & 56.0 \\
\hline 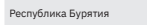 & 206 & 324 & 47.5 \\
\hline & 1.50 & 1.44 & 0.9 \\
\hline
\end{tabular}

Удельный вес работников организаций отрасли в общей численности

работников организаций

в субъекте Российской Федерации

2018, \%

Среднемесячная начисленная заработная плата работников организаций отрасли в субъекте Российской Федерации, 2018, тыс. руб.

Удельный вес работников организаций отрасли

субъекта Российской Федерации

в общей численности работников

организаций отрасли в России, 2018, \% 


\section{Авиастроение и космос}
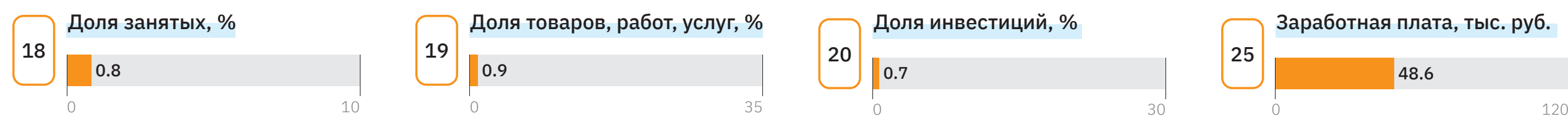

X- Ранг отрасли среди торгуемых отраслей

\section{Регионы, специализирующиеся в отрасли}

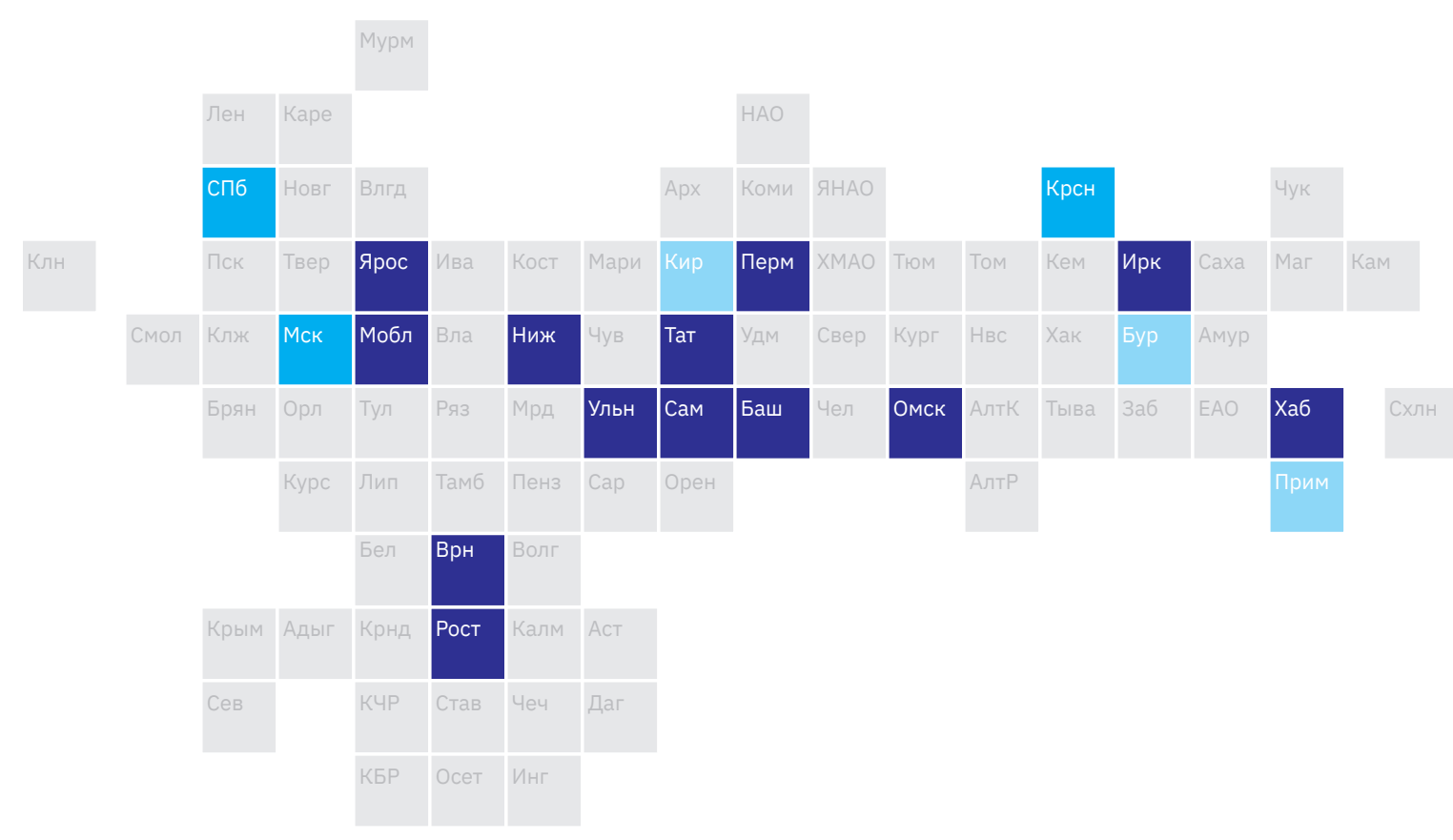

\begin{tabular}{|c|c|c|c|}
\hline & $\begin{array}{l}\text { Доля региона } \\
\text { в отраслевой } \\
\text { занятости, \% }\end{array}$ & $\begin{array}{l}\text { Доля отрасли } \\
\text { в региональной } \\
\text { занятости, \% }\end{array}$ & $\begin{array}{l}\text { Заработная } \\
\text { плата, } \\
\text { тыс. руб. }\end{array}$ \\
\hline Самарская область & 12.06 & 4.30 & 39.7 \\
\hline Республика Башкортостан & 9.42 & 3.32 & 44.0 \\
\hline Московская область & 7.35 & 1.22 & 59.3 \\
\hline Ростовская область & 5.31 & 1.86 & 50.2 \\
\hline Иркутская область & 4.72 & 2.23 & 55.2 \\
\hline Пермский край & 4.52 & 2.06 & 47.0 \\
\hline Нижегородская область & 4.45 & 1.50 & 50.0 \\
\hline Хабаровский край & 4.36 & 3.50 & 57.6 \\
\hline Воронежская область & 3.77 & 2.14 & 38.1 \\
\hline Республика Татарстан & 3.42 & 0.98 & 44.5 \\
\hline Ульяновская область & 3.11 & 3.26 & 34.3 \\
\hline Ярославская область & 3.01 & 2.58 & 39.7 \\
\hline Омская область & 2.43 & 1.65 & 41.2 \\
\hline Москва & 10.01 & 0.80 & 66.9 \\
\hline Красноярский край & 3.32 & 1.20 & 52.3 \\
\hline Санкт-Петербург & 2.58 & 0.48 & 59.0 \\
\hline Приморский край & 2.44 & 1.65 & 56.0 \\
\hline Республика Бурятия & 2.06 & 3.24 & 47.5 \\
\hline Кировская область & 1.50 & 1.44 & 40.9 \\
\hline
\end{tabular}




\section{Автомобилестроение}
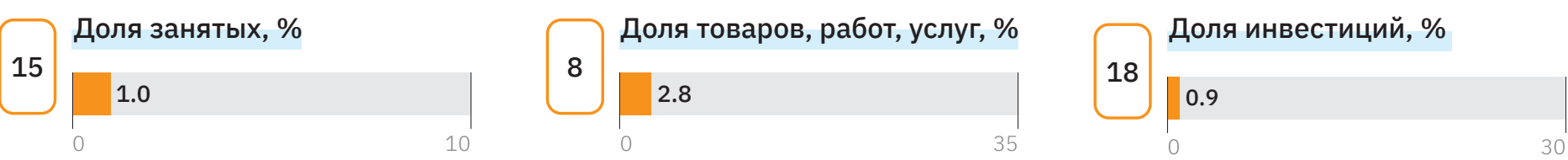

33

Заработная плата, тыс. руб.

X Ранг отрасли среди торгуемых отраслей

Регионы, специализирующиеся в отрасли

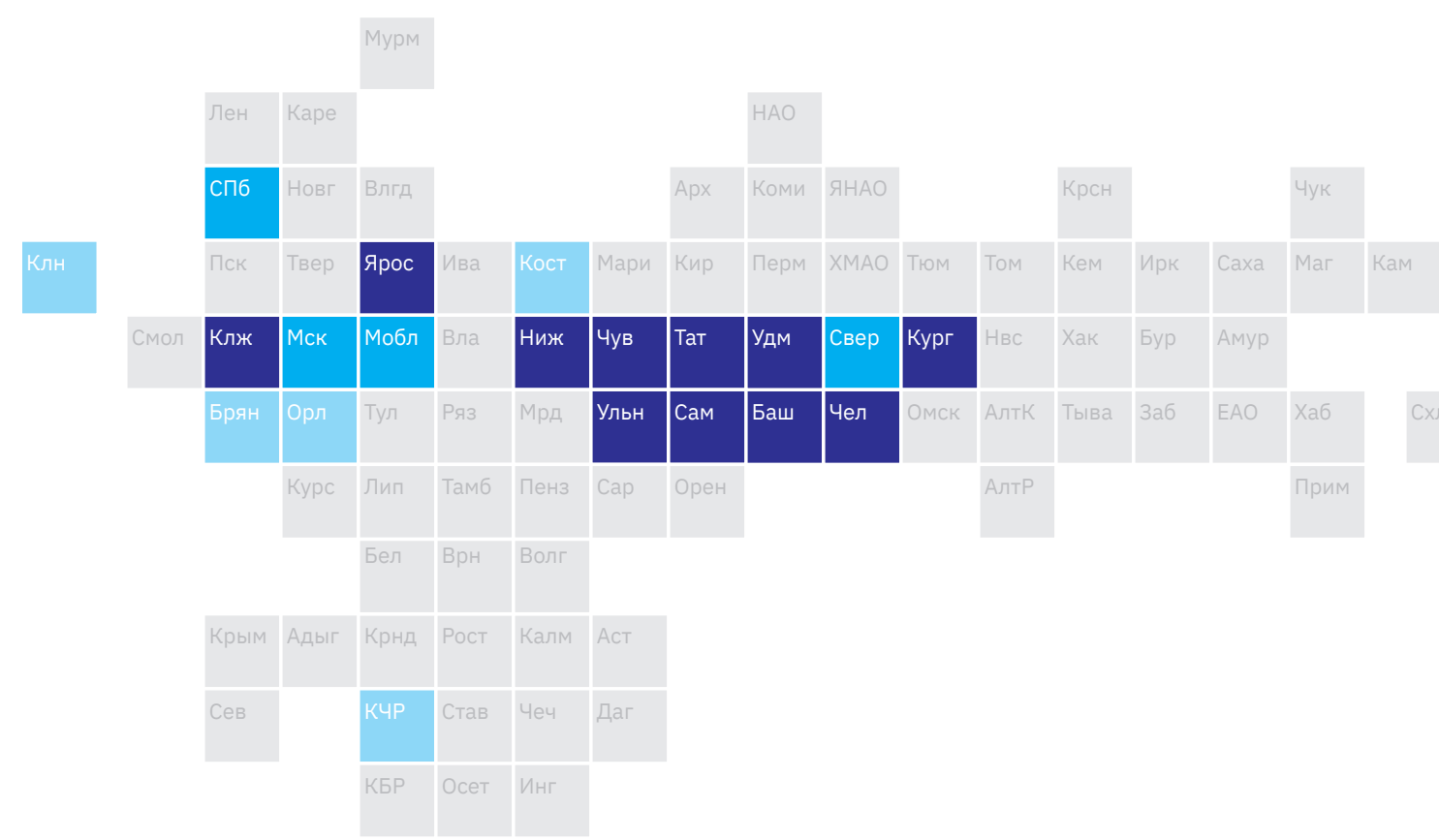

О Отрасль национальной и локальной значимости

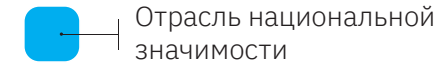

значимости

\begin{tabular}{|c|c|c|c|}
\hline & $\begin{array}{l}\text { Доля региона } \\
\text { В отраслевой } \\
\text { занятости, \% }\end{array}$ & $\begin{array}{l}\text { Доля отрасли } \\
\text { в региональной } \\
\text { занятости, \% }\end{array}$ & $\begin{array}{l}\text { Заработная } \\
\text { плата, } \\
\text { тыс. руб. }\end{array}$ \\
\hline Самарская область & 15.95 & 6.52 & 45.4 \\
\hline Республика Татарстан & 15.38 & 5.06 & 38.6 \\
\hline Нижегородская область & 10.30 & 3.96 & 37.8 \\
\hline Ульяновская область & 5.80 & 6.96 & 31.7 \\
\hline Челябинская область & 4.42 & 1.70 & 40.3 \\
\hline Калужская область & 3.97 & 5.15 & 63.4 \\
\hline Курганская область & 3.25 & 5.68 & 32.8 \\
\hline Ярославская область & 2.54 & 2.49 & 39.0 \\
\hline Республика Башкортостан & 2.42 & 0.98 & 32.6 \\
\hline Удмуртская Республика & 1.94 & 1.62 & 47.3 \\
\hline Чувашская Республика & 1.91 & 2.58 & 32.1 \\
\hline Санкт-Петербург & 4.03 & 0.85 & 90.2 \\
\hline Свердловская область & 3.32 & 0.93 & 43.1 \\
\hline Москва & 2.61 & 0.24 & 93.1 \\
\hline Московская область & 1.68 & 0.32 & 62.0 \\
\hline Орловская область & 1.65 & 3.06 & 29.2 \\
\hline Костромская область & 0.98 & 2.30 & 27.6 \\
\hline Брянская область & 0.95 & 1.25 & 32.6 \\
\hline Калининградская область & 0.76 & 1.25 & 46.5 \\
\hline Карачаево-Черкесская Республика & 0.37 & 1.69 & 10.0 \\
\hline
\end{tabular}




\section{Бытовая техника}
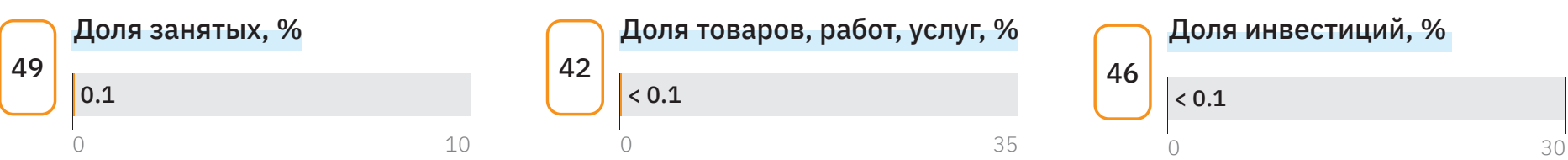

38

38

Заработная плата, тыс. руб.

X Ранг отрасли среди торгуемых отраслей

\section{Регионы, специализирующиеся в отрасли}

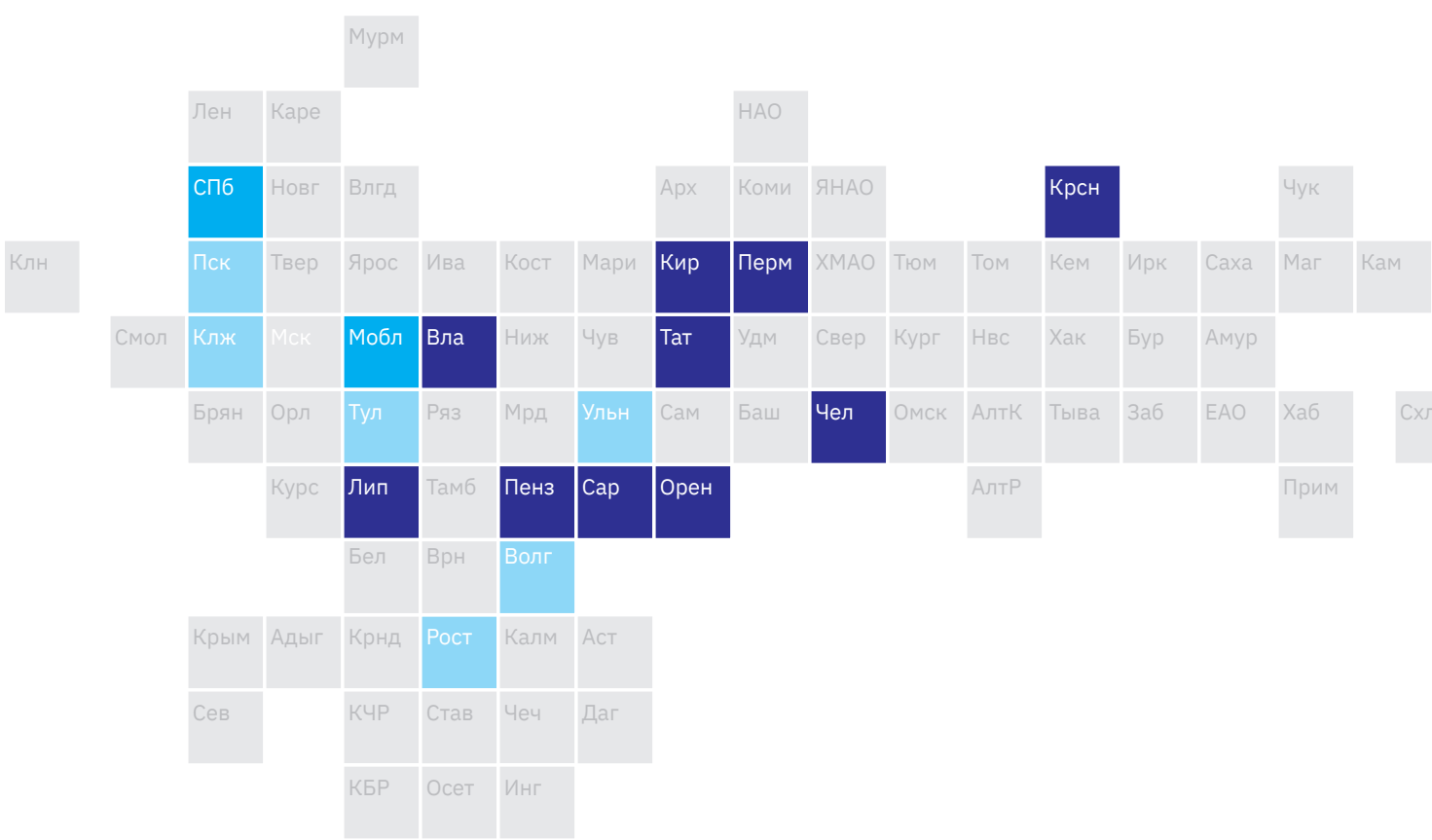

Отрасль национальной и локальной значимости
Отрасль национальной значимости

\begin{tabular}{|l|lll|} 
& $\begin{array}{l}\text { Доля региона } \\
\text { Вотраслевой } \\
\text { занятости, \% }\end{array}$ & $\begin{array}{l}\text { Доля отрасли } \\
\text { занятонали, \% }\end{array}$ & $\begin{array}{l}\text { 3аработная } \\
\text { плата, } \\
\text { тыс. руб. }\end{array}$ \\
\hline Республика Татарстан & 15.88 & 0.31 & 34.5 \\
\hline Липецкая область & 14.29 & 1.02 & 42.7 \\
\hline Саратовская область & 9.46 & 0.35 & 31.9 \\
\hline Красноярский край & 9.05 & 0.22 & 27.0 \\
\hline Владимирская область & 8.82 & 0.54 & 50.1 \\
\hline Пермский край & 6.77 & 0.21 & 31.2 \\
\hline Челябинская область & 4.17 & 0.09 & 19.3 \\
\hline Пензенская область & 3.69 & 0.28 & 37.5 \\
\hline Кировская область & 3.35 & 0.22 & 33.6 \\
\hline Оренбургская область & 1.44 & 0.06 & 20.9 \\
\hline Московская область & 4.90 & 0.05 & 99.4 \\
\hline Санкт-Петербург & 4.63 & 0.06 & 83.5 \\
\hline Ростовская область & 2.73 & 0.06 & 37.9 \\
\hline Волгоградская область & 2.14 & 0.08 & 21.2 \\
\hline Калужская область & 1.26 & 0.10 & 47.8 \\
\hline Ульяновская область & 1.19 & 0.08 & 22.7 \\
\hline Тульская область & 1.11 & 0.06 & 42.0 \\
\hline Псковская область & 0.96 & 0.13 & 31.8 \\
\hline
\end{tabular}




\section{Вторичные металлические изделия}

$20 \underbrace{0.7}_{0}$ Доля занятых, \%

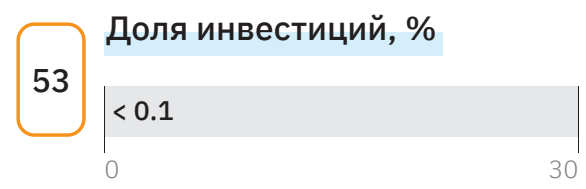

$\left.32\right|_{0} ^{3 \text { Заработная плата, тыс. руб. }}$

$\mathrm{x}-$ Ранг отрасли среди торгуемых отраслей

Регионы, специализирующиеся в отрасли

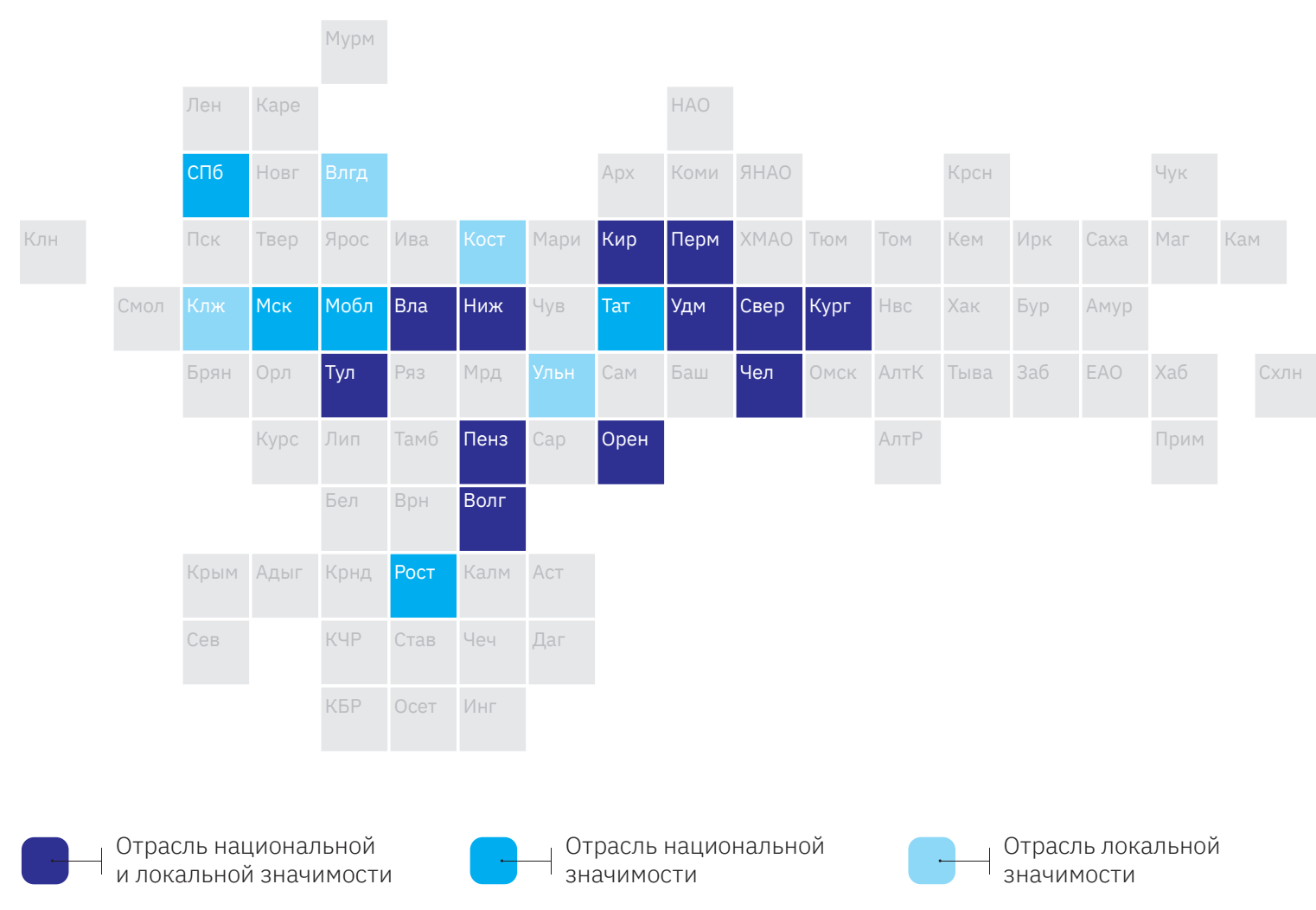

\begin{tabular}{|c|c|c|c|}
\hline & $\begin{array}{l}\text { Доля региона } \\
\text { в отраслевой } \\
\text { занятости, \% }\end{array}$ & $\begin{array}{l}\text { Доля отрасли } \\
\text { в региональной } \\
\text { занятости, \% }\end{array}$ & $\begin{array}{l}\text { Заработная } \\
\text { плата, } \\
\text { тыс. руб. }\end{array}$ \\
\hline Удмуртская Республика & 11.76 & 7.67 & 45.1 \\
\hline Тульская область & 10.49 & 7.66 & 46.6 \\
\hline Нижегородская область & 7.68 & 2.30 & 40.7 \\
\hline Владимирская область & 5.85 & 4.76 & 39.4 \\
\hline Свердловская область & 5.41 & 1.18 & 56.9 \\
\hline Челябинская область & 5.29 & 1.59 & 44.6 \\
\hline Пермский край & 4.34 & 1.77 & 35.3 \\
\hline Кировская область & 3.02 & 2.60 & 31.6 \\
\hline Волгоградская область & 2.20 & 1.16 & 48.6 \\
\hline Курганская область & 2.02 & 2.75 & 36.0 \\
\hline Пензенская область & 1.56 & 1.60 & 36.1 \\
\hline Оренбургская область & 0.97 & 0.57 & 29.7 \\
\hline Московская область & 6.50 & 0.96 & 62.3 \\
\hline Москва & 4.82 & 0.34 & 94.1 \\
\hline Санкт-Петербург & 4.10 & 0.68 & 64.0 \\
\hline Ростовская область & 2.63 & 0.82 & 38.2 \\
\hline Республика Татарстан & 1.57 & 0.40 & 33.2 \\
\hline Вологодская область & 1.42 & 1.30 & 36.9 \\
\hline Ульяновская область & 1.06 & 0.99 & 24.7 \\
\hline Костромская область & 0.53 & 0.96 & 28.0 \\
\hline Калужская область & 0.31 & 0.31 & 32.2 \\
\hline
\end{tabular}




\section{Деловые и ИТ-услуги}

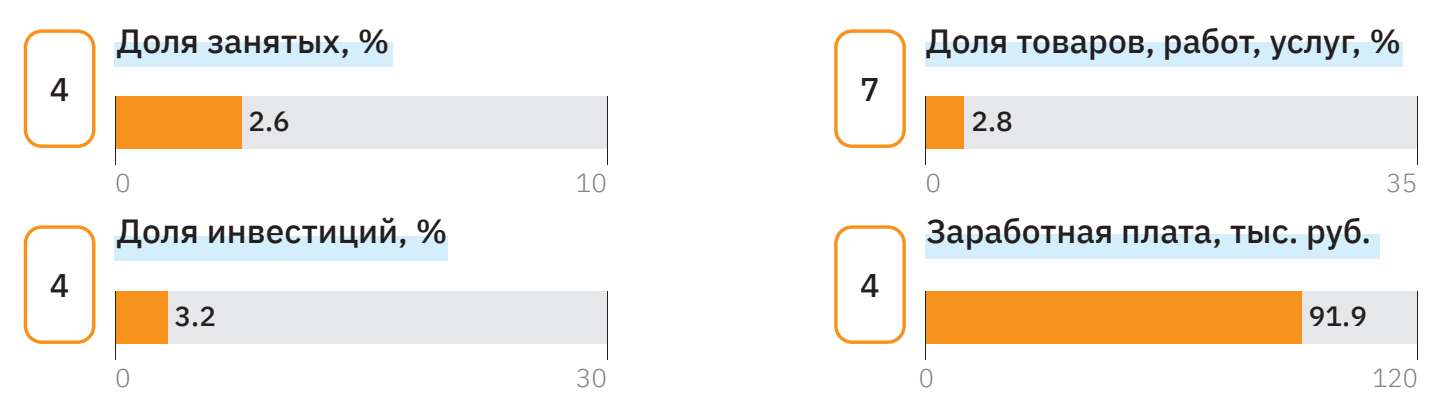

x Ранг отрасли среди торгуемых отраслей

\section{Регионы, специализирующиеся в отрасли}

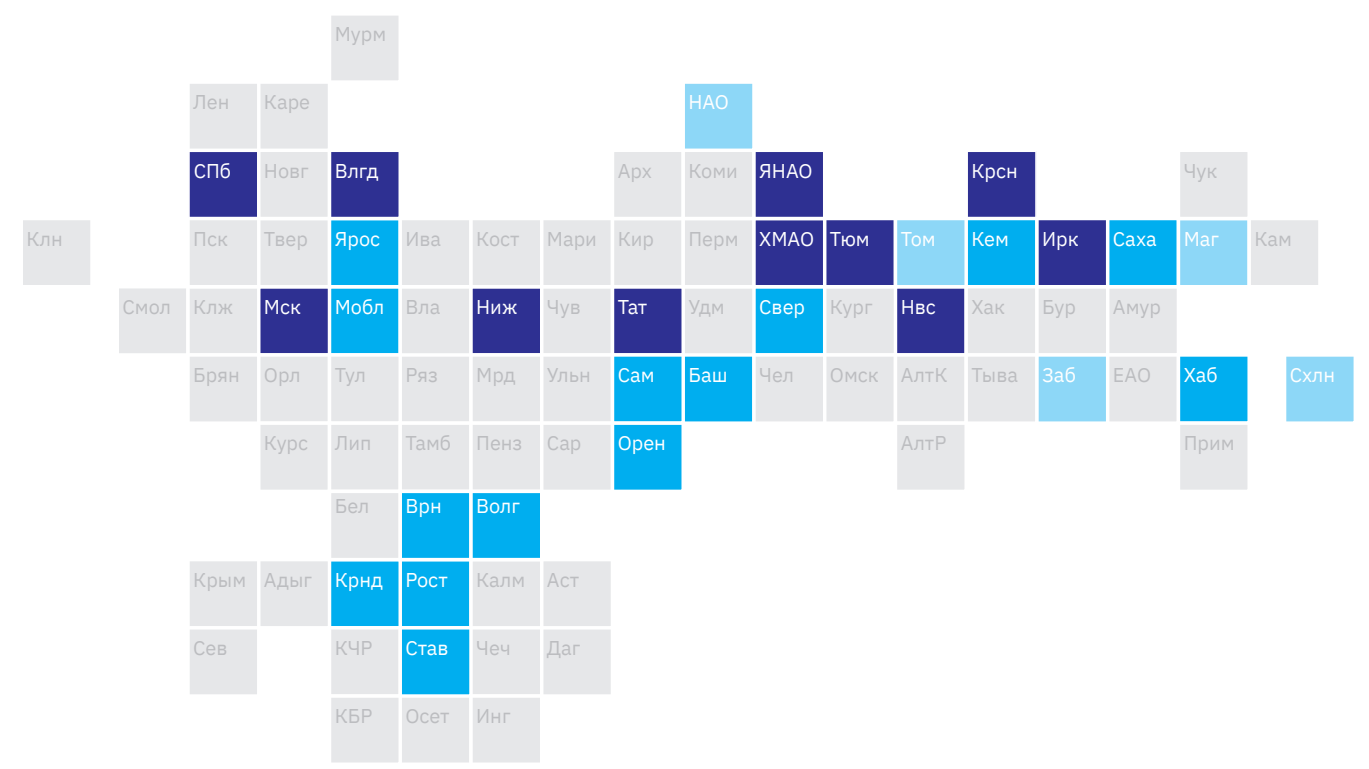

\begin{tabular}{|c|c|c|c|}
\hline & $\begin{array}{l}\text { Доля региона } \\
\text { в отраслевой } \\
\text { занятости, \% }\end{array}$ & $\begin{array}{l}\text { Доля отрасли } \\
\text { в региональной } \\
\text { занятости, \% }\end{array}$ & $\begin{array}{l}\text { Заработная } \\
\text { плата, } \\
\text { тыс. руб. }\end{array}$ \\
\hline Москва & 25.99 & 6.38 & 160.6 \\
\hline Санкт-Петербург & 9.20 & 5.26 & 117.2 \\
\hline Республика Татарстан & 3.24 & 2.88 & 57.1 \\
\hline Красноярский край & 2.60 & 2.91 & 66.9 \\
\hline Нижегородская область & 2.44 & 2.54 & 81.9 \\
\hline Ханты-Мансийский автономный округ - Югра & 2.39 & 3.08 & 76.8 \\
\hline Ямало-Ненецкий автономный округ & 1.84 & 5.18 & 96.3 \\
\hline Новосибирская область & 1.82 & 2.50 & 70.2 \\
\hline Иркутская область & 1.75 & 2.56 & 58.6 \\
\hline Тюменская область & 1.52 & 3.69 & 85.7 \\
\hline Вологодская область & 0.84 & 2.66 & 69.7 \\
\hline Московская область & 3.15 & 1.62 & 78.7 \\
\hline Свердловская область & 2.61 & 1.97 & 62.6 \\
\hline Республика Башкортостан & 2.25 & 2.45 & 61.9 \\
\hline Самарская область & 2.22 & 2.45 & 62.7 \\
\hline Краснодарский край & 2.20 & 1.81 & 57.0 \\
\hline Кемеровская область & 1.63 & 2.18 & 55.6 \\
\hline Ростовская область & 1.42 & 1.53 & 48.1 \\
\hline Воронежская область & 1.08 & 1.89 & 60.7 \\
\hline Республика Саха (Якутия) & 1.01 & 2.76 & 85.2 \\
\hline Ярославская область & 0.95 & 2.50 & 45.8 \\
\hline Волгоградская область & 0.94 & 1.70 & 45.6 \\
\hline Оренбургская область & 0.91 & 1.87 & 41.4 \\
\hline Хабаровский край & 0.91 & 2.25 & 80.0 \\
\hline Ставропольский край & 0.81 & 1.54 & 39.0 \\
\hline Томская область & 0.82 & 2.81 & 67.3 \\
\hline Забайкальский край & 0.81 & 2.90 & 45.3 \\
\hline Сахалинская область & 0.54 & 3.11 & 167.5 \\
\hline Магаданская область & 0.31 & 4.62 & 137.2 \\
\hline Ненецкий автономный округ & 0.14 & 4.16 & 78.5 \\
\hline
\end{tabular}




\section{Деятельность в области связи}

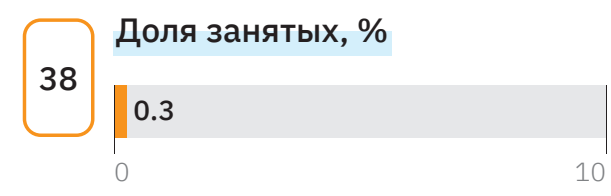

Доля инвестиций, \%

14

$$
1.2
$$

X Ранг отрасли среди торгуемых отраслей

Регионы, специализирующиеся в отрасли

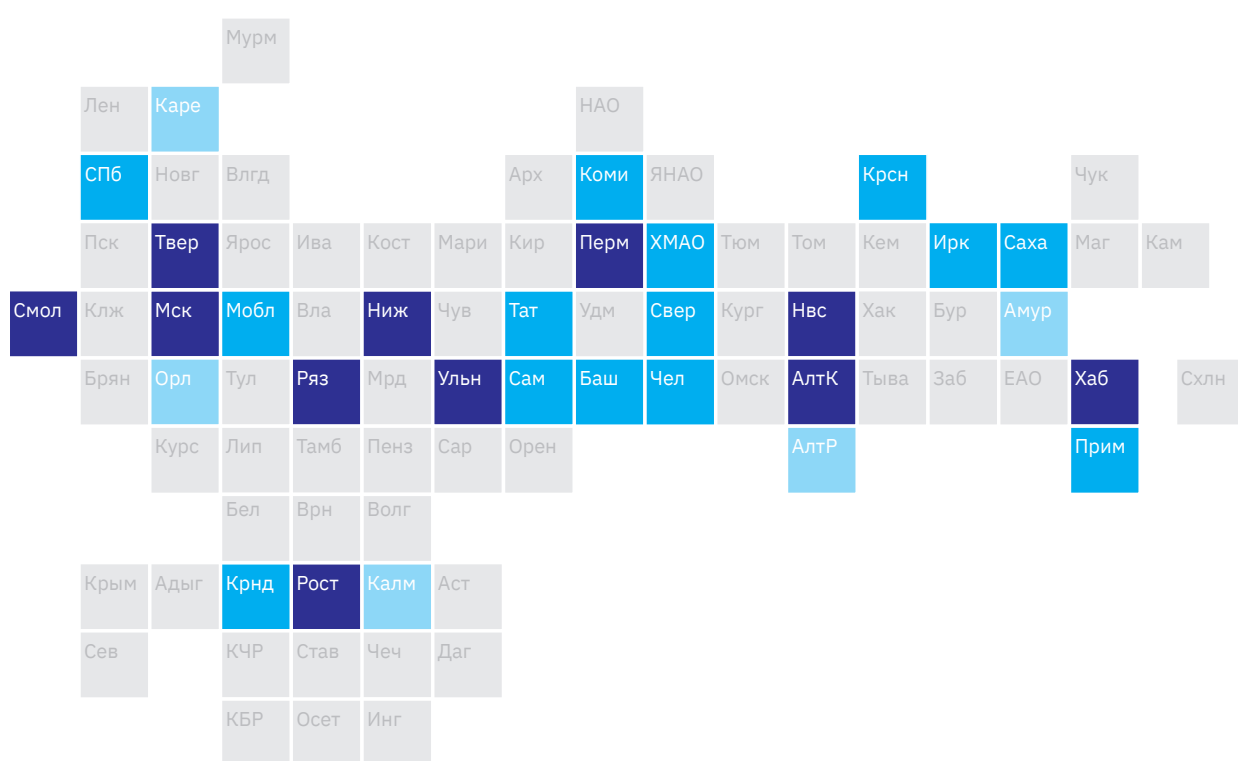

Отрасль национальной и локальной значимости
15

Доля товаров, работ, услуг, \% 1.2

Заработная плата, тыс. руб.

10

70.0
0

120 в отраслевой в региональной плата, занятости, \% занятости, \% тыс. руб.

\begin{tabular}{|c|c|c|c|}
\hline Москва & 16.19 & 0.40 & 176.7 \\
\hline Нижегородская область & 5.74 & 0.60 & 48.5 \\
\hline Ростовская область & 3.91 & 0.42 & 51.9 \\
\hline Новосибирская область & 2.64 & 0.36 & 64.7 \\
\hline Пермский край & 2.59 & 0.37 & 44.2 \\
\hline Ульяновская область & 2.21 & 0.72 & 30.2 \\
\hline Рязанская область & 1.95 & 0.68 & 37.1 \\
\hline Алтайский край & 1.92 & 0.38 & 34.7 \\
\hline Смоленская область & 1.52 & 0.60 & 35.1 \\
\hline Хабаровский край & 1.21 & 0.30 & 62.5 \\
\hline Тверская область & 1.07 & 0.33 & 41.4 \\
\hline Свердловская область & 4.44 & 0.33 & 55.3 \\
\hline Краснодарский край & 4.03 & 0.33 & 50.7 \\
\hline Санкт-Петербург & 2.67 & 0.15 & 77.9 \\
\hline Республика Татарстан & 2.42 & 0.21 & 46.0 \\
\hline Самарская область & 2.30 & 0.25 & 37.1 \\
\hline Челябинская область & 1.87 & 0.19 & 44.1 \\
\hline Иркутская область & 1.55 & 0.23 & 55.3 \\
\hline Красноярский край & 1.29 & 0.14 & 62.8 \\
\hline Республика Башкортостан & 1.25 & 0.14 & 42.2 \\
\hline Московская область & 1.14 & 0.06 & 78.8 \\
\hline Приморский край & 1.04 & 0.22 & 61.5 \\
\hline Ханты-Мансийский автономный округ - Югра & 1.01 & 0.13 & 64.3 \\
\hline Республика Саха (Якутия) & 0.76 & 0.21 & 62.2 \\
\hline Республика Коми & 0.58 & 0.19 & 61.0 \\
\hline Орловская область & 0.92 & 0.46 & 32.7 \\
\hline Амурская область & 0.49 & 0.20 & 51.2 \\
\hline Республика Карелия & 0.41 & 0.25 & 48.7 \\
\hline Республика Калмыкия & 0.26 & 0.49 & 34.4 \\
\hline Республика Алтай & 0.21 & 0.44 & 47.5 \\
\hline
\end{tabular}




\section{Добыча металлических руд}
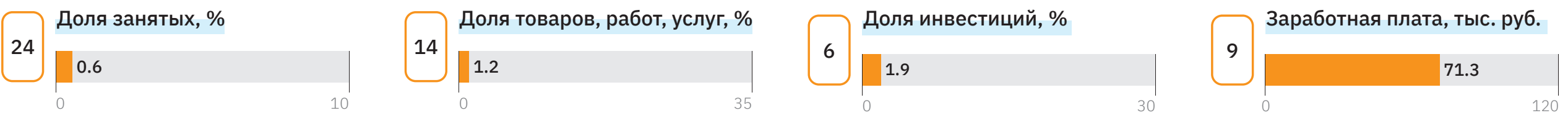

X Ранг отрасли среди торгуемых отраслей

Регионы, специализирующиеся в отрасли

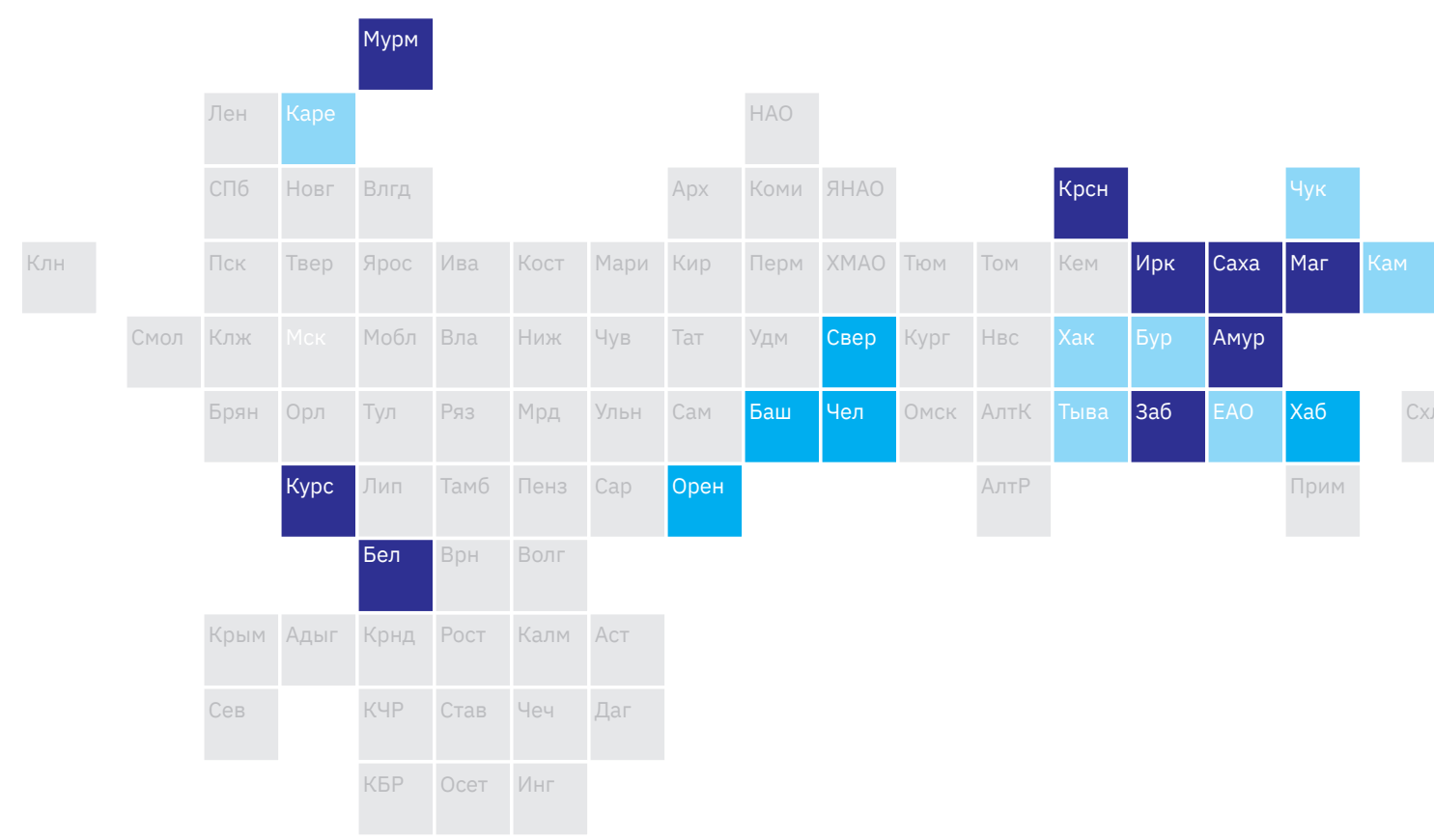

Отрасль национальной и локальной значимости

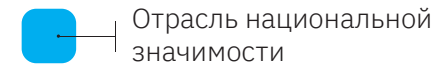
значимости

\begin{tabular}{|c|c|c|c|}
\hline & $\begin{array}{l}\text { Доля региона } \\
\text { в отраслевой } \\
\text { занятости, \% }\end{array}$ & $\begin{array}{l}\text { Доля отрасли } \\
\text { в региональной } \\
\text { занятости, \% }\end{array}$ & $\begin{array}{l}\text { Заработная } \\
\text { плата, } \\
\text { тыс. руб. }\end{array}$ \\
\hline Белгородская область & 11.32 & 5.61 & 47.0 \\
\hline Красноярский край & 10.92 & 2.70 & 103.3 \\
\hline Иркутская область & 6.64 & 2.14 & 83.6 \\
\hline Забайкальский край & 5.51 & 4.35 & 71.0 \\
\hline Магаданская область & 5.13 & 16.91 & 129.2 \\
\hline Амурская область & 4.88 & 4.49 & 67.3 \\
\hline Республика Саха (Якутия) & 4.68 & 2.83 & 94.2 \\
\hline Мурманская область & 4.26 & 3.55 & 74.2 \\
\hline Курская область & 3.10 & 2.24 & 46.6 \\
\hline Свердловская область & 9.29 & 1.55 & 46.6 \\
\hline Челябинская область & 5.01 & 1.15 & 48.1 \\
\hline Оренбургская область & 3.90 & 1.76 & 57.1 \\
\hline Хабаровский край & 3.45 & 1.89 & 95.5 \\
\hline Республика Башкортостан & 3.25 & 0.78 & 51.3 \\
\hline Чукотский автономный округ & 2.94 & 19.33 & 117.9 \\
\hline Республика Бурятия & 2.09 & 2.24 & 77.9 \\
\hline Республика Хакасия & 2.02 & 3.49 & 35.9 \\
\hline Республика Карелия & 1.68 & 2.21 & 76.4 \\
\hline Камчатский край & 1.37 & 2.59 & 80.8 \\
\hline Республика Тыва & 0.91 & 2.82 & 69.7 \\
\hline Еврейская автономная область & 0.70 & 3.62 & 47.8 \\
\hline
\end{tabular}




\section{Добыча неметаллических руд}

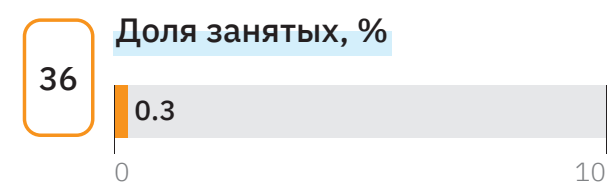

Доля инвестиций, \%

270.4

$\mathrm{x}-$ Ранг отрасли среди торгуемых отраслей

Регионы, специализирующиеся в отрасли

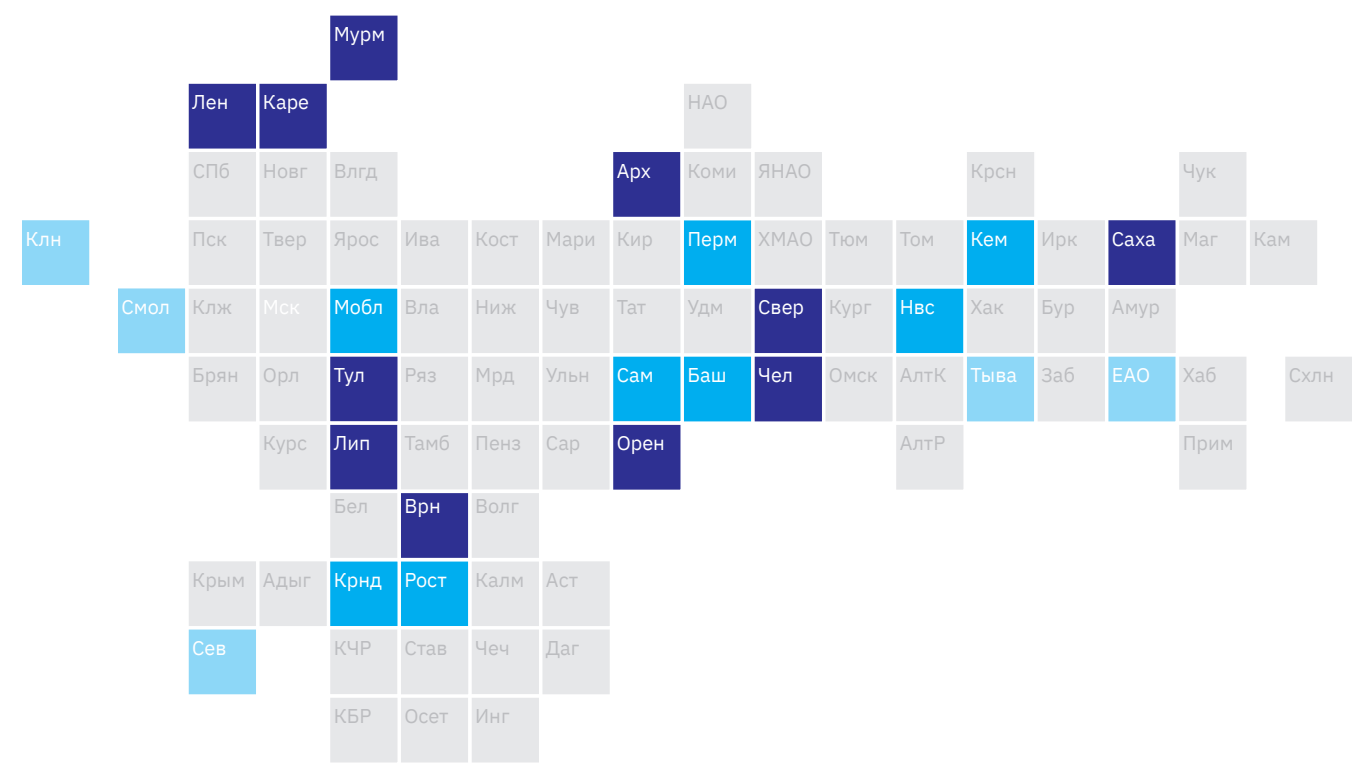

Отрасль национальной и локальной значимости

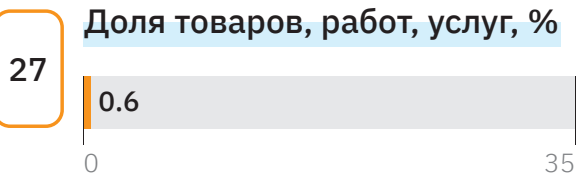

15

15

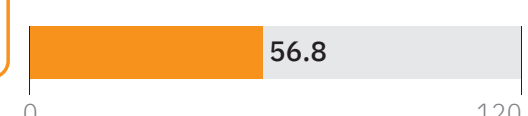

Доля региона Доля отрасли Заработная вотраслевой в региональной плата,

\begin{tabular}{|c|c|c|c|}
\hline Республика Саха (Якутия) & 15.75 & 4.64 & 140.0 \\
\hline Свердловская область & 8.74 & 0.71 & 33.9 \\
\hline Челябинская область & 7.29 & 0.81 & 31.4 \\
\hline Мурманская область & 6.80 & 2.76 & 84.3 \\
\hline Оренбургская область & 5.43 & 1.19 & 36.2 \\
\hline Ленинградская область & 4.39 & 1.05 & 38.9 \\
\hline Архангельская область & 3.22 & 1.00 & 75.2 \\
\hline Республика Карелия & 3.00 & 1.92 & 44.0 \\
\hline Воронежская область & 2.88 & 0.54 & 28.5 \\
\hline Липецкая область & 2.22 & 0.79 & 36.2 \\
\hline Тульская область & 1.34 & 0.36 & 40.3 \\
\hline Ростовская область & 2.83 & 0.33 & 26.8 \\
\hline Московская область & 2.64 & 0.15 & 61.9 \\
\hline Новосибирская область & 2.32 & 0.34 & 36.5 \\
\hline Республика Башкортостан & 2.23 & 0.26 & 36.3 \\
\hline Самарская область & 1.82 & 0.22 & 26.2 \\
\hline Кемеровская область & 1.57 & 0.23 & 40.4 \\
\hline Пермский край & 1.47 & 0.22 & 41.9 \\
\hline Краснодарский край & 1.35 & 0.12 & 26.5 \\
\hline Калининградская область & 0.96 & 0.46 & 47.9 \\
\hline Смоленская область & 0.74 & 0.31 & 36.8 \\
\hline Севастополь & 0.66 & 0.81 & 33.0 \\
\hline Еврейская автономная область & 0.14 & 0.35 & 37.5 \\
\hline Республика Тыва & 0.06 & 0.09 & 33.3 \\
\hline
\end{tabular}




\section{Добыча угля}

29

Доля занятых, \% 0.4

0
10

Доля товаров, работ, услуг, \%
15 151.
12

Заработная плата, тыс. руб. 59.7

X Ранг отрасли среди торгуемых отраслей

\section{Регионы, специализирующиеся в отрасли}

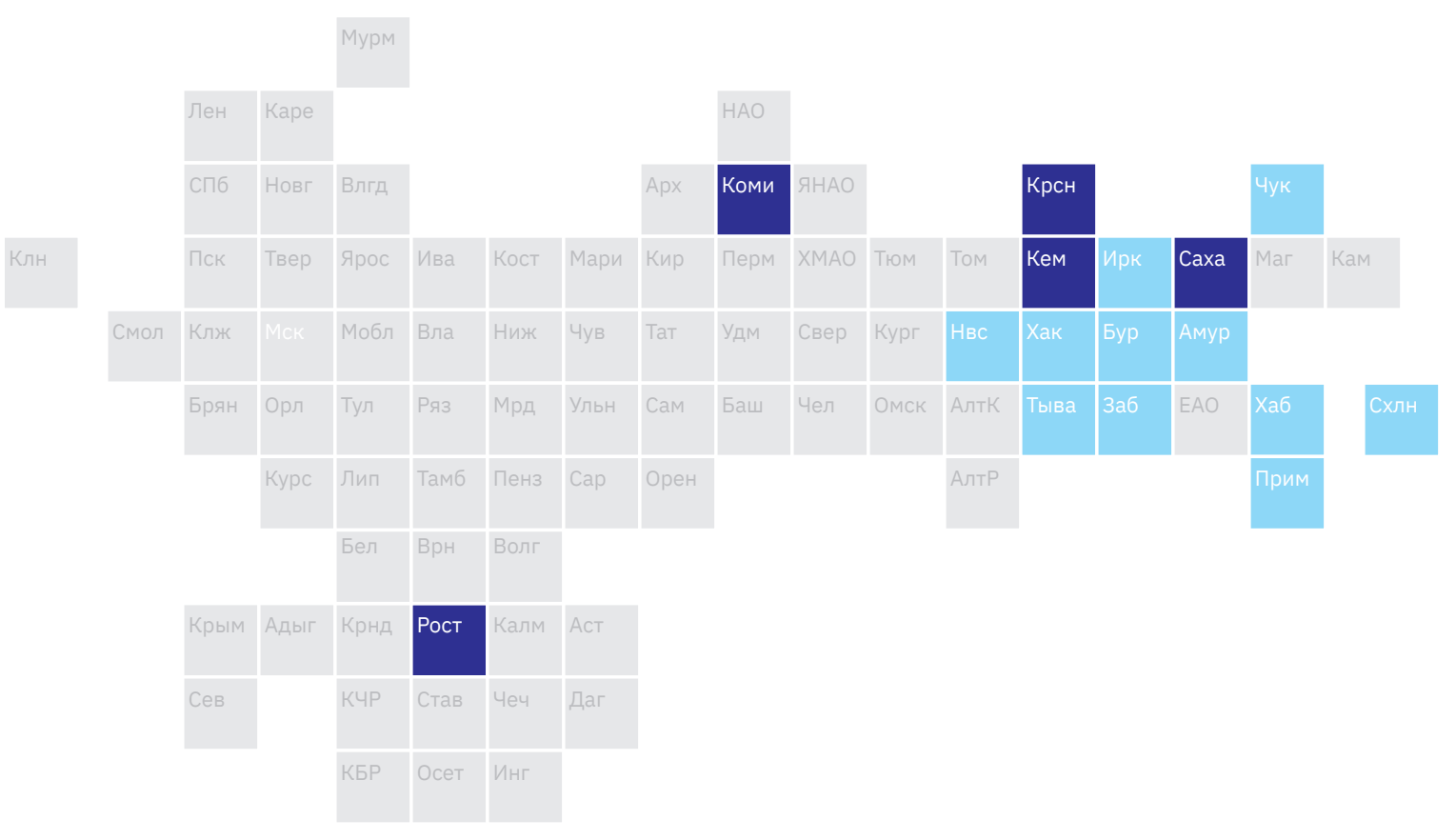

\begin{tabular}{|c|c|c|c|}
\hline & $\begin{array}{l}\text { Доля региона } \\
\text { в отраслевой } \\
\text { занятости, \% }\end{array}$ & $\begin{array}{l}\text { Доля отрасли } \\
\text { в региональной } \\
\text { занятости, \% }\end{array}$ & $\begin{array}{l}\text { Заработная } \\
\text { плата, } \\
\text { тыс. руб. }\end{array}$ \\
\hline Кемеровская область & 64.03 & 14.02 & 59.2 \\
\hline Республика Саха (Якутия) & 4.81 & 2.16 & 77.9 \\
\hline Ростовская область & 4.33 & 0.77 & 38.3 \\
\hline Республика Коми & 3.98 & 2.19 & 78.7 \\
\hline Красноярский край & 3.68 & 0.68 & 50.8 \\
\hline Республика Хакасия & 3.18 & 4.08 & 59.7 \\
\hline Иркутская область & 2.60 & 0.62 & 45.5 \\
\hline Приморский край & 2.33 & 0.80 & 55.6 \\
\hline Новосибирская область & 2.23 & 0.50 & 61.8 \\
\hline Хабаровский край & 1.75 & 0.71 & 64.8 \\
\hline Забайкальский край & 1.72 & 1.01 & 61.6 \\
\hline Сахалинская область & 1.59 & 1.51 & 72.7 \\
\hline Амурская область & 1.23 & 0.84 & 39.1 \\
\hline Республика Бурятия & 0.85 & 0.68 & 67.6 \\
\hline Республика Тыва & 0.65 & 1.48 & 66.4 \\
\hline Чукотский автономный округ & 0.31 & 1.51 & 103.3 \\
\hline
\end{tabular}




\section{Животноводство и смешанное сельское хозяйство}
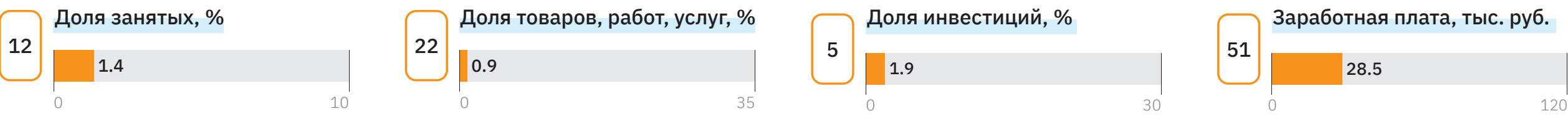

X Ранг отрасли среди торгуемых отраслей

Регионы, специализирующиеся в отрасли

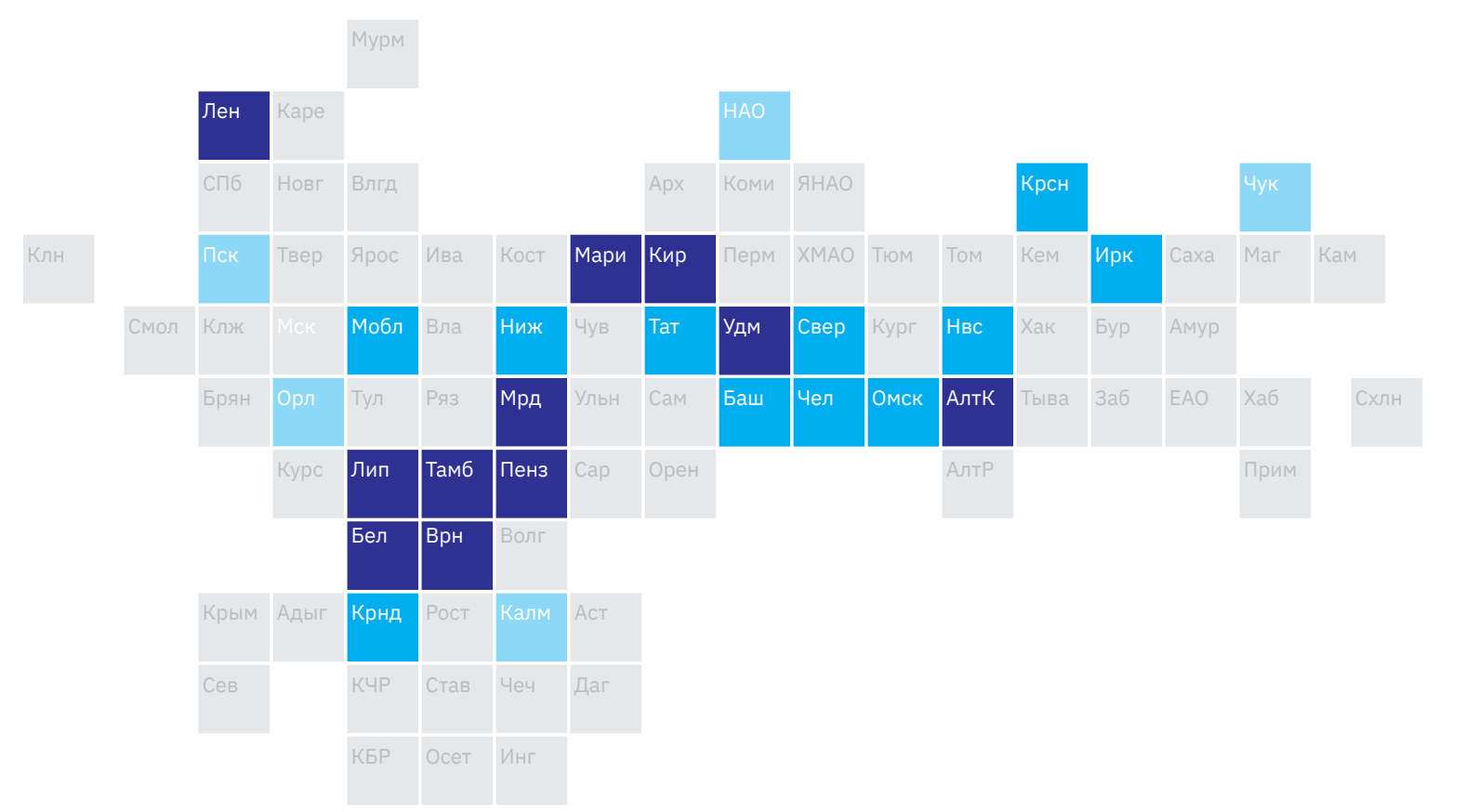

\begin{tabular}{|c|c|c|c|}
\hline & $\begin{array}{l}\text { Доля региона } \\
\text { в отраслевой } \\
\text { занятости, \% }\end{array}$ & $\begin{array}{l}\text { Доля отрасли } \\
\text { в региональной } \\
\text { занятости, \% }\end{array}$ & $\begin{array}{l}\text { Заработная } \\
\text { плата, } \\
\text { тыс. руб. }\end{array}$ \\
\hline Белгородская область & 6.37 & 7.54 & 33.9 \\
\hline Воронежская область & 3.48 & 3.22 & 29.7 \\
\hline Удмуртская Республика & 3.36 & 4.00 & 22.7 \\
\hline Алтайский край & 3.13 & 3.27 & 21.1 \\
\hline Ленинградская область & 2.97 & 3.49 & 41.2 \\
\hline Кировская область & 2.39 & 3.76 & 25.0 \\
\hline Республика Мордовия & 2.09 & 5.21 & 26.9 \\
\hline Липецкая область & 1.69 & 2.95 & 33.8 \\
\hline Пензенская область & 1.66 & 3.11 & 31.8 \\
\hline Тамбовская область & 1.37 & 2.98 & 35.3 \\
\hline Республика Марий Эл & 1.24 & 4.03 & 30.7 \\
\hline Республика Татарстан & 5.30 & 2.48 & 23.1 \\
\hline Краснодарский край & 4.94 & 2.14 & 30.7 \\
\hline Московская область & 3.61 & 0.98 & 40.1 \\
\hline Свердловская область & 3.35 & 1.33 & 29.2 \\
\hline Новосибирская область & 3.35 & 2.44 & 22.0 \\
\hline Челябинская область & 2.69 & 1.47 & 28.2 \\
\hline Красноярский край & 2.69 & 1.59 & 24.5 \\
\hline Омская область & 2.43 & 2.69 & 23.5 \\
\hline Республика Башкортостан & 2.41 & 1.38 & 23.6 \\
\hline Нижегородская область & 2.39 & 1.31 & 23.9 \\
\hline Иркутская область & 1.36 & 1.05 & 35.8 \\
\hline Псковская область & 1.17 & 3.75 & 20.4 \\
\hline Орловская область & 1.00 & 2.64 & 27.5 \\
\hline Республика Калмыкия & 0.31 & 3.04 & 15.3 \\
\hline Чукотский автономный округ & 0.26 & 4.14 & 48.6 \\
\hline Ненецкий автономный округ & 0.18 & 2.78 & 34.1 \\
\hline
\end{tabular}




\section{Звукозапись}

55

\section{Доля занятых, \%}

$<0.1$

0

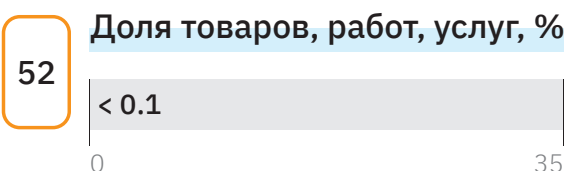

55

Доля инвестиций, \% $<0.1$

x Ранг отрасли среди торгуемых отраслей

\section{Регионы, специализирующиеся в отрасли}

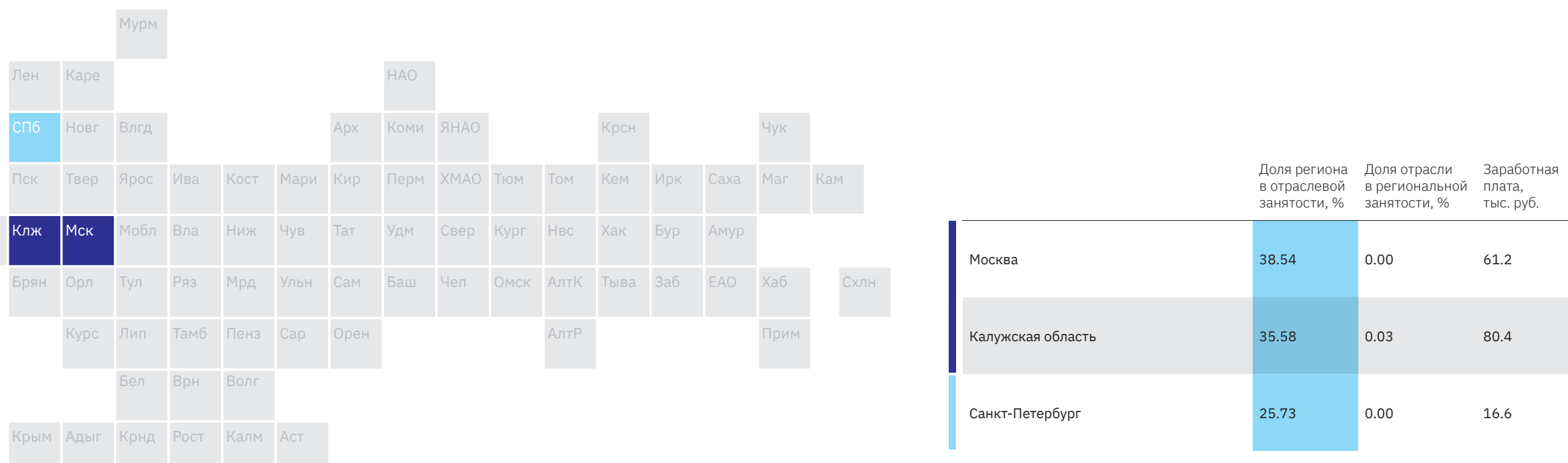

0




\section{Издательское дело, дизайн и маркетинг}

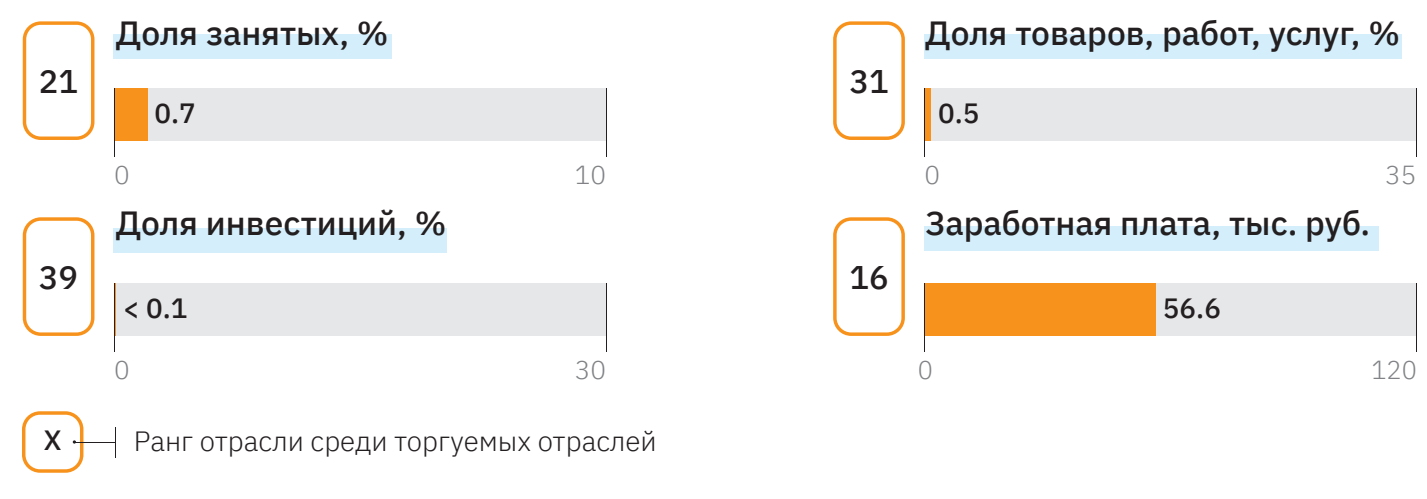

Регионы, специализирующиеся в отрасли

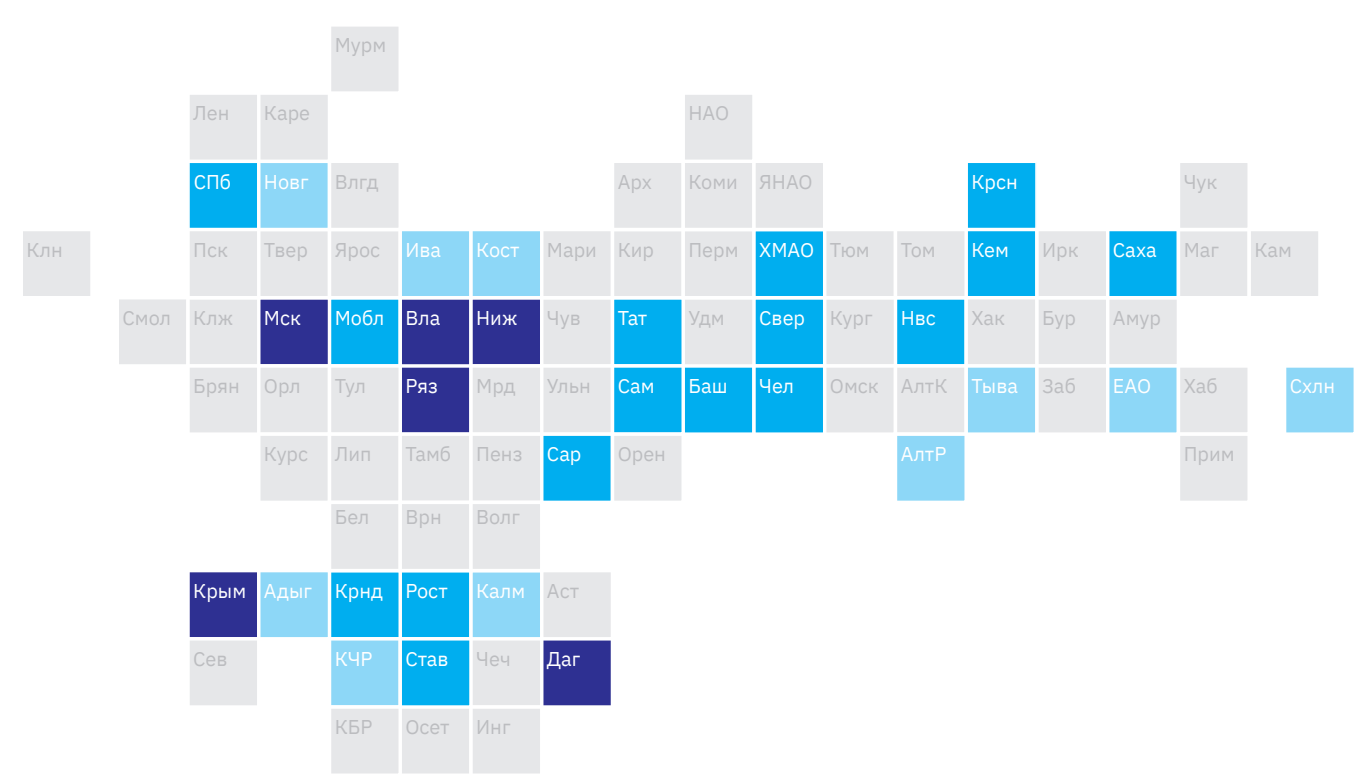

Отрасль национальной и локальной значимости Отрасль национальной значимости

\begin{tabular}{|c|c|c|c|}
\hline & $\begin{array}{l}\text { Доля региона } \\
\text { в отраслевой } \\
\text { занятости, \% }\end{array}$ & $\begin{array}{l}\text { Доля отрасли } \\
\text { в региональной } \\
\text { занятости, \% }\end{array}$ & $\begin{array}{l}\text { Заработная } \\
\text { плата, } \\
\text { тыс. руб. }\end{array}$ \\
\hline Москва & 23.95 & 1.55 & 118 \\
\hline Нижегородская область & 2.88 & 0.79 & 45.5 \\
\hline Владимирская область & 1.31 & 0.98 & 26.9 \\
\hline Республика Крым & 1.08 & 0.76 & 25.2 \\
\hline Рязанская область & 1.00 & 0.91 & 27.5 \\
\hline Республика Дагестан & 0.84 & 0.68 & 20.3 \\
\hline Санкт-Петербург & 5.24 & 0.79 & 66.1 \\
\hline Московская область & 3.69 & 0.5 & 55.6 \\
\hline Краснодарский край & 3.54 & 0.77 & 32.9 \\
\hline Республика Татарстан & 3.09 & 0.72 & 35.4 \\
\hline Свердловская область & 2.35 & 0.47 & 44.7 \\
\hline Ростовская область & 2.20 & 0.63 & 31.4 \\
\hline Новосибирская область & 2.09 & 0.76 & 47.8 \\
\hline Республика Башкортостан & 1.89 & 0.54 & 27.9 \\
\hline Красноярский край & 1.74 & 0.51 & 37.4 \\
\hline Самарская область & 1.57 & 0.46 & 38.1 \\
\hline Челябинская область & 1.49 & 0.41 & 33.4 \\
\hline Ставропольский край & 1.46 & 0.73 & 24.5 \\
\hline Саратовская область & 1.44 & 0.64 & 25.3 \\
\hline Кемеровская область & 1.27 & 0.45 & 32.3 \\
\hline Республика Саха (Якутия) & 0.86 & 0.62 & 66.0 \\
\hline Ханты-Мансийский автономный округ - Югра & 0.81 & 0.28 & 61.8 \\
\hline Сахалинская область & 0.60 & 0.91 & 60.5 \\
\hline Новгородская область & 0.50 & 0.77 & 27.9 \\
\hline Ивановская область & 0.43 & 0.59 & 24.0 \\
\hline Костромская область & 0.43 & 0.71 & 23.0 \\
\hline Карачаево-Черкесская Республика & 0.33 & 1.08 & 18.8 \\
\hline Республика Тыва & 0.31 & 1.14 & 27.1 \\
\hline Республика Адыгея & 0.24 & 0.77 & 23.3 \\
\hline Республика Калмыкия & 0.21 & 1.04 & 18.2 \\
\hline Республика Алтай & 0.15 & 0.83 & 26.6 \\
\hline Еврейская автономная область & 0.15 & 0.96 & 30.7 \\
\hline
\end{tabular}




\section{Изделия из дерева}
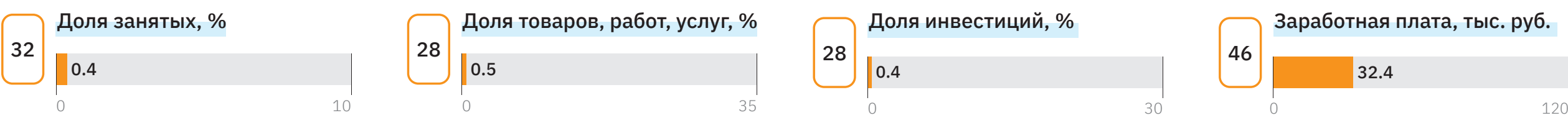

X Ранг отрасли среди торгуемых отраслей

Регионы, специализирующиеся в отрасли

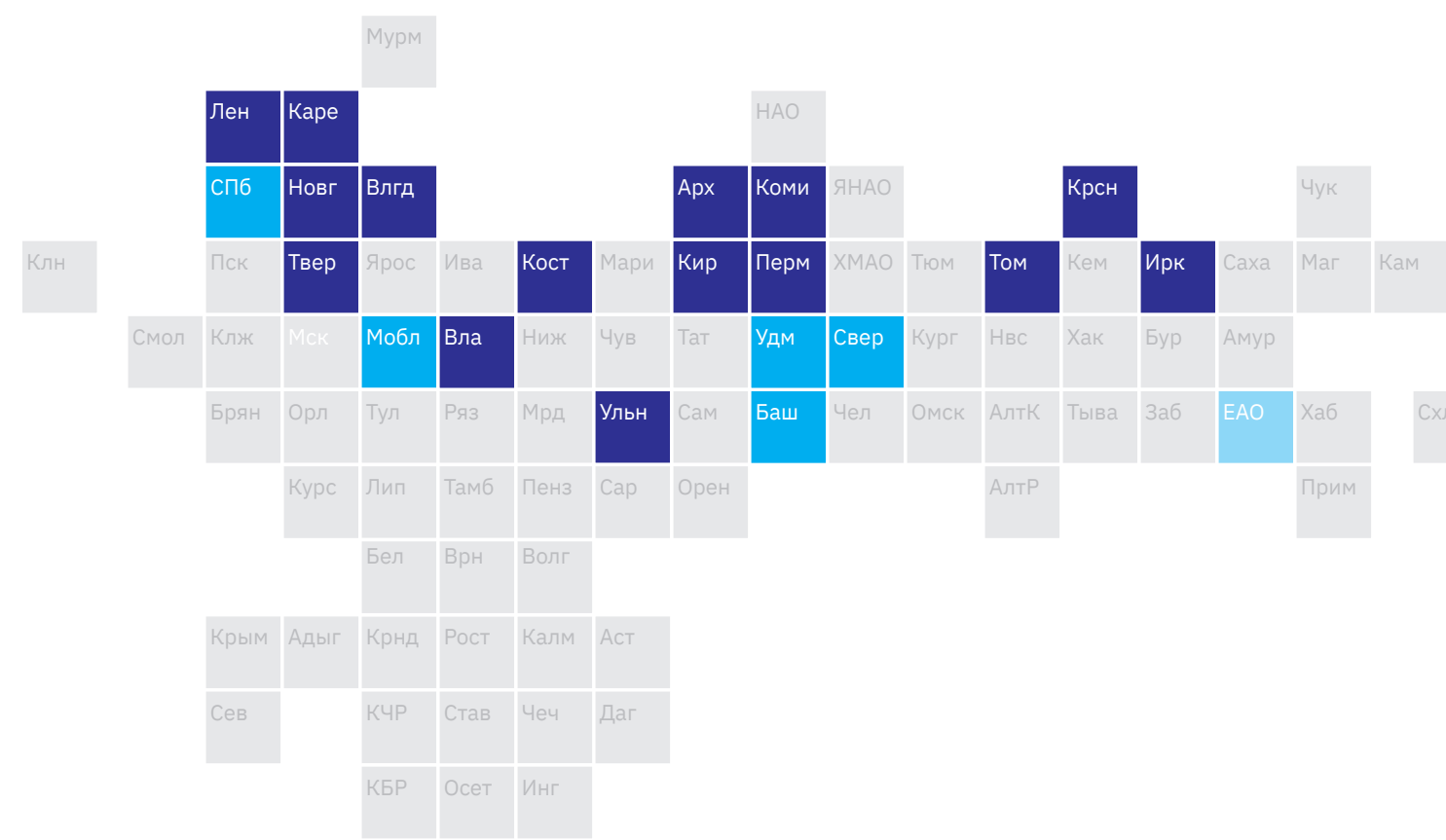

Отрасль национальной и локальной значимости
Отрасль национальной значимости

\begin{tabular}{|l|l|ll|} 
& $\begin{array}{l}\text { Доля региона } \\
\text { Вотраслевой } \\
\text { занятости, \% }\end{array}$ & $\begin{array}{c}\text { Доля отрасли } \\
\text { занятонасти, \% }\end{array}$ & $\begin{array}{l}\text { 3аработная } \\
\text { плата, } \\
\text { тыс. руб. }\end{array}$ \\
\hline Красноярский край & 7.03 & 1.11 & 31.3 \\
\hline Иркутская область & 6.74 & 1.39 & 35.3 \\
\hline Вологодская область & 5.74 & 2.57 & 35.4 \\
\hline Республика Коми & 5.09 & 2.40 & 42.8 \\
\hline Архангельская область & 5.00 & 2.03 & 34.3 \\
\hline Кировская область & 4.36 & 1.83 & 25.9 \\
\hline Пермский край & 4.13 & 0.82 & 20.9 \\
\hline Новгородская область & 3.19 & 2.64 & 43.6 \\
\hline Томская область & 2.89 & 1.40 & 33.1 \\
\hline Тверская область & 2.88 & 1.24 & 28.6 \\
\hline Владимирская область & 2.61 & 1.04 & 27.8 \\
\hline Костромская область & 2.48 & 2.22 & 42.1 \\
\hline Ленинградская область & 2.32 & 0.73 & 44.9 \\
\hline Республика Карелия & 2.11 & 1.77 & 40.0 \\
\hline Ульяновская область & 2.09 & 0.95 & 18.6 \\
\hline Свердловская область & 3.19 & 0.34 & 25.7 \\
\hline Удмуртская Республика & 2.50 & 0.8 & 32.6 \\
\hline Московская область & 2.46 & 0.18 & 44.8 \\
\hline Республика Башкортостан & 2.28 & 0.35 & 24.9 \\
\hline Санкт-Петербург & 1.73 & 0.14 & 51.6 \\
\hline Еврейская автономная область & 0.29 & 0.95 & 21.4 \\
\hline
\end{tabular}




\section{Киноиндустрия}

53

Доля занятых, \%

$<0.1$

0

\section{1}

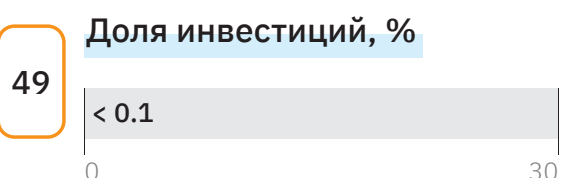

6 Заработная плата, тыс. руб. 83.1

$\mathrm{x}-$ Ранг отрасли среди торгуемых отраслей

\section{Регионы, специализирующиеся в отрасли}

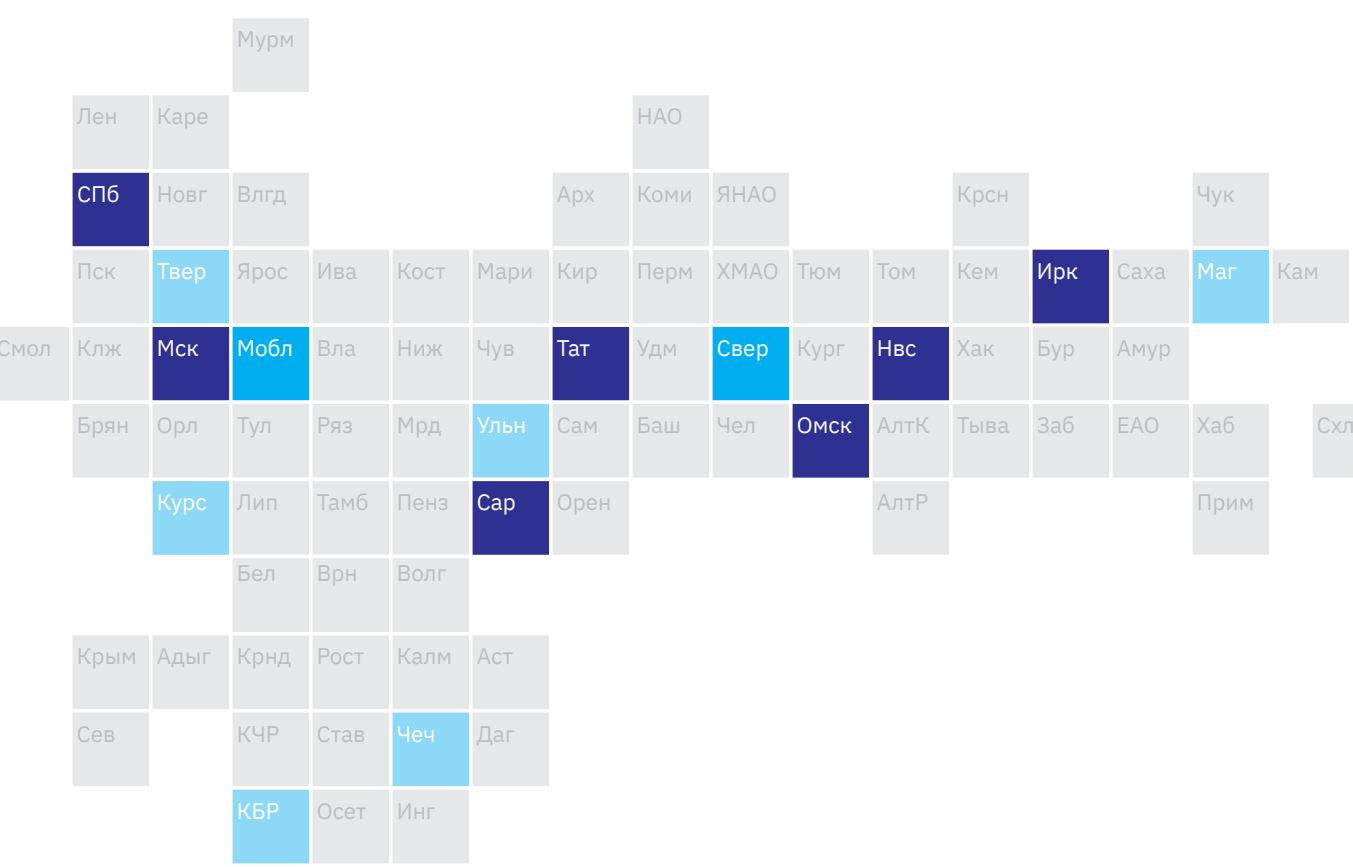

Отрасль национальной и локальной значимости
Отрасль национальной значимости

\begin{tabular}{|c|c|c|c|}
\hline & $\begin{array}{l}\text { Доля региона } \\
\text { в отраслевой } \\
\text { занятости, \% }\end{array}$ & $\begin{array}{l}\text { Доля отрасли } \\
\text { в региональной } \\
\text { занятости, \% }\end{array}$ & $\begin{array}{l}\text { Заработная } \\
\text { плата, } \\
\text { тыс. руб. }\end{array}$ \\
\hline Москва & 53.6 & 0.06 & 124.5 \\
\hline Санкт-Петербург & 9.52 & 0.03 & 38.7 \\
\hline Республика Татарстан & 4.71 & 0.02 & 29.0 \\
\hline Саратовская область & 4.66 & 0.04 & 23.5 \\
\hline Иркутская область & 2.03 & 0.01 & 35.0 \\
\hline Новосибирская область & 2.03 & 0.01 & 42.1 \\
\hline Омская область & 0.59 & 0.01 & 37.3 \\
\hline Московская область & 3.28 & 0.01 & 71.1 \\
\hline Свердловская область & 1.36 & 0.01 & 34.4 \\
\hline Магаданская область & 2.31 & 0.17 & 38.4 \\
\hline Курская область & 1.00 & 0.02 & 26.4 \\
\hline Тверская область & 0.92 & 0.01 & 22.5 \\
\hline Ульяновская область & 0.78 & 0.01 & 32.0 \\
\hline Чеченская Республика & 0.72 & 0.02 & 20.8 \\
\hline Кабардино-Балкарская Республика & 0.48 & 0.02 & 20.3 \\
\hline
\end{tabular}




\section{Кожаные изделия}

$\left.54\right|_{0} ^{<0.1}$ Доля занятых, \%
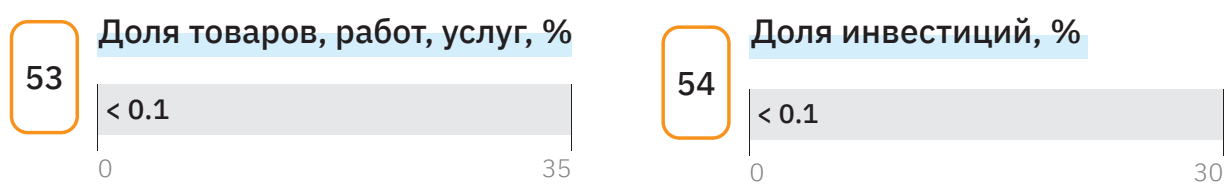

$\mathrm{x}-$ Ранг отрасли среди торгуемых отраслей

\section{Регионы, специализирующиеся в отрасли}

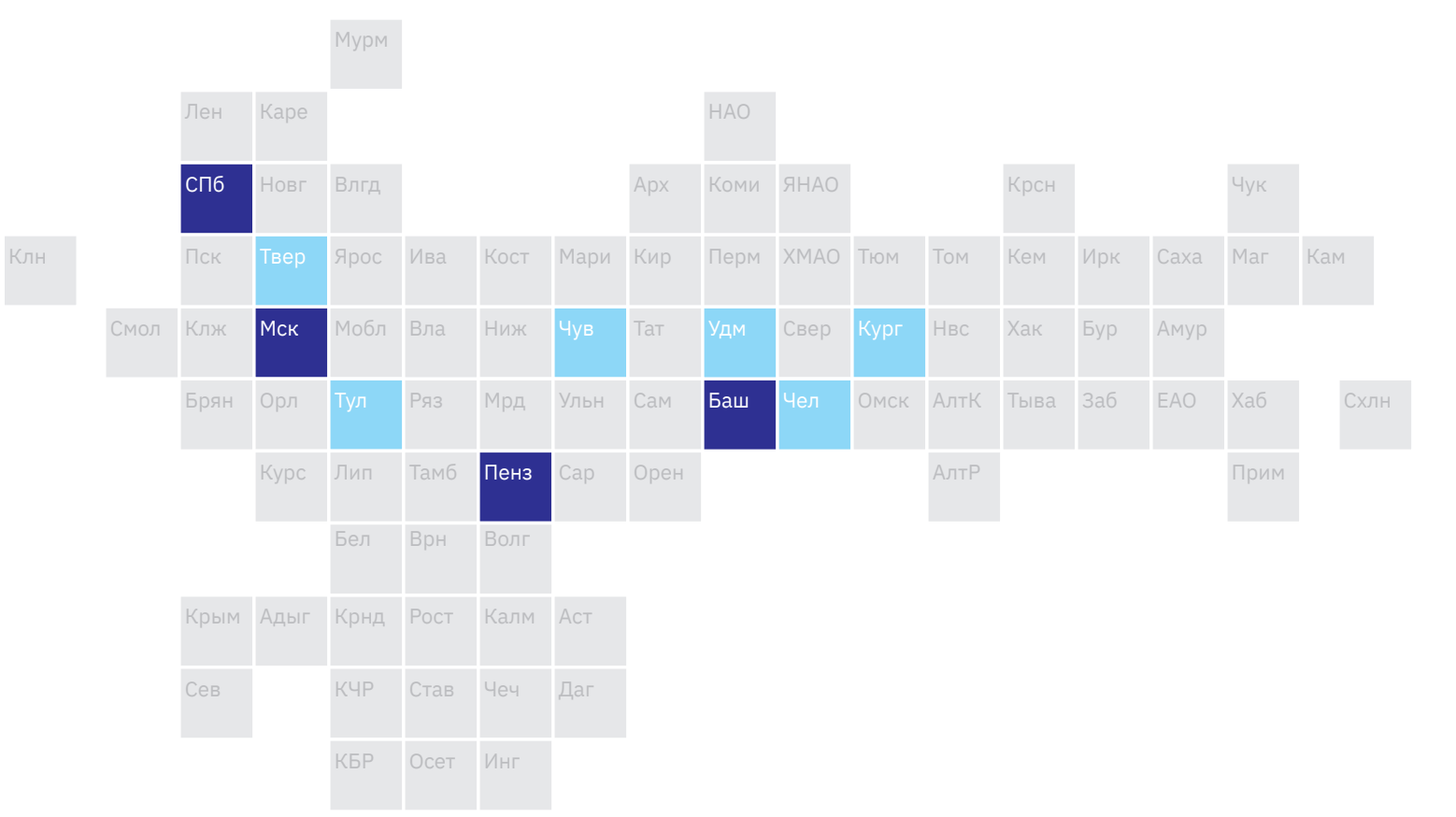

Отрасль национальной и локальной значимости

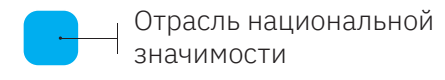
значимости

\begin{tabular}{|c|c|c|c|}
\hline & $\begin{array}{l}\text { Доля региона } \\
\text { в отраслевой } \\
\text { занятости, \% }\end{array}$ & $\begin{array}{l}\text { Доля отрасли } \\
\text { в региональной } \\
\text { занятости, \% }\end{array}$ & $\begin{array}{l}\text { Заработнаs } \\
\text { плата, } \\
\text { тыс. руб. }\end{array}$ \\
\hline Москва & 55.30 & 0.02 & 37.3 \\
\hline Пензенская область & 10.00 & 0.04 & 18.9 \\
\hline Республика Башкортостан & 6.92 & 0.01 & 16.8 \\
\hline Санкт-Петербург & 4.88 & 0.00 & 20.0 \\
\hline Тверская область & 6.20 & 0.02 & 4.4 \\
\hline Челябинская область & 4.68 & 0.01 & 20.3 \\
\hline Чувашская Республика & 3.84 & 0.02 & 17.6 \\
\hline Курганская область & 3.53 & 0.02 & 14.0 \\
\hline Удмуртская Республика & 2.22 & 0.01 & 6.4 \\
\hline Тульская область & 1.31 & 0.00 & 17.0 \\
\hline
\end{tabular}
53 Заработная плата, тыс. руб. 3 27.5




\section{Культура}

Доля занятых, \%

17 0.8 0

\section{Доля инвестиций, \%}

36

0.2

0
Доля товаров, работ, услуг, \%

48 $<0.1$ 35

Заработная плата, тыс. руб.

41

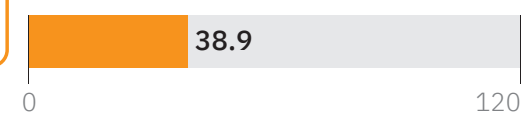

X Ранг отрасли среди торгуемых отраслей

Регионы, специализирующиеся в отрасли

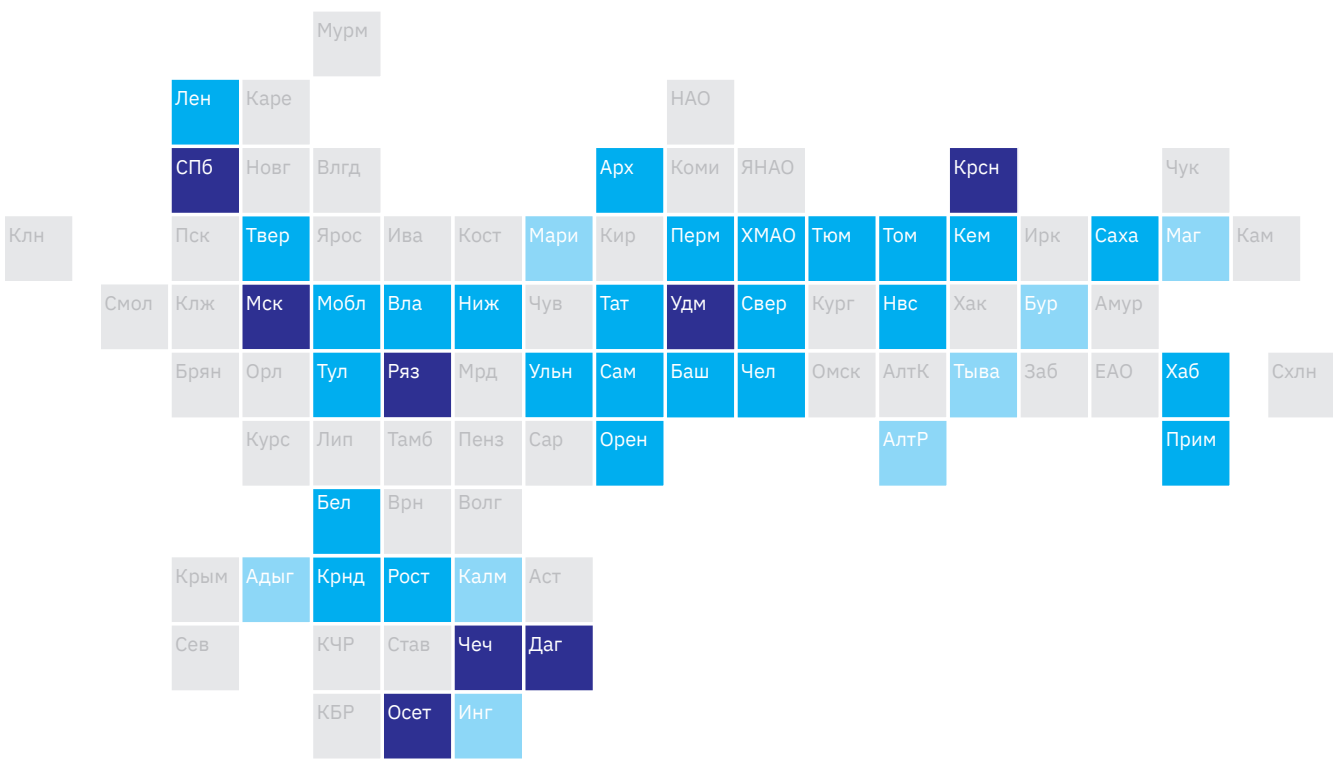

Отрасль национальной
Доля региона Доля отрасли Заработная в отраслевой в региональной плата, занятости, \% занятости, \% тыс. руб.

\begin{tabular}{|c|c|c|c|}
\hline Москва & 11.36 & 0.91 & 71.1 \\
\hline Санкт-Петербург & 6.27 & 1.18 & 63.7 \\
\hline Красноярский край & 2.98 & 1.09 & 39.7 \\
\hline Удмуртская Республика & 1.52 & 1.12 & 27.7 \\
\hline Республика Дагестан & 1.33 & 1.34 & 20.7 \\
\hline Рязанская область & 1.09 & 1.24 & 26.6 \\
\hline Чеченская Республика & 0.96 & 1.55 & 22.8 \\
\hline Республика Северная Осетия - Алания & 0.64 & 1.78 & 25.4 \\
\hline Московская область & 4.21 & 0.71 & 45.3 \\
\hline Свердловская область & 3.45 & 0.85 & 34.6 \\
\hline Краснодарский край & 3.18 & 0.86 & 31.2 \\
\hline Республика Башкортостан & 2.96 & 1.06 & 30.7 \\
\hline Ростовская область & 2.12 & 0.75 & 26.6 \\
\hline Кемеровская область & 2.11 & 0.92 & 30.9 \\
\hline Новосибирская область & 2.09 & 0.95 & 37.0 \\
\hline Республика Татарстан & 2.07 & 0.60 & 35.5 \\
\hline Челябинская область & 2.01 & 0.69 & 29.1 \\
\hline Нижегородская область & 1.99 & 0.68 & 30.1 \\
\hline Пермский край & 1.72 & 0.80 & 30.2 \\
\hline Самарская область & 1.53 & 0.55 & 29.7 \\
\hline Белгородская область & 1.27 & 0.93 & 27.8 \\
\hline Ханты-Мансийский автономный округ - Югра & 1.24 & 0.52 & 64.3 \\
\hline Оренбургская область & 1.12 & 0.75 & 26.8 \\
\hline Республика Саха (Якутия) & 1.12 & 1.01 & 65.9 \\
\hline Хабаровский край & 1.05 & 0.86 & 40.8 \\
\hline Ленинградская область & 1.01 & 0.74 & 36.1 \\
\hline Приморский край & 1.01 & 0.70 & 43.5 \\
\hline Владимирская область & 0.98 & 0.91 & 25.8 \\
\hline Тюменская область & 0.93 & 0.74 & 42.3 \\
\hline Тверская область & 0.88 & 0.88 & 25.7 \\
\hline Ульяновская область & 0.88 & 0.93 & 25.1 \\
\hline Томская область & 0.88 & 0.99 & 35.0 \\
\hline Архангельская область & 0.86 & 0.81 & 36.7 \\
\hline Тульская область & 0.82 & 0.68 & 27.3 \\
\hline Республика Марий Эл & 0.75 & 1.50 & 23.3 \\
\hline Республика Бурятия & 0.64 & 1.02 & 33.1 \\
\hline Республика Адыгея & 0.45 & 1.81 & 23.4 \\
\hline Республика Ингушетия & 0.36 & 2.10 & 20.8 \\
\hline Республика Алтай & 0.30 & 2.05 & 25.4 \\
\hline Республика Тыва & 0.29 & 1.31 & 27.4 \\
\hline Республика Калмыкия & 0.23 & 1.41 & 20.3 \\
\hline & & & \\
\hline
\end{tabular}




\section{Лесная промышленность}
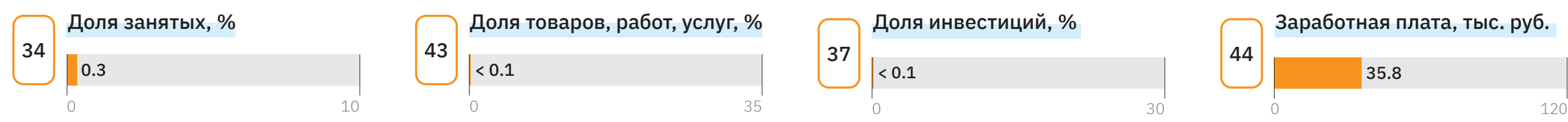

X- Ранг отрасли среди торгуемых отраслей

Регионы, специализирующиеся в отрасли

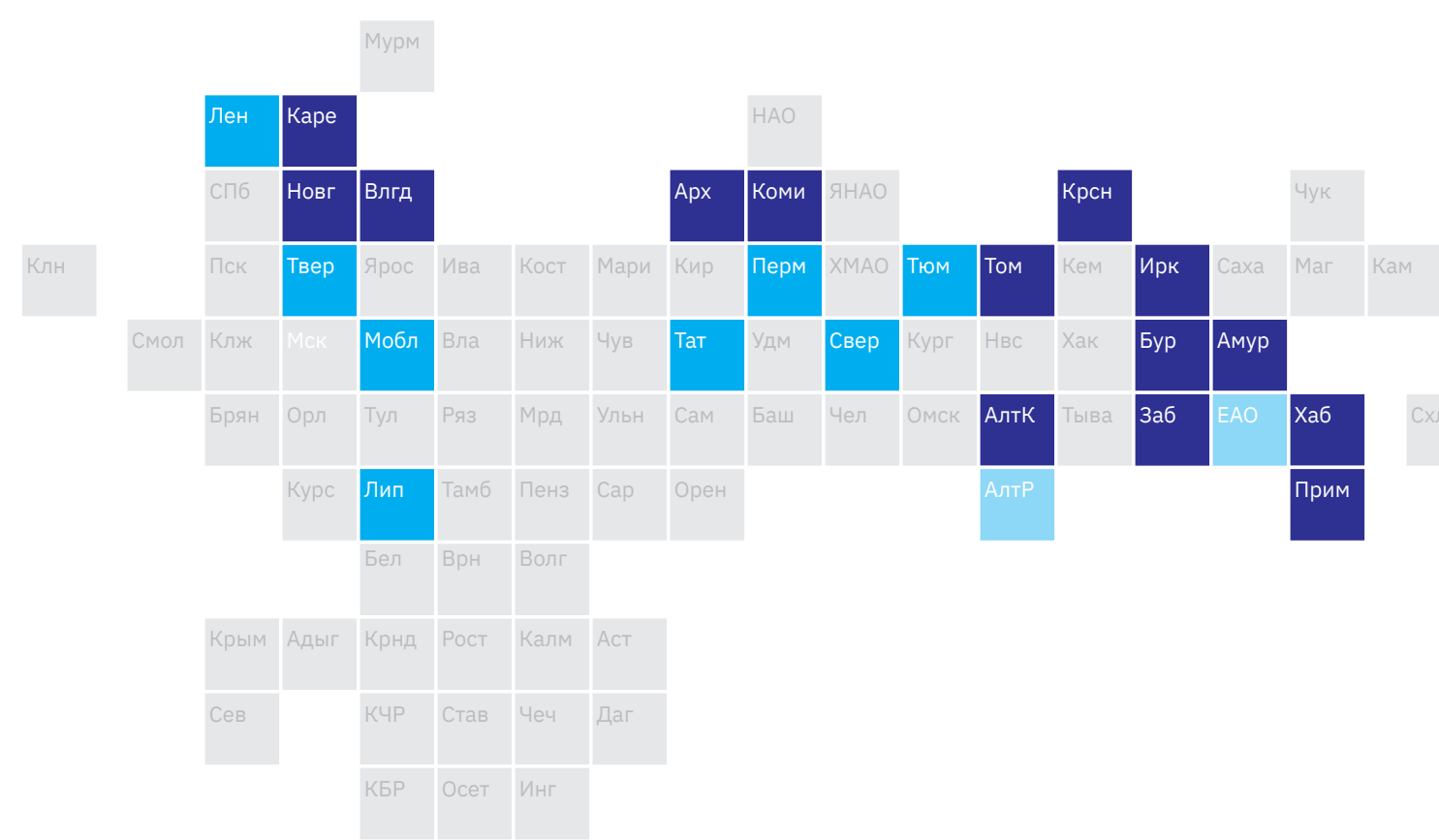

Отрасль национальной и локальной значимости
Отрасль национальной значимости

\begin{tabular}{|c|c|c|c|}
\hline & $\begin{array}{l}\text { Доля региона } \\
\text { в отраслевой } \\
\text { занятости, \% }\end{array}$ & $\begin{array}{l}\text { Доля отрасли } \\
\text { в региональной } \\
\text { занятости, \% }\end{array}$ & $\begin{array}{l}\text { Заработная } \\
\text { плата, } \\
\text { тыс. руб. }\end{array}$ \\
\hline Иркутская область & 8.71 & 1.68 & 54.4 \\
\hline Красноярский край & 6.73 & 0.99 & 36.9 \\
\hline Хабаровский край & 5.54 & 1.81 & 48.4 \\
\hline Архангельская область & 4.99 & 1.90 & 49.8 \\
\hline Вологодская область & 4.53 & 1.90 & 44.3 \\
\hline Приморский край & 4.36 & 1.21 & 46.2 \\
\hline Республика Коми & 2.96 & 1.31 & 40.8 \\
\hline Республика Карелия & 2.80 & 2.19 & 42.5 \\
\hline Алтайский край & 2.80 & 0.73 & 21.9 \\
\hline Республика Бурятия & 2.03 & 1.30 & 34.0 \\
\hline Забайкальский край & 1.96 & 0.93 & 34.7 \\
\hline Томская область & 1.55 & 0.70 & 31.9 \\
\hline Амурская область & 1.44 & 0.79 & 38.3 \\
\hline Новгородская область & 1.22 & 0.94 & 21.1 \\
\hline Свердловская область & 2.96 & 0.29 & 21.2 \\
\hline Республика Татарстан & 2.40 & 0.28 & 21.3 \\
\hline Пермский край & 2.32 & 0.43 & 25.4 \\
\hline Ленинградская область & 2.27 & 0.67 & 44.6 \\
\hline Московская область & 2.22 & 0.15 & 59.8 \\
\hline Тюменская область & 1.72 & 0.55 & 29.1 \\
\hline Тверская область & 1.15 & 0.46 & 31.1 \\
\hline Липецкая область & 0.93 & 0.41 & 23.7 \\
\hline Республика Алтай & 0.60 & 1.65 & 20.3 \\
\hline Еврейская автономная область & 0.30 & 0.94 & 28.1 \\
\hline
\end{tabular}




\section{Мебель}

$45 \underbrace{\text { Доля занятых, \% }}_{0} 0.2$

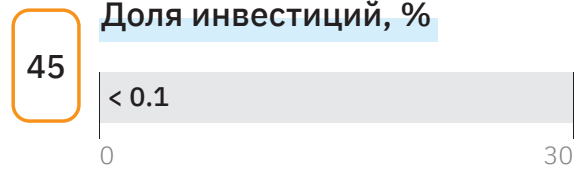

48

Заработная плата, тыс. руб.

X Ранг отрасли среди торгуемых отраслей

\section{Регионы, специализирующиеся в отрасли}

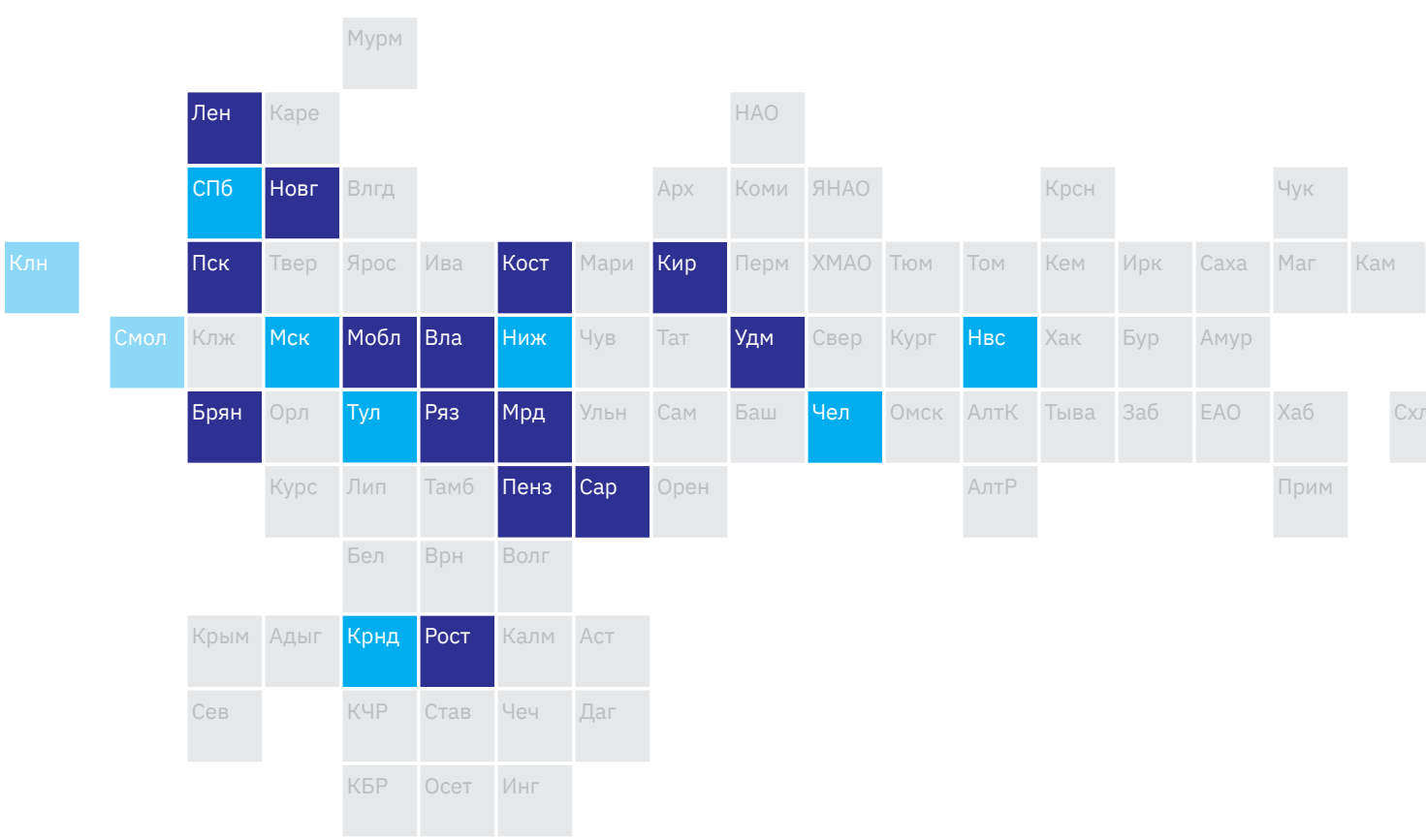

\begin{tabular}{|l|lll|} 
& $\begin{array}{l}\text { Доля региона } \\
\text { В отраслевой } \\
\text { занятости, \% }\end{array}$ & $\begin{array}{l}\text { Доля отрасли } \\
\text { занятонасти, \% }\end{array}$ & $\begin{array}{l}\text { 3аработная } \\
\text { плата, } \\
\text { тыс. руб. }\end{array}$ \\
\hline Московская область & 18.23 & 0.57 & 41.2 \\
\hline Саратовская область & 8.19 & 0.85 & 20.7 \\
\hline Владимирская область & 7.68 & 1.33 & 36.3 \\
\hline Ростовская область & 3.96 & 0.26 & 30.7 \\
\hline Рязанская область & 3.27 & 0.70 & 22.2 \\
\hline Ленинградская область & 3.15 & 0.43 & 39.6 \\
\hline Удмуртская Республика & 2.86 & 0.40 & 21.1 \\
\hline Кировская область & 2.76 & 0.50 & 31.9 \\
\hline Пензенская область & 2.60 & 0.57 & 32.5 \\
\hline Брянская область & 2.59 & 0.56 & 19.4 \\
\hline Псковская область & 2.18 & 0.81 & 45.8 \\
\hline Новгородская область & 2.10 & 0.76 & 25.7 \\
\hline Костромская область & 1.97 & 0.77 & 33.6 \\
\hline Республика Мордовия & 1.54 & 0.45 & 21.6 \\
\hline Москва & 3.20 & 0.05 & 41.0 \\
\hline Челябинская область & 3.11 & 0.20 & 34.5 \\
\hline Нижегородская область & 2.67 & 0.17 & 18.2 \\
\hline Санкт-Петербург & 2.30 & 0.08 & 44.6 \\
\hline Краснодарский край & 2.17 & 0.11 & 20.8 \\
\hline Новосибирская область & 1.80 & 0.15 & 20.7 \\
\hline Тульская область & 1.09 & 0.17 & 30.5 \\
\hline Калининградская область & 1.23 & 0.33 & 32.5 \\
\hline Смоленская область & 1.22 & 0.30 & 30.3 \\
\hline
\end{tabular}




\section{Медицинские услуги*}

9.1

Доля инвестиций, \%

1.3
Доля занятых, \%
Доля товаров, работ, услуг, \%

$$
2.1
$$

41.4
Заработная плата, тыс. руб.

Регионы, специализирующиеся в отрасли

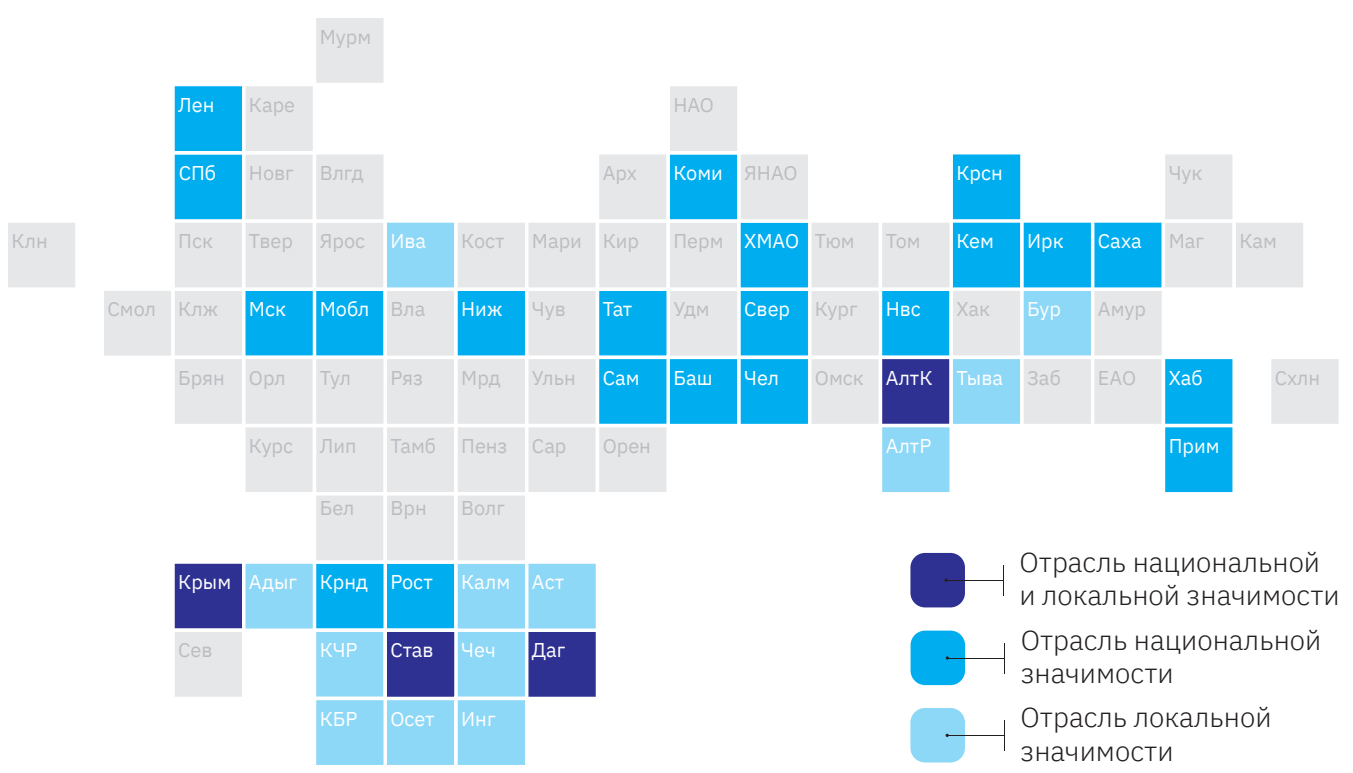

* Отрасль «Медицинские услуги» не входит в перечень торгуемых отраслей, принятый Гарвардской школой бизнеса и Европейской кластерной обсерваторией, и не учитывается в составе торгуемого сектора в Атласе экономической специализации регионов России, в связи с чем не сравнивается с другими отраслями торгуемого сектора. В то же

\begin{tabular}{|c|c|c|c|}
\hline & $\begin{array}{l}\text { Доля региона } \\
\text { в отраслевой } \\
\text { занятости, \% }\end{array}$ & $\begin{array}{l}\text { Доля отрасли } \\
\text { в региональной } \\
\text { занятости, \% }\end{array}$ & $\begin{array}{l}\text { Заработная } \\
\text { плата, } \\
\text { тыс. руб. }\end{array}$ \\
\hline Алтайский край & 1.68 & 11.76 & 26.9 \\
\hline Республика Дагестан & 1.65 & 17.77 & 25.5 \\
\hline Ставропольский край & 1.63 & 10.84 & 29.1 \\
\hline Республика Крым & 1.28 & 12.02 & 30.4 \\
\hline Москва & 7.93 & 6.85 & 88.6 \\
\hline Санкт-Петербург & 4.27 & 8.60 & 64.3 \\
\hline Московская область & 3.98 & 7.18 & 53.7 \\
\hline Краснодарский край & 3.20 & 9.25 & 34.4 \\
\hline Свердловская область & 3.04 & 8.06 & 37.9 \\
\hline Ростовская область & 2.58 & 9.82 & 30.8 \\
\hline Республика Башкортостан & 2.56 & 9.82 & 33.8 \\
\hline Республика Татарстан & 2.39 & 7.48 & 35.2 \\
\hline Красноярский край & 2.36 & 9.30 & 40.8 \\
\hline Челябинская область & 2.31 & 8.42 & 34.6 \\
\hline Нижегородская область & 2.19 & 8.00 & 31.0 \\
\hline Самарская область & 2.08 & 8.08 & 34.1 \\
\hline Кемеровская область & 1.99 & 9.36 & 34.2 \\
\hline Новосибирская область & 1.93 & 9.34 & 38.3 \\
\hline Иркутская область & 1.92 & 9.88 & 39.8 \\
\hline Ханты-Мансийский автономный округ - Югра & 1.57 & 7.08 & 65.7 \\
\hline Приморский край & 1.29 & 9.52 & 42.9 \\
\hline Хабаровский край & 1.10 & 9.57 & 46.2 \\
\hline Ленинградская область & 0.89 & 7.01 & 43.8 \\
\hline Республика Саха (Якутия) & 0.86 & 8.29 & 66.9 \\
\hline Республика Коми & 0.85 & 9.98 & 45.5 \\
\hline Астраханская область & 0.80 & 12.62 & 31.7 \\
\hline Республика Бурятия & 0.77 & 13.12 & 34.8 \\
\hline Чеченская Республика & 0.69 & 11.88 & 27.3 \\
\hline Ивановская область & 0.68 & 12.53 & 25.8 \\
\hline Кабардино-Балкарская Республика & 0.53 & 15.82 & 25.1 \\
\hline Республика Северная Осетия - Алания & 0.51 & 15.31 & 26.3 \\
\hline Республика Тыва & 0.32 & 15.89 & 33.3 \\
\hline Республика Адыгея & 0.29 & 12.30 & 26.3 \\
\hline Карачаево-Черкесская Республика & 0.29 & 12.82 & 23.9 \\
\hline Республика Ингушетия & 0.28 & 17.95 & 26.4 \\
\hline Республика Калмыкия & 0.20 & 13.07 & 24.1 \\
\hline Республика Алтай & 0.17 & 12.72 & 31.7 \\
\hline
\end{tabular}




\section{Медоборудование}

$\left.50\right|_{0} ^{\text {Доля занятых, \% } 0.1}$
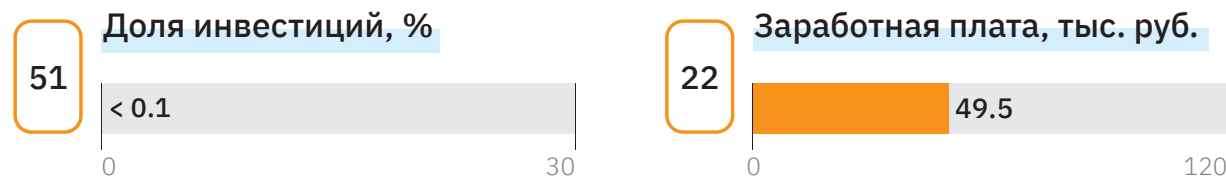

X Ранг отрасли среди торгуемых отраслей

\section{Регионы, специализирующиеся в отрасли}
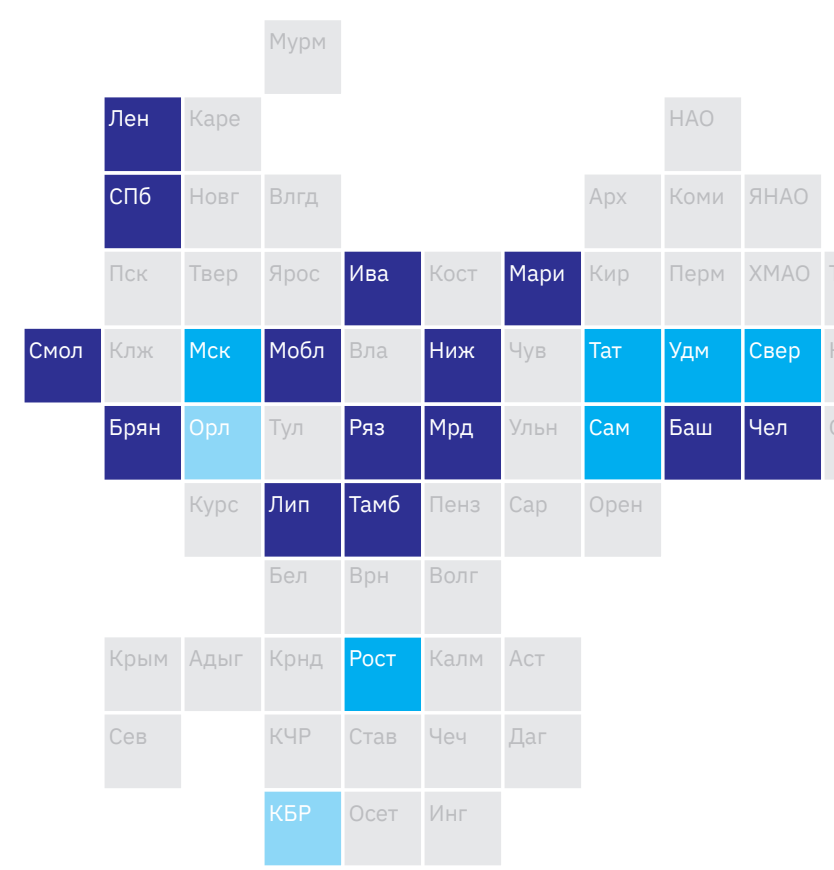

Орен
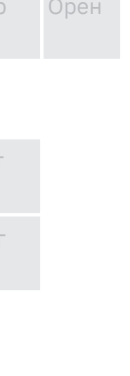

\begin{tabular}{|c|c|c|c|}
\hline & $\begin{array}{l}\text { Доля региона } \\
\text { в отраслевой } \\
\text { занятости, \% }\end{array}$ & $\begin{array}{l}\text { Доля отрасли } \\
\text { в региональной } \\
\text { занятости, \% }\end{array}$ & $\begin{array}{l}\text { Заработная } \\
\text { плата, } \\
\text { тыс. руб. }\end{array}$ \\
\hline Московская область & 14.36 & 0.15 & 54.6 \\
\hline Рязанская область & 9.65 & 0.66 & 34.3 \\
\hline Нижегородская область & 5.31 & 0.11 & 23.4 \\
\hline Челябинская область & 4.93 & 0.10 & 36.8 \\
\hline Санкт-Петербург & 4.16 & 0.05 & 57.8 \\
\hline Республика Башкортостан & 3.01 & 0.06 & 34.2 \\
\hline Республика Марий Эл & 2.32 & 0.28 & 45.5 \\
\hline Республика Мордовия & 2.24 & 0.21 & 29.0 \\
\hline Ивановская область & 1.90 & 0.20 & 58.1 \\
\hline Ленинградская область & 1.90 & 0.08 & 86.5 \\
\hline Липецкая область & 1.85 & 0.12 & 19.9 \\
\hline Смоленская область & 1.41 & 0.11 & 35.5 \\
\hline Брянская область & 1.40 & 0.10 & 27.5 \\
\hline Тамбовская область & 1.25 & 0.10 & 27.9 \\
\hline Москва & 11.05 & 0.05 & 105.5 \\
\hline Свердловская область & 3.88 & 0.06 & 46.3 \\
\hline Республика Татарстан & 2.52 & 0.04 & 43.4 \\
\hline Самарская область & 1.78 & 0.04 & 45.2 \\
\hline Ростовская область & 1.49 & 0.03 & 45.8 \\
\hline Новосибирская область & 1.37 & 0.04 & 40.1 \\
\hline Удмуртская Республика & 1.29 & 0.06 & 33.5 \\
\hline Кабардино-Балкарская Республика & 0.94 & 0.16 & 15.8 \\
\hline Орловская область & 0.53 & 0.05 & 24.5 \\
\hline
\end{tabular}




\section{Металлообрабатывающая промышленность}
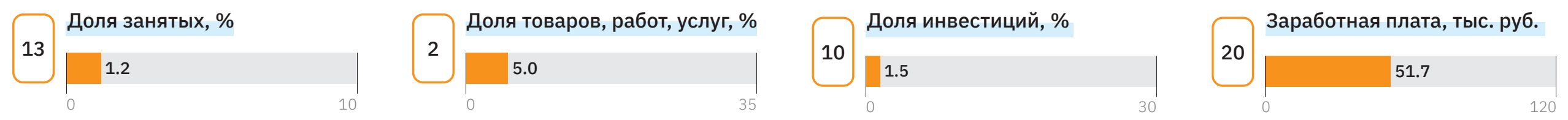

X- Ранг отрасли среди торгуемых отраслей

Регионы, специализирующиеся в отрасли

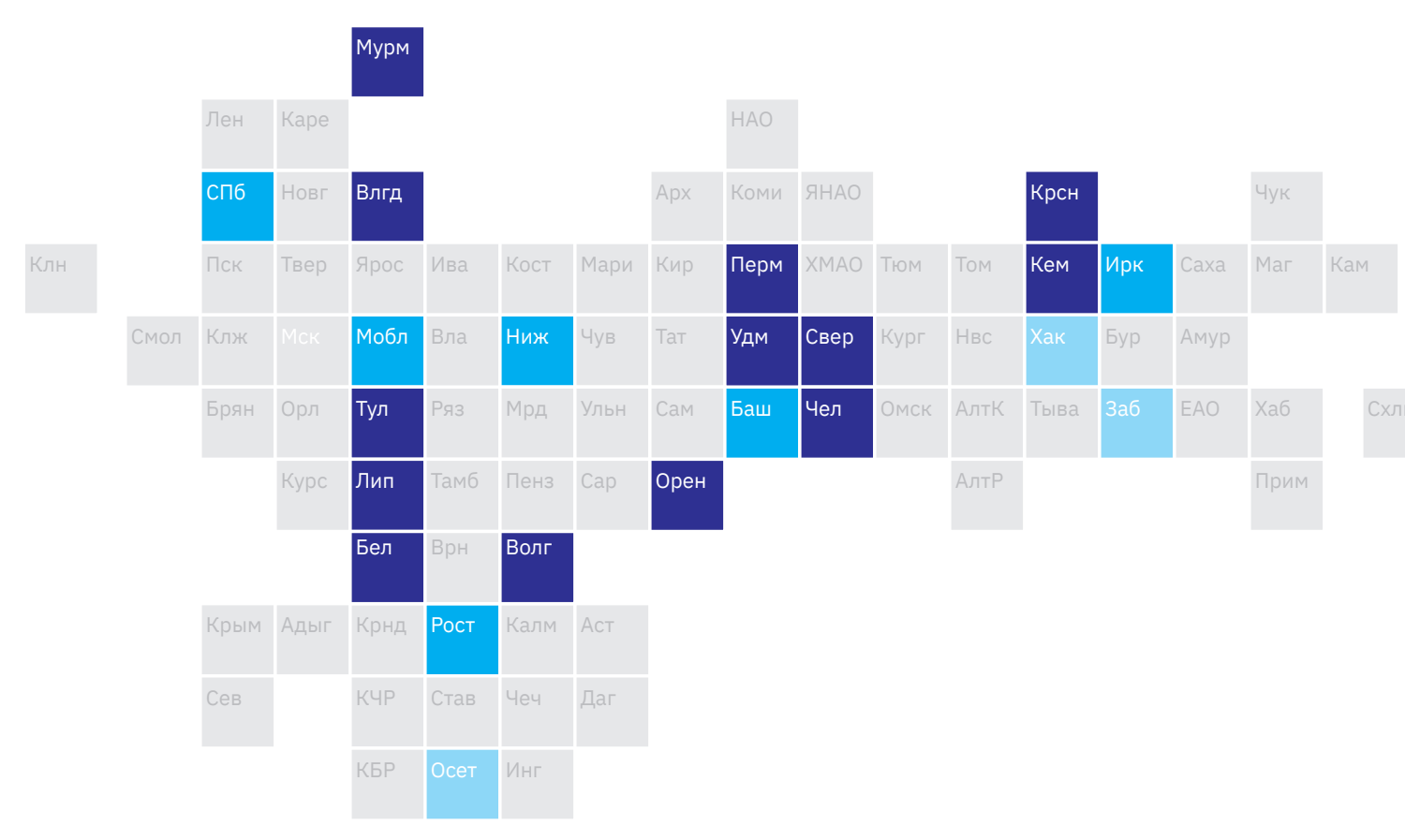

\begin{tabular}{|l|lll} 
& $\begin{array}{l}\text { Доля региона } \\
\text { В отраслевой } \\
\text { занятости, } \%\end{array}$ & $\begin{array}{l}\text { Доля отрасли } \\
\text { в региональной }\end{array}$ & $\begin{array}{l}\text { 3аработная } \\
\text { плата, } \\
\text { тыс. руб. }\end{array}$ \\
\hline Свердловская область & 15.58 & 5.41 & 52.3 \\
\hline Челябинская область & 13.02 & 6.23 & 44.5 \\
\hline Липецкая область & 7.11 & 10.85 & 60.6 \\
\hline Красноярский край & 6.37 & 3.28 & 87.5 \\
\hline Кемеровская область & 5.27 & 3.25 & 46.5 \\
\hline Вологодская область & 3.89 & 5.68 & 65.7 \\
\hline Оренбургская область & 2.96 & 2.79 & 43.9 \\
\hline Пермский край & 2.90 & 1.89 & 38.8 \\
\hline Тульская область & 2.51 & 2.92 & 47.3 \\
\hline Белгородская область & 2.44 & 2.53 & 52.5 \\
\hline Волгоградская область & 2.22 & 1.87 & 38.6 \\
\hline Удмуртская Республика & 1.94 & 2.02 & 41.5 \\
\hline Мурманская область & 1.66 & 2.88 & 81.1 \\
\hline Московская область & 3.75 & 0.89 & 53.9 \\
\hline Нижегородская область & 2.43 & 1.16 & 40.8 \\
\hline Иркутская область & 2.01 & 1.35 & 61.7 \\
\hline Ростовская область & 1.93 & 0.96 & 36.0 \\
\hline Республика Башкортостан & 1.78 & 0.89 & 31.8 \\
\hline Санкт-Петербург & 1.38 & 0.36 & 53.3 \\
\hline Забайкальский край & 1.24 & 2.04 & 48.9 \\
\hline Республика Хакасия & 0.96 & 3.45 & 54.4 \\
\hline Республика Северная Осетия -Алания & 0.70 & 2.75 & 34.2 \\
\hline & & & \\
\hline
\end{tabular}




\section{Микроэлектроника и приборостроение}
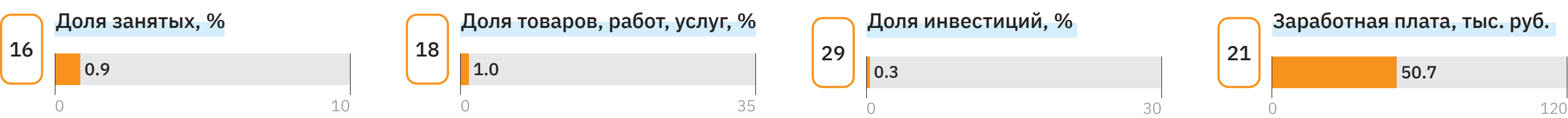

X Ранг отрасли среди торгуемых отраслей

Регионы, специализирующиеся в отрасли

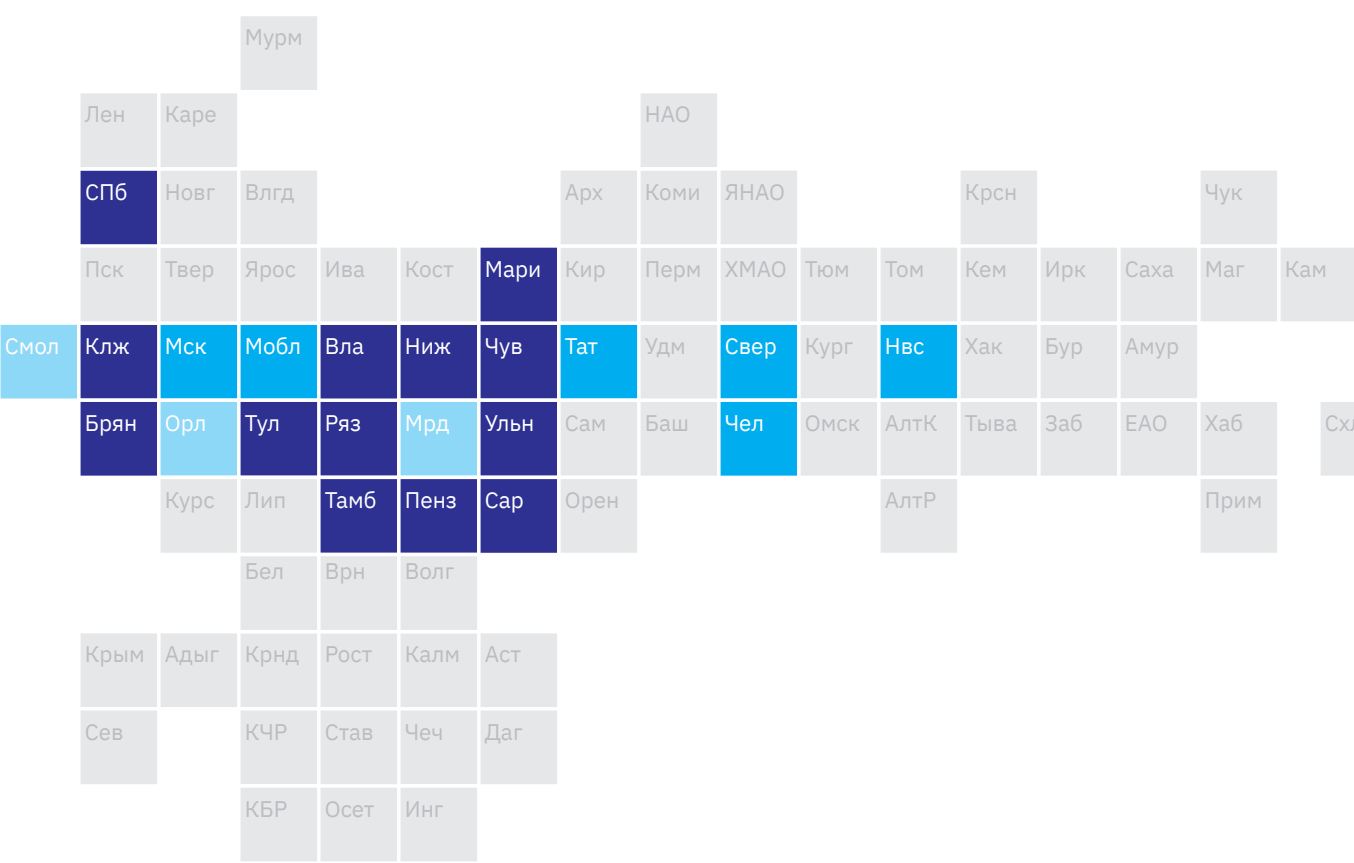

Отрасль национальной и локальной значимости
Отрасль национальной значимости

\begin{tabular}{|l|lll} 
& $\begin{array}{l}\text { Доля региона } \\
\text { В отраслевой } \\
\text { занятости, \% }\end{array}$ & $\begin{array}{l}\text { Доля отрасли } \\
\text { врегиональной }\end{array}$ & $\begin{array}{l}\text { 3аработная } \\
\text { плата, } \\
\text { тыс. руб. }\end{array}$ \\
\hline Санкт-Петербург & 9.17 & 1.75 & 66.4 \\
\hline Нижегородская область & 5.47 & 1.90 & 56.1 \\
\hline Саратовская область & 5.22 & 2.96 & 36.7 \\
\hline Рязанская область & 4.13 & 4.78 & 41.8 \\
\hline Ульяновская область & 3.74 & 4.05 & 50.6 \\
\hline Пензенская область & 3.08 & 3.64 & 39.2 \\
\hline Владимирская область & 2.95 & 2.77 & 36.6 \\
\hline Республика Марий эл & 2.89 & 5.92 & 46.7 \\
\hline Тульская область & 2.82 & 2.38 & 43.0 \\
\hline Тамбовская область & 2.11 & 2.91 & 33.6 \\
\hline Чувашская Республика & 1.81 & 2.21 & 47.3 \\
\hline Калужская область & 1.78 & 2.08 & 69.5 \\
\hline Брянская область & 1.63 & 1.93 & 38.2 \\
\hline Москва & 8.82 & 0.72 & 82.4 \\
\hline Московская область & 8.29 & 1.42 & 58.8 \\
\hline Свердловская область & 3.70 & 0.93 & 50.3 \\
\hline Новосибирская область & 3.16 & 1.46 & 42.2 \\
\hline Республика Татарстан & 2.96 & 0.88 & 43.8 \\
\hline Челябинская область & 1.95 & 0.67 & 37.6 \\
\hline Республика Мордовия & 1.42 & 2.24 & 33.1 \\
\hline Смоленская область & 1.38 & 1.83 & 47.2 \\
\hline Орловская область & 1.12 & 1.87 & 35.6 \\
\hline
\end{tabular}




\section{Мясная продукция}

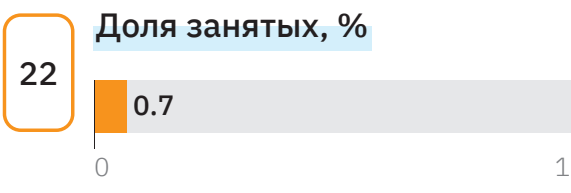

Доля инвестиций, \%

30

0.3

0

X Ранг отрасли среди торгуемых отраслей

Регионы, специализирующиеся в отрасли

Клн

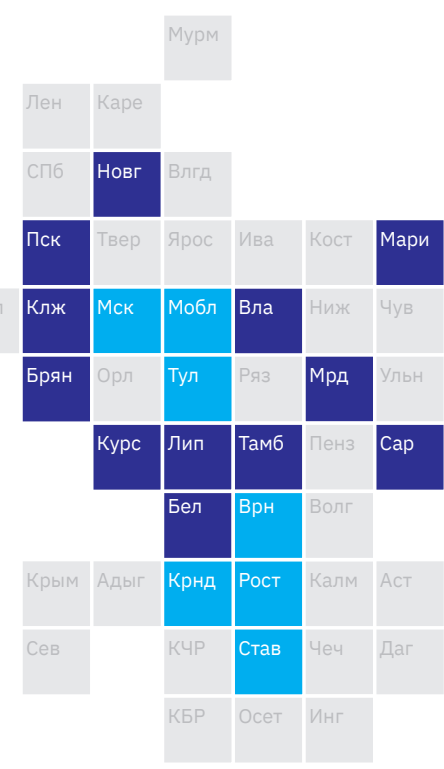

Отрасль национальной и локальной значимости
11

Доля товаров, работ, услуг, \% 1.5

Заработная плата, тыс. руб.

47

$$
32.4
$$

Доля региона Доля отрасли Заработная в отраслевой в региональной плата, занятости, $\%$ занятости, \% тыс. руб.

\begin{tabular}{|c|c|c|c|}
\hline Белгородская область & 8.13 & 4.61 & 32.6 \\
\hline Челябинская область & 5.01 & 1.32 & 28.7 \\
\hline Псковская область & 2.77 & 4.26 & 18.3 \\
\hline Саратовская область & 2.69 & 1.16 & 13.4 \\
\hline Курская область & 2.63 & 2.17 & 29.7 \\
\hline Брянская область & 2.60 & 2.33 & 32.3 \\
\hline Владимирская область & 2.49 & 1.77 & 40.7 \\
\hline Омская область & 2.17 & 1.15 & 30.9 \\
\hline Тамбовская область & 2.16 & 2.25 & 29.0 \\
\hline Республика Мордовия & 2.16 & 2.58 & 36.1 \\
\hline Калужская область & 1.85 & 1.64 & 38.1 \\
\hline Республика Марий Эл & 1.76 & 2.74 & 35.0 \\
\hline Новгородская область & 1.62 & 2.41 & 31.6 \\
\hline Калининградская область & 1.52 & 1.70 & 28.4 \\
\hline Томская область & 1.35 & 1.17 & 31.1 \\
\hline Липецкая область & 1.28 & 1.08 & 32.0 \\
\hline Московская область & 6.64 & 0.86 & 38.7 \\
\hline Москва & 5.72 & 0.36 & 56.2 \\
\hline Краснодарский край & 3.39 & 0.71 & 34.9 \\
\hline Новосибирская область & 2.75 & 0.96 & 33.6 \\
\hline Ростовская область & 2.35 & 0.64 & 31.9 \\
\hline Свердловская область & 2.19 & 0.42 & 29.5 \\
\hline Ставропольский край & 2.00 & 0.96 & 26.5 \\
\hline Воронежская область & 1.89 & 0.84 & 23.0 \\
\hline Республика Башкортостан & 1.44 & 0.40 & 27.8 \\
\hline Тульская область & 1.26 & 0.80 & 32.8 \\
\hline
\end{tabular}




\section{Наука}

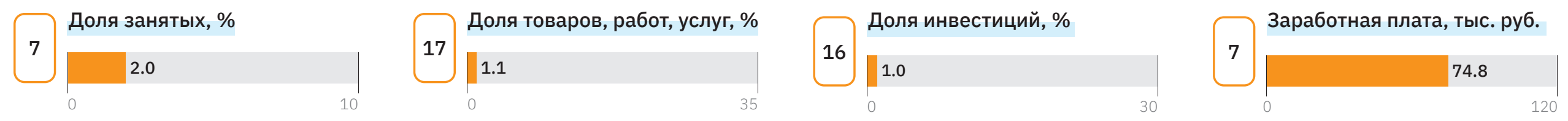

X Ранг отрасли среди торгуемых отраслей

\section{Регионы, специализирующиеся в отрасли}
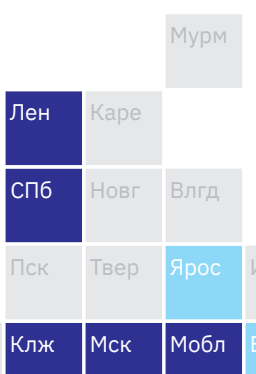

Брян

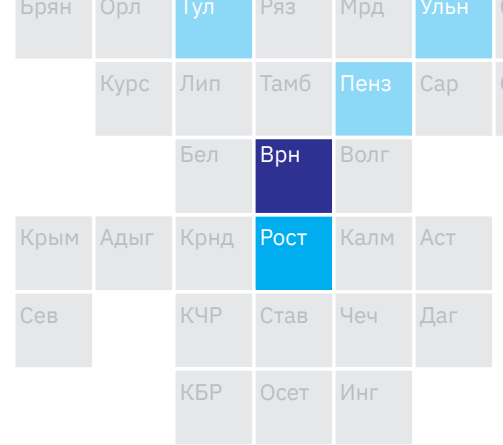

Отрасль национальной и локальной значимости
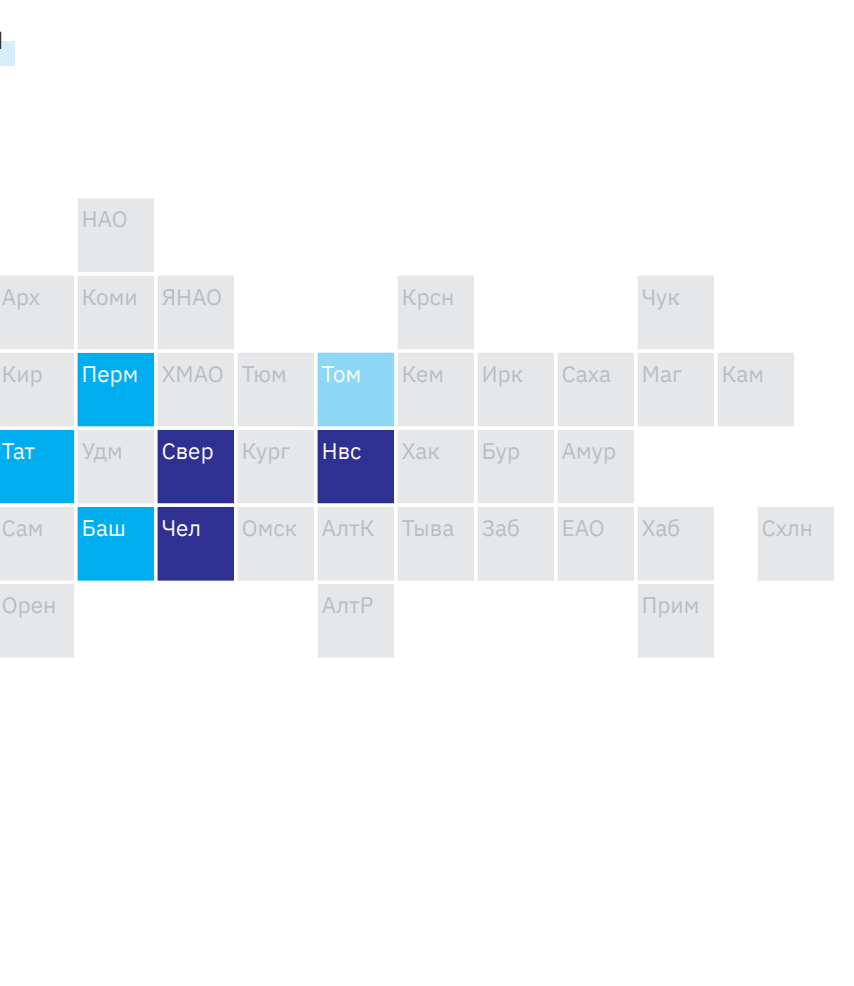

\begin{tabular}{|l|l|l|l|} 
& $\begin{array}{l}\text { Доля региона } \\
\text { в отраслевой } \\
\text { занятости, \% }\end{array}$ & $\begin{array}{l}\text { Воля отраслиональной } \\
\text { занятости, \% }\end{array}$ & $\begin{array}{l}\text { Заработная } \\
\text { плата, } \\
\text { тыс. руб. }\end{array}$ \\
\hline Москва & 31.44 & 6.00 & 93.6 \\
\hline Московская область & 14.38 & 5.73 & 73.6 \\
\hline Санкт-Петербург & 10.71 & 4.77 & 84.5 \\
\hline Нижегородская область & 5.79 & 4.68 & 66.2 \\
\hline Новосибирская область & 3.05 & 3.27 & 51.4 \\
\hline Свердловская область & 2.84 & 1.67 & 60.6 \\
\hline Челябинская область & 2.19 & 1.77 & 60.3 \\
\hline Воронежская область & 1.74 & 2.37 & 58.7 \\
\hline Калужская область & 1.31 & 3.57 & 55.9 \\
\hline Ленинградская область & 1.14 & 1.97 & 62.3 \\
\hline Ростовская область & 1.70 & 1.43 & 62.2 \\
\hline Республика Татарстан & 1.58 & 1.09 & 59.1 \\
\hline Пермский край & 1.31 & 1.44 & 63.9 \\
\hline Республика Башкортостан & 1.23 & 1.04 & 63.6 \\
\hline Томская область & 1.05 & 2.79 & 68.7 \\
\hline Тульская область & 0.98 & 1.93 & 73.6 \\
\hline Владимирская область & 0.87 & 1.90 & 51.2 \\
\hline Пензенская область & 0.83 & 2.30 & 54.5 \\
\hline Ярославская область & 0.70 & 1.44 & 39.4 \\
\hline Ульяновская область & 0.66 & 1.66 & 59.8 \\
\hline
\end{tabular}




\section{Образование}

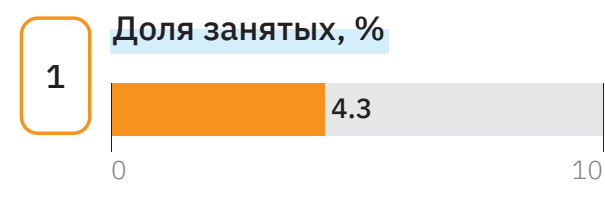

Доля инвестиций, \%

21 0.7 0

X Ранг отрасли среди торгуемых отраслей

Регионы, специализирующиеся в отрасли

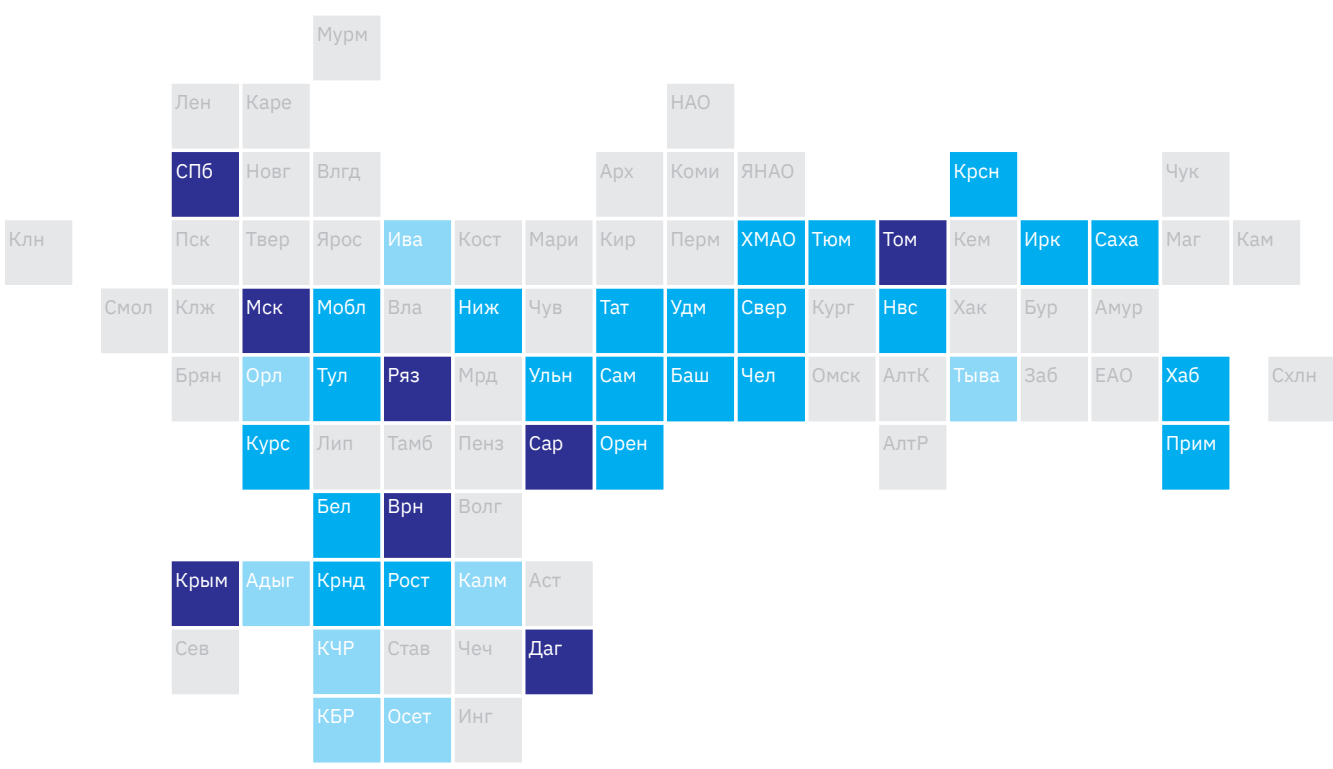

Отрасль национальной и локальной значимости

\begin{tabular}{|c|c|c|c|}
\hline & $\begin{array}{l}\text { Доля региона } \\
\text { в отраслевой } \\
\text { занятости, \% }\end{array}$ & $\begin{array}{l}\text { Доля отрасли } \\
\text { в региональной } \\
\text { занятости, \% }\end{array}$ & $\begin{array}{l}\text { Заработная } \\
\text { плата, } \\
\text { тыс. руб. }\end{array}$ \\
\hline Москва & 12.25 & 5.07 & 82.9 \\
\hline Санкт-Петербург & 6.88 & 6.64 & 57.4 \\
\hline Воронежская область & 1.86 & 5.50 & 30.9 \\
\hline Саратовская область & 1.84 & 5.27 & 25.2 \\
\hline Республика Крым & 1.32 & 5.93 & 30.6 \\
\hline Томская область & 1.09 & 6.31 & 43.0 \\
\hline Республика Дагестан & 1.04 & 5.39 & 22.9 \\
\hline Рязанская область & 0.94 & 5.47 & 30.7 \\
\hline Московская область & 3.40 & 2.94 & 50.4 \\
\hline Свердловская область & 3.18 & 4.04 & 34.6 \\
\hline Краснодарский край & 3.06 & 4.24 & 31.2 \\
\hline Республика Татарстан & 3.06 & 4.58 & 35.0 \\
\hline Ростовская область & 2.64 & 4.80 & 30.1 \\
\hline Нижегородская область & 2.41 & 4.21 & 31.1 \\
\hline Самарская область & 2.36 & 4.38 & 31.4 \\
\hline Челябинская область & 2.35 & 4.10 & 31.8 \\
\hline Красноярский край & 2.19 & 4.13 & 39.4 \\
\hline Республика Башкортостан & 2.15 & 3.94 & 33.9 \\
\hline Новосибирская область & 2.02 & 4.69 & 37.2 \\
\hline Иркутская область & 1.72 & 4.22 & 38.0 \\
\hline Приморский край & 1.26 & 4.45 & 44.5 \\
\hline Оренбургская область & 1.22 & 4.19 & 27.2 \\
\hline Белгородская область & 1.16 & 4.40 & 29.2 \\
\hline Удмуртская Республика & 1.08 & 4.11 & 27.9 \\
\hline Хабаровский край & 1.06 & 4.42 & 43.1 \\
\hline Тюменская область & 0.98 & 4.01 & 45.2 \\
\hline Ханты-Мансийский автономный округ - Югра & 0.98 & 2.12 & 60.7 \\
\hline Республика Саха (Якутия) & 0.90 & 4.16 & 57.3 \\
\hline Тульская область & 0.86 & 3.66 & 30.7 \\
\hline Ульяновская область & 0.85 & 4.62 & 27.1 \\
\hline Курская область & 0.81 & 4.46 & 27.5 \\
\hline Орловская область & 0.68 & 5.71 & 27.8 \\
\hline Ивановская область & 0.66 & 5.81 & 25.8 \\
\hline Республика Северная Осетия - Алания & 0.52 & 7.40 & 23.2 \\
\hline Кабардино-Балкарская Республика & 0.38 & 5.46 & 25.0 \\
\hline Республика Адыгея & 0.29 & 6.02 & 27.1 \\
\hline Карачаево-Черкесская Республика & 0.28 & 5.78 & 21.6 \\
\hline Республика Тыва & 0.23 & 5.46 & 29.7 \\
\hline Республика Калмыкия & 0.18 & 5.50 & 22.7 \\
\hline
\end{tabular}




\section{Обувь}

$\left.47\right|_{0} ^{\text {Доля занятых, \% }} 0.1$

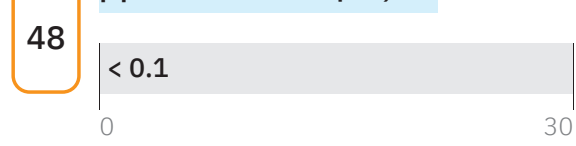

54

Заработная плата, тыс. руб.

X Ранг отрасли среди торгуемых отраслей

\section{Регионы, специализирующиеся в отрасли}
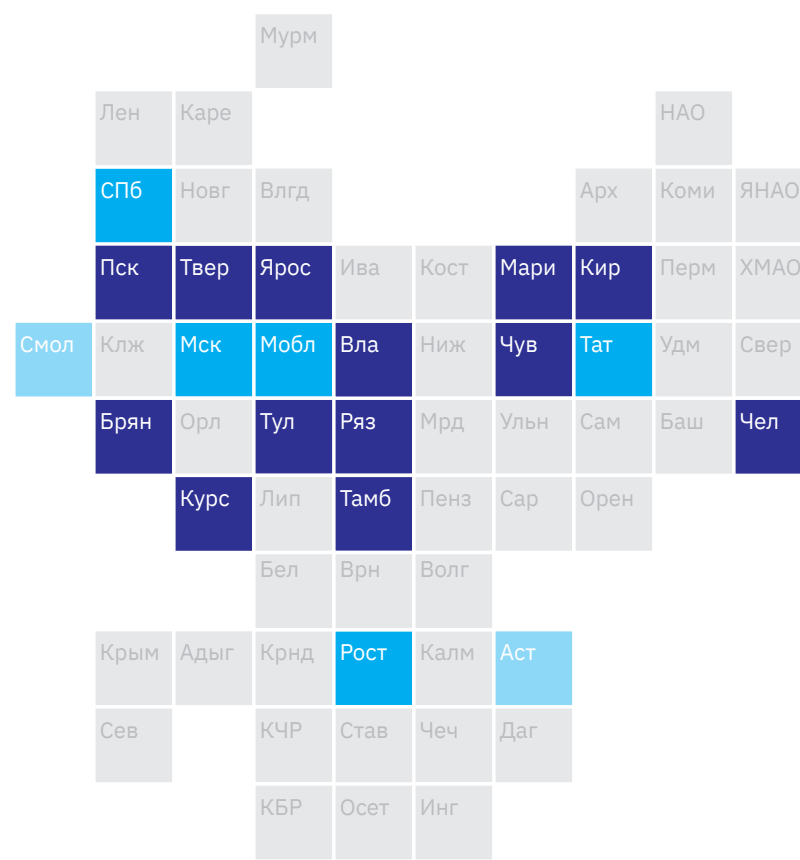

Отрасль национальной и локальной значимости
Отрасль национальной значимости

\begin{tabular}{|c|c|c|c|}
\hline & $\begin{array}{l}\text { Доля региона } \\
\text { в отраслевой } \\
\text { занятости, \% }\end{array}$ & $\begin{array}{l}\text { Доля отрасли } \\
\text { в региональной } \\
\text { занятости, \% }\end{array}$ & $\begin{array}{l}\text { Заработная } \\
\text { плата, } \\
\text { тыс. руб. }\end{array}$ \\
\hline Тверская область & 8.66 & 0.84 & 26.3 \\
\hline Рязанская область & 7.86 & 0.87 & 35.2 \\
\hline Кировская область & 7.33 & 0.70 & 26.0 \\
\hline Челябинская область & 7.27 & 0.24 & 24.5 \\
\hline Ярославская область & 4.75 & 0.40 & 36.9 \\
\hline Тамбовская область & 3.94 & 0.52 & 21.6 \\
\hline Владимирская область & 3.64 & 0.33 & 24.3 \\
\hline Тульская область & 3.42 & 0.28 & 25.6 \\
\hline Чувашская Республика & 2.99 & 0.35 & 24.2 \\
\hline Курская область & 2.93 & 0.31 & 24.7 \\
\hline Республика Марий Эл & 2.68 & 0.53 & 27.1 \\
\hline Брянская область & 2.41 & 0.27 & 15.2 \\
\hline Псковская область & 2.37 & 0.46 & 25.8 \\
\hline Москва & 6.90 & 0.05 & 52.7 \\
\hline Московская область & 5.51 & 0.09 & 28.6 \\
\hline Республика Татарстан & 3.26 & 0.09 & 20.9 \\
\hline Санкт-Петербург & 3.06 & 0.06 & 32.4 \\
\hline Ростовская область & 2.99 & 0.10 & 25.0 \\
\hline Томская область & 1.39 & 0.15 & 14.2 \\
\hline Смоленская область & 1.33 & 0.17 & 26.8 \\
\hline Астраханская область & 0.93 & 0.13 & 14.2 \\
\hline
\end{tabular}




\section{Огнеупорные материалы и резиновые изделия}
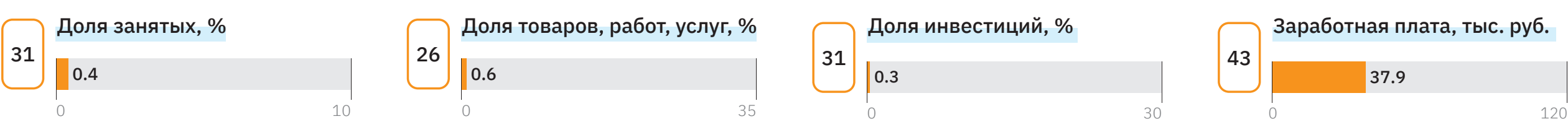

X Ранг отрасли среди торгуемых отраслей

Регионы, специализирующиеся в отрасли

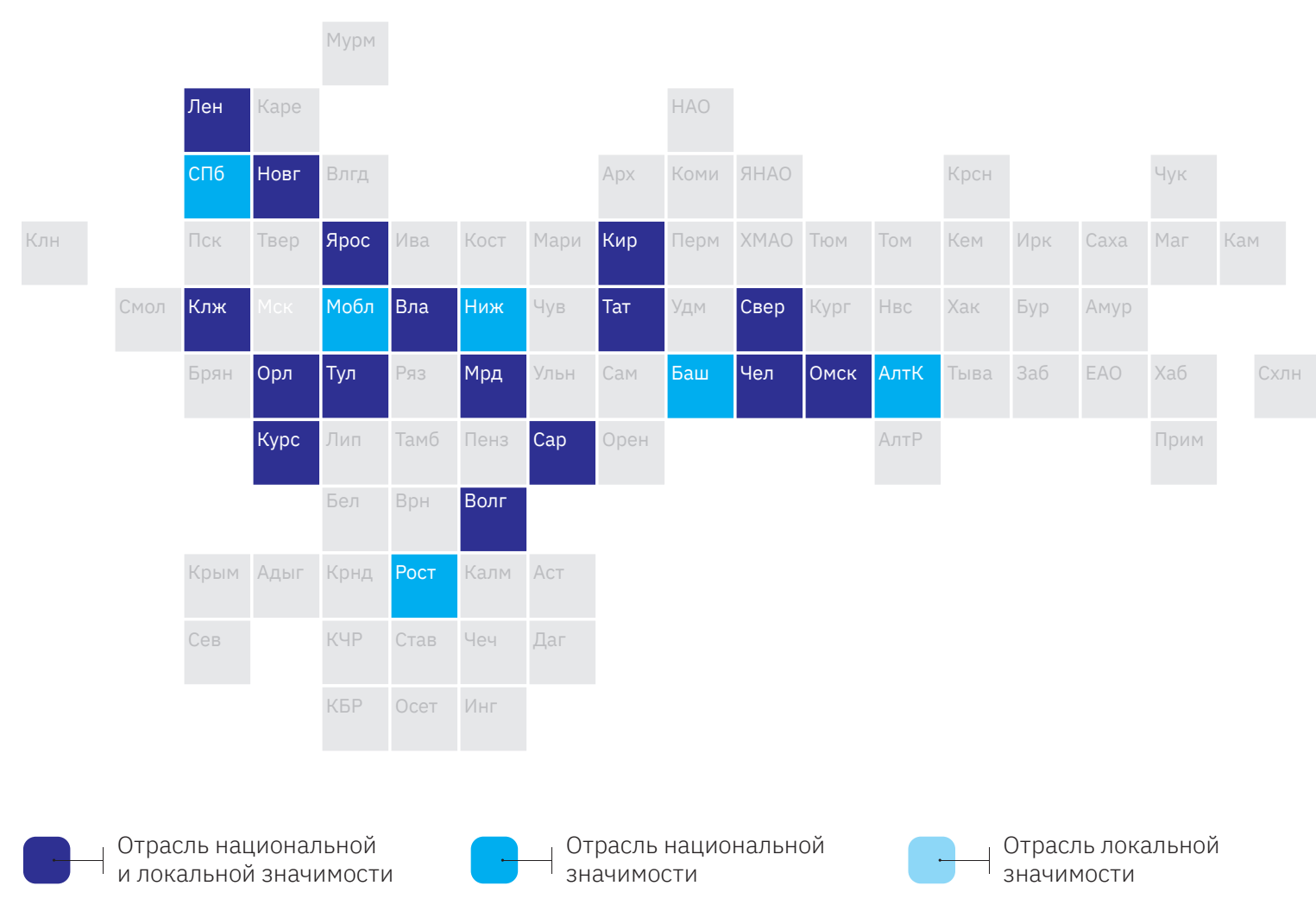

\begin{tabular}{|c|c|c|c|}
\hline & $\begin{array}{l}\text { Доля региона } \\
\text { в отраслевой } \\
\text { занятости, \% }\end{array}$ & $\begin{array}{l}\text { Доля отрасли } \\
\text { в региональной } \\
\text { занятости, \% }\end{array}$ & $\begin{array}{l}\text { Заработная } \\
\text { плата, } \\
\text { тыс. руб. }\end{array}$ \\
\hline Свердловская область & 6.71 & 0.81 & 37.2 \\
\hline Республика Татарстан & 6.14 & 0.87 & 44.2 \\
\hline Челябинская область & 6.13 & 1.02 & 34.0 \\
\hline Калужская область & 3.70 & 2.07 & 64.1 \\
\hline Саратовская область & 3.63 & 0.99 & 25.4 \\
\hline Владимирская область & 3.51 & 1.58 & 33.7 \\
\hline Ярославская область & 3.27 & 1.39 & 32.5 \\
\hline Ленинградская область & 2.97 & 1.06 & 58.0 \\
\hline Тульская область & 2.95 & 1.19 & 30.7 \\
\hline Волгоградская область & 2.91 & 0.85 & 33.1 \\
\hline Новгородская область & 2.75 & 2.58 & 36.1 \\
\hline Омская область & 2.50 & 0.84 & 30.9 \\
\hline Курская область & 2.14 & 1.12 & 32.6 \\
\hline Кировская область & 1.94 & 0.92 & 37.2 \\
\hline Орловская область & 1.70 & 1.35 & 42.2 \\
\hline Республика Мордовия & 1.36 & 1.03 & 26.5 \\
\hline Московская область & 8.69 & 0.71 & 49.5 \\
\hline Республика Башкортостан & 3.41 & 0.59 & 38.6 \\
\hline Ростовская область & 2.90 & 0.50 & 34.7 \\
\hline Нижегородская область & 2.84 & 0.47 & 44.3 \\
\hline Санкт-Петербург & 2.69 & 0.25 & 39.0 \\
\hline Алтайский край & 2.22 & 0.71 & 28.3 \\
\hline
\end{tabular}




\section{Одежда}

\begin{tabular}{|c|c|c|c|}
\hline & Доля занятых, \% & & Доля товаров, работ, услуг, \% \\
\hline 40 & 0.2 & 45 & $<0.1$ \\
\hline
\end{tabular}

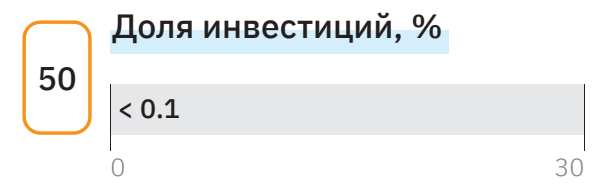

55

Заработная плата, тыс. руб.

X Ранг отрасли среди торгуемых отраслей

\section{Регионы, специализирующиеся в отрасли}

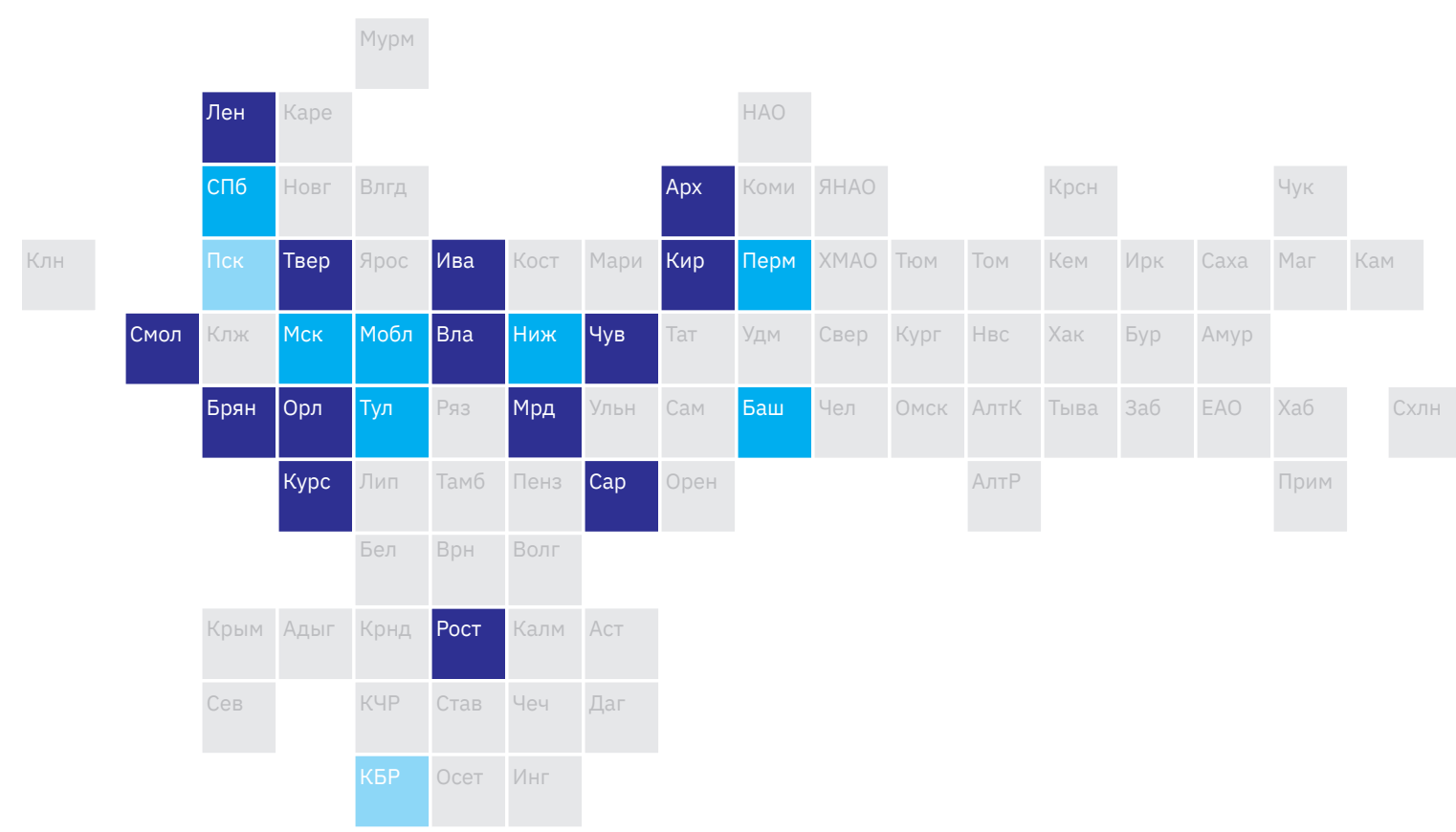

Отрасль национальной и локальной значимости
Отрасль национальной значимости

\begin{tabular}{|l|l|ll|} 
& $\begin{array}{l}\text { Доля региона } \\
\text { В отраслевой } \\
\text { занятости, \% }\end{array}$ & $\begin{array}{l}\text { Доля отрасли } \\
\text { занятонасти, \% }\end{array}$ & $\begin{array}{l}\text { 3аработная } \\
\text { плата, } \\
\text { тыс. руб. }\end{array}$ \\
\hline Ростовская область & 9.32 & 0.90 & 25.8 \\
\hline Республика Мордовия & 6.28 & 2.65 & 7.4 \\
\hline Чувашская Республика & 5.12 & 1.67 & 11.5 \\
\hline Кировская область & 4.41 & 1.18 & 10.4 \\
\hline Смоленская область & 4.16 & 1.48 & 22.7 \\
\hline Ивановская область & 2.77 & 1.31 & 11.5 \\
\hline Курская область & 2.75 & 0.81 & 10.6 \\
\hline Владимирская область & 2.70 & 0.68 & 14.2 \\
\hline Орловская область & 2.62 & 1.17 & 5.5 \\
\hline Саратовская область & 2.51 & 0.38 & 7.5 \\
\hline Тверская область & 2.50 & 0.68 & 18.8 \\
\hline Ленинградская область & 1.83 & 0.36 & 22.9 \\
\hline Брянская область & 1.71 & 0.54 & 16.3 \\
\hline Архангельская область & 1.65 & 0.43 & 5.3 \\
\hline Московская область & 6.19 & 0.28 & 32.8 \\
\hline Москва & 3.36 & 0.07 & 67.1 \\
\hline Нижегородская область & 3.03 & 0.28 & 22.5 \\
\hline Пермский край & 2.46 & 0.31 & 8.5 \\
\hline Республика Башкортостан & 2.38 & 0.23 & 16.5 \\
\hline Санкт-Петербург & 1.94 & 0.10 & 52.3 \\
\hline Тульская область & 1.31 & 0.30 & 25.2 \\
\hline Псковская область & 1.14 & 0.62 & 32.0 \\
\hline Кабардино-Балкарская Республика & 0.82 & 0.62 & 14.2 \\
\hline
\end{tabular}




\section{Оптовая торговля и электронная коммерция}

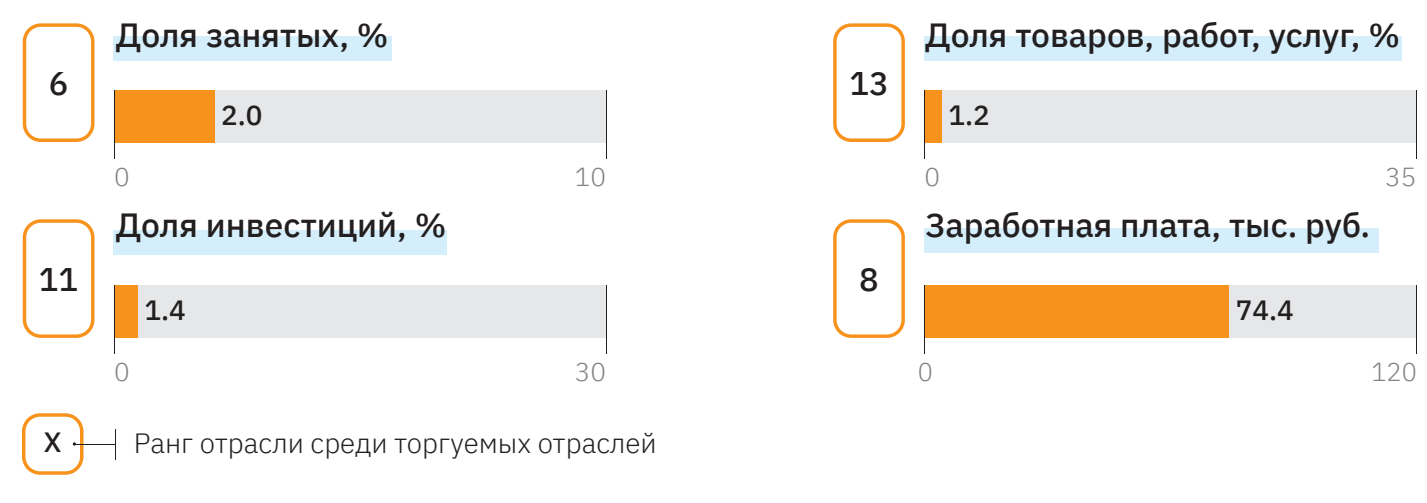

Регионы, специализирующиеся в отрасли

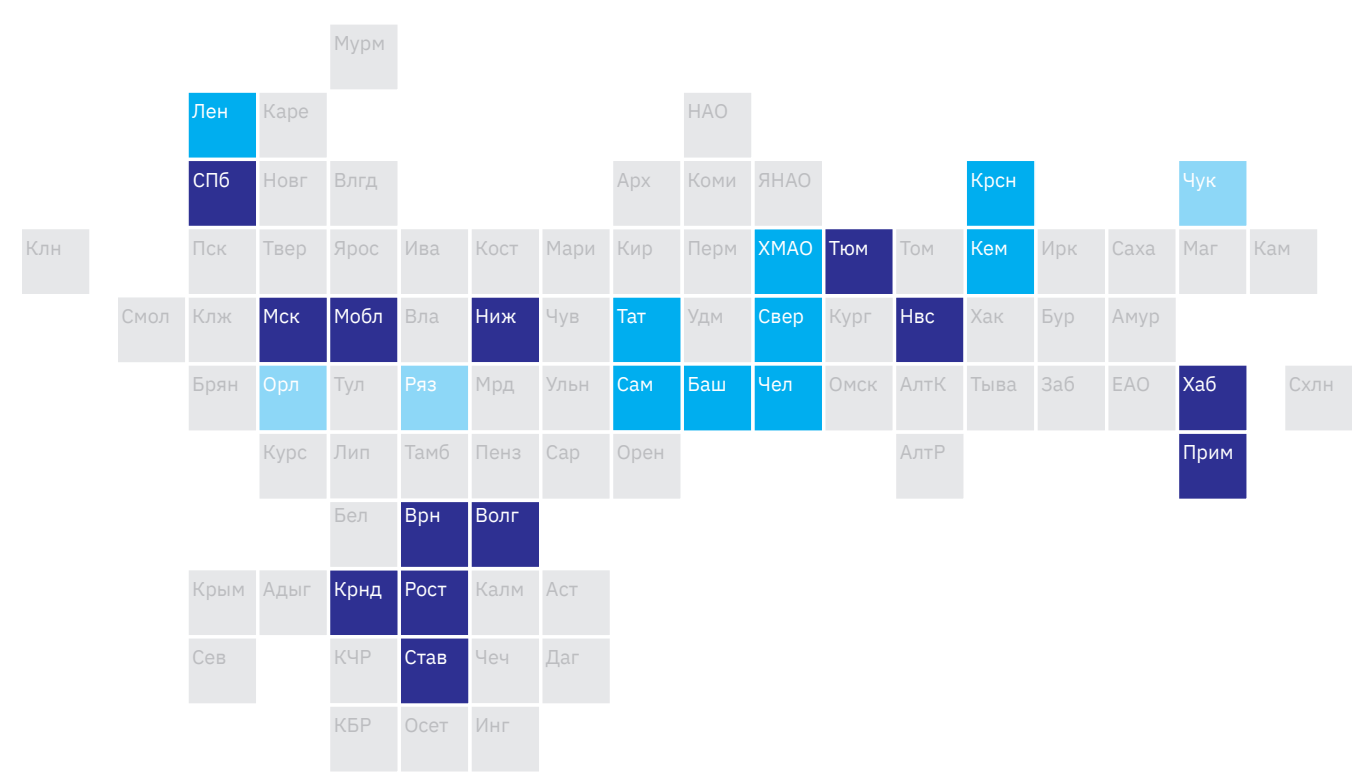
и локальной значимости

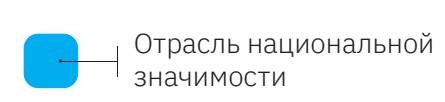
значимости

\begin{tabular}{|c|c|c|c|}
\hline & $\begin{array}{l}\text { Доля региона } \\
\text { в отраслевой } \\
\text { занятости, \% }\end{array}$ & $\begin{array}{l}\text { Доля отрасли } \\
\text { в региональной } \\
\text { занятости, \% }\end{array}$ & $\begin{array}{l}\text { Заработная } \\
\text { плата, } \\
\text { тыс. руб. }\end{array}$ \\
\hline Москва & 23.73 & 4.61 & 143 \\
\hline Московская область & 10.34 & 4.20 & 70.7 \\
\hline Санкт-Петербург & 6.49 & 2.94 & 106.2 \\
\hline Краснодарский край & 3.35 & 2.18 & 46.6 \\
\hline Ростовская область & 3.35 & 2.86 & 44.1 \\
\hline Нижегородская область & 2.79 & 2.29 & 37.9 \\
\hline Новосибирская область & 2.23 & 2.44 & 55.1 \\
\hline Воронежская область & 2.01 & 2.78 & 37.7 \\
\hline Приморский край & 1.61 & 2.66 & 49.2 \\
\hline Ставропольский край & 1.54 & 2.30 & 37.8 \\
\hline Волгоградская область & 1.30 & 1.87 & 31.8 \\
\hline Хабаровский край & 1.06 & 2.08 & 46.7 \\
\hline Тюменская область & 1.02 & 1.97 & 49.4 \\
\hline Свердловская область & 2.49 & 1.48 & 59.0 \\
\hline Республика Татарстан & 2.19 & 1.54 & 43.9 \\
\hline Самарская область & 2.04 & 1.78 & 40.5 \\
\hline Челябинская область & 1.89 & 1.55 & 42.9 \\
\hline Красноярский край & 1.73 & 1.53 & 56.0 \\
\hline Республика Башкортостан & 1.63 & 1.40 & 37.6 \\
\hline Кемеровская область & 0.88 & 0.93 & 57.0 \\
\hline Ханты-Мансийский автономный округ - Югра & 0.87 & 0.89 & 70.6 \\
\hline Ленинградская область & 0.81 & 1.43 & 46.6 \\
\hline Рязанская область & 0.69 & 1.89 & 48.1 \\
\hline Орловская область & 0.55 & 2.19 & 37.7 \\
\hline Чукотский автономный округ & 0.10 & 2.39 & 95.8 \\
\hline
\end{tabular}




\section{Офисное оборудование и товары для досуга}
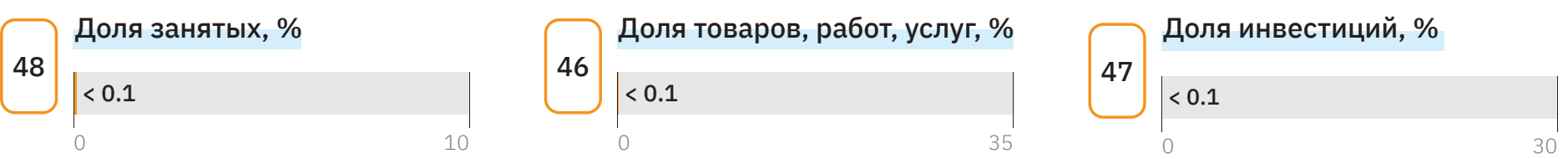

$\left.50\right|_{0} ^{28.5}$

X Ранг отрасли среди торгуемых отраслей

\section{Регионы, специализирующиеся в отрасли}

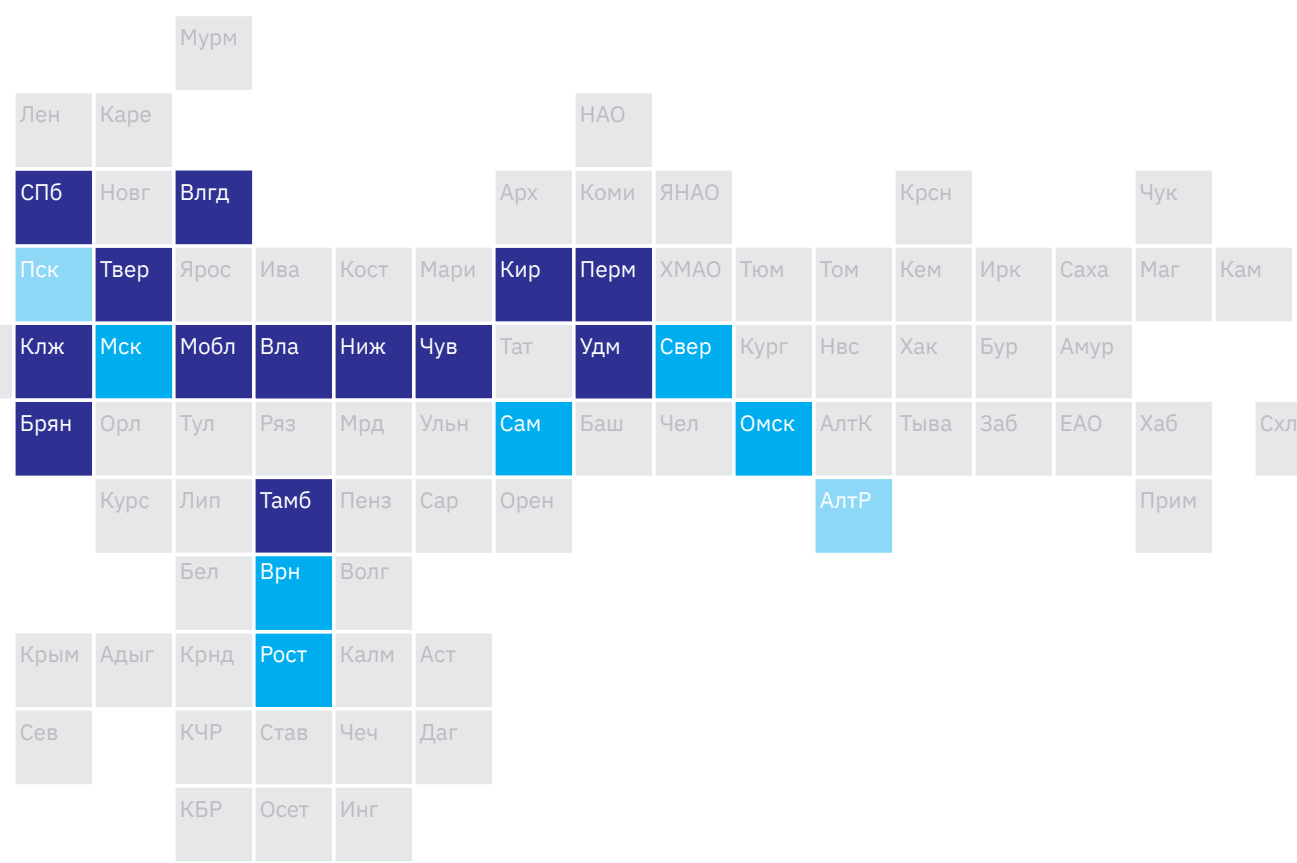

\begin{tabular}{|c|c|c|c|}
\hline & $\begin{array}{l}\text { Доля региона } \\
\text { в отраслевой } \\
\text { занятости, \% }\end{array}$ & $\begin{array}{l}\text { Доля отрасли } \\
\text { в региональной } \\
\text { занятости, \% }\end{array}$ & $\begin{array}{l}\text { Заработная } \\
\text { плата, } \\
\text { тыс. руб. }\end{array}$ \\
\hline Московская область & 14.29 & 0.19 & 41.7 \\
\hline Санкт-Петербург & 8.75 & 0.13 & 32.1 \\
\hline Тамбовская область & 7.34 & 0.81 & 28.9 \\
\hline Пермский край & 6.81 & 0.26 & 30.5 \\
\hline Нижегородская область & 5.19 & 0.14 & 19.9 \\
\hline Брянская область & 4.26 & 0.40 & 26.0 \\
\hline Калужская область & 3.87 & 0.36 & 33.6 \\
\hline Кировская область & 3.55 & 0.28 & 22.6 \\
\hline Тверская область & 2.91 & 0.24 & 11.0 \\
\hline Вологодская область & 2.51 & 0.21 & 29.0 \\
\hline Удмуртская Республика & 2.27 & 0.14 & 27.9 \\
\hline Чувашская Республика & 1.98 & 0.19 & 42.0 \\
\hline Владимирская область & 1.70 & 0.13 & 25.2 \\
\hline Ростовская область & 3.48 & 0.10 & 24.6 \\
\hline Воронежская область & 3.08 & 0.14 & 34.5 \\
\hline Москва & 2.20 & 0.01 & 80.6 \\
\hline Самарская область & 2.15 & 0.06 & 19.0 \\
\hline Омская область & 2.01 & 0.11 & 13.4 \\
\hline Свердловская область & 1.97 & 0.04 & 26.4 \\
\hline Псковская область & 1.02 & 0.17 & 19.3 \\
\hline Республика Алтай & 0.42 & 0.23 & 7.0 \\
\hline
\end{tabular}




\section{Очистка и распределение воды, обработка отходов}

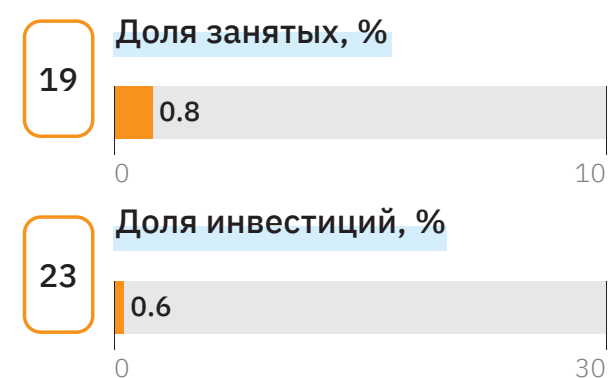

$\mathrm{x}-$ Ранг отрасли среди торгуемых отраслей

Регионы, специализирующиеся в отрасли

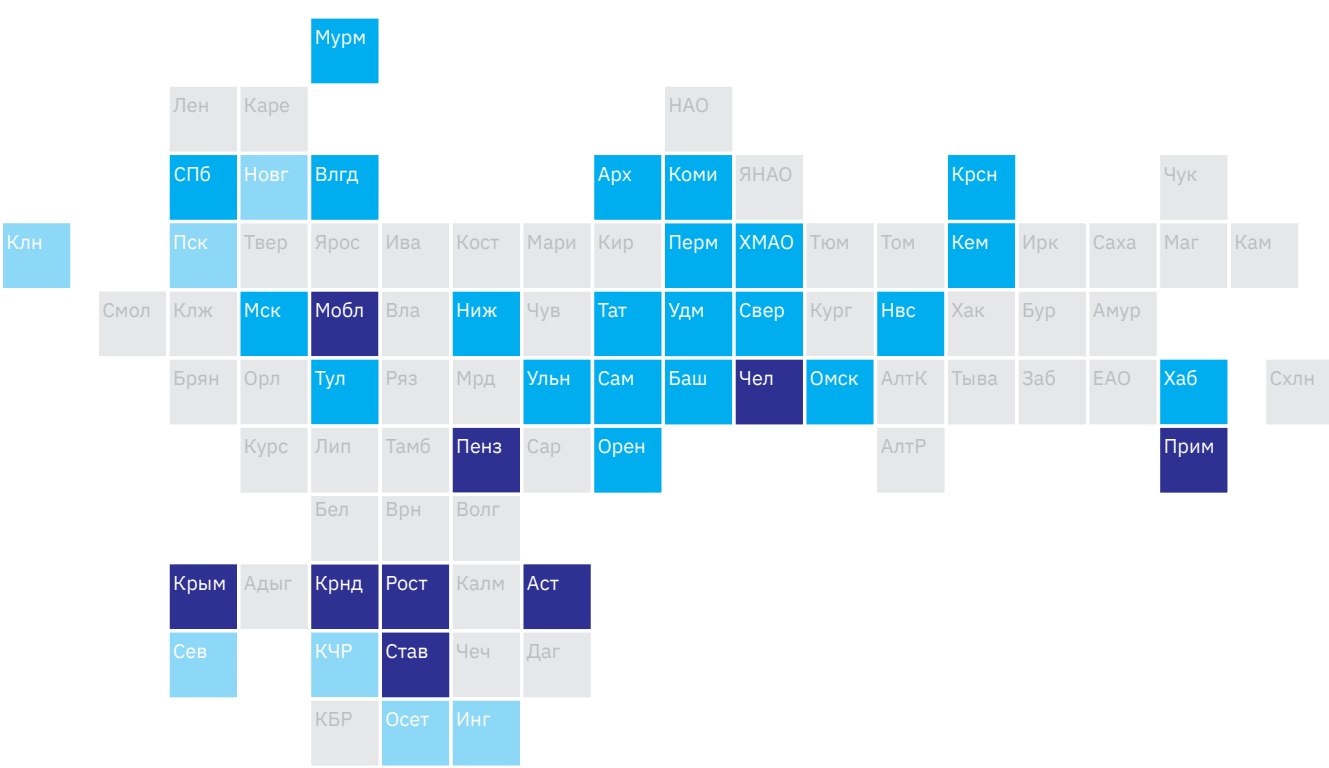

и локальной значимости

Отрасль национальной значимости

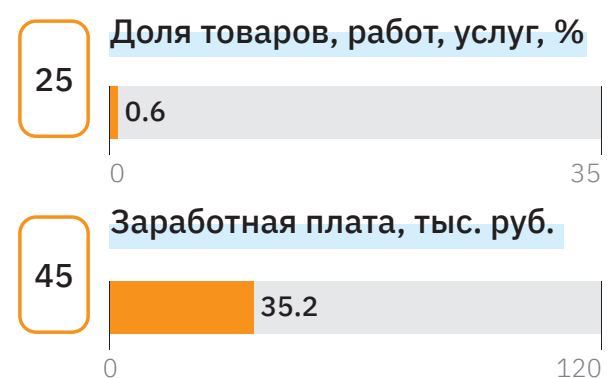

20

\begin{tabular}{|l|lll|} 
& $\begin{array}{c}\text { Доля региона } \\
\text { В Отраслевой }\end{array}$ & $\begin{array}{l}\text { Доля отрасли } \\
\text { в региональной }\end{array}$ & $\begin{array}{l}\text { Заработная } \\
\text { плата, }\end{array}$ \\
\hline занятости, \% & занятости, \% & тыс. руб. \\
\hline Московская область & 6.56 & 1.01 & 35.7 \\
\hline Ростовская область & 4.57 & 1.48 & 25.0 \\
\hline Краснодарский край & 4.14 & 1.03 & 27.7 \\
\hline Челябинская область & 3.52 & 1.10 & 30.5 \\
\hline Ставропольский край & 2.95 & 1.68 & 24.1 \\
\hline Республика Крым & 1.78 & 1.43 & 28.4 \\
\hline Приморский край & 1.67 & 1.05 & 33.4 \\
\hline Астраханская область & 1.03 & 1.39 & 22.4 \\
\hline Пензенская область & 0.91 & 0.97 & 22.4 \\
\hline Москва & 5.87 & 0.43 & 91.2 \\
\hline Свердловская область & 4.21 & 0.95 & 35.1 \\
\hline Красноярский край & 3.06 & 1.03 & 58.0 \\
\hline Самарская область & 2.57 & 0.85 & 26.7 \\
\hline Нижегородская область & 2.56 & 0.80 & 32.5 \\
\hline Республика Татарстан & 2.43 & 0.65 & 30.4 \\
\hline Кемеровская область & 2.08 & 0.84 & 28.8 \\
\hline Новосибирская область & 2.06 & 0.86 & 29.9 \\
\hline Республика Башкортостан & 2.03 & 0.66 & 28.4 \\
\hline Санкт-Петербург & 1.93 & 0.33 & 57.1 \\
\hline Ханты-Мансийский автономный округ - Югра & 1.85 & 0.72 & 45.4 \\
\hline Пермский край & 1.78 & 0.76 & 30.8 \\
\hline Оренбургская область & 1.38 & 0.85 & 27.6 \\
\hline Тульская область & 1.14 & 0.87 & 25.3 \\
\hline Омская область & 1.13 & 0.71 & 27.8 \\
\hline Архангельская область & 1.10 & 0.95 & 39.7 \\
\hline Вологодская область & 1.09 & 1.04 & 39.5 \\
\hline Республика Коми & 0.95 & 0.96 & 38.1 \\
\hline Ульяновская область & 0.95 & 0.93 & 24.1 \\
\hline удмуртская Республика & 0.86 & 0.59 & 28.2 \\
\hline Хабаровский край & 0.84 & 0.63 & 41.0 \\
\hline Мурманская область & 0.80 & 0.91 & 59.1 \\
\hline Псковская область & 0.62 & 1.13 & 21.2 \\
\hline Новгородская область & 0.61 & 1.08 & 24.6 \\
\hline Калининградская область & 0.60 & 0.80 & 28.1 \\
\hline Республика Северная Осетия -Алания & 0.40 & 1.03 & 20.9 \\
\hline Севастополь & 0.40 & 1.38 & 34.2 \\
\hline Карачаево-Черкесская Республика & 0.25 & 0.94 & 18.2 \\
\hline Республика Ингушетия & 0.22 & 1.20 & 16.9 \\
\hline
\end{tabular}




\section{Первичные металлические изделия}
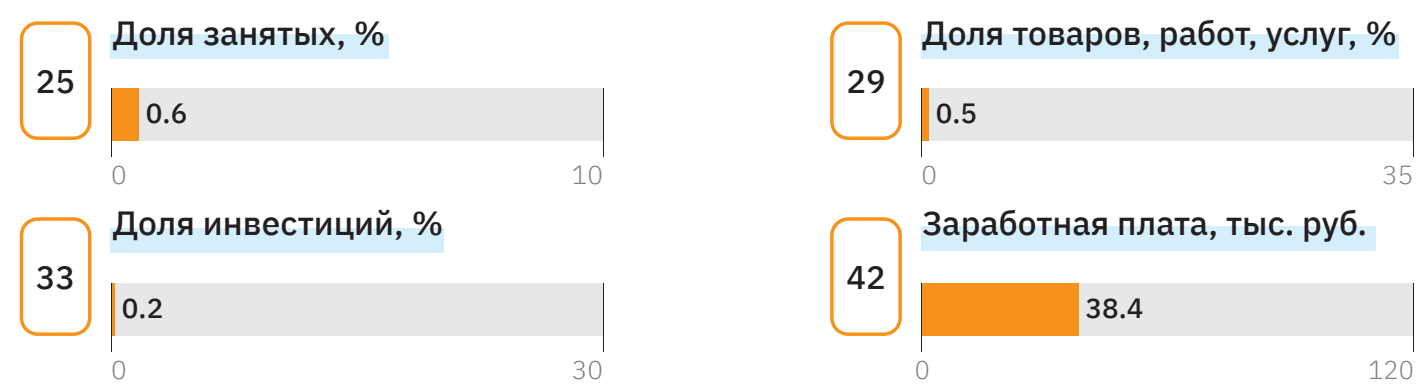

$\mathrm{X}-$ Ранг отрасли среди торгуемых отраслей

Регионы, специализирующиеся в отрасли

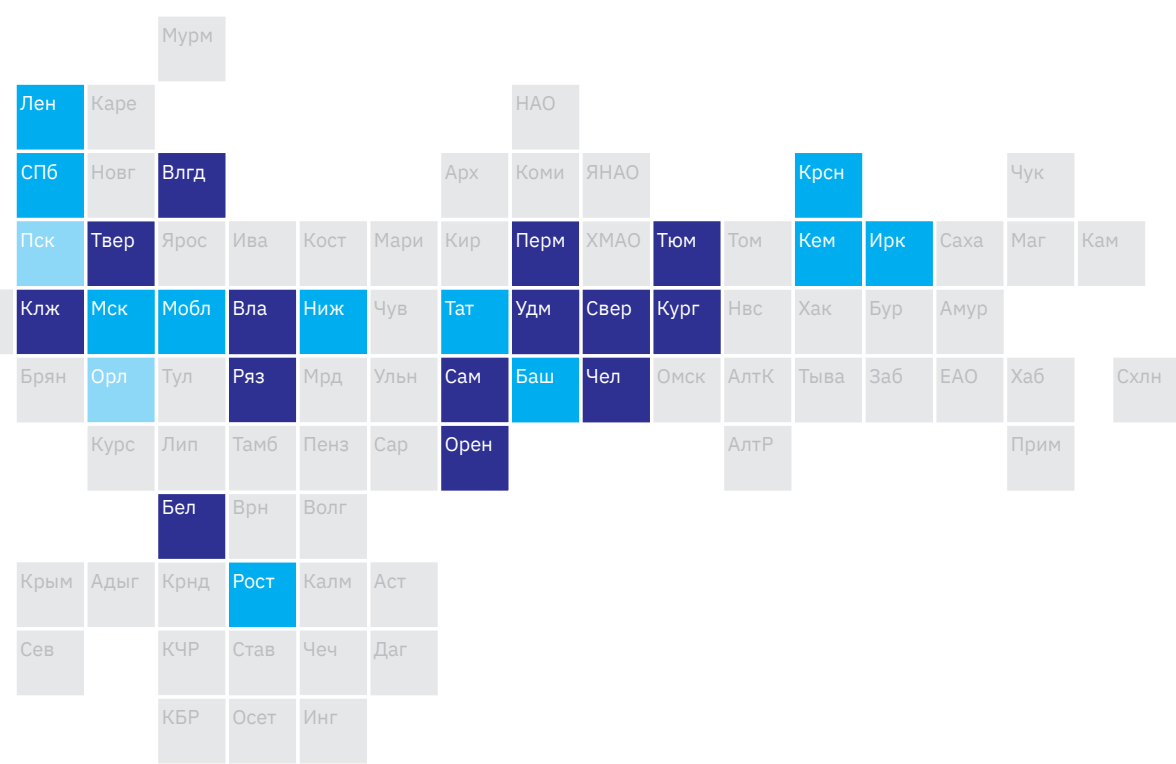

\begin{tabular}{|c|c|c|c|}
\hline & $\begin{array}{l}\text { Доля региона } \\
\text { в отраслевой } \\
\text { занятости, \% }\end{array}$ & $\begin{array}{l}\text { Доля отрасли } \\
\text { в региональной } \\
\text { занятости, \% }\end{array}$ & $\begin{array}{l}\text { Заработная } \\
\text { плата, } \\
\text { тыс. руб. }\end{array}$ \\
\hline Самарская область & 7.65 & 1.86 & 40.2 \\
\hline Свердловская область & 7.08 & 1.18 & 36.7 \\
\hline Челябинская область & 6.58 & 1.51 & 38.4 \\
\hline Белгородская область & 3.75 & 1.86 & 38.1 \\
\hline Пермский край & 3.03 & 0.94 & 36.0 \\
\hline Оренбургская область & 2.86 & 1.29 & 22.7 \\
\hline Калужская область & 2.02 & 1.56 & 35.9 \\
\hline Курганская область & 1.96 & 2.04 & 43.6 \\
\hline Тюменская область & 1.86 & 1.00 & 44.2 \\
\hline Рязанская область & 1.84 & 1.41 & 29.9 \\
\hline Владимирская область & 1.72 & 1.07 & 39.3 \\
\hline Удмуртская Республика & 1.63 & 0.81 & 32.8 \\
\hline Тверская область & 1.58 & 1.07 & 26.7 \\
\hline Вологодская область & 1.37 & 0.96 & 53.8 \\
\hline Московская область & 5.41 & 0.61 & 52.0 \\
\hline Республика Татарстан & 3.79 & 0.74 & 37.1 \\
\hline Санкт-Петербург & 3.78 & 0.48 & 53.6 \\
\hline Республика Башкортостан & 3.57 & 0.86 & 25.8 \\
\hline Кемеровская область & 2.76 & 0.81 & 29.2 \\
\hline Нижегородская область & 2.60 & 0.60 & 33.5 \\
\hline Ростовская область & 2.01 & 0.48 & 30.1 \\
\hline Красноярский край & 1.97 & 0.49 & 51.3 \\
\hline Ленинградская область & 1.76 & 0.87 & 50.5 \\
\hline Иркутская область & 1.31 & 0.42 & 52.3 \\
\hline Москва & 1.22 & 0.07 & 62.9 \\
\hline Псковская область & 0.93 & 1.24 & 44.8 \\
\hline Орловская область & 0.91 & 1.00 & 31.5 \\
\hline
\end{tabular}




\section{Пластмассовые изделия}
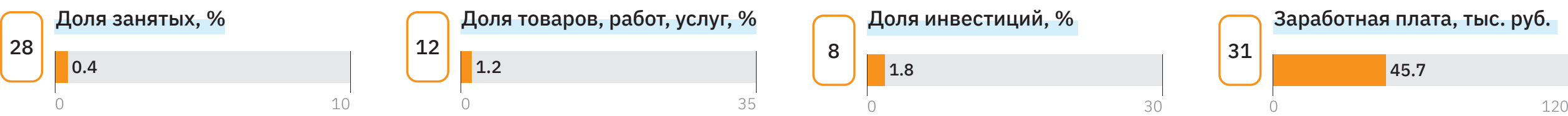

X- Ранг отрасли среди торгуемых отраслей

\section{Регионы, специализирующиеся в отрасли}

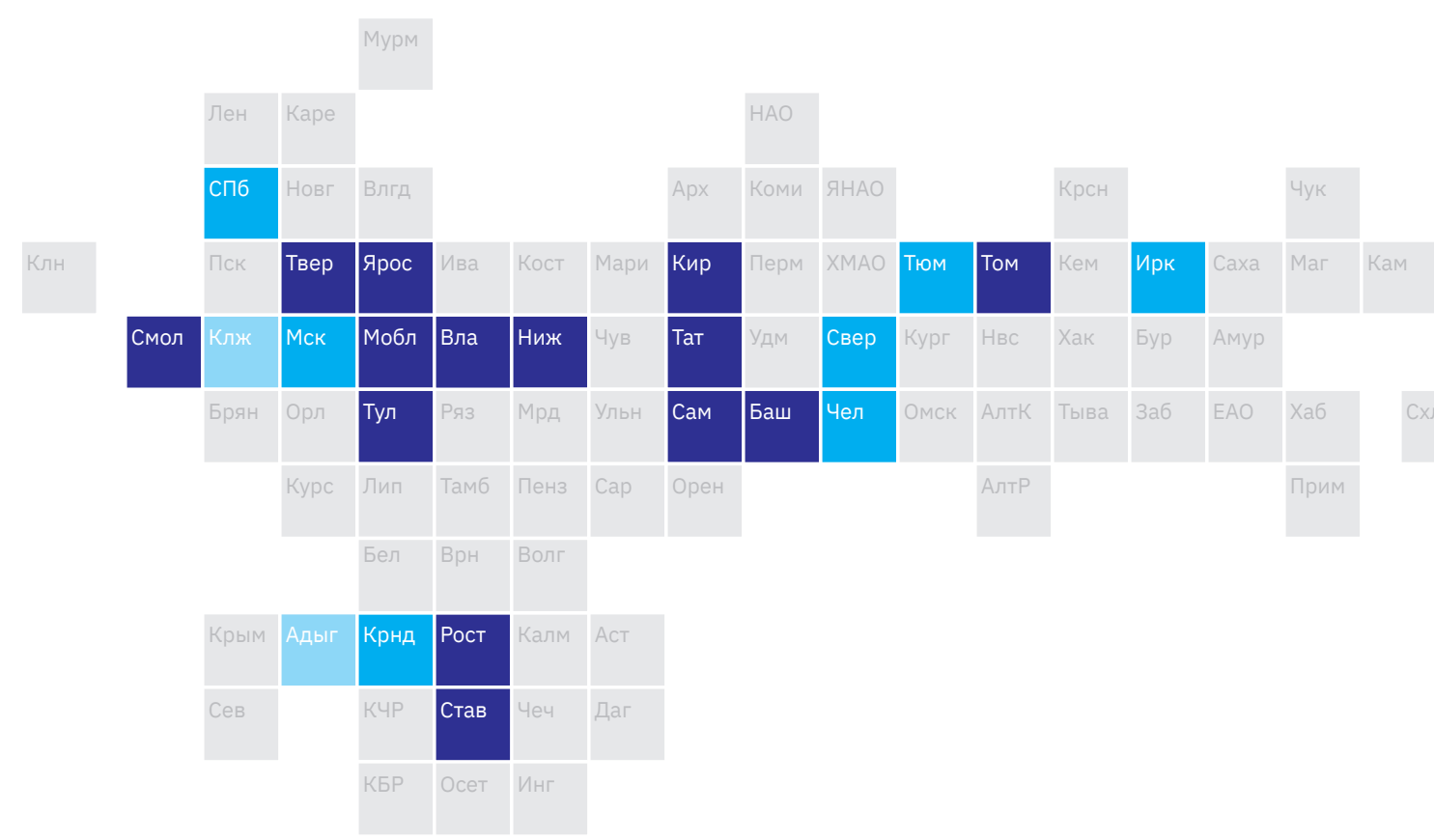

Отрасль национальной и локальной значимости

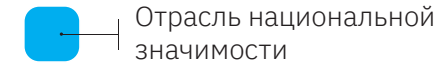

значимости

\begin{tabular}{|l|l|ll|} 
& $\begin{array}{l}\text { Доля региона } \\
\text { В отраслевой } \\
\text { занятости, \% }\end{array}$ & $\begin{array}{l}\text { Доля отрасли } \\
\text { занятонасти, \% }\end{array}$ & $\begin{array}{l}\text { 3аработная } \\
\text { плата, } \\
\text { тыс. руб. }\end{array}$ \\
\hline Московская область & 14.29 & 1.20 & 46.1 \\
\hline Республика Татарстан & 10.75 & 1.57 & 48.3 \\
\hline Республика Башкортостан & 6.99 & 1.25 & 53.1 \\
\hline Самарская область & 6.23 & 1.13 & 50.1 \\
\hline Ростовская область & 4.29 & 0.76 & 39.4 \\
\hline Нижегородская область & 3.91 & 0.67 & 43.6 \\
\hline Смоленская область & 3.46 & 2.25 & 32.8 \\
\hline Владимирская область & 2.42 & 1.12 & 39.8 \\
\hline Тверская область & 2.08 & 1.04 & 41.2 \\
\hline Ярославская область & 2.04 & 0.89 & 39.7 \\
\hline Тульская область & 1.90 & 0.79 & 36.0 \\
\hline Кировская область & 1.73 & 0.85 & 37.2 \\
\hline Ставропольский край & 1.67 & 0.52 & 48.7 \\
\hline Томская область & 1.64 & 0.92 & 66.2 \\
\hline Москва & 3.65 & 0.15 & 76.1 \\
\hline Санкт-Петербург & 2.81 & 0.26 & 61.1 \\
\hline Иркутская область & 2.32 & 0.56 & 43.8 \\
\hline Свердловская область & 2.30 & 0.28 & 40.9 \\
\hline Тюменская область & 1.76 & 0.70 & 120.8 \\
\hline Краснодарский край & 1.63 & 0.22 & 36.8 \\
\hline Челябинская область & 1.47 & 0.25 & 29.4 \\
\hline Калужская область & 1.09 & 0.63 & 46.8 \\
\hline Республика Адыгея & 0.61 & 1.21 & 34.0 \\
\hline
\end{tabular}




\section{Полиграфия и печать}
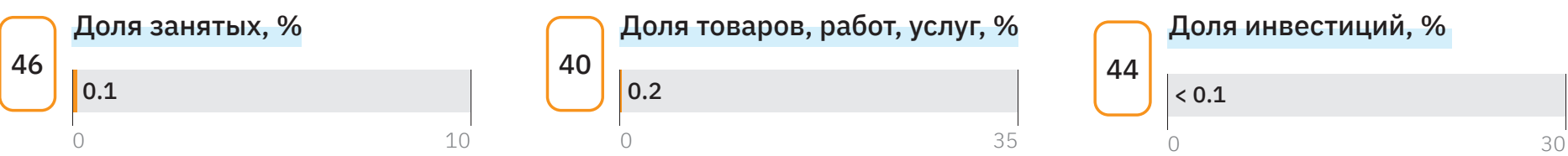

27

Заработная плата, тыс. руб.

X Ранг отрасли среди торгуемых отраслей

\section{Регионы, специализирующиеся в отрасли}

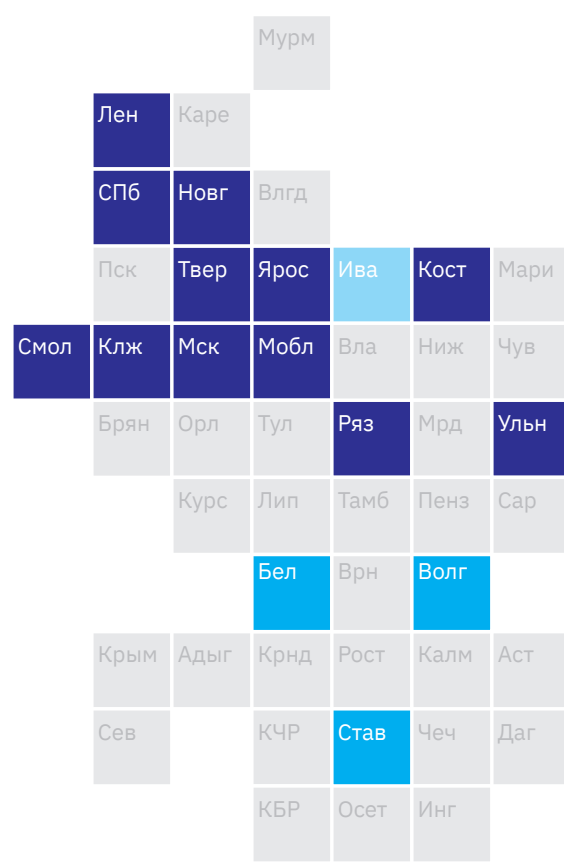

Отрасль национальной и локальной значимости

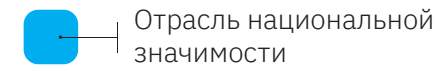

значимости

\begin{tabular}{|c|c|c|c|}
\hline & $\begin{array}{l}\text { Доля региона } \\
\text { в отраслевой } \\
\text { занятости, \% }\end{array}$ & $\begin{array}{l}\text { Доля отрасли } \\
\text { в региональной } \\
\text { занятости, \% }\end{array}$ & $\begin{array}{l}\text { Заработная } \\
\text { плата, } \\
\text { тыс. руб. }\end{array}$ \\
\hline Москва & 19.95 & 0.21 & 74.6 \\
\hline Московская область & 11.79 & 0.26 & 58.9 \\
\hline Санкт-Петербург & 7.60 & 0.18 & 51.9 \\
\hline Тверская область & 6.12 & 0.79 & 30.5 \\
\hline Пермский край & 4.97 & 0.30 & 69.2 \\
\hline Республика Татарстан & 3.54 & 0.13 & 40.6 \\
\hline Ленинградская область & 3.45 & 0.32 & 53.7 \\
\hline Ульяновская область & 3.35 & 0.46 & 28.1 \\
\hline Смоленская область & 2.81 & 0.47 & 27.1 \\
\hline Калужская область & 1.73 & 0.26 & 27.7 \\
\hline Костромская область & 1.73 & 0.46 & 26.8 \\
\hline Ярославская область & 1.69 & 0.19 & 28.2 \\
\hline Рязанская область & 1.28 & 0.19 & 30.0 \\
\hline Кировская область & 1.08 & 0.14 & 25.7 \\
\hline Новгородская область & 0.89 & 0.22 & 74.9 \\
\hline Новосибирская область & 2.14 & 0.12 & 46.1 \\
\hline Свердловская область & 1.90 & 0.06 & 37.6 \\
\hline Волгоградская область & 1.44 & 0.11 & 20.6 \\
\hline Республика Башкортостан & 1.33 & 0.06 & 25.5 \\
\hline Ставропольский край & 1.08 & 0.09 & 35.5 \\
\hline Белгородская область & 1.06 & 0.10 & 37.7 \\
\hline Ивановская область & 0.81 & 0.18 & 34.7 \\
\hline
\end{tabular}




\section{Продукты питания}

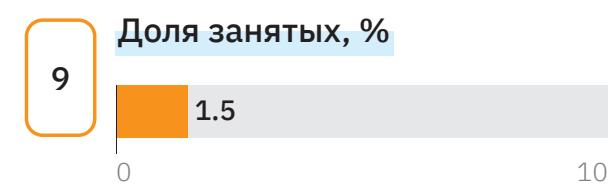

Доля инвестиций, \%

12

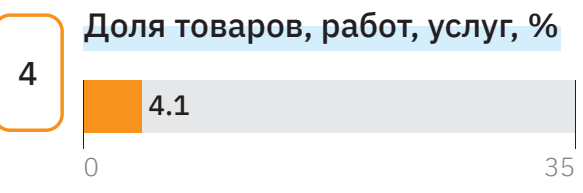

Заработная плата, тыс. руб.
39

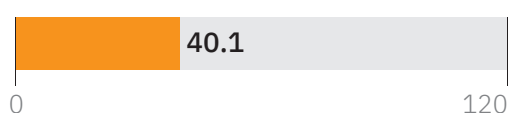

$\mathrm{X}-$ Ранг отрасли среди торгуемых отраслей

Регионы, специализирующиеся в отрасли
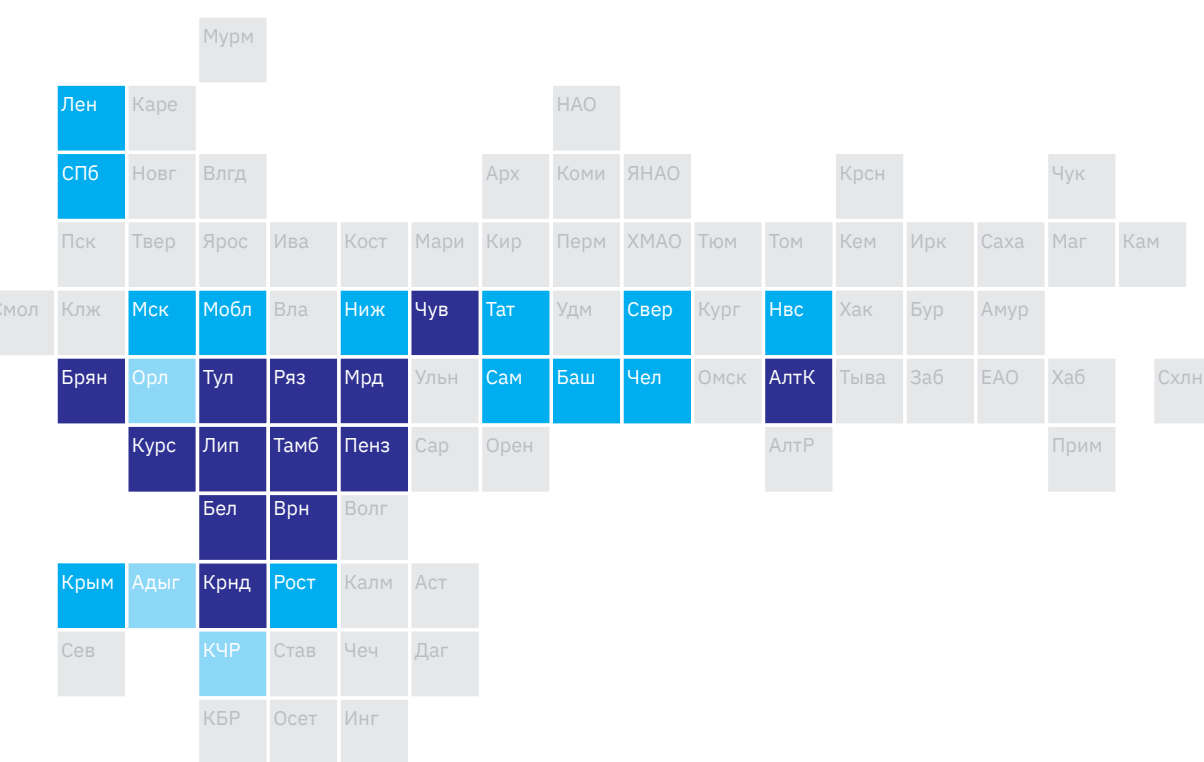

\section{Клн}

и локальной значимости

Отрасль национальной значимости
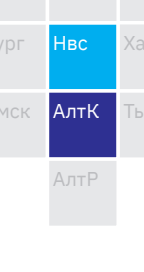

\begin{tabular}{|c|c|c|c|}
\hline & $\begin{array}{l}\text { Доля региона } \\
\text { в отраслевой } \\
\text { занятости, \% }\end{array}$ & $\begin{array}{l}\text { Доля отрасли } \\
\text { в региональной } \\
\text { занятости, \% }\end{array}$ & $\begin{array}{l}\text { Заработная } \\
\text { плата, } \\
\text { тыс. руб. }\end{array}$ \\
\hline Краснодарский край & 7.08 & 3.30 & 33.2 \\
\hline Воронежская область & 4.22 & 4.19 & 33.4 \\
\hline Белгородская область & 4.07 & 5.17 & 32.0 \\
\hline Алтайский край & 3.67 & 4.13 & 25.1 \\
\hline Липецкая область & 2.39 & 4.47 & 38.6 \\
\hline Курская область & 2.08 & 3.85 & 27.3 \\
\hline Пензенская область & 1.88 & 3.76 & 28.0 \\
\hline Тульская область & 1.83 & 2.62 & 40.1 \\
\hline Тамбовская область & 1.25 & 2.93 & 29.2 \\
\hline Брянская область & 1.20 & 2.41 & 30.4 \\
\hline Республика Мордовия & 1.19 & 3.19 & 30.6 \\
\hline Рязанская область & 1.18 & 2.31 & 33.2 \\
\hline Чувашская Республика & 1.08 & 2.22 & 28.5 \\
\hline Московская область & 7.62 & 2.21 & 64.1 \\
\hline Москва & 5.12 & 0.71 & 87.6 \\
\hline Республика Татарстан & 3.42 & 1.72 & 38.2 \\
\hline Санкт-Петербург & 2.47 & 0.80 & 77.4 \\
\hline Ростовская область & 2.40 & 1.47 & 34.5 \\
\hline Челябинская область & 2.39 & 1.40 & 36.2 \\
\hline Нижегородская область & 2.15 & 1.27 & 34.2 \\
\hline Новосибирская область & 2.05 & 1.60 & 41.5 \\
\hline Свердловская область & 1.97 & 0.84 & 44.6 \\
\hline Республика Башкортостан & 1.95 & 1.20 & 31.7 \\
\hline Самарская область & 1.91 & 1.19 & 38.8 \\
\hline Ленинградская область & 1.37 & 1.73 & 53.3 \\
\hline Республика Крым & 1.20 & 1.82 & 29.6 \\
\hline Республика Адыгея & 0.85 & 5.87 & 25.0 \\
\hline Орловская область & 0.72 & 2.03 & 28.3 \\
\hline Карачаево-Черкесская Республика & 0.56 & 3.91 & 21.4 \\
\hline
\end{tabular}




\section{Производство и передача электроэнергии}
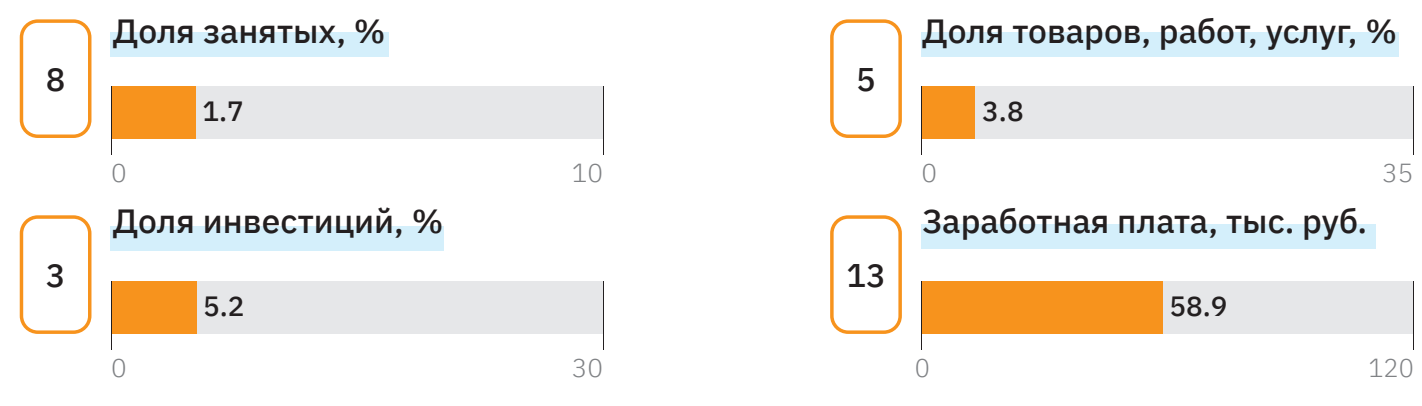

$\mathrm{x}-$ Ранг отрасли среди торгуемых отраслей

Регионы, специализирующиеся в отрасли

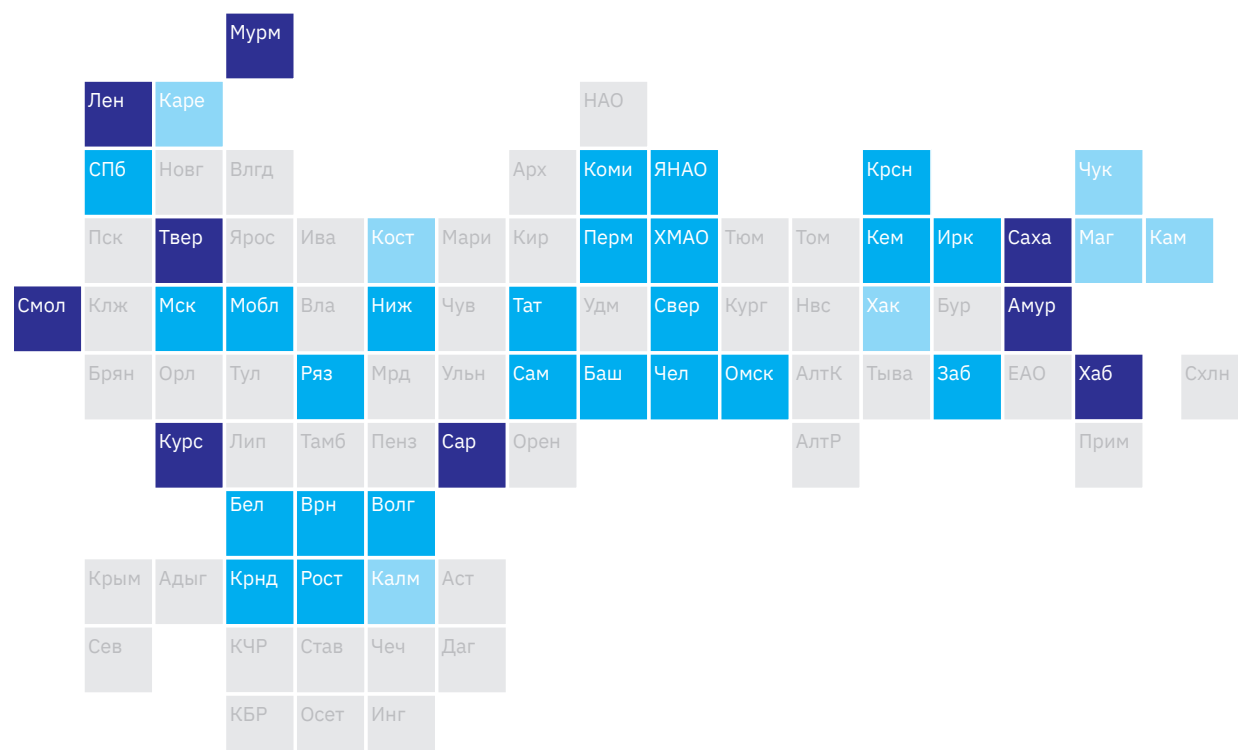

\begin{tabular}{|c|c|c|c|}
\hline & $\begin{array}{l}\text { Доля региона } \\
\text { в отраслевой } \\
\text { занятости, \% }\end{array}$ & $\begin{array}{l}\text { Доля отрасли } \\
\text { в региональной } \\
\text { занятости, \% }\end{array}$ & $\begin{array}{l}\text { Заработная } \\
\text { плата, } \\
\text { тыс. руб. }\end{array}$ \\
\hline Саратовская область & 2.65 & 3.01 & 47.3 \\
\hline Ленинградская область & 2.25 & 3.35 & 68.9 \\
\hline Тверская область & 1.76 & 3.58 & 54.7 \\
\hline Хабаровский край & 1.74 & 2.88 & 66.8 \\
\hline Смоленская область & 1.70 & 4.50 & 54.8 \\
\hline Республика Саха (Якутия) & 1.62 & 2.96 & 79.3 \\
\hline Курская область & 1.58 & 3.46 & 52.9 \\
\hline Мурманская область & 1.16 & 2.93 & 100.7 \\
\hline Амурская область & 0.95 & 2.64 & 76.3 \\
\hline Москва & 4.69 & 0.77 & 124 \\
\hline Свердловская область & 3.51 & 1.76 & 57.6 \\
\hline Ростовская область & 3.31 & 2.38 & 48.0 \\
\hline Красноярский край & 3.08 & 2.30 & 64.9 \\
\hline Московская область & 2.89 & 0.99 & 75.3 \\
\hline Республика Башкортостан & 2.56 & 1.86 & 44.7 \\
\hline Краснодарский край & 2.49 & 1.37 & 47.3 \\
\hline Ханты-Мансийский автономный округ - Югра & 2.42 & 2.08 & 100.7 \\
\hline Кемеровская область & 2.42 & 2.16 & 43.6 \\
\hline Иркутская область & 2.37 & 2.31 & 60.2 \\
\hline Республика Татарстан & 2.28 & 1.35 & 59.7 \\
\hline Пермский край & 2.00 & 1.89 & 50.5 \\
\hline Воронежская область & 1.95 & 2.29 & 55.1 \\
\hline Челябинская область & 1.93 & 1.33 & 52.9 \\
\hline Санкт-Петербург & 1.91 & 0.73 & 75.3 \\
\hline Самарская область & 1.87 & 1.38 & 41.9 \\
\hline Нижегородская область & 1.85 & 1.29 & 54.0 \\
\hline Волгоградская область & 1.62 & 1.97 & 45.3 \\
\hline Ямало-Ненецкий автономный округ & 1.24 & 2.33 & 102.4 \\
\hline Рязанская область & 1.07 & 2.47 & 45.5 \\
\hline Омская область & 1.00 & 1.40 & 44.2 \\
\hline Республика Коми & 0.96 & 2.13 & 68.2 \\
\hline Забайкальский край & 0.96 & 2.29 & 54.0 \\
\hline Белгородская область & 0.87 & 1.30 & 47.7 \\
\hline Республика Карелия & 0.72 & 2.84 & 56.5 \\
\hline Костромская область & 0.61 & 2.60 & 48.3 \\
\hline Камчатский край & 0.53 & 3.04 & 89.1 \\
\hline Республика Хакасия & 0.52 & 2.69 & 64.0 \\
\hline Магаданская область & 0.38 & 3.84 & 80.7 \\
\hline Чукотский автономный округ & 0.26 & 5.15 & 130.0 \\
\hline Республика Калмыкия & 0.24 & 2.98 & 34.4 \\
\hline
\end{tabular}




\section{Производство и транспортировка нефти и газа}
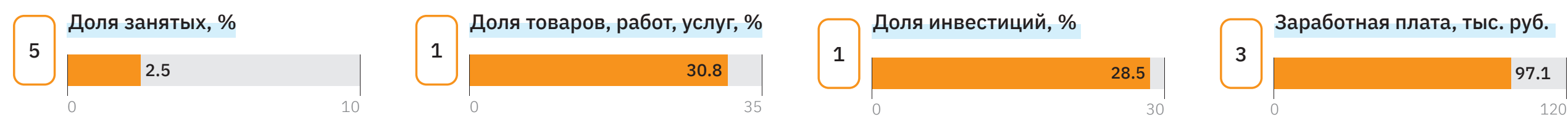

X Ранг отрасли среди торгуемых отраслей

\section{Регионы, специализирующиеся в отрасли}

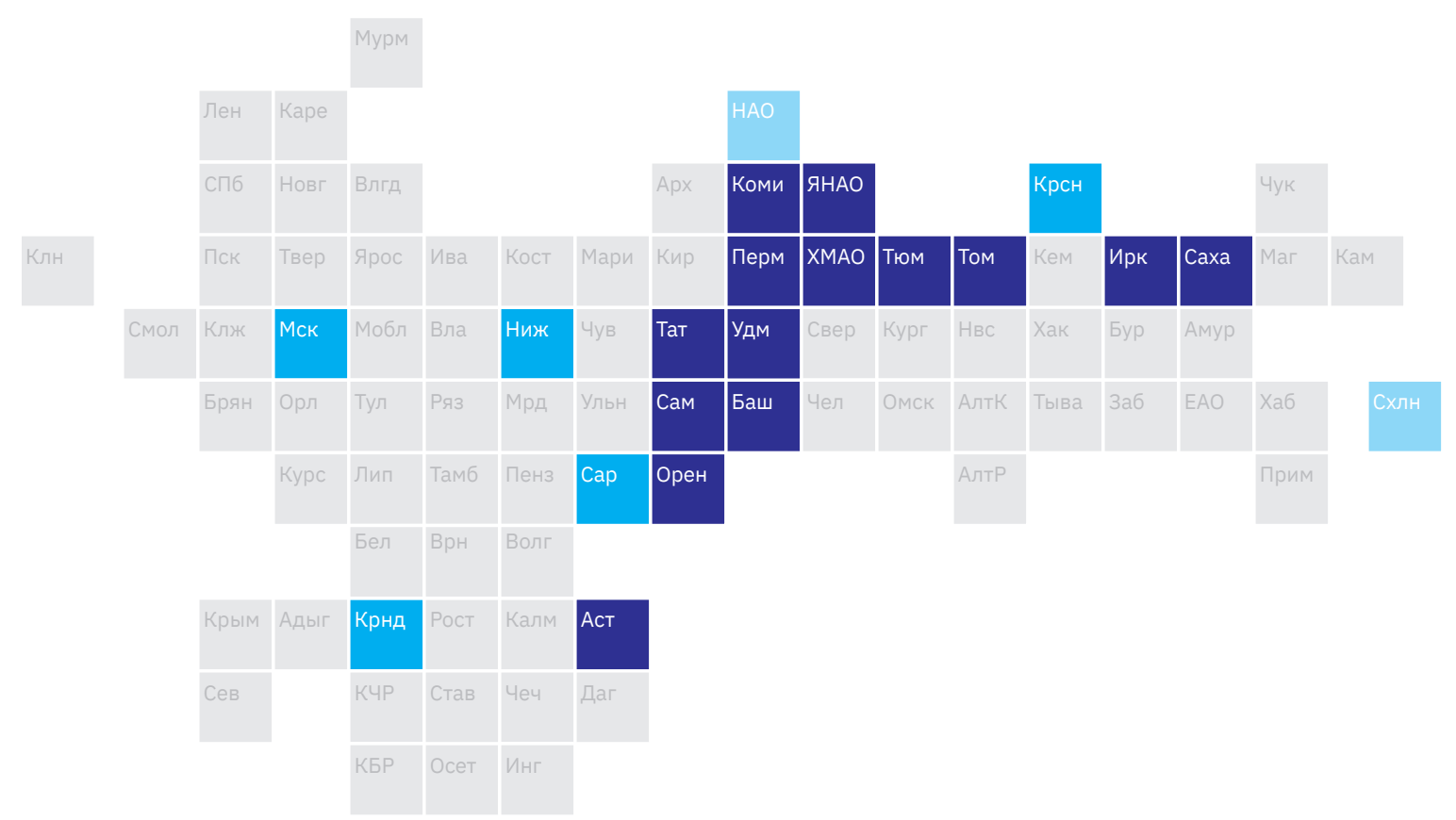

Отрасль национальной и локальной значимости
Отрасль национальной значимости

\begin{tabular}{|c|c|c|c|}
\hline & $\begin{array}{l}\text { Доля региона } \\
\text { в отраслевой } \\
\text { занятости, \% }\end{array}$ & $\begin{array}{l}\text { Доля отрасли } \\
\text { в региональной } \\
\text { занятости, \% }\end{array}$ & $\begin{array}{l}\text { Заработная } \\
\text { плата, } \\
\text { тыс. руб. }\end{array}$ \\
\hline Ханты-Мансийский автономный округ - Югра & 26.76 & 33.58 & 98.8 \\
\hline Ямало-Ненецкий автономный округ & 9.78 & 26.89 & 141.1 \\
\hline Республика Татарстан & 5.58 & 4.84 & 61.8 \\
\hline Республика Башкортостан & 4.75 & 5.04 & 68.0 \\
\hline Оренбургская область & 4.47 & 8.91 & 62.8 \\
\hline Самарская область & 4.03 & 4.34 & 62.6 \\
\hline Республика Коми & 2.93 & 9.56 & 100.7 \\
\hline Пермский край & 2.90 & 3.99 & 61.0 \\
\hline Иркутская область & 2.46 & 3.50 & 103.6 \\
\hline Томская область & 2.06 & 6.91 & 89.5 \\
\hline Тюменская область & 1.96 & 4.66 & 108.0 \\
\hline Республика Саха (Якутия) & 1.53 & 4.10 & 115.0 \\
\hline Удмуртская Республика & 1.51 & 3.33 & 55.7 \\
\hline Астраханская область & 1.33 & 5.82 & 96.1 \\
\hline Москва & 2.15 & 0.51 & 327.2 \\
\hline Краснодарский край & 2.05 & 1.64 & 70.8 \\
\hline Красноярский край & 1.88 & 2.06 & 118.3 \\
\hline Саратовская область & 1.43 & 2.37 & 54.9 \\
\hline Нижегородская область & 1.29 & 1.31 & 66.0 \\
\hline Ненецкий автономный округ & 1.03 & 30.40 & 116.4 \\
\hline Сахалинская область & 0.87 & 4.92 & 278.4 \\
\hline
\end{tabular}




\section{Производство коммуникационного оборудования}
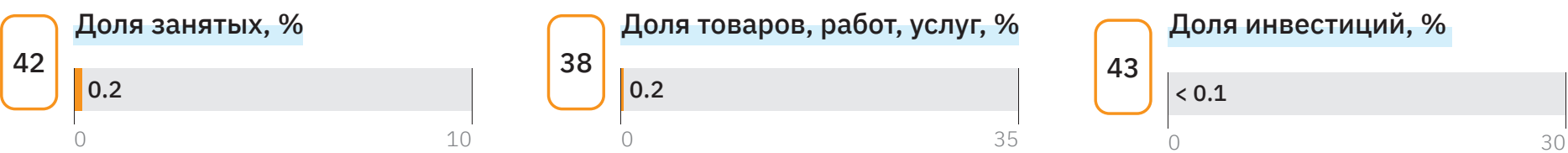

$\left.19\right|_{0} ^{3 a р а б о т н а я ~ п л а т а, ~ т ы с . ~ р у б . ~}$

X Ранг отрасли среди торгуемых отраслей

Регионы, специализирующиеся в отрасли

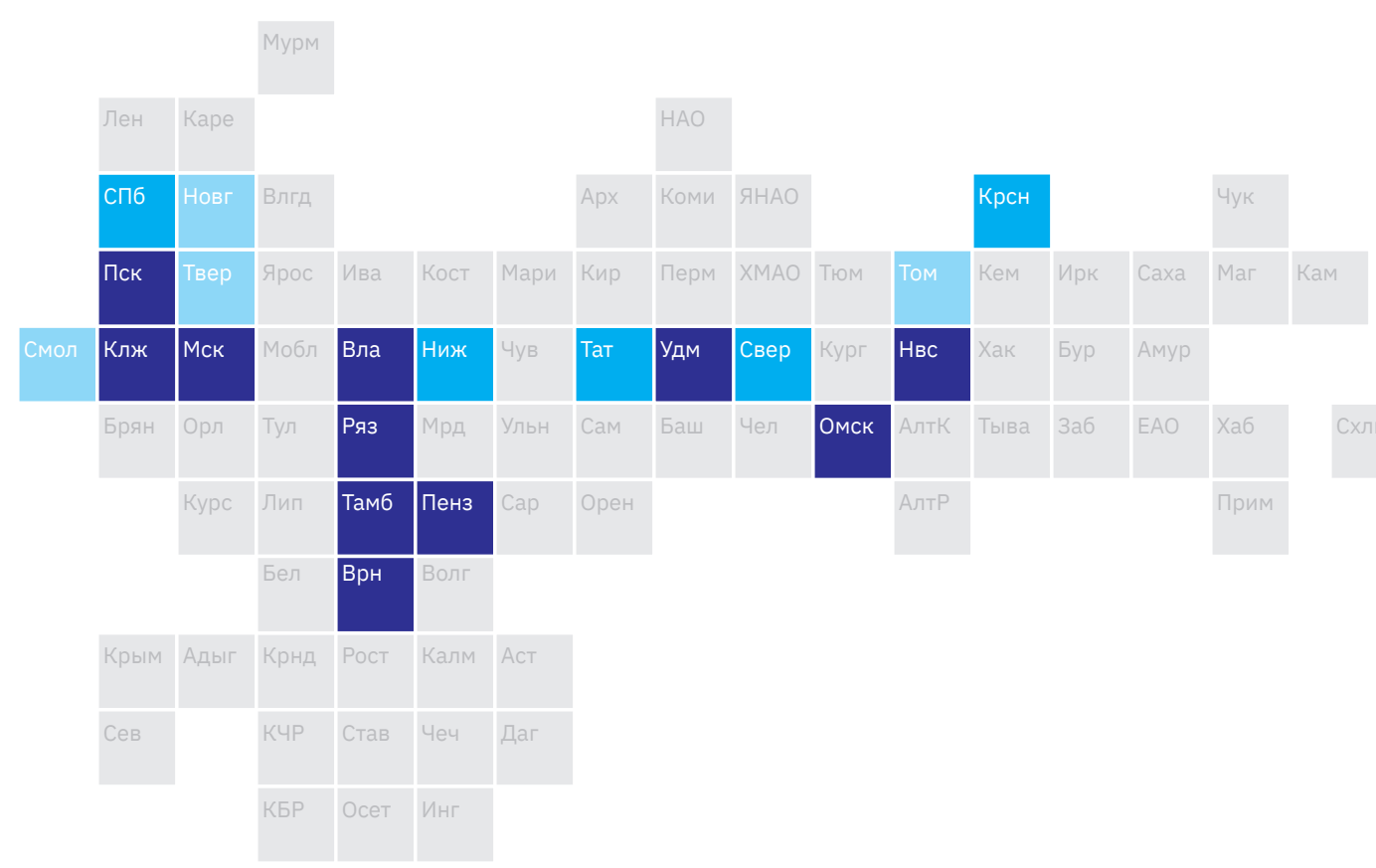

\begin{tabular}{|l|l|ll|} 
& $\begin{array}{l}\text { Доля региона } \\
\text { В отраслевой } \\
\text { занятости, \% }\end{array}$ & $\begin{array}{l}\text { Доля отрасли } \\
\text { занятонаси, \% }\end{array}$ & $\begin{array}{l}\text { 3аработная } \\
\text { плата, } \\
\text { тыс. руб. }\end{array}$ \\
\hline Удмуртская Республика & 18.58 & 3.29 & 47.0 \\
\hline Москва & 11.19 & 0.22 & 91.5 \\
\hline Омская область & 8.90 & 1.46 & 45.8 \\
\hline Калужская область & 6.01 & 1.65 & 41.2 \\
\hline Воронежская область & 4.16 & 0.57 & 48.4 \\
\hline Тамбовская область & 4.15 & 1.34 & 35.3 \\
\hline Пензенская область & 3.16 & 0.88 & 33.0 \\
\hline Рязанская область & 2.78 & 0.76 & 41.0 \\
\hline Владимирская область & 2.51 & 0.55 & 34.4 \\
\hline Новосибирская область & 2.16 & 0.23 & 53.5 \\
\hline Псковская область & 0.79 & 0.38 & 24.0 \\
\hline Санкт-Петербург & 9.01 & 0.40 & 68.3 \\
\hline Свердловская область & 4.12 & 0.24 & 39.6 \\
\hline Красноярский край & 3.05 & 0.27 & 55.6 \\
\hline Нижегородская область & 1.89 & 0.15 & 52.0 \\
\hline Республика Татарстан & 1.53 & 0.11 & 43.8 \\
\hline Томская область & 1.16 & 0.31 & 51.6 \\
\hline Новгородская область & 1.13 & 0.52 & 37.6 \\
\hline Тверская область & 0.95 & 0.23 & 48.2 \\
\hline Смоленская область & 0.88 & 0.27 & 52.5 \\
\hline
\end{tabular}




\section{Растениеводство}

$14 \underbrace{\text { Доля занятых, \% }}_{0}$

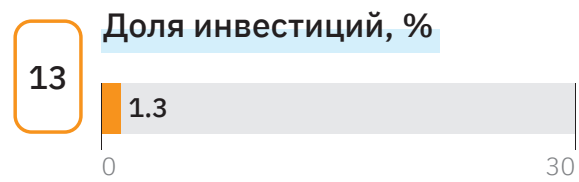
49
Заработная плата, тыс. руб.

X Ранг отрасли среди торгуемых отраслей

\section{Регионы, специализирующиеся в отрасли}

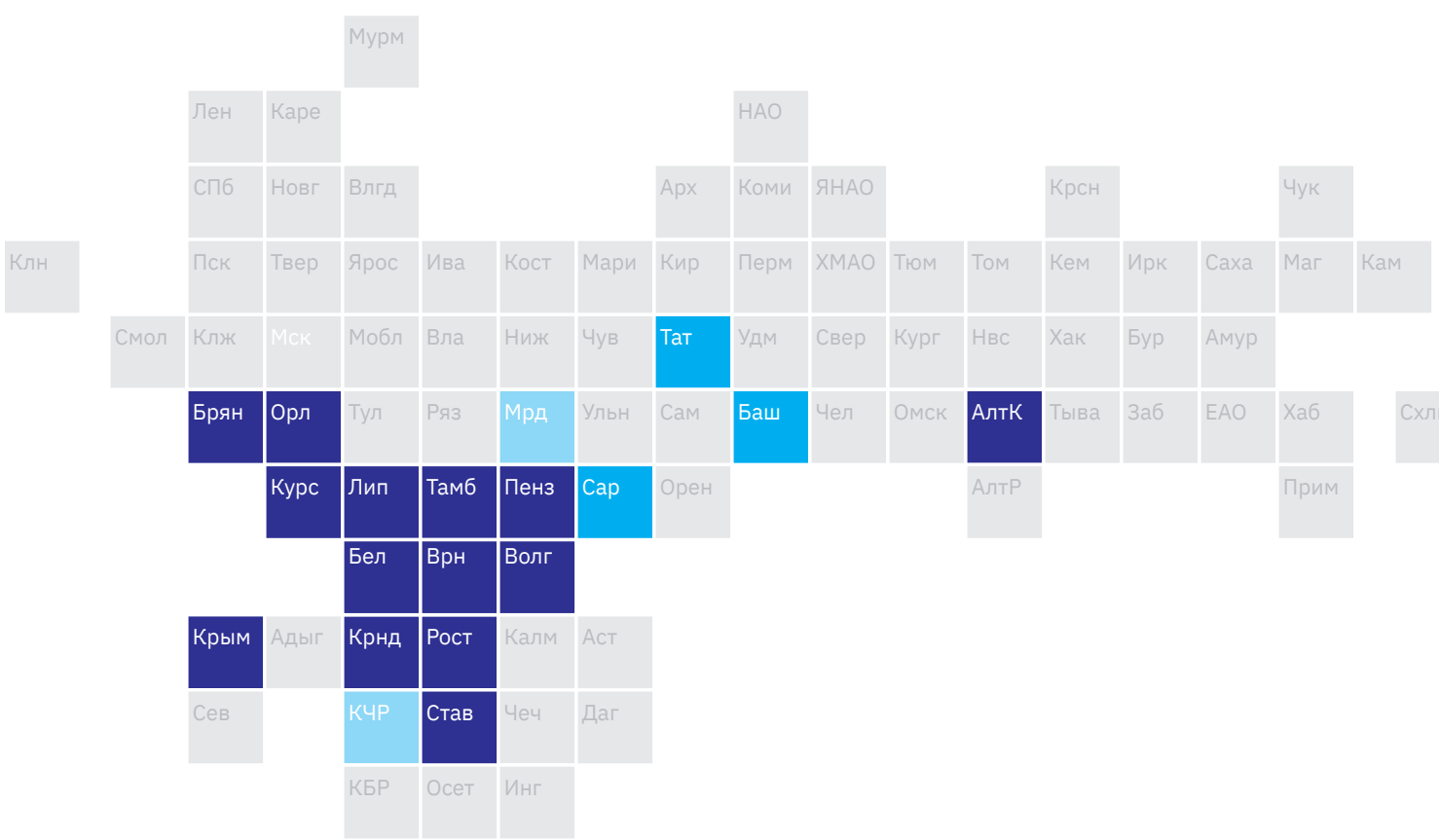

\begin{tabular}{|l|lll} 
& $\begin{array}{l}\text { Доля региона } \\
\text { В отраслевой } \\
\text { занятости, \% }\end{array}$ & $\begin{array}{l}\text { Доля отрасли } \\
\text { ванятонали, \% }\end{array}$ & $\begin{array}{l}\text { 3аработная } \\
\text { плата, } \\
\text { тыс. руб. }\end{array}$ \\
\hline Краснодарский край & 14.14 & 4.42 & 31.4 \\
\hline Ставропольский край & 8.33 & 5.99 & 30.8 \\
\hline Ростовская область & 6.24 & 2.56 & 29.3 \\
\hline Воронежская область & 3.78 & 2.52 & 29.9 \\
\hline Липецкая область & 3.61 & 4.54 & 32.9 \\
\hline Курская область & 3.56 & 4.42 & 31.5 \\
\hline Волгоградская область & 3.18 & 2.20 & 26.8 \\
\hline Белгородская область & 3.17 & 2.70 & 32.9 \\
\hline Алтайский край & 2.86 & 2.16 & 23.6 \\
\hline Орловская область & 2.83 & 5.37 & 29.5 \\
\hline Тамбовская область & 2.44 & 3.82 & 32.3 \\
\hline Республика Крым & 2.06 & 2.10 & 25.3 \\
\hline Пензенская область & 1.98 & 2.66 & 27.5 \\
\hline Брянская область & 1.57 & 2.11 & 32.6 \\
\hline Республика Татарстан & 3.76 & 1.27 & 22.4 \\
\hline Саратовская область & 2.31 & 1.49 & 24.2 \\
\hline Республика Башкортостан & 2.11 & 0.87 & 22.7 \\
\hline Республика Мордовия & 0.95 & 1.70 & 27.3 \\
\hline Карачаево-Черкесская Республика & 0.67 & 3.16 & 29.6 \\
\hline
\end{tabular}




\section{Рыболовство и производство рыбопродуктов}
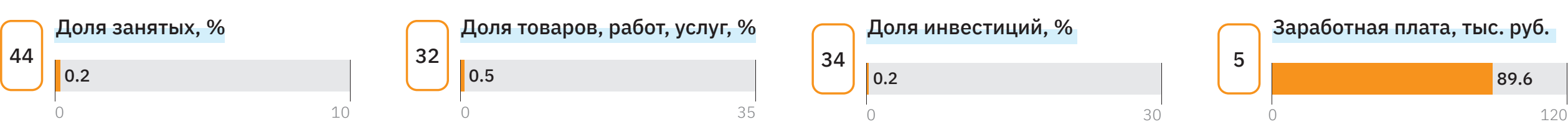

X Ранг отрасли среди торгуемых отраслей

Регионы, специализирующиеся в отрасли

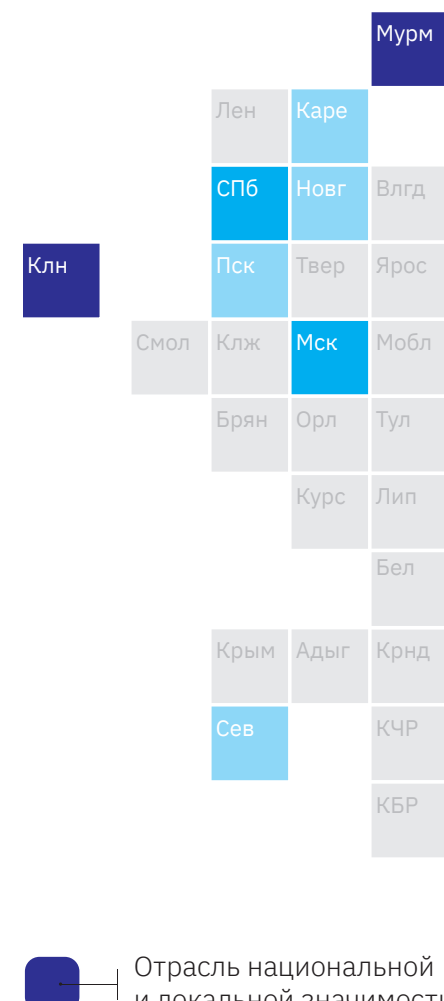

Отрасль национальной значимости

\begin{tabular}{|llll} 
& $\begin{array}{l}\text { Доля региона } \\
\text { в отраслевой } \\
\text { занятости, \% }\end{array}$ & $\begin{array}{l}\text { Доля отрасли } \\
\text { заняосости, \% }\end{array}$ & $\begin{array}{l}\text { 3аработная } \\
\text { плата, } \\
\text { тыс. руб. }\end{array}$ \\
\hline Камчатский край & 21.06 & 12.37 & 130.8 \\
\hline Приморский край & 20.37 & 2.93 & 73.0 \\
\hline Сахалинская область & 10.84 & 4.30 & 108.2 \\
\hline Калининградская область & 8.06 & 2.45 & 53.1 \\
\hline Мурманская область & 7.26 & 1.88 & 166.9 \\
\hline Хабаровский край & 5.84 & 0.99 & 74.8 \\
\hline Ямало-Ненецкий автономный округ & 3.06 & 0.59 & 30.9 \\
\hline Санкт-Петербург & 3.67 & 0.14 & 47.9 \\
\hline Москва & 2.51 & 0.04 & 46.4 \\
\hline Архангельская область & 2.69 & 0.53 & 108.7 \\
\hline Астраханская область & 1.77 & 0.55 & 12.3 \\
\hline Магаданская область & 1.43 & 1.46 & 199.6 \\
\hline Псковская область & 1.04 & 0.44 & 23.0 \\
\hline Севастополь & 0.94 & 0.75 & 35.3 \\
\hline Новгородская область & 0.80 & 0.32 & 29.5 \\
\hline Республика Карелия & 0.60 & 0.24 & 161.4 \\
\hline Ненецкий автономный округ & 0.31 & 0.64 & 143.3 \\
\hline Чукотский автономный округ & 0.16 & 0.33 & 152.7 \\
\hline
\end{tabular}




\section{Сельскохозяйственные услуги и производство удобрений}

35 Доля занятых, \%

(1)

X Ранг отрасли среди торгуемых отраслей

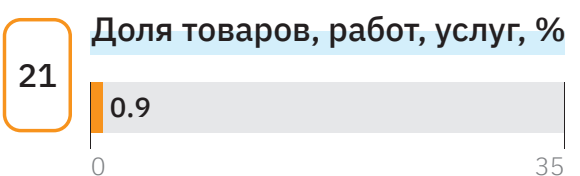

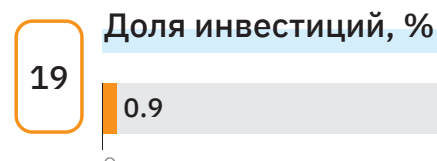

30 Заработная плата, тыс. руб. 46.0

\section{Регионы, специализирующиеся в отрасли}

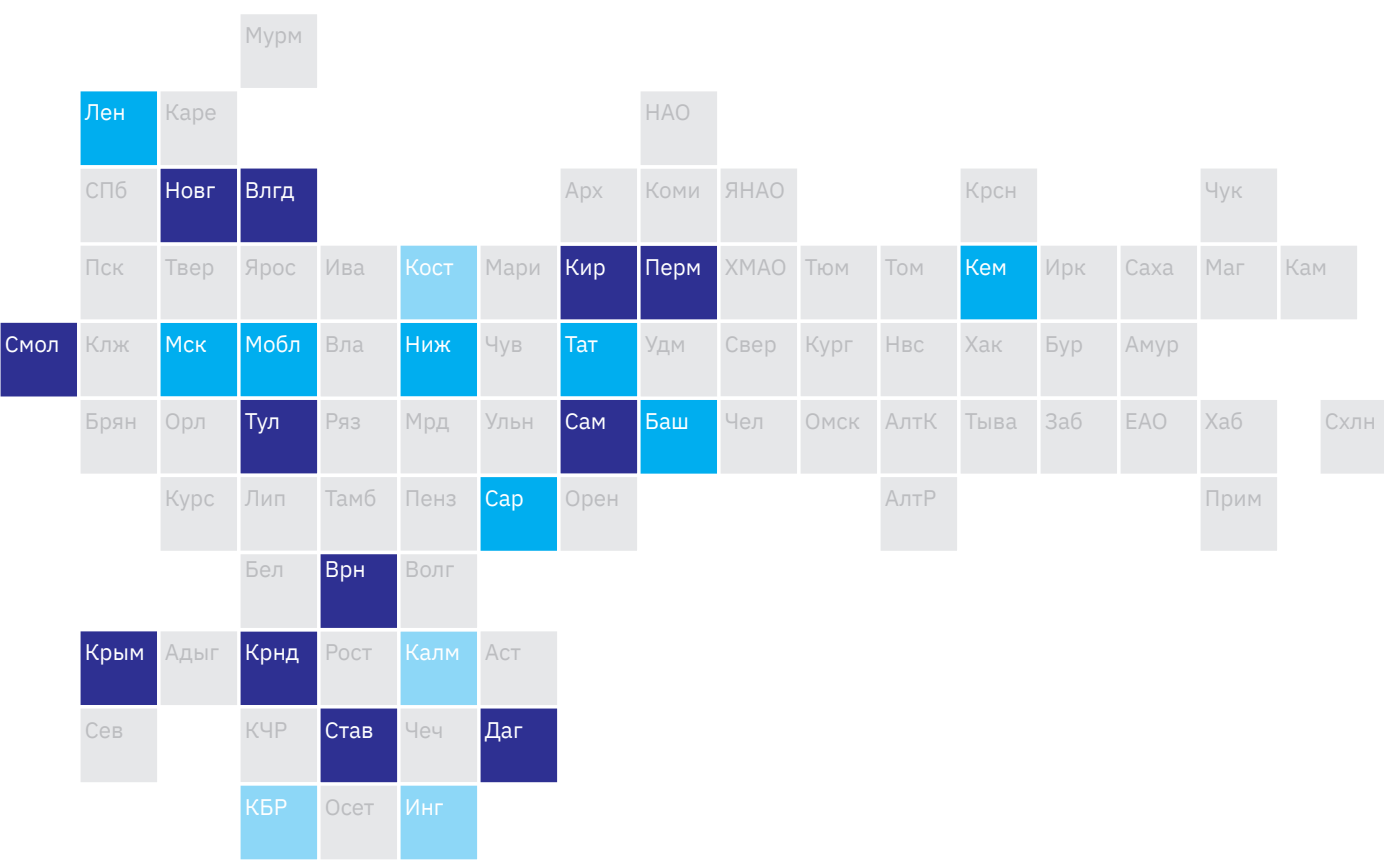

\begin{tabular}{|l|lll} 
& $\begin{array}{l}\text { Доля региона } \\
\text { В отраслевой } \\
\text { занятости, \% }\end{array}$ & $\begin{array}{l}\text { Доля отрасли } \\
\text { вреняонтальной, }\end{array}$ & $\begin{array}{l}\text { 3аработная } \\
\text { плата, } \\
\text { Tыс. руб. }\end{array}$ \\
\hline Пермский край & 17.66 & 2.90 & 70.6 \\
\hline Краснодарский край & 5.36 & 0.51 & 28.8 \\
\hline Самарская область & 4.68 & 0.60 & 45.3 \\
\hline Воронежская область & 4.56 & 0.93 & 45.9 \\
\hline Новгородская область & 4.36 & 2.98 & 54.8 \\
\hline Ставропольский край & 4.15 & 0.91 & 37.4 \\
\hline Республика Крым & 3.53 & 1.10 & 16.3 \\
\hline Вологодская область & 3.43 & 1.27 & 58.0 \\
\hline Тульская область & 2.70 & 0.79 & 49.7 \\
\hline Кировская область & 2.35 & 0.81 & 50.2 \\
\hline Смоленская область & 2.09 & 0.96 & 45.0 \\
\hline Республика Дагестан & 1.84 & 0.65 & 12.0 \\
\hline Кемеровская область & 3.36 & 0.52 & 50.7 \\
\hline Республика Татарстан & 3.22 & 0.33 & 36.7 \\
\hline Саратовская область & 2.37 & 0.47 & 35.8 \\
\hline Москва & 2.31 & 0.07 & 173.3 \\
\hline Республика Башкортостан & 2.25 & 0.28 & 35.1 \\
\hline Ленинградская область & 2.04 & 0.53 & 57.2 \\
\hline Московская область & 1.89 & 0.11 & 50.8 \\
\hline Нижегородская область & 0.94 & 0.11 & 25.4 \\
\hline Костромская область & 0.96 & 0.71 & 33.7 \\
\hline Кабардино-Балкарская Республика & 0.86 & 0.85 & 17.8 \\
\hline Республика Калмыкия & 0.42 & 0.91 & 19.5 \\
\hline Республика Ингушетия & 0.31 & 0.64 & 15.4 \\
\hline
\end{tabular}




\section{Страхование}

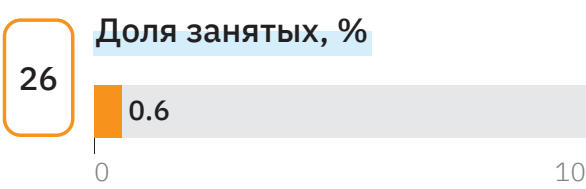

Доля инвестиций, \%

42
Заработная плата, тыс. руб.

26

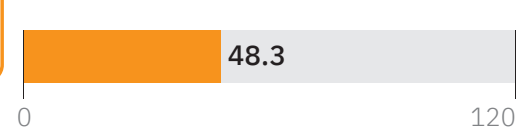

$\mathrm{x}-$ Ранг отрасли среди торгуемых отраслей

Регионы, специализирующиеся в отрасли

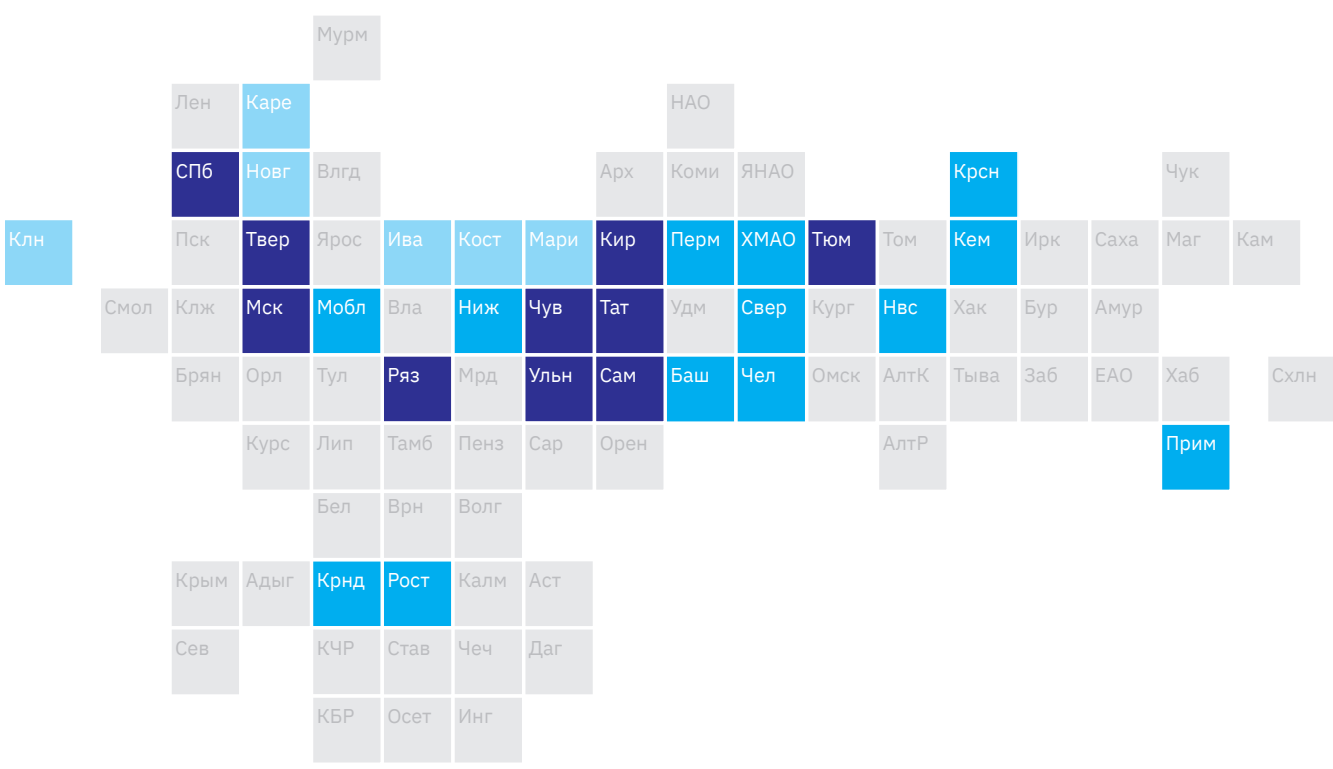

Отрасль национальной

\begin{tabular}{|c|c|c|c|}
\hline & $\begin{array}{l}\text { Доля региона } \\
\text { в отраслевой } \\
\text { занятости, \% }\end{array}$ & $\begin{array}{l}\text { Доля отрасли } \\
\text { в региональьой } \\
\text { занятости, \% }\end{array}$ & $\begin{array}{l}\text { Заработная } \\
\text { плата, } \\
\text { тыс. руб. }\end{array}$ \\
\hline Москва & 32.38 & 1.74 & 88.3 \\
\hline Санкт-Петербург & 5.47 & 0.68 & 47.2 \\
\hline Республика Татарстан & 4.79 & 0.93 & 21.9 \\
\hline Самарская область & 2.29 & 0.55 & 24.4 \\
\hline Кировская область & 1.31 & 0.85 & 18.2 \\
\hline Чувашская Республика & 1.12 & 0.89 & 17.9 \\
\hline Тюменская область & 0.98 & 0.52 & 35.2 \\
\hline Тверская область & 0.94 & 0.63 & 25.8 \\
\hline Ульяновская область & 0.88 & 0.62 & 23.8 \\
\hline Рязанская область & 0.80 & 0.60 & 31.8 \\
\hline Свердловская область & 2.43 & 0.40 & 27.9 \\
\hline Московская область & 2.33 & 0.26 & 43.4 \\
\hline Республика Башкортостан & 2.21 & 0.53 & 23.3 \\
\hline Нижегородская область & 1.87 & 0.42 & 25.6 \\
\hline Пермский край & 1.75 & 0.54 & 26.8 \\
\hline Красноярский край & 1.66 & 0.41 & 28.4 \\
\hline Ханты-Мансийский автономный округ - Югра & 1.64 & 0.46 & 49.8 \\
\hline Ростовская область & 1.62 & 0.38 & 25.9 \\
\hline Челябинская область & 1.62 & 0.37 & 25.0 \\
\hline Кемеровская область & 1.52 & 0.44 & 24.2 \\
\hline Краснодарский край & 1.44 & 0.26 & 32.0 \\
\hline Новосибирская область & 1.18 & 0.35 & 35.5 \\
\hline Приморский край & 0.83 & 0.38 & 40.9 \\
\hline Ивановская область & 0.84 & 0.97 & 23.6 \\
\hline Республика Карелия & 0.54 & 0.70 & 23.1 \\
\hline Новгородская область & 0.52 & 0.67 & 26.3 \\
\hline Костромская область & 0.50 & 0.69 & 20.4 \\
\hline Калининградская область & 0.49 & 0.47 & 28.2 \\
\hline Республика Марий Эл & 0.48 & 0.64 & 18.6 \\
\hline
\end{tabular}




\section{Строительство и строительные материалы}

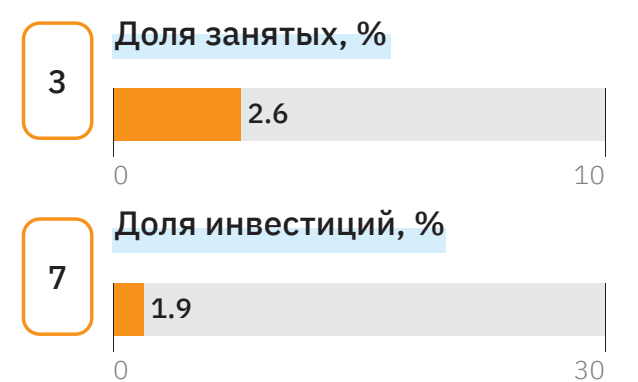

$\mathrm{x}-$ Ранг отрасли среди торгуемых отраслей

Регионы, специализирующиеся в отрасли

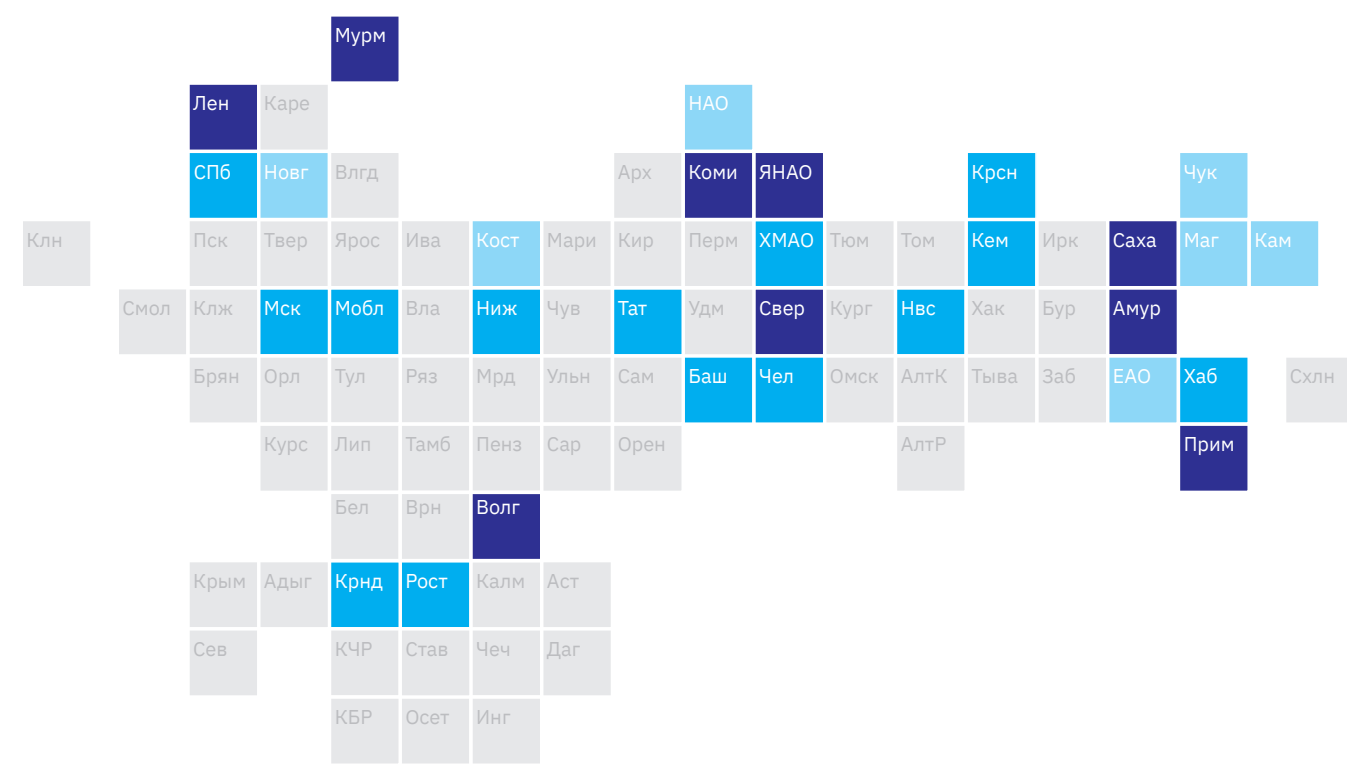

Доля региона Доля отрасли Заработная в отраслевой в региональной плата,
6 3.4

Заработная плата, тыс. руб.

36

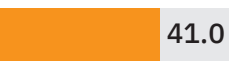

\begin{tabular}{|c|c|c|c|}
\hline & $\begin{array}{l}\text { Доля региона } \\
\text { в отраслевой } \\
\text { занятости, \% }\end{array}$ & $\begin{array}{l}\text { Доля отрасли } \\
\text { в региональной } \\
\text { занятости, \% }\end{array}$ & $\begin{array}{l}\text { Заработная } \\
\text { плата, } \\
\text { тыс. руб. }\end{array}$ \\
\hline Свердловская область & 6.18 & 4.69 & 39.0 \\
\hline Волгоградская область & 2.42 & 4.45 & 34.1 \\
\hline Приморский край & 2.00 & 4.23 & 34.4 \\
\hline Республика Саха (Якутия) & 1.83 & 5.05 & 49.1 \\
\hline Ленинградская область & 1.60 & 3.60 & 47.7 \\
\hline Ямало-Ненецкий автономный округ & 1.09 & 3.08 & 75.1 \\
\hline Республика Коми & 1.05 & 3.55 & 44.8 \\
\hline Мурманская область & 1.01 & 3.84 & 50.2 \\
\hline Амурская область & 0.93 & 3.89 & 47.3 \\
\hline Московская область & 6.27 & 3.24 & 49.8 \\
\hline Москва & 5.30 & 1.31 & 77.3 \\
\hline Челябинская область & 3.66 & 3.83 & 40.4 \\
\hline Санкт-Петербург & 3.10 & 1.79 & 56.5 \\
\hline Нижегородская область & 3.09 & 3.24 & 45.2 \\
\hline Ростовская область & 3.05 & 3.32 & 35.0 \\
\hline Красноярский край & 2.70 & 3.05 & 43.9 \\
\hline Краснодарский край & 2.46 & 2.04 & 32.7 \\
\hline Кемеровская область & 2.31 & 3.11 & 30.0 \\
\hline Республика Татарстан & 2.28 & 2.04 & 37.0 \\
\hline Новосибирская область & 2.17 & 3.02 & 37.3 \\
\hline Республика Башкортостан & 2.10 & 2.31 & 36.6 \\
\hline Ханты-Мансийский автономный округ - Югра & 1.52 & 1.98 & 55.1 \\
\hline Хабаровский край & 1.09 & 2.71 & 49.1 \\
\hline Костромская область & 0.66 & 4.19 & 29.6 \\
\hline Новгородская область & 0.66 & 3.88 & 31.5 \\
\hline Камчатский край & 0.53 & 4.60 & 71.6 \\
\hline Магаданская область & 0.36 & 5.48 & 66.7 \\
\hline Еврейская автономная область & 0.26 & 6.23 & 41.6 \\
\hline Чукотский автономный округ & 0.19 & 5.74 & 85.3 \\
\hline Ненецкий автавтономный округ & 0.10 & 3.01 & 61.3 \\
\hline
\end{tabular}




\section{Судостроение и водный транспорт}
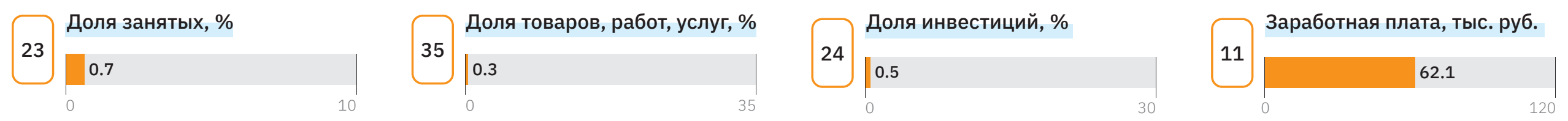

X Ранг отрасли среди торгуемых отраслей

Регионы, специализирующиеся в отрасли

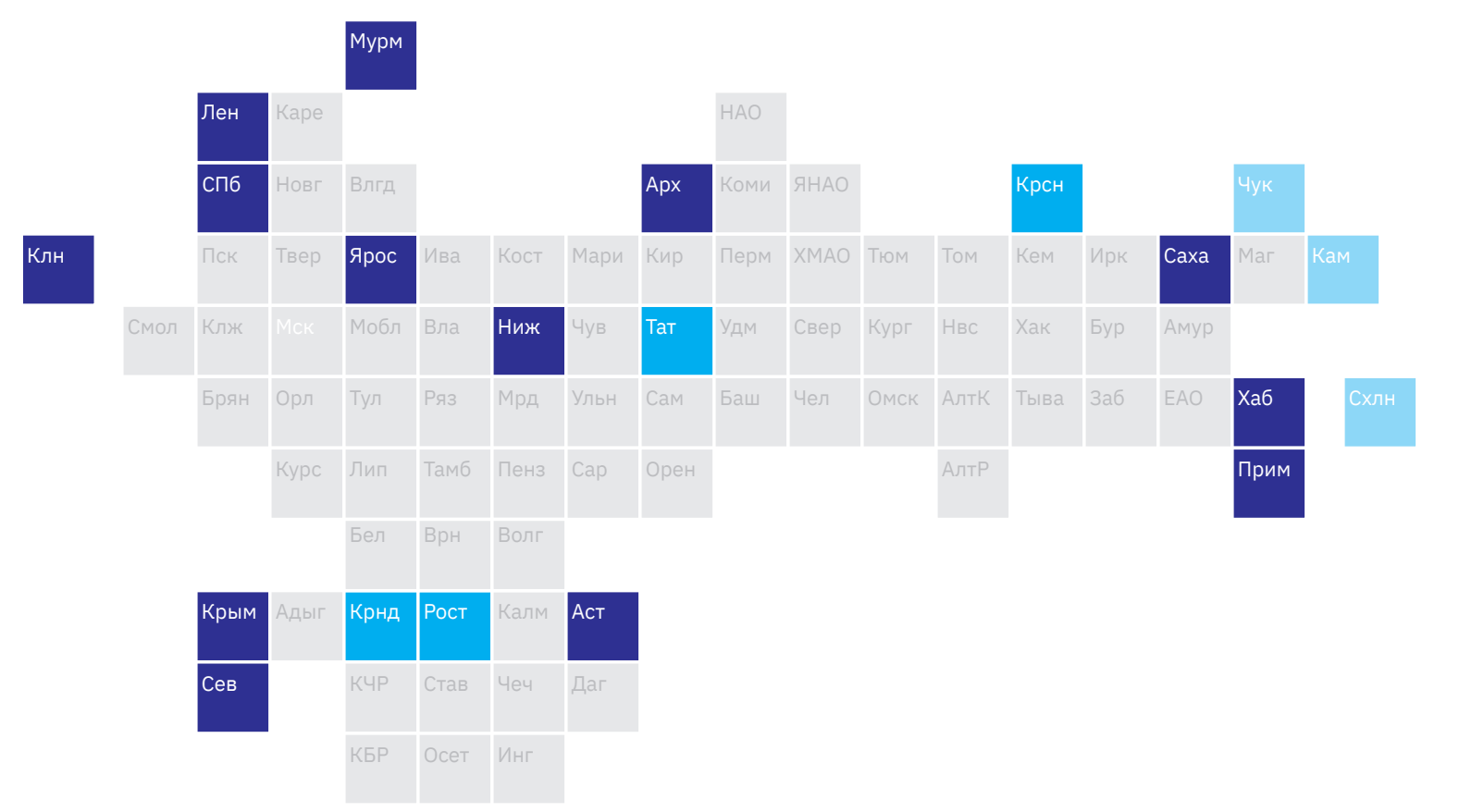

\begin{tabular}{|c|c|c|c|}
\hline & $\begin{array}{l}\text { Доля региона } \\
\text { в отраслевой } \\
\text { занятости, \% }\end{array}$ & $\begin{array}{l}\text { Доля отрасли } \\
\text { в региональной } \\
\text { занятости, \% }\end{array}$ & $\begin{array}{l}\text { Заработная } \\
\text { плата, } \\
\text { тыс. руб. }\end{array}$ \\
\hline Архангельская область & 19.36 & 14.11 & 68.0 \\
\hline Санкт-Петербург & 13.84 & 2.00 & 80.4 \\
\hline Приморский край & 9.25 & 4.90 & 72.2 \\
\hline Мурманская область & 5.88 & 5.61 & 73.9 \\
\hline Нижегородская область & 4.64 & 1.22 & 43.6 \\
\hline Республика Крым & 3.17 & 2.15 & 41.1 \\
\hline Ленинградская область & 3.15 & 1.77 & 59.4 \\
\hline Хабаровский край & 3.15 & 1.98 & 54.9 \\
\hline Калининградская область & 3.05 & 3.42 & 65.4 \\
\hline Астраханская область & 1.92 & 2.18 & 43.0 \\
\hline Республика Саха (Якутия) & 1.87 & 1.30 & 59.7 \\
\hline Ярославская область & 1.68 & 1.12 & 41.7 \\
\hline Севастополь & 1.27 & 3.71 & 47.6 \\
\hline Краснодарский край & 3.30 & 0.69 & 70.5 \\
\hline Республика Татарстан & 2.89 & 0.65 & 37.0 \\
\hline Ростовская область & 2.62 & 0.72 & 45.3 \\
\hline Красноярский край & 2.18 & 0.62 & 54.9 \\
\hline Сахалинская область & 0.91 & 1.32 & 97.6 \\
\hline Камчатский край & 0.75 & 1.63 & 86.5 \\
\hline Чукотский автономный округ & 0.23 & 1.76 & 102.2 \\
\hline
\end{tabular}




\section{Табачные изделия}
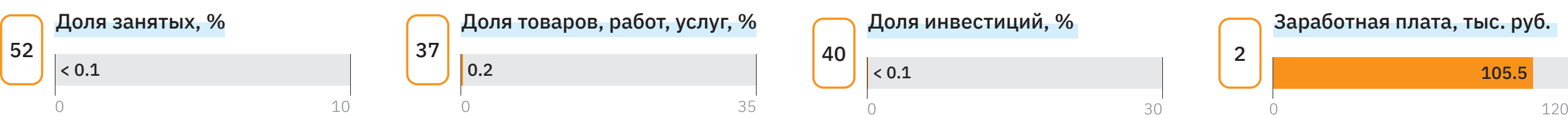

X Ранг отрасли среди торгуемых отраслей

Регионы, специализирующиеся в отрасли

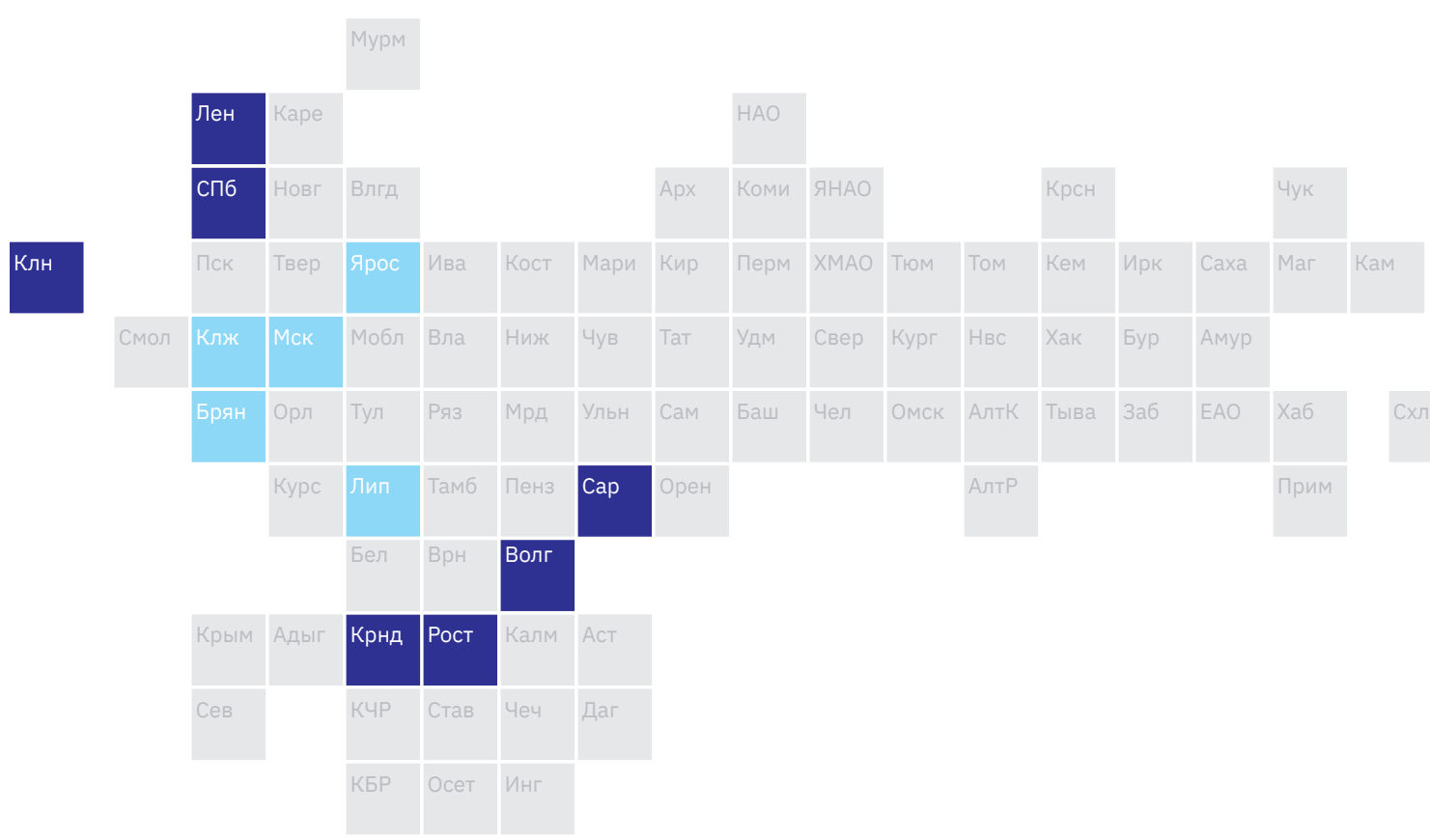

\begin{tabular}{|c|c|c|c|}
\hline & $\begin{array}{l}\text { Доля региона } \\
\text { в отраслевой } \\
\text { занятости, \% }\end{array}$ & $\begin{array}{l}\text { Доля отрасли } \\
\text { в региональной } \\
\text { занятости, \% }\end{array}$ & $\begin{array}{l}\text { Заработная } \\
\text { плата, } \\
\text { тыс. руб. }\end{array}$ \\
\hline Санкт-Петербург & 29.39 & 0.12 & 124.4 \\
\hline Ленинградская область & 20.60 & 0.34 & 164.6 \\
\hline Ростовская область & 13.21 & 0.10 & 56.5 \\
\hline Волгоградская область & 7.06 & 0.09 & 69.2 \\
\hline Краснодарский край & 6.24 & 0.04 & 113.5 \\
\hline Саратовская область & 6.22 & 0.08 & 81.0 \\
\hline Калининградская область & 5.59 & 0.18 & 47.8 \\
\hline Липецкая область & 4.53 & 0.11 & 51.4 \\
\hline Брянская область & 4.28 & 0.11 & 25.9 \\
\hline Калужская область & 1.60 & 0.04 & 100.3 \\
\hline Москва & 1.07 & 0.00 & 254.1 \\
\hline Ярославская область & 0.17 & 0.00 & 57.7 \\
\hline
\end{tabular}




\section{Текстильное производство}
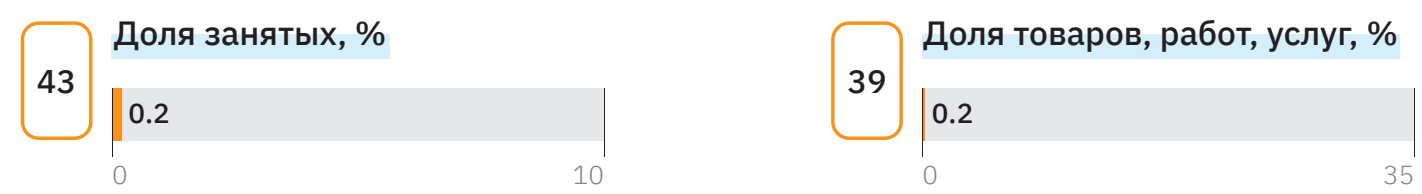

Доля инвестиций, \%

41

\section{$\mid<0.1$}

$\left.\right|_{0}$

X Ранг отрасли среди торгуемых отраслей

Регионы, специализирующиеся в отрасли

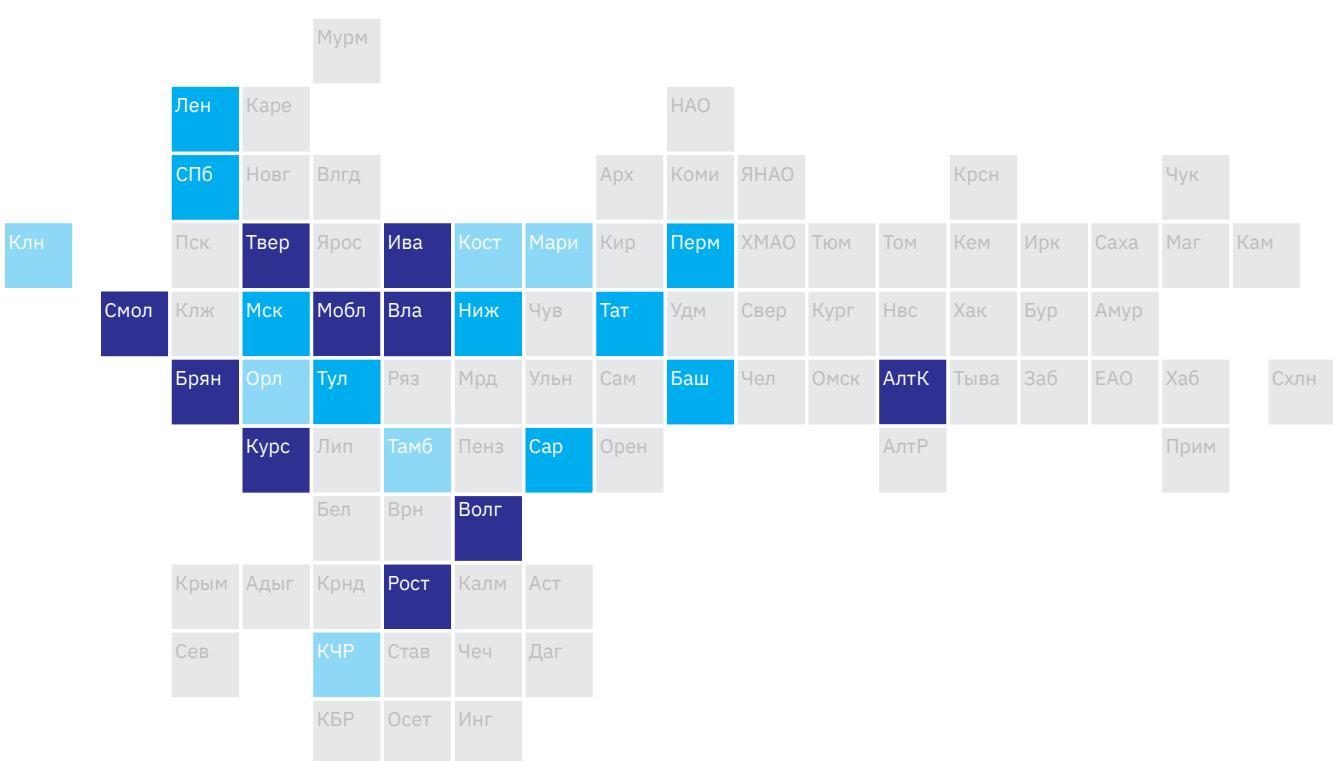

Отрасль национальной и локальной значимости

\begin{tabular}{|c|c|c|c|}
\hline & $\begin{array}{l}\text { Доля региона } \\
\text { в отраслевой } \\
\text { занятости, \% }\end{array}$ & $\begin{array}{l}\text { Доля отрасли } \\
\text { в региоональной } \\
\text { занятости, \% }\end{array}$ & $\begin{array}{l}\text { Заработная } \\
\text { плата, } \\
\text { тыс. руб. }\end{array}$ \\
\hline Ивановская область & 16.57 & 6.44 & 22.5 \\
\hline Московская область & 10.03 & 0.38 & 38.6 \\
\hline Ростовская область & 9.78 & 0.78 & 32.4 \\
\hline Владимирская область & 4.74 & 0.99 & 25.9 \\
\hline Волгоградская область & 4.70 & 0.63 & 24.1 \\
\hline Тверская область & 3.28 & 0.74 & 24.3 \\
\hline Курская область & 3.18 & 0.77 & 26.2 \\
\hline Алтайский край & 3.10 & 0.45 & 24.0 \\
\hline Смоленская область & 2.01 & 0.59 & 27.5 \\
\hline Брянская область & 1.08 & 0.28 & 17.7 \\
\hline Санкт-Петербург & 3.54 & 0.15 & 42.3 \\
\hline Нижегородская область & 2.96 & 0.23 & 18.2 \\
\hline Пермский край & 2.77 & 0.29 & 25.9 \\
\hline Москва & 2.64 & 0.05 & 57.6 \\
\hline Саратовская область & 2.26 & 0.28 & 28.5 \\
\hline Республика Башкортостан & 2.00 & 0.16 & 23.0 \\
\hline Ленинградская область & 1.84 & 0.30 & 45.3 \\
\hline Республика Татарстан & 1.62 & 0.11 & 32.8 \\
\hline Тульская область & 1.52 & 0.28 & 37.6 \\
\hline Тамбовская область & 1.70 & 0.52 & 19.3 \\
\hline Орловская область & 1.23 & 0.45 & 24.0 \\
\hline Калининградская область & 1.12 & 0.37 & 47.1 \\
\hline Республика Марий Эл & 0.84 & 0.38 & 21.3 \\
\hline Костромская область & 0.53 & 0.25 & 20.1 \\
\hline Карачаево-Черкесская Респуб & 0.45 & 0.41 & 10.7 \\
\hline
\end{tabular}




\section{Транспорт и логистика}

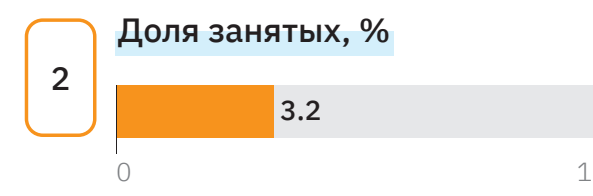

2

2

\section{Доля инвестиций, \%}

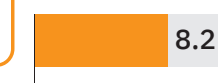

0

X Ранг отрасли среди торгуемых отраслей

Регионы, специализирующиеся в отрасли

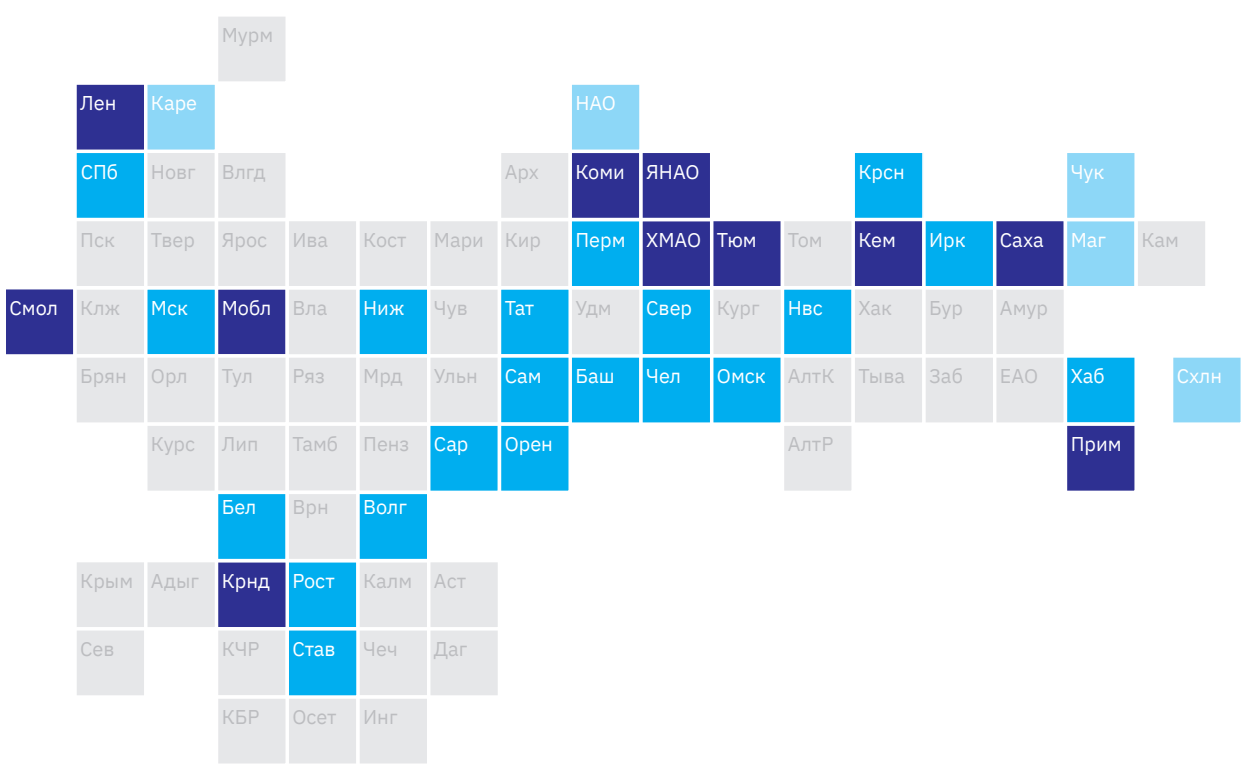

Отрасль национальной и локальной значимости
Доля товаров, работ, услуг, \%

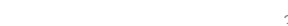

Заработная плата, тыс. руб.

18

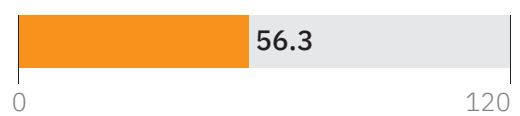

Доля региона Доля отрасли Заработная в отраслевой в региональной плата, занятости, \% занятости, \% тыс. руб.

\begin{tabular}{|l|l|l|l|}
\hline Московская область & 7.56 & 4.81 & 90.5 \\
\hline Краснодарский край & 4.39 & 4.48 & 45.9 \\
\hline Ханты-Мансийский автономный округ - Югра & 3.46 & 5.52 & 60.9 \\
\hline Кемеровская область & 2.95 & 4.89 & 44.8 \\
\hline Ямало-Ненецкий автономный округ & 2.00 & 6.98 & 93.1 \\
\hline Приморский край & 1.96 & 5.09 & 57.6 \\
\hline Ленинградская область & 1.85 & 5.11 & 55.7 \\
\hline Тюменская область & 1.60 & 4.85 & 57.0 \\
\hline Республика Саха (Якутия) & 1.47 & 5.00 & 83.9 \\
\hline Смоленская область & 1.16 & 5.71 & 30.0 \\
\hline Республика Коми & 1.14 & 4.74 & 64.5 \\
\hline Москва & 7.64 & 2.33 & 96.1 \\
\hline Санкт-Петербург & 4.88 & 3.47 & 75.6 \\
\hline Республика Татарстан & 3.43 & 3.78 & 41.9 \\
\hline Красноярский край & 3.28 & 4.56 & 61.7 \\
\hline Свердловская область & 2.71 & 2.54 & 53.9 \\
\hline Ростовская область & 2.54 & 3.40 & 43.3 \\
\hline Иркутская область & 2.39 & 4.34 & 55.1 \\
\hline Самарская область & 2.30 & 3.15 & 39.9 \\
\hline Республика Башкортостан & 2.11 & 2.85 & 40.6 \\
\hline Челябинская область & 1.79 & 2.30 & 42.7 \\
\hline Омская область & 1.74 & 4.52 & 34.6 \\
\hline Новосибирская область & 1.71 & 2.93 & 51.8 \\
\hline Пермский край & 1.62 & 2.84 & 39.3 \\
\hline Оренбургская область & 1.46 & 3.71 & 39.6 \\
\hline Нижегородская область & 1.33 & 1.71 & 38.1 \\
\hline Волгоградская область & 1.31 & 2.97 & 33.6 \\
\hline Хабаровский край & 1.25 & 3.83 & 61.2 \\
\hline Саратовская область & 1.18 & 2.50 & 34.7 \\
\hline Белгородская область & 0.94 & 2.61 & 35.7 \\
\hline Ставропольский край & 0.92 & 2.17 & 30.5 \\
\hline Сахалинская область & 0.81 & 5.83 & 76.9 \\
\hline Республика Карелия & 0.62 & 4.55 & 49.6 \\
\hline Магаданская область & 0.28 & 5.10 & 88.5 \\
\hline Ненецкий автономный округ & 7.38 & 82.9 \\
\hline Чукотский автономный округ & 5.72 & 125.1 \\
\hline
\end{tabular}




\section{Туризм}

10

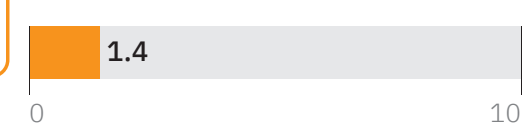

Доля инвестиций, \%

9 1.5 0

X Ранг отрасли среди торгуемых отраслей

Регионы, специализирующиеся в отрасли

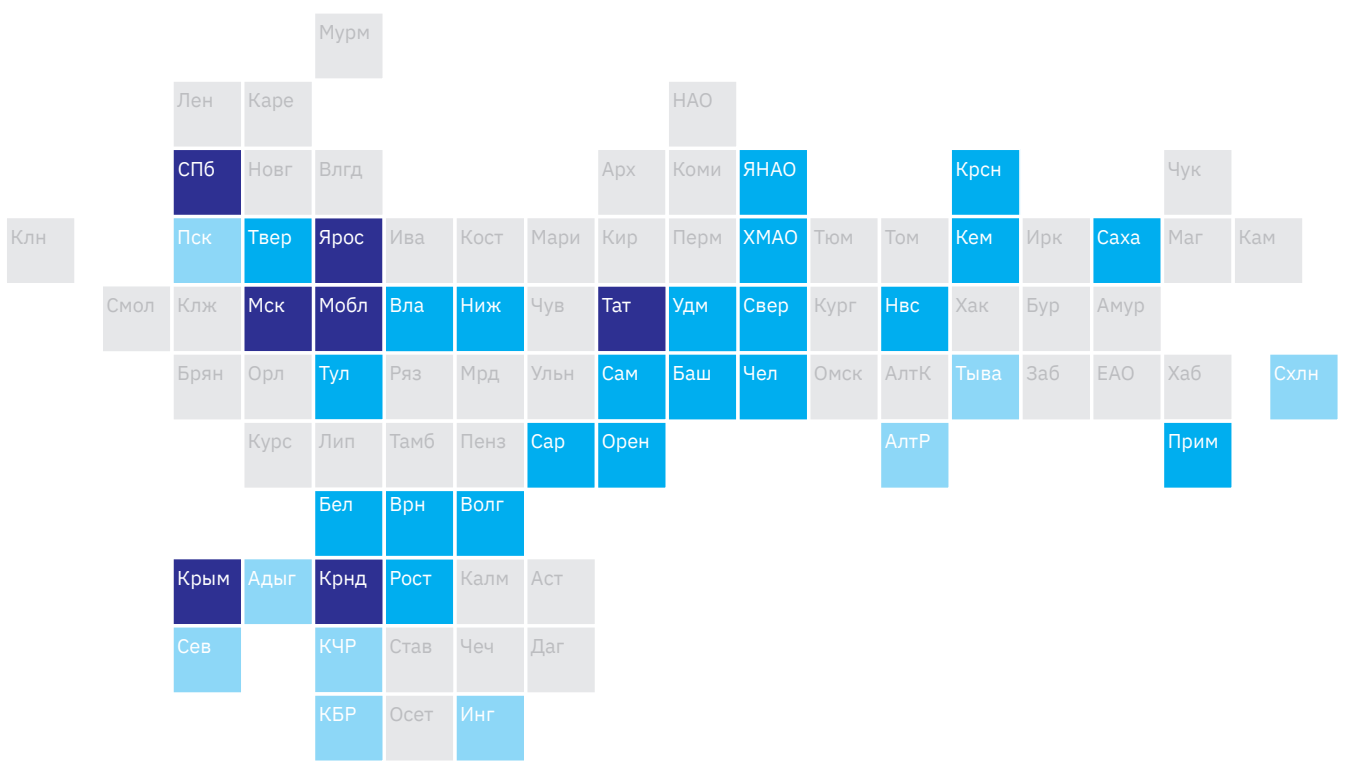

Отрасль национальной и локальной значимости

\begin{tabular}{|c|c|c|c|}
\hline & $\begin{array}{l}\text { Доля региона } \\
\text { в отраслевой } \\
\text { занятости, \% }\end{array}$ & $\begin{array}{l}\text { Доля отрасли } \\
\text { в региональной } \\
\text { занятости, \% }\end{array}$ & $\begin{array}{l}\text { Заработная } \\
\text { плата, } \\
\text { тыс. руб. }\end{array}$ \\
\hline Москва & 14.12 & 1.94 & 89.9 \\
\hline Московская область & 7.07 & 2.03 & 42.1 \\
\hline Санкт-Петербург & 6.89 & 2.21 & 75.9 \\
\hline Краснодарский край & 6.20 & 2.86 & 48.5 \\
\hline Республика Татарстан & 2.56 & 1.28 & 65.2 \\
\hline Республика Крым & 1.65 & 2.47 & 29.6 \\
\hline Ярославская область & 1.35 & 2.01 & 42.7 \\
\hline Свердловская область & 3.17 & 1.34 & 40.7 \\
\hline Красноярский край & 2.61 & 1.64 & 43.0 \\
\hline Челябинская область & 2.15 & 1.25 & 47.3 \\
\hline Ханты-Мансийский автономный округ - Югра & 2.02 & 1.46 & 52.8 \\
\hline Ростовская область & 1.97 & 1.20 & 30.5 \\
\hline Самарская область & 1.94 & 1.20 & 38.3 \\
\hline Нижегородская область & 1.81 & 1.06 & 33.5 \\
\hline Республика Башкортостан & 1.79 & 1.10 & 50.0 \\
\hline Новосибирская область & 1.72 & 1.33 & 39.8 \\
\hline Кемеровская область & 1.38 & 1.03 & 26.0 \\
\hline Приморский край & 1.19 & 1.40 & 46.2 \\
\hline Саратовская область & 1.11 & 1.06 & 23.8 \\
\hline Волгоградская область & 1.06 & 1.09 & 26.8 \\
\hline Тульская область & 1.05 & 1.48 & 45.6 \\
\hline Воронежская область & 1.02 & 1.00 & 23.7 \\
\hline Тверская область & 1.02 & 1.75 & 25.5 \\
\hline Белгородская область & 1.00 & 1.25 & 22.5 \\
\hline Удмуртская Республика & 0.94 & 1.19 & 25.6 \\
\hline Оренбургская область & 0.93 & 1.07 & 36.5 \\
\hline Ямало-Ненецкий автономный округ & 0.86 & 1.35 & 73.2 \\
\hline Владимирская область & 0.80 & 1.26 & 24.4 \\
\hline Республика Саха (Якутия) & 0.74 & 1.14 & 49.1 \\
\hline Сахалинская область & 0.62 & 2.00 & 62.1 \\
\hline Кабардино-Балкарская Республика & 0.50 & 2.38 & 17.7 \\
\hline Псковская область & 0.47 & 1.60 & 22.0 \\
\hline Республика Ингушетия & 0.32 & 3.27 & 17.6 \\
\hline Севастополь & 0.27 & 1.74 & 30.6 \\
\hline Республика Тыва & 0.26 & 2.01 & 26.4 \\
\hline Карачаево-Черкесская Республика & 0.25 & 1.73 & 17.3 \\
\hline Республика Адыгея & 0.24 & 1.63 & 20.8 \\
\hline Республика Алтай & 0.21 & 2.41 & 32.2 \\
\hline
\end{tabular}




\section{Тяжелое машиностроение}

\section{1}

Доля занятых, \%

11

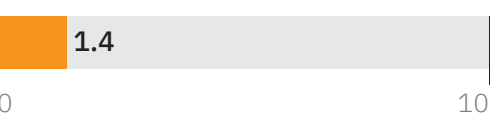

Доля инвестиций, \%

25

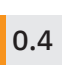

0.4

X Ранг отрасли среди торгуемых отраслей

Регионы, специализирующиеся в отрасли

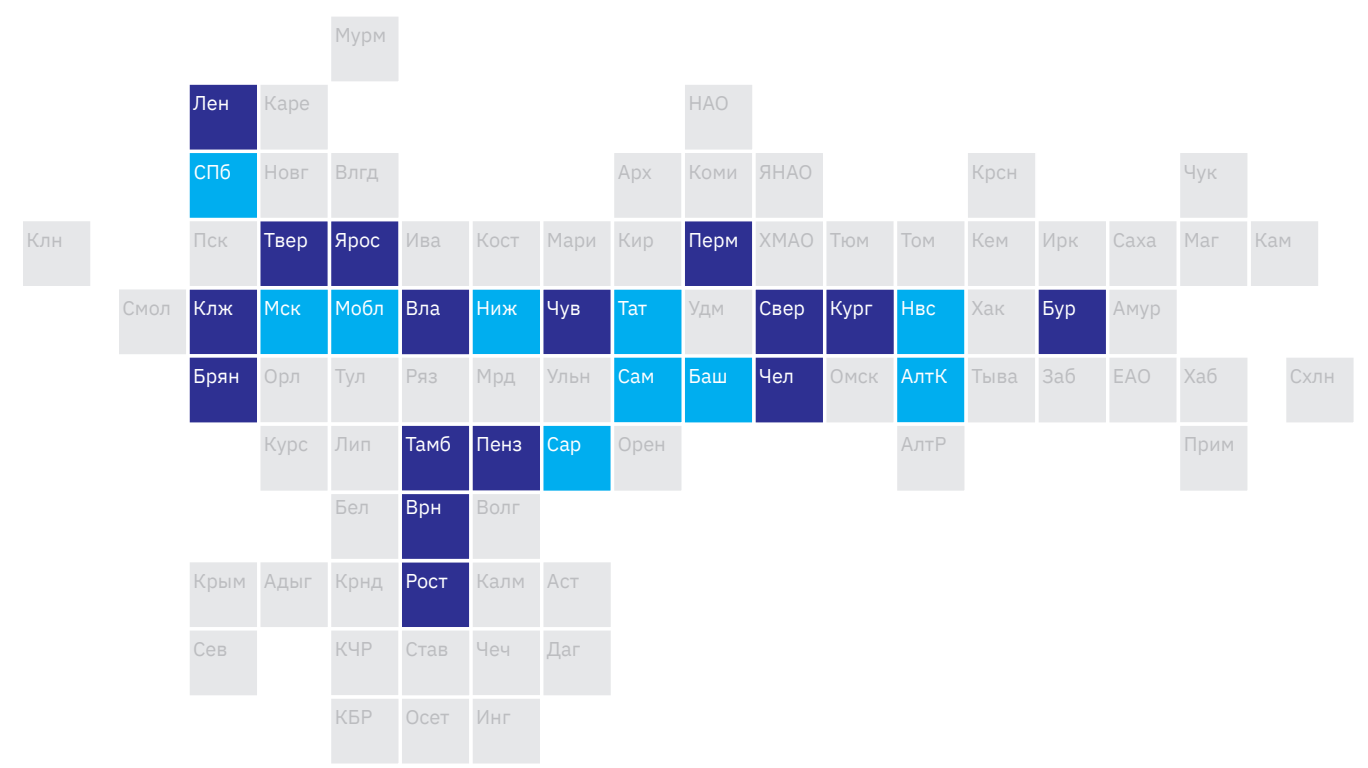

Отрасль национальной и локальной значимости Отрасль национальной значимости

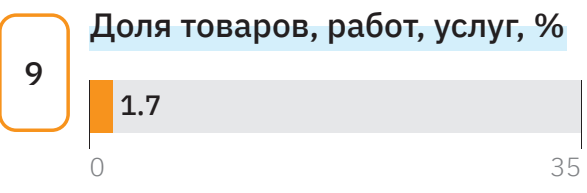

Заработная плата, тыс. руб

34

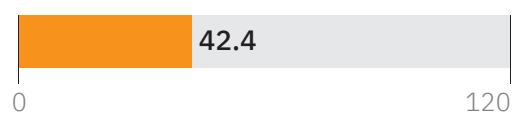

\begin{tabular}{|c|c|c|c|}
\hline & $\begin{array}{l}\text { Доля региона } \\
\text { в отраслевой } \\
\text { занятости, \% }\end{array}$ & $\begin{array}{l}\text { Доля отрасли } \\
\text { в региональной } \\
\text { занятости, \% }\end{array}$ & $\begin{array}{l}\text { Заработная } \\
\text { плата, } \\
\text { тыс. руб. }\end{array}$ \\
\hline Свердловская область & 9.14 & 3.77 & 41.2 \\
\hline Челябинская область & 5.41 & 3.08 & 35.7 \\
\hline Ростовская область & 4.37 & 2.58 & 36.9 \\
\hline Пермский край & 3.26 & 2.52 & 43.4 \\
\hline Тверская область & 2.89 & 4.83 & 50.0 \\
\hline Ленинградская область & 2.70 & 3.29 & 53.5 \\
\hline Воронежская область & 2.68 & 2.57 & 33.8 \\
\hline Калужская область & 2.03 & 3.88 & 40.4 \\
\hline Ярославская область & 2.02 & 2.93 & 41.6 \\
\hline Владимирская область & 1.76 & 2.71 & 37.1 \\
\hline Брянская область & 1.74 & 3.38 & 37.3 \\
\hline Тамбовская область & 1.63 & 3.68 & 31.8 \\
\hline Республика Бурятия & 1.50 & 4.00 & 44.3 \\
\hline Пензенская область & 1.33 & 2.59 & 33.0 \\
\hline Чувашская Республика & 1.25 & 2.50 & 28.1 \\
\hline Курганская область & 1.21 & 3.13 & 34.6 \\
\hline Московская область & 5.86 & 1.64 & 57.8 \\
\hline Санкт-Петербург & 5.42 & 1.70 & 68.3 \\
\hline Республика Башкортостан & 2.80 & 1.67 & 38.1 \\
\hline Москва & 2.51 & 0.34 & 73.5 \\
\hline Саратовская область & 2.21 & 2.06 & 31.6 \\
\hline Республика Татарстан & 2.07 & 1.01 & 35.8 \\
\hline Самарская область & 2.02 & 1.22 & 36.1 \\
\hline Нижегородская область & 1.85 & 1.05 & 42.3 \\
\hline Новосибирская область & 1.84 & 1.39 & 36.5 \\
\hline Алтайский край & 1.51 & 1.65 & 35.9 \\
\hline
\end{tabular}




\section{Фармацевтическая продукция}
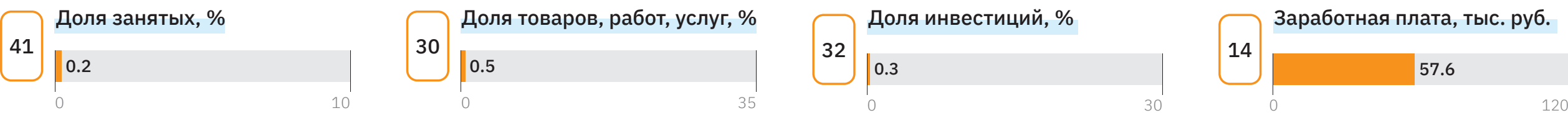

X Ранг отрасли среди торгуемых отраслей

\section{Регионы, специализирующиеся в отрасли}

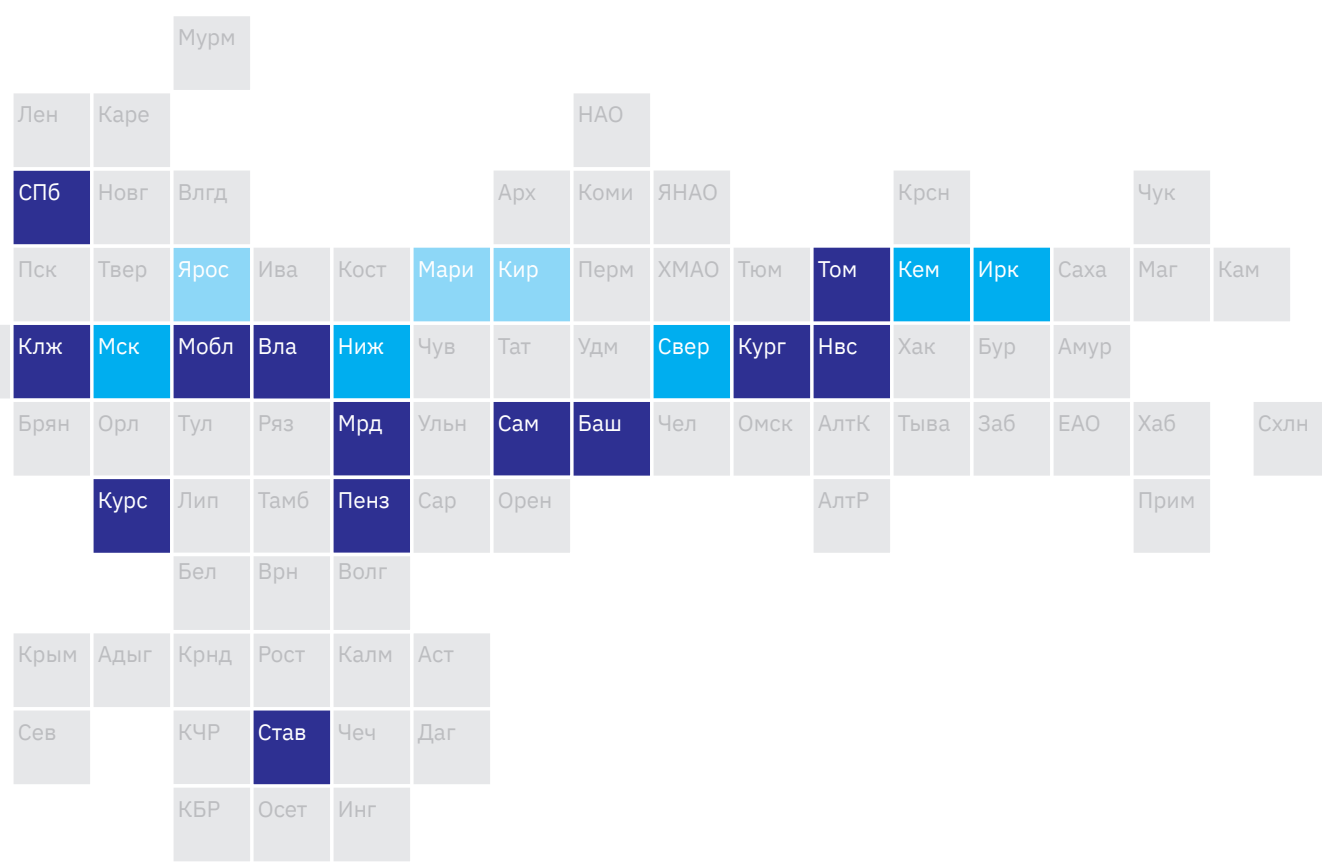

Отрасль национальной и локальной значимости

\begin{tabular}{|c|c|c|c|}
\hline & $\begin{array}{l}\text { Доля региона } \\
\text { в отраслевой } \\
\text { занятости, \% }\end{array}$ & $\begin{array}{l}\text { Доля отрасли } \\
\text { в региональной } \\
\text { занятости, \% }\end{array}$ & $\begin{array}{l}\text { Заработная } \\
\text { плата, } \\
\text { тыс. руб. }\end{array}$ \\
\hline Московская область & 18.88 & 0.82 & 63.7 \\
\hline Санкт-Петербург & 9.13 & 0.44 & 86.0 \\
\hline Новосибирская область & 4.75 & 0.56 & 54.6 \\
\hline Республика Башкортостан & 3.90 & 0.36 & 37.9 \\
\hline Курганская область & 3.76 & 1.51 & 27.7 \\
\hline Владимирская область & 2.97 & 0.71 & 51.8 \\
\hline Курская область & 2.91 & 0.81 & 44.2 \\
\hline Самарская область & 2.86 & 0.27 & 34.8 \\
\hline Калужская область & 2.35 & 0.70 & 108.7 \\
\hline Пензенская область & 1.91 & 0.58 & 24.6 \\
\hline Томская область & 1.56 & 0.45 & 40.0 \\
\hline Республика Мордовия & 1.50 & 0.60 & 23.6 \\
\hline Ставропольский край & 1.37 & 0.22 & 34.2 \\
\hline Москва & 10.33 & 0.22 & 115.1 \\
\hline Нижегородская область & 2.87 & 0.25 & 54.9 \\
\hline Свердловская область & 2.68 & 0.17 & 25.1 \\
\hline Иркутская область & 2.09 & 0.26 & 38.9 \\
\hline Кемеровская область & 1.96 & 0.22 & 28.0 \\
\hline Кировская область & 1.83 & 0.46 & 34.9 \\
\hline Ярославская область & 1.55 & 0.35 & 58.8 \\
\hline Республика Марий Эл & 0.98 & 0.51 & 22.8 \\
\hline
\end{tabular}




\section{Финансовые услуги}

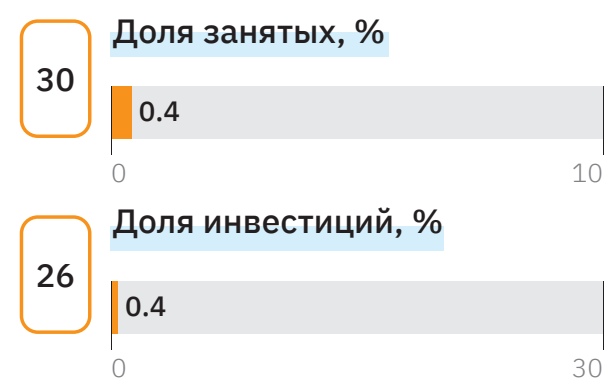

$\mathrm{X}-$ Ранг отрасли среди торгуемых отраслей

Регионы, специализирующиеся в отрасли

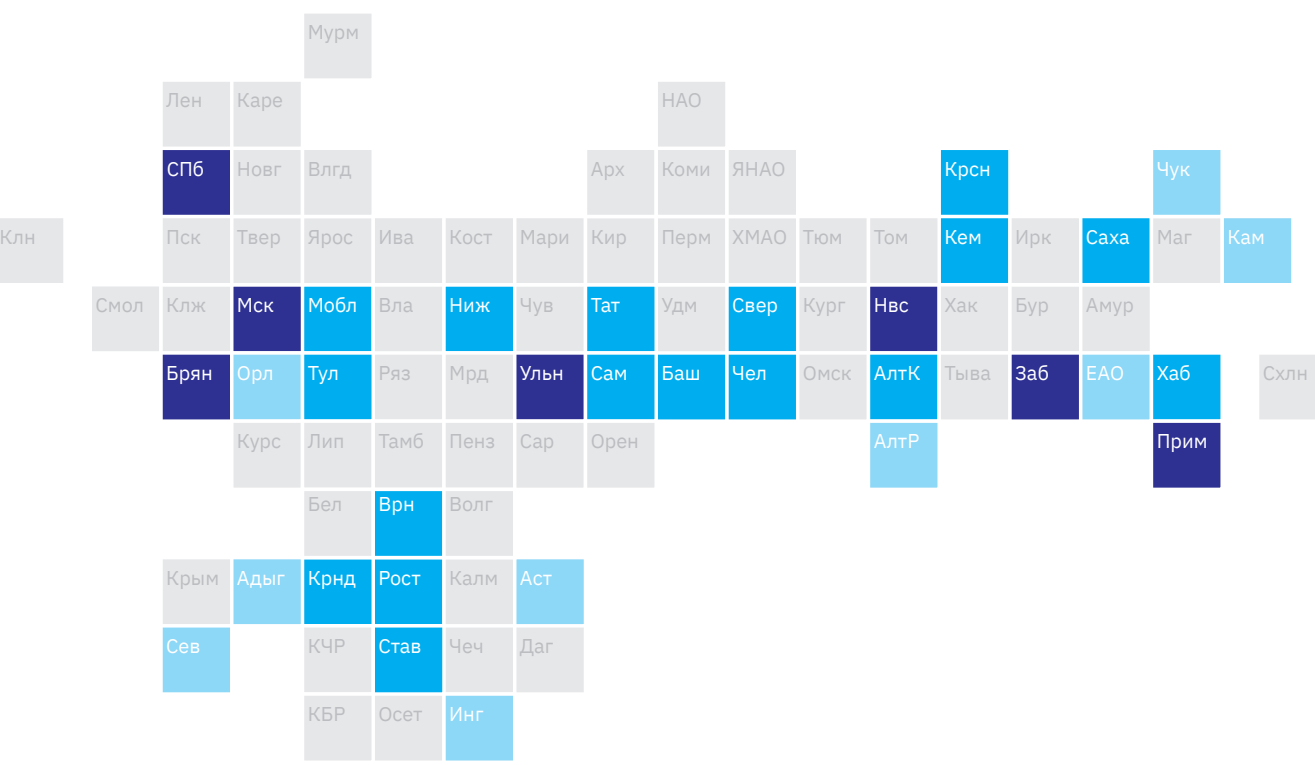

Отрасль национальной

\begin{tabular}{|c|c|c|c|}
\hline & $\begin{array}{l}\text { Доля региона } \\
\text { в отраслевой } \\
\text { занятости, \% }\end{array}$ & $\begin{array}{l}\text { Доля отрасли } \\
\text { в региональной } \\
\text { занятости, \% }\end{array}$ & $\begin{array}{l}\text { Заработная } \\
\text { плата, } \\
\text { тыс. руб. }\end{array}$ \\
\hline Москва & 37.14 & 1.49 & 185.7 \\
\hline Санкт-Петербург & 6.55 & 0.61 & 81.1 \\
\hline Новосибирская область & 2.42 & 0.55 & 90.8 \\
\hline Приморский край & 1.38 & 0.47 & 115.6 \\
\hline Брянская область & 0.91 & 0.53 & 43.0 \\
\hline Ульяновская область & 0.79 & 0.42 & 54.1 \\
\hline Забайкальский край & 0.73 & 0.43 & 70.6 \\
\hline Московская область & 3.43 & 0.29 & 78.9 \\
\hline Свердловская область & 3.13 & 0.39 & 84.9 \\
\hline Краснодарский край & 2.78 & 0.37 & 69.7 \\
\hline Республика Татарстан & 2.07 & 0.30 & 64.8 \\
\hline Челябинская область & 1.94 & 0.33 & 53.8 \\
\hline Самарская область & 1.71 & 0.31 & 56.7 \\
\hline Нижегородская область & 1.65 & 0.28 & 88.8 \\
\hline Красноярский край & 1.34 & 0.25 & 76.6 \\
\hline Ростовская область & 1.30 & 0.23 & 75.0 \\
\hline Кемеровская область & 1.27 & 0.28 & 59.7 \\
\hline Республика Башкортостан & 1.07 & 0.19 & 68.0 \\
\hline Республика Саха (Якутия) & 1.07 & 0.48 & 106 \\
\hline Хабаровский край & 0.92 & 0.37 & 93.3 \\
\hline Алтайский край & 0.91 & 0.30 & 65.5 \\
\hline Воронежская область & 0.79 & 0.23 & 76.3 \\
\hline Ставропольский край & 0.74 & 0.23 & 79.8 \\
\hline Тульская область & 0.67 & 0.28 & 63.4 \\
\hline Орловская область & 0.62 & 0.51 & 59.1 \\
\hline Астраханская область & 0.44 & 0.33 & 60.1 \\
\hline Камчатский край & 0.38 & 0.54 & 174 \\
\hline Севастополь & 0.32 & 0.60 & 69.9 \\
\hline Республика Адыгея & 0.19 & 0.38 & 75.2 \\
\hline Чукотский автономный округ & 0.17 & 0.81 & 189.4 \\
\hline Республика Алтай & 0.16 & 0.53 & 106.6 \\
\hline Республика Ингушетия & 0.15 & 0.46 & 67.9 \\
\hline Еврейская автономная область & 0.15 & 0.56 & 91.7 \\
\hline
\end{tabular}




\section{Химические вещества}
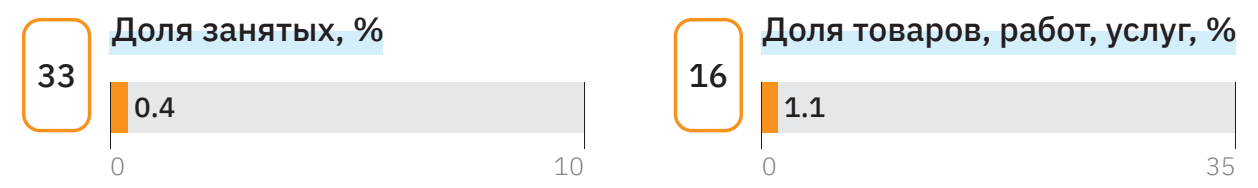

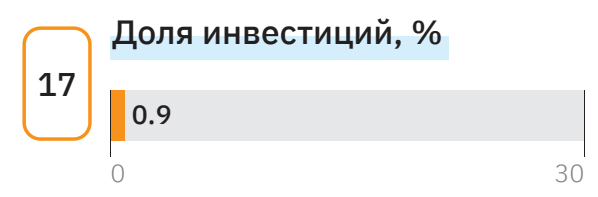

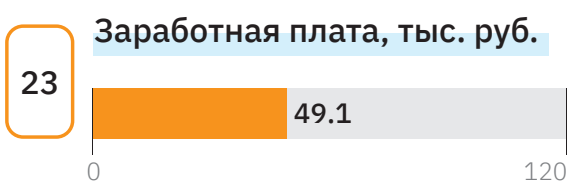

X- Ранг отрасли среди торгуемых отраслей

Регионы, специализирующиеся в отрасли

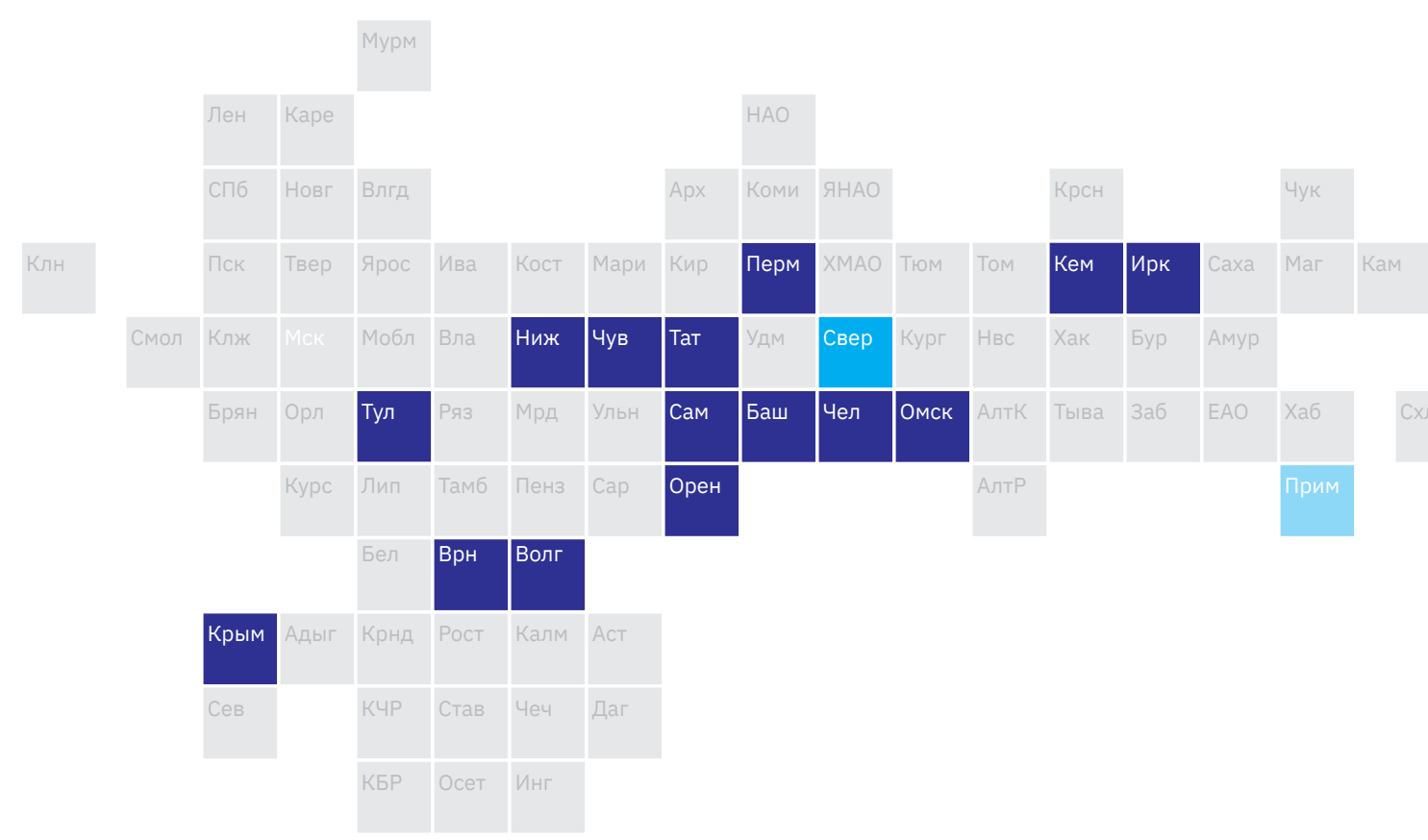

\begin{tabular}{|l|lll|} 
& $\begin{array}{l}\text { Доля региона } \\
\text { в отраслевой } \\
\text { занятости, \% }\end{array}$ & $\begin{array}{l}\text { Доля отраслиональной } \\
\text { занятоси, \% }\end{array}$ & $\begin{array}{l}\text { Заработная } \\
\text { плата, } \\
\text { тыс. руб. }\end{array}$ \\
\hline Республика Татарстан & 11.34 & 1.42 & 49.6 \\
\hline Республика Башкортостан & 10.94 & 1.68 & 46.3 \\
\hline Челябинская область & 10.34 & 1.51 & 59.2 \\
\hline Пермский край & 8.46 & 1.68 & 46.6 \\
\hline Волгоградская область & 5.57 & 1.43 & 45.0 \\
\hline Самарская область & 4.97 & 0.77 & 50.7 \\
\hline Иркутская область & 4.39 & 0.90 & 65.5 \\
\hline Тульская область & 4.17 & 1.49 & 42.6 \\
\hline Нижегородская область & 3.84 & 0.56 & 51.2 \\
\hline Омская область & 3.44 & 1.01 & 40.1 \\
\hline Чувашская Республика & 3.19 & 1.64 & 36.4 \\
\hline Республика Крым & 2.91 & 1.10 & 30.2 \\
\hline Кемеровская область & 2.45 & 0.46 & 46.4 \\
\hline Воронежская область & 1.99 & 0.49 & 56.6 \\
\hline Оренбургская область & 1.80 & 0.52 & 41.2 \\
\hline Свердловская область & 3.07 & 0.33 & 40.2 \\
\hline Приморский край & 1.71 & 0.50 & 30.1 \\
\hline
\end{tabular}




\section{Химические продукты}
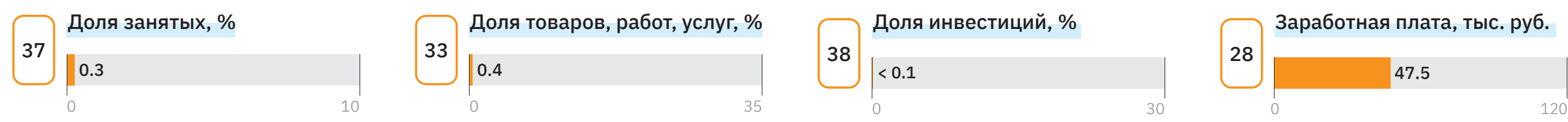

X- Ранг отрасли среди торгуемых отраслей

\section{Регионы, специализирующиеся в отрасли}

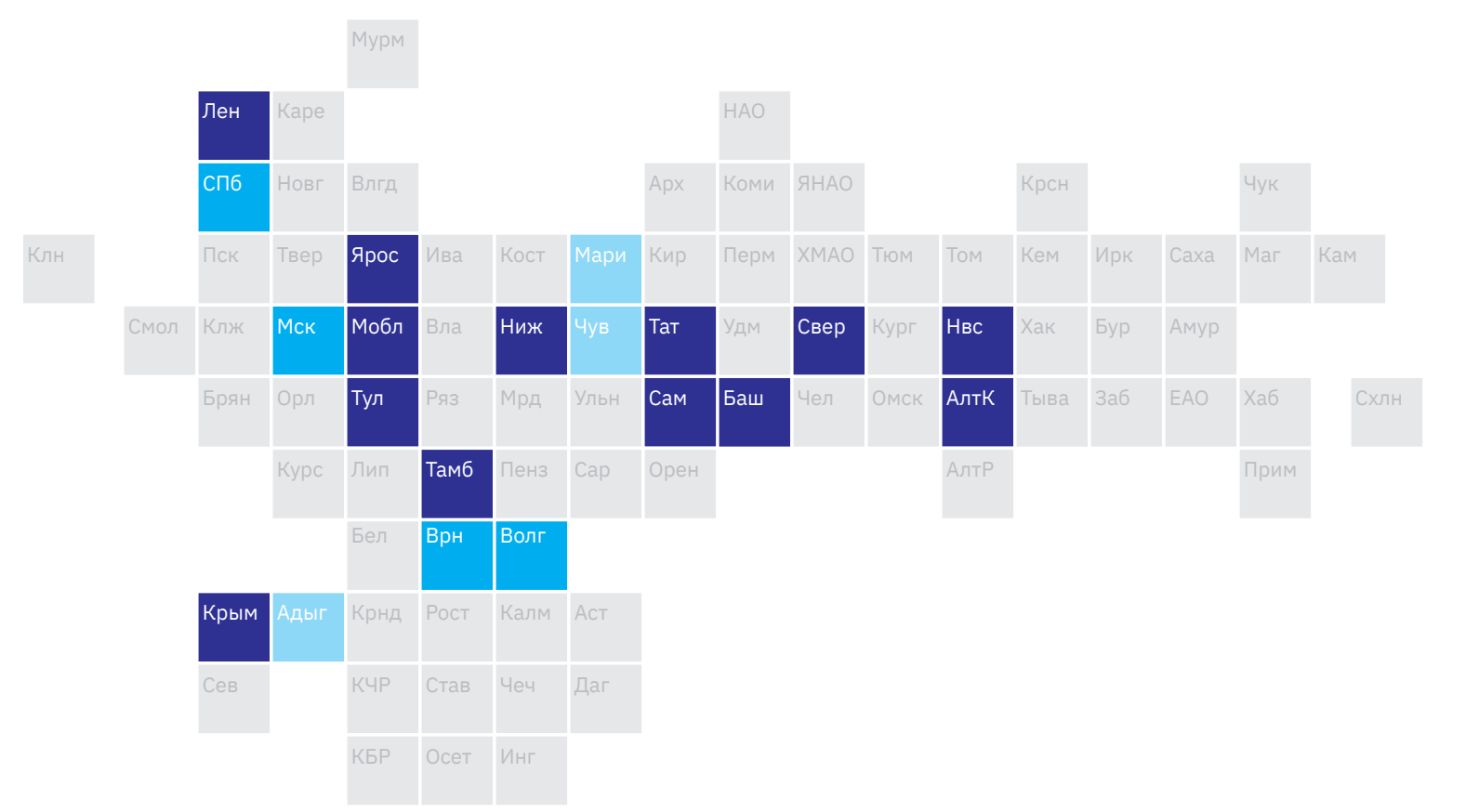

\begin{tabular}{|c|c|c|c|}
\hline & $\begin{array}{l}\text { Доля региона } \\
\text { в отраслевой } \\
\text { занятости, \% }\end{array}$ & $\begin{array}{l}\text { Доля отрасли } \\
\text { в региональной } \\
\text { занятости, \% }\end{array}$ & $\begin{array}{l}\text { Заработная } \\
\text { плата, } \\
\text { тыс. руб. }\end{array}$ \\
\hline Московская область & 9.90 & 0.53 & 53.0 \\
\hline Свердловская область & 8.27 & 0.65 & 43.2 \\
\hline Республика Татарстан & 5.68 & 0.52 & 45.1 \\
\hline Самарская область & 5.31 & 0.61 & 32.9 \\
\hline Новосибирская область & 4.94 & 0.71 & 45.2 \\
\hline Нижегородская область & 4.88 & 0.53 & 43.8 \\
\hline Тульская область & 4.64 & 1.22 & 41.2 \\
\hline Ярославская область & 4.11 & 1.13 & 59.6 \\
\hline Республика Башкортостан & 4.04 & 0.46 & 44.3 \\
\hline Республика Крым & 3.72 & 1.03 & 28.8 \\
\hline Тамбовская область & 3.00 & 1.28 & 27.8 \\
\hline Алтайский край & 2.90 & 0.60 & 27.6 \\
\hline Ленинградская область & 1.92 & 0.45 & 56.1 \\
\hline Москва & 6.25 & 0.16 & 80.4 \\
\hline Санкт-Петербург & 5.76 & 0.34 & 75.6 \\
\hline Воронежская область & 2.11 & 0.38 & 32.9 \\
\hline Волгоградская область & 1.92 & 0.36 & 43.2 \\
\hline Чувашская Республика & 1.03 & 0.39 & 34.5 \\
\hline Республика Марий Эл & 0.49 & 0.31 & 48.3 \\
\hline Республика Адыгея & 0.29 & 0.37 & 15.7 \\
\hline
\end{tabular}




\section{Целлюлозно-бумажные изделия}
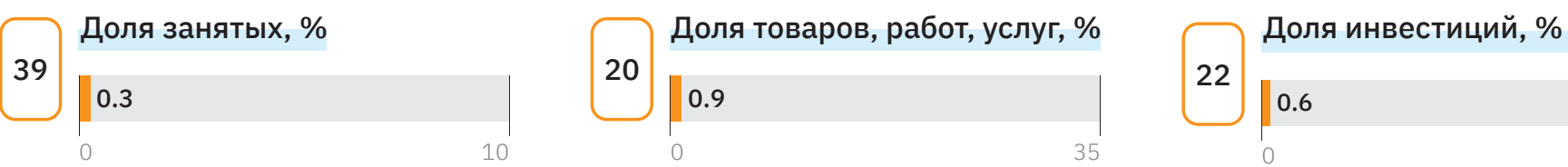

Заработная плата, тыс. руб.

$\mathrm{x}-$ Ранг отрасли среди торгуемых отраслей

Регионы, специализирующиеся в отрасли

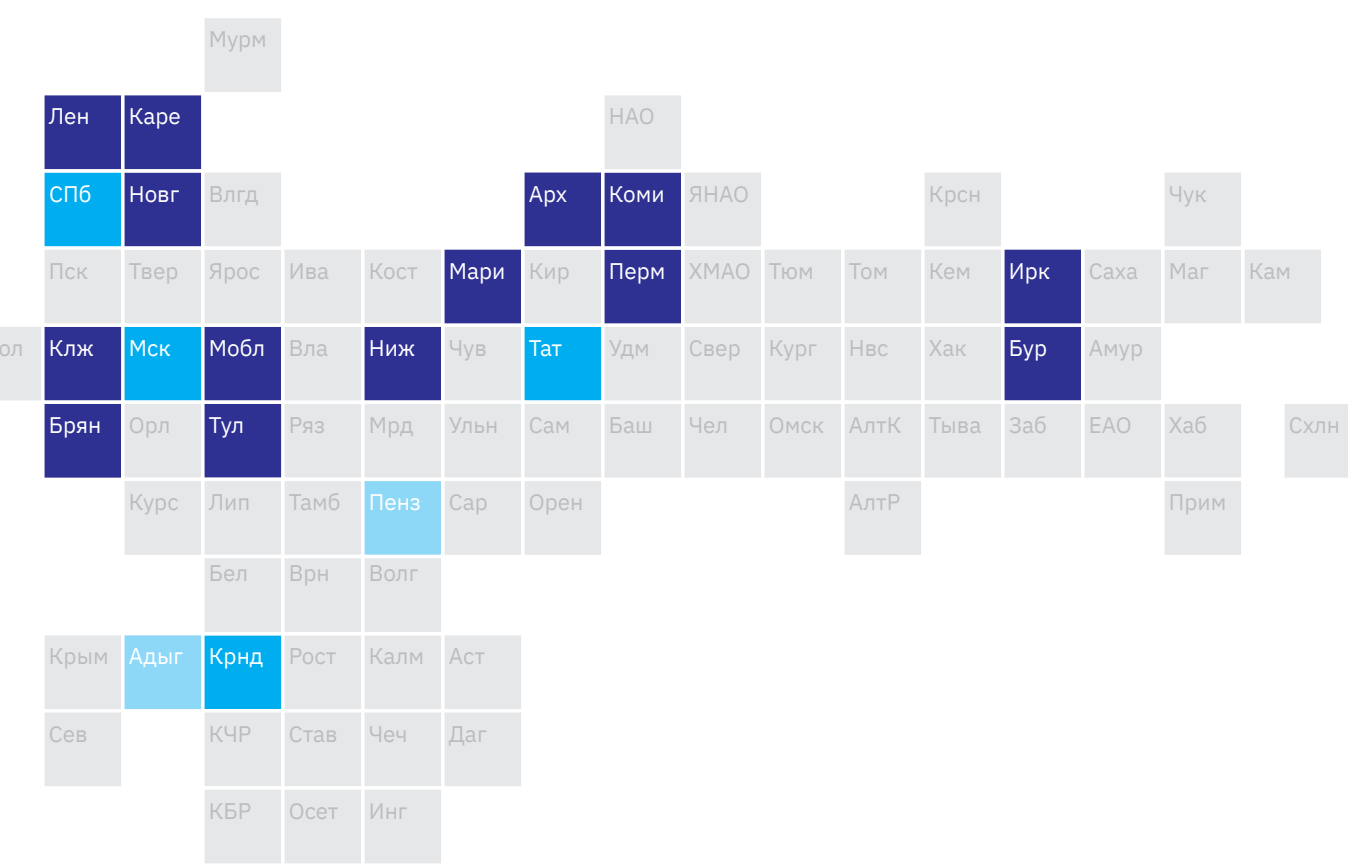

\begin{tabular}{|c|c|c|c|}
\hline & $\begin{array}{l}\text { Доля региона } \\
\text { в отраслевой } \\
\text { занятости, \% }\end{array}$ & $\begin{array}{l}\text { Доля отрасли } \\
\text { в региональной } \\
\text { занятости, \% }\end{array}$ & $\begin{array}{l}\text { Заработная } \\
\text { плата, } \\
\text { тыс. руб. }\end{array}$ \\
\hline Московская область & 10.61 & 0.54 & 56.1 \\
\hline Ленинградская область & 8.77 & 1.95 & 56.7 \\
\hline Архангельская область & 7.90 & 2.27 & 52.7 \\
\hline Пермский край & 7.55 & 1.06 & 35.7 \\
\hline Республика Карелия & 6.52 & 3.86 & 38.5 \\
\hline Иркутская область & 6.41 & 0.93 & 57.9 \\
\hline Нижегородская область & 4.19 & 0.43 & 39.7 \\
\hline Республика Коми & 3.38 & 1.13 & 74.3 \\
\hline Калужская область & 3.03 & 1.06 & 39.2 \\
\hline Республика Марий Эл & 2.56 & 1.57 & 54.2 \\
\hline Тульская область & 2.31 & 0.58 & 50.4 \\
\hline Брянская область & 2.03 & 0.72 & 34.8 \\
\hline Республика Бурятия & 1.65 & 0.80 & 29.7 \\
\hline Новгородская область & 1.39 & 0.81 & 50.1 \\
\hline Республика Татарстан & 3.44 & 0.31 & 59.0 \\
\hline Москва & 3.39 & 0.08 & 73.0 \\
\hline Санкт-Петербург & 2.81 & 0.16 & 118.6 \\
\hline Краснодарский край & 1.91 & 0.16 & 36.5 \\
\hline Пензенская область & 1.34 & 0.47 & 45.7 \\
\hline Республика Адыгея & 1.12 & 1.36 & 37.8 \\
\hline
\end{tabular}




\section{Электрооборудование и осветительные приборы}
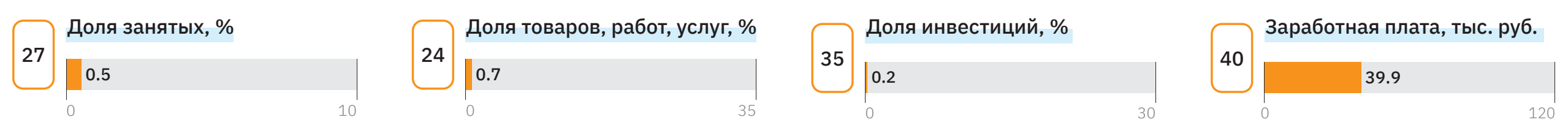

X- Ранг отрасли среди торгуемых отраслей

Регионы, специализирующиеся в отрасли

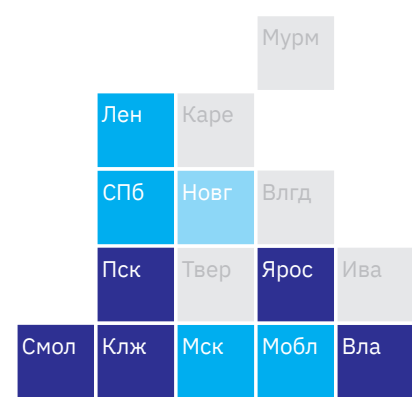

Kypc

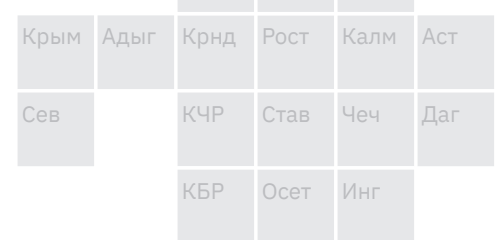

Отрасль национальной и локальной значимости

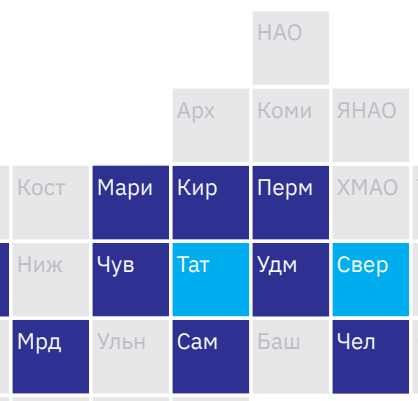

Пенз

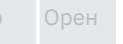

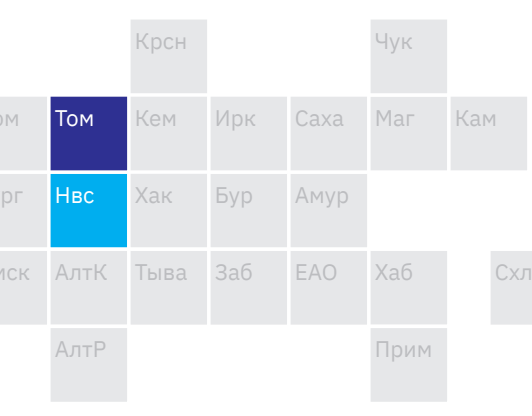

\begin{tabular}{|l|lll} 
& $\begin{array}{l}\text { Доля региона } \\
\text { В отраслевой } \\
\text { занятости, \% }\end{array}$ & $\begin{array}{l}\text { Доля отрасли } \\
\text { в региональной }\end{array}$ & $\begin{array}{l}\text { 3аработная } \\
\text { плата, } \\
\text { тыс. руб. }\end{array}$ \\
\hline Чувашская Республика & 4.98 & 3.63 & 37.7 \\
\hline Республика Мордовия & 4.74 & 4.47 & 29.3 \\
\hline Самарская область & 4.34 & 0.96 & 33.1 \\
\hline Кировская область & 3.57 & 2.12 & 36.6 \\
\hline Пермский край & 3.36 & 0.95 & 33.6 \\
\hline Курская область & 2.95 & 1.93 & 28.3 \\
\hline Удмуртская Республика & 2.82 & 1.27 & 43.6 \\
\hline Псковская область & 2.81 & 3.42 & 32.4 \\
\hline Челябинская область & 2.60 & 0.54 & 34.6 \\
\hline Томская область & 2.58 & 1.77 & 43.1 \\
\hline Ярославская область & 2.13 & 1.13 & 41.4 \\
\hline Калужская область & 2.10 & 1.47 & 39.6 \\
\hline Республика Марий Эл & 2.10 & 2.57 & 28.2 \\
\hline Владимирская область & 2.06 & 1.16 & 32.6 \\
\hline Смоленская область & 1.63 & 1.29 & 36.1 \\
\hline Санкт-Петербург & 5.90 & 0.67 & 63.3 \\
\hline Москва & 5.34 & 0.26 & 67.6 \\
\hline Московская область & 5.26 & 0.54 & 53.8 \\
\hline Свердловская область & 4.17 & 0.63 & 39.8 \\
\hline Республика Татарстан & 3.77 & 0.67 & 36.2 \\
\hline Новосибирская область & 2.82 & 0.78 & 40.9 \\
\hline Ленинградская область & 1.99 & 0.89 & 50.6 \\
\hline Новгородская область & 0.91 & 1.07 & 27.9 \\
\hline
\end{tabular}




\section{Ювелирные изделия}
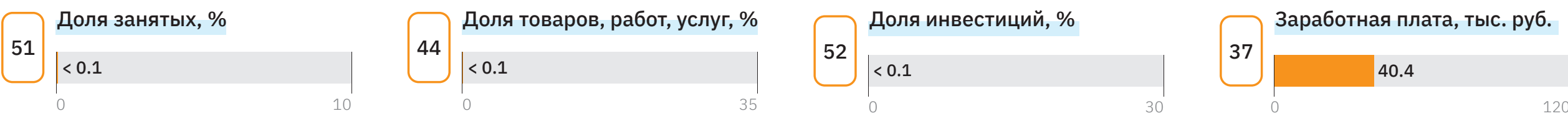

X Ранг отрасли среди торгуемых отраслей

Регионы, специализирующиеся в отрасли

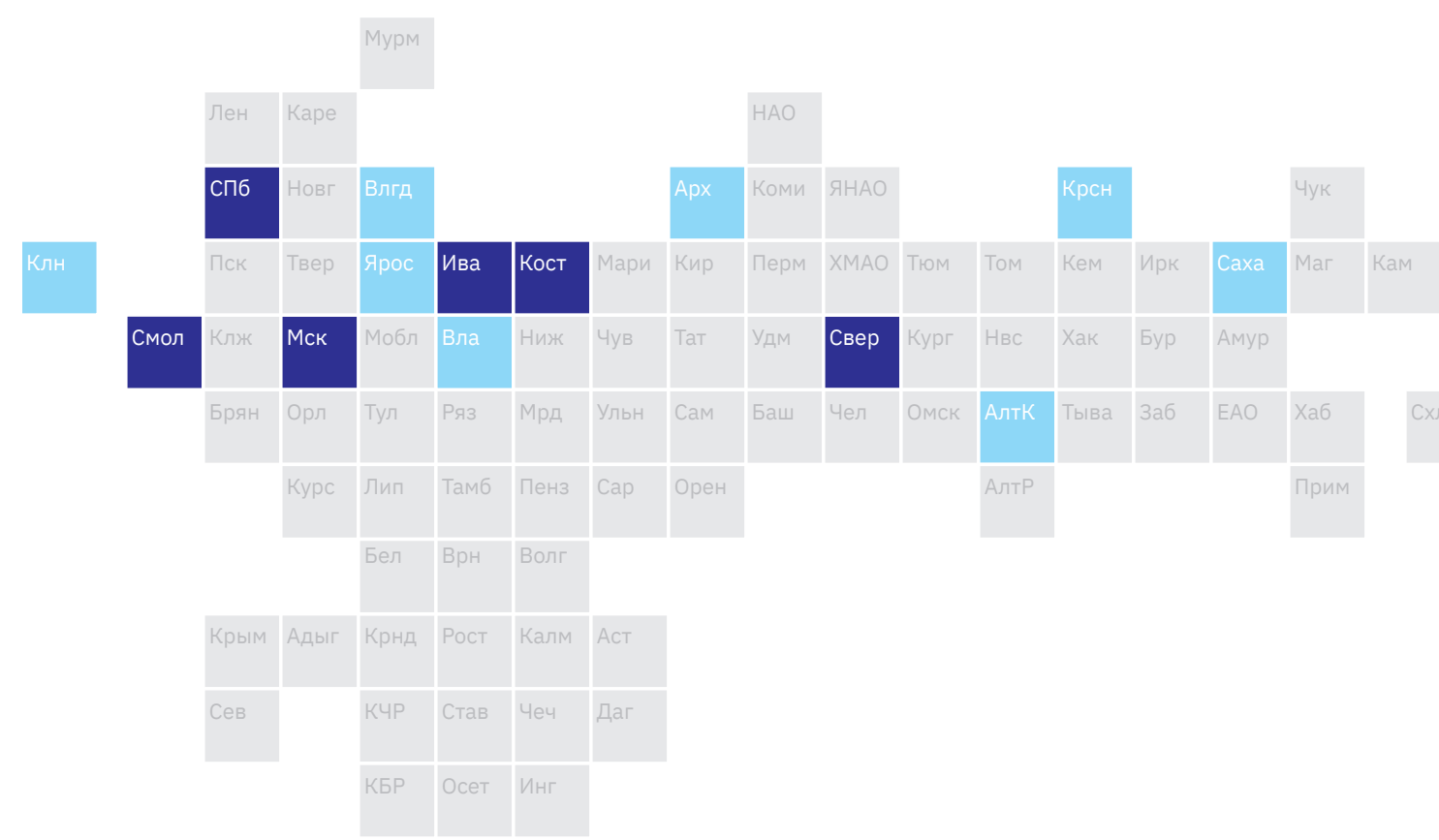

Отрасль национальной и локальной значимости
Отрасль национальной значимости

\begin{tabular}{|l|lll} 
& $\begin{array}{l}\text { Доля региона } \\
\text { В отраслевой } \\
\text { занятости, } \%\end{array}$ & $\begin{array}{l}\text { Доля отрасли } \\
\text { врегиональной }\end{array}$ & $\begin{array}{l}\text { Заработная } \\
\text { плата, } \\
\text { тыс. руб. }\end{array}$ \\
\hline Костромская область & 41.25 & 4.44 & 33.7 \\
\hline Смоленская область & 13.51 & 0.91 & 44.8 \\
\hline Москва & 12.79 & 0.05 & 63.4 \\
\hline Санкт-Петербург & 7.30 & 0.07 & 50.8 \\
\hline Ивановская область & 4.04 & 0.36 & 27.6 \\
\hline Свердловская область & 1.94 & 0.02 & 29.3 \\
\hline Республика Саха (Якутия) & 3.05 & 0.14 & 37.5 \\
\hline Владимирская область & 2.03 & 0.10 & 39.4 \\
\hline Вологодская область & 1.80 & 0.10 & 23.3 \\
\hline Алтайский край & 1.50 & 0.05 & 28.0 \\
\hline Красноярский край & 1.38 & 0.03 & 43.0 \\
\hline Калининградская область & 1.26 & 0.09 & 42.9 \\
\hline Ярославская область & 1.15 & 0.05 & 33.3 \\
\hline Архангельская область & 0.65 & 0.03 & 38.7 \\
\hline
\end{tabular}





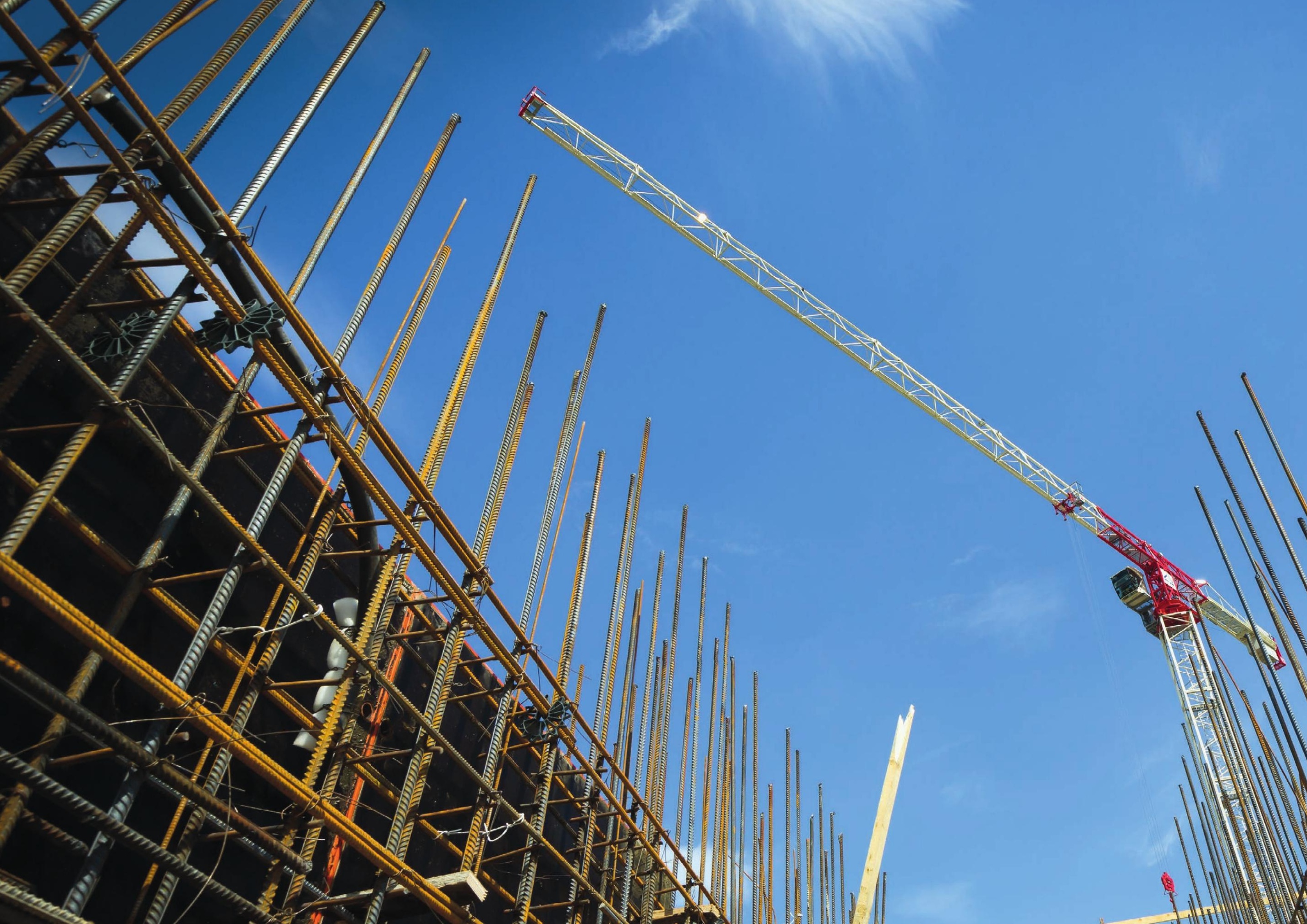




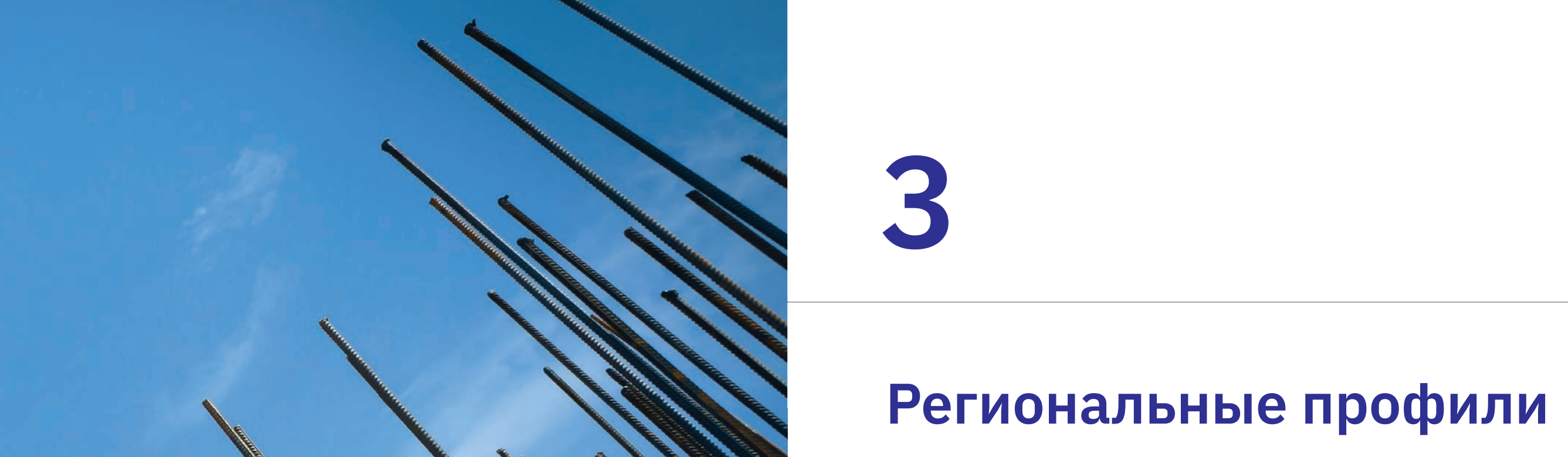


Удельный вес работников организаций отраслей специализации в общей численности работников организаций в субъекте Российской Федерации, 2018, \%

Среднемесячная начисленная заработная плата работников организаций отраслей специализации в субъекте Российской Федерации, 2018, тыс. руб.

\section{Субъект РФ}

Прирост численности работников организаций отраслей специализации в субъекте Российскои Федерации за год, 2018 к 2017, \%

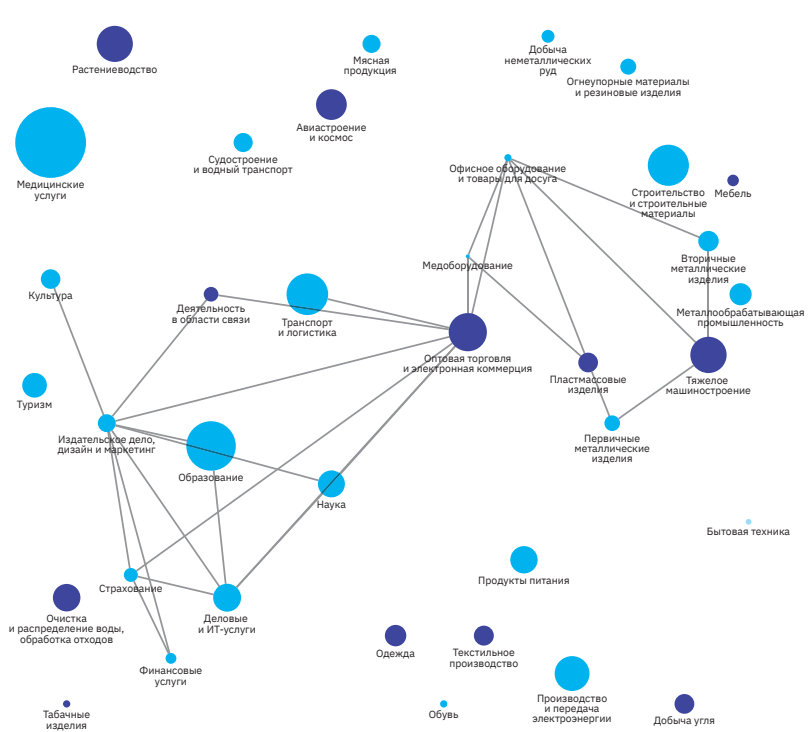

субъекта РФ, 2018, чел. 
Центральный федеральный округ 


\section{Белгородская область}

Число отраслей специализации, ед.

$7 \quad 6$

\begin{tabular}{lllllll}
\hline 8 & 16 & 24 & 32 & 40 & 48 & 56
\end{tabular}

Доля занятых, \%

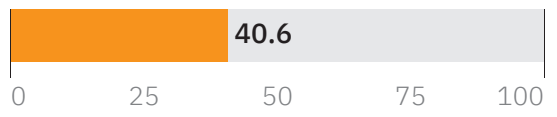

Прирост занятых, \%

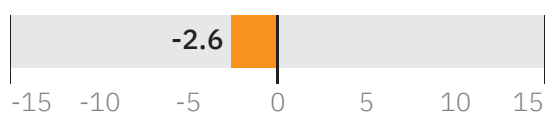

Заработная плата, тыс. руб.

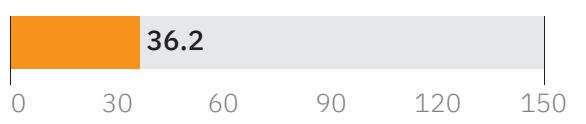

Отрасль национальной

и локальной значимости

Отрасль национальной

значимости

Отрасль локальной

значимости

Высокий уровень взаимосвязи отраслей

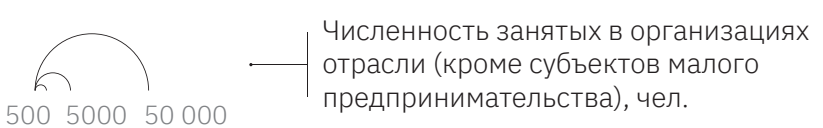

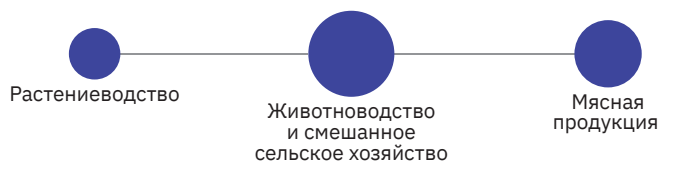

Культура
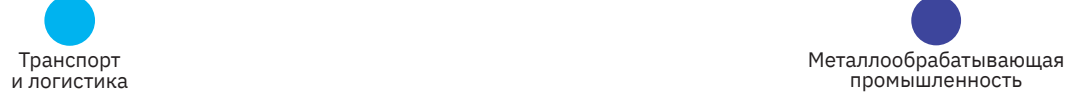

Туризм
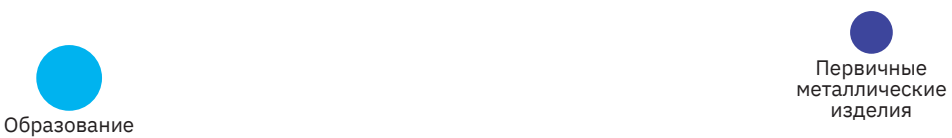

образование

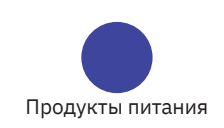

$\underset{\substack{\text { Полиграфия } \\ \text { и печать }}}{\substack{0 \\ 0}}$ 


\section{Брянская область}

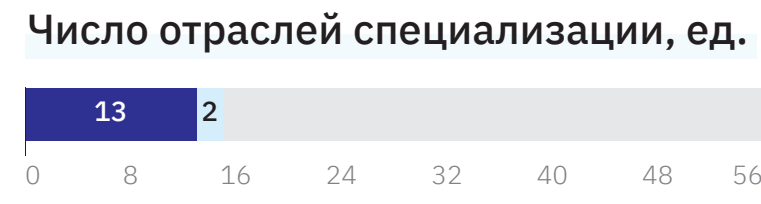

Доля занятых, \%

\begin{tabular}{|ccccc|}
\hline & 16.9 & & & \\
0 & 25 & 50 & 75 & 100
\end{tabular}

Прирост занятых, \%

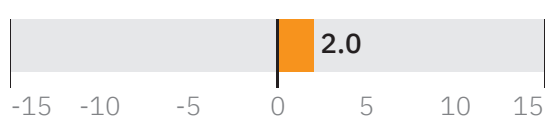

Заработная плата, тыс. руб.

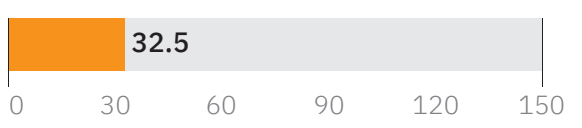

Отрасль национальной

и локальной значимости

Отрасль национальной

значимости

Отрасль локальной

значимости

Высокий уровень взаимосвязи отраслей

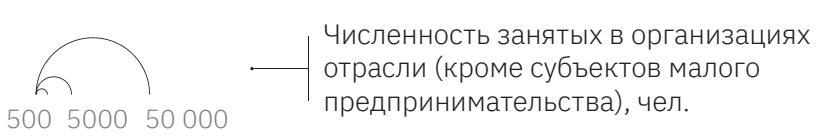

Растениеводство

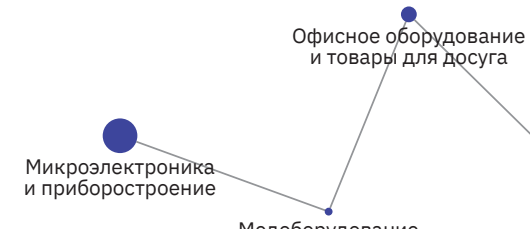

Медоборудование

$\underset{\substack{\text { Мясная } \\ \text { продукция }}}{ }$
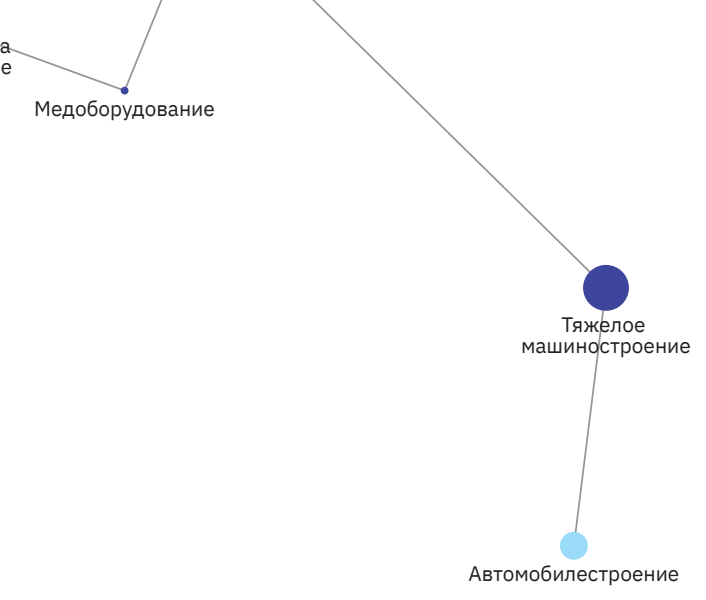

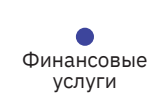

Финансовые
услуги

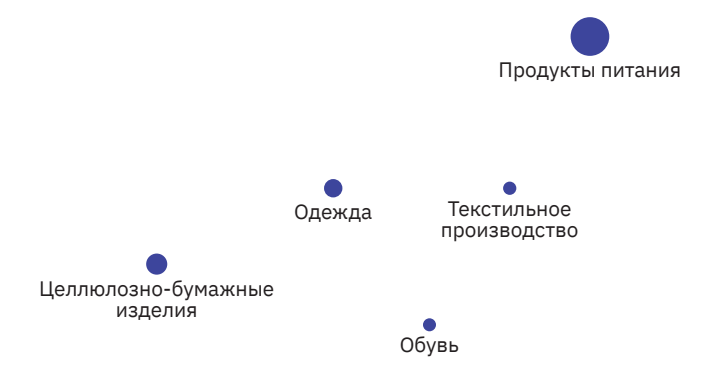

Автомобилестроение

мебель

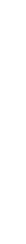




\section{Владимирская область}

Число отраслей специализации, ед.

\begin{tabular}{|llllllll|}
\hline & 18 & 2 & 2 & & & & \\
\hline 0 & 8 & 16 & 24 & 32 & 40 & 48 & 56
\end{tabular}

Доля занятых, \%

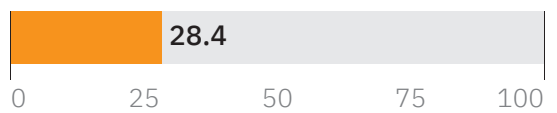

Прирост занятых, \%

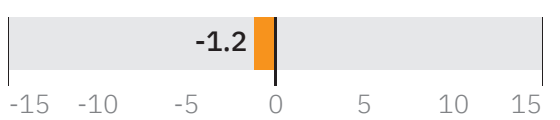

Заработная плата, тыс. руб.

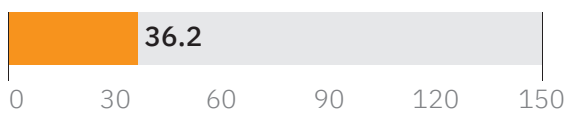

Отрасль национальной
и локальной значимости

значимости

Отрасль локальной

значимости

Высокий уровень взаимосвязи отраслей

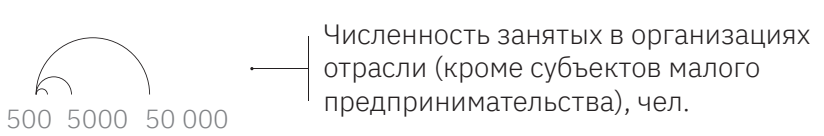

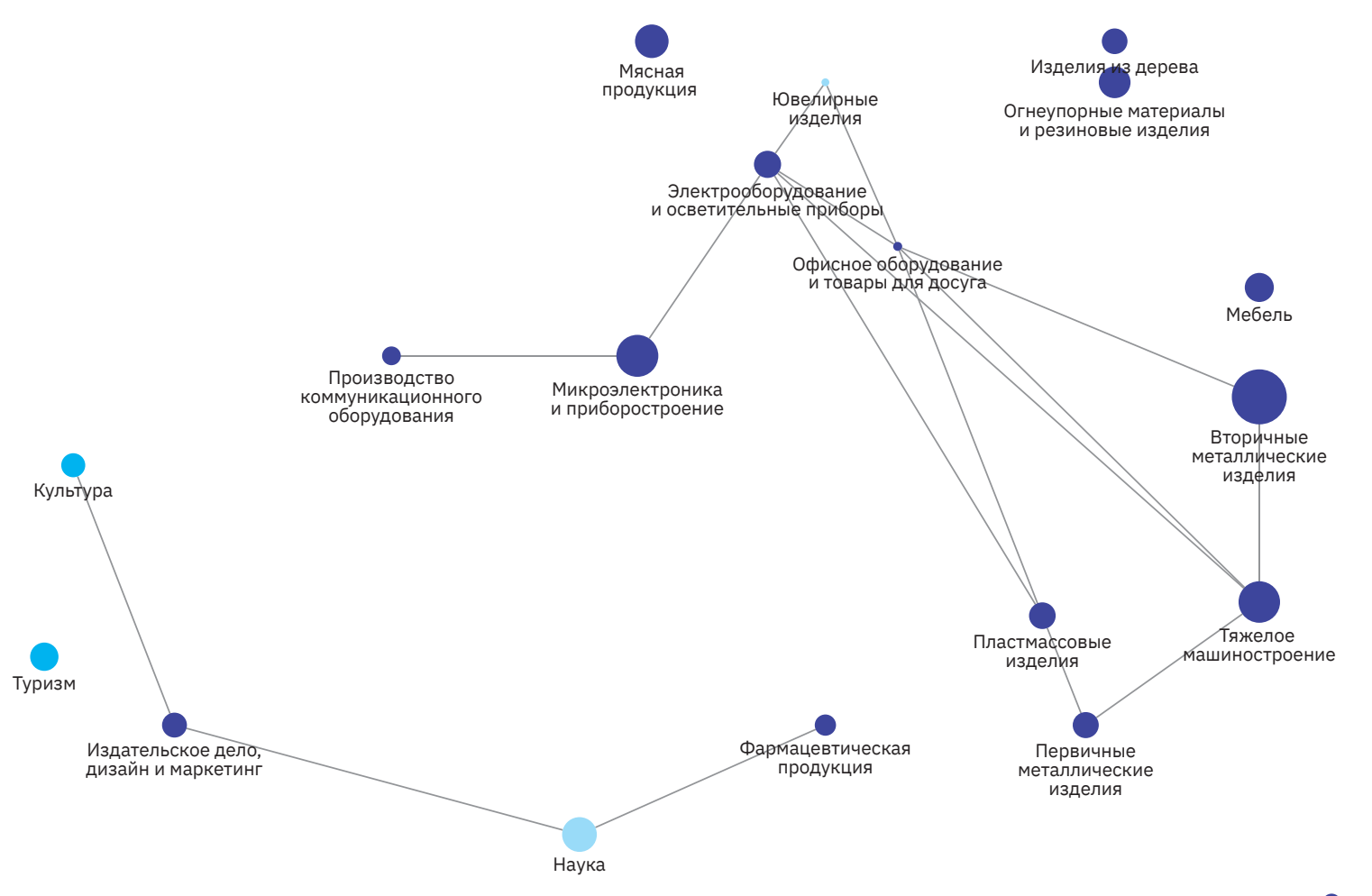

ытовая техника 


\section{Воронежская область}

Число отраслей специализации, ед.

$12 \quad 7$

$\begin{array}{llllllll}0 & 8 & 16 & 24 & 32 & 40 & 48 & 56\end{array}$

Доля занятых, \%

\begin{tabular}{|lrrrr|}
\hline & 34.6 & & \\
\hline & 25 & 50 & 75 & 100
\end{tabular}

Прирост занятых, \%

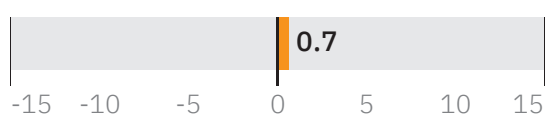

Заработная плата, тыс. руб.

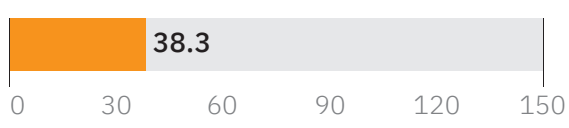

Отрасль национальной

и локальной значимости

Отрасль национальной

значимости

Отрасль локальной

значимости

Высокий уровень взаимосвязи отраслей

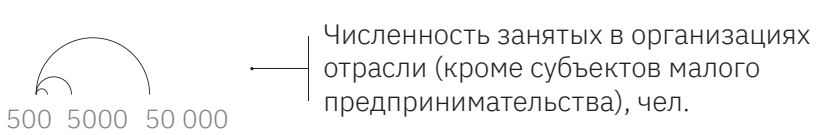

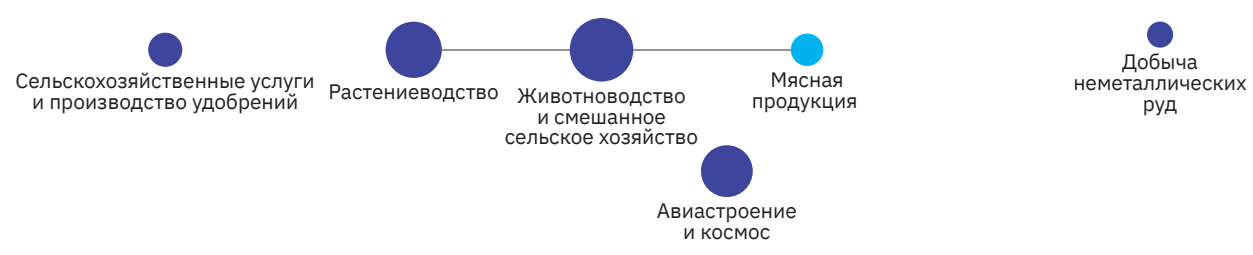

Туризм

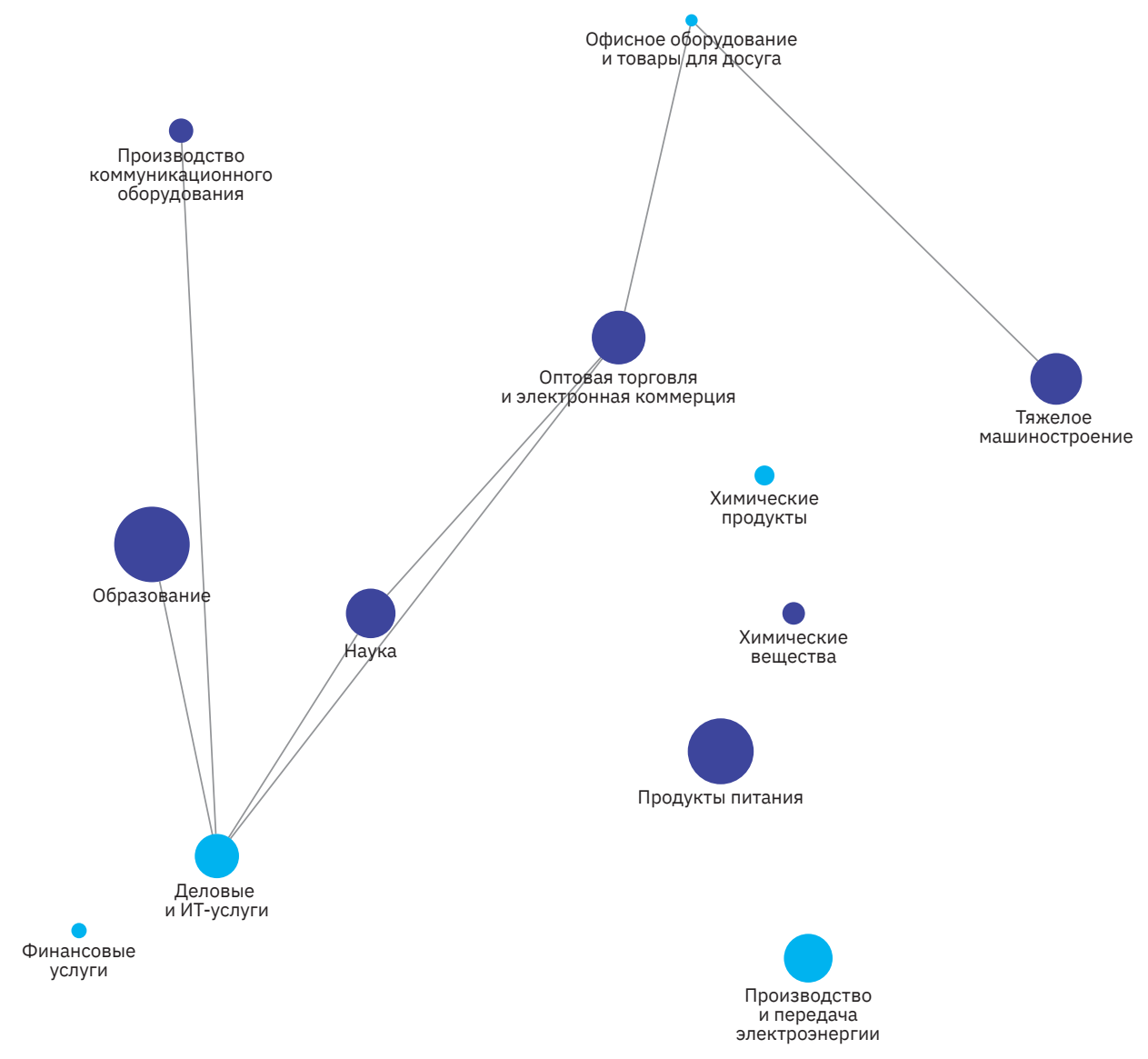




\section{Ивановская область}

Число отраслей специализации, ед.

\begin{tabular}{|llllllll|}
\hline 4 & 5 & & & & & & \\
0 & 8 & 16 & 24 & 32 & 40 & 48 & 56
\end{tabular}

Доля занятых, \%

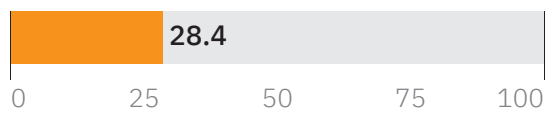

Прирост занятых, \%

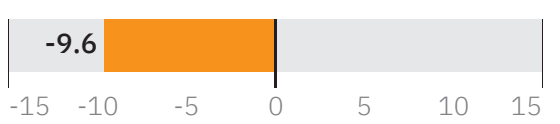

Заработная плата, тыс. руб.

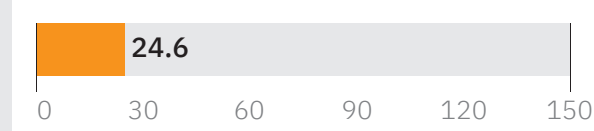

Отрасль национальной

и локальной значимости

Отрасль национальной

значимости

Отрасль локальной

значимости

Высокий уровень взаимосвязи отраслей
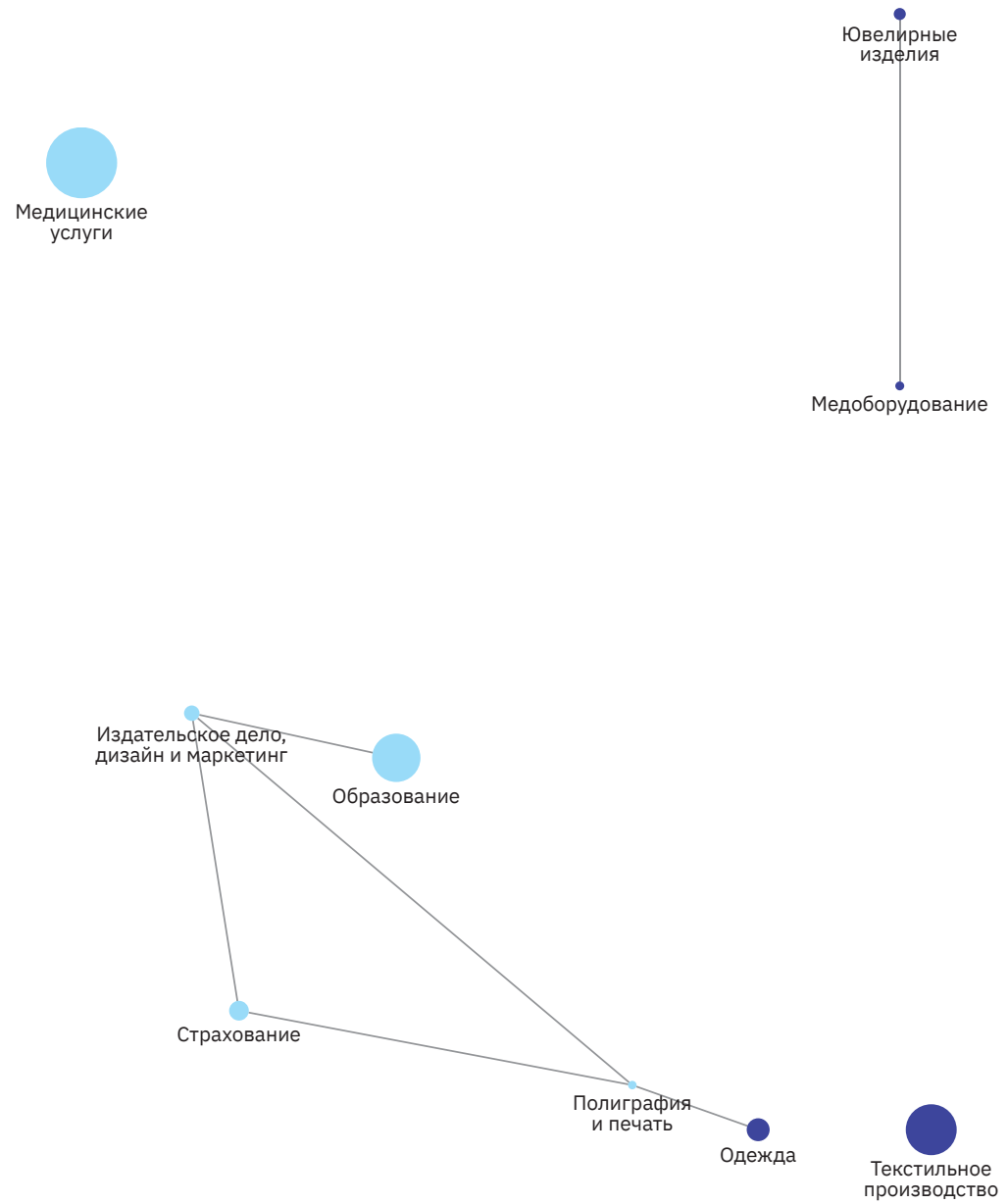

\footnotetext{
Численность занятых в организациях

$\curvearrowleft \quad$ отрасли (кроме субъектов малого 


\section{Калужская область}

\section{Число отраслей специализации, ед.}

14 4

r

\section{Доля занятых, \%}

\begin{tabular}{|lllll|}
\hline & 26.5 & & & \\
0 & 25 & 50 & 75 & 100
\end{tabular}

Прирост занятых, \%

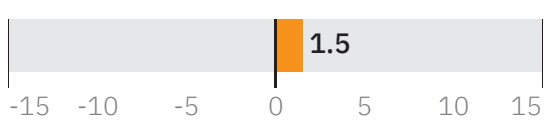

Заработная плата, тыс. руб.

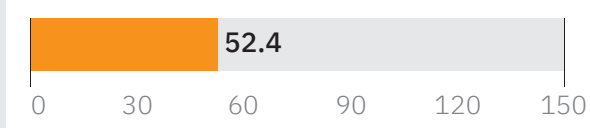

Отрасль национальной
и локальной значимости

значимости

Отрасль локальной

значимости

Высокий уровень взаимосвязи отраслей

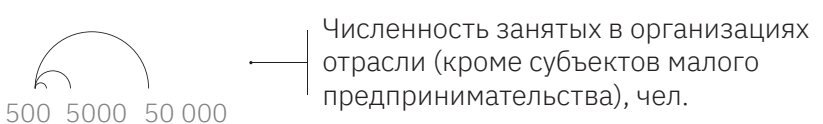

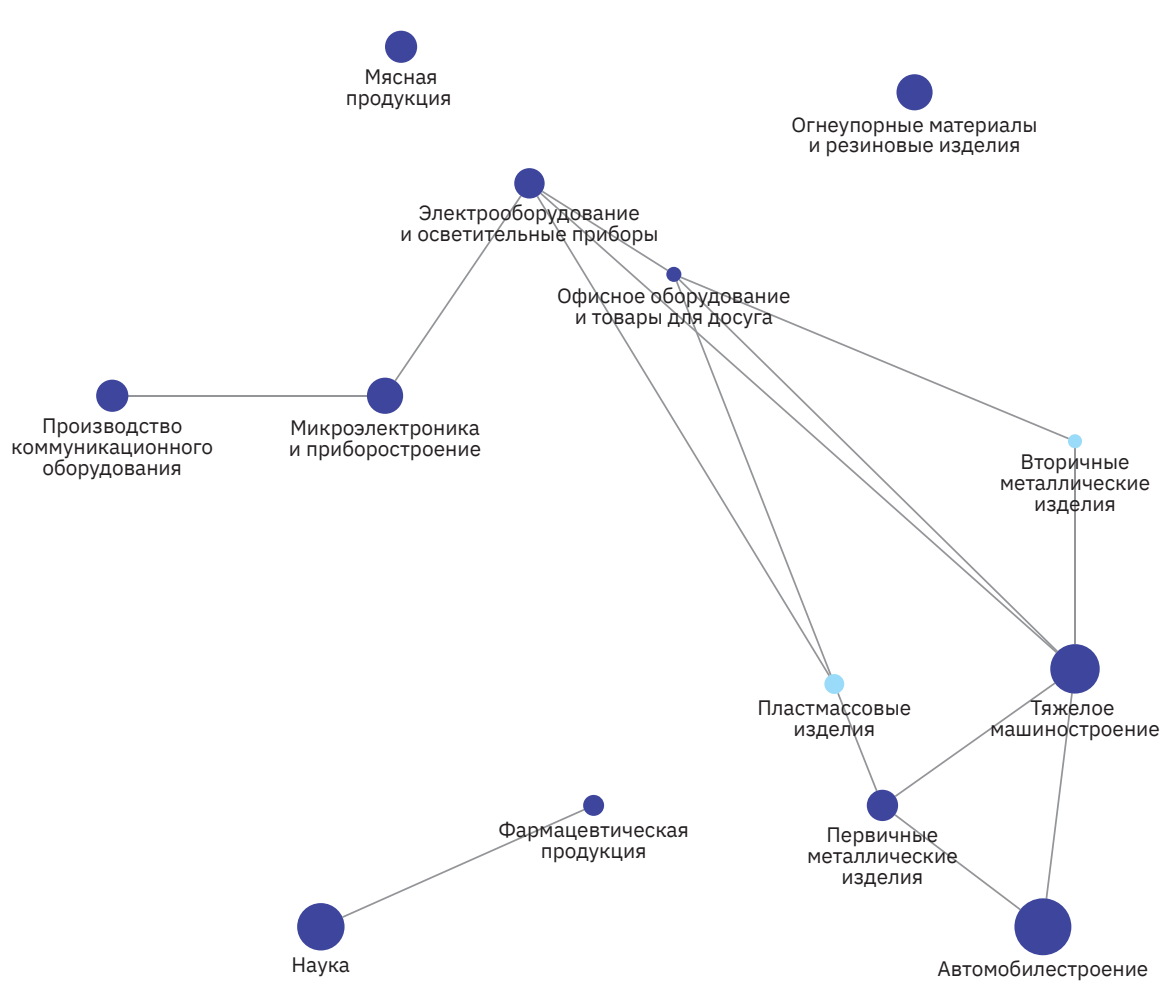

Бытовая техника

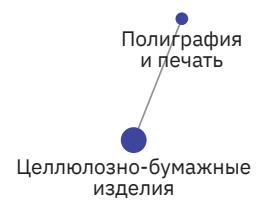

Звукозапись 


\section{Костромская область}

\section{Число отраслей специализации, ед.}

\begin{tabular}{|llllllll}
\hline 4 & 8 & & & & & & \\
0 & 8 & 16 & 24 & 32 & 40 & 48 & 56
\end{tabular}

Доля занятых, \%

\begin{tabular}{|lllll|}
\hline & 20.3 & & & \\
0 & 25 & 50 & 75 & 100
\end{tabular}

Прирост занятых, \%

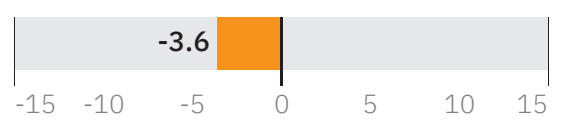

Заработная плата, тыс. руб.

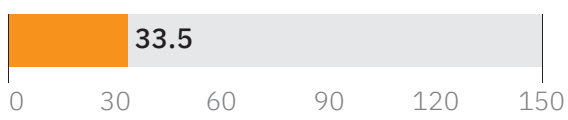

Отрасль национальной

и локальной значимости

Отрасль национальной

значимости

Отрасль локальной

значимости

Высокий уровень взаимосвязи отраслей

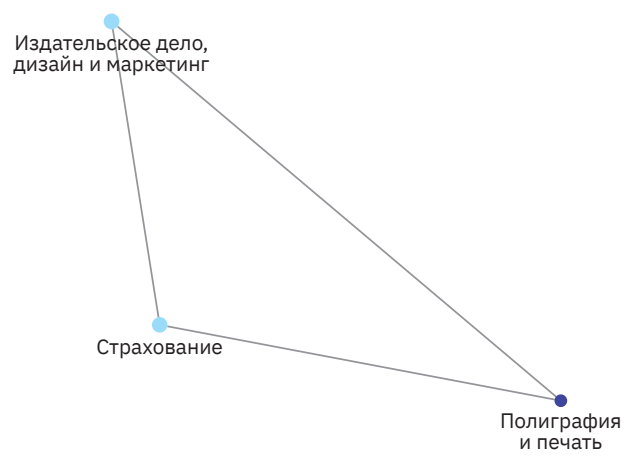

Текстильное

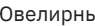

Ивелирные

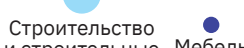

мебе материаль

\section{Вторичные}

изделия

\footnotetext{
Численность занятых в организациях

$\curvearrowleft \quad$ отрасли (кроме субъектов малого предпринимательства), чел.
} 


\section{Курская область}

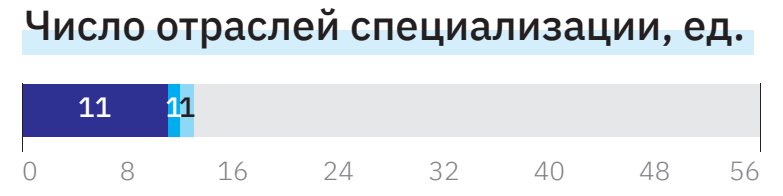

Доля занятых, \%

\begin{tabular}{|c|c|c|c|c|}
\hline \multicolumn{3}{|c|}{26.3} & & \\
\hline 0 & 25 & 50 & 75 & 100 \\
\hline
\end{tabular}

Прирост занятых, \%

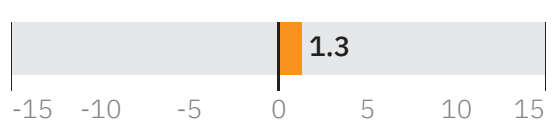

Заработная плата, тыс. руб.

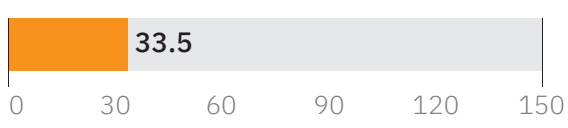

Отрасль национальной

и локальной значимости

Отрасль национальной

значимости

Отрасль локальной

значимости

Высокий уровень взаимосвязи отраслей

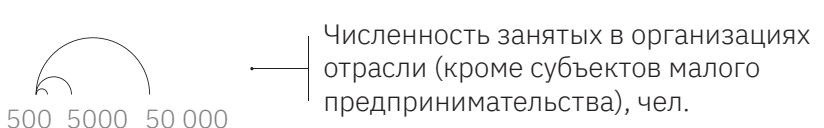

Растениеводство $\overbrace{\substack{\text { Мясная } \\ \text { продукция }}}$

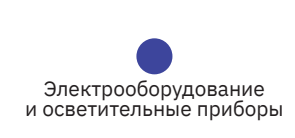

Электрооборудование
и осветительные приборы

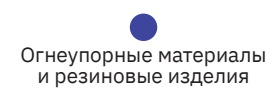

и резиновые изделия 


\section{Липецкая область}

\section{Число отраслей специализации, ед.}

811

8

$\begin{array}{llllll}16 & 24 & 32 & 40 & 48 & 56\end{array}$

Доля занятых, \%

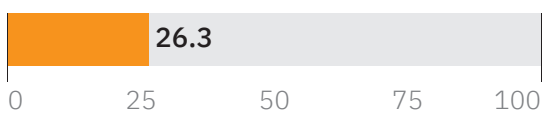

Прирост занятых, \%

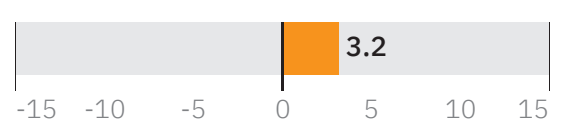

Заработная плата, тыс. руб.

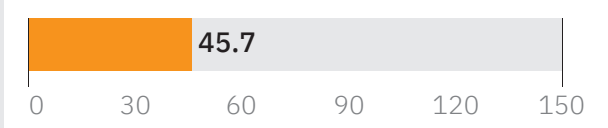

Отрасль национальной

и локальной значимости

Отрасль национальной

значимости

Отрасль локальной

значимости

Высокий уровень взаимосвязи отраслей

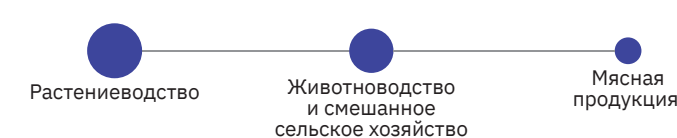

сельское хозяйство

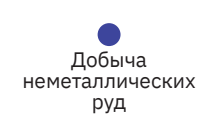

Лесная
промышленность

Медоборудование

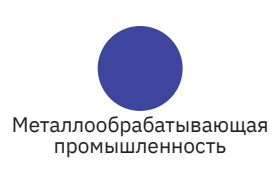

O 


\section{Московская область}

Число отраслей специализации, ед.

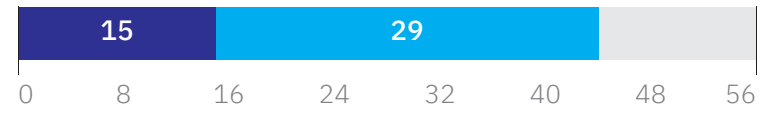

Доля занятых, \%

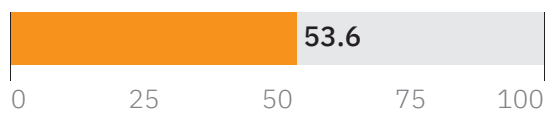

Прирост занятых, \%

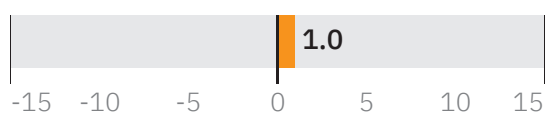

Заработная плата, тыс. руб.

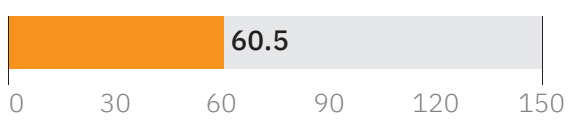

Отрасль национальной
и локальной значимости

Отрасль нац

Отрасль локальной

значимости

Высокий уровень взаимосвязи отраслей

$\curvearrowleft \begin{aligned} & \text { Численность занятых в организациях } \\ & \text { отрасли (кроме субъектов малого }\end{aligned}$ предпринимательства), чел.

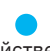

Сельскохозяйственные услуги
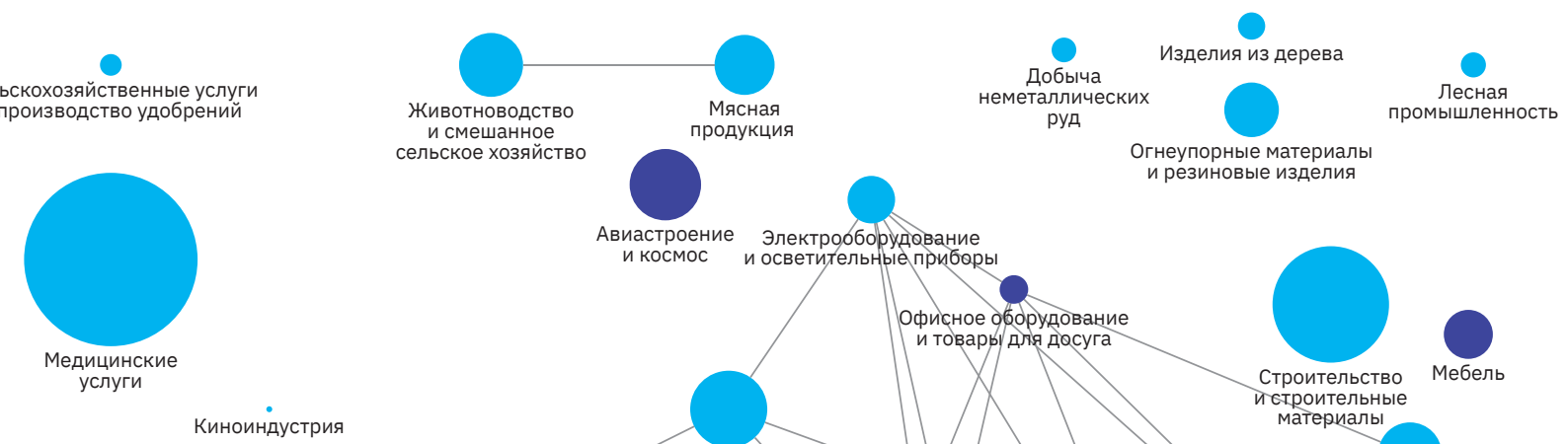

Огнеупорные материалы
и резиновые изделия

оборудование
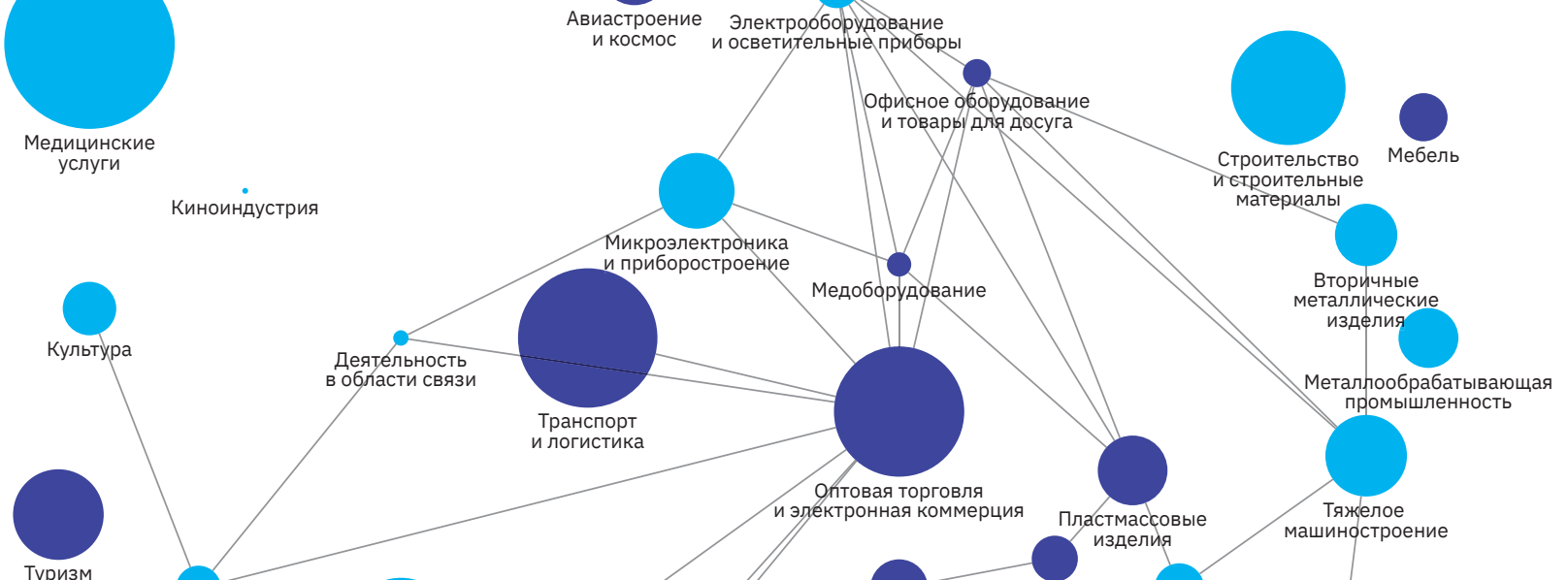

Химические изделия машиностроение

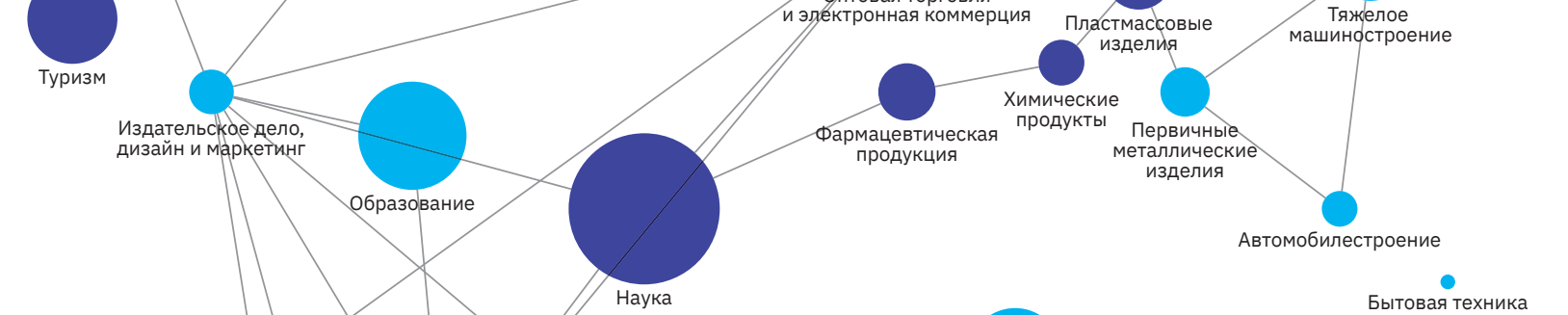

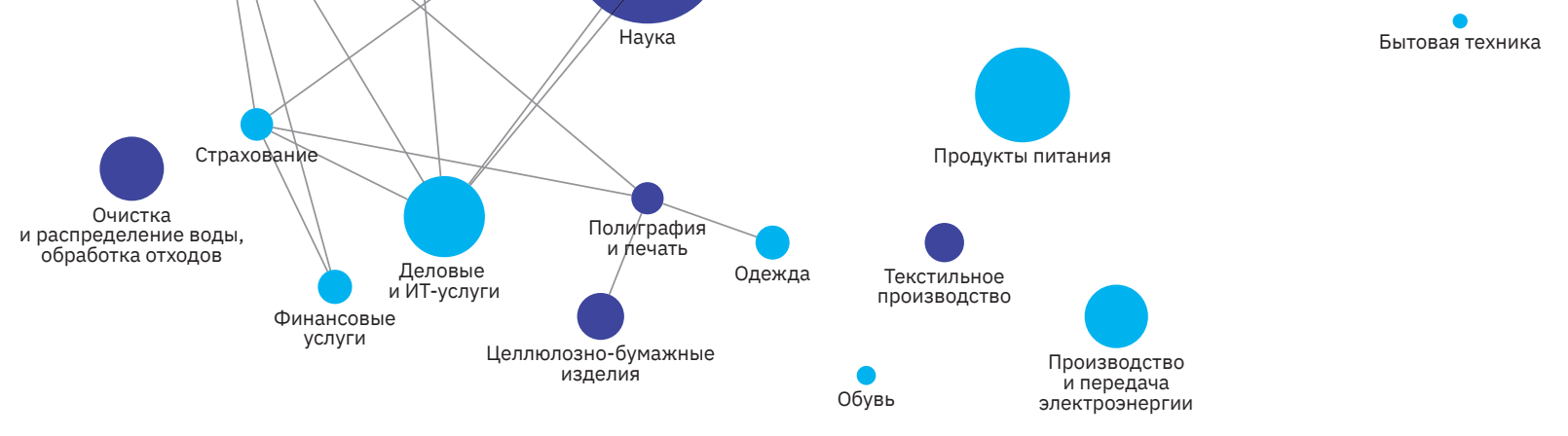




\section{Орловская область}

\section{Число отраслей специализации, ед.

\begin{tabular}{|lllllllll|}
\hline 3 & 11 & & & & & & \\
0 & 8 & 16 & 24 & 32 & 40 & 48 & 56
\end{tabular}

Доля занятых, \%

\begin{tabular}{|llll|}
\hline \multicolumn{7}{|c|}{$\begin{array}{llll}27.9 \\
0\end{array}$} & 25 & 50 & 75 & 100
\end{tabular}

Прирост занятых, \%

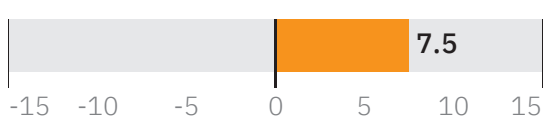

Заработная плата, тыс. руб.

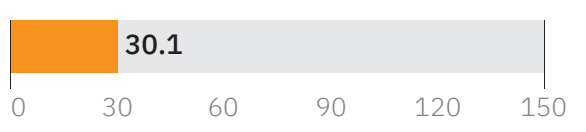

Отрасль национальной

и локальной значимости

Отрасль национальной

значимости

Отрасль локальной

значимости

Высокий уровень взаимосвязи отраслей

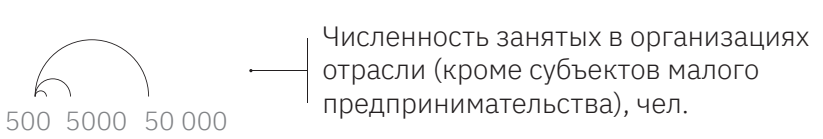

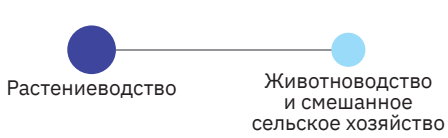

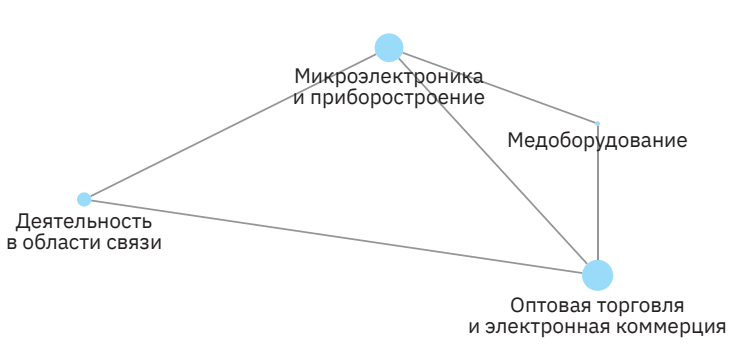

Образование

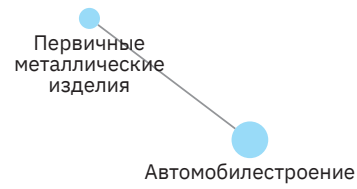

Огнеупорные материалы

Автомобилестроени 


\section{Рязанская область}

Число отраслей специализации, ед.

$13 \quad 11$

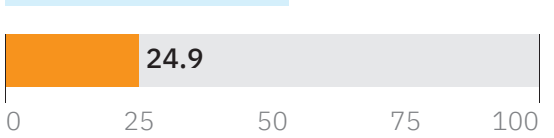

Прирост занятых, \%

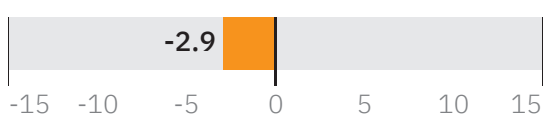

Заработная плата, тыс. руб.

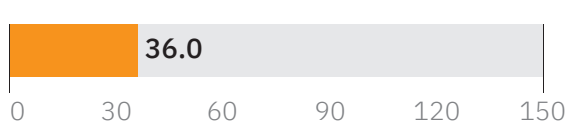

Отрасль национальной

и локальной значимости

Отрасль национальной

значимости

Отрасль локальной

значимости

Высокий уровень взаимосвязи отраслей

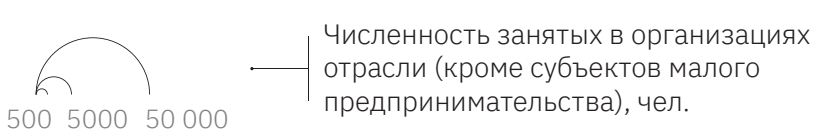

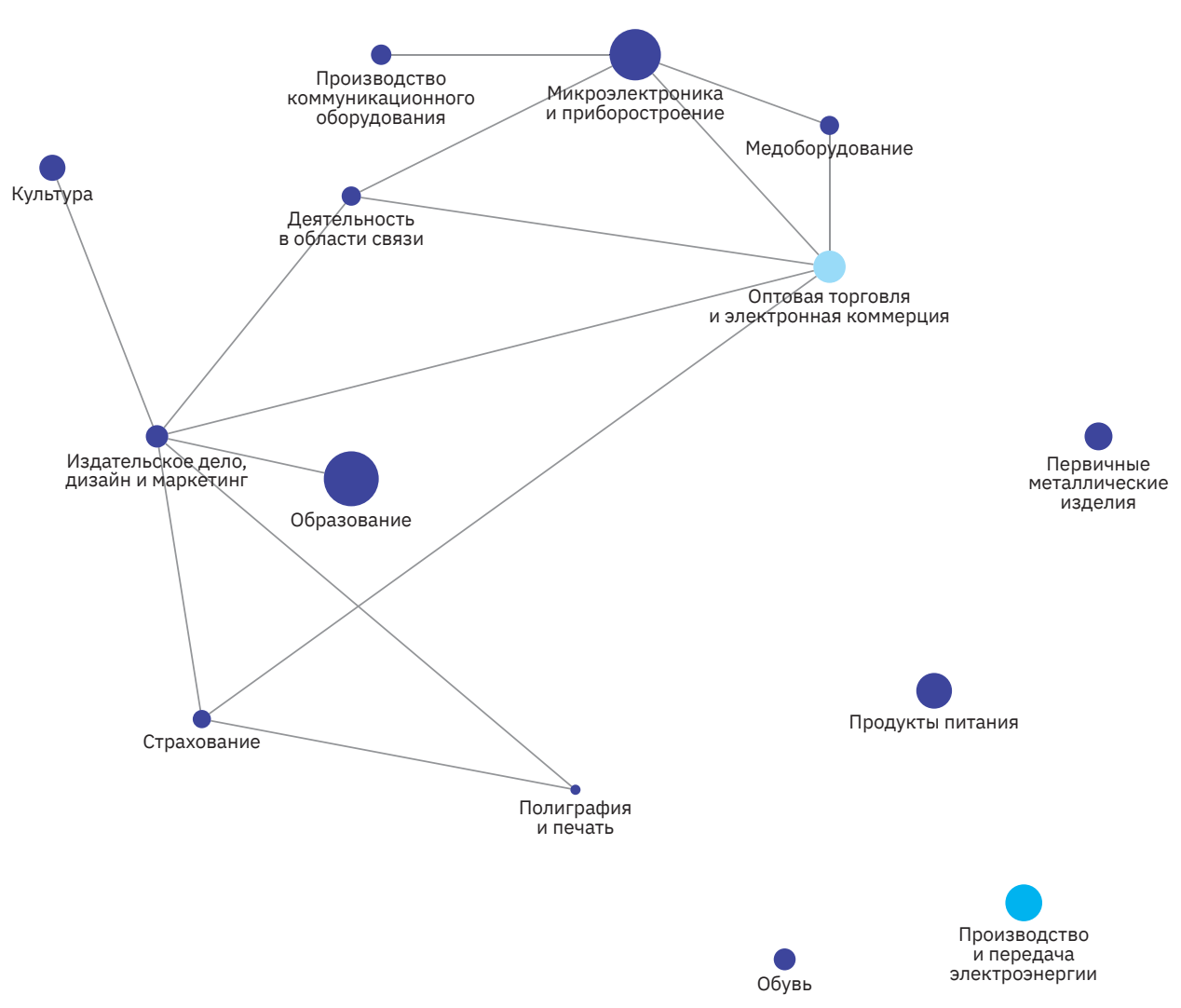

меํำ 


\section{Смоленская область}

\section{Число отраслей специализации, ед.}

11

$\begin{array}{llllllll}0 & 8 & 16 & 24 & 32 & 40 & 48 & 56\end{array}$

Доля занятых, \%

$\begin{array}{|lllll|} & 21.7 & & & \\ 0 & 25 & 50 & 75 & 100\end{array}$

Прирост занятых, \%

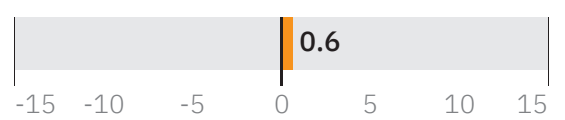

Заработная плата, тыс. руб.

\begin{tabular}{|lrrrrr}
\hline & 38.4 & & & \\
0 & 30 & 60 & 90 & 120 & 150
\end{tabular}

Отрасль национальной

и локальной значимости

Отрасль национальной

значимости

Отрасль локальной

значимости

Высокий уровень взаимосвязи отраслей

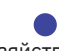

Сельскохозяйственные услуги

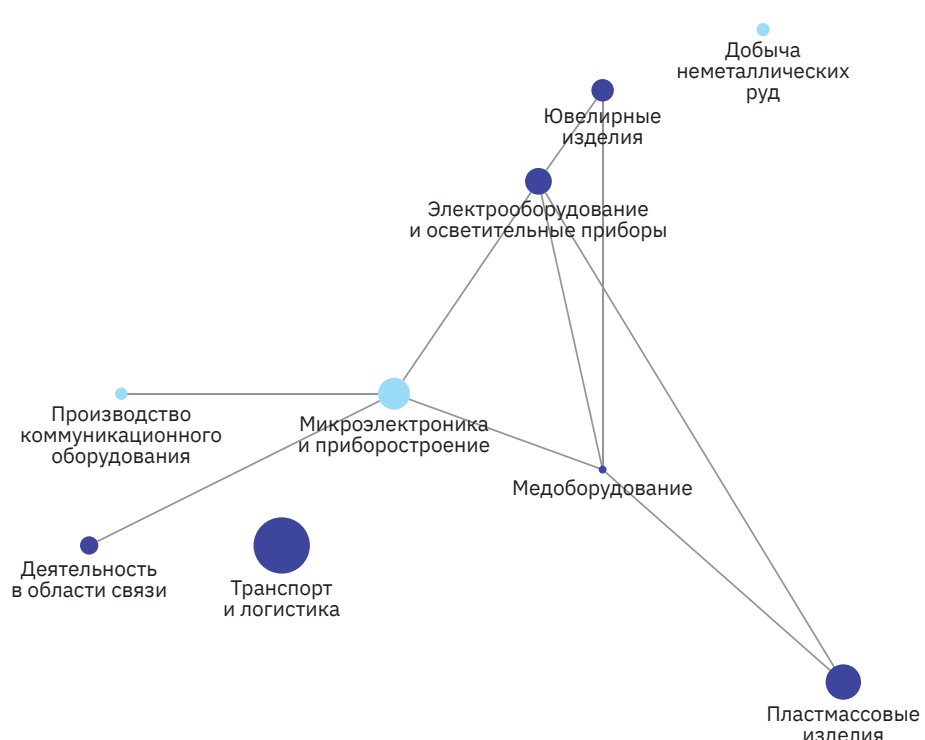

Мебель

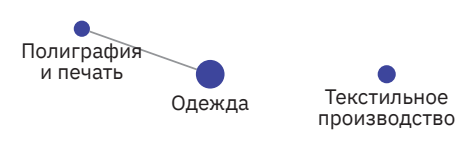

Численность занятых в организациях 


\section{Тамбовская область}

Число отраслей специализации, ед.

11

$\begin{array}{llllllll}0 & 8 & 16 & 24 & 32 & 40 & 48 & 56\end{array}$

Доля занятых, \%

\begin{tabular}{|lllll|}
\hline & 23.1 & & & \\
0 & 25 & 50 & 75 & 100
\end{tabular}

Прирост занятых, \%

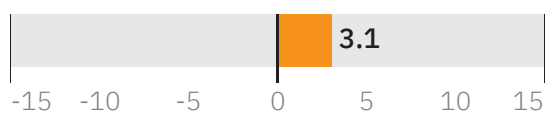

Заработная плата, тыс. руб.

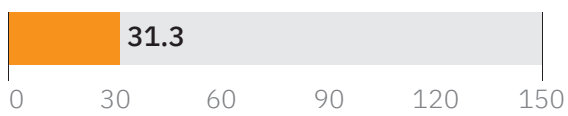

Отрасль национальной

и локальной значимости

Отрасль национальной

значимости

Отрасль локальной

значимости

Высокий уровень взаимосвязи отраслей

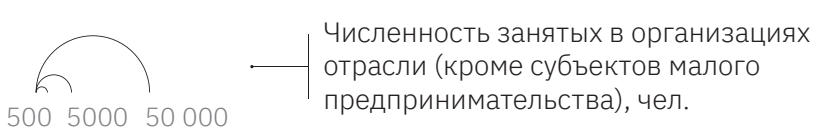

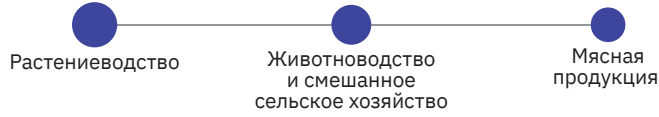

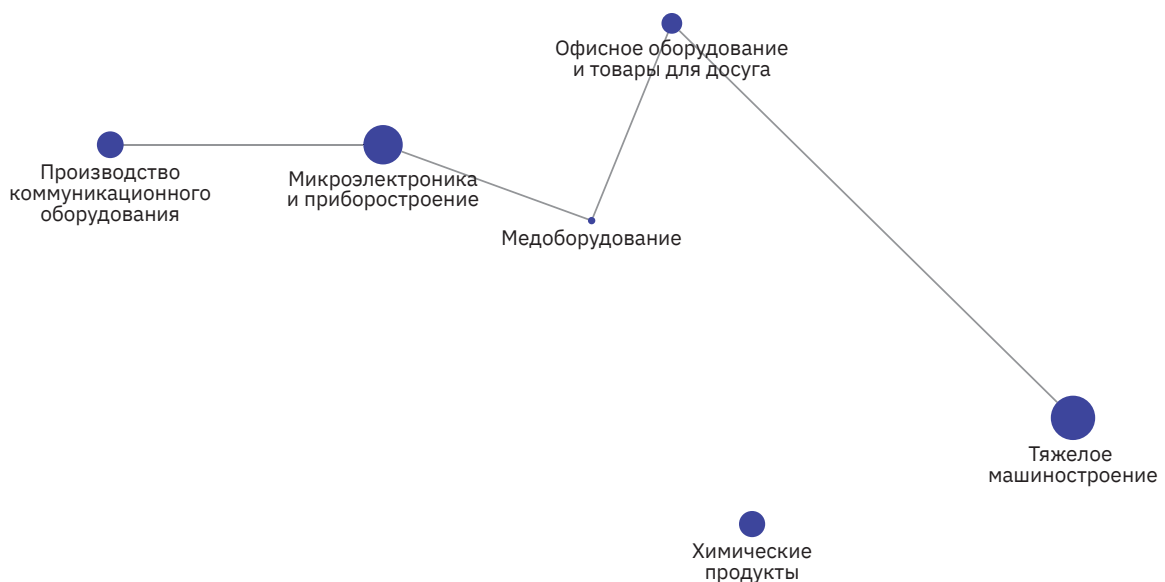

Продукты питания

Текстильное
производство

обувь 


\section{Тверская область}

\section{Число отраслей специализации, ед.}

\begin{tabular}{|l|rrrrrr|}
12 & 3 & 3 & & & & \\
8 & 16 & 24 & 32 & 40 & 48 & 56
\end{tabular}

Доля занятых, \%

\begin{tabular}{|lllll|}
\hline & 19.3 & & & \\
0 & 25 & 50 & 75 & 100
\end{tabular}

Прирост занятых, \%

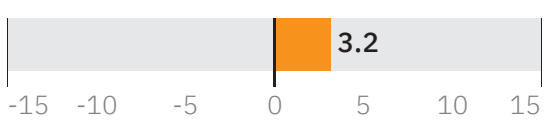

Заработная плата, тыс. руб.

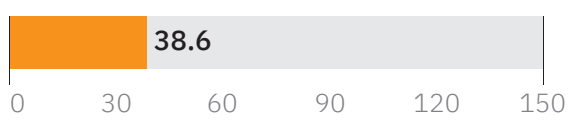

Отрасль национальной

и локальной значимости

Отрасль национальной

значимости

Отрасль локальной

значимости

Высокий уровень взаимосвязи отраслей

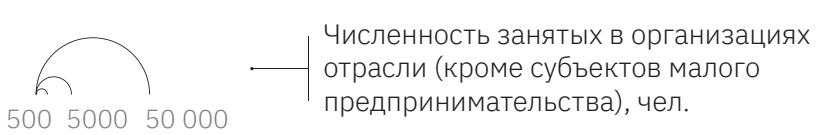

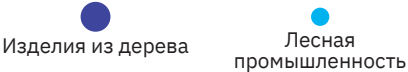
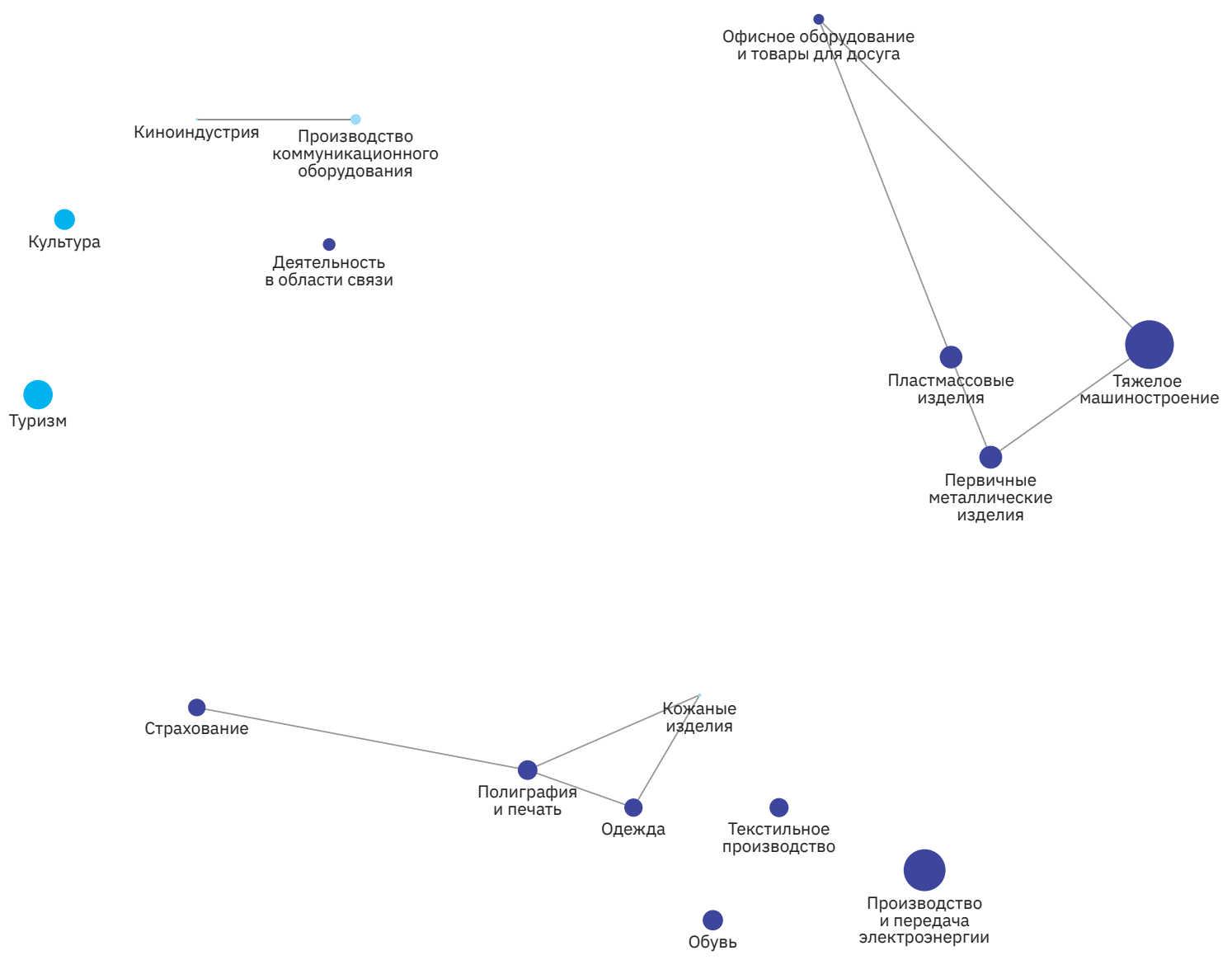


\section{Тульская область}

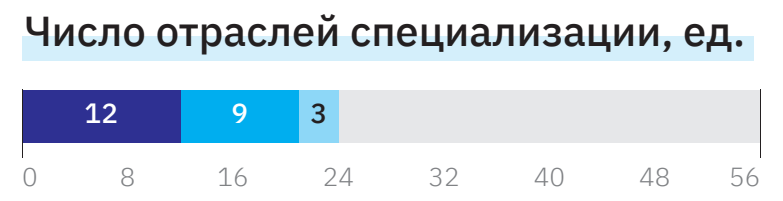

Доля занятых, \%

\begin{tabular}{|c|c|c|c|}
\hline & 32.8 & & \\
\hline 25 & 50 & 75 & 100 \\
\hline
\end{tabular}

Прирост занятых, \%

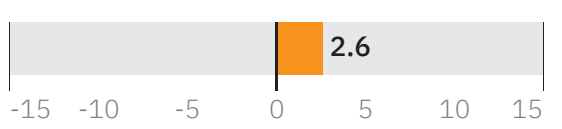

Заработная плата, тыс. руб.

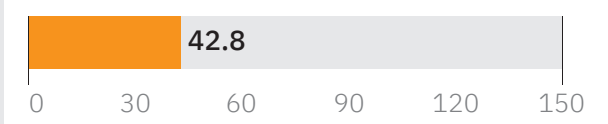

Отрасль национальной

и локальной значимости

Отрасль национальной

значимости

Отрасль локальной

значимости

Высокий уровень взаимосвязи отраслей

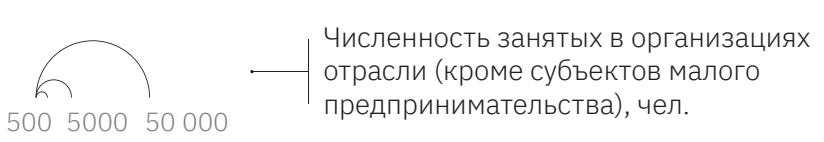

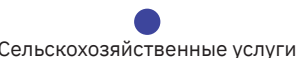

Сельскохозяйственные услуги
и производство удобрений

Machag

Мясная
продукция

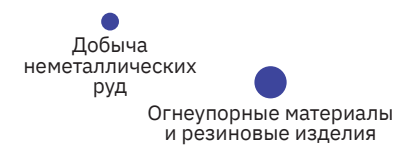

Огнеупорные материалы
и резиновые изделия

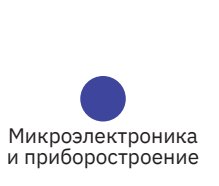

$$
\text { Культура }
$$

Туризм
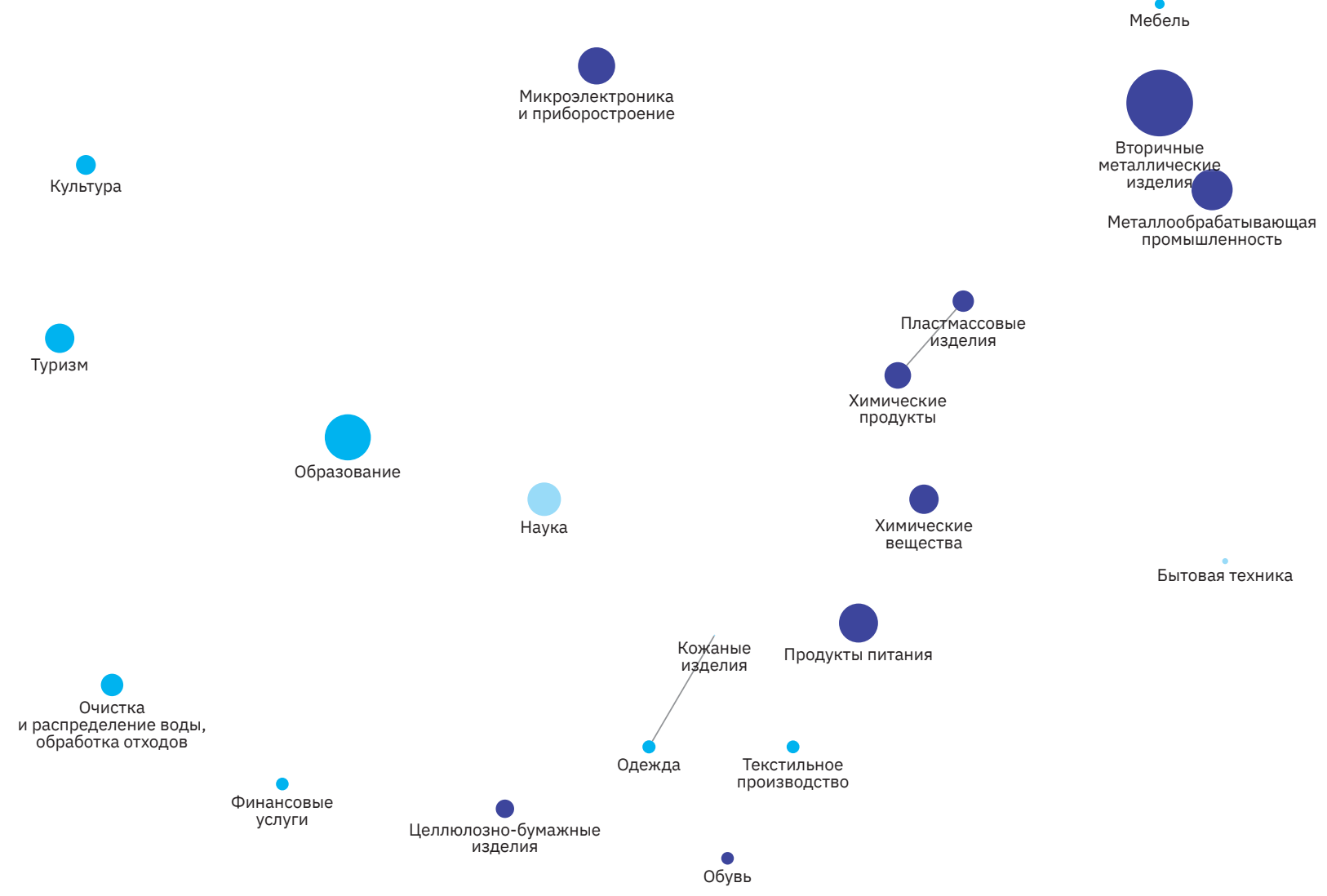


\section{Ярославская область}

\section{Число отраслей специализации, ед.}

$\begin{array}{|llllllll|}11 & 1 & 4 & & & & & \\ 0 & 8 & 16 & 24 & 32 & 40 & 48 & 56\end{array} \mid$

Доля занятых, \%

\begin{tabular}{|lllll|}
\hline & 20.6 & & & \\
0 & 25 & 50 & 75 & 100
\end{tabular}

Прирост занятых, \%

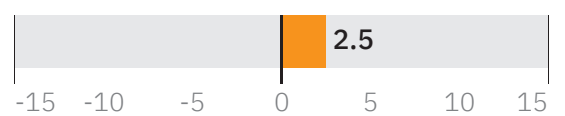

Заработная плата, тыс. руб.

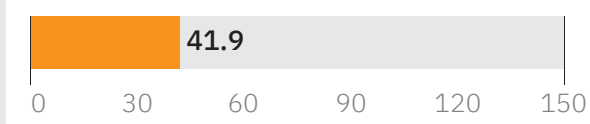

Отрасль национальной

и локальной значимости

Отрасль национальной

значимости

Отрасль локальной

значимости

Высокий уровень взаимосвязи отраслей

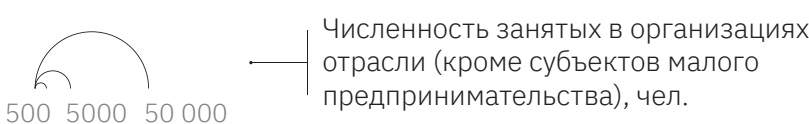

Туризм

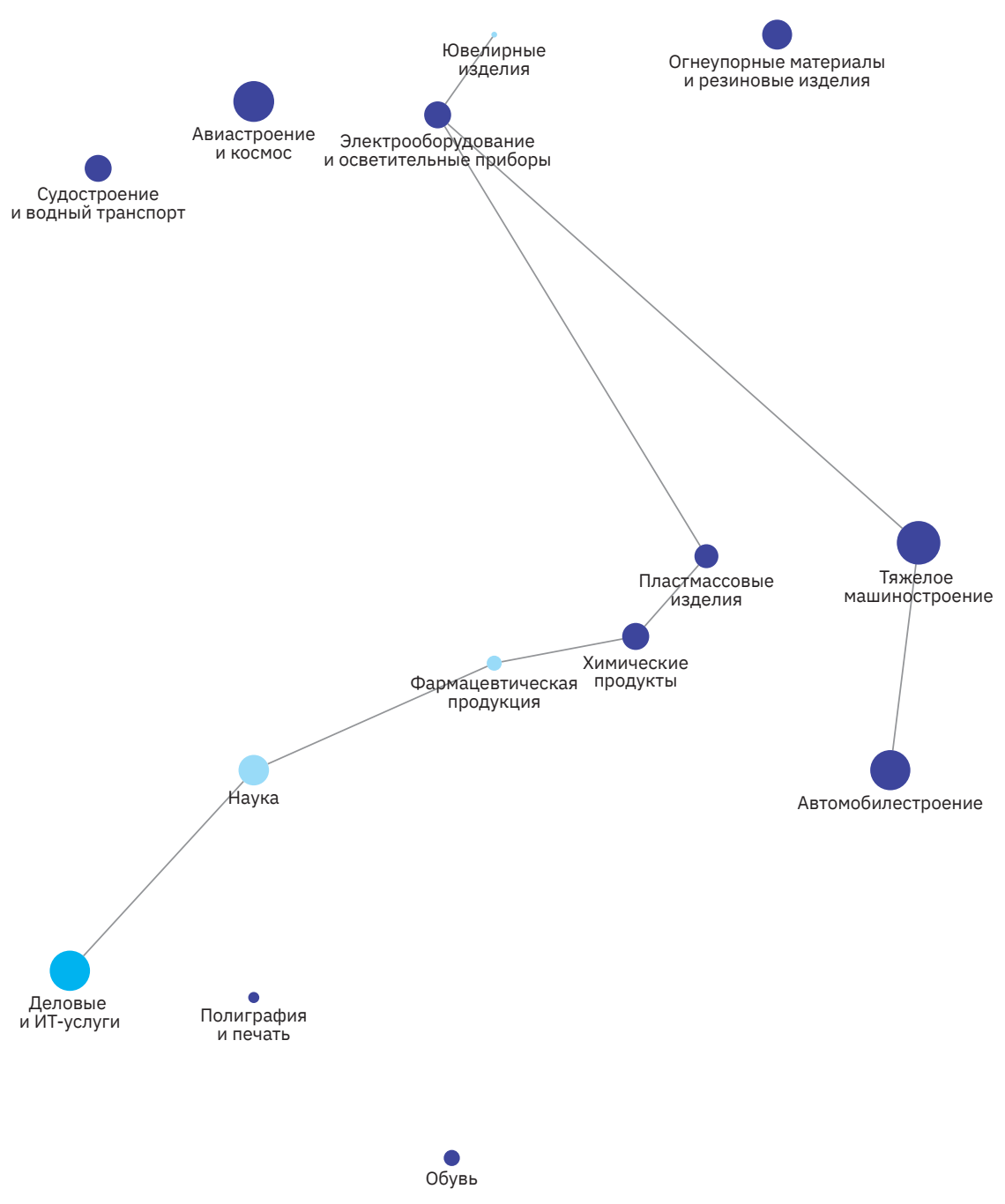




\section{Москва}

Число отраслей специализации, ед.

\begin{tabular}{|llllllll|}
\hline & 16 & & & 27 & & 1 & \\
0 & 8 & 16 & 24 & 32 & 40 & 48 & 56
\end{tabular}

Доля занятых, \%

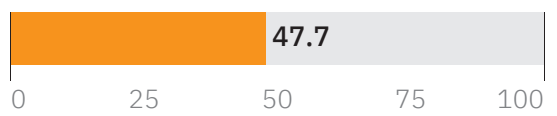

Прирост занятых, \%

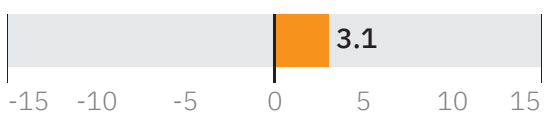

Заработная плата, тыс. руб.

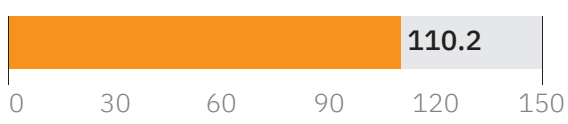

Отрасль национальной
и локальной значимости

Отрасль национальной

значимости

Отрасль локальной

значимости

Высокий уровень взаимосвязи отраслей

$\left\{\begin{array}{l}\text { Численность занятых в организациях } \\ \text { отрасли (кроме субъектов малого }\end{array}\right.$ предпринимательства), чел.

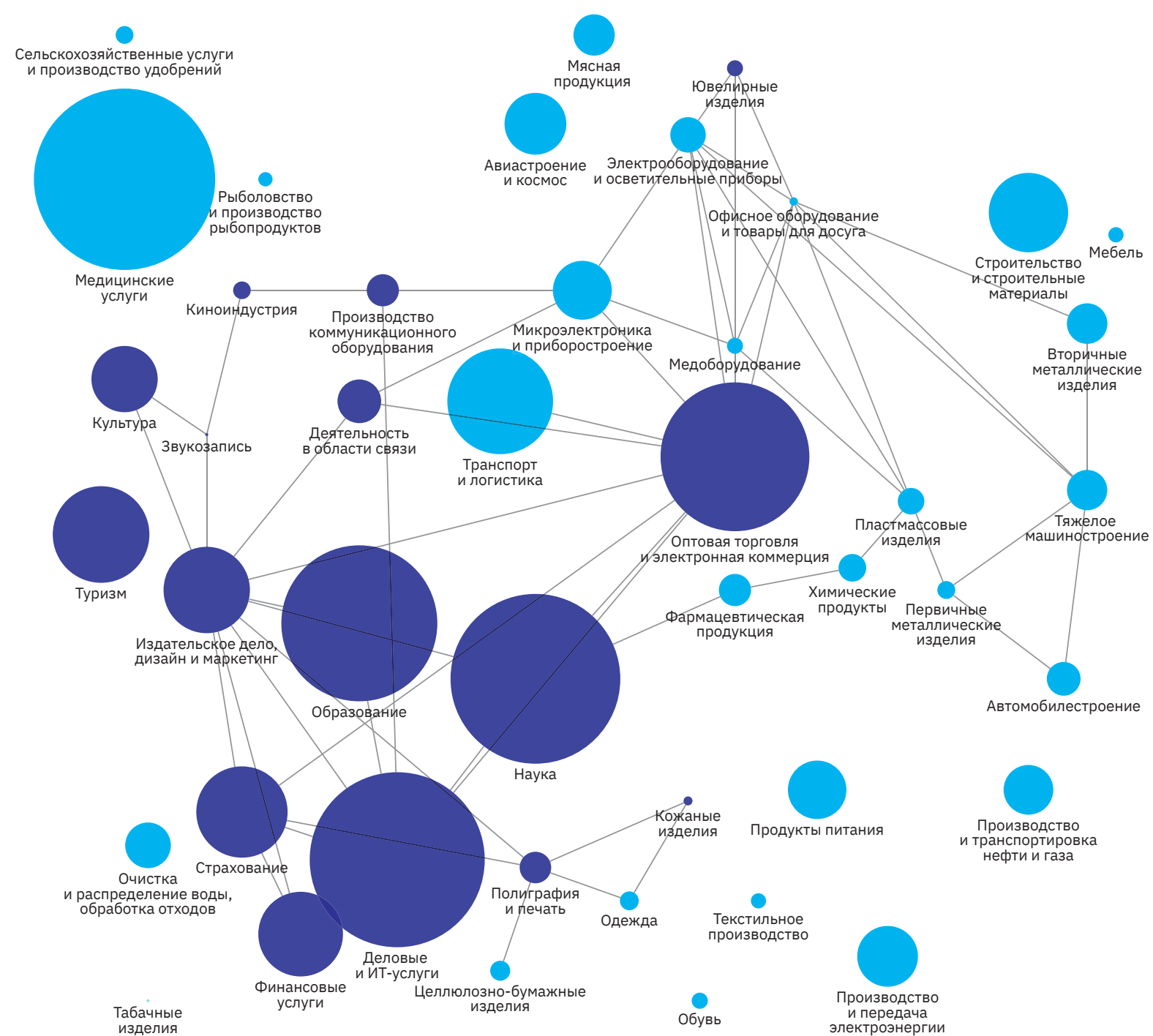



Северо-Западный федеральный округ 


\section{Республика Карелия}

\section{Число отраслей специализации, ед.

\begin{tabular}{|llllllll|}
\hline 4 & 6 & & & & & & \\
0 & 8 & 16 & 24 & 32 & 40 & 48 & 56
\end{tabular}

Доля занятых, \%

\begin{tabular}{|c|c|c|c|c|}
\hline & 20. & & & \\
\hline 0 & 25 & 50 & 75 & 100 \\
\hline
\end{tabular}

Прирост занятых, \%

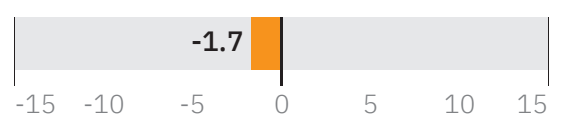

Заработная плата, тыс. руб.

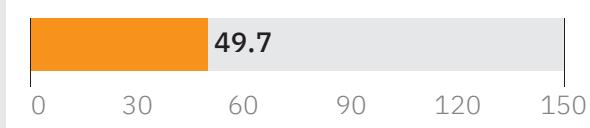

Отрасль национальной

и локальной значимости

Отрасль национальной

значимости

Отрасль локальной

значимости

Высокий уровень взаимосвязи отраслей

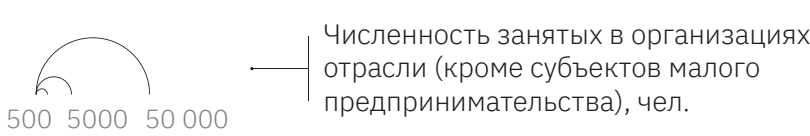

Рыболовство

ипроизвосство
рыбопродуктов

Деятельность

Транспорт

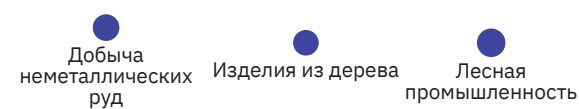

Страхование

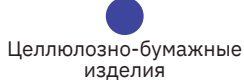

Производство

и передача
электроэнергии

изделия 


\section{Республика Коми}

\section{Число отраслей специализации, ед. \\ $7 \quad 4$}

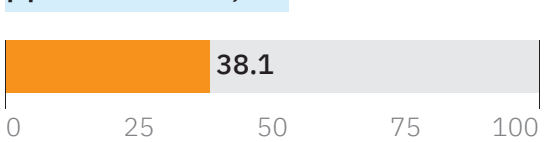

Прирост занятых, \%

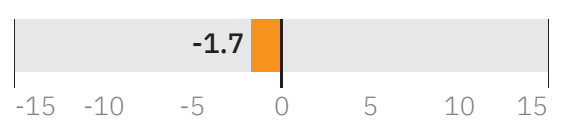

Заработная плата, тыс. руб.

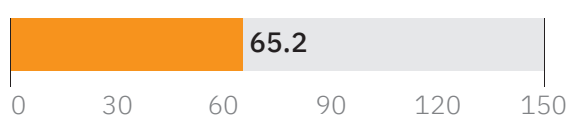

Отрасль национальной
и локальной значимости

Отрасль национальной

значимости

Отрасль локальной

значимости

Высокий уровень взаимосвязи отраслей

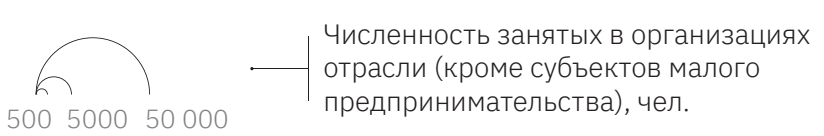

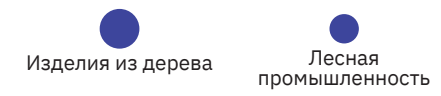

$\underset{\substack{\text { Деятельность } \\ \text { вобласти связи }}}{\substack{\text { Транспорт } \\ \text { и логистика }}}$

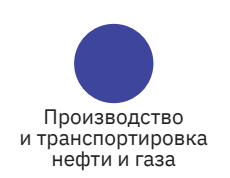

и распределение вори,

обработка отходов

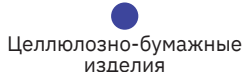

изделия
Производство Производство
ипередаа
электроэнергии предпринимательства), чел. 


\section{Архангельская область}

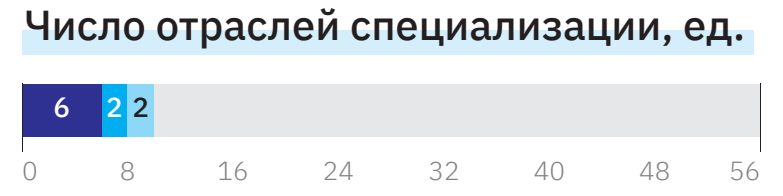

Доля занятых, \%

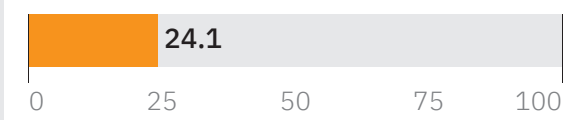

Прирост занятых, \%

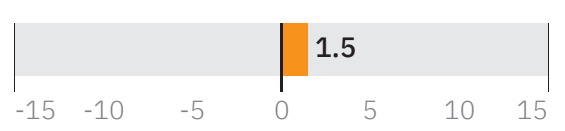

Заработная плата, тыс. руб.

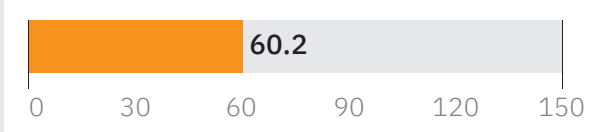

Отрасль национальной
и локальной значимости

Отрасль национальной

значимости

Отрасль локальной

значимости

Высокий уровень взаимосвязи отраслей

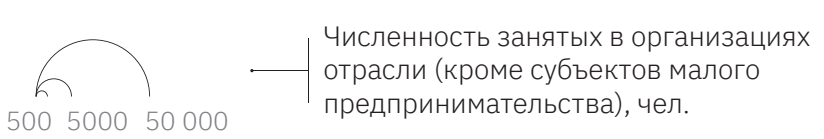

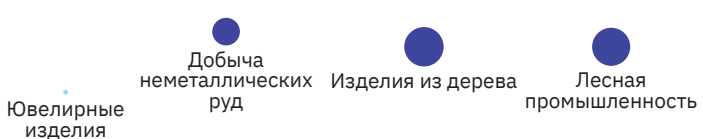

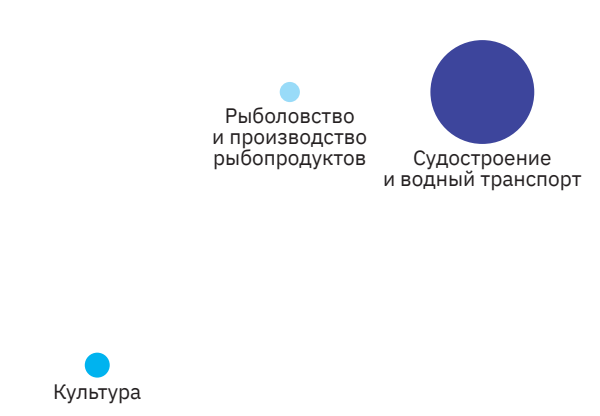

купьтура

Очистка 


\section{Ненецкий автономный округ}

Число отраслей специализации, ед.

\begin{tabular}{|llllllll|}
\hline 6 & & & & & & & \\
0 & 8 & 16 & 24 & 32 & 40 & 48 & 56
\end{tabular} \mid

Доля занятых, \%

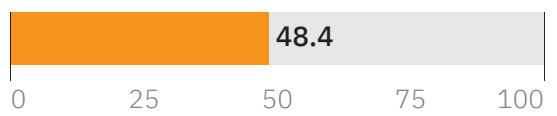

Прирост занятых, \%

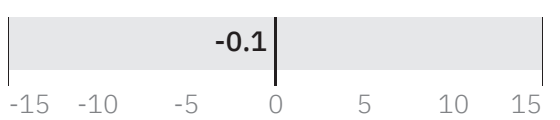

Заработная плата, тыс. руб.

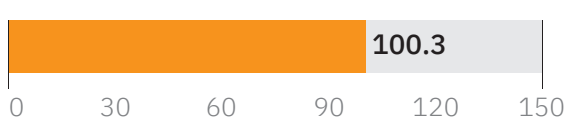

Отрасль национальной

и локальной значимости

Отрасль национальной

значимости

Отрасль локальной

значимости

Высокий уровень взаимосвязи отраслей

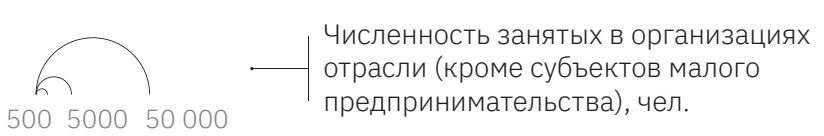

Животноводство

и смешанное
сельское хозяйств

Рыболовство

и производство

Строительство Строительство
и строительные
материалы

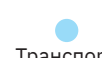

Транспорт
и логистика 


\section{Вологодская область}

\section{Число отраслей специализации, ед.}

$\begin{array}{ll}7 & 12\end{array}$

\begin{tabular}{llllllll}
\hline & 16 & 24 & 32 & 40 & 48 & 56
\end{tabular}

Доля занятых, \%

$\begin{array}{|ccccc|} & 17.7 & & & \\ 0 & 25 & 50 & 75 & 100\end{array}$

Прирост занятых, \%

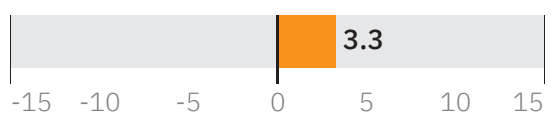

Заработная плата, тыс. руб.

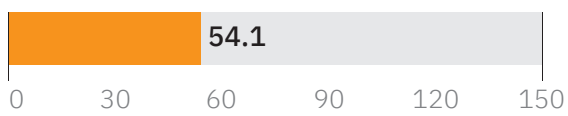

Отрасль национальной

и локальной значимости

Отрасль национальной

значимости

Отрасль локальной

значимости

Высокий уровень взаимосвязи отраслей

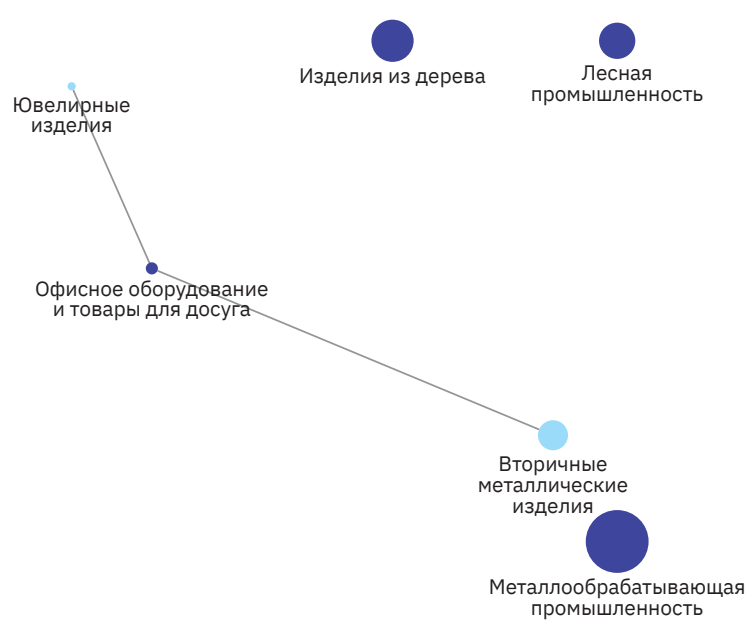

промышленность
пров

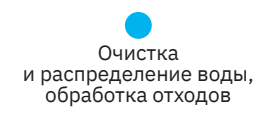

обработка отходов 


\section{Калининградская область}

\section{Число отраслей специализации, ед.

$\begin{array}{llllllll}4 & 7 & & & & & & \\ 0 & 8 & 16 & 24 & 32 & 40 & 48 & 56\end{array}$

Доля занятых, \%

$\begin{array}{|ccccc|} & 11.5 & & & \\ 0 & 25 & 50 & 75 & 100\end{array}$

Прирост занятых, \%

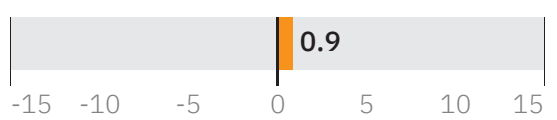

Заработная плата, тыс. руб.

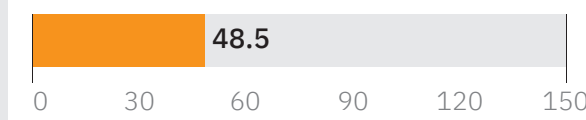

Отрасль национальной

и локальной значимости

Отрасль национальной

значимости

Отрасль локальной

значимости

Высокий уровень взаимосвязи отраслей

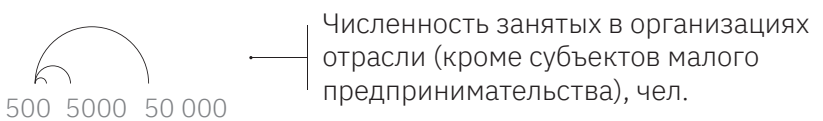

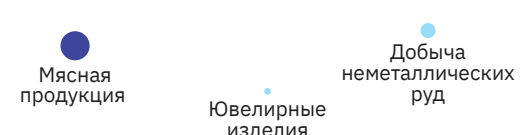

(евелирные

Мебель
Очистка

и распределение воды,
обработка отходов

Табачные 


\section{Ленинградская область}

\section{Число отраслей специализации, ед.}

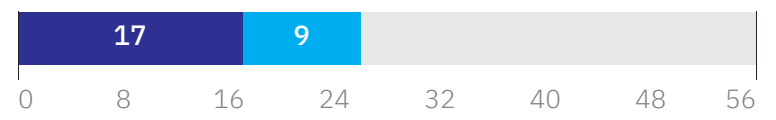

Доля занятых, \%

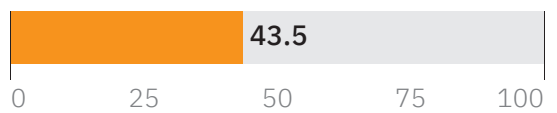

Прирост занятых, \%

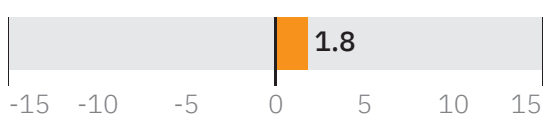

Заработная плата, тыс. руб.

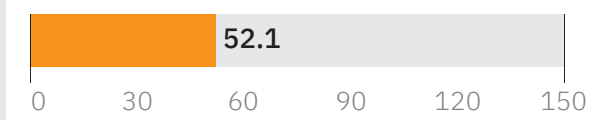

Отрасль национальной
и локальной значимости

Отрасль национальной

значимости

Отрасль локальной

значимости

Высокий уровень взаимосвязи отраслей

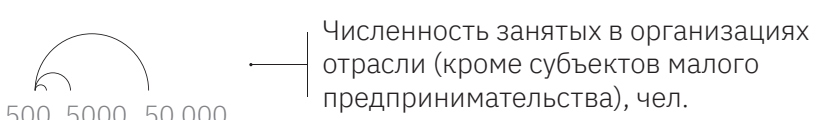

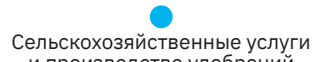

Сельскохозяйственные услуги
и производство удобрений

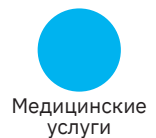

культура

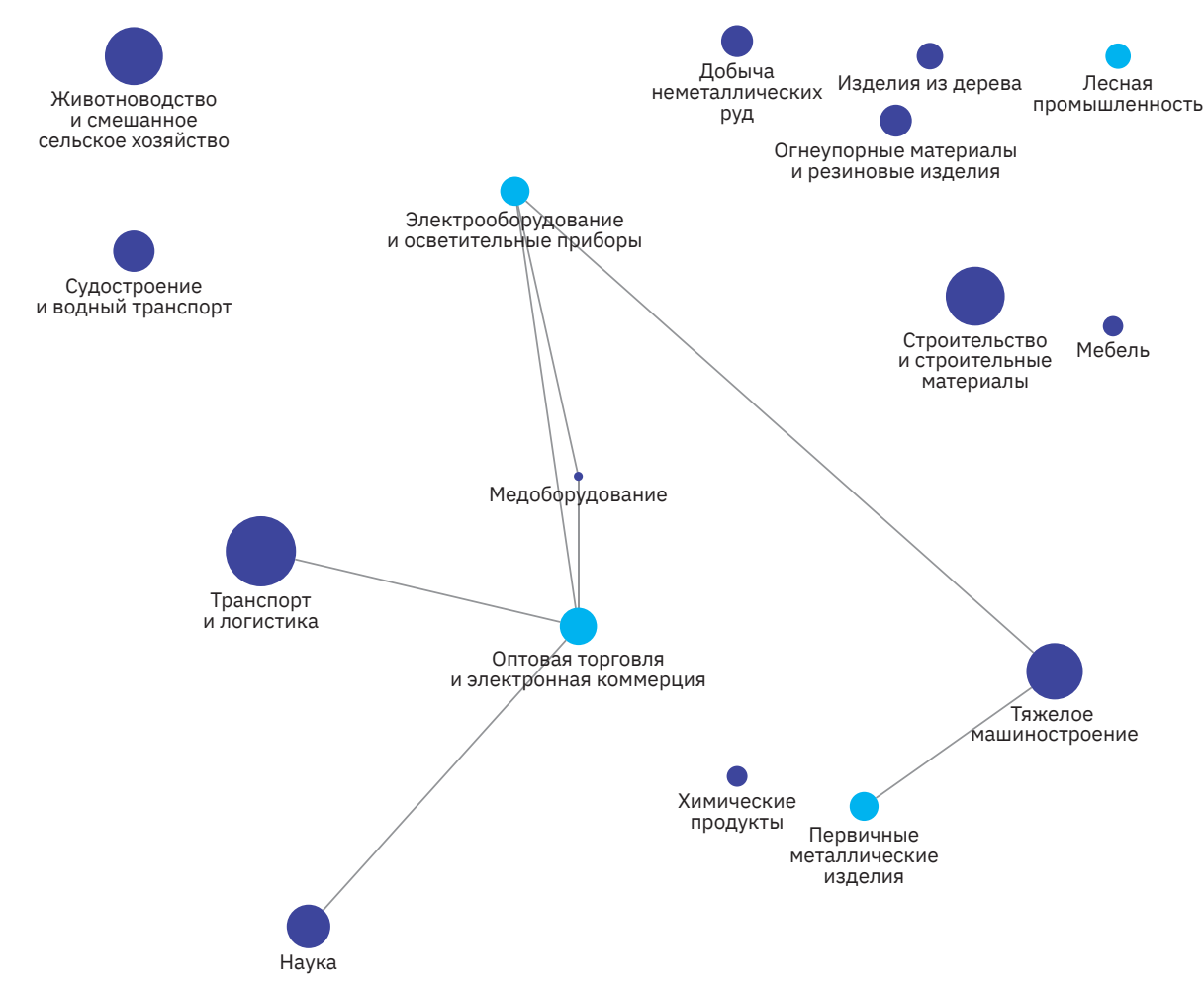

Табачные

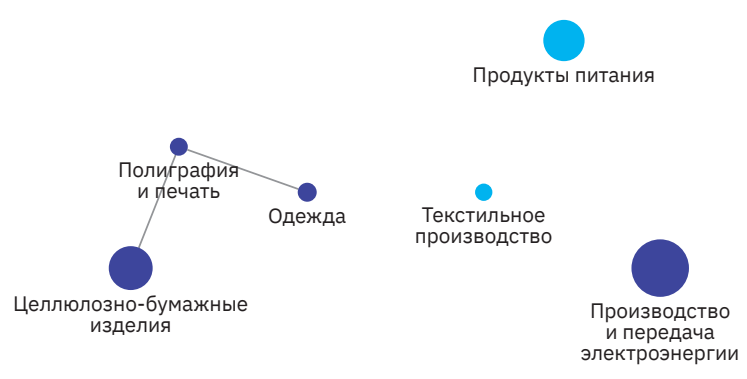




\section{Мурманская область}

\section{Число отраслей специализации, ед.}

7

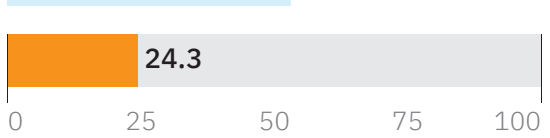

Прирост занятых, \%

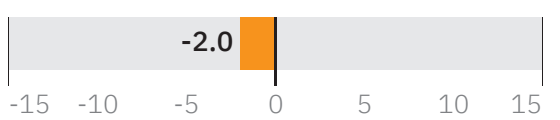

Заработная плата, тыс. руб.

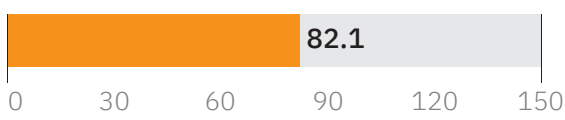

Отрасль национальной

и локальной значимости

Отрасль национальной

значимости

Отрасль локальной

значимости

Высокий уровень взаимосвязи отраслей

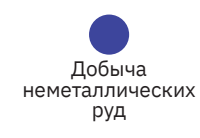

$$
\text { Рыболовство }
$$

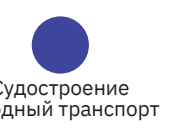

ипроизводство Судостроение
рыбопродуктов и водный транспорт

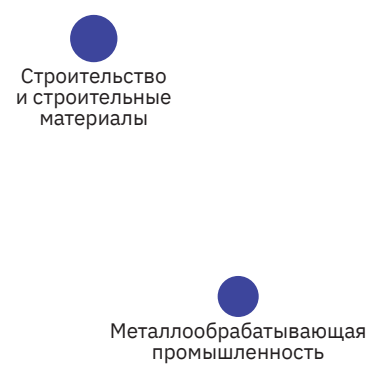

$$
\text { Очистка }
$$

и распределение воды,

обработка отходов 


\section{Новгородская область}

\section{Число отраслей специализации, ед.}

$\begin{array}{ll}8 & 7\end{array}$

$\begin{array}{llllllll}0 & 8 & 16 & 24 & 32 & 40 & 48 & 56\end{array}$

Доля занятых, \%

$\begin{array}{|lllll|} & 21.7 & & & \\ 0 & 25 & 50 & 75 & 100\end{array}$

Прирост занятых, \%

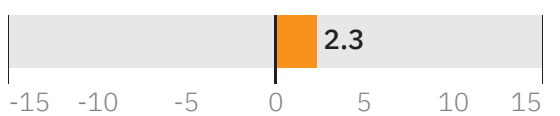

Заработная плата, тыс. руб.

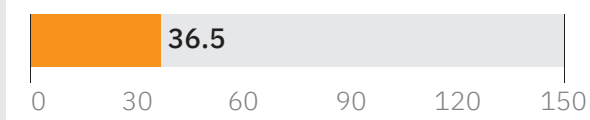

Отрасль национальной

и локальной значимости

Отрасль национальной

значимости

Отрасль локальной

значимости

Высокий уровень взаимосвязи отраслей

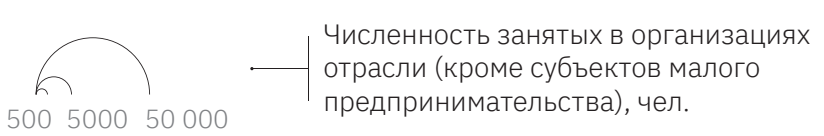

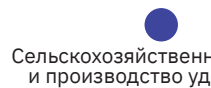

иелькохозяйственные услуги

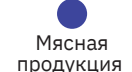

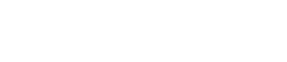
электрооборудование

Рыболовство

и пролзводство

рыбопродуктов

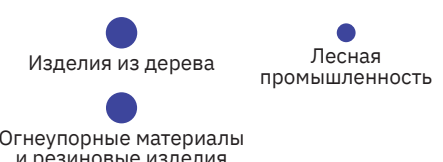

и резиновые изделия

Производство

осмуникационного
оборудования

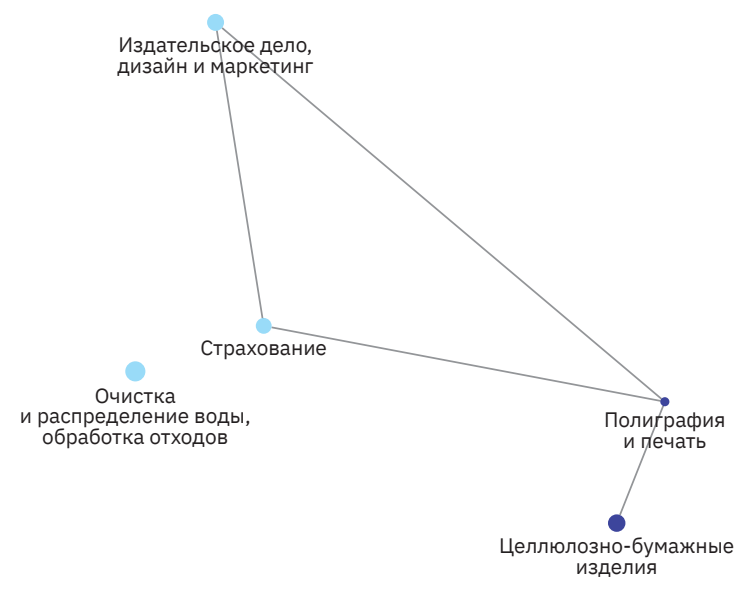

роительство

и строительн

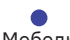




\section{Псковская область}

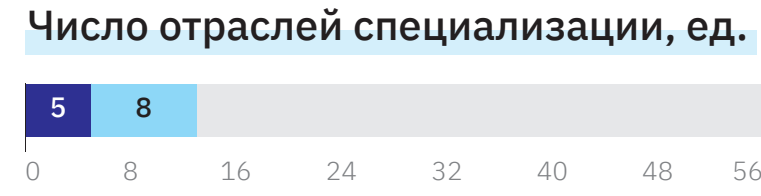

Доля занятых, \%

$\begin{array}{|ccccc|} & \mathbf{1 8 . 4} & & & \\ 0 & 25 & 50 & 75 & 100\end{array}$

Прирост занятых, \%

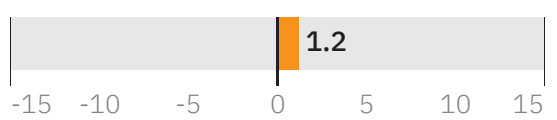

Заработная плата, тыс. руб.

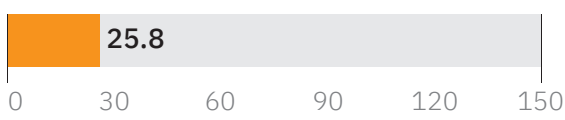

Отрасль национальной

и локальной значимости

Отрасль национальной

значимости

Отрасль локальной

значимости

Высокий уровень взаимосвязи отраслей

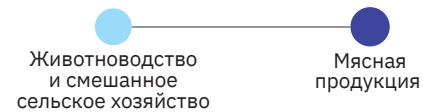

и смешанное
сельское хозяйств

продукция

Рыболовство

ип производство

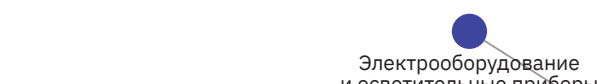

и осветительные приборы

Офисное оборудование

меํำเ

Производство

коммуникационно оо

оборудования

туризм

Первичные
металлические

изделия 


\section{Санкт-Петербург}

Число отраслей специализации, ед.

\begin{tabular}{|llllllll|}
\hline & 18 & & & 27 & \multicolumn{3}{c|}{1} \\
\hline 0 & 8 & 16 & 24 & 32 & 40 & 48 & 56
\end{tabular}

Доля занятых, \%

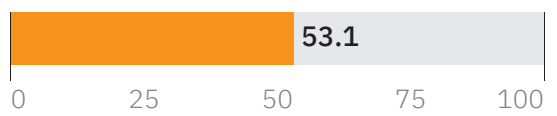

Прирост занятых, \%

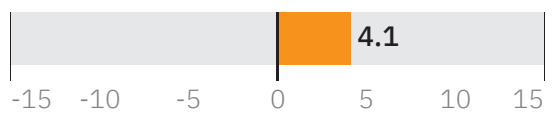

Заработная плата, тыс. руб.

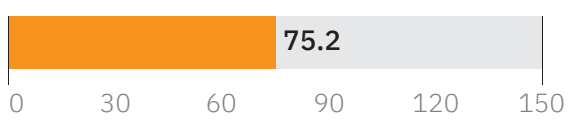

Отрасль национальной
и локальной значимости

значимости

Отрасль локальной

значимости

Высокий уровень взаимосвязи отраслей

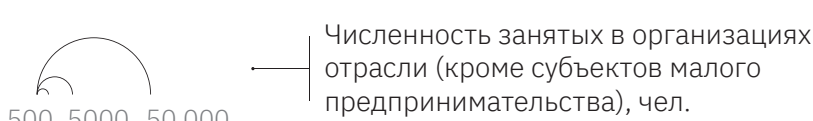

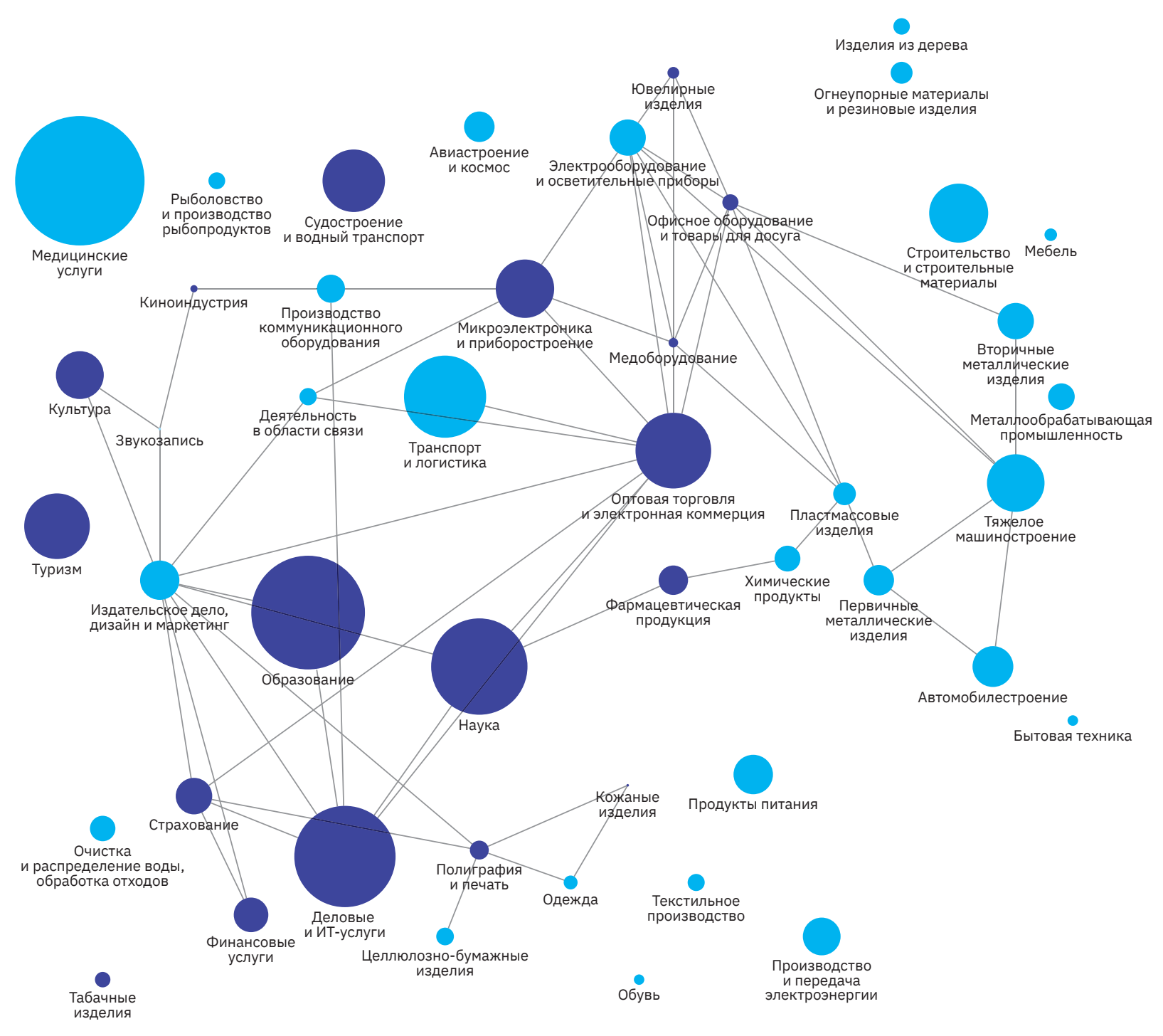


Южный

федеральный округ 


\section{Республика Адыгея}

Число отраслей специализации, ед.

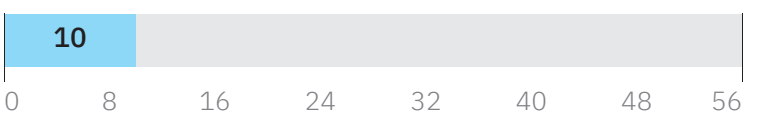

Доля занятых, \%

\begin{tabular}{|lllll|}
\hline & 31.7 & & \\
0 & 25 & 50 & 75 & 100
\end{tabular}

Прирост занятых, \%

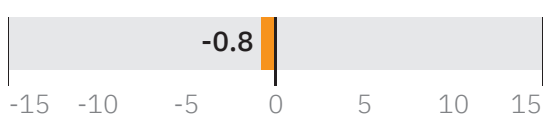

Заработная плата, тыс. руб.

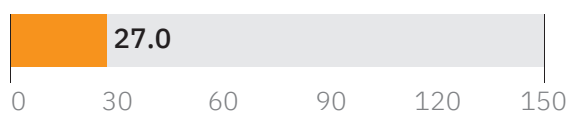

Отрасль национальной

и локальной значимости

Отрасль национальной

значимости

Отрасль локальной

значимости

Высокий уровень взаимосвязи отраслей

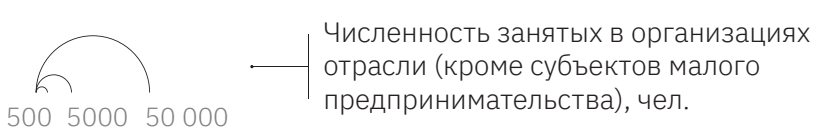

$\underset{\text { Медицинские }}{\text { услуги }}$
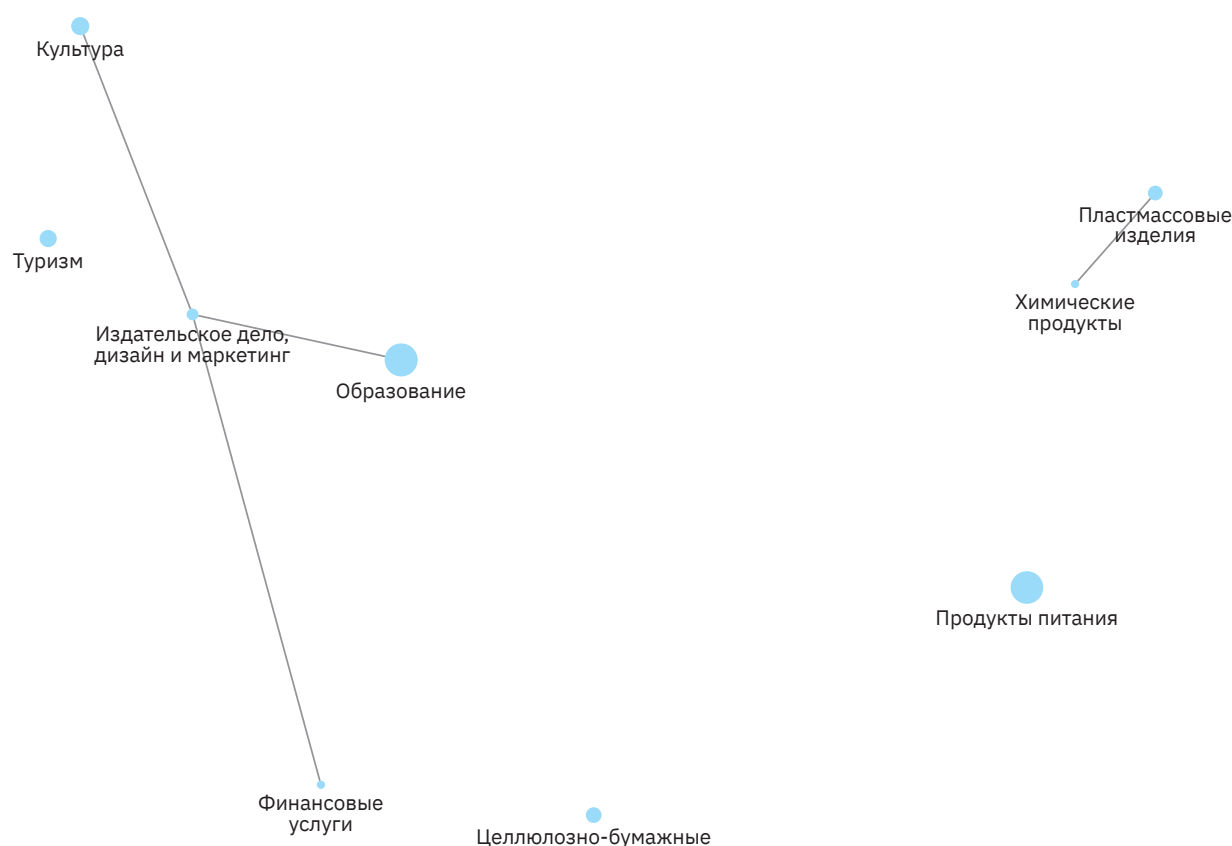


\section{Республика Калмыкия}

\section{Число отраслей специализации, ед.}

$$
8
$$

$\begin{array}{lllllll}8 & 16 & 24 & 32 & 40 & 48 & 56\end{array}$

Доля занятых, \%

\begin{tabular}{|lllll|}
\hline & 28.4 & & & \\
0 & 25 & 50 & 75 & 100
\end{tabular}

Прирост занятых, \%

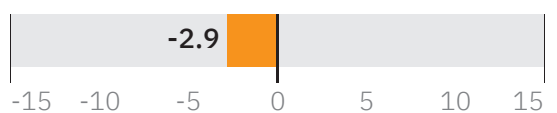

Заработная плата, тыс. руб.

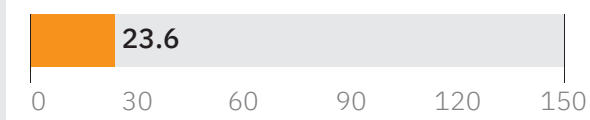

Отрасль национальной

и локальной значимости

Отрасль национальной

значимости

Отрасль локальной

значимости

Высокий уровень взаимосвязи отраслей

\footnotetext{
Численность занятых в организациях

- отрасли (кроме субъектов малого

$$
\begin{array}{cc}
\text { Сельскохозяйственные уссуги } \\
\text { и производство удобрений }
\end{array}
$$

Медицинские

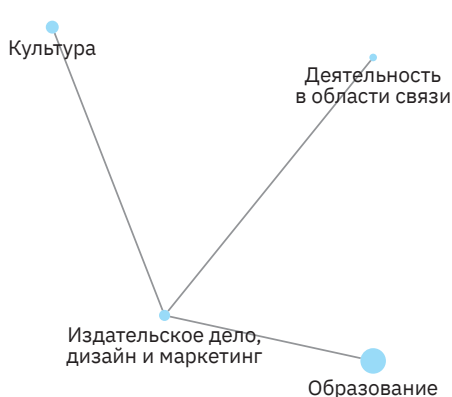




\section{Республика Крым}

Число отраслей специализации, ед.

10

\begin{tabular}{llllllll}
\hline 8 & 16 & 24 & 32 & 40 & 48 & 56
\end{tabular}

Доля занятых, \%

\begin{tabular}{|lllll|}
\hline \multicolumn{3}{|c|}{31.9} & & \\
0 & 25 & 50 & 75 & 100
\end{tabular}

Прирост занятых, \%

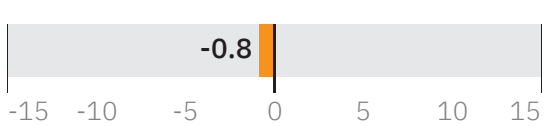

Заработная плата, тыс. руб.

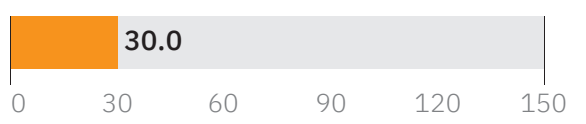

Отрасль национальной

и локальной значимости

значимости

Отрасль локальной

значимости

Высокий уровень взаимосвязи отраслей

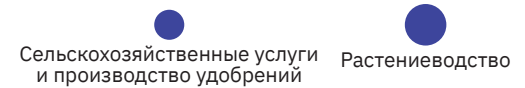

и производство удобренугй растениеводст
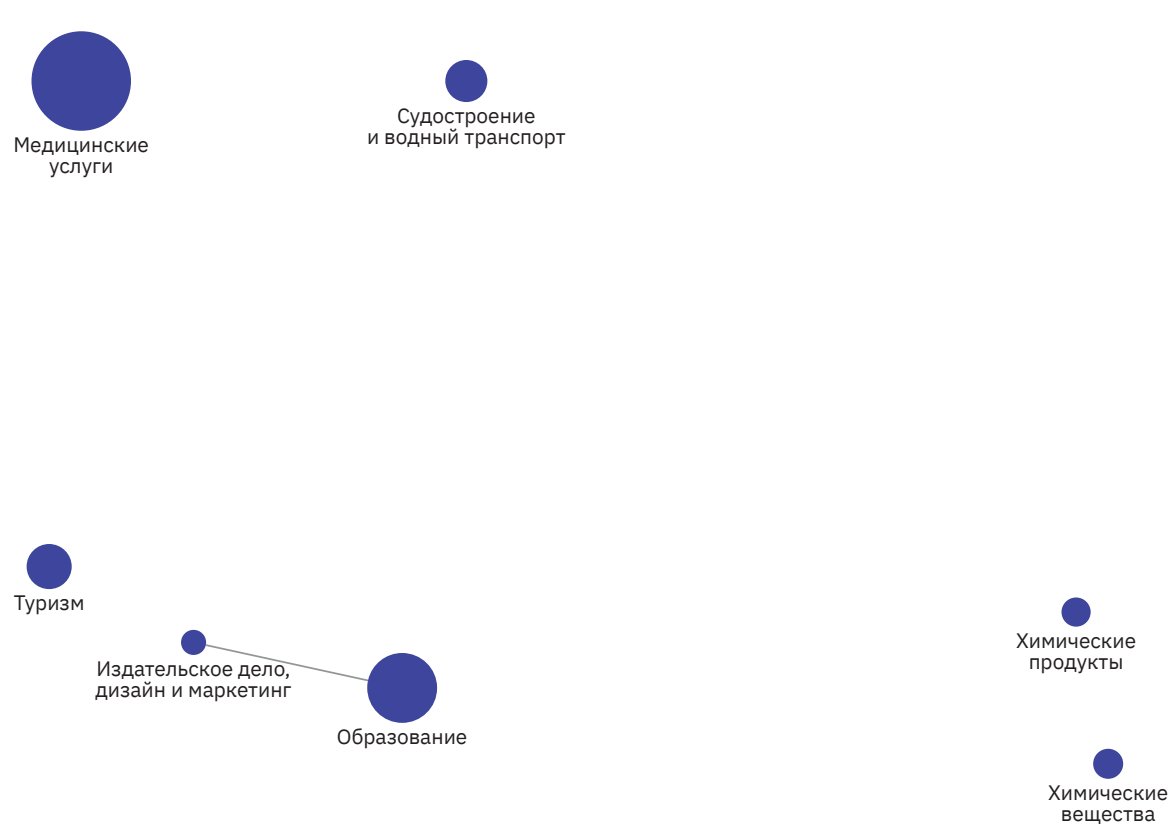

вещества

Продукты питания

\footnotetext{
Численность занятых в организация $\curvearrowleft \quad \begin{aligned} & \text { отрасли (кроме субъектов малого } \\ & \text { предпринимательства), чел. }\end{aligned}$
} 500 


\section{Краснодарский край}

Число отраслей специализации, ед.

\begin{tabular}{|llllllll|}
\hline 8 & & 18 & & & & & \\
0 & 8 & 16 & 24 & 32 & 40 & 48 & 56
\end{tabular}

Доля занятых, \%

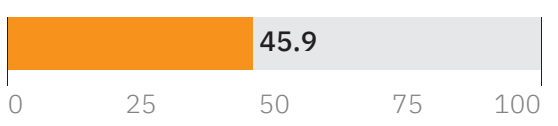

Прирост занятых, \%

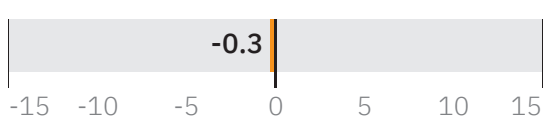

Заработная плата, тыс. руб.

\begin{tabular}{|llllll}
\hline & 39.3 & & & \\
0 & 30 & 60 & 90 & 120 & 150
\end{tabular}

Отрасль национальной
и локальной значимости

Отрасль национальной

значимости

Отрасль локальной

значимости

Высокий уровень взаимосвязи отраслей

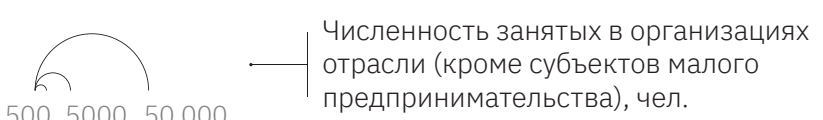

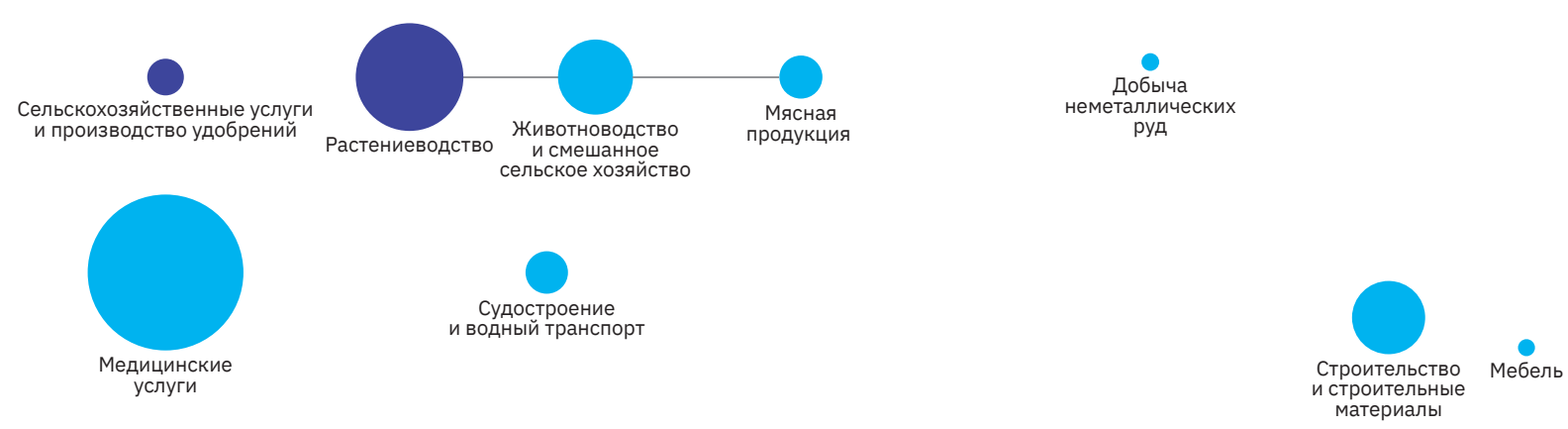

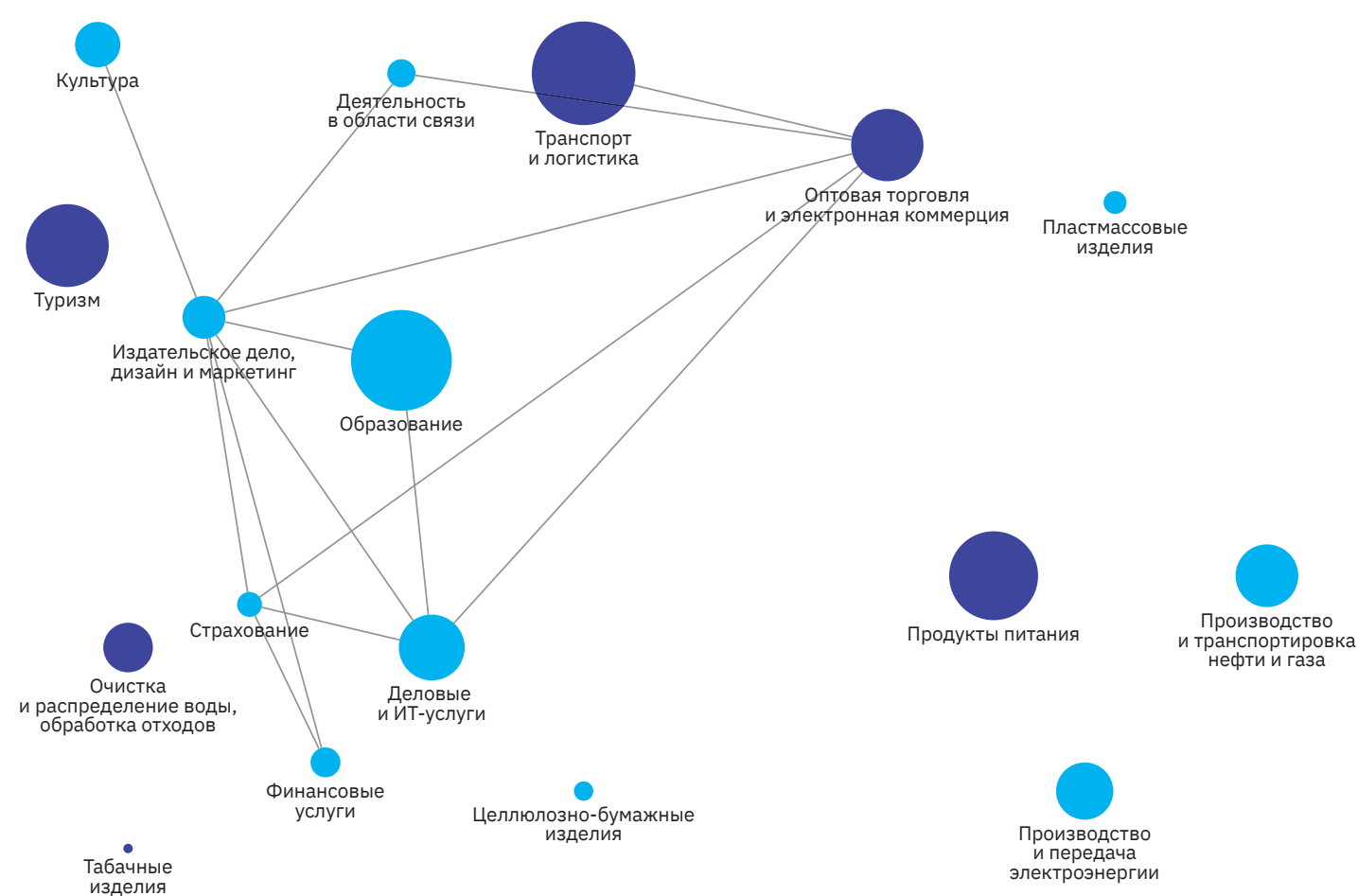




\section{Астраханская область}

\section{Число отраслей специализации, ед.

\begin{tabular}{|llllllll|}
\hline 3 & 4 & & & & & & \\
0 & 8 & 16 & 24 & 32 & 40 & 48 & 56
\end{tabular}

Доля занятых, \%

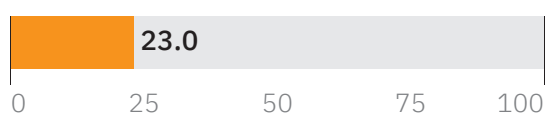

Прирост занятых, \%

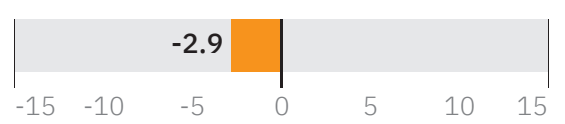

Заработная плата, тыс. руб.

\begin{tabular}{|c|c|c|c|c|}
\hline 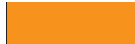 & 48.3 & & & \\
\hline 30 & 60 & 90 & 120 & 150 \\
\hline
\end{tabular}

Отрасль национальной

и локальной значимости

Отрасль национальной

значимости

Отрасль локальной

значимости

Высокий уровень взаимосвязи отраслей

\footnotetext{
Численность занятых в организациях

$\curvearrowleft \quad$ отрасли (кроме субъектов малого

500500050000

предпринимательства), чел.
}

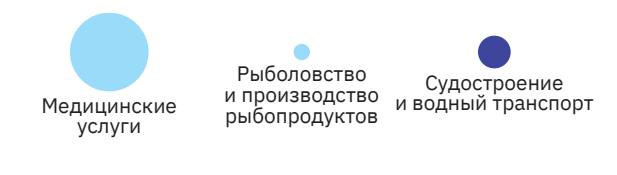




\section{Волгоградская область}

Число отраслей специализации, ед.

$\begin{array}{lll}9 & 6 & 1\end{array}$

$\begin{array}{llllllll}0 & 8 & 16 & 24 & 32 & 40 & 48 & 56\end{array}$

Доля занятых, \%

\begin{tabular}{|lllll|}
\hline & 22.8 & & & \\
\hline & 25 & 50 & 75 & 100
\end{tabular}

Прирост занятых, \%

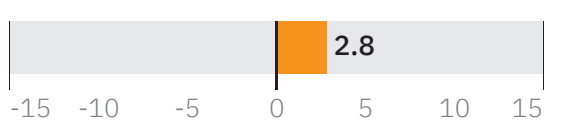

Заработная плата, тыс. руб.

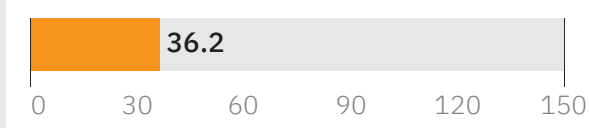

Отрасль национальной

и локальной значимости

Отрасль национальной

значимости

Отрасль локальной

значимости

Высокий уровень взаимосвязи отраслей

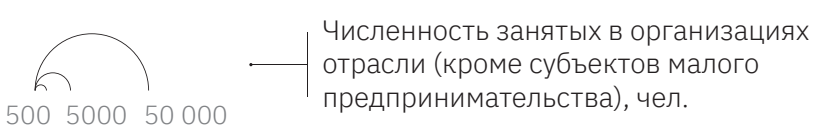

Туризм

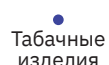

Растениеводство

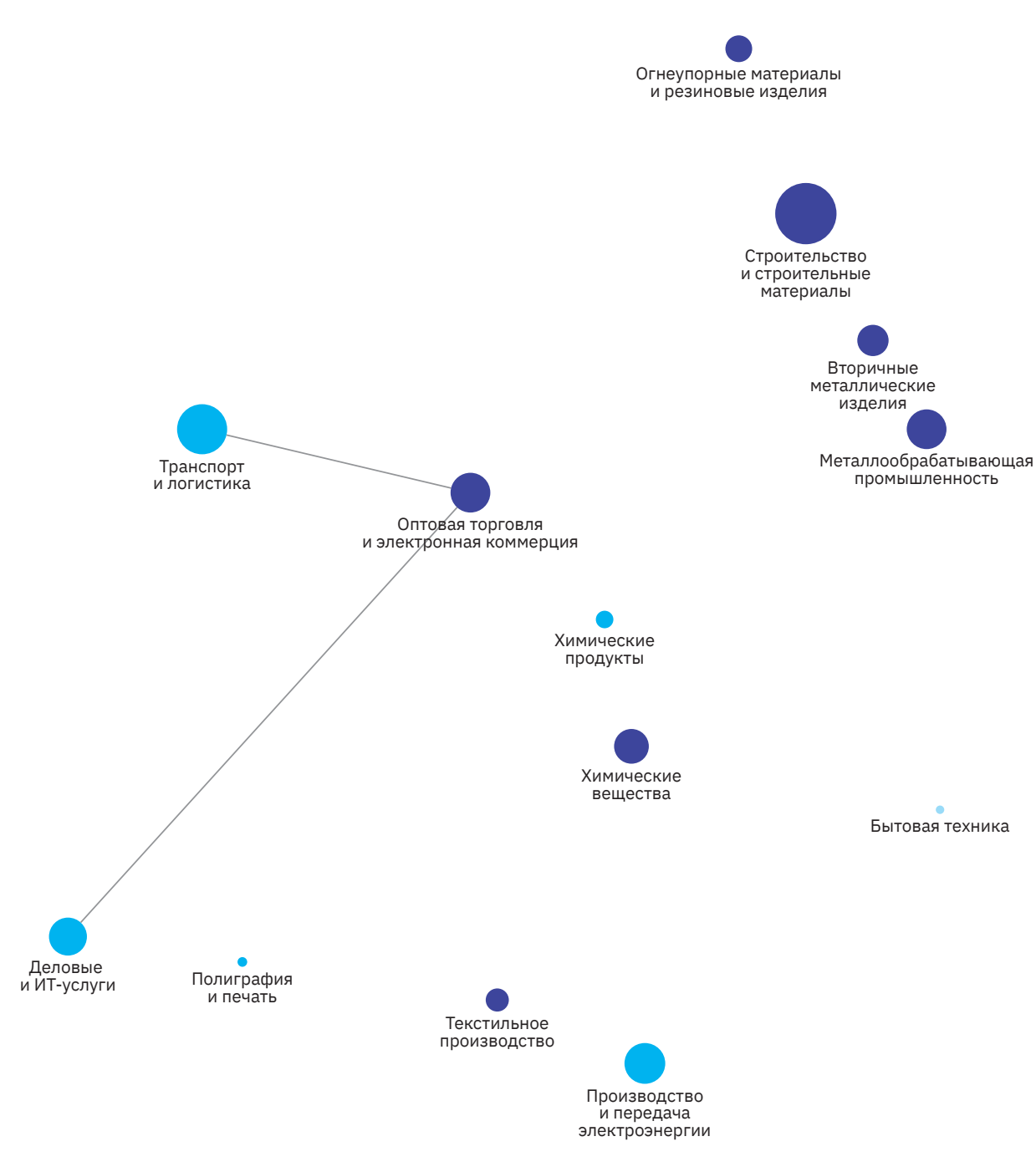




\section{Ростовская область}

\section{Число отраслей специализации, ед.}

$\begin{array}{|llllllll|} & 12 & & 23 & & 1 & & \\ \\ 0 & 8 & 16 & 24 & 32 & 40 & 48 & 56\end{array}$

Доля занятых, \%

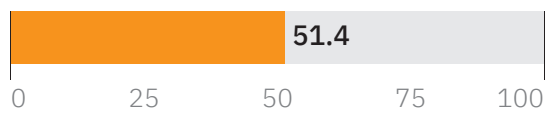

Прирост занятых, \%

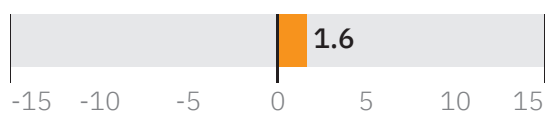

Заработная плата, тыс. руб.

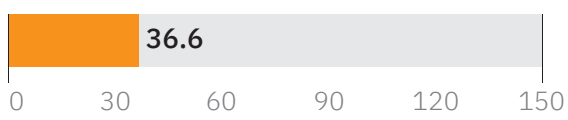

Отрасль национальной
и локальной значимости

Отрасль национальной

значимости

Отрасль локальной

значимости

Высокий уровень взаимосвязи отраслей

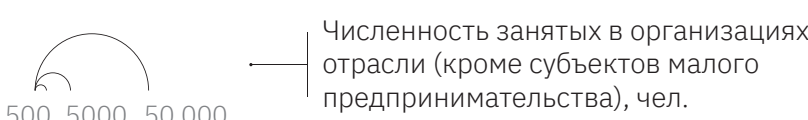

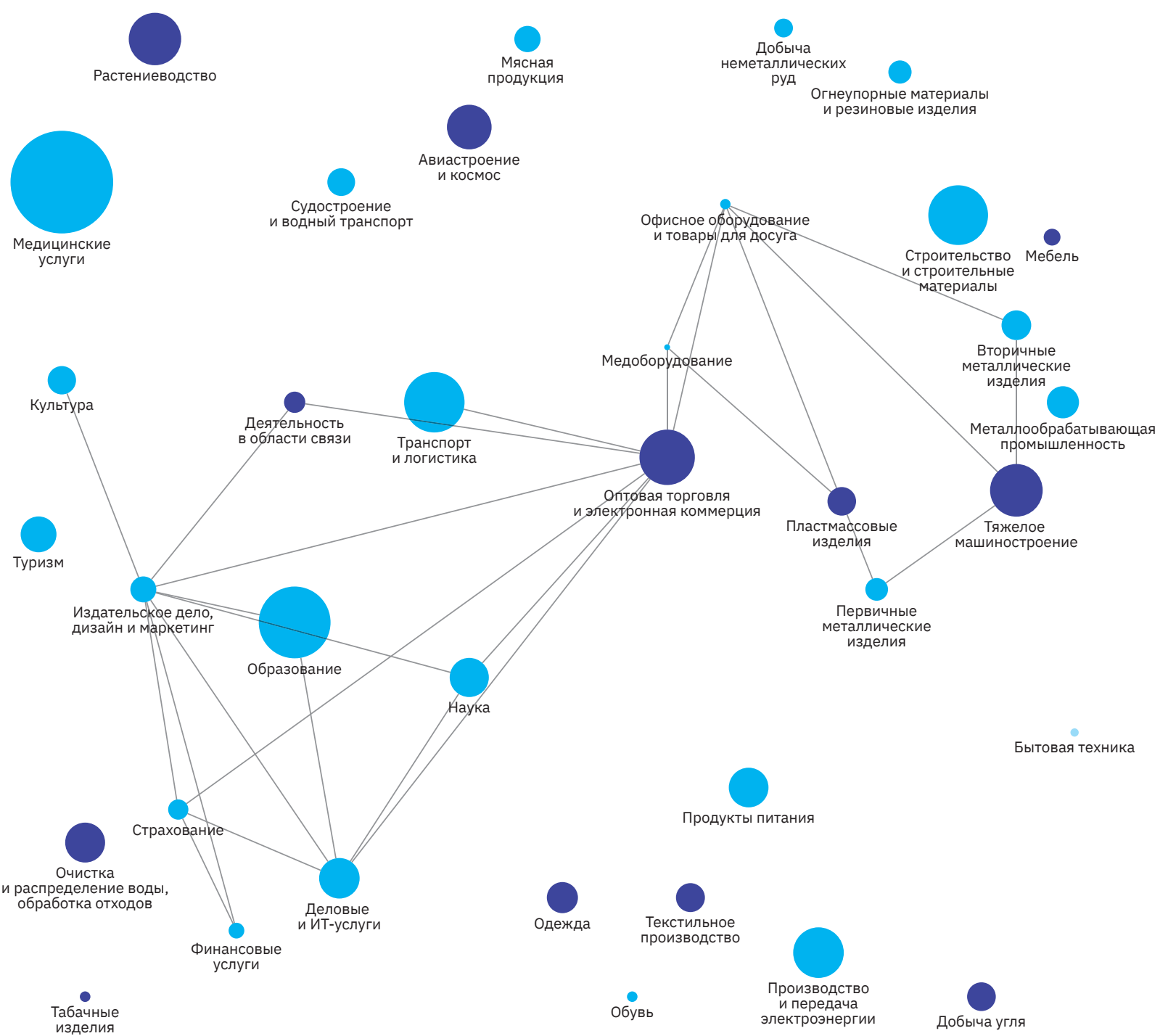




\section{Севастополь}

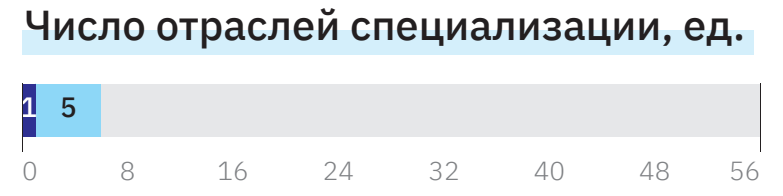

Доля занятых, \%

$\begin{array}{|lllll|} & 9.0 & & & \\ 0 & 25 & 50 & 75 & 100\end{array}$

Прирост занятых, \%

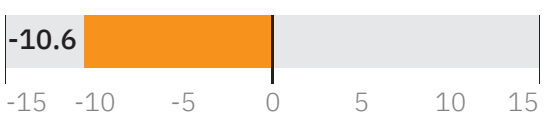

Заработная плата, тыс. руб.

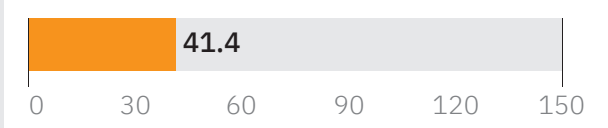

Отрасль национальной

и локальной значимости

Отрасль национальной

значимости

Отрасль локальной

значимости

Высокий уровень взаимосвязи отраслей

\footnotetext{
$\left\{\begin{array}{l}\text { Численность занятых в организациях } \\ \text { отрасли (кроме субъектов малого }\end{array}\right.$ 500500050000 предпринимательства), чел.

Добыча
неметаллических

Рыболовство

рыболовство
ироизвоство $\begin{gathered}\text { Судостроение } \\ \text { рыбопродуктов }\end{gathered}$ и водный транспор

Туризм

$$
\text { Очистка }
$$

и распределение воды,
обработка отходов

Финансовые 

Северо-Кавказский федеральный округ 


\section{Республика Дагестан}

\section{Число отраслей специализации, ед.}

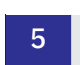

0

$\begin{array}{llllll}16 & 24 & 32 & 40 & 48 & 56\end{array}$

Доля занятых, \%

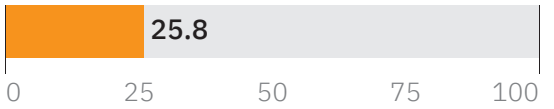

Прирост занятых, \%

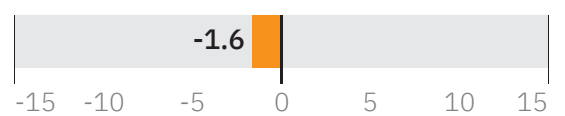

Заработная плата, тыс. руб.

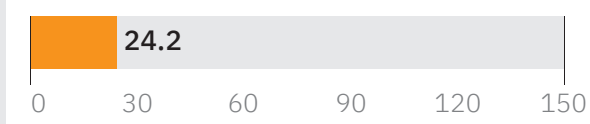

Отрасль национальной

и локальной значимости

Отрасль национальной

значимости

Отрасль локальной

значимости

Высокий уровень взаимосвязи отраслей

\footnotetext{
Численность занятых в организациях
отрасли (кроме субъектов малого предпринимательства), чел.

Сельскохозяйственные услуги

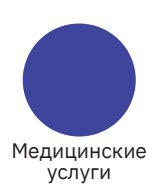

услуги

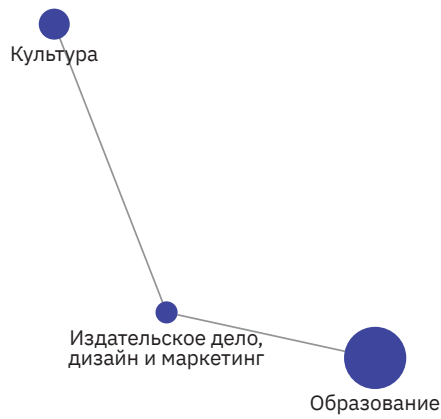




\section{Республика Ингушетия}

\section{Число отраслей специализации, ед.}

$\left|\begin{array}{llllllll}\hline 6 & & & & & & & \\ 0 & 8 & 16 & 24 & 32 & 40 & 48 & 56\end{array}\right|$

Доля занятых, \%

\begin{tabular}{|c|c|c|c|c|}
\hline \multicolumn{3}{|c|}{25.6} & & \\
\hline 0 & 25 & 50 & 75 & 100 \\
\hline
\end{tabular}

Прирост занятых, \%

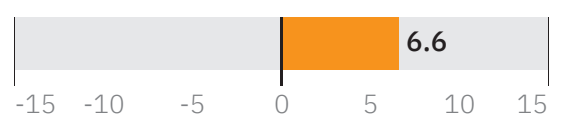

Заработная плата, тыс. руб.

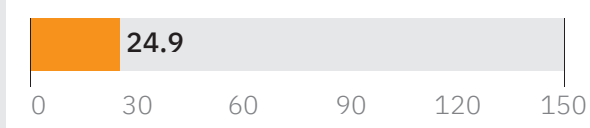

Отрасль национальной

и локальной значимости

Отрасль национальной

значимости

Отрасль локальной

значимости

Высокий уровень взаимосвязи отраслей

\footnotetext{
$\left\{\begin{array}{l}\text { Численность занятых в организациях } \\ \text { отрасли (кроме субъектов малого }\end{array}\right.$ 500500050000 предпринимательства), чел.
}

Сельскохозяйственные услуги
и производство удобрений

Медицинские

услуги

Культура

Туризм 


\section{Кабардино-Балкарская Республика}

Число отраслей специализации, ед.

$\left|\begin{array}{llllllll|}7 & & & & & & & \\ 0 & 8 & 16 & 24 & 32 & 40 & 48 & 56\end{array}\right|$

Доля занятых, \%

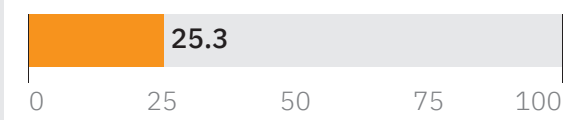

Прирост занятых, \%

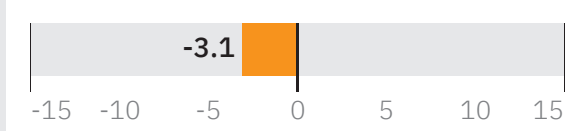

Заработная плата, тыс. руб.

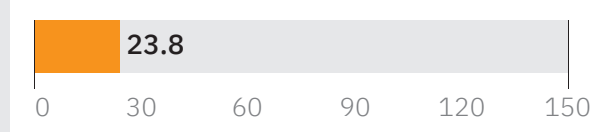

Отрасль национальной
и локальной значимости

Отрасль национальной

значимости

Отрасль локальной

значимости

Высокий уровень взаимосвязи отраслей
Сельскохозяйственные услуги
и производство удобрений

Медицинские

услуги

Киноиндустрия

Туризм

Образование 


\section{Карачаево-Черкесская Республика}

Число отраслей специализации, ед.

$\left|\begin{array}{llllllll|}9 & & & & & & & \\ 0 & 8 & 16 & 24 & 32 & 40 & 48 & 56\end{array}\right|$

Доля занятых, \%

\begin{tabular}{|lllll|}
\hline & 31.5 & & \\
0 & 25 & 50 & 75 & 100
\end{tabular}

Прирост занятых, \%

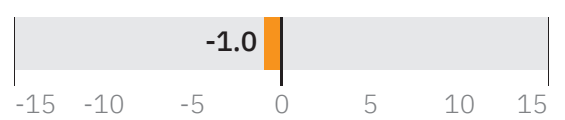

Заработная плата, тыс. руб.

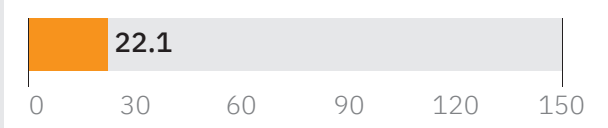

Отрасль национальной

и локальной значимости

Отрасль национальной

значимости

Отрасль локальной

значимости

Высокий уровень взаимосвязи отраслей
Растениеводство

Медицинские

услуги

Образование 


\section{Республика Северная Осетия - Алания}

Число отраслей специализации, ед.

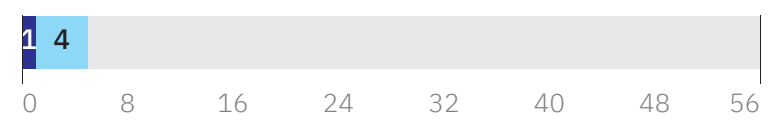

Доля занятых, \%

\begin{tabular}{|lllll|}
\hline \multicolumn{7}{|c|}{$\begin{array}{llll}28.3 \\
1\end{array}$} & 25 & 50 & 75 & 100
\end{tabular}

Прирост занятых, \%

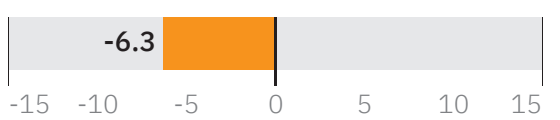

Заработная плата, тыс. руб.

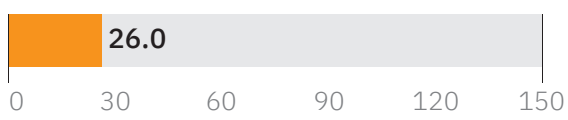

Отрасль национальной
и локальной значимости

Отрасль национальной

значимости

Отрасль локальной

значимости

Высокий уровень взаимосвязи отраслей

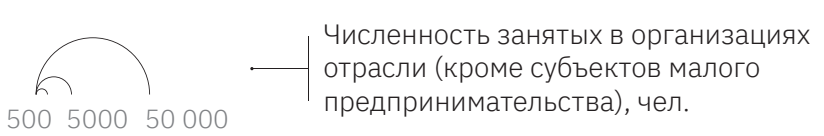

Медицинские

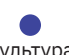

Металлообрабатывающая

промышленность 


\section{Чеченская Республика}

Число отраслей специализации, ед.

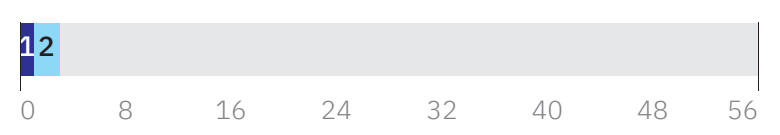

Доля занятых, \%

$\begin{array}{|rrrrr|} & 13.4 & & & \\ 0 & 25 & 50 & 75 & 100\end{array}$

Прирост занятых, \%

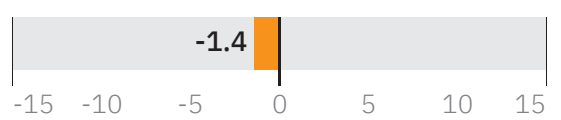

Заработная плата, тыс. руб.

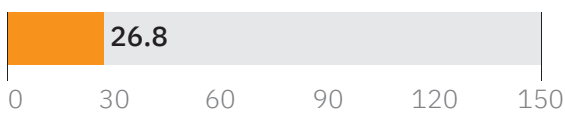

Отрасль национальной

и локальной значимости

Отрасль национальной

значимости

Отрасль локальной

значимости

Высокий уровень взаимосвязи отраслей

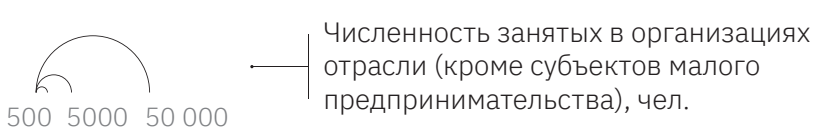

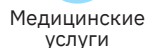

Киноиндустрия

( 


\section{Ставропольский край}

Число отраслей специализации, ед.

$7 \quad 6$

Доля занятых, \%

\begin{tabular}{|lllll|}
\hline \multicolumn{7}{|c|}{28.2} & & & \\
0 & 25 & 50 & 75 & 100
\end{tabular}

Прирост занятых, \%

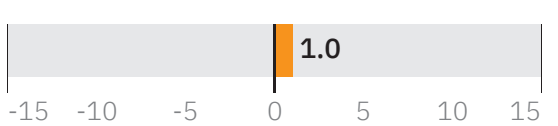

Заработная плата, тыс. руб.

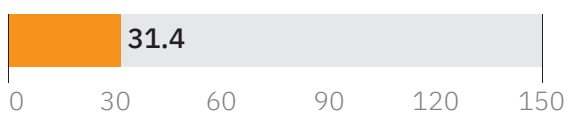

Отрасль национальной

и локальной значимости

Отрасль национальной

значимости

Отрасль локальной

значимости

Высокий уровень взаимосвязи отраслей

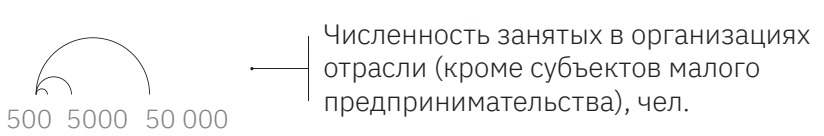

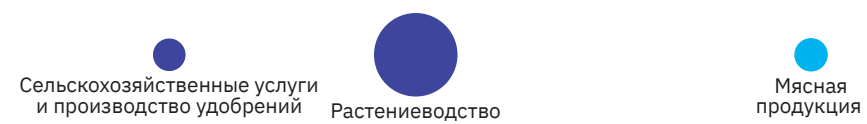
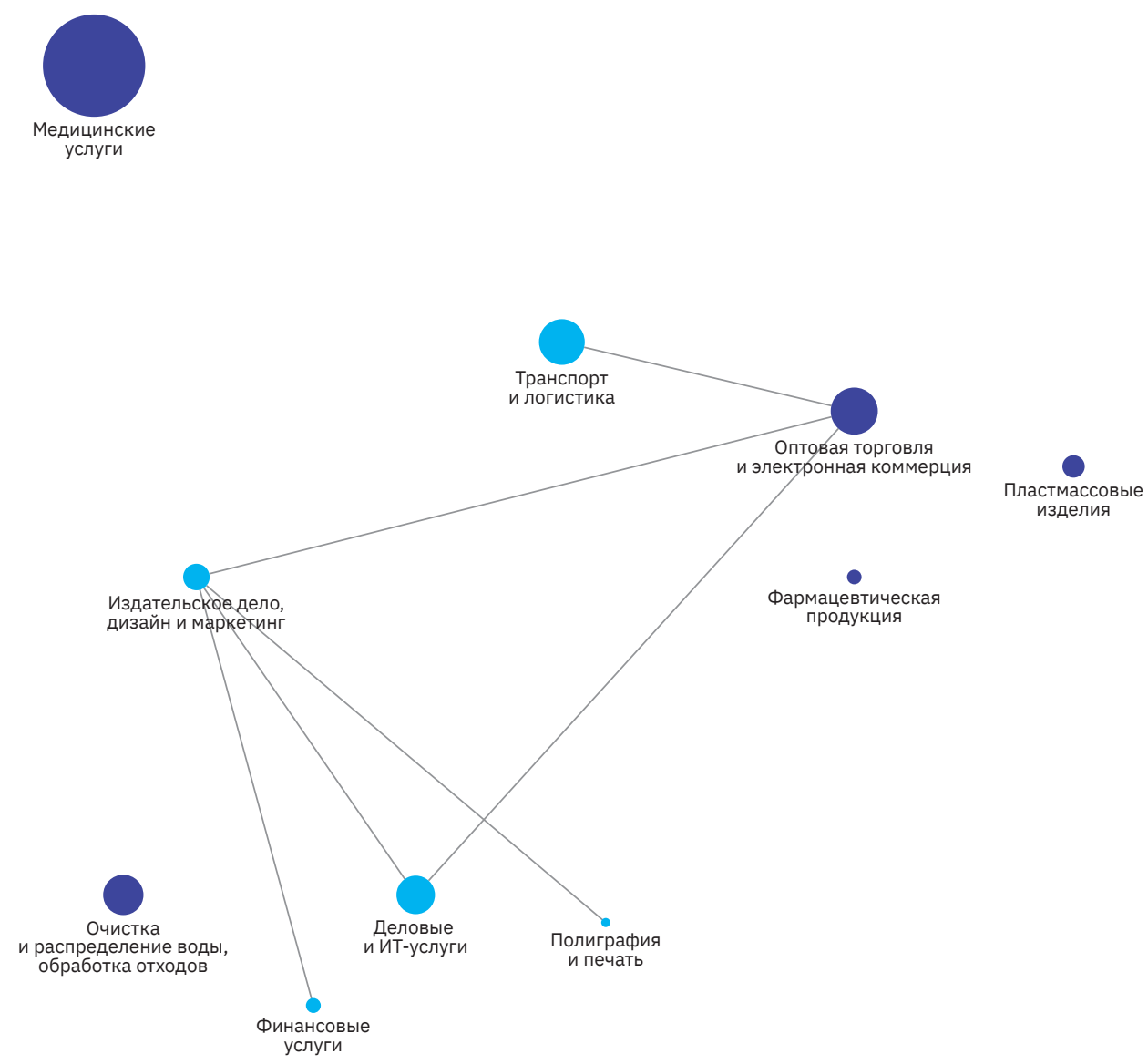
Приволжский федеральный округ 


\section{Республика Башкортостан}

Число отраслей специализации, ед.

\begin{tabular}{|llllllll} 
& 9 & \multicolumn{9}{c}{30} & & & & \\
0 & 8 & 16 & 24 & 32 & 40 & 48 & 56
\end{tabular}

Доля занятых, \%

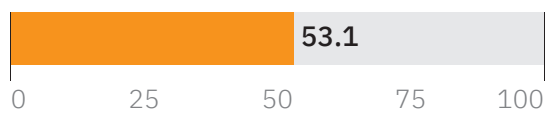

Прирост занятых, \%

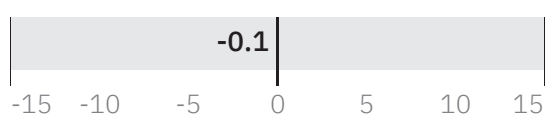

Заработная плата, тыс. руб.

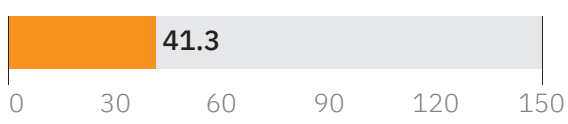

Отрасль национальной
и локальной значимости

Отрасль национальной

значимости

Отрасль локальной

значимости

Высокий уровень взаимосвязи отраслей

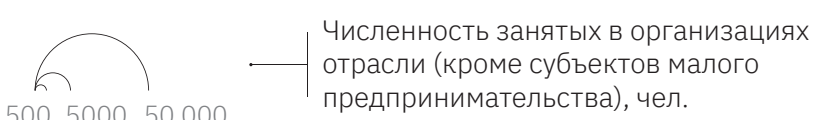

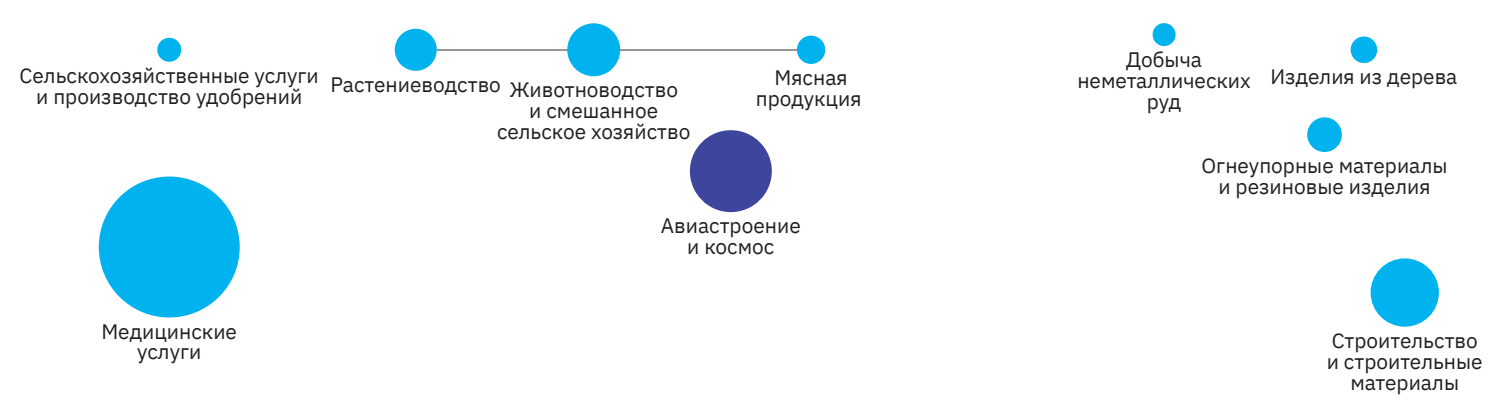

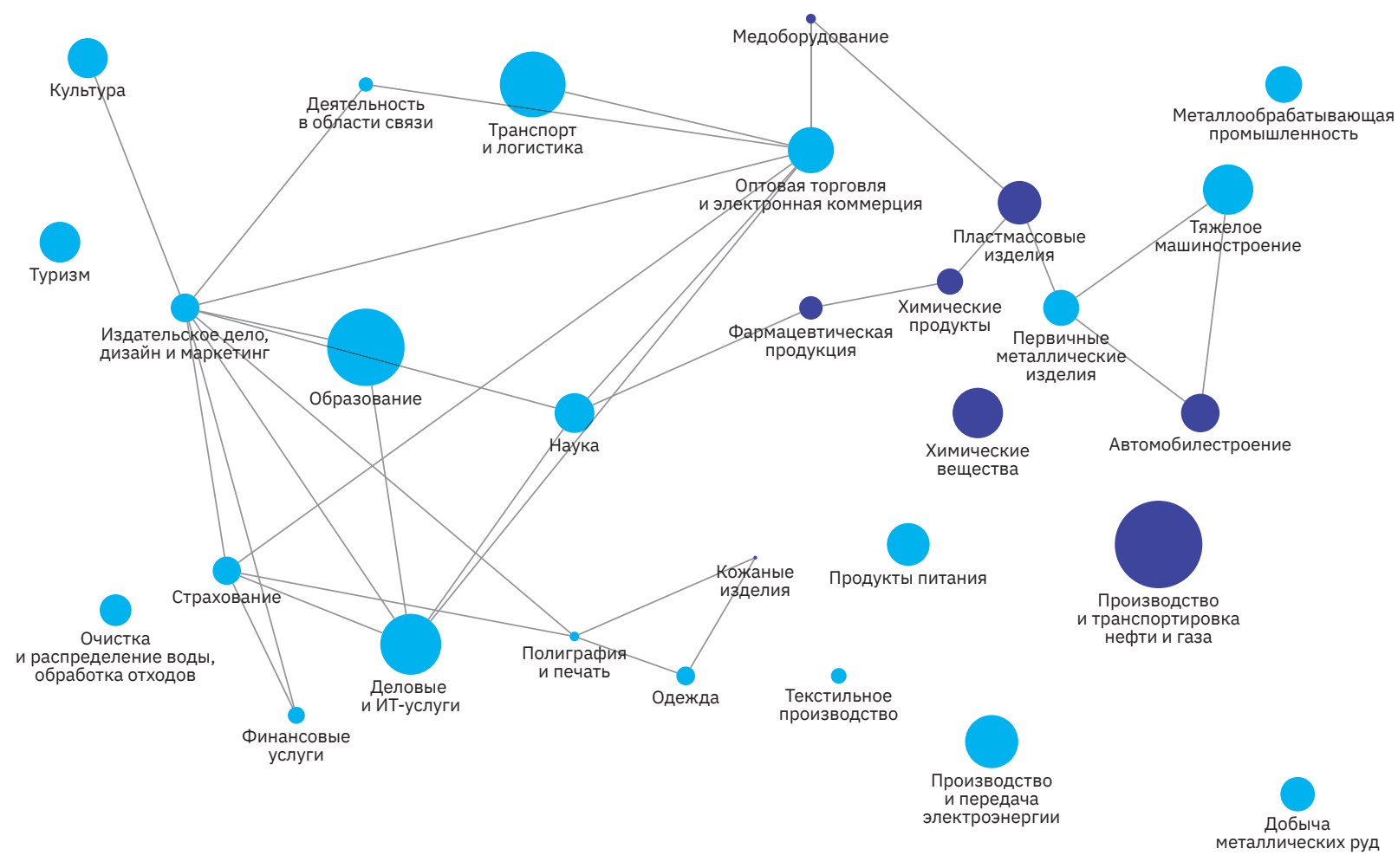




\section{Республика Марий Эл}

\section{Число отраслей специализации, ед.}

$\begin{array}{ll}7 & 5\end{array}$

$\begin{array}{llllllll}8 & 16 & 24 & 32 & 40 & 48 & 56\end{array}$

Доля занятых, \%

$\begin{array}{|lllll|} & \mathbf{2 1 . 0} & & & \\ 0 & 25 & 50 & 75 & 100\end{array}$

Прирост занятых, \%

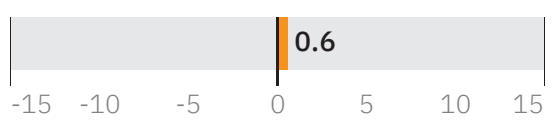

Заработная плата, тыс. руб.

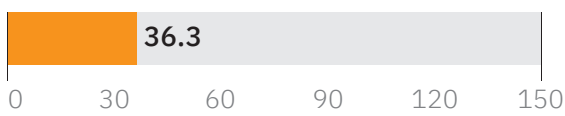

Отрасль национальной

и локальной значимости

Отрасль национальной

значимости

Отрасль локальной

значимости

Высокий уровень взаимосвязи отраслей

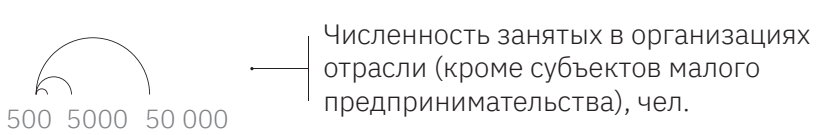

Культура

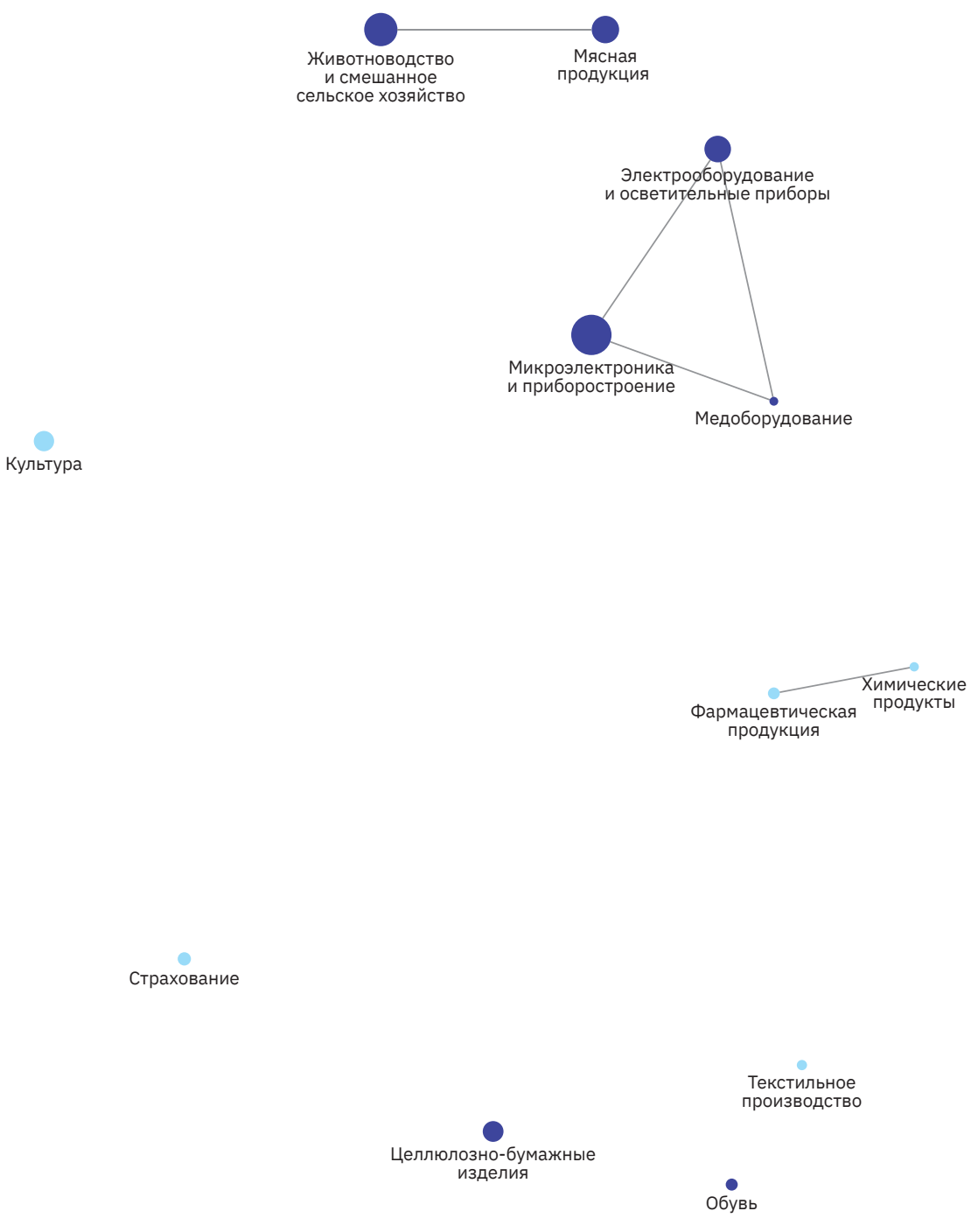




\section{Республика Мордовия}

Число отраслей специализации, ед.

92

\section{Доля занятых, \%}

\begin{tabular}{|c|c|c|c|c|}
\hline \multicolumn{5}{|c|}{24.3} \\
\hline 0 & 25 & 50 & 75 & 100 \\
\hline
\end{tabular}

Прирост занятых, \%

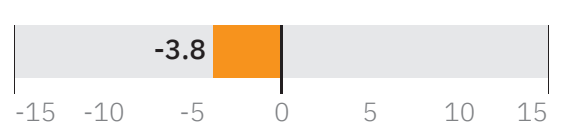

Заработная плата, тыс. руб.

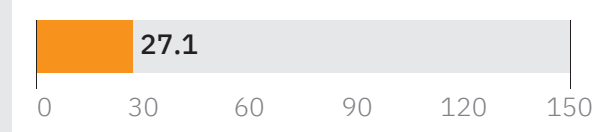

Отрасль национальной

и локальной значимости

Отрасль национальной

значимости

Отрасль локальной

значимости

Высокий уровень взаимосвязи отраслей
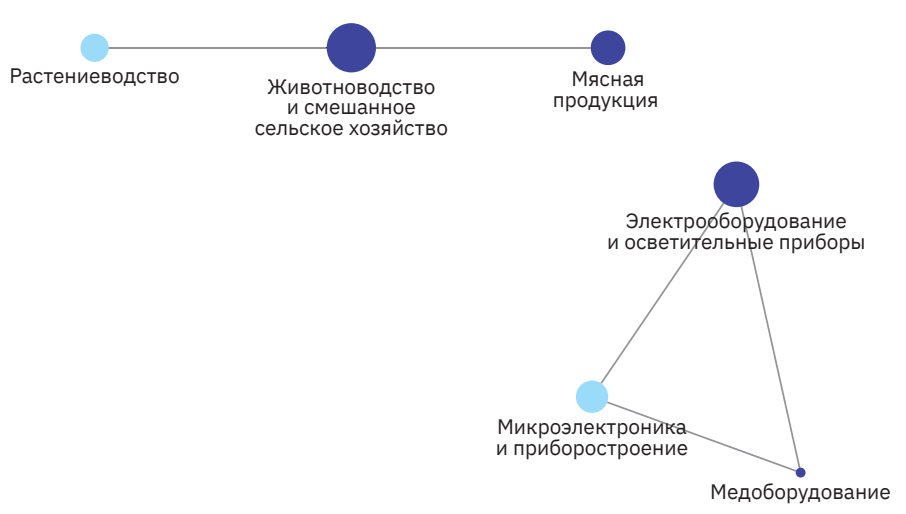

Мебеำ
Огнеупорные материалы

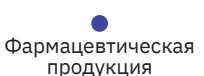

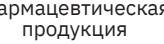

Продукты питания

Одежда

$$
\text { Одежд }
$$




\section{Республика Татарстан}

Число отраслей специализации, ед.

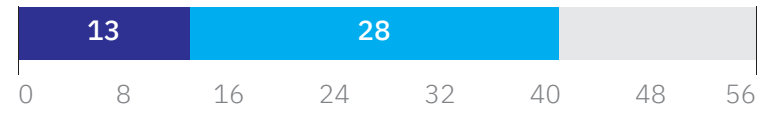

Доля занятых, \%

\begin{tabular}{|lllll|}
\hline \multicolumn{5}{c}{56.2} \\
0 & 25 & 50 & 75 & 100
\end{tabular}

Прирост занятых, \%

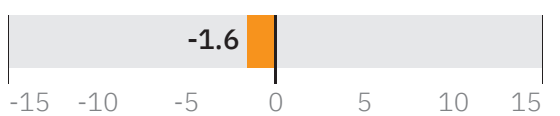

Заработная плата, тыс. руб.

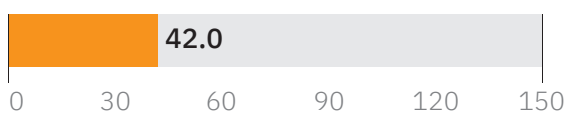

Отрасль национальной
и локальной значимости

Отрасль нацио

Отрасль локальной

значимости

Высокий уровень взаимосвязи отраслей

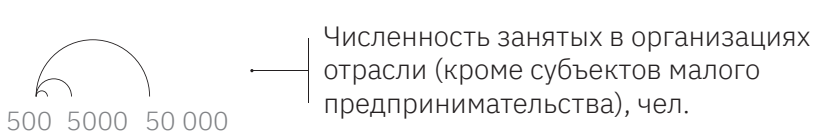

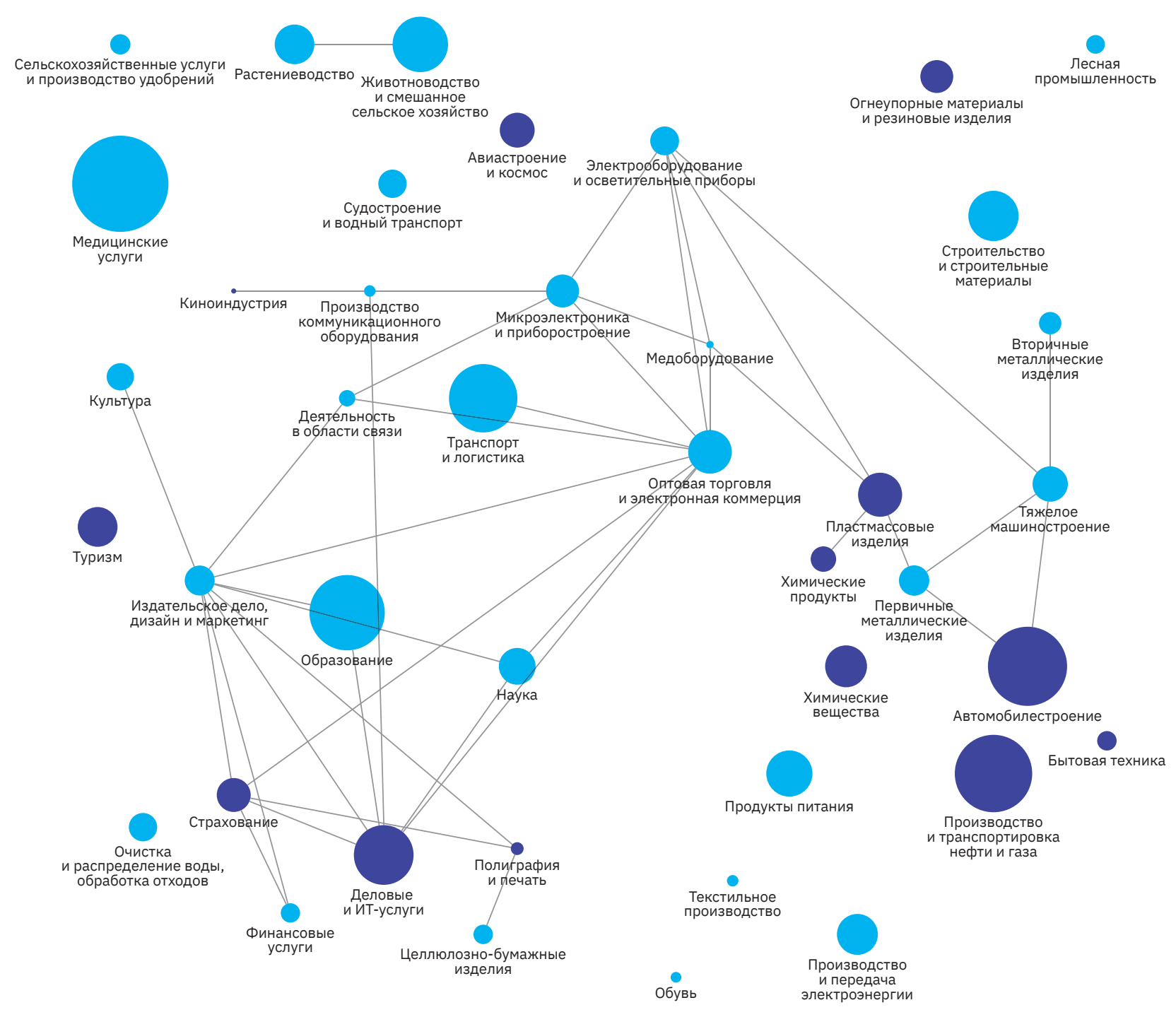




\section{Удмуртская Республика}

\section{Число отраслей специализации, ед.}

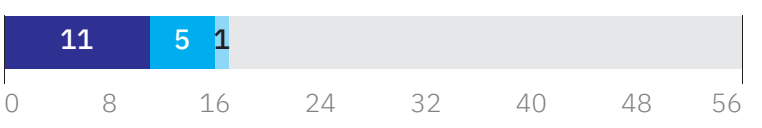

Доля занятых, \%

\begin{tabular}{|lllll|}
\hline & 32.4 & & \\
0 & 25 & 50 & 75 & 100
\end{tabular}

Прирост занятых, \%

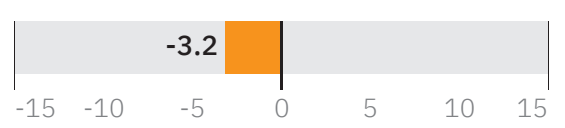

Заработная плата, тыс. руб.

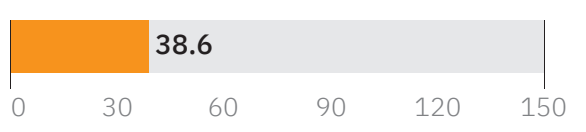

Отрасль национальной

Отрасль национальной

значимости

Отрасль локальной

значимости

Высокий уровень взаимосвязи отраслей

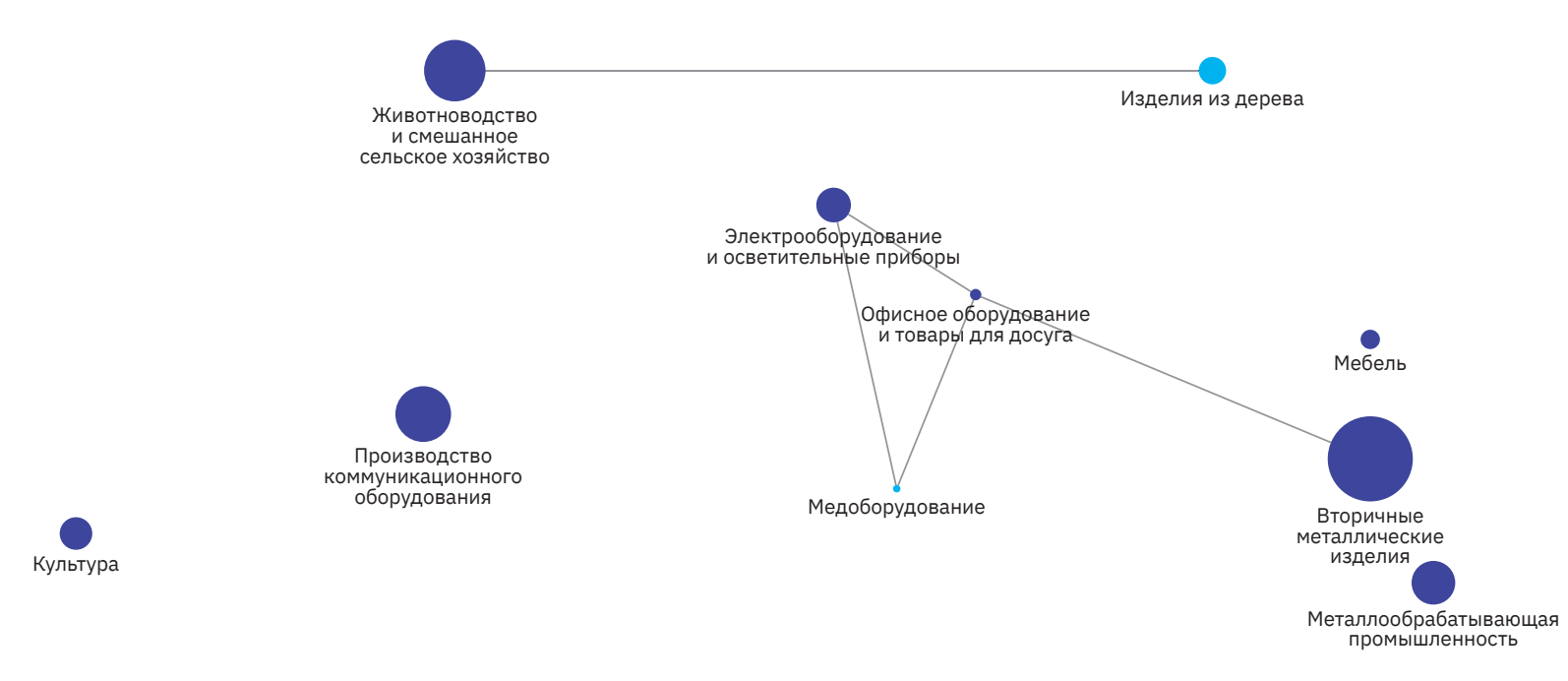

Trpana

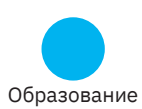

Кожаные
изделия

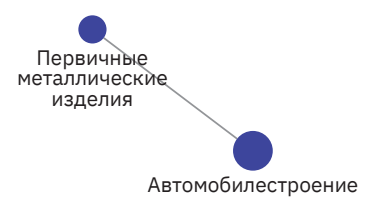

Автомобилестроени 


\section{Чувашская Республика}

\section{Число отраслей специализации, ед.}

10

$\begin{array}{llllllll}0 & 8 & 16 & 24 & 32 & 40 & 48 & 56\end{array}$

Доля занятых, \%

\begin{tabular}{|ccccc|}
\hline & 18.3 & & & \\
0 & 25 & 50 & 75 & 100
\end{tabular}

Прирост занятых, \%

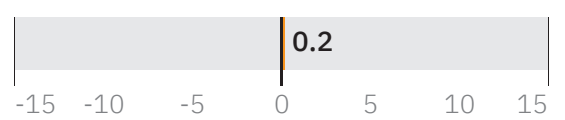

Заработная плата, тыс. руб.

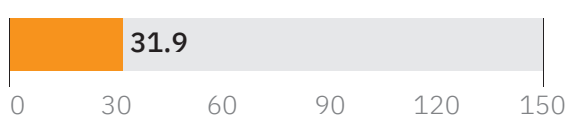

Отрасль национальной
и локальной значимости

значимости

Отрасль локальной

значимости

Высокий уровень взаимосвязи отраслей

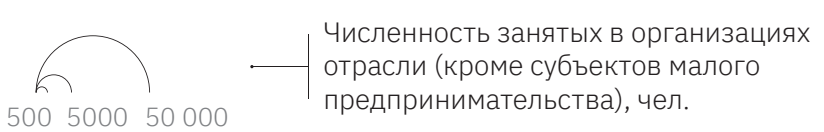

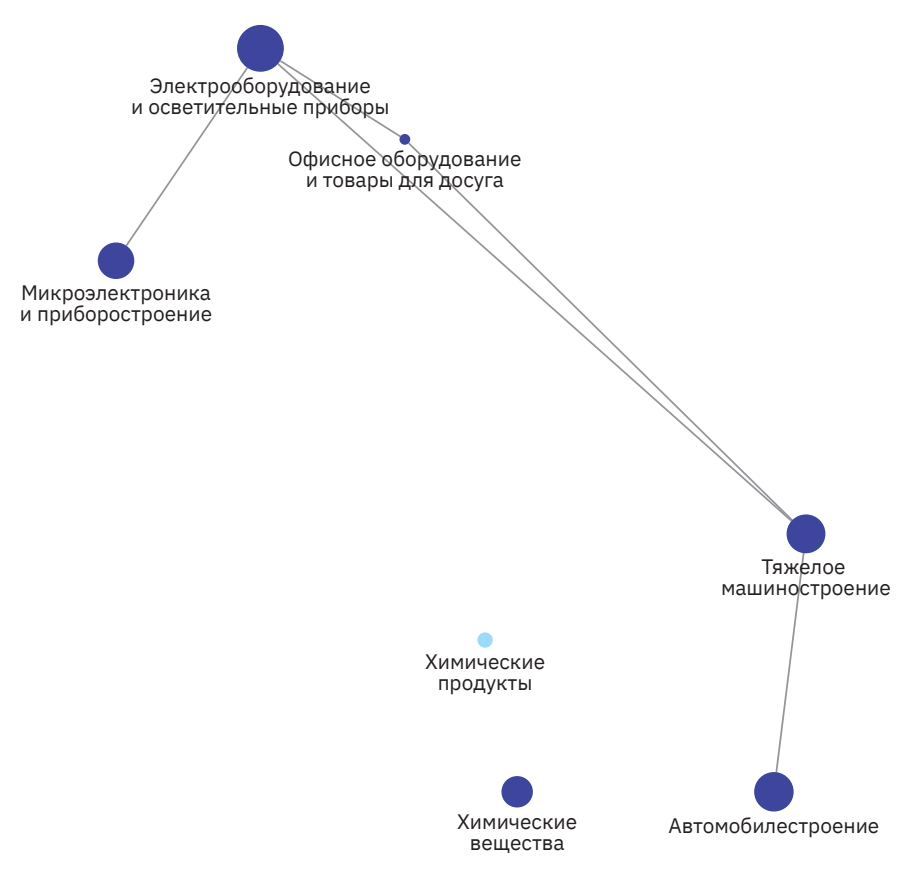

кожаные

Продукты питания

Одежда

обув 


\section{Пермский край}

\section{Число отраслей специализации, ед.}

\begin{tabular}{|rrrrrrrr|} 
& 15 & \multicolumn{2}{c}{10} & & & & \\
\hline 0 & 8 & 16 & 24 & 32 & 40 & 48 & 56
\end{tabular}

Доля занятых, \%

\begin{tabular}{|lllll|}
\hline \multicolumn{3}{|c|}{31.2} & & \\
0 & 25 & 50 & 75 & 100
\end{tabular}

Прирост занятых, \%

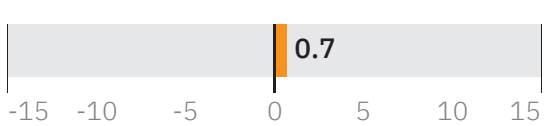

Заработная плата, тыс. руб.

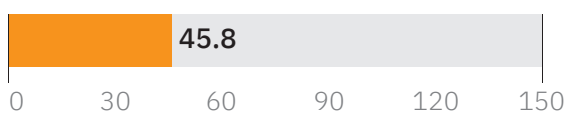

Отрасль национальной

Отрасль национальной

значимости

Отрасль локальной

значимости

Высокий уровень взаимосвязи отраслей

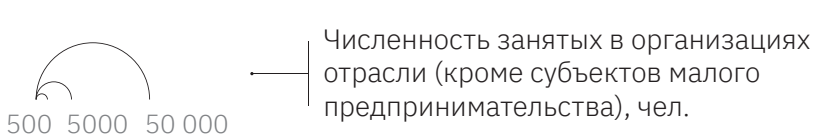

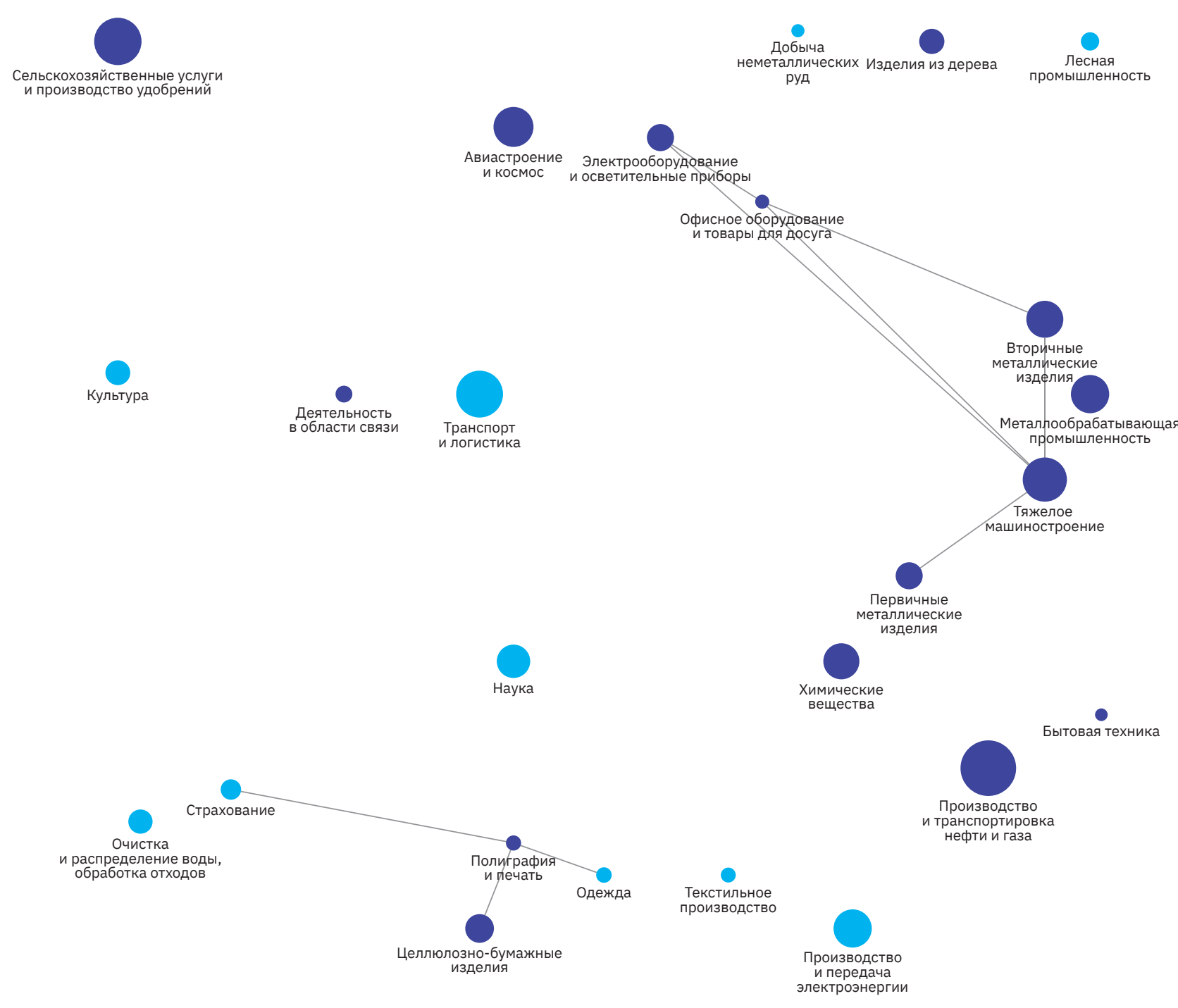




\section{Кировская область}

Число отраслей специализации, ед.

14 2

Доля занятых, \%

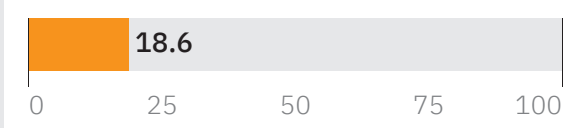

Прирост занятых, \%

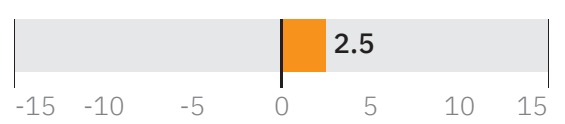

Заработная плата, тыс. руб.

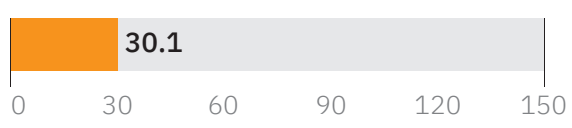

Отрасль национальной
и локальной значимости

Отрасль национальной

значимости

Отрасль локальной

значимости

Высокий уровень взаимосвязи отраслей

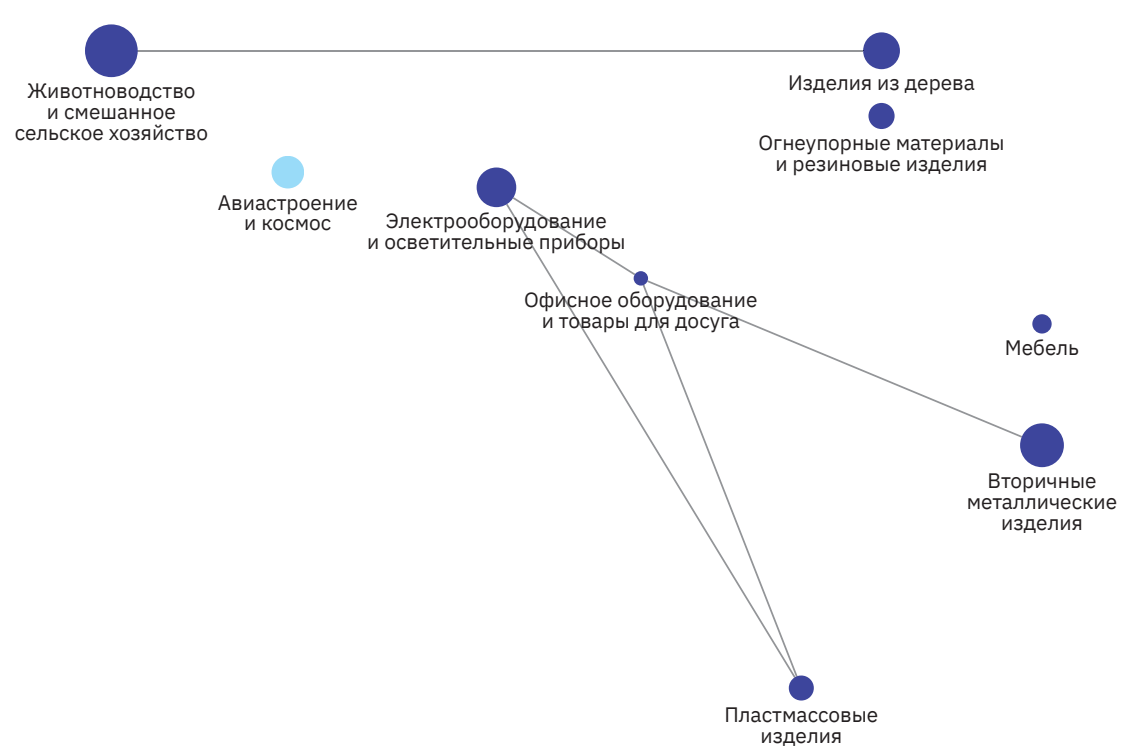

Фармацевтическая

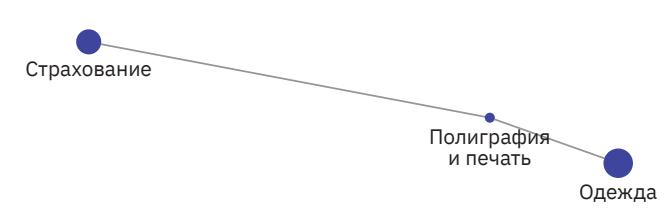

\footnotetext{
Численность занятых в организациях

$\curvearrowleft \quad$ отрасли (кроме субъектов малого 


\section{Нижегородская область}

Число отраслей специализации, ед.

\begin{tabular}{|llllllll|}
\hline & 16 & \multicolumn{1}{c|}{23} & & & \\
\hline 0 & 8 & 16 & 24 & 32 & 40 & 48 & 56
\end{tabular}

Доля занятых, \%

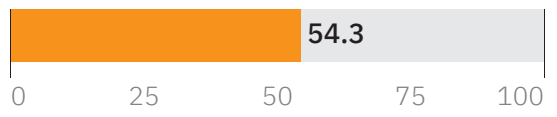

Прирост занятых, \%

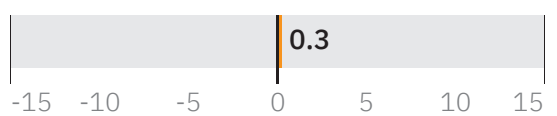

Заработная плата, тыс. руб.

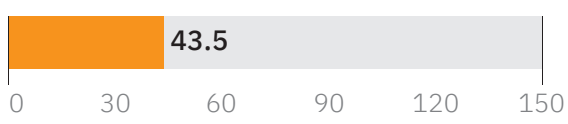

Отрасль национальной
и локальной значимости

Отрасль национальной

значимости

Отрасль локальной

значимости

Высокий уровень взаимосвязи отраслей

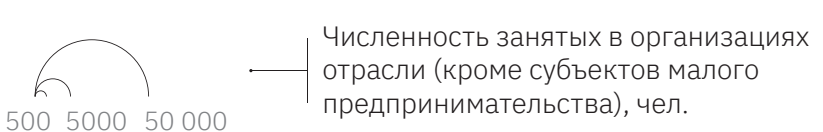

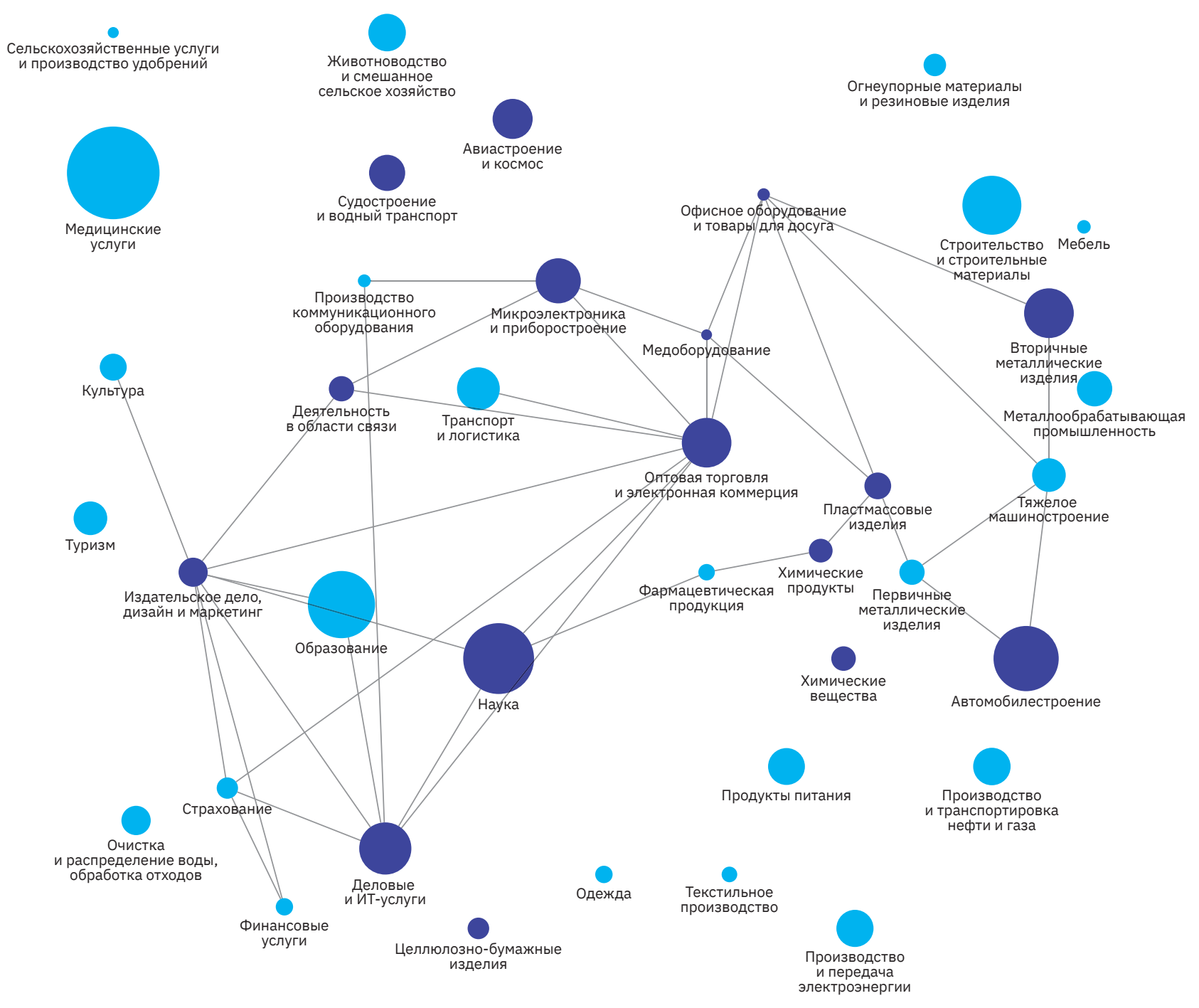




\section{Оренбургская область}

\section{Число отраслей специализации, ед.}

\begin{tabular}{l|l}
7 & 7
\end{tabular}

$\begin{array}{llllllll}8 & 16 & 24 & 32 & 40 & 48 & 56\end{array}$

Доля занятых, \%

\begin{tabular}{|lllll|}
\hline & & 29.5 & & \\
0 & 25 & 50 & 75 & 100
\end{tabular}

Прирост занятых, \%

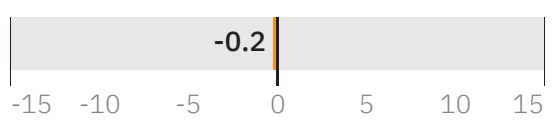

Заработная плата, тыс. руб.

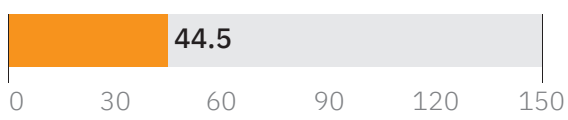

Отрасль национальной

и локальной значимости

Отрасль национальной

значимости

Отрасль локальной

значимости

Высокий уровень взаимосвязи отраслей
Культура

$\underset{\text { yypum }}{\bigodot}$

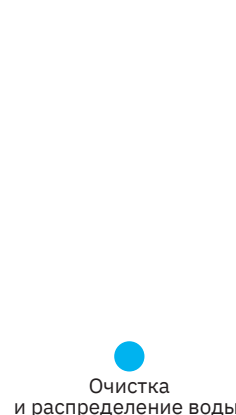

и распределение воды,
обработка отходов

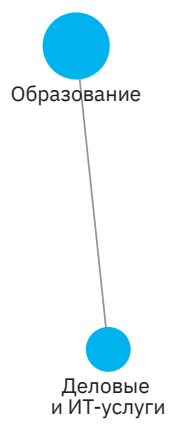

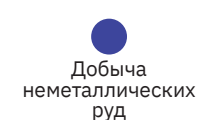

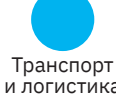

Транспорт
и логистика

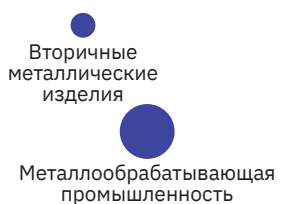

промышленность
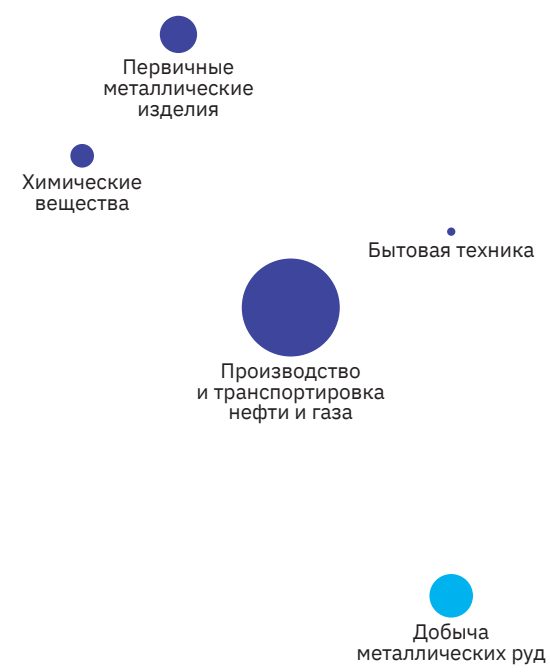


\section{Пензенская область}

\section{Число отраслей специализации, ед.}

$12 \quad 2$

Доля занятых, \%

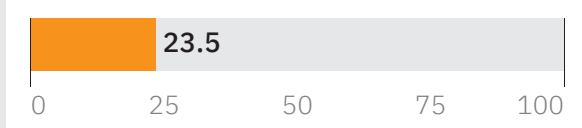

Прирост занятых, \%

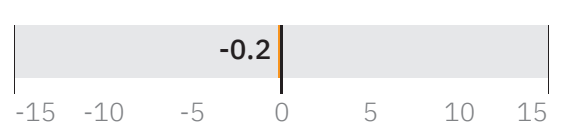

Заработная плата, тыс. руб.

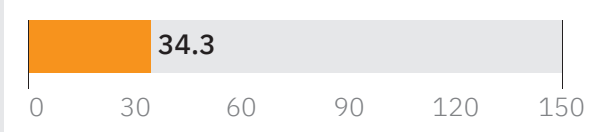

Отрасль национальной

и локальной значимости

Отрасль национальной

значимости

Отрасль локальной

значимости

- Высокий уровень взаимосвязи отраслей

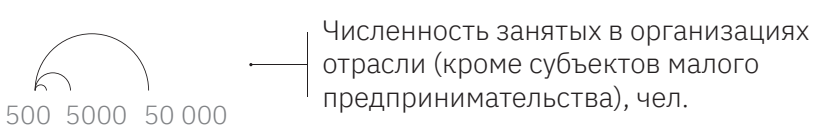

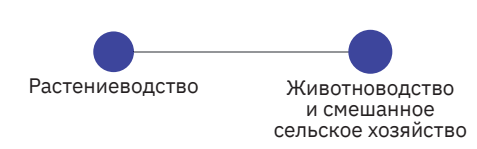

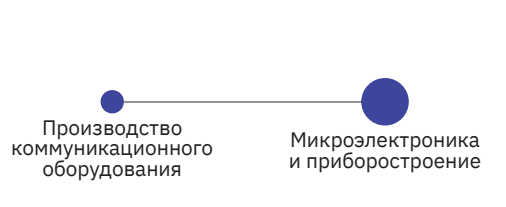

мอำกรь

коммуниканс

и приборостроение

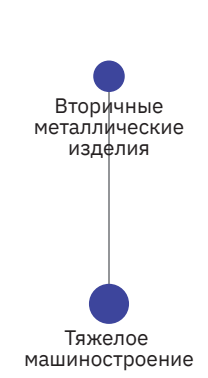

Бытовая техника 


\section{Самарская область}

Число отраслей специализации, ед.

11 17

$\begin{array}{llllllll}0 & 8 & 16 & 24 & 32 & 40 & 48 & 56\end{array}$

Доля занятых, \%

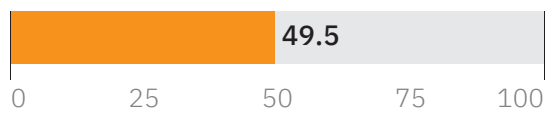

Прирост занятых, \%

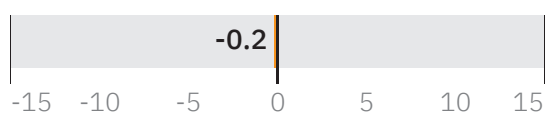

Заработная плата, тыс. руб.

\begin{tabular}{|rrrrrr}
\hline & 41.7 & & & \\
0 & 30 & 60 & 90 & 120 & 150
\end{tabular}

Отрасль национальной

и локальной значимости

Отрасль национальной

значимости

Отрасль локальной

значимости

Высокий уровень взаимосвязи отраслей

\footnotetext{
Численность занятых в организациях

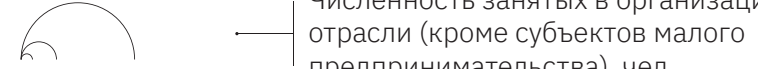
500500050000

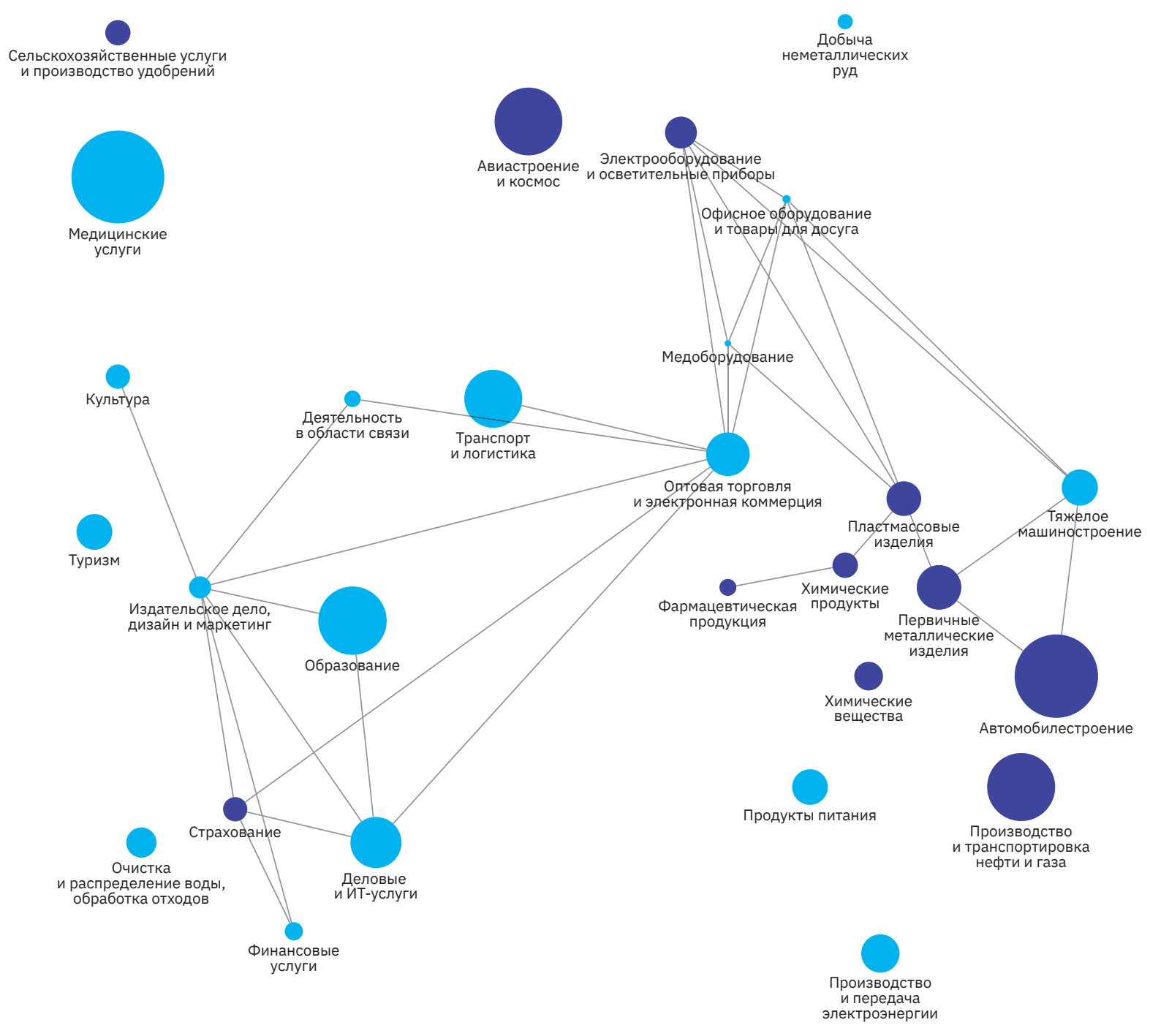




\section{Саратовская область}

\section{Число отраслей специализации, ед.}

$10 \quad 8$

$\begin{array}{llllllll}0 & 8 & 16 & 24 & 32 & 40 & 48 & 56\end{array}$

Доля занятых, \%

\begin{tabular}{|lllll|}
\hline & 25.9 & & & \\
0 & 25 & 50 & 75 & 100
\end{tabular}

Прирост занятых, \%

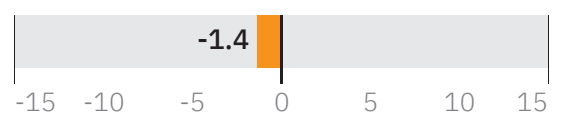

Заработная плата, тыс. руб.

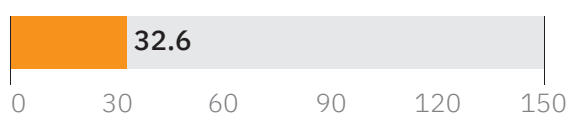

Отрасль национальной
и локальной значимости

Отрасль национальной

значимости

Отрасль локальной

значимости

Высокий уровень взаимосвязи отраслей

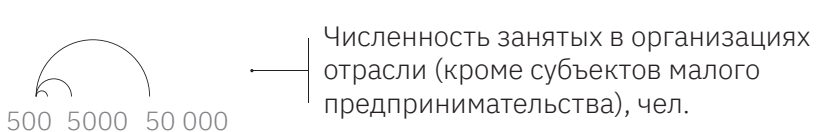

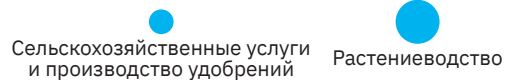

ельскохозяйственные услуги Растениеводств
и производство удобрений (a)

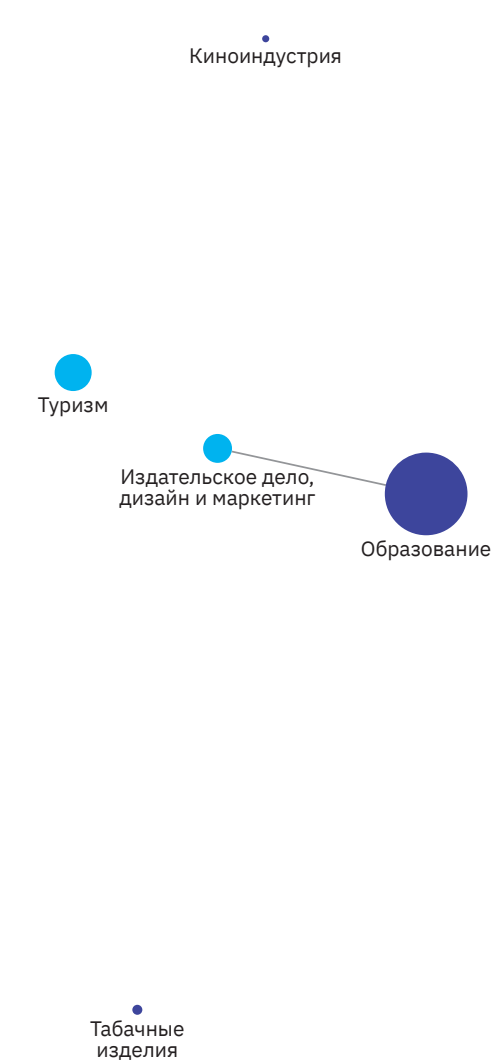

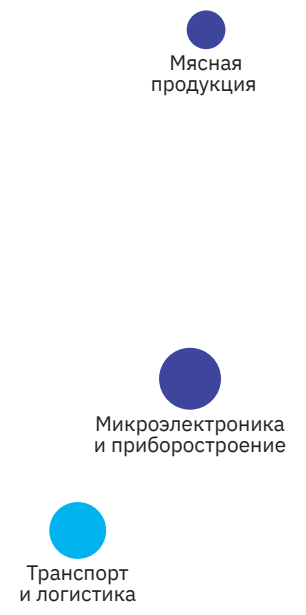

Огнеупорные материалы и резиновые изделия
Одежда Текстильное

Текстильное
производство

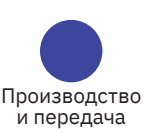




\section{Ульяновская область}

Число отраслей специализации, ед.

$\begin{array}{lll}8 & 3 & 4\end{array}$

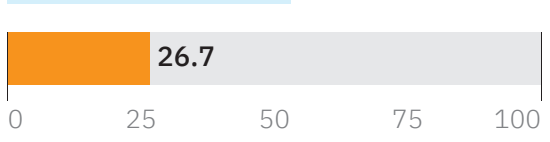

Прирост занятых, \%

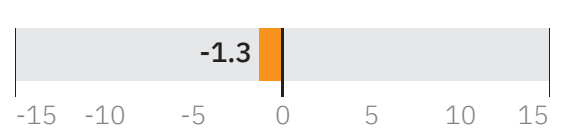

Заработная плата, тыс. руб.

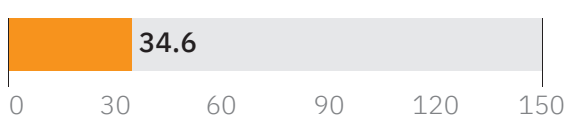

Отрасль национальной
и локальной значимости

Отрасль национальной

значимости

Отрасль локальной

значимости

Высокий уровень взаимосвязи отраслей

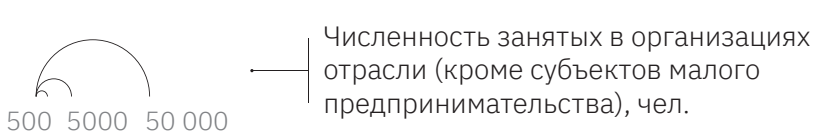

Изделия из дерева

воричные металлически

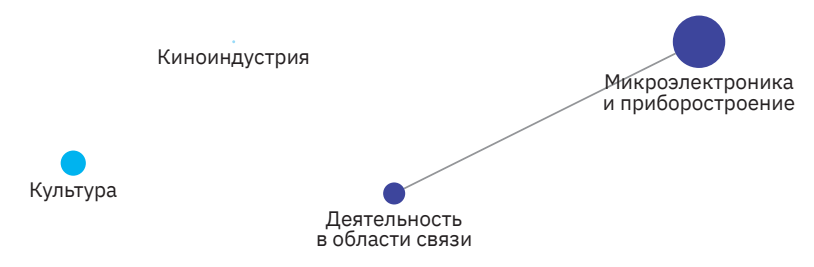

образование

Наука

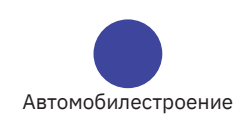

Бытовая техника

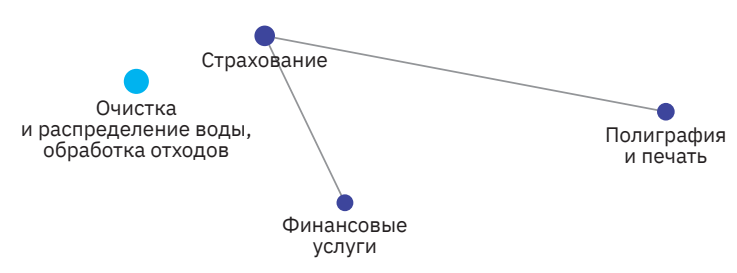





\section{Уральский \\ федеральный округ}




\section{Курганская область}

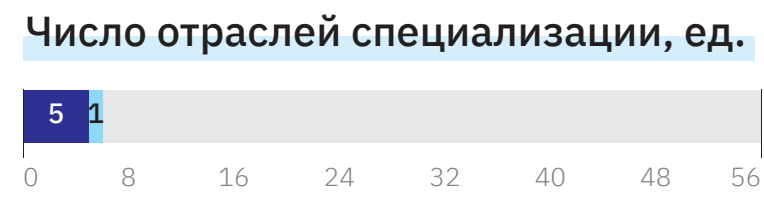

Доля занятых, \%

$\begin{array}{|rrrrr|} & 15.1 & & & \\ 0 & 25 & 50 & 75 & 100\end{array}$

Прирост занятых, \%

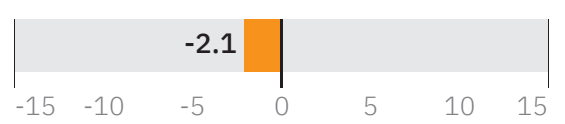

Заработная плата, тыс. руб.
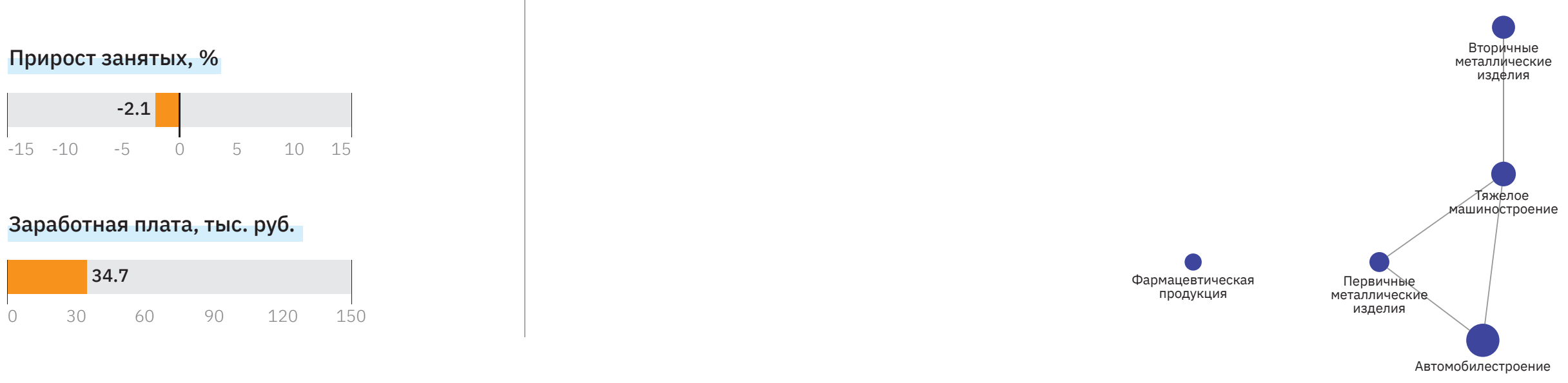

Отрасль национальной

и локальной значимости

Отрасль национальной

значимости

Кожаные
изделия

Отрасль локальной

значимости

Высокий уровень взаимосвязи отраслей

Численность занятых в организациях

отрасли (кроме субъектов малого

предпринимательства), чел. 


\section{Свердловская область}

Число отраслей специализации, ед.

\section{0}

$\begin{array}{llllllll}0 & 8 & 16 & 24 & 32 & 40 & 48 & 56\end{array}$

Доля занятых, \%

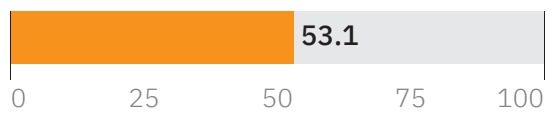

Прирост занятых, \%

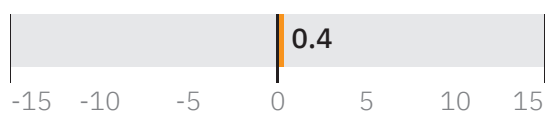

Заработная плата, тыс. руб.

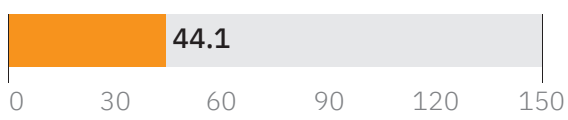

Отрасль национальной

Отрасль нащиональной

значимости

Отрасль локальной

значимости

Высокий уровень взаимосвязи отраслей

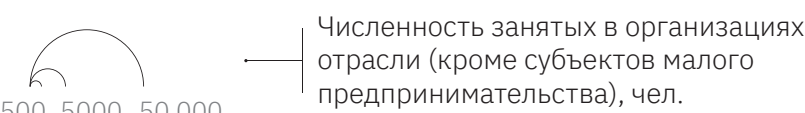

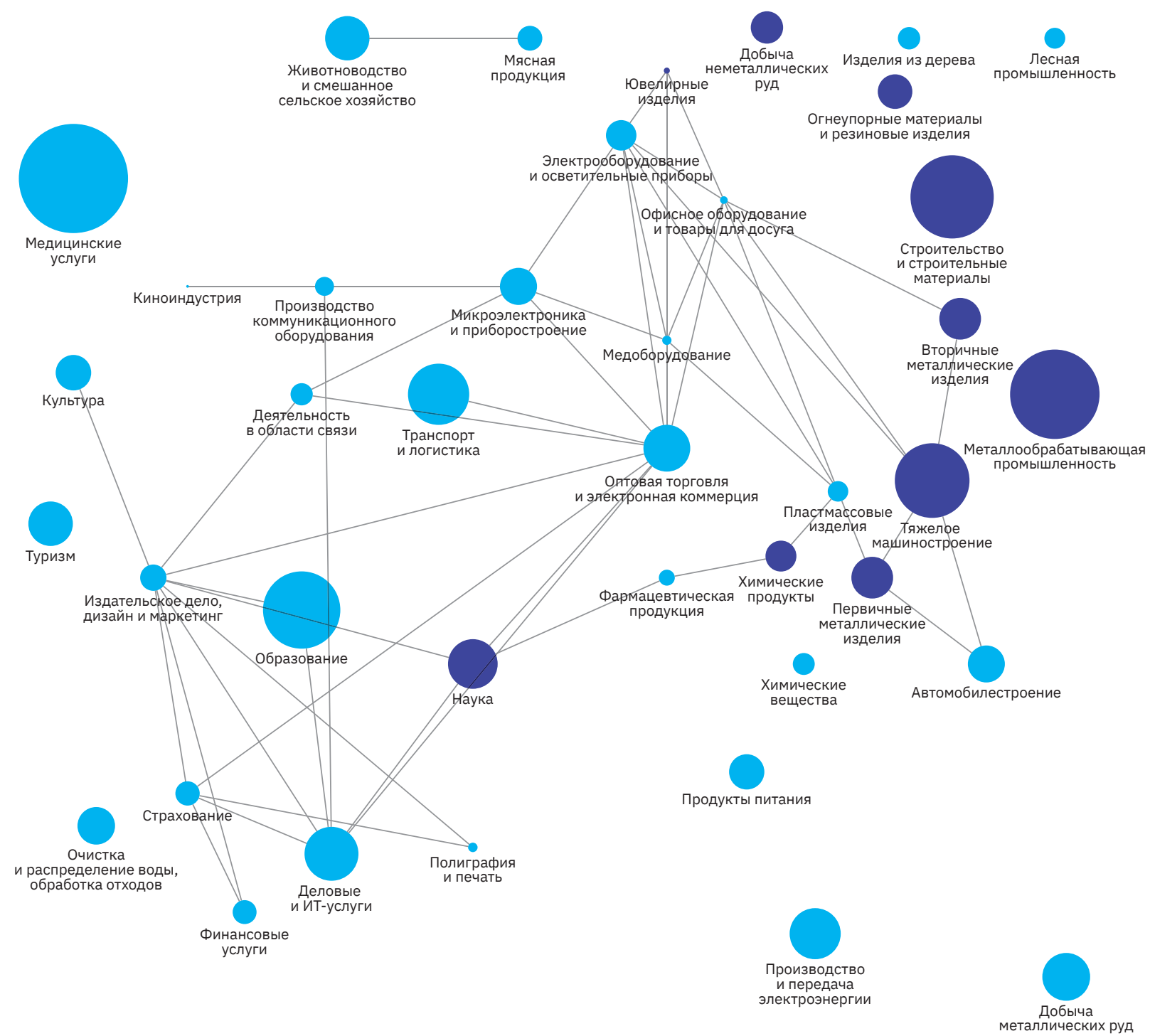




\section{Тюменская область}

\section{Число отраслей специализации, ед.}

$\begin{array}{ll}6 & 4\end{array}$

$\begin{array}{lllllll}8 & 16 & 24 & 32 & 40 & 48 & 56\end{array}$

Доля занятых, \%

\begin{tabular}{|lllll|}
\hline & 22.7 & & & \\
0 & 25 & 50 & 75 & 100
\end{tabular}

Прирост занятых, \%

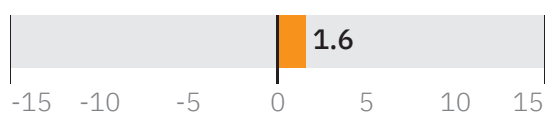

Заработная плата, тыс. руб.

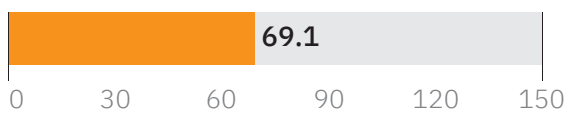

Отрасль национальной

и локальной значимости

Отрасль национальной

значимости

Отрасль локальной

значимости

Высокий уровень взаимосвязи отраслей

\footnotetext{
Численность занятых в организациях

$\curvearrowleft \quad$ отрасли (кроме субъектов малого

505500050000

предпринимательства), чел.
}

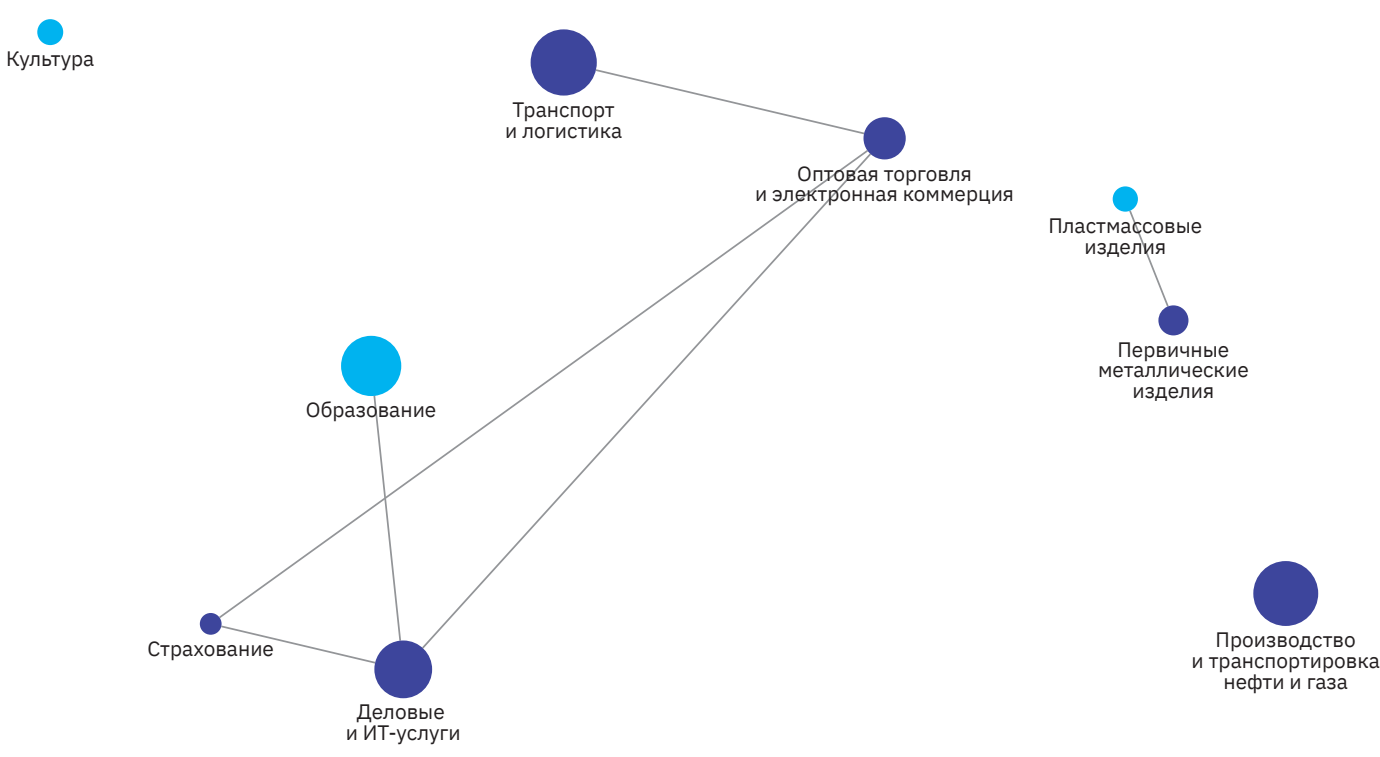
пестая 


\section{Ханты-Мансийский автономный округ - Югра}

Число отраслей специализации, ед.

\begin{tabular}{|llllllll}
3 & 11 & & & & & & \\
0 & 8 & 16 & 24 & 32 & 40 & 48 & 56
\end{tabular} \mid

Доля занятых, \%

\begin{tabular}{|llrrr|}
\hline & & 59.9 & \\
0 & 25 & 50 & 75 & 100
\end{tabular}

Прирост занятых, \%

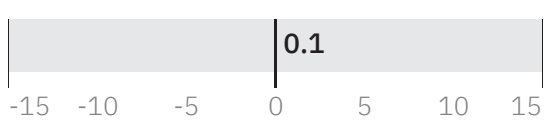

Заработная плата, тыс. руб.

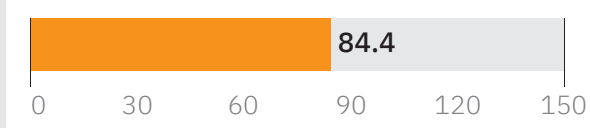

Отрасль национальной
и локальной значимости

Отрасль национальной

значимости

Отрасль локальной

значимости

Высокий уровень взаимосвязи отраслей
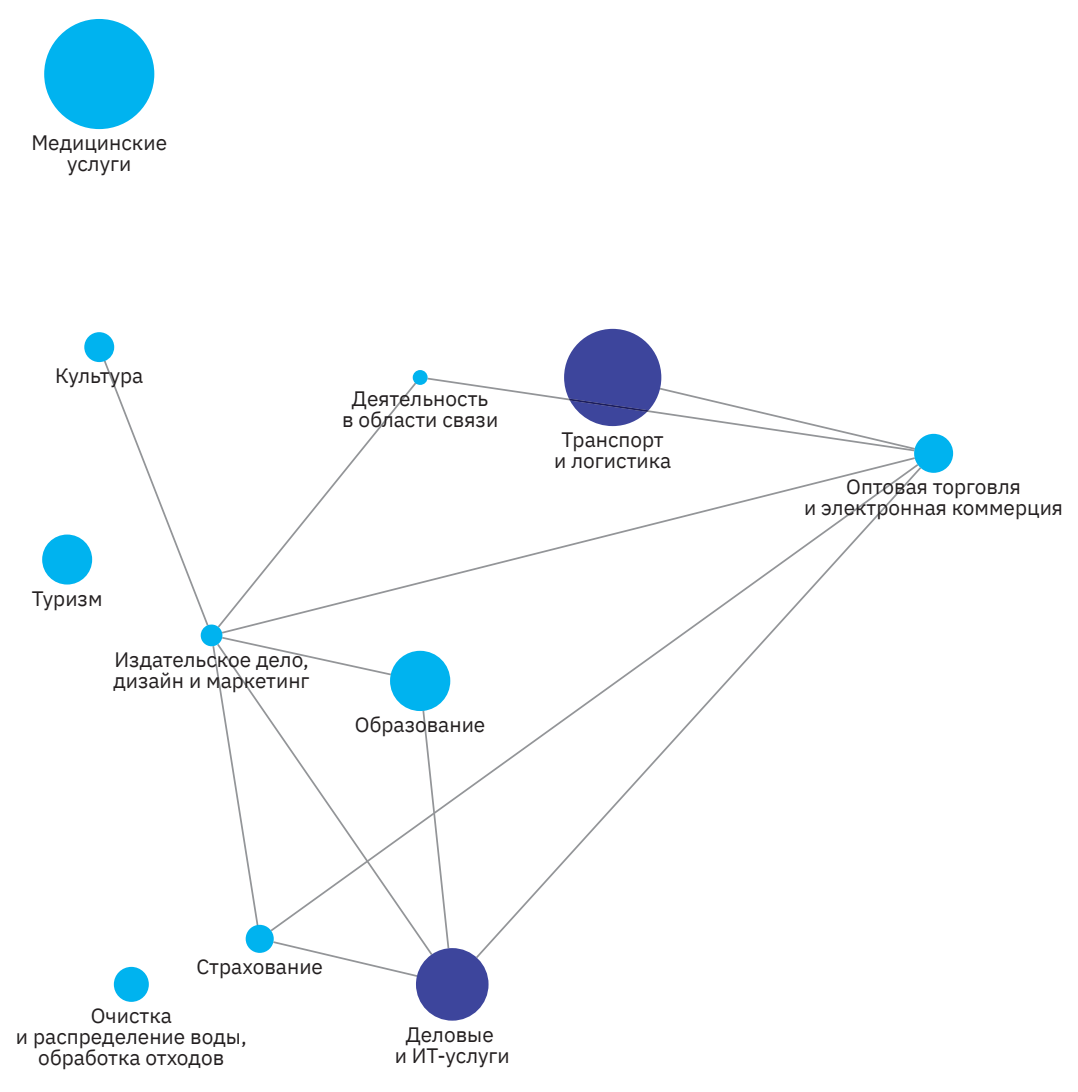

Строительство Строительство
и строительные материалы

\footnotetext{
Численность занятых в организациях

$\curvearrowleft \quad$ отрасли (кроме субъектов малого предпринимательства), чел. 


\section{Ямало-Ненецкий автономный округ}

Число отраслей специализации, ед.

$\begin{array}{|llllllll|}5 & 2 & & & & & & \\ 0 & 8 & 16 & 24 & 32 & 40 & 48 & 56\end{array} \mid$

Доля занятых, \%

\begin{tabular}{|c|c|c|c|}
\hline & 46. & & \\
\hline 25 & 50 & 75 & 100 \\
\hline
\end{tabular}

Прирост занятых, \%

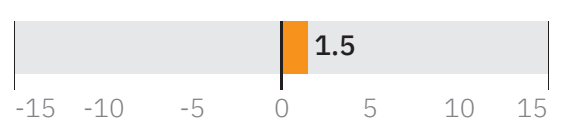

Заработная плата, тыс. руб.

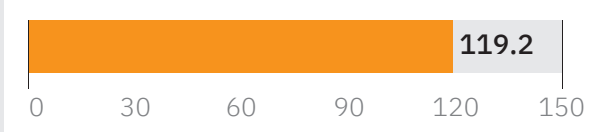

Отрасль национальной
и локальной значимости

Отрасль национальной

значимости

Отрасль локальной

значимости

Высокий уровень взаимосвязи отраслей
Рыболовство
и производство
рыбопродуктов
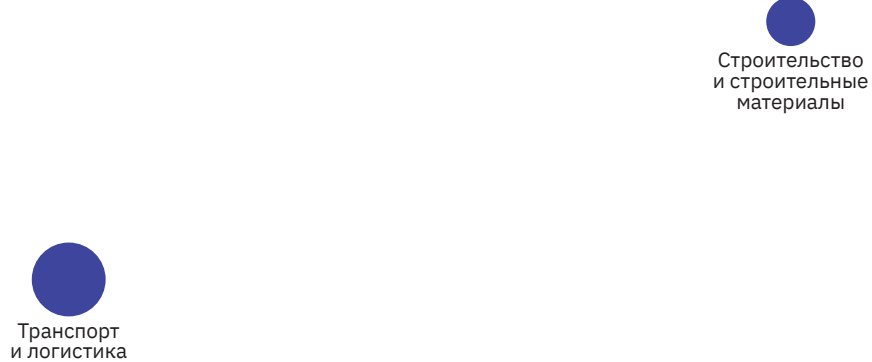

тур口из

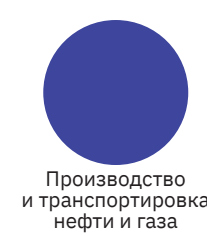

\footnotetext{
Численность занятых в организациях 


\section{Челябинская область}

Число отраслей специализации, ед.

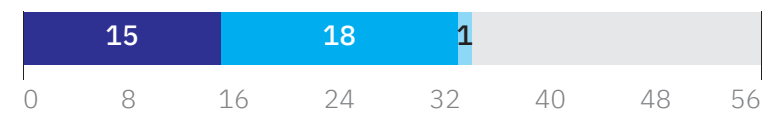

Доля занятых, \%

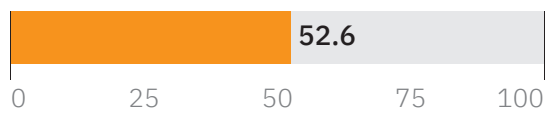

Прирост занятых, \%

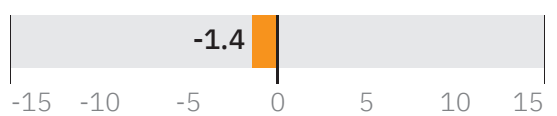

Заработная плата, тыс. руб.

\begin{tabular}{|llllll}
\hline & 39.4 & & & \\
0 & 30 & 60 & 90 & 120 & 150
\end{tabular}

Отрасль национальной
и локальной значимости

Отрасль национальной

значимости

Отрасль локальной

значимости

Высокий уровень взаимосвязи отраслей

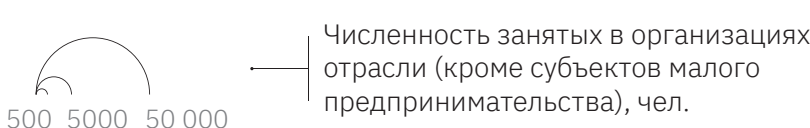

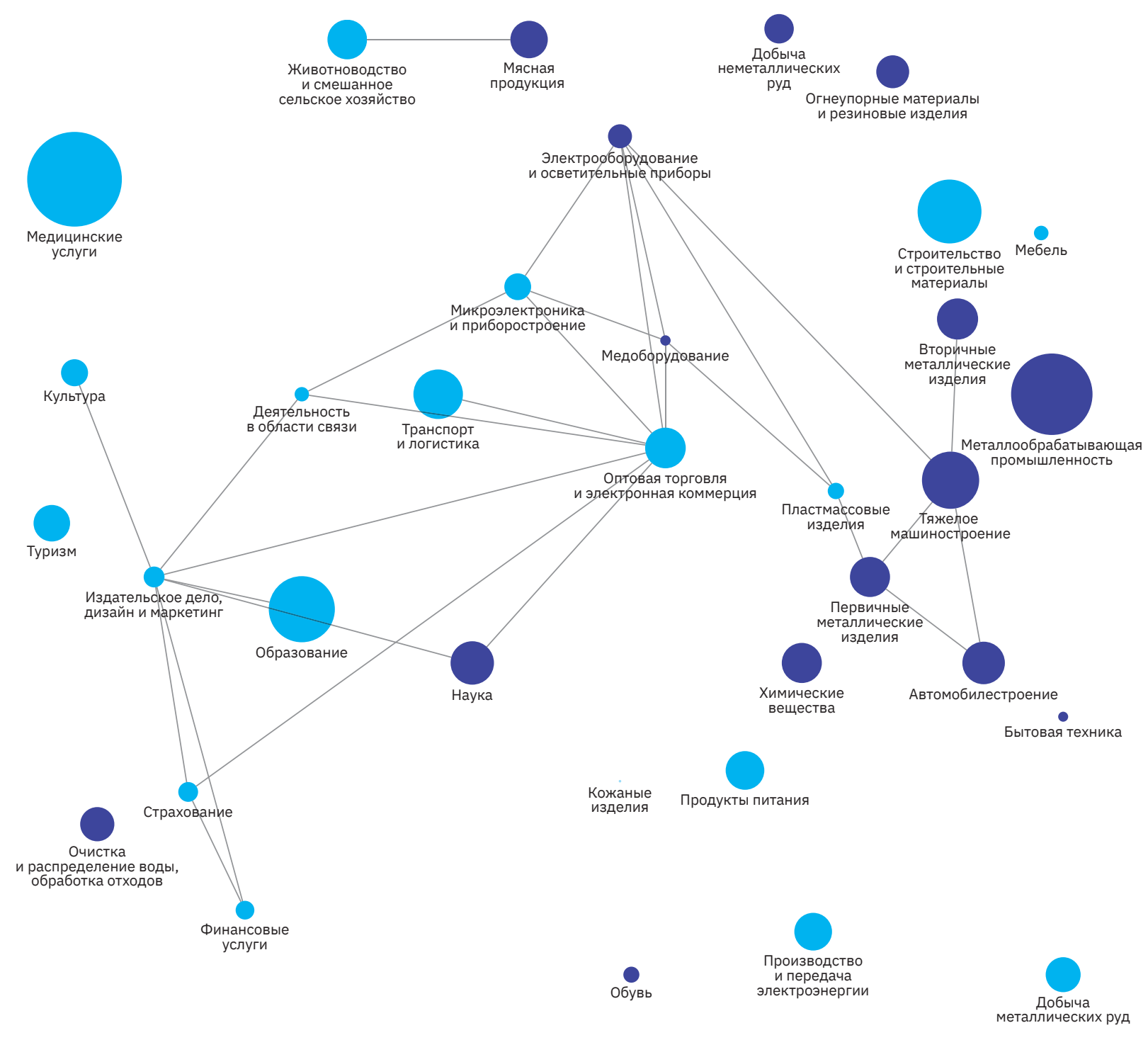



Сибирский федеральный округ 


\section{Республика Алтай}

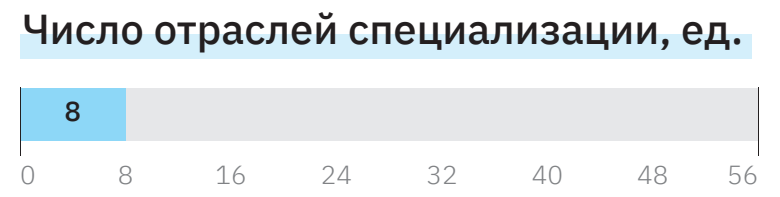

Доля занятых, \%

\begin{tabular}{|lllll|}
\hline & 20.9 & & & \\
0 & 25 & 50 & 75 & 100
\end{tabular}

$\underset{\text { Медицинские }}{\text { услуги }}$

Прирост занятых, \%

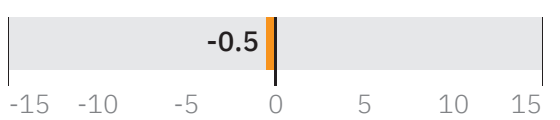

Заработная плата, тыс. руб.

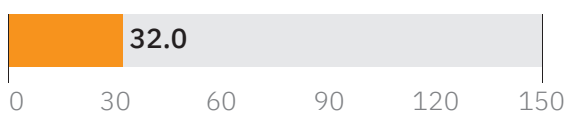

Отрасль национальной

и локальной значимости

Отрасль национальной

значимости

Отрасль локальной

значимости

Высокий уровень взаимосвязи отраслей

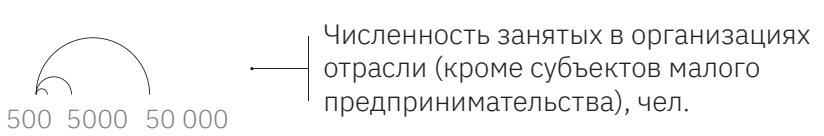

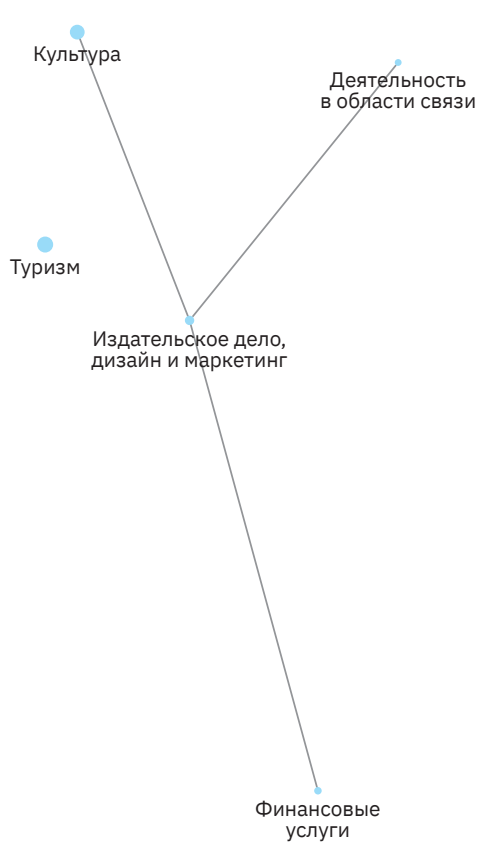

Офисное оборудование 


\section{Республика Тыва}

\section{Число отраслей специализации, ед. \\ 8

$\begin{array}{llllllll}0 & 8 & 16 & 24 & 32 & 40 & 48 & 56\end{array}$

Доля занятых, \%

\begin{tabular}{|lllll|}
\hline \multicolumn{7}{c}{30.2} & & \\
0 & 25 & 50 & 75 & 100
\end{tabular}

Прирост занятых, \%

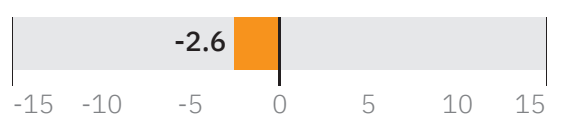

Заработная плата, тыс. руб.

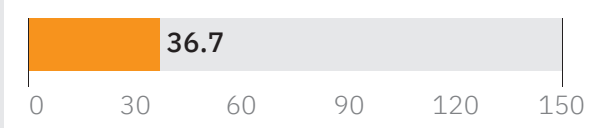

Отрасль национальной

и локальной значимости

Отрасль национальной

значимости

Отрасль локальной

значимости

Высокий уровень взаимосвязи отраслей
Добыча
неметаллических

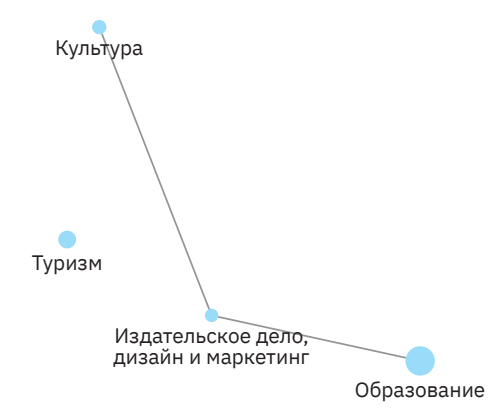

Добычаугля добыча металлических руд 


\section{Республика Хакасия}

\section{Число отраслей специализации, ед.}

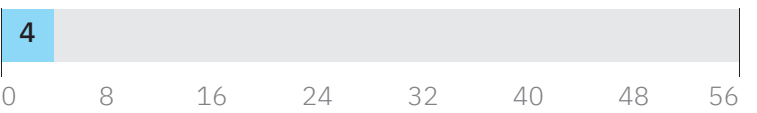

Доля занятых, \%

$\begin{array}{|rrrrr|} & 13.7 & & & \\ 0 & 25 & 50 & 75 & 100\end{array}$

Прирост занятых, \%

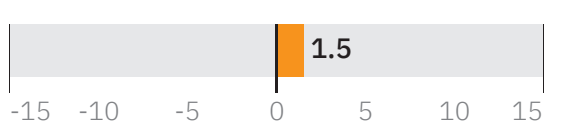

Заработная плата, тыс. руб.

\begin{tabular}{|llllll|}
\hline & & 53.2 & & & \\
0 & 30 & 60 & 90 & 120 & 150
\end{tabular}

Отрасль национальной

и локальной значимости

Отрасль национальной

значимости

Отрасль локальной

значимости

Высокий уровень взаимосвязи отраслей

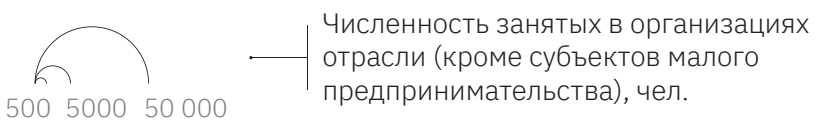




\section{Алтайский край}

\section{Число отраслей специализации, ед.}

$8 \quad 31$

$\begin{array}{lllllll}8 & 16 & 24 & 32 & 40 & 48 & 56\end{array}$

Доля занятых, \%

\begin{tabular}{|lllll|}
\hline & 26.2 & & & \\
0 & 25 & 50 & 75 & 100
\end{tabular}

Прирост занятых, \%

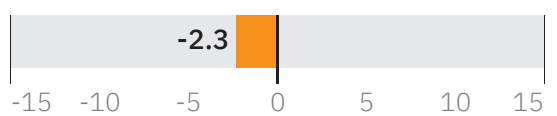

Заработная плата, тыс. руб.

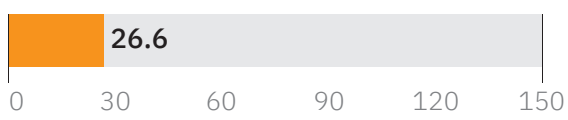

Отрасль национальной

и локальной значимости

Отрасль национальной

значимости

Отрасль локальной

значимости

Высокий уровень взаимосвязи отраслей

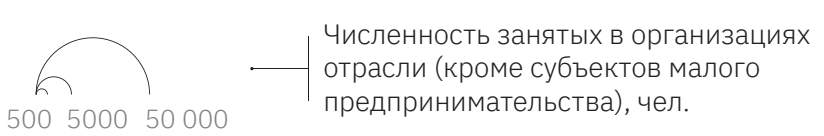

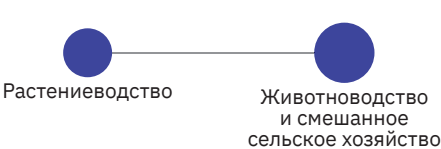
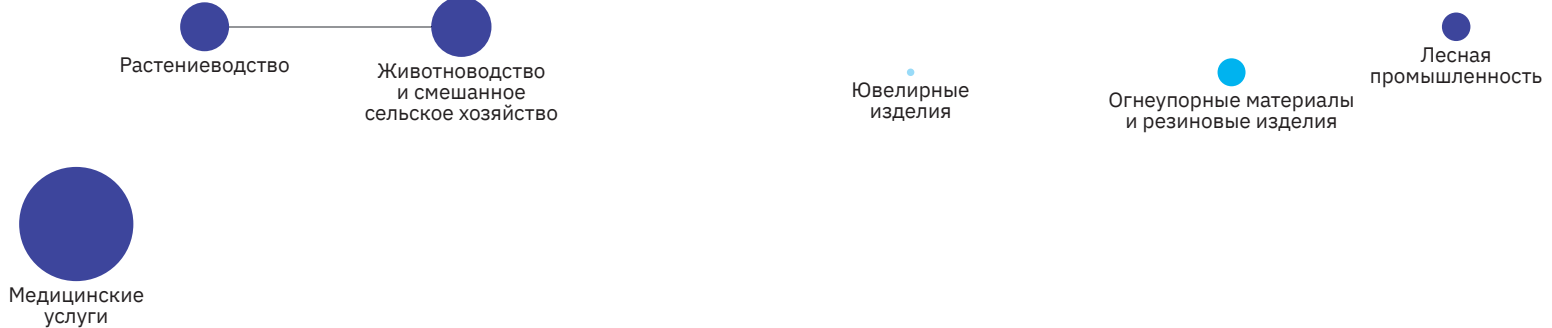

услуги

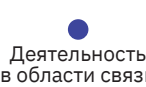

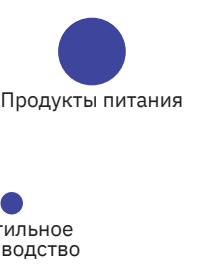




\section{Красноярский край}

\section{Число отраслей специализации, ед.}

\begin{tabular}{|llllllll} 
& 8 & & 18 & 1 & & & \\
0 & 8 & 16 & 24 & 32 & 40 & 48 & 56
\end{tabular}

Доля занятых, \%

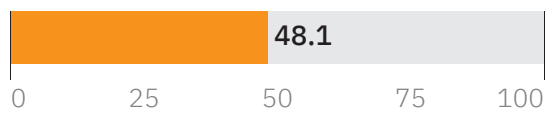

Прирост занятых, \%

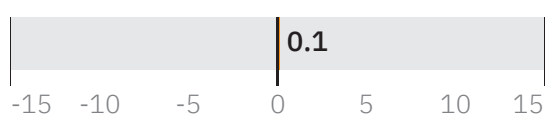

Заработная плата, тыс. руб.

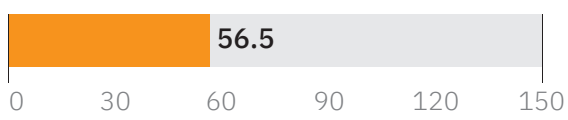

Отрасль национальной
и локальной значимости

Отрасль национальной

значимости

Отрасль локальной

значимости

Высокий уровень взаимосвязи отраслей

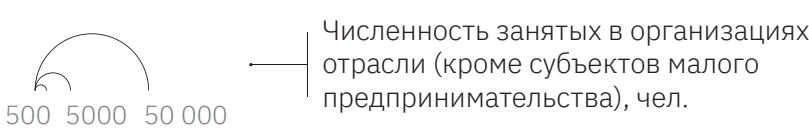

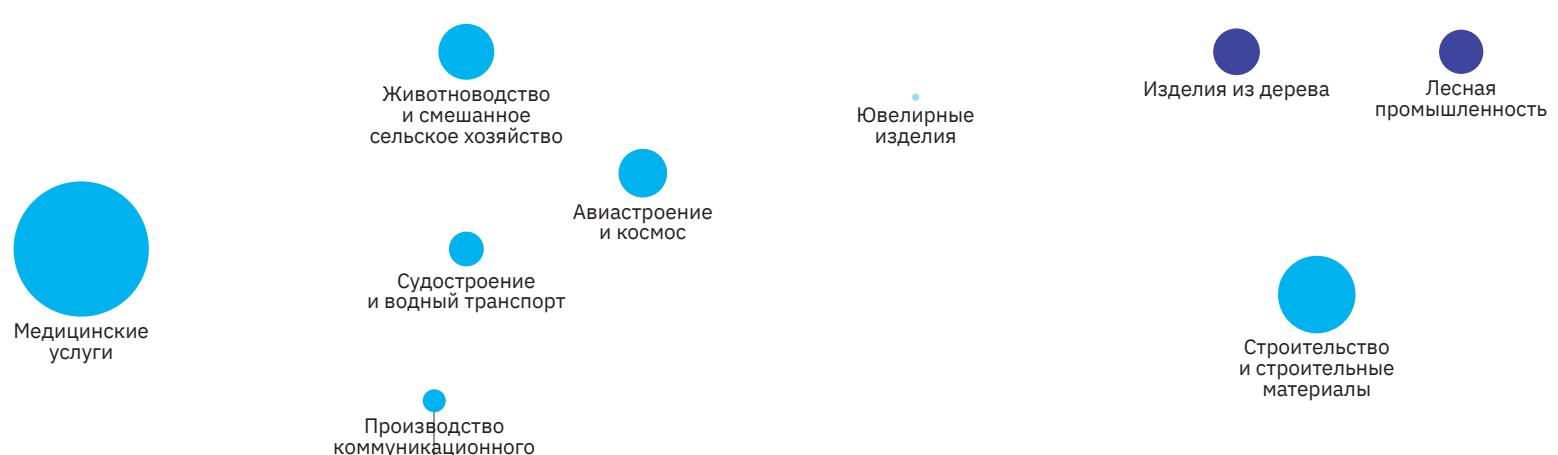
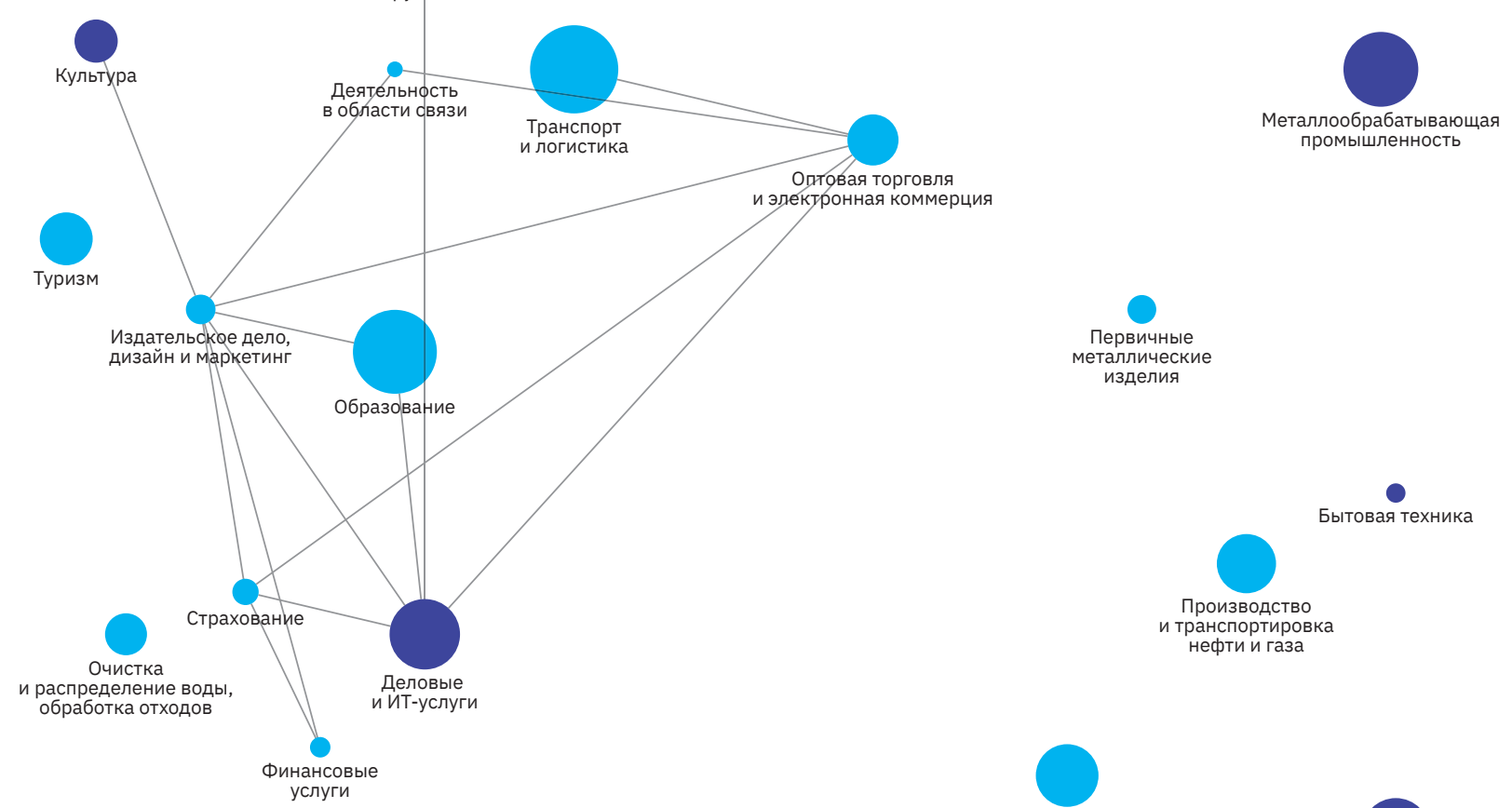

Бытовая техника

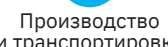
нефти и газа

(1) 


\section{Иркутская область}

\section{Число отраслей специализации, ед.}

\begin{tabular}{|lllllllll} 
& 9 & 10 & 1 & & & & & \\
0 & & 8 & 16 & 24 & 32 & 40 & 48 & 56
\end{tabular}

Доля занятых, \%

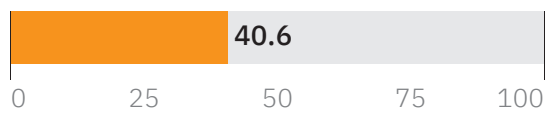

Прирост занятых, \%

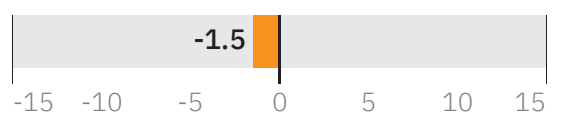

Заработная плата, тыс. руб.

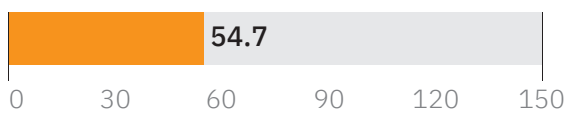

Отрасль национальной

и локальной значимости

Отрасль национальной

значимости

Отрасль локальной

значимости

Высокий уровень взаимосвязи отраслей

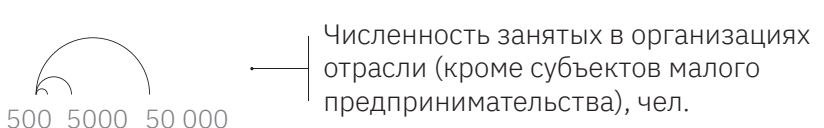

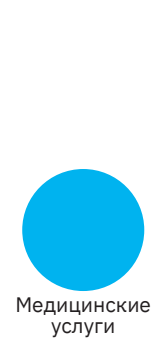

Животноводство и смешаное
сельское хозяйств

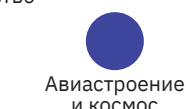

Киноиндустрия
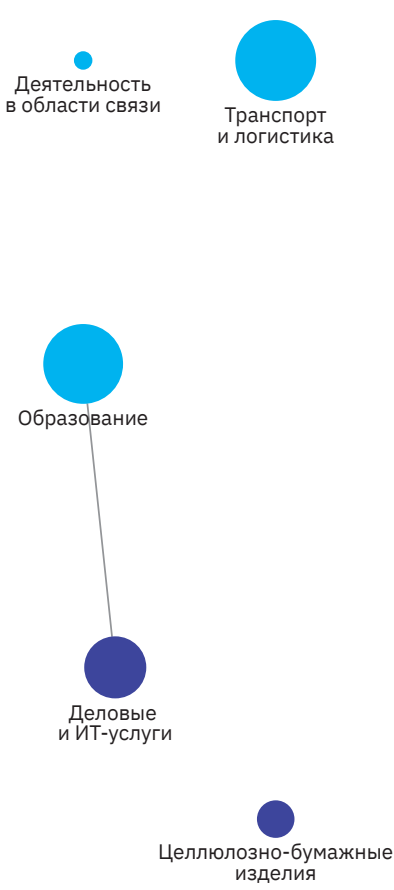
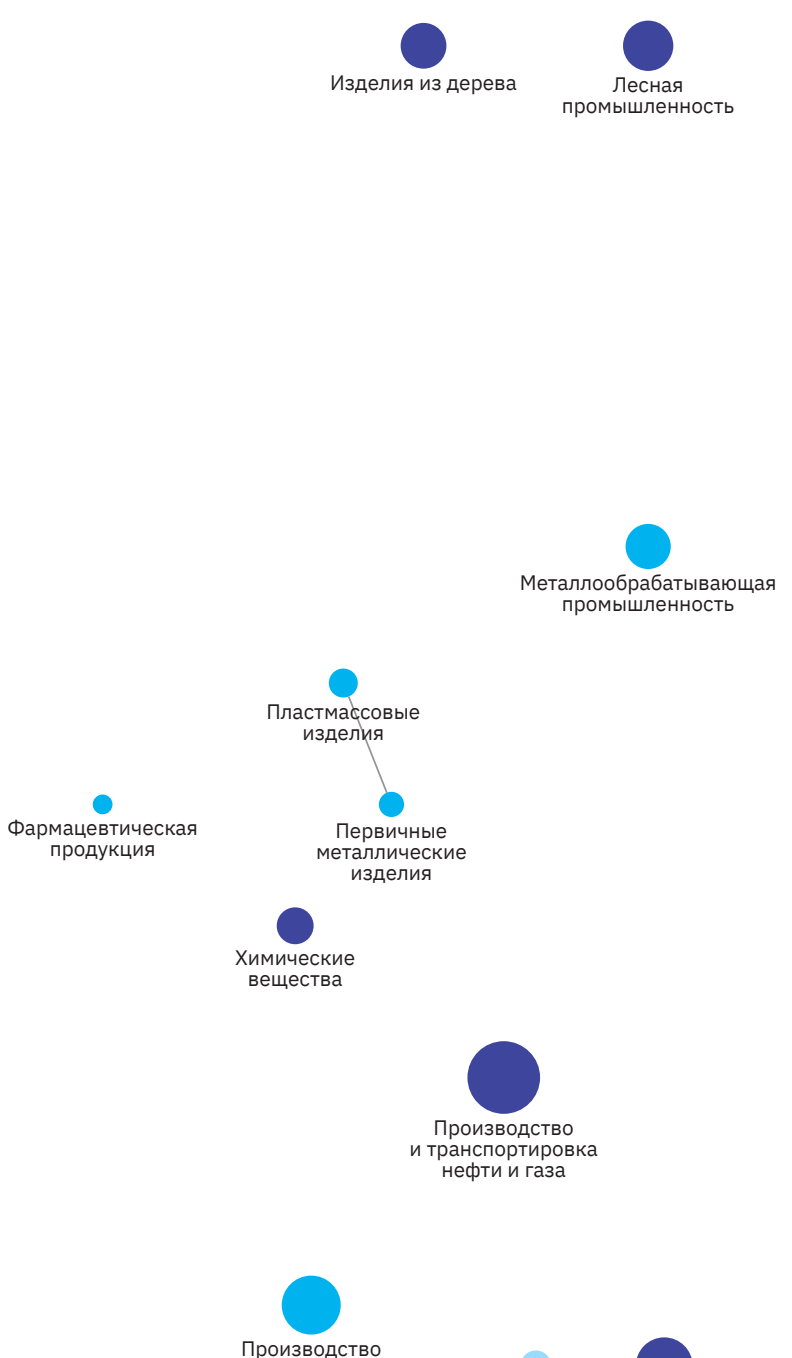
Производство иередача
электроэнергии

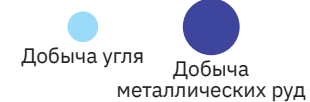




\section{Кемеровская область}

Число отраслей специализации, ед.

\begin{tabular}{|llllllll|}
\hline 4 & \multicolumn{1}{|c|}{15} & & & & & & \\
0 & 8 & 16 & 24 & 32 & 40 & 48 & 56
\end{tabular}

Доля занятых, \%

\begin{tabular}{|c|c|c|c|}
\hline 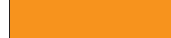 & 46. & & \\
\hline 25 & 50 & 75 & \\
\hline
\end{tabular}

Прирост занятых, \%

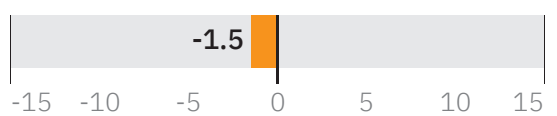

Заработная плата, тыс. руб.

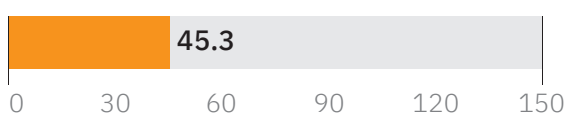

Отрасль национальной

и локальной значимости

Отрасль национальной

значимости

Отрасль локальной

значимости

Высокий уровень взаимосвязи отраслей

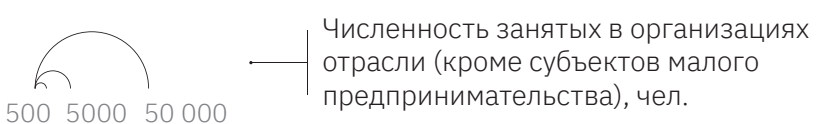

Сельскохозяйственные услуги
и производство удобрений
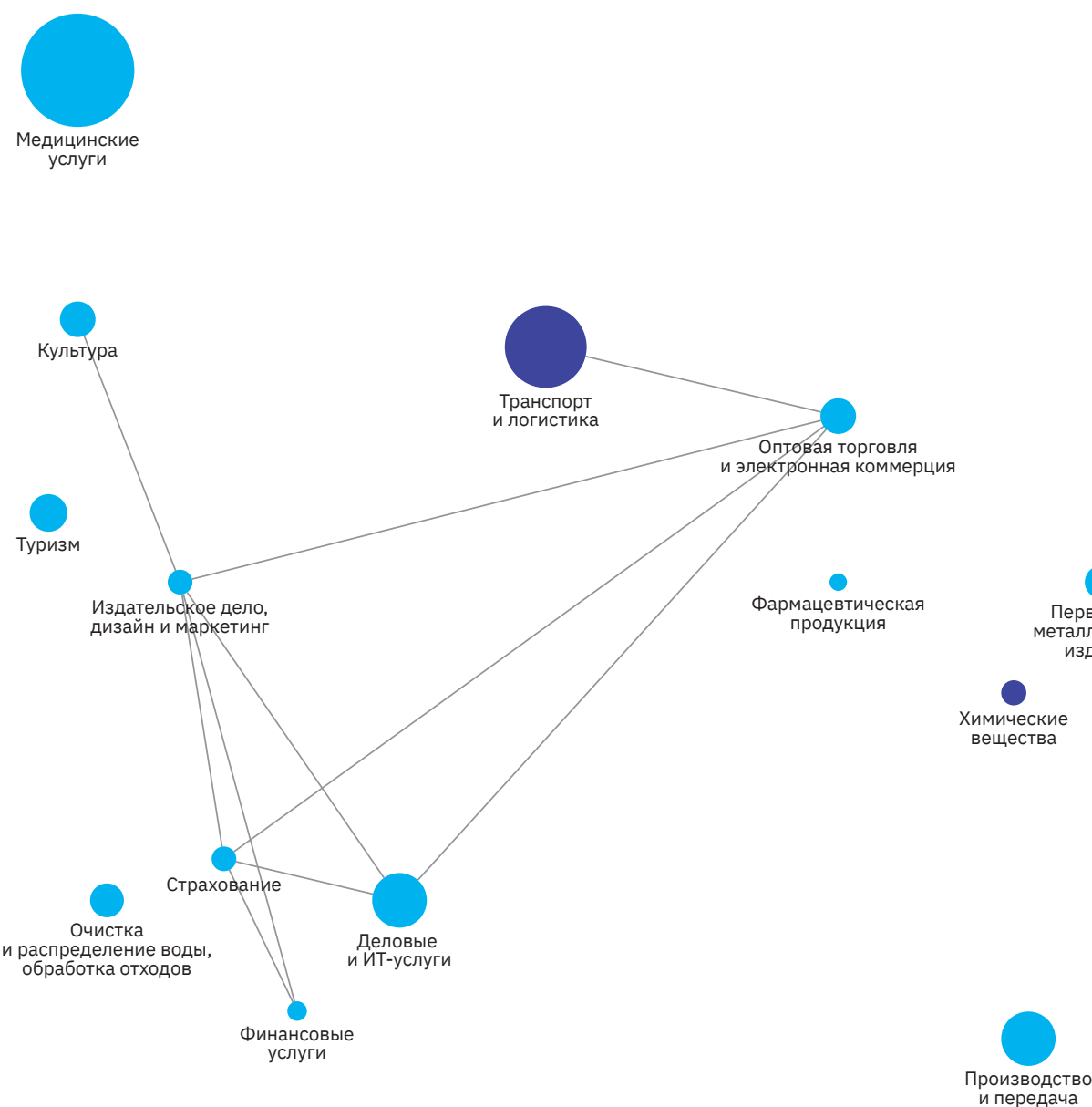


\section{Новосибирская область}

Число отраслей специализации, ед.

$\begin{array}{|lllllllll|} & 9 & & 19 & & 1 & & & \\ 0 & 8 & 16 & 24 & 32 & 40 & 48 & 56\end{array}$

Доля занятых, \%

\begin{tabular}{|c|c|c|c|}
\hline & 44.6 & & \\
\hline 25 & 50 & 75 & 100 \\
\hline
\end{tabular}

Прирост занятых, \%

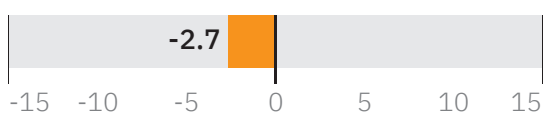

Заработная плата, тыс. руб.

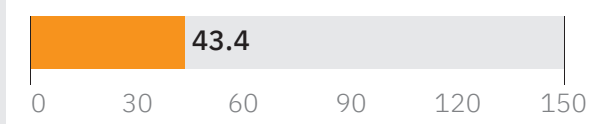

Отрасль национальной

и локальной значимости

Отрасль национальной

значимости

Отрасль локальной

значимости

Высокий уровень взаимосвязи отраслей

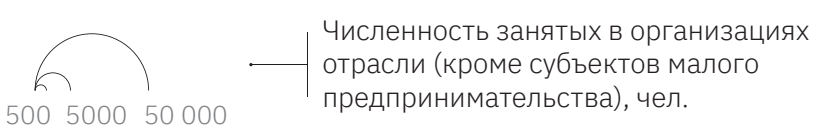

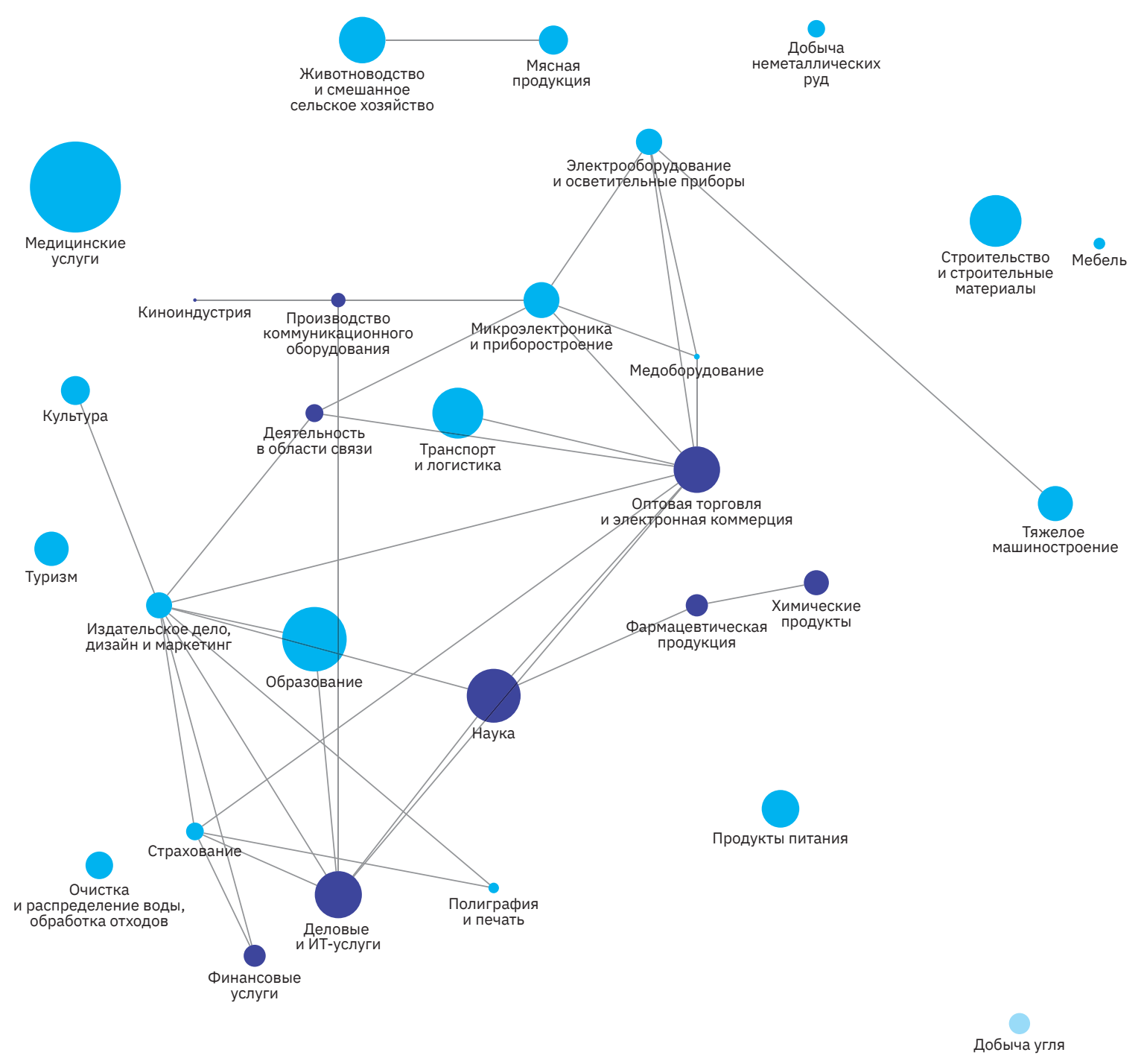

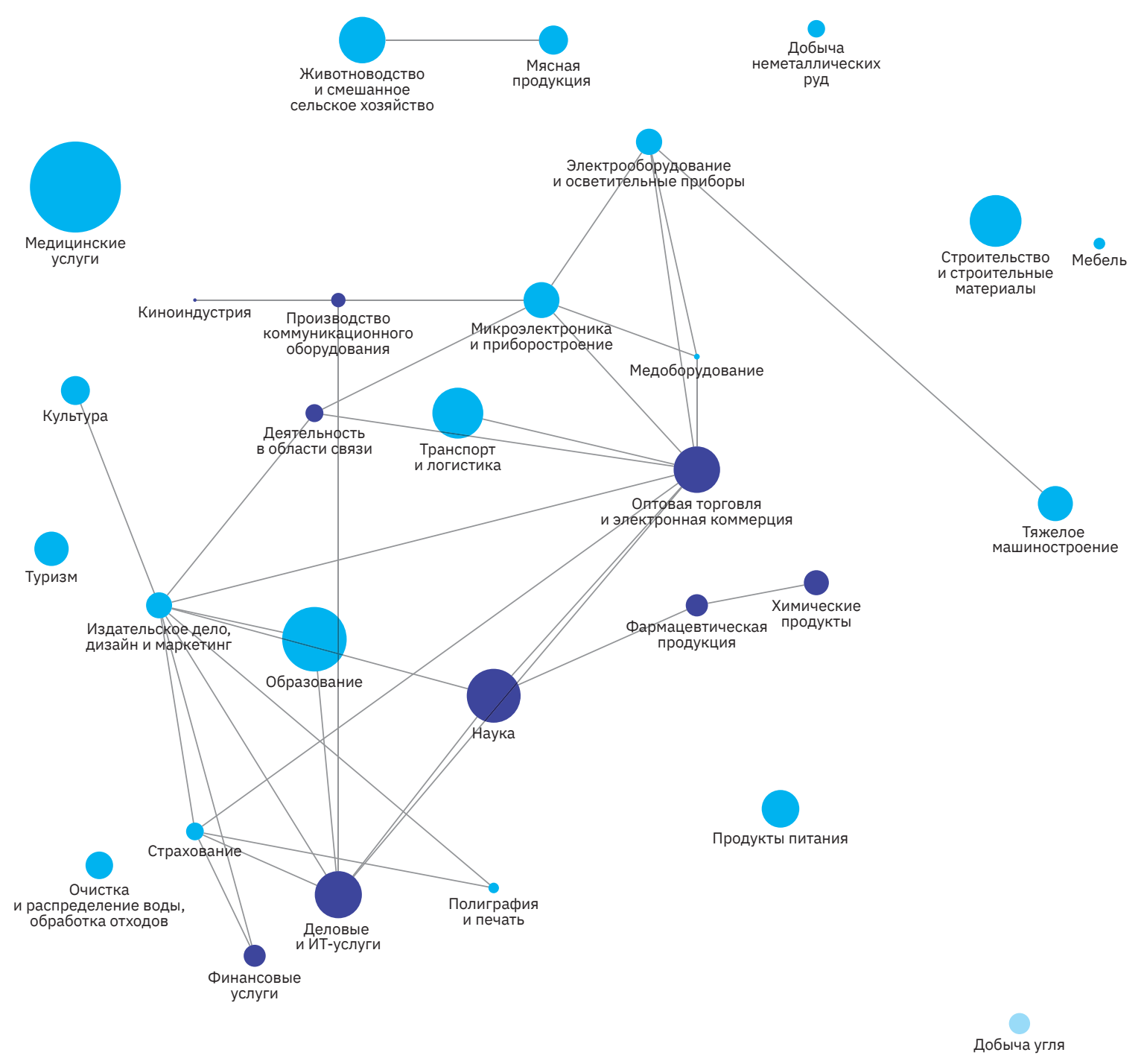

Добыча угля 


\section{Омская область}

\section{Число отраслей специализации, ед.}

6

$\begin{array}{lllllll}8 & 16 & 24 & 32 & 40 & 48 & 56\end{array}$

Доля занятых, \%

\begin{tabular}{|rrrrr|}
\hline & 15.6 & & & \\
0 & 25 & 50 & 75 & 100
\end{tabular}

Прирост занятых, \%

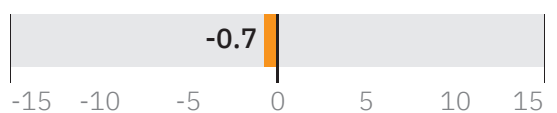

Заработная плата, тыс. руб.

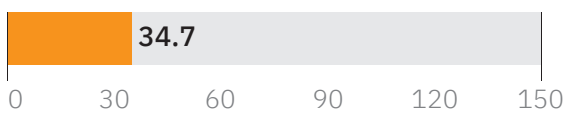

Отрасль национальной
и локальной значимости

Отраспь национальной

значимости

Отрасль локальной

значимости

Высокий уровень взаимосвязи отраслей

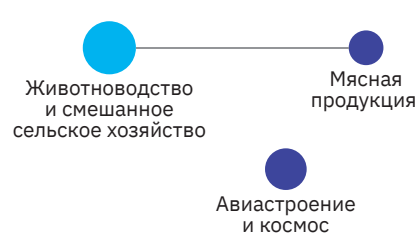
и и резиновые изделия
Офисное оборудование

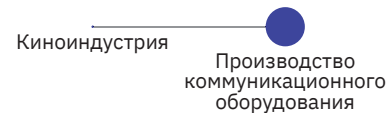

оборудования
ову
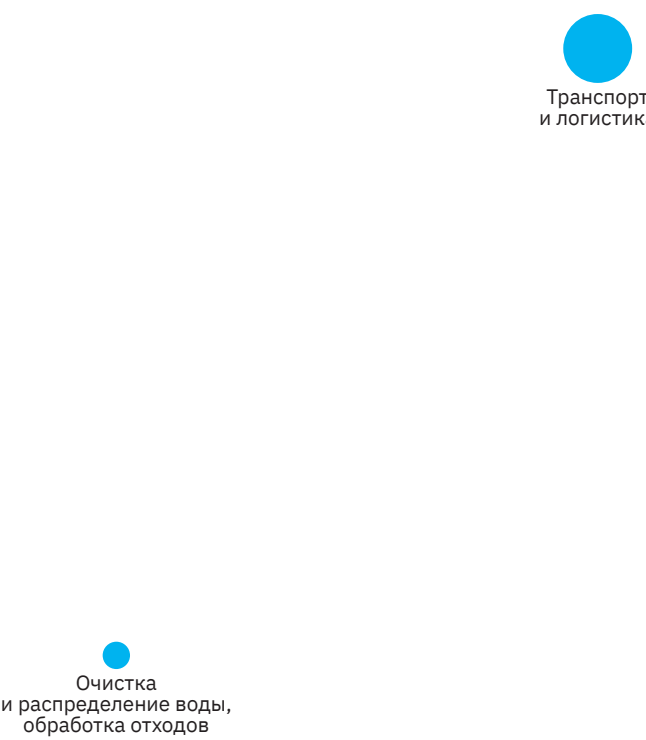

обработка отходов

Численность занятых в организациях
отрасли (кроме субъектов малого

предпринимательства), чел. 


\section{Томская область}

\section{Число отраслей специализации, ед.}

$\begin{array}{lll}8 & 1 & 4\end{array}$

$\begin{array}{llllllll}0 & 8 & 16 & 24 & 32 & 40 & 48 & 56\end{array}$

Доля занятых, \%

\begin{tabular}{|lllll|}
\hline & 26.7 & & & \\
0 & 25 & 50 & 75 & 100
\end{tabular}

Прирост занятых, \%

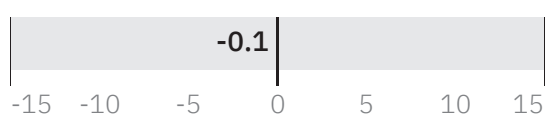

Заработная плата, тыс. руб.

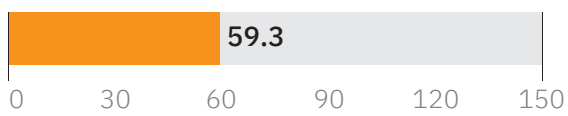

Отрасль национальной

и локальной значимости

Отрасль национальной

значимости

Отрасль локальной

значимости

Высокий уровень взаимосвязи отраслей

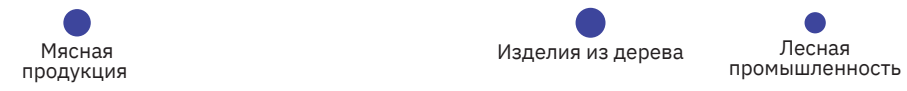

Культура

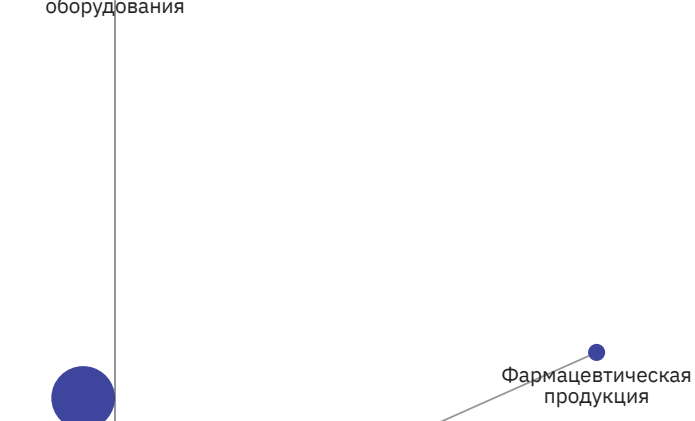

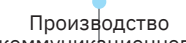

Производство

оммуникационного
оборудования

илектрооборудование
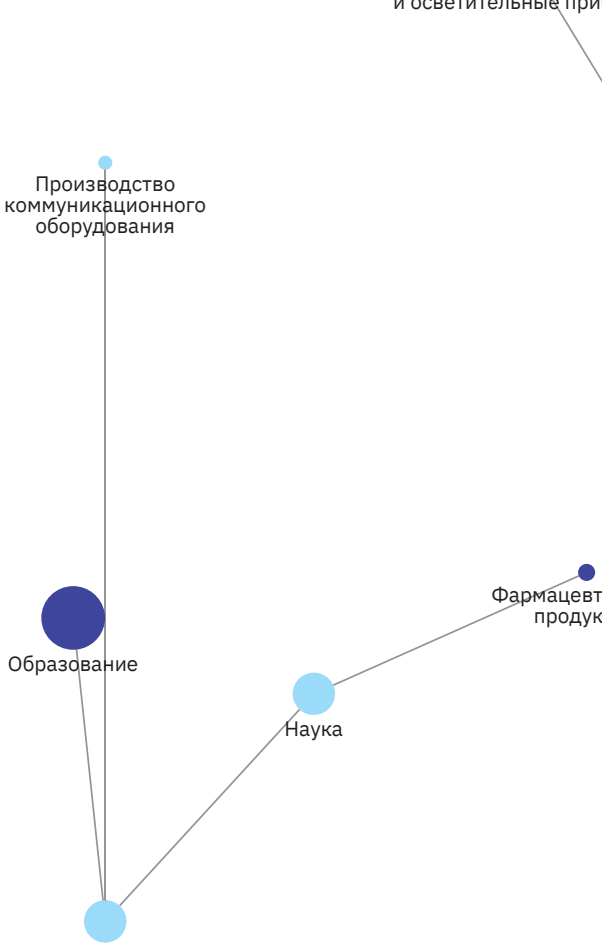

Наука

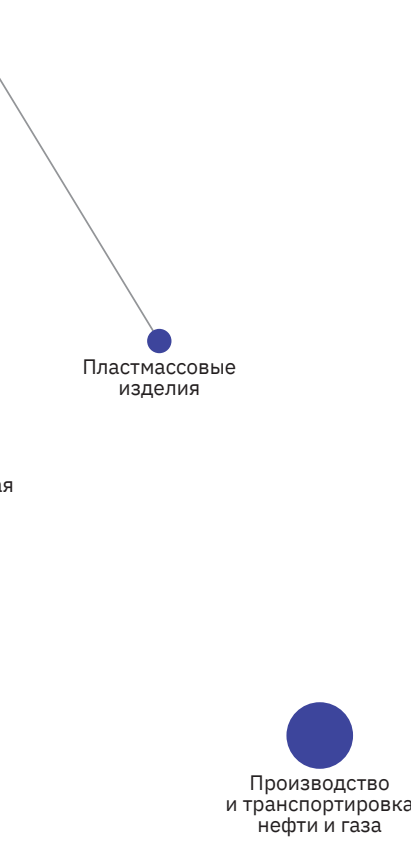

ииТ-услуги 



\section{Дальневосточный}

федеральный округ 


\section{Республика Бурятия}

\section{Число отраслей специализации, ед.

\begin{tabular}{|l|l|llllll|}
3 & 5 & & & & & & \\
0 & 8 & 16 & 24 & 32 & 40 & 48 & 56
\end{tabular}

Доля занятых, \%

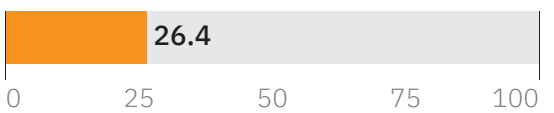

Прирост занятых, \%

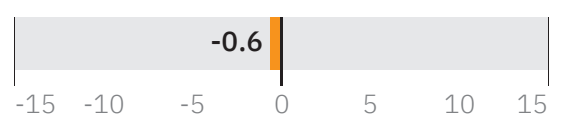

Заработная плата, тыс. руб.

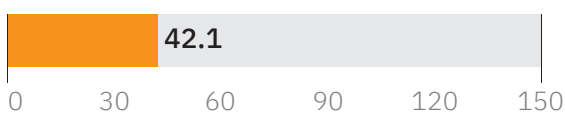

Отрасль национальной

и локальной значимости

Отрасль национальной

значимости

Отрасль локальной

значимости

Высокий уровень взаимосвязи отраслей

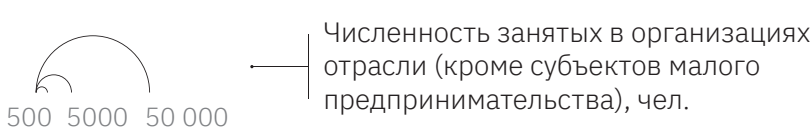

Культура

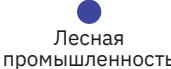

Авиастроени 


\section{Республика Саха (Якутия)}

\section{Число отраслей специализации, ед.}

\begin{tabular}{l|ll}
8 & 8 & 1
\end{tabular}

Доля занятых, \%

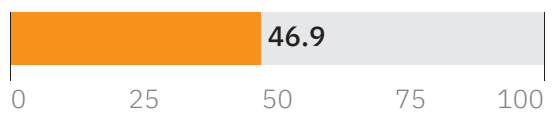

Прирост занятых, \%

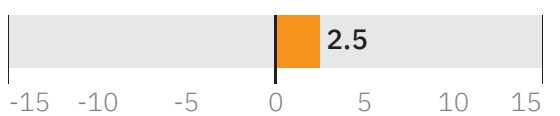

Заработная плата, тыс. руб.

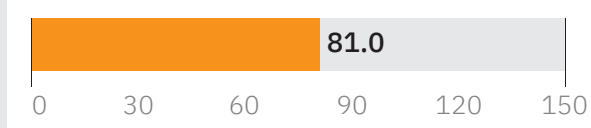

Отрасль национальной

и локальной значимости

Отрасль национальной

значимости

Отрасль локальной

значимости

Высокий уровень взаимосвязи отраслей

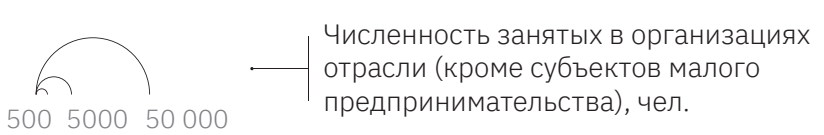

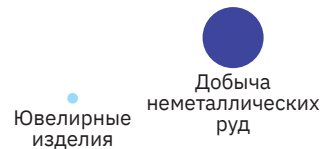
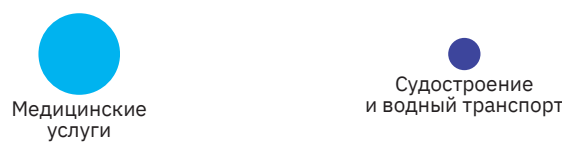

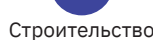

Строительство

и строттельные
материалы
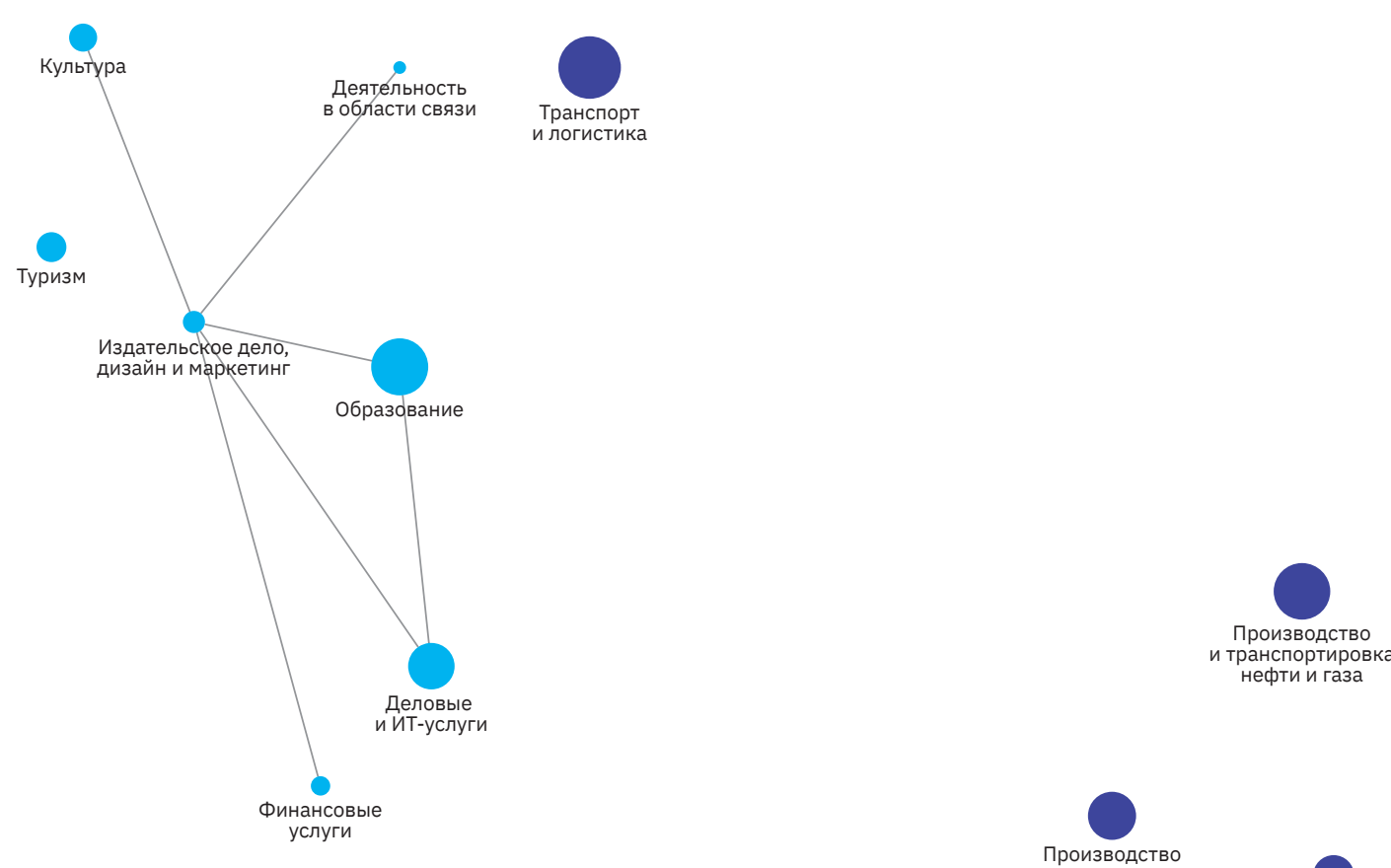


\section{Забайкальский край}

\section{Число отраслей специализации, ед.

$\begin{array}{|llllllll|}3 & 13 & & & & & & \\ 0 & 8 & 16 & 24 & 32 & 40 & 48 & 56\end{array}$

Доля занятых, \%

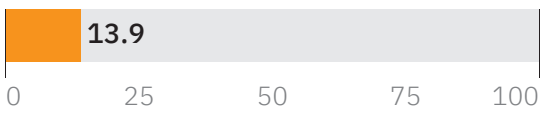

Прирост занятых, \%

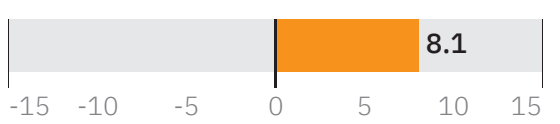

Заработная плата, тыс. руб.

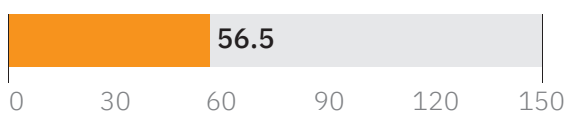

Отрасль национальной

и локальной значимости

Отрасль национальной

значимости

Отрасль локальной

значимости

Высокий уровень взаимосвязи отраслей

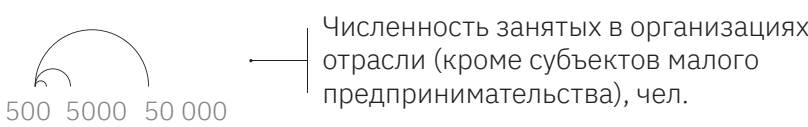

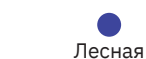

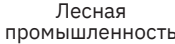




\section{Камчатский край}

Число отраслей специализации, ед.

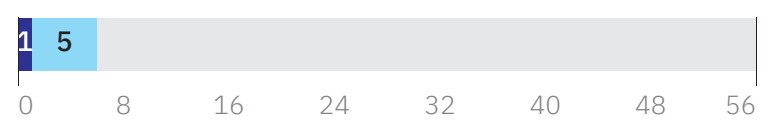

Доля занятых, \%

\begin{tabular}{|lllll|}
\hline & $\mathbf{2 4 . 8}$ & & & \\
0 & 25 & 50 & 75 & 100
\end{tabular}

Рыболовство и судостроение

ипроизводство
рыбопродуктов

Прирост занятых, \%

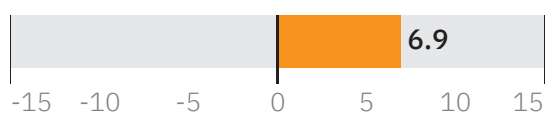

Заработная плата, тыс. руб.

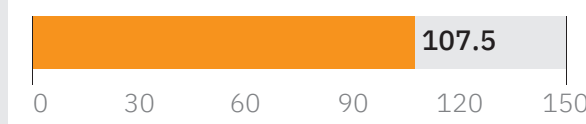

Отрасль национальной

и локальной значимости

Отрасль национальной

значимости

Отрасль локальной

значимости

Высокий уровень взаимосвязи отраслей 


\section{Приморский край}

\section{Число отраслей специализации, ед.}

\begin{tabular}{|lllllllll|}
\hline 8 & 6 & 3 & & & & & & \\
0 & 8 & 16 & 24 & 32 & 40 & 48 & 56
\end{tabular}

Доля занятых, \%

\begin{tabular}{|c|c|c|c|}
\hline 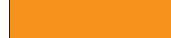 & 42.1 & & \\
\hline 25 & 50 & 75 & 100 \\
\hline
\end{tabular}

Прирост занятых, \%

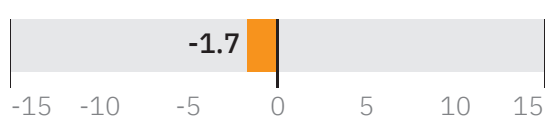

Заработная плата, тыс. руб.

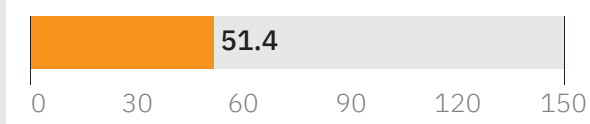

Отрасль национальной

и локальной значимости

Отрасль национальной

значимости

Отрасль локальной

значимости

Высокий уровень взаимосвязи отраслей

\footnotetext{
Численность занятых в организациях

$\curvearrowleft \quad$ отрасли (кроме субъектов малого

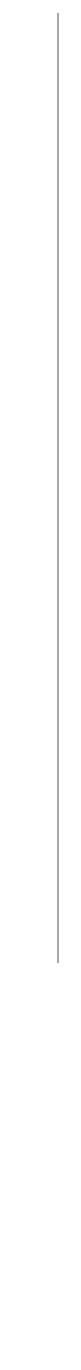

промышленность
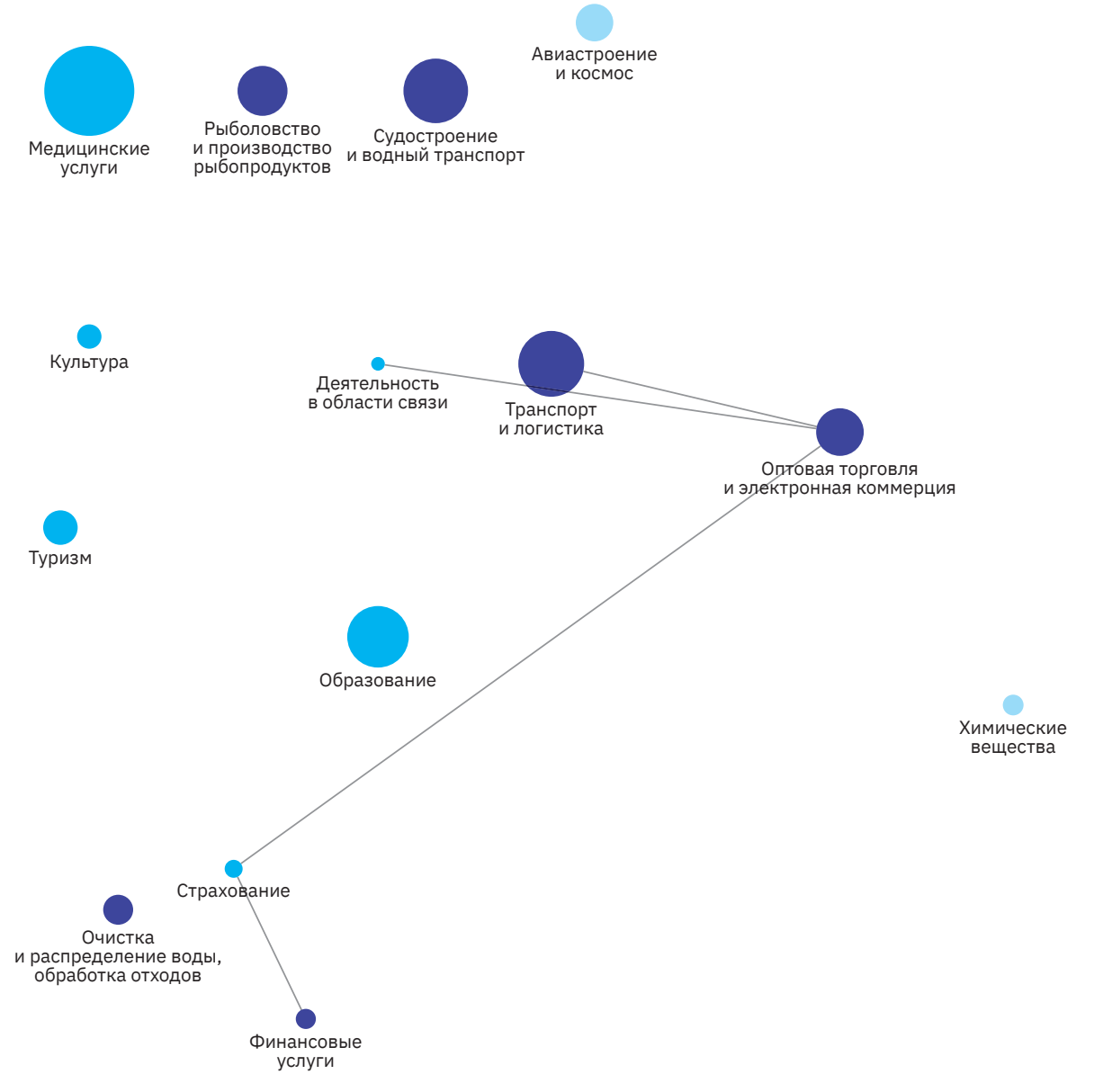


\section{Хабаровский край}

\section{Число отраслей специализации, ед.}

\begin{tabular}{|l|rrrrrrr|}
$\mathbf{7}$ & 9 & $\mathbf{1}$ & & & & & \\
0 & 8 & 16 & 24 & 32 & 40 & 48 & 56
\end{tabular}

Доля занятых, \%

\begin{tabular}{|c|c|c|c|}
\hline & 40.8 & & \\
\hline 25 & 50 & 75 & 100 \\
\hline
\end{tabular}

Прирост занятых, \%

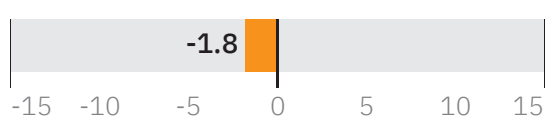

Заработная плата, тыс. руб.

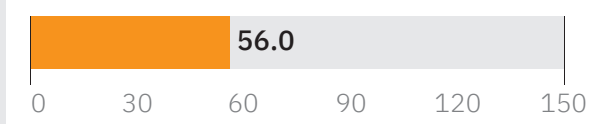

Отрасль национальной

и локальной значимости

Отрасль национальной

значимости

Отрасль локальной

значимости

Высокий уровень взаимосвязи отраслей

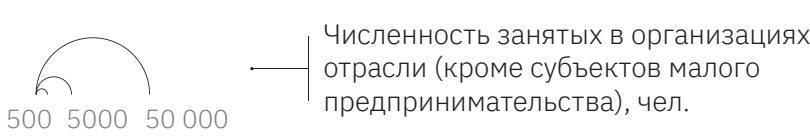

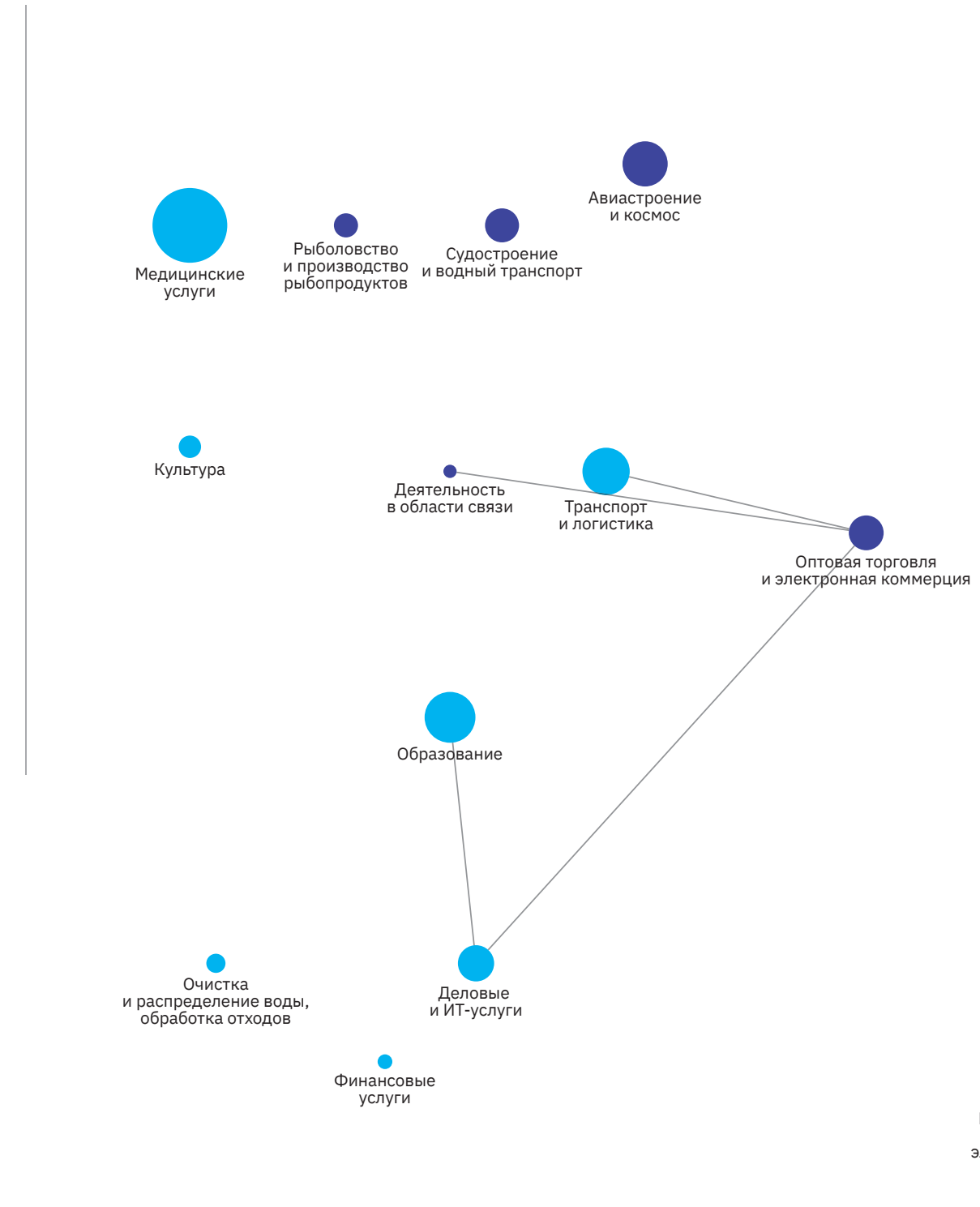

O

промышленность
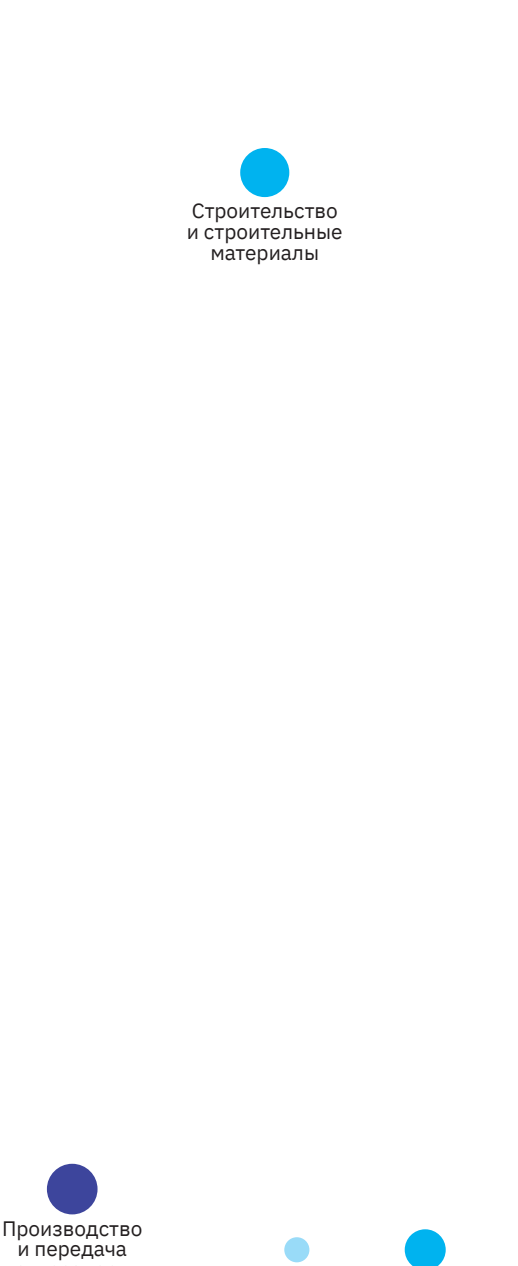
ектроэнергии 


\section{Амурская область}

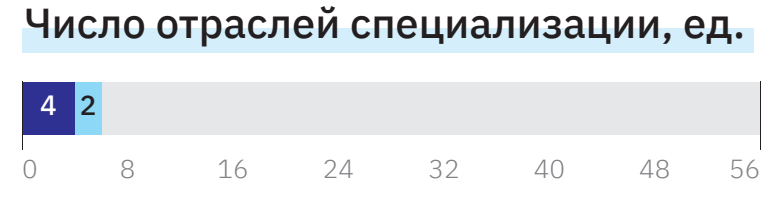

Доля занятых, \%

$\begin{array}{|rrrrr|} & 12.9 & & & \\ 0 & 25 & 50 & 75 & 100\end{array}$

Прирост занятых, \%

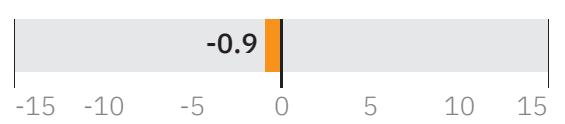

Заработная плата, тыс. руб.

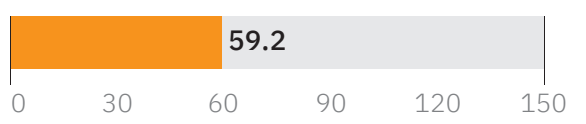

Отрасль национальной

и локальной значимости

Отрасль национальной

значимости

Отрасль локальной

значимости

\section{Высокий уровень взаимосвязи отраслей}

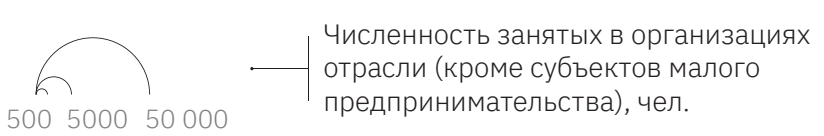

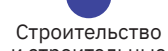

Строительство
и строительные
материальь 


\section{Магаданская область}

Число отраслей специализации, ед.

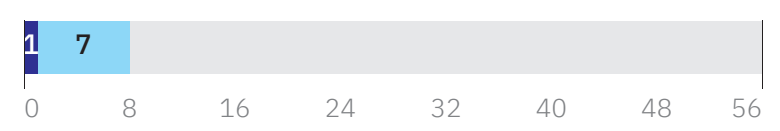

Доля занятых, \%

\begin{tabular}{|c|c|c|c|c|}
\hline & & 8.7 & & \\
\hline P & 25 & 50 & 75 & 100 \\
\hline
\end{tabular}

Прирост занятых, \%

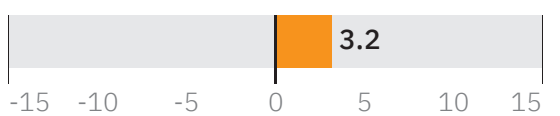

Заработная плата, тыс. руб.

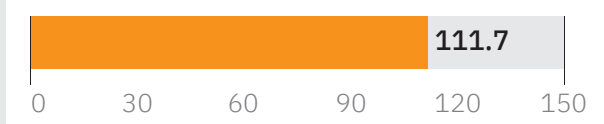

Отрасль национальной

и локальной значимости

Отрасль национальной

значимости

Отрасль локальной

значимости

Высокий уровень взаимосвязи отраслей

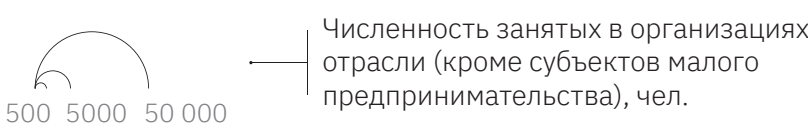

500500050000

предпринимательства), чел.

в малого
Рыболовство

Рыболовство
ипроивоство
рыбопродуктов

Киноиндустрия

Строительство Строительство
и строительные
материалы

культура

(1)

Транспорт
и логистика

10

Деловые

Производство

и передача
электроэнергии 


\section{Сахалинская область}

Число отраслей специализации, ед.

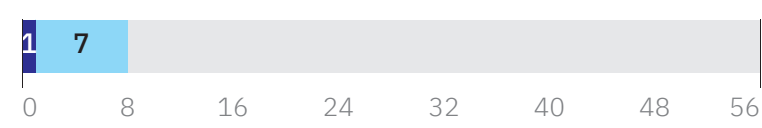

Доля занятых, \%

\begin{tabular}{|lllll|}
\hline & 23.9 & & & \\
0 & 25 & 50 & 75 & 100
\end{tabular}

Прирост занятых, \%

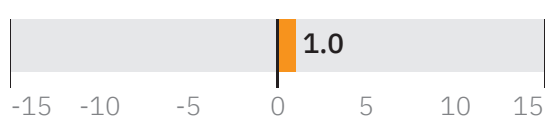

Заработная плата, тыс. руб.

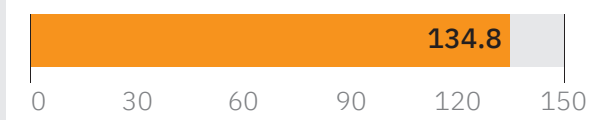

Отрасль национальной

и локальной значимости

Отрасль национальной

значимости

Отрасль локальной

значимости

Высокий уровень взаимосвязи отраслей

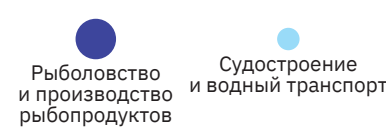

ипроизводство
рыбопродуктов

Производство транспортировка

Tro Издательское дело,
дизайн и маркетинг 


\section{Еврейская автономная область}

Число отраслей специализации, ед.

$\begin{array}{|llllllll|}7 & & & & & & & \\ 0 & 8 & 16 & 24 & 32 & 40 & 48 & 56\end{array} \mid$

Доля занятых, \%

\begin{tabular}{|c|c|c|c|}
\hline 13.6 & & & \\
\hline 25 & 50 & 75 & 100 \\
\hline
\end{tabular}

Прирост занятых, \%

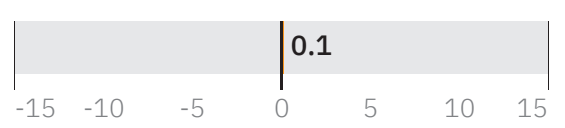

Заработная плата, тыс. руб.

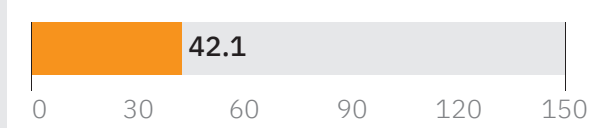

Отрасль национальной

и локальной значимости

Отрасль национальной

значимости

Отрасль локальной

значимости

Высокий уровень взаимосвязи отраслей

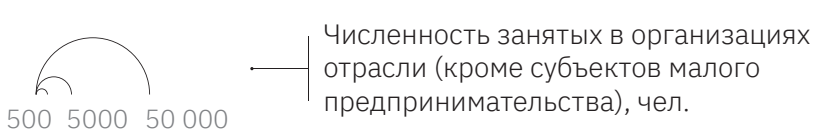

Добыча

руеталических Изделия из дерева $\begin{aligned} & \text { Лесная } \\ & \text { руд }\end{aligned}$
промышленность

Издательское дело,

дизайн и маркетинг

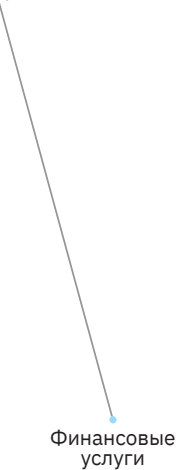

(1)

Строительство
истроительные

и строительные
материалы 


\section{Чукотский автономный округ}

Число отраслей специализации, ед.

\begin{tabular}{|llllllll|}
\hline 10 & & & & & & & \\
0 & 8 & 16 & 24 & 32 & 40 & 48 & 56
\end{tabular}

Доля занятых, \%

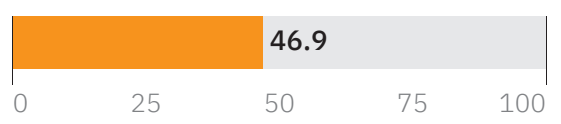

Прирост занятых, \%

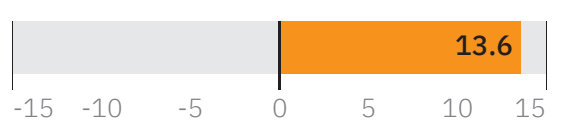

Заработная плата, тыс. руб.

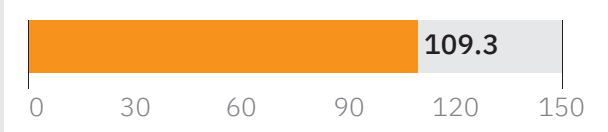

Отрасль национальной
и локальной значимости

Отрасль национальной

значимости

Отрасль локальной

значимости

Высокий уровень взаимосвязи отраслей

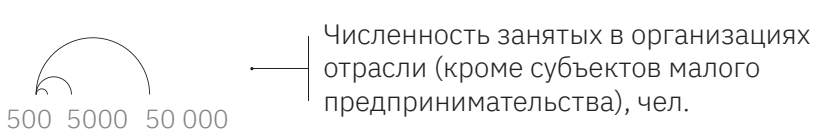

Животноводство и смешанное
сельское хозяйство

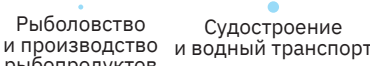
рыбопродуктов

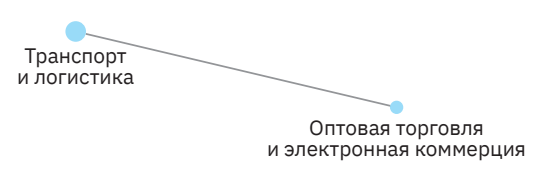

Финансовые

услуги Производство
передача
лектроэнергии
Добыча угля металлических руд 



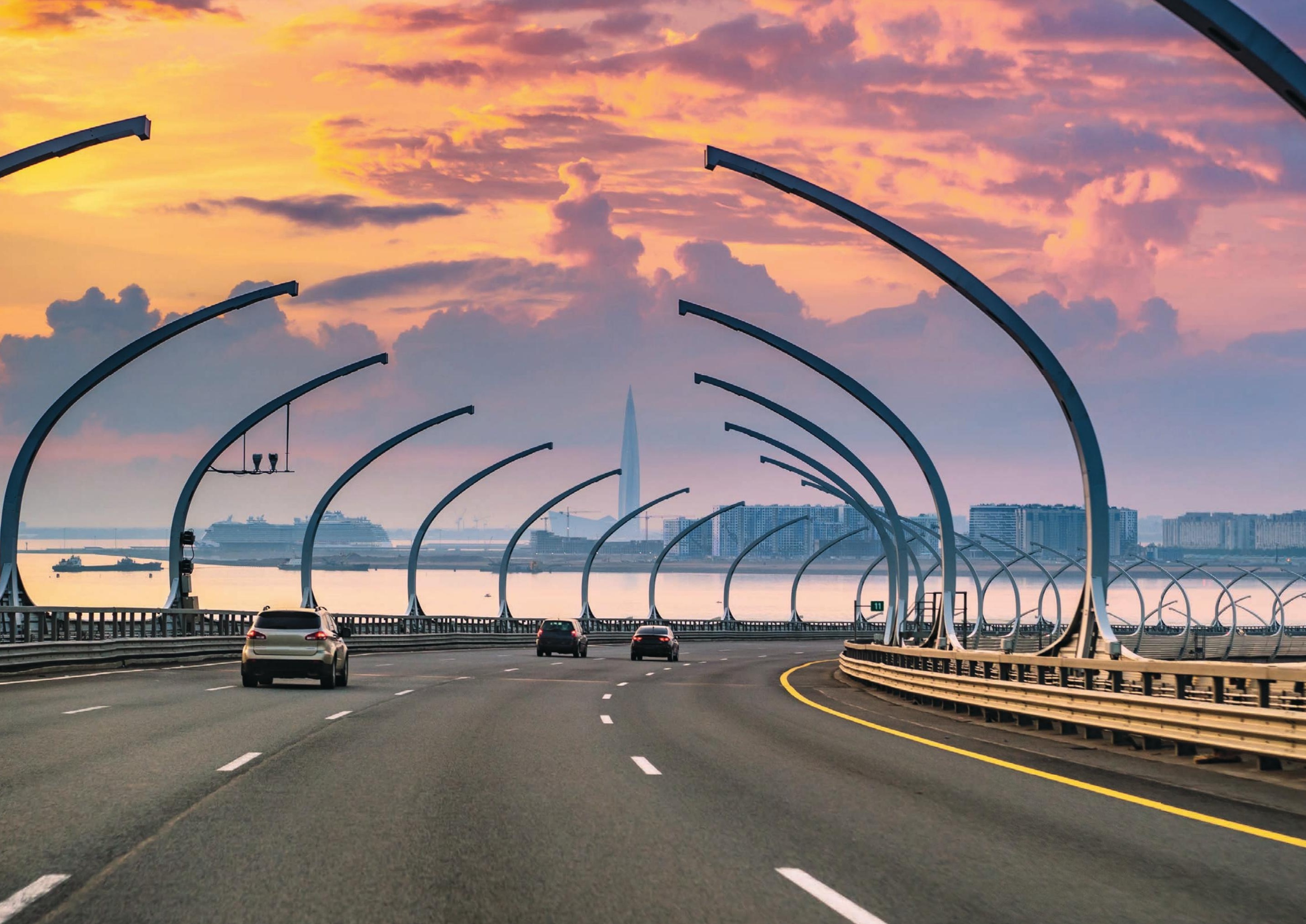




\section{4}

Рейтинги отраслей специализации полиотраслевых регионов

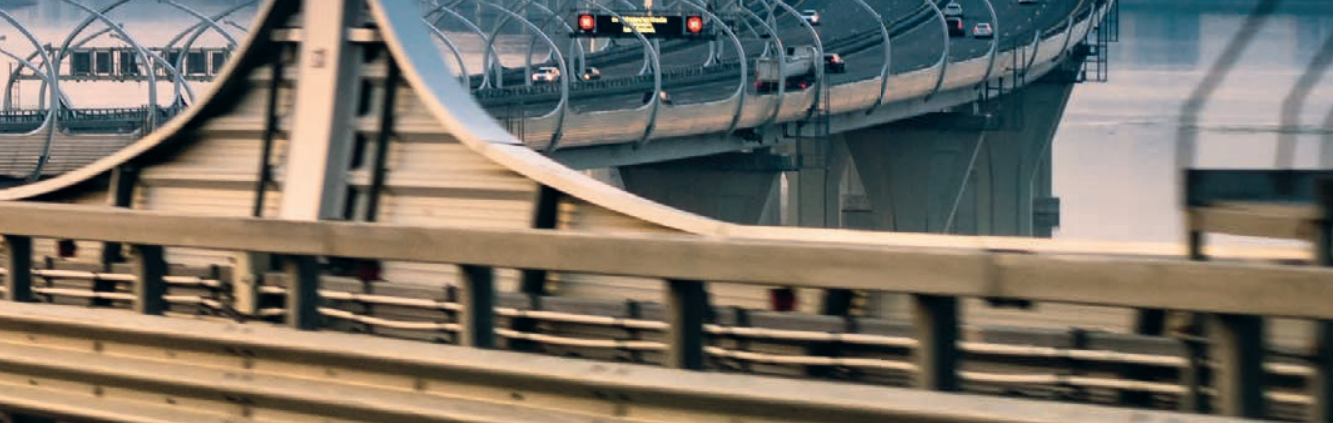




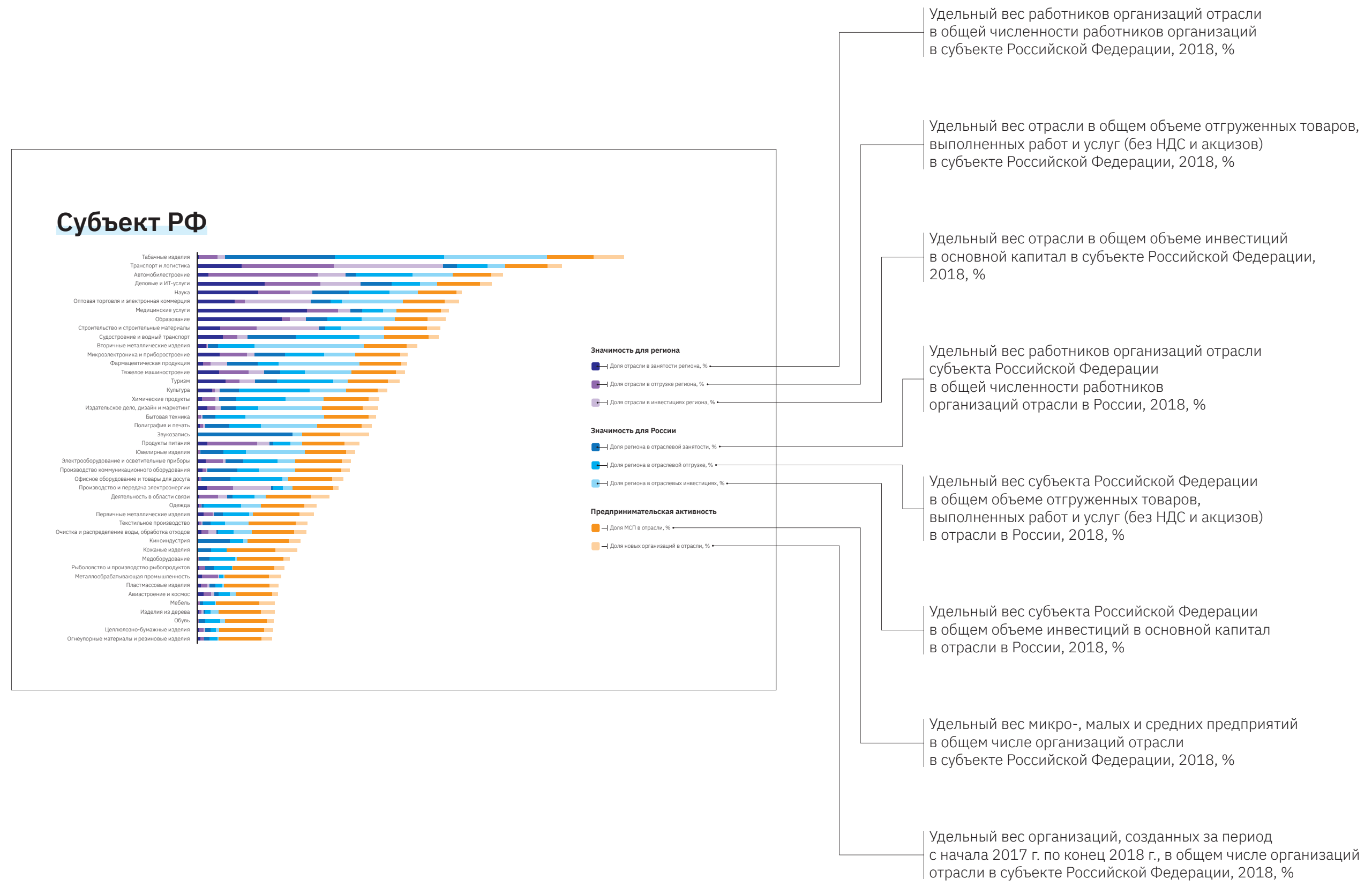




\section{Санкт-Петербург}

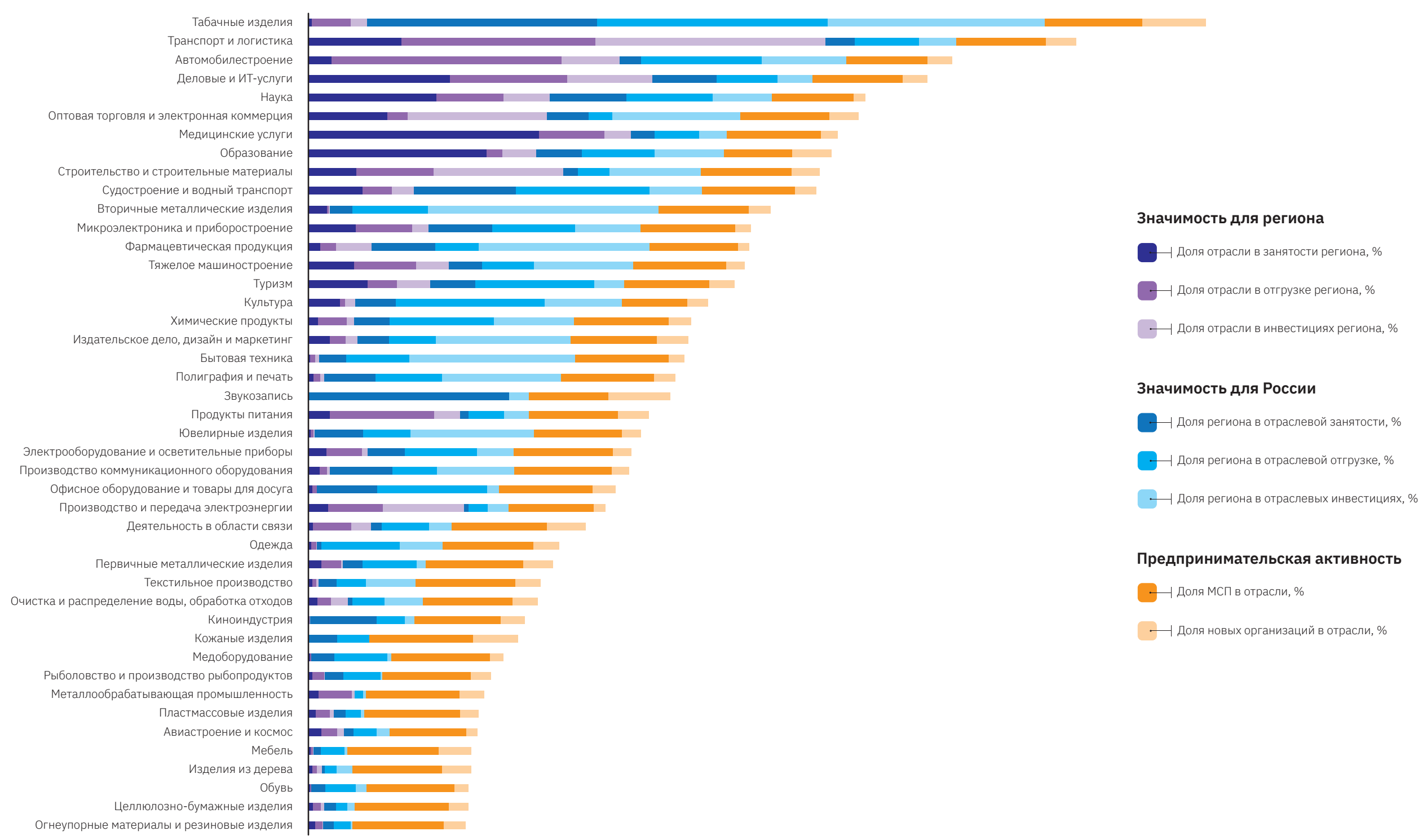




\section{Московская область}

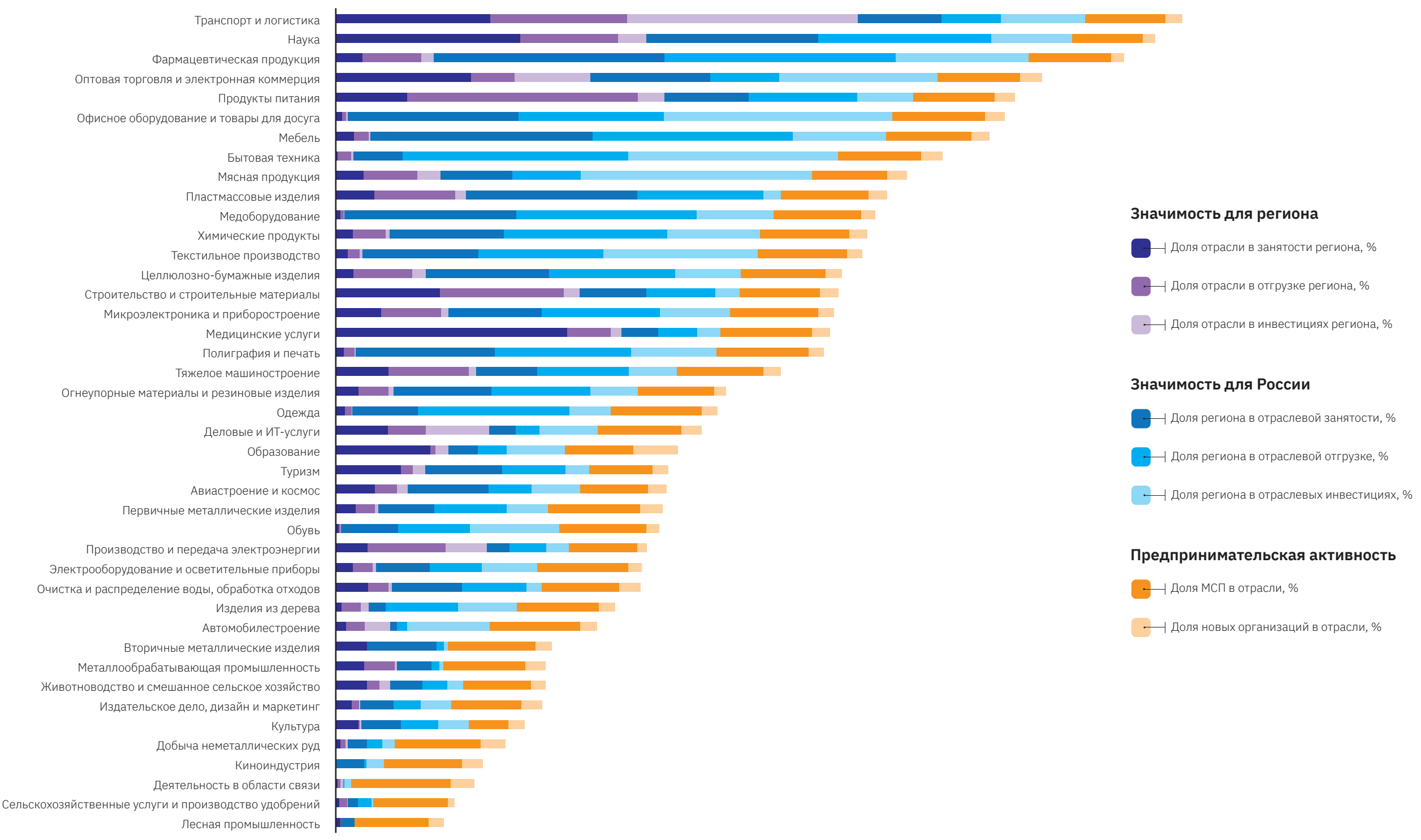




\section{Москва}

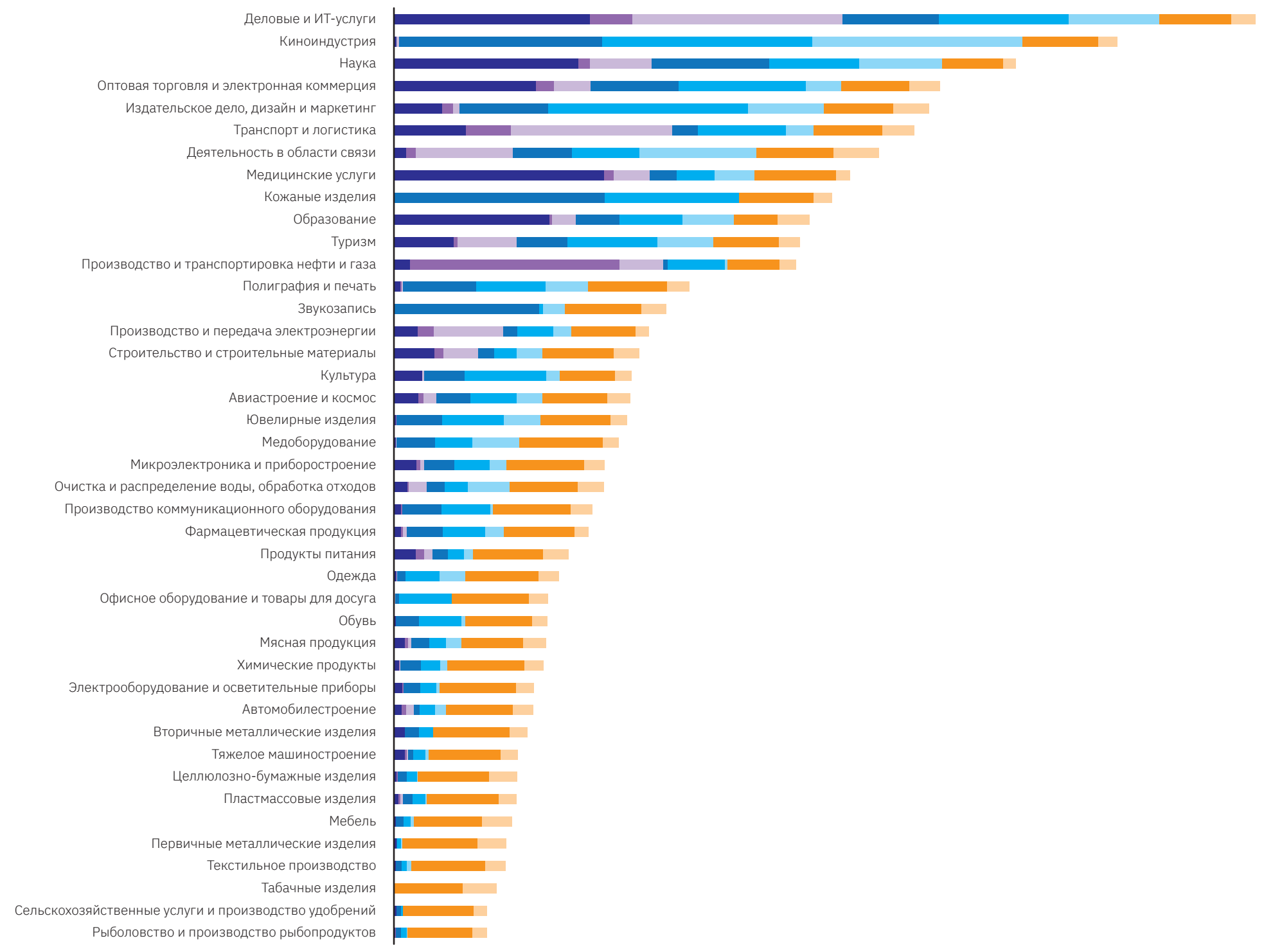

Значимость для региона

Доля отрасли в занятости региона, \%

Доля отрасли в отгрузке региона, \%

- Доля отрасли в инвестициях региона, $\%$

Значимость для России

Доля региона в отраслевой занятости, \%

Доля региона в отраслевой отгрузке, \%

Доля региона в отраслевых инвестициях, \%

Предпринимательская активность

Доля мСп в отрасли, \%

Доля новых организаций в отрасли, \% 


\section{Республика Татарстан}

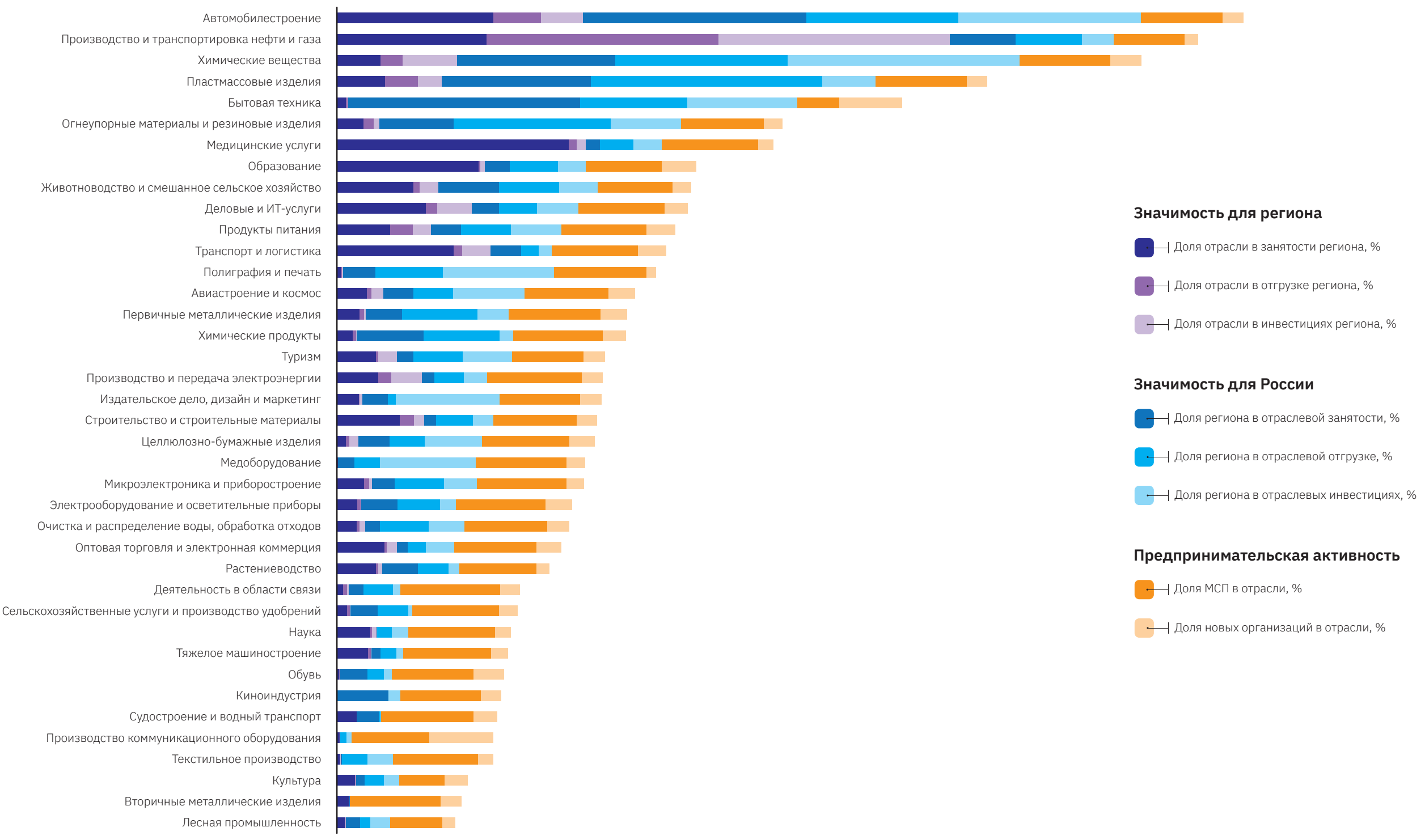




\section{Свердловская область}

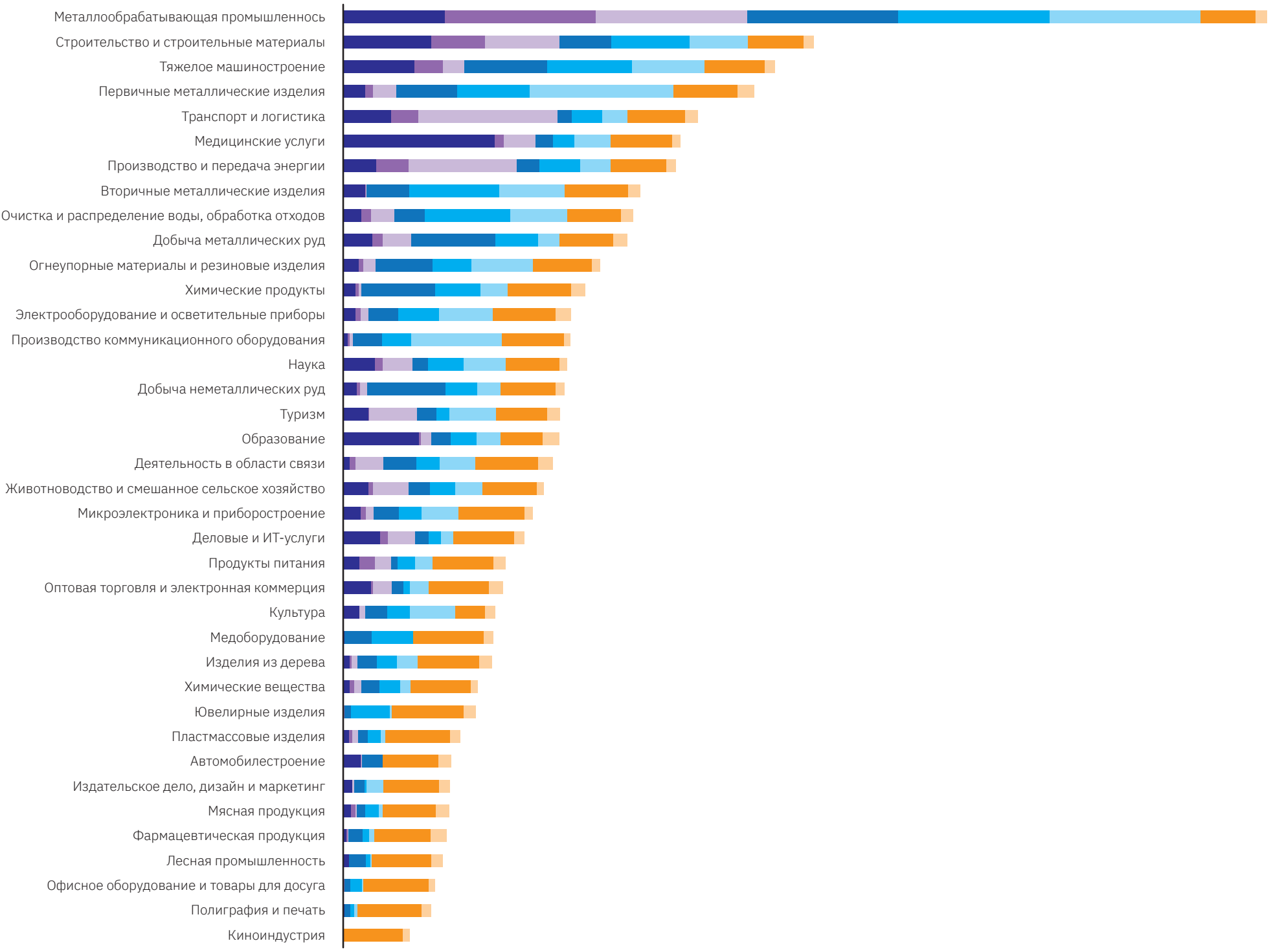

Значимость для региона

Доля отрасли в занятости региона, \%

Доля отрасли в отгрузке региона, \%

Д- Доля отрасли в инвестициях региона, \%

Значимость для России

Доля региона в отраслевой занятости, \%

_- Доля региона в отраслевой отгрузке, \%

Доля региона в отраслевых инвестициях, $\%$

Предпринимательская активность

Доля мСП в отрасли, \% 


\section{Республика Башкортостан}

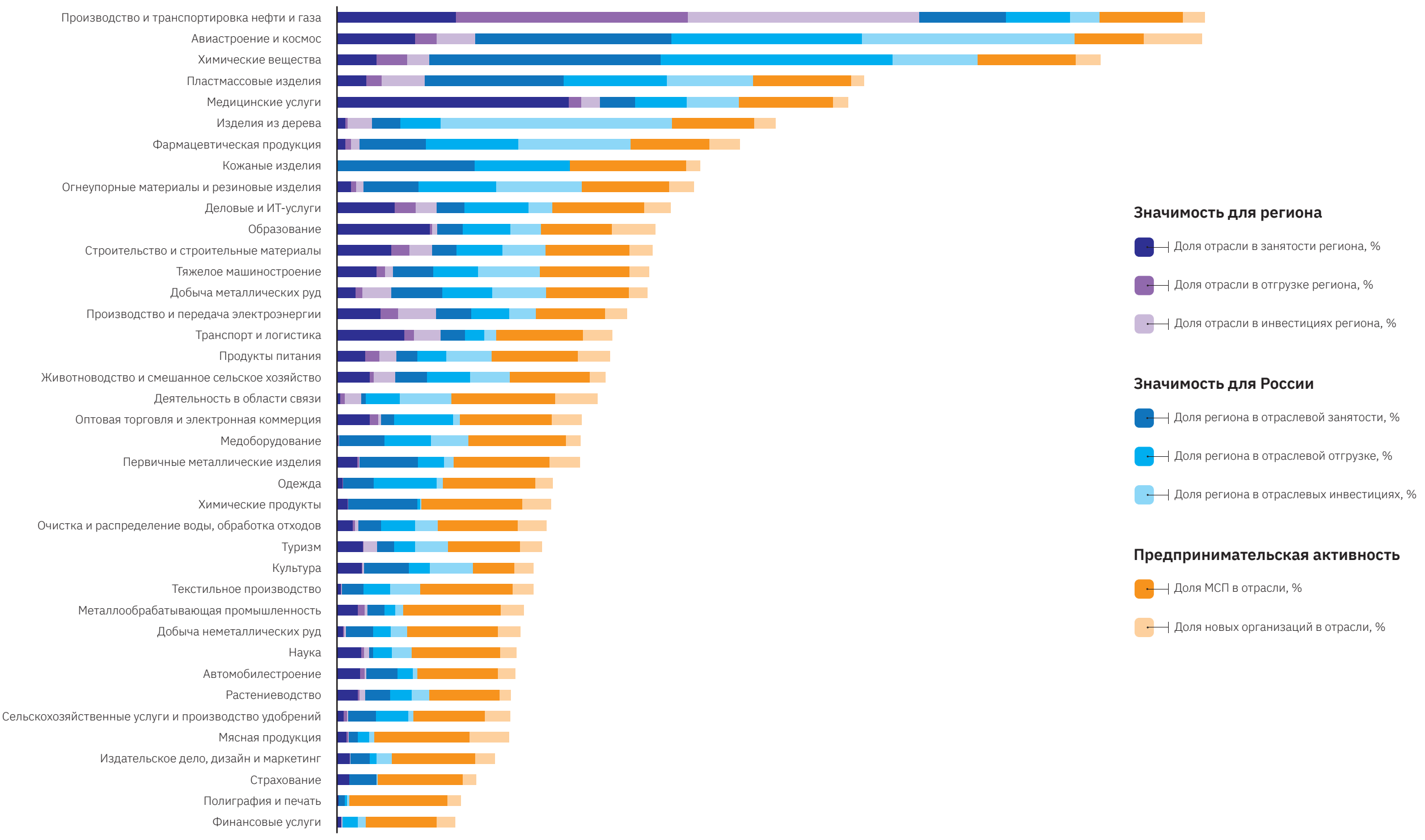




\section{Нижегородская область}

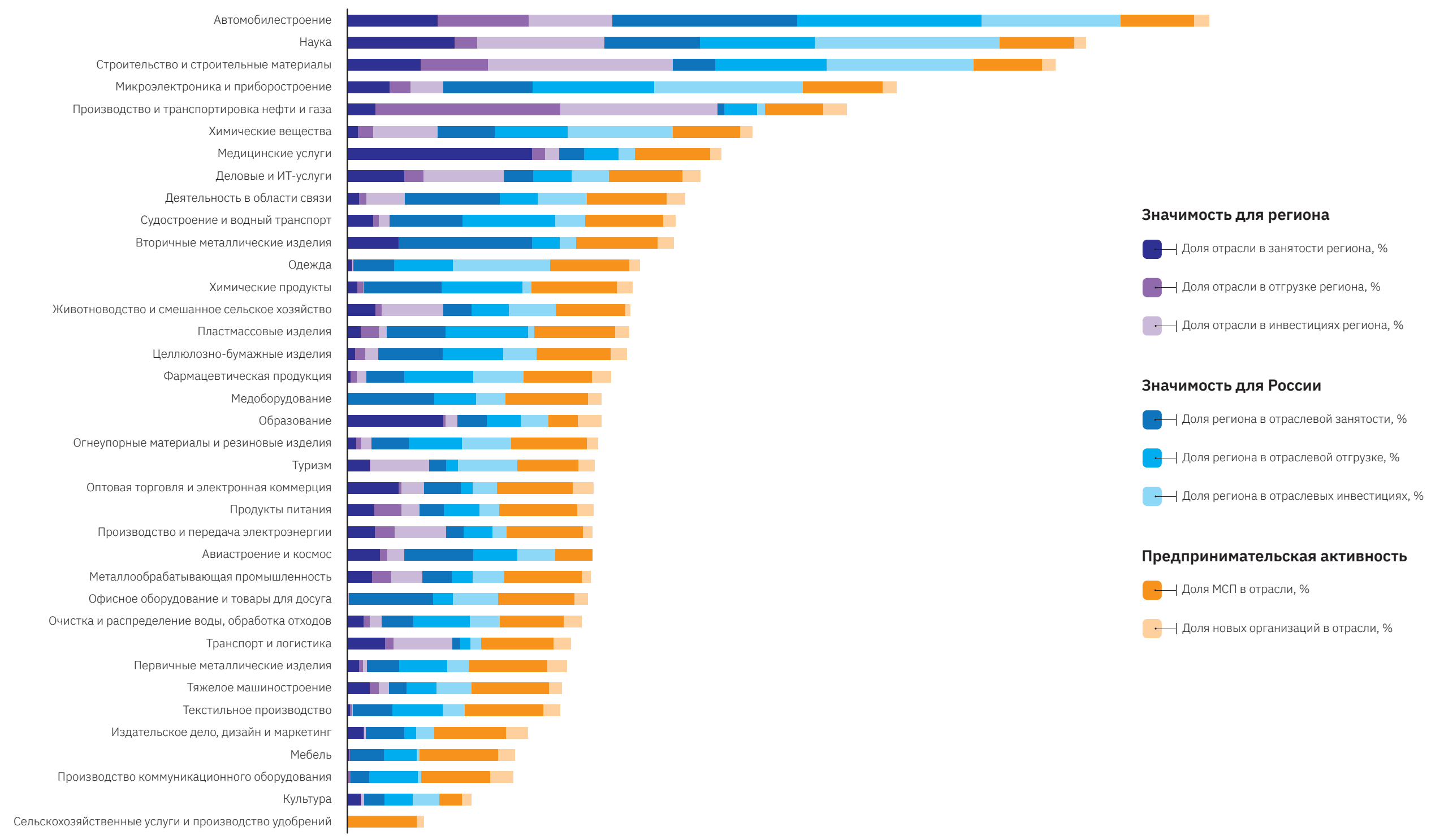




\section{Ростовская область}

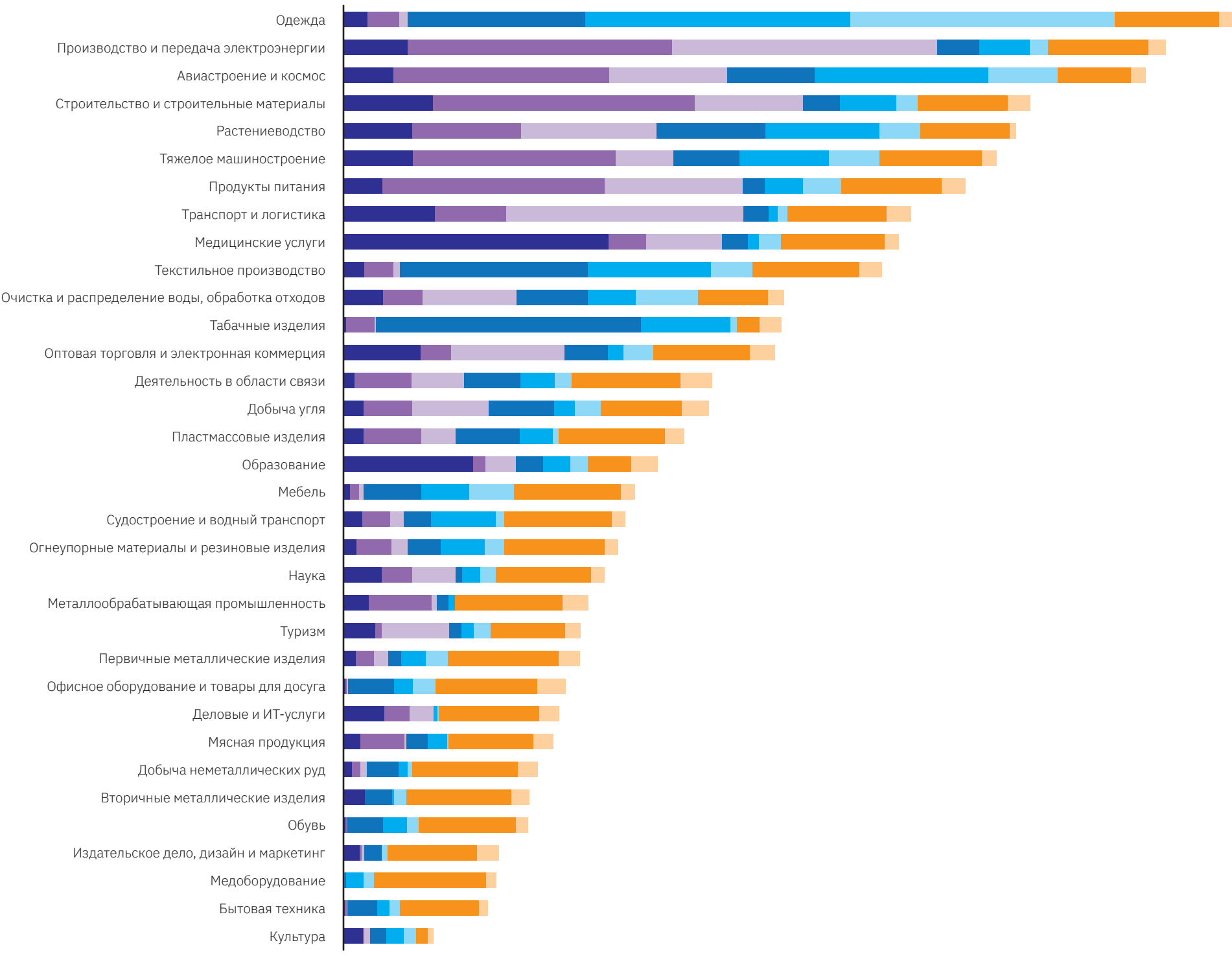

Значимость для региона

Доля отрасли в занятости региона, \%

Доля отрасли в отгрузке региона, \%

Доля отрасли в инвестициях региона, \%

Значимость для России

Доля региона в отраслевой занятости, \%

Доля региона в отраслевой отгрузке, \%

Доля региона в отраслевых инвестициях, \%

Предпринимательская активность

Доля мСП в отрасли, \%

Доля новых организаций в отрасли, \% 


\section{Челябинская область}

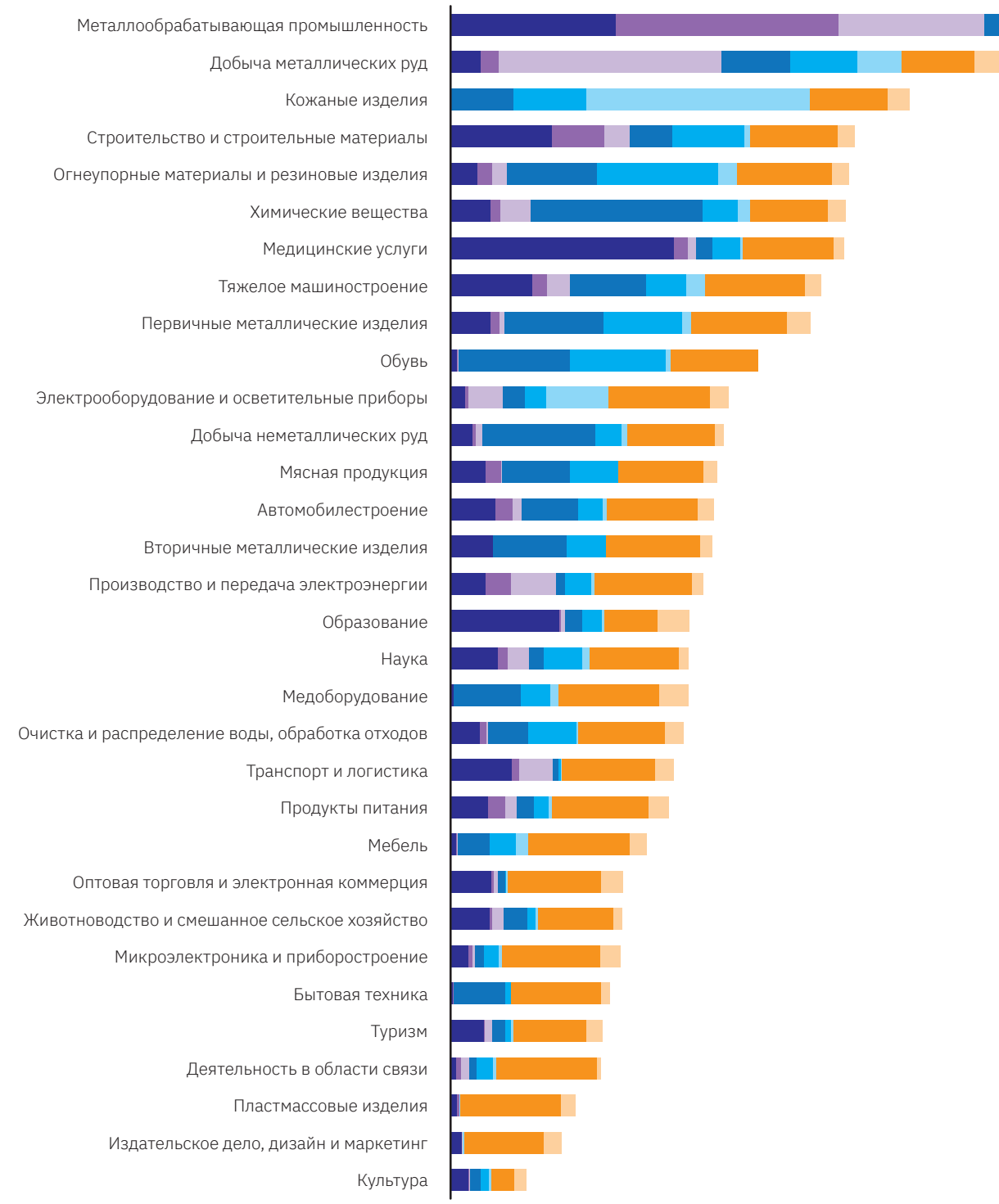

Значимость для региона

Доля отрасли в занятости региона, \%

Доля отрасли в отгрузке региона, \%

- Доля отрасли в инвестициях региона, \%

Значимость для России

Доля региона в отраслевой занятости, \%

Доля региона в отраслевой отгрузке, \%

Доля региона в отраслевых инвестициях, 9

Предпринимательская активность

Доля мСП в отрасли, \% 


\section{Новосибирская область}

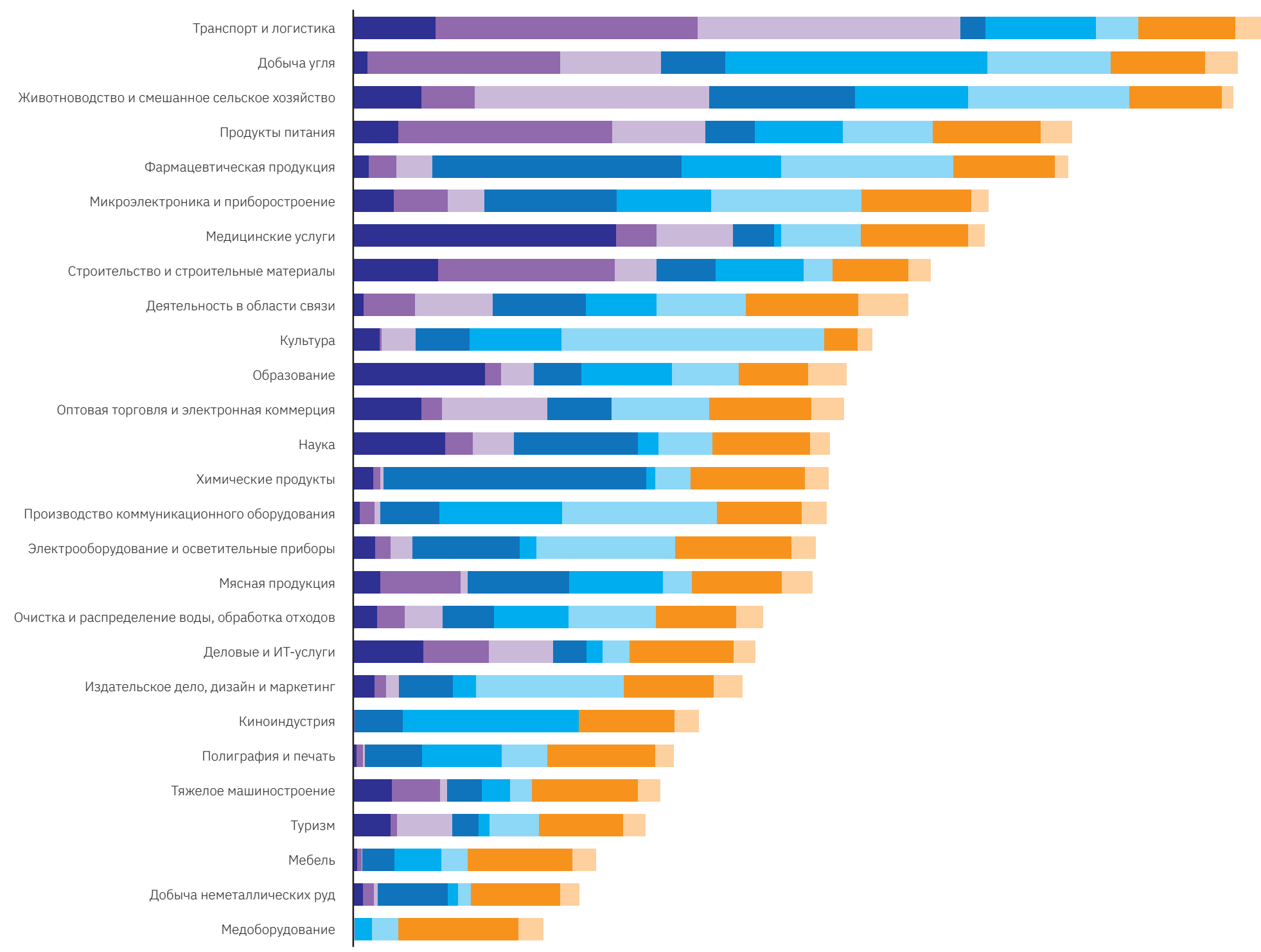

Значимость для региона

Доля отрасли в занятости региона, \%

Доля отрасли в отгрузке региона, \%

Доля отрасли в инвестициях региона, \%

Значимость для России

Доля региона в отраслевой занятости, \%

Доля региона в отраслевой отгрузке, \%

Доля региона в отраслевых инвестициях, \%

Предпринимательская активность

Доля мСП в отрасли, \%

Доля новых организаций в отрасли, \% 


\section{Самарская область}

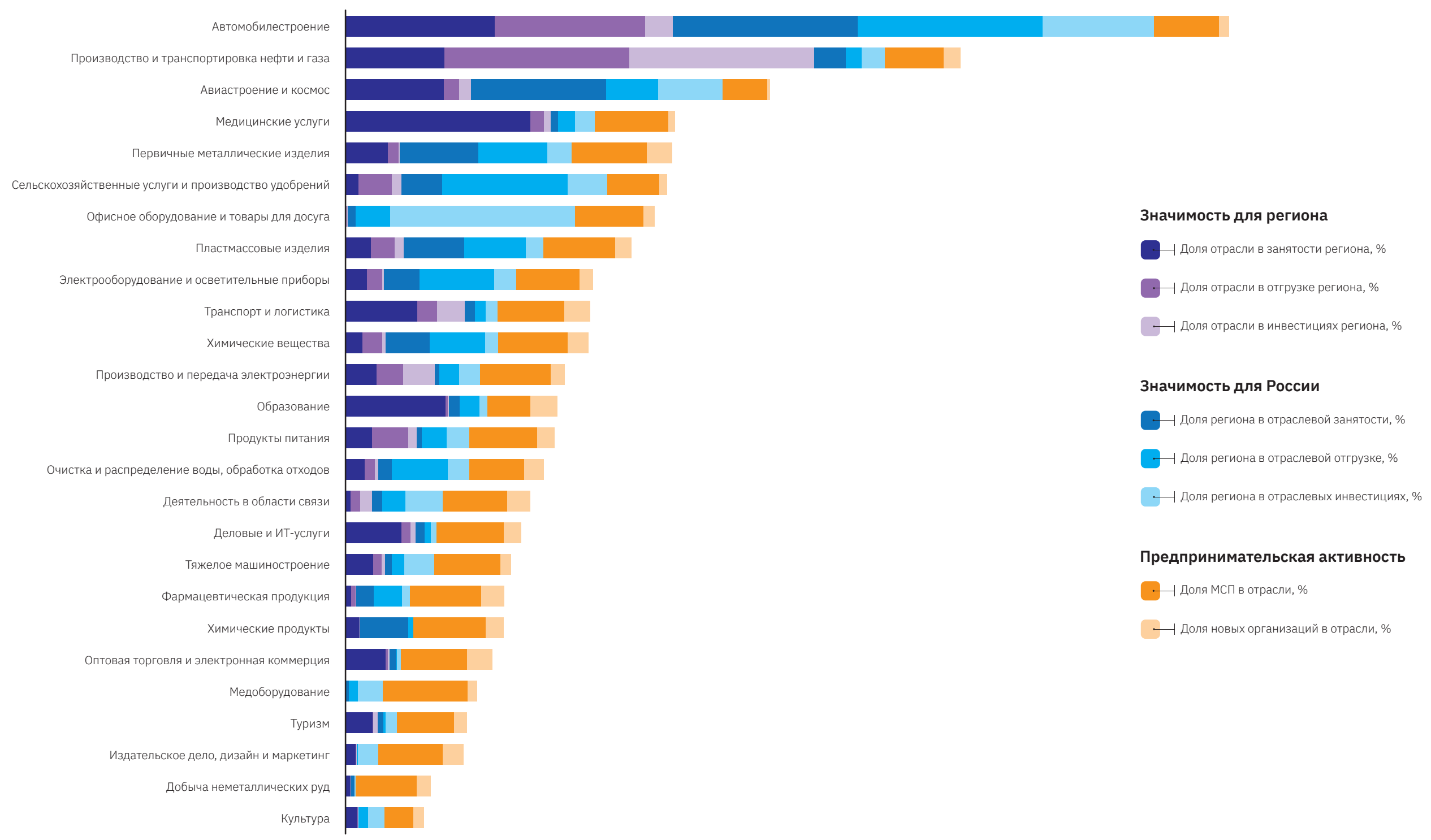




\section{Красноярский край}

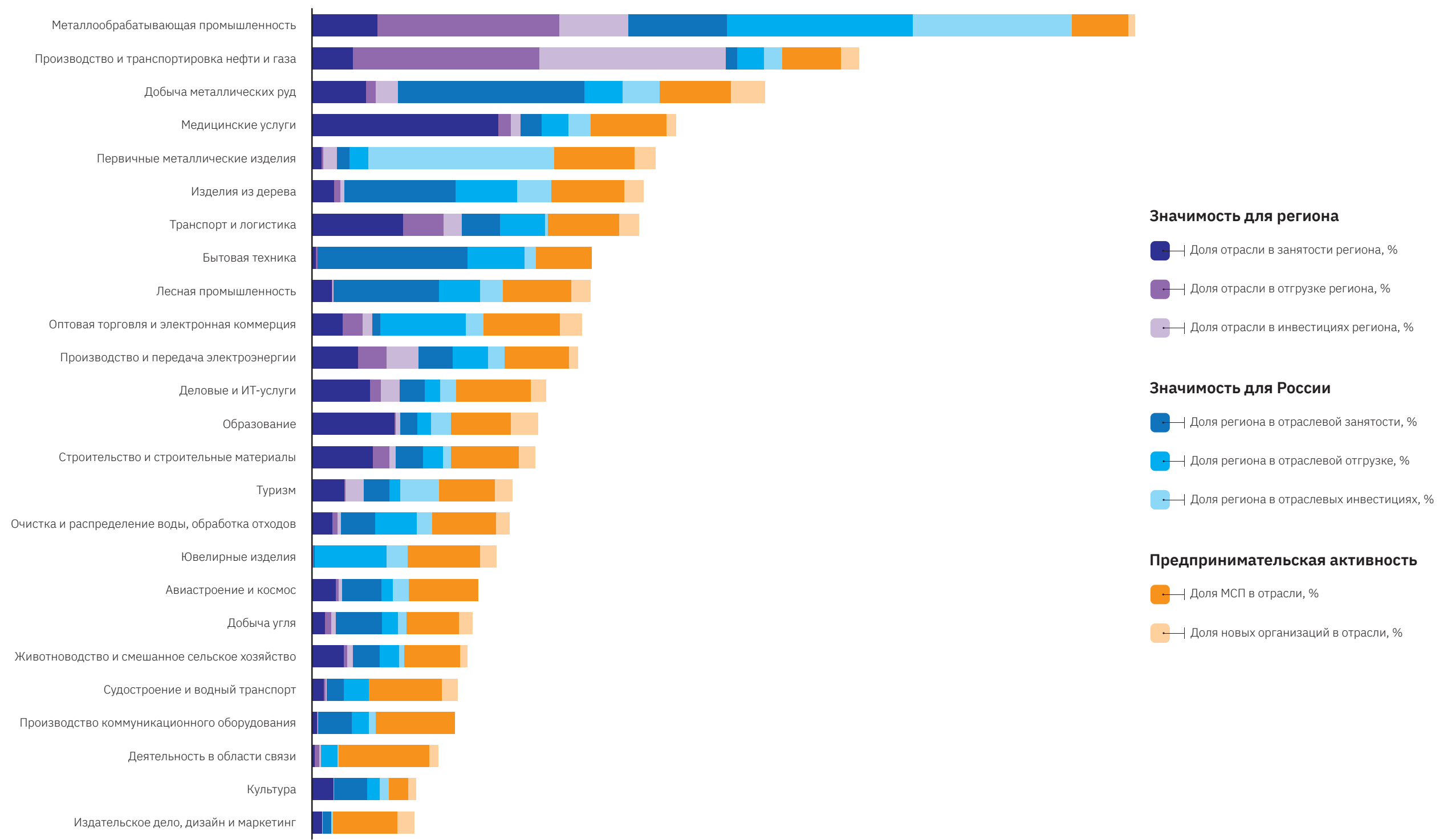




\section{Краснодарский край}

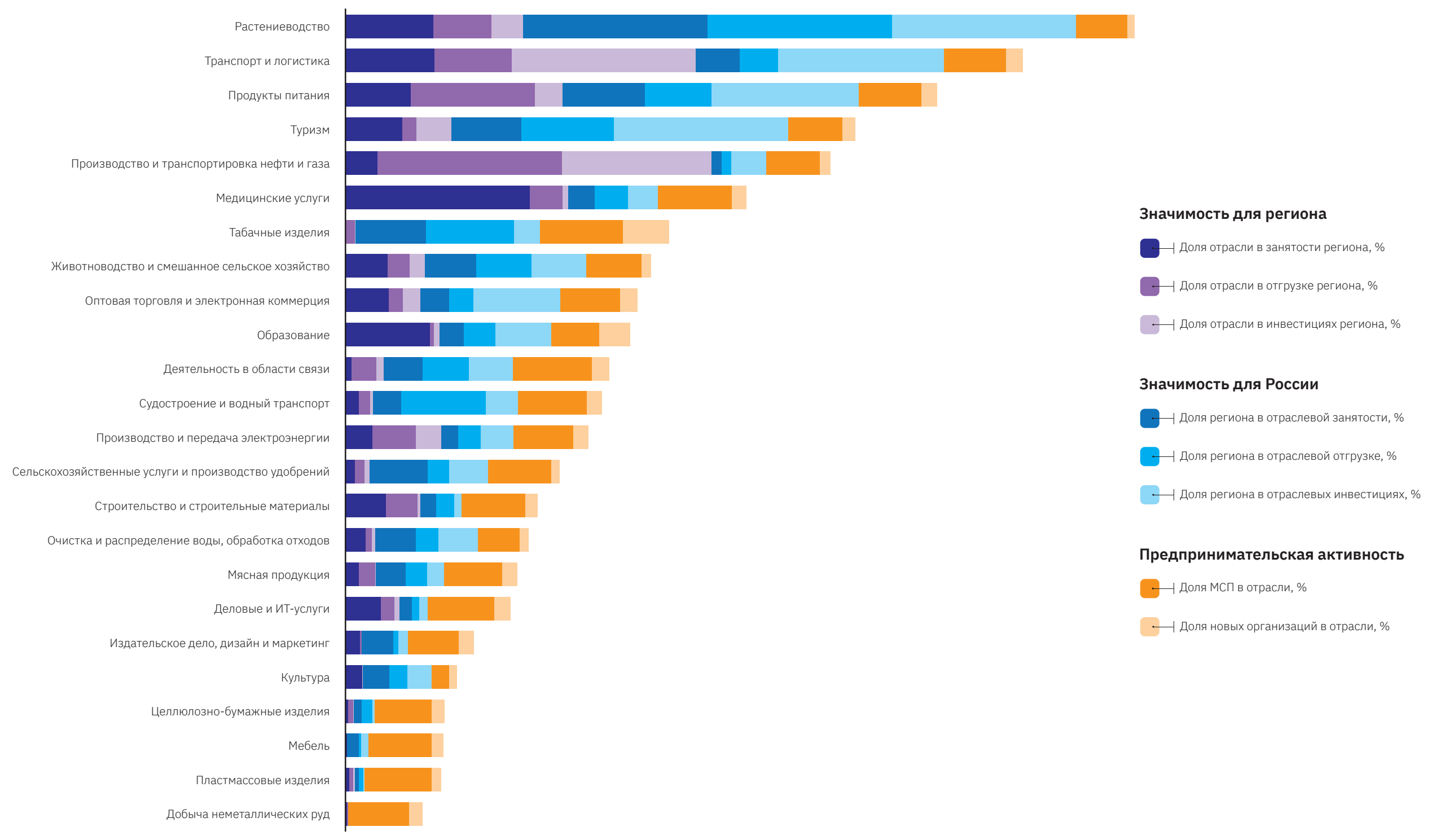




\section{Ленинградская область}

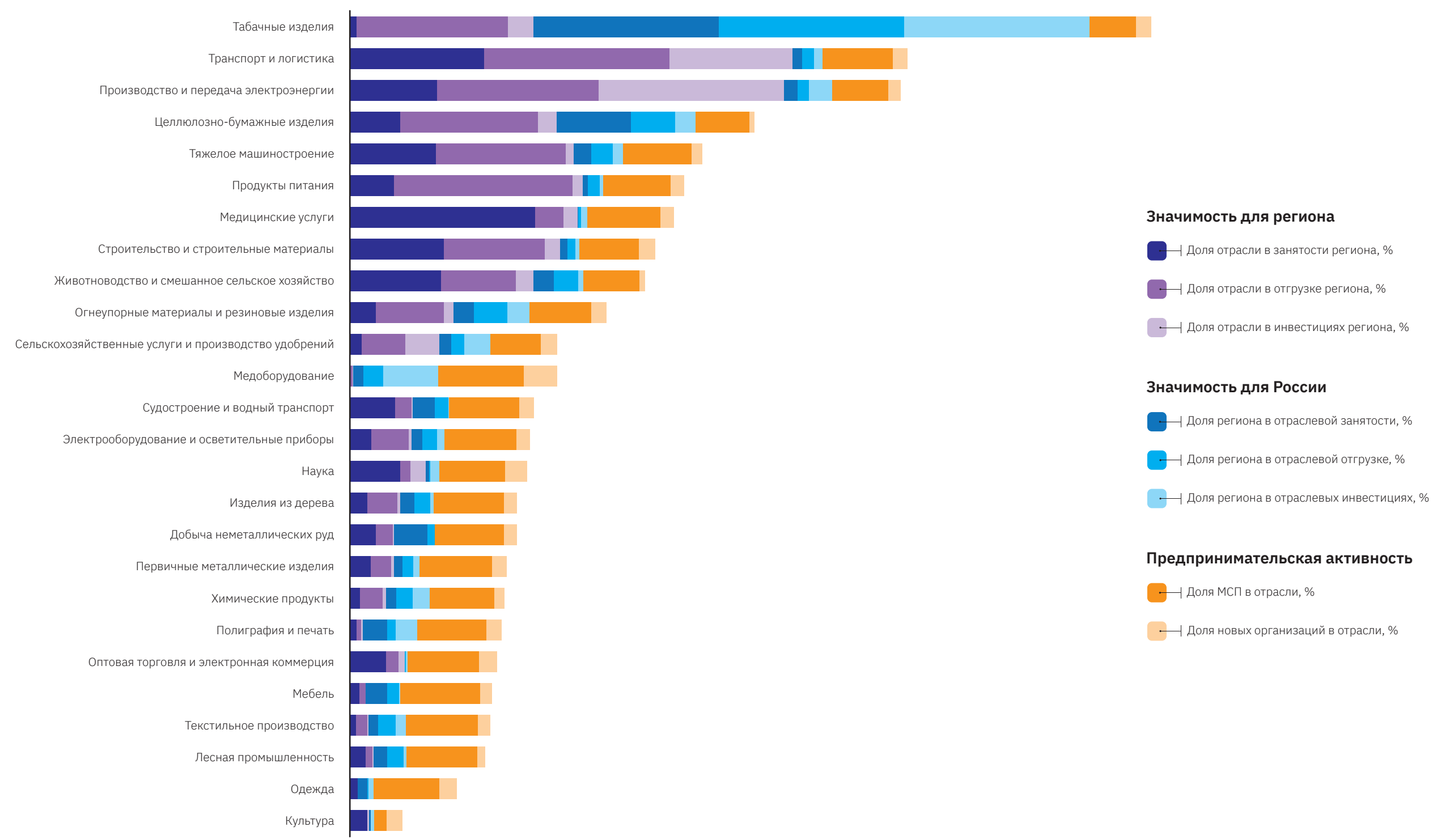




\section{Пермский край}

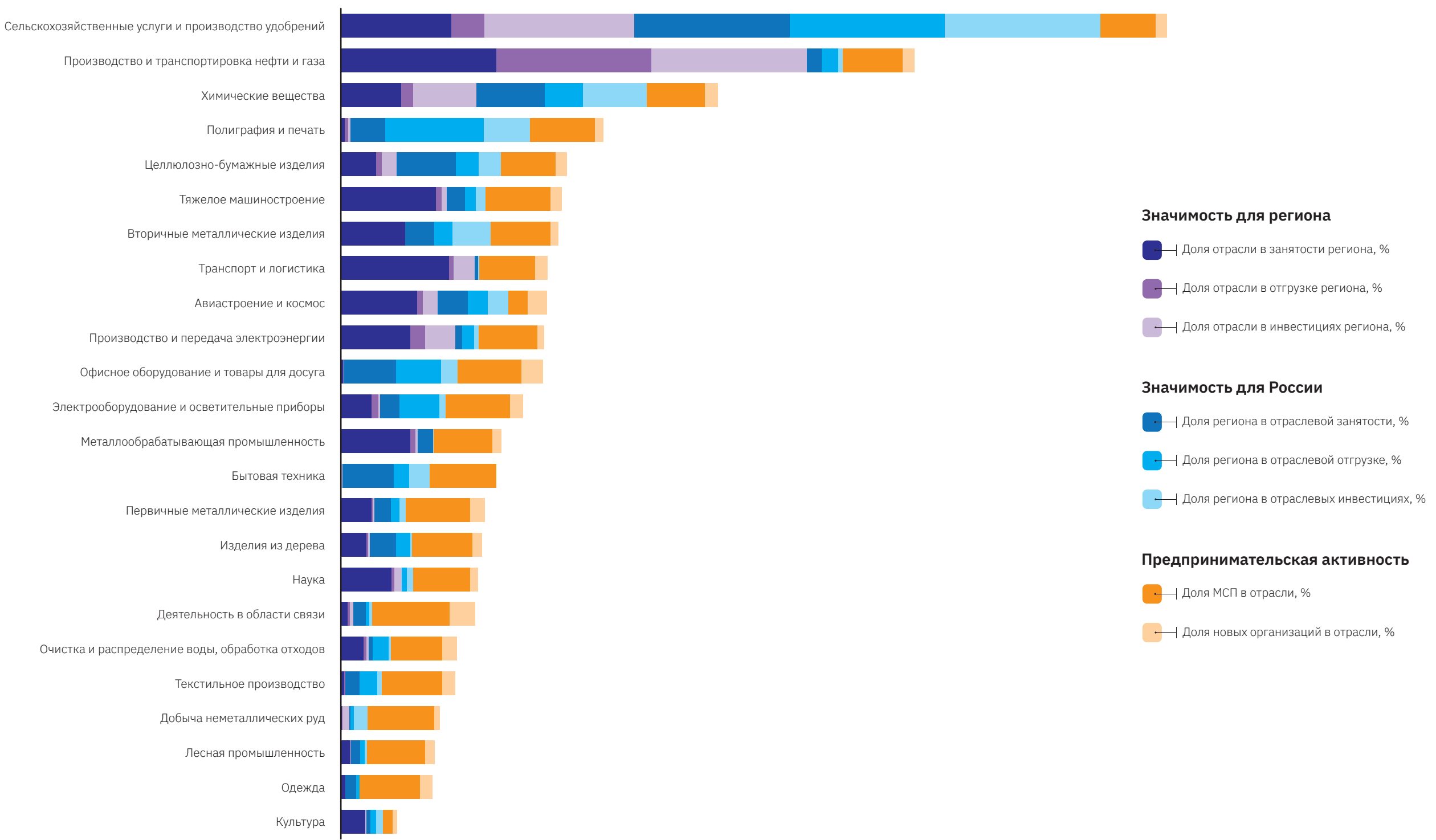




\section{Список литературы}

Аналитический центр при Правительстве Российской Федерации (2016) Динамика спроса на туристские услуги в России // Бюллетень о текущих тенденциях российской экономики. № 19. Режим доступа: https://ac.gov.ru/ files/publication/a/11063.pdf (дата обращения: 05.10.2020).

Аналитический центр при Правительстве Российской Федерации (2017) Восстановление спроса на туристские услуги в России // Бюллетень о текущих тенденциях российской экономики. № 31. Режим доступа: https://ac.gov.ru/ archive/files/publication/a/15422.pdf (дата обращения: 05.10.2020).

Аналитический центр при Правительстве Российской Федерации (2019) Грузовые перевозки в России: обзор текущей статистики // Бюллетень о текущих тенденциях российской экономики. № 53. Режим доступа: https://ac.gov.ru/files/publication/a/24196.pdf (дата обращения: 05.10.2020)

Вакуленко Е.С., Гурвич Е.Т. (2015) Моделирование механизмов российского рынка труда // Вопросы экономики. № 11. С. 5-29.

Данилов Ю.А., Абрамов А.Е., Буклемишев О.В. (2017) Реформа финансовых рынков и небанковского финансового сектора. Режим доступа: https://www.csr.ru/ upload/iblock/0b6/0b6cf2cc1c001dbfd98d2ef1729b63fe.pdf (дата обращения: 05.10.2020)

Дёмина О.В. (2016) Рынки тепловой энергии: тенденции пространственной организации // Пространственная экономика. №4. С. 33-60.

Дом.РФ (2017) Развитие рынков ипотеки и жилищного строительства в 2000-2017 годах. Режим доступа: https://xn--d1aqf.xn--p1ai/wp-content/ uploads/2016/04/AHML_17-let_2017.12.11.pdf (дата обращения: 05.10.2020).
Доронкин М.А., Лопатин Е.В. (2019) Банковская пятилетка: консолидация, «Базель III» и уход в розницу // РБК. Режим доступа: https://www.rbc.ru/economics/ 26/09/2019/5d88d0c19a794771ae4a6aа5 (дата обращения: 05.10.2020).

Единый архив экономических и социологических данных (2020) Режим доступа: http://sophist.hse.ru/rstat_data/vvoz2016/pBBF2_2016/pBВФ2_99.htm (дата обращения: 05.10.2020).

Кузьминов Я.И., Семенов Д.С., Фрумин И.Д. (2013) Структура вузовской сети: от советского к российскому «мастер-плану» // Вопросы образования. № 4. C. 8-69.

Кузьминов Я.И., Яковлев А.А., Гохберг Л.М., Ларионова М.В., Кузнецов Б.В. (2003) Россия: формирование институтов новой экономики. Тезисы. М.: Изд-во ГУ-ВШЭ.

Куценко Е.С., Абашкин В.Л., Исланкина Е.А. (2019) Фокусировка региональной промышленной политики через отраслевую специализацию // Вопросы экономики. № 5. С. 65-89.

Министерство строительства и жилищно-коммунального хозяйства Российской Федерации (2020) Мониторинг объемов жилищного строительства. Режим доступа: https://www.minstroyrf.ru/trades/zhilishnaya-politika/8/ (дата обращения: 05.10.2020).

Министерство финансов Российской Федерации (2020) Краткая информация об исполнении федерального бюджета. Режим доступа: https://www.minfin.ru/ ru/statistics/fedbud/execute/?id_65=80041-yezhegodnaya_informatsiya_ob ispolnenii_federalnogo_byudzhetadannye_s_1_yanvarya_2006_g.\# (дата обращения: 05.10.2020). 
НИУ ВШЭ (2018) Структурные изменения в российской экономике и структурная политика. Режим доступа: https://cutt.ly/mymgMnx (дата обращения: 05.10.2020)

Правительство Российской Федерации (2019) Стратегия пространственного развития Российской Федерации на период до 2025 года. Утверждена распоряжением Правительства Российской Федерации от 13 февраля 2019 г. № 207-р.

Российская ассоциация электронных коммуникаций (2018) Экономика Рунета Режим доступа: https://raec.ru/upload/files/ru-ec_booklet.pdf (дата обращения: 05.10.2020)

Росстат (2018) Транспорт в России. 2018: Стат. сб. М.: Росстат.

Росстат (2019) Российский статистический ежегодник. 2019: Стат. сб.

М.: Росстат.

Acs Z.J. (2003) Innovation and the Growth of Cities. Cheltenham: Edward Elgar Publishing

Barca F. (2009) An Agenda for a Reformed Cohesion Policy. A place-based approach to meeting European Union challenges and expectations. Independent Report. Режим доступа: https://ec.europa.eu/regional_policy/archive/policy/future/pdf/ report_barca_v0306.pdf (дата обращения: 05.10.2020).

Belousova V., Chichkanov N. (2016) Knowledge-Intensive Business Services in Russia: 2014-2015 Crisis Aftermath // Foresight and STI Governance. Vol. 10. № 4.

P. 46-58.
Biege S., Borowiecki M., Dachs B., Francois J.F., Hanzl-Weiss D., Hauknes J., Schartinger D. (2012) Convergence of Knowledge-intensive Sectors and the EU's External Competitiveness. WIIW Research Report. № 377. Режим доступа: https://wiiw.ac.at/convergence-of-knowledge-intensive-sectors-and-the-eu-sexternal-competitiveness-p-2588.html (дата обращения: 05.10.2020).

Brennan L., Rakhmatullin R. (2015) Global Value Chains and Smart Specialisation Strategy. Thematic Work on the Understanding of Global Value Chains and their Analysis within the Context of Smart Specialisation. Режим доступа:

https://s3platform.jrc.ec.europa.eu/documents/20182/96243/Global+Value+Chain s+and+Smart+Specialisation+Strategy/8546d7e1-0219-4ed4-905ae637731d4846 (дата обращения: 05.10.2020)

Caragliu A., de Dominicis L., de Groot H.L.F. (2016) Both Marshall and Jacobs were Right! // Economic Geography. Vol. 92. № 1. P. 87-111.

Content J., Frenken K. (2016) Related Variety and Economic Development: a Literature Review // European Planning Studies. Vol. 24. № 12. P. 2097-2112.

De Gregorio J., Giovannini A., Wolf H.C. (1994) International evidence on tradables and nontradables inflation // European Economic Review. Vol. 38. № 6. P. 1225-1244.

Delgado M., Porter M.E., Stern S. (2016) Defining clusters of related industries // Journal of Economic Geography. Vol. 16. № 1. P. 1-38.

Deutsch A. (2019) The 5 Industries Driving the U.S Economy // Investopedia. Режим доступа: https://www.investopedia.com/articles/investing/042915/5industries-driving-us-economy.asp (дата обращения: 05.10.2020). 
Duranton G., Puga D. (2000) Diversity and Specialisation in Cities: Why, Where and When Does it Matter? // Urban studies. Vol. 37. № 3. P. 533-555.

Essletzbichler J. (2015) Relatedness, Industrial Branching and Technological Cohesion in US Metropolitan Areas // Regional Studies. Vol. 49. № 5. P. 752-766.

European Commission (2012) Guide to Research and Innovation Strategies for Smart Specialisations. Brussels: European Commission. Режим доступа: http://s3platform.jrc.ec.europa.eu/documents/20182/84453/RIS3+Guide.pdf/ fceb8c58-73a9-4863-8107-752aef77e7b4 (дата обращения: 05.10.2020).

European Commission (2020) Smart Specialisation Platform. Brussels: European Commission. Режим доступа: https://s3platform.jrc.ec.europa.eu/ (дата обращения: 05.04.2020).

European Parliament (2013) The Regulation (EU) 1303/2013 of the European Parliament and of the Council of 17 December 2013 // Official Journal of the European Union. № 347. Р. 320-469. Режим доступа: https://eur-lex.europa.eu/ legal-content/EN/TXT/PDF/?uri=CELEX:32013R1303\&from=LV (дата обращения 05.10.2020)

Eurostat (2020) Statistics Explained. Режим доступа: https://ec.europa.eu/ eurostat/statistics-explained/index.php/Electricity,_gas,_steam_and_air conditioning_supply_statistics_-_NACE_Rev._2\#Structural_profile (дата обращения: 05.10.2020).

Feldman M., Audretsch D. (1999) Innovation in cities: Science-Based Diversity, Specialization and Localized Competition // European Economic Review. Vol. 43. № 2. P. 409-429.
Feldstein M. (2008) Did wages reflect growth in productivity? // Journal of Policy Modeling. Vol. 30. № 4. P. 591-594.

Foray D. (2013) Smart specialisation and the new industrial policy agenda. Paper presented at the 2013 ERAC Mutual Learning Seminar, 20th March 2013. Режим доступа: https://era.gv.at/object/document/360/attach/industrial_policy_ agenda.ppt (дата обращения: 05.10.2020).

Foray D., David P., Hall B. (2009) Smart Specialization-the Concept // Knowledge Economists Policy Brief. Vol. 9. № 85. P. 1-5.

Foray D., David P.A., Hall B.H. (2011) Smart specialization. From academic idea to political instrument, the surprising career of a concept and the difficulties involved in its implementation. MTEI Working Paper. Lausanne: École polytechnique fédérale de Lausanne.

Foray D., Goenaga X. (2013) The Goals of Smart Specialisation. European Commission. JRC Scientific and Policy Reports. S3 Policy Brief Series. № 01/2013.

Foray D., van Ark B. (2007) Smart specialisation in a truly integrated research area is the key to attracting more R\&D to Europe // Knowledge Economists Policy Brief. № 1. P. 1-4.

Fortune (2020) Global 500. Режим доступа: https://fortune.com/global500/ (дата обращения: 05.10.2020).

Frenken K., van Oort F., Verburg T. (2007) Related variety, unrelated variety and regional economic growth // Regional Studies. Vol. 41. № 5. P. 685-697. 
GFCI (2020) The Global Financial Centres Index 27. Режим доступа:

https://www.longfinance.net/media/documents/GFCI_27_Full_ Report_2020.03.26_v1.1_.pdf (дата обращения: 05.10.2020).

Giannitsis T. (2009) Technology and specialisation: strategies, options and risks // Knowledge Economists Policy Brief. № 8. P. 25-30.

Glaeser E.L., Kallal H.D., Scheinkman J.A., Shleifer A. (1992) Growth in Cities // Journal of political economy. Vol. 100. № 6. P. 1126-1152.

Grashof N., Hesse K., Fornahl D. (2019) Radical or Not? The Role of Clusters in the Emergence of Radical Innovations // European Planning Studies. Vol. 27. № 10. P. 1904-1923.

Greunz L. (2004). Industrial Structure and Innovation-Evidence from European Regions // Journal of evolutionary economics. Vol. 14. № 5. P. 563-592.

Harvard Business School (2020). U.S. Cluster mapping. Режим доступа: https://www.clustermapping.us/cluster (дата обращения: 05.10.2020).

Hausmann R., Rodrik D. (2003) Economic development as self-discovery // Journal of Development Economics. Vol. 72. № 2. P. 603-633.

Heckscher E.F. (1949) The Effect of Foreign Trade on the Distribution of Nationa Income. Readings in the Theory of International Trade. Philadelphia: Blackiston.

Helpman E., Krugman P.R. (1985) Market structure and foreign trade:

Increasing returns, imperfect competition, and the international economy. Cambridge, MA: MIT Press.

Henderson V., Kuncoro A., Turner M. (1995) Industrial development in cities // Journal of political economy. Vol. 103. № 5. P. 1067-1090.
Hidalgo C., Hausmann R. (2009) The building blocks of economic complexity // Proceedings of the National Academy of Sciences of the United States of America. Vol. 106. № 26. P. 10570-10575.

Iacobucci D. (2014) Designing and implementing a smart specialisation strategy at regional level: Some open questions // Scienze Regionali. Vol. 13. № 1. P. 107126.

Iacobucci D., Guzzini E. (2016) Relatedness and connectivity in technological domains: missing links in S3 design and implementation // European Planning Studies. Vol. 24. № 8. P. 1511-1526.

Jacobs J. (1969) The Economy of Cities. Random House: New York.

Joint Organisations Data Initiative (2020) JODI Highlights. Режим доступа: https://www.jodidata.org/ (дата обращения: 05.10.2020)

Kahn R.F. (1931) The relation of home investment to unemployment // The Economic Journal. Vol. 41. № 162. P. 173-198.

Kemeny T., Storper M. (2015) Is specialization good for regional economic development? // Regional Studies. Vol. 49. № 6. P. 1003-1018.

Ketels C., Protsiv S. (2014) Methodology and Findings Report for a Cluster Mapping of Related Sectors. Stockholm: Stockholm School of Economics.

Ketels C., Protsiv S. (2016) European Cluster Panorama. Stockholm: Stockholm School of Economics.

Komiya R. (1967) Non-Traded Goods and the Pure Theory of International Trade // International Economic Review. Vol. 8. № 2. P. 132-152. 
Kroll H. (2015) Efforts to Implement Smart Specialization in Practice-Leading Unlike Horses to the Water // European Planning Studies. Vol. 23. № 10. P. 2079-2098.

Krugman P. (1994) Complex landscapes in economic geography // The American Economic Review. Vol. 84. № 2. P. 412-416.

Krumme G. (1968) Werner Sombart and the Economic Base Concept // Land Economics. Vol. 44. № 1. P. 112-116.

Kutsenko E., Eferin Y. (2019) "Whirlpools" and "Safe Harbors" in the Dynamics of Industrial Specialization in Russian Regions // Foresight and STI Governance. Vol. 13. № 3. P. 24-40.

Kutsenko E., Islankina E., Kindras A. (2018) Smart by Oneself? An Analysis of Russian Regional Innovation Strategies within the RIS3 Framework // Foresight and STI Governance. Vol. 12. № 1. P. 25-45.

Lindqvist G. (2009) Disentangling Clusters: Agglomeration and Proximity Effects Dissertation for the Degree of Doctor of Philosophy, Ph.D. Stockholm School of Economics.

Lorenzen M., Frederiksen L. (2008) Why Do Cultural Industries Cluster? Localization, urbanization, products and projects // In Cooke, P and Rossella Lazzeretti (eds.), Creative Cities, Cultural Clusters, and Local Economic Development. P. 155-179. Cheltenham: Edward Elgar.

Mano R., Castillo M. (2015) The Level of Productivity in Traded and Non-Traded Sectors for a Large Panel of Countries. International Monetary Fund. № WP/15/48. P. 15-48.
Massard N., Riou S. (2002) L'impact des Structures Locales sur l'innovation en France: Specialization ou Diversité? // Revue Région et Développement. Vol. 16. P. 111-136.

McCann P., Ortega-Argilés R. (2015) Smart Specialization, Regional Growth and Applications to European Union Cohesion Policy // Regional Studies. Vol. 49 № 8. P. 1291-1302.

McCann P., Ortega-Argilés R. (2016) The early experience of smart specialization implementation in EU cohesion policy // European Planning Studies. Vol. 24. № 8. P. 1407-1427.

Midtkandal I., Rakhmatullin R. (2014) The S3 Platform Peer Review Methodology. European Commission. JRC Technical Reports. S3 Working Paper Series. № 02/2014.

Miles I.D., Belousova V., Chichkanov N. (2018) Knowledge intensive business services: ambiguities and continuities // Foresight. Vol. 20. № 1. P. 1-26.

Morgan K. (2017) Nurturing novelty: Regional innovation policy in the age of smart specialization // Environment and Planning C: Politics and Space. Vol. 35. № 4. P. 569-583.

Navarro M., Gibaja J.J., Franco S., Murciego A., Gianelle C., Hegyi F.B., Kleibrink A. (2014) Regional benchmarking in the smart specialization process: Identification of reference regions based on structural similarity. European Commission. JRC Technical Reports. S3 Working Paper Series. № 03/2014.

Niosi J. (2002) National systems of innovations are "x-efficient" (and x-efective). Why some are slow learners // Research Policy. Vol. 31. № 2. P. 291-302. 
OECD (2013a) Innovation-driven growth in regions: The role of smart specialisation. Paris: OECD.

OECD (2013b) Regions and Innovation: Collaborating across Borders. Paris: OECD.

OECD (2020) OECD. Stat. Domestic tourism. Режим доступа: https://stats.oecd.org/ Index.aspx?DataSetCode=TOURISM_DOMESTIC\# (дата обращения: 05.10.2020).

Paci R., Usai S. (1999) Externalities, Knowledge Spillovers and the Spatial Distribution of Innovation // GeoJournal. Vol. 49. № 4. P. 381-390.

Porter M. (2003) The economic performance of regions // Regional studies. Vol. 37. № 6-7. P. 549-578.

Samuelson P.A. (1953) Prices of factors and good in general equilibrium // The Review of Economic Studies, Vol. 21, № 1. P. 1-20.

Sörvik J., Midtkandal I., Marzocchi C., Uyarra E. (2016) How Outward-looking is Smart Specialisation. Results from a survey on inter-regional collaboration in Smart Specialisation Strategies (RIS3). European Commission. JRC Technical Reports. S3 Policy Brief Series. № 16/2016.

Statista (2020a) Global market share of the information and communication technology (ICT) market from 2013 tо 2019. Режим доступа: https://www.statista.com/ statistics/263801/global-market-share-held-by-selected-countries-in-the-ictmarket/ (дата обращения: 05.10.2020).

Statista (2020b) Pharmaceutical R\&D expenditure per employee compared to other U.S. manufacturing sectors 2001-2015. Режим доступа: https://www.statista.com/ statistics/240032/randd-expenditure-per-employee-in-us-sectors/ (дата обращения: 05.10.2020).
Thissen M., Oort F., Diodato D. (2013) Integration and Convergence in Regional Europe: European Regional Trade Flows from 2000 to 2010. The Hague: PBL Netherlands Environmental Assessment Agency. Режим доступа: https://www.econstor.eu/bitstream/10419/124122/1/ERSA2013_01116.pdf (дата обращения: 05.10.2020).

Tiebout C.M. (1962) The Community Economic Base Study. Supplementary paper № 16. New York, NY: Committee for Economic Development.

Van der Panne G. (2004) Agglomeration Externalities: Marshall versus Jacobs // Journal of evolutionary economics. Vol. 14. № 5. P. 593-604.

Wang X., Hofe R. (2008) Research Methods in Urban and Regional Planning. Tsinghua University Press, Beijing and Springer-Verlag GmbH Berlin.

Wee R.Y. (2017) Biggest Pharmaceutical Markets in the World by Country // WorldAtlas. Режим доступа: https://www.worldatlas.com/articles/countries-withthe-biggest-global-pharmaceutical-markets-in-the-world.html (дата обращения: 05.10.2020).

World Bank (2015) Toward an innovative Poland: the entrepreneurial discovery process and business needs analysis (Vol. 2): final report (English). Washington, D.C.: World Bank Group. Режим доступа: http://documents.worldbank.org/curated/ en/801221468186841613/final-report (дата обращения: 05.10.2020).

World Bank (2018) International Logistics Performance Index. Режим доступа: https://pi.worldbank.org/international/global (дата обращения: 05.10.2020). 


\section{Приложение 1. Методология и показатели Атласа экономической специализации регионов России}

\section{Особенности и эволюция метода}

В основе идентификации отраслей специализации регионов лежит метод определения значимых кластерных групп, применяемый с 2000 г. в разных вариантах Гарвардской школой бизнеса и Администрацией экономического развития США в рамках проекта U.S. Cluster Mapping Project. С 2005 г. эта методология также используется для выявления отраслей специализации в Европейском союзе. Эволюция метода представлена в табл. 1.

\section{Данный поход к изучению экономики страны и ее регионов имеет ряд} преимуществ:

- используются данные по занятости и заработным платам, которые лишены чрезмерной волатильности, присущей стоимостным показателям, что позволяет оценивать динамику развития отраслей и проводить сравнение специализаций регионов на международном и межрегиональном уровнях;

- из анализа исключаются локальные виды деятельности, ограниченные местным спросом, и делается акцент на торгуемых отраслях, ориентированных на национальные и международные рынки;

- перестраивается стандартный отраслевой классификатор: направления специализации формируются из функционально связанных видов деятельности, в том числе относящихся к сферам производства и оказания услуг;

- предлагается эффективное решение дилеммы уровня агрегации при межрегиональных и международных сравнениях. Анализ базируется на 51 отрасли, в каждую из которых входят от 1 до 37 связанных друг с другом видов экономической деятельности, детализированных до четвертого знака отраслевого классификатора. В совокупности они позволяют одновременно охватить национальный экономический ландшафт и определить уникальные преимущества каждой территории.

Список торгуемых отраслей, рассматриваемых в Атласе экономической специализации регионов России, имеет следующие отличия от аналогичного перечня, используемого Гарвардской школой бизнеса и Европейской кластерной обсерваторией:

- отрасль «Образование и наука» разделена на отрасли «Образование» и «Наука»;

- отрасль «Коммуникационное оборудование и услуги связи» разделена на отрасли «Производство коммуникационного оборудования» и «Деятельность в области связи»;

- дополнительно анализируются отрасли «Растениеводство» и «Животноводство и смешанное сельское хозяйство»;

- при определении специализаций субъектов Российской Федерации дополнительно анализируется отрасль «Медицинские услуги», не входящая в состав торгуемого сектора США и стран ЕС и не учитываемая при расчете показателей его результативности в России.

Таким образом, подход НИУ ВШЭ предполагает включение в состав торгуемого сектора 55 функционально связанных друг с другом отраслей. 
Табл. 1. Эволюция метода выявления отраслевой специализации регионов на основе кластерного подхода

\begin{tabular}{|c|c|c|c|c|c|}
\hline Анализ кейсов & $\begin{array}{l}\text { United States Cluster } \\
\text { Mapping Project (2000) }\end{array}$ & $\begin{array}{l}\text { European Union Cluster } \\
\text { Mapping Project (2005-2012) }\end{array}$ & $\begin{array}{l}\text { United States Cluster } \\
\text { Mapping Project (2012) }\end{array}$ & $\begin{array}{l}\text { European Union Cluster } \\
\text { Mapping }(2014,2016)\end{array}$ & $\begin{array}{l}\text { Атлас экономической } \\
\text { специализации регионов } \\
\text { России (2021) }\end{array}$ \\
\hline & $\begin{array}{l}\text { Институт стратегии } \\
\text { и конкурентоспособности } \\
\text { Гарвардской школы бизнеса }\end{array}$ & $\begin{array}{l}\text { Первая методика } \\
\text { Европейской кластерной } \\
\text { обсерватории }\end{array}$ & $\begin{array}{l}\text { Гарвардская школа } \\
\text { бизнеса и Администрация } \\
\text { экономического } \\
\text { развития США }\end{array}$ & $\begin{array}{l}\text { Вторая методика } \\
\text { Европейской кластерной } \\
\text { обсерватории } \\
\text { (обновлена в } 2016 \text { г.), } \\
\text { реализуемая под эгидой } \\
\text { Европейской комиссии }\end{array}$ & $\begin{array}{l}\text { Методический подход } \\
\text { НИУ ВшЭ }\end{array}$ \\
\hline $\begin{array}{l}\text { - Описание отдельных } \\
\text { кейсов, не отражающих } \\
\text { общих закономерностей } \\
\text { - Попытки преувеличить } \\
\text { размеры кластера, } \\
\text { невозможность } \\
\text { сравнения с другими } \\
\text { кластерами }\end{array}$ & $\begin{array}{l}\text { - Первые систематические, } \\
\text { основанные на данных } \\
\text { статистики попытки } \\
\text { выявления кластеров } \\
\text { в масштабах всей } \\
\text { экономики } \\
\text { - Соответствующий задаче, } \\
\text { но имеющий ограничения } \\
\text { по использованию, в силу } \\
\text { необходимости сбора } \\
\text { экспертных мнений для } \\
\text { коррекции статистических } \\
\text { выбросов }\end{array}$ & $\begin{array}{l}\text { - Использование } \\
\text { полученных в США } \\
\text { результатов } \\
\text { для формирования } \\
\text { Европейской карты } \\
\text { кластеров } \\
\text { - Учет данных о кластерных } \\
\text { инициативах } \\
\text { и региональном } \\
\text { предпринимательском } \\
\text { климате }\end{array}$ & $\begin{array}{l}\text { - Развитие подхода, } \\
\text { основанного } \\
\text { на статистических данных } \\
\text { - Опора на европейский } \\
\text { опыт в части учета } \\
\text { кластерных инициатив } \\
\text { и регионального } \\
\text { предпринимательского } \\
\text { климата }\end{array}$ & $\begin{array}{l}\text { - Фокус на межотраслевых } \\
\text { связях и трансформациях } \\
\text { в возникающих отраслях } \\
\text { - Уменьшение числа } \\
\text { отраслей специализации } \\
\text { за счет их фильтрации } \\
\text { по коэффициенту } \\
\text { локализации }\end{array}$ & $\begin{array}{l}\text { - В основе - методики } \\
\text { Европейской кластерной } \\
\text { обсерватории } 2014 \text { и } 2016 \\
\text { годов, адаптированные } \\
\text { с учетом отечественной } \\
\text { специфики } \\
\text { - Выделение трех типов } \\
\text { отраслей специализации } \\
\text { (национальной } \\
\text { и локальной значимости; } \\
\text { национальной } \\
\text { значимости; локальной } \\
\text { значимости) }\end{array}$ \\
\hline
\end{tabular}


В региональных профилях отрасли специализации и потенциальные связи между ними (учитывается только высокий уровень взаимосвязи) отображены в соответствии с рис. 1. Они были определены в рамках проекта U.S. Cluster Mapping Project путем вычисления связанности между отраслями (Between Cluster Relatedness) и между отдельными видами деятельности (Related Industries) [Delgado et al., 2016]. При расчете оценивались пространственные корреляции занятости и размещения предприятий, межотраслевые балансы по модели «затраты-выпуск», профессиональная однородность работников. Для наглядного изображения групп смежных отраслей используется единое цветовое обозначение. Поскольку в исследовании был уточнен состав торгуемых отраслей, возникла необходимость установить связи дополнительно включенных видов деятельности с выделенными ранее в публикации [Delgado et al., 2016]. Эта задача была решена путем расчета корреляций на основе статистики отраслевой занятости.

Для оценки результативности торгуемого сектора используются показатели численности занятых, фонда оплаты труда, объемов отгрузки и инвестиций. Данные по ним аккумулируются на основе форм федерального статистическо- го наблюдения (табл. 2) в разрезе «чистых» видов экономической деятельности с уровнем детализации не менее четырех знаков по ОКВЭД. Это позволяет объективно оценить уровень развития отрасли исходя из фактической хозяйственной деятельности организации, которая может не ограничиваться присвоенным ей основным кодом ОКВЭД. Иными словами, при использовании статистических данных в разрезе «чистых» видов экономической деятельности учитывается вклад всех организаций соответствующего отраслевого профиля независимо от присвоенного им основного кода ОКВЭД.

Ограничением используемых источников выступает наличие данных только по крупным и средним организациям. Таким образом, в расчетах не учитываются организации, средняя численность работников которых не превышает 15 человек. Кроме того, в разделе 3 Атласа в отраслевых профилях «Финансовые услуги» и «Страхование» не указаны данные по показателю «Доля товаров, работ, услуг, \%». Это обусловлено тем, что банки, страховые компании и прочие финансово-кредитные организации не представляют сведения по форме статистического наблюдения № П-1 «Сведения о производстве и отгрузке товаров и услуг» (Приказ Росстата от 21.11.2017 № 772). 


\section{Рис. 1. Состав и связи торгуемых отраслей}

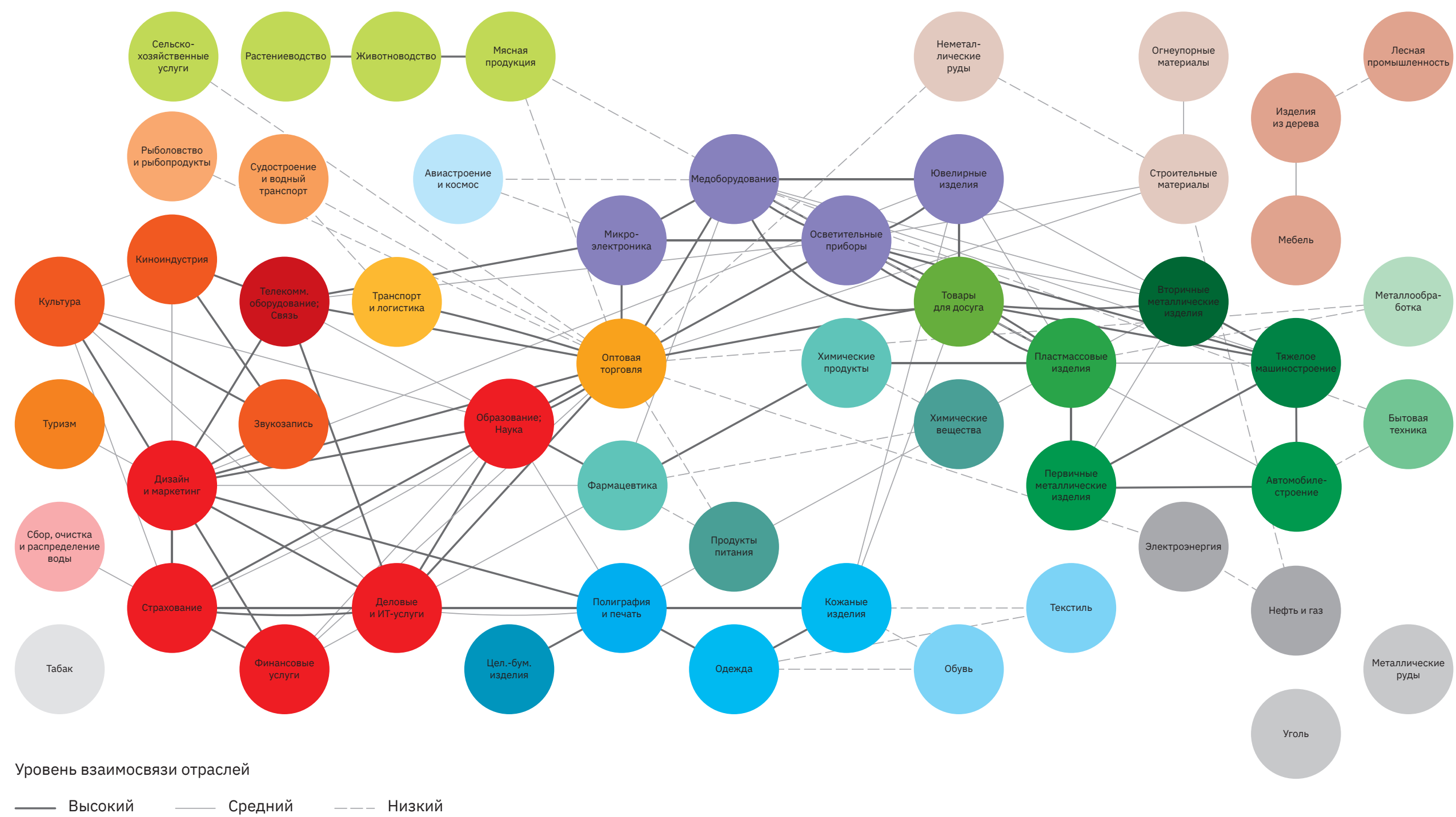




\section{Выявление специализаций регионов России}

Направления специализации субъекта Российской Федерации определяются путем проверки соответствия каждой торгуемой отрасли четырем критериям: концентрации (S), локализации (LQ), производительности труда (Productivity) и динамичности развития (Dynamism). Для подтверждения лидерства в отрасли регион должен входить в первые $20 \%$ хотя бы по одному из критериев. Прохождение этого порога позволяет говорить о специализации региона в отрасли.

Концентрация показывает удельный вес занятых в отрасли в том или ином регионе и рассчитывается по формуле:

$$
S_{i j}=\frac{A E_{i j}}{\sum_{i=1}^{m} E_{i j}},
$$

где

$i$ - порядковый номер региона $(i=1 \ldots m), m=85$;

$j$ - порядковый номер отрасли $(j=1 \ldots n), n=56$;

$A E-$ средняя численность занятых в период с 2016 по 2018 г.18
Локализация позволяет оценить, насколько удельный вес занятых в отрасли в регионе отличается от соответствующего среднероссийского показателя, и рассчитывается по формуле:

где

$$
L Q_{i j}=\frac{A E_{i j}}{\sum_{i=1}^{m} E_{i j}} / \frac{T E_{i j}}{\sum_{i=1}^{m} T E_{i}},
$$

$i$ - порядковый номер региона $(i=1 \ldots m), m=85$;

$j$ - порядковый номер отрасли $(j=1 \ldots n), n=56$;

$A E-$ средняя численность занятых в период с 2016 по 2018 г.;

$T E$ - общая численность занятых.

Производительность труда используется для оценки уровня заработных плат в отрасли в регионе и рассчитывается по формуле:

$$
\text { Productivity }_{i j}=\frac{A W_{i j}}{12 \cdot A E_{i j}} \cdot 1000,
$$

где

$i$ - порядковый номер региона $(i=1 \ldots m), m=85$;

$j$ - порядковый номер отрасли $(j=1 \ldots n), n=56$;

$A W$ - средний объем фонда оплаты труда в период с 2016 по 2018 г.;

$A E-$ средняя численность занятых в период с 2016 по 2018 г.

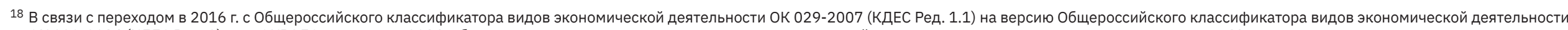
ОК 029-2014 (КДЕС Ред. 2), или ОКВЭД2, данные за 2016 г. были получены путем соотнесения видов экономической деятельности, приведенных в переходном ключе Министерства экономического развития Российской Федерации. 
Динамичность развития демонстрирует, с какой скоростью растет численность занятых в отрасли в регионе, и рассчитывается по формуле:

$$
\text { Dynamism }_{i j}=\frac{A E_{i j}^{2016-2018}}{A E_{i j}^{2015-2017}}-1 \text {, }
$$

где

$i$ - порядковый номер региона $(i=1 \ldots m), m=85$;

$j$ - порядковый номер отрасли $(j=1 \ldots n), n=56$;

$A E^{2016-2018}$ - средняя численность занятых в период с 2016 по 2018 г.;

$A E^{2015-2017}$ - средняя численность занятых в период с 2015 по 2017 г.

Дополнительно при определении специализаций региона применяются два независимых друг от друга ограничивающих условия. Отраслью специализации региона признается отрасль, отвечающая хотя бы одному из условий:

1. концентрация - регион должен относиться к числу субъектов Российской Федерации, формирующих 80\% общестрановой занятости в данной отрасли (начиная с регионов, имеющих наибольшую занятость в оцениваемой отрасли);

2. локализация - субъект Российской Федерации должен соответствовать критерию локализации (LQ).
Первое условие позволяет исключать из анализа слабые с экономической точки зрения регионы, которые могут получать завышенные значения при расчете локализации отрасли и динамичности ее развития за счет эффекта низкой базы. В свою очередь, соответствие второму условию позволяет выявлять отрасли специализации и в меньших по размеру экономики регионах. Второе условие также позволяет исключать отрасли, удовлетворяющие лишь критерию динамичности.

Сведение результатов, получаемых с использованием этих условий, позволяет выделить три типа отраслей специализации регионов:

1. отрасли национальной и локальной значимости (удовлетворяют обоим ограничивающим условиям и хотя бы одному из четырех критериев);

2. отрасли национальной значимости (соответствуют только условию концентрации и как минимум одному из четырех критериев);

3. отрасли локальной значимости (отвечают только условию локализации и не менее чем одному из четырех критериев).

Стоит отметить, что ряд торгуемых отраслей («Кожаные изделия», «Киноиндустрия», «Звукозапись», «Табачные изделия», «Ювелирные изделия», «Офисное оборудование и товары для досуга», «Производство коммуникационного оборудования») получили развитие лишь в небольшом числе субъектов Российской Федерации и при этом характеризуются малой численностью занятых. Учитывая эту особенность, для ряда регионов мы исключили из перечня выявленных отраслей специализации те, в которых занятость составила менее 10 человек (по данным за 2018 г.). 


\section{Рейтингование отраслей специализации полиотраслевых регионов}

Для полиотраслевых регионов (т.е. имеющих 25 и более профильных отраслей любых типов) были рассчитаны рейтинги направлений специализации, представленные в разделе 4 Атласа. Они сформированы на основе трех факторов: значимости отрасли для региона, для России в целом, и внутриотраслевой предпринимательской активности. Первые два фактора позволяют оценить значимость отрасли по шести показателям, отражающим ее долю в региональной и общеотраслевой занятости, отгрузке и инвестициях. Третий фактор характеризует уровень предпринимательской активности в отрасли и определяется в рейтинге по двум показателям: доле малых и средних предприятий и удельному весу новых организаций в отрасли. Источники статистических данных, использованных при расчетах рейтингов, указаны в табл. 2 данного приложения. При расчете не учитывались отрасли «Финансовые услуги» и «Страхование», поскольку банки, страховые компании и прочие финансово-кредитные организации не представляют сведения по форме статистического наблюдения № П-1 «Сведения о производстве и отгрузке товаров и услуг» (Приказ Росстата от 21.11.2017 № 772).

Показатели, составляющие факторы «Значимость для региона» и «Значимость для России», нормируются относительно других отраслей специализации региона по формуле:

$$
x_{i}^{\text {норм }}=\frac{x_{i}-x_{\min }}{x_{\max }-x_{\min }},
$$

Общий индекс развития отрасли (DI - Development Index) рассчитывается по формуле:

$$
\begin{aligned}
D I_{i j}=R E S_{i j}^{\text {норм }} & +R V S_{i j}^{\text {норм }}+R I S_{i j}^{\text {норм }}+I E S_{i j}^{\text {норм }}+I V S_{i j}^{\text {норм }}+ \\
& +I I S_{i j}^{\text {норм }}+0,5 \cdot\left(S M E_{i j}+I R_{i j}\right),
\end{aligned}
$$

где

$i$ - порядковый номер региона $(i=1 \ldots m), m=85$;

$j$ - порядковый номер отрасли $(j=1 \ldots n), n=56$;

$R E S^{\text {норм }}$ - нормированное значение доли отрасли в занятости региона;

$R V S^{\text {норм }}-$ нормированное значение доли отрасли в отгрузке региона;

$R I S^{\text {норм }}$ - нормированное значение доли отрасли в инвестициях региона;

$I E S^{\text {норм }}$ - нормированное значение доли региона в отраслевой занятости;

$I V S^{\text {норм }}$ - нормированное значение доли региона в отраслевой отгрузке;

$I I S^{\text {норм }}$ - нормированное значение доли региона в отраслевых инвестициях;

$S M E$ - доля МСП в отрасли;

$I R$ - доля новых организаций в отрасли.

Формулы расчета показателей рейтингов отраслей специализации субъектов Российской Федерации представлены в табл. 3 данного приложения. 


\section{Источники данных и показатели Атласа}

Источники данных, используемых в Атласе экономической специализации регионов России, представлены в табл. 2, показатели Атласа и формулы их расчета - в табл. 3.

\section{Табл. 2. Источники статистических данных, используемых в Атласе экономической специализации регионов России}

\begin{tabular}{|c|c|c|c|c|}
\hline $\begin{array}{l}\text { № } \\
\Pi / \Pi\end{array}$ & $\begin{array}{l}\text { Краткое } \\
\text { наименование } \\
\text { показателя }\end{array}$ & Статистический показатель & Источник & Период \\
\hline 1 & $\begin{array}{l}\text { Численность } \\
\text { занятых }\end{array}$ & $\begin{array}{l}\text { Средняя численность работников - всего } \\
\text { (число замещенных рабочих мест) }\end{array}$ & $\begin{array}{l}\text { Форма № П-4 «Сведения о численности } \\
\text { и заработной плате работников» }\end{array}$ & $2009-2018$ \\
\hline 2 & Фонд оплаты труда & Фонд начисленной заработной платы - всего & $\begin{array}{l}\text { Форма № П-4 «Сведения о численности } \\
\text { и заработной плате работников» }\end{array}$ & $2009-2018$ \\
\hline 3 & Объем отгрузки & $\begin{array}{l}\text { Отгружено товаров собственного производства, } \\
\text { выполнено работ и услуг собственными силами (без НДС и акцизов) }\end{array}$ & $\begin{array}{l}\text { Форма № П-1 «Сведения о производстве } \\
\text { и отгрузке товаров и услуг» }\end{array}$ & 2018 \\
\hline 4 & Объем инвестиций & $\begin{array}{l}\text { Инвестиции в основной капитал по видам деятельности } \\
\text { (использование) }\end{array}$ & $\begin{array}{l}\text { Форма № П-2 (инвест) «Сведения } \\
\text { об инвестиционной деятельности» }\end{array}$ & 2018 \\
\hline 5 & Число организаций & Число объектов. Типы предприятий: все типы предприятий & & $\begin{array}{l}\text { По состоянию } \\
\text { на } 01.01 .2019\end{array}$ \\
\hline 6 & $\begin{array}{l}\text { Число организаций } \\
\text { МСп }\end{array}$ & $\begin{array}{l}\text { Число объектов. Типы предприятий: микропредприятия, } \\
\text { малые и средние предприятия и организации }\end{array}$ & Статрегистр Росстата & $\begin{array}{l}\text { По состоянию } \\
\text { на } 01.01 .2019\end{array}$ \\
\hline 7 & $\begin{array}{l}\text { Число новых } \\
\text { организаций }\end{array}$ & Число объектов. Вновь созданные в период с 01.01.2017 по 31.12.2018 & & $\begin{array}{l}\text { с 01.01.2017 } \\
\text { по 31.12.2018 }\end{array}$ \\
\hline
\end{tabular}


Табл. 3. Система показателей Атласа экономической специализации регионов России и формулы их расчета

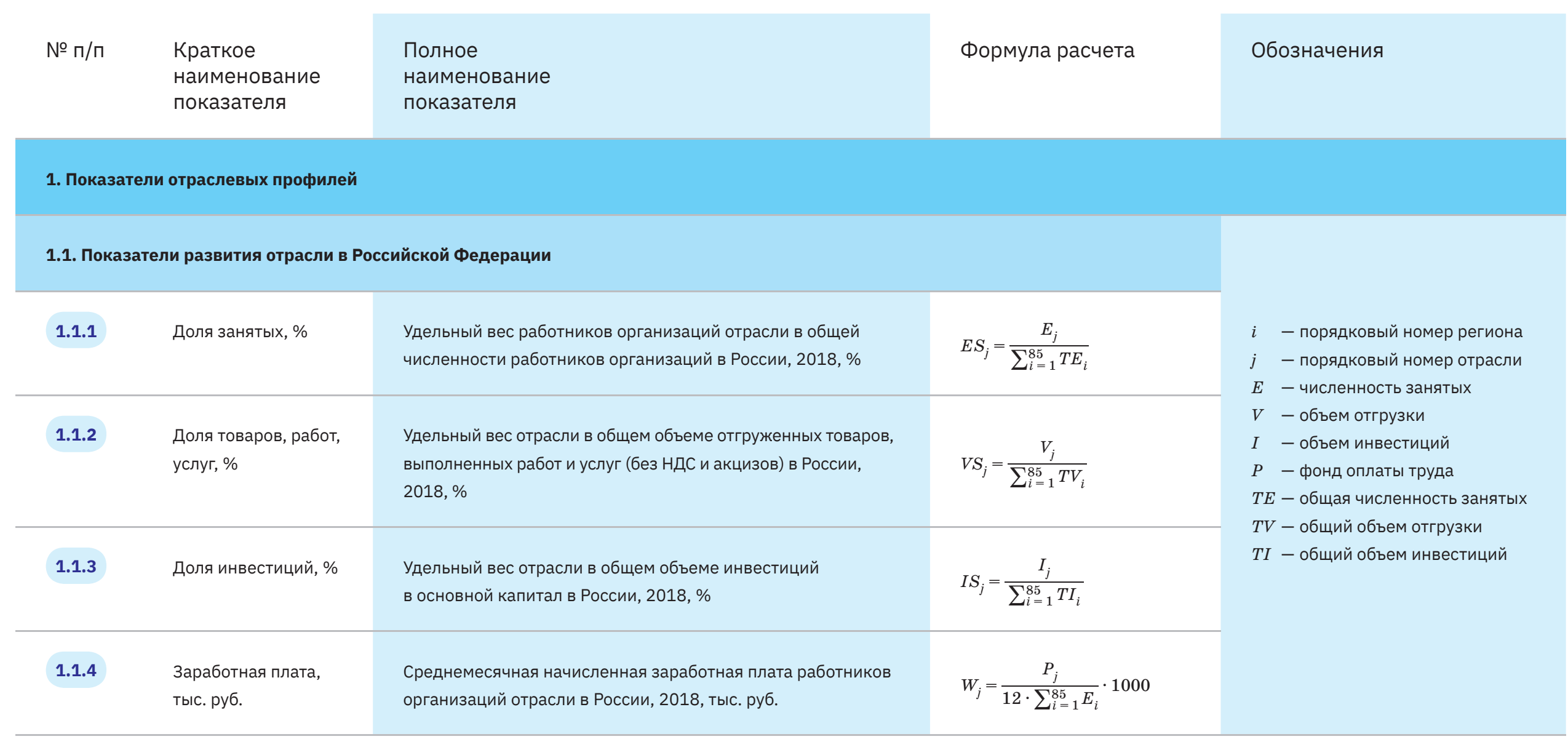


(продолжение)

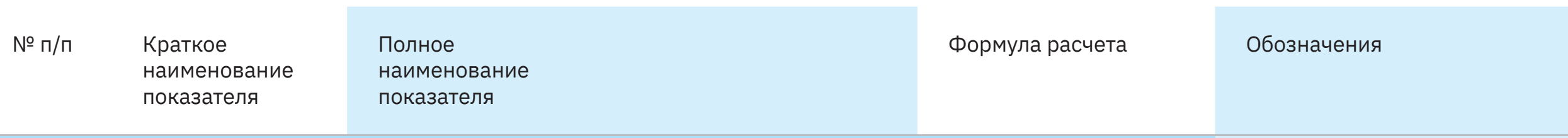

\section{2. Показатели развития отрасли в субъектах Российской Федерации}

\begin{tabular}{|c|c|c|c|}
\hline 1.2.1 & $\begin{array}{l}\text { Доля региона } \\
\text { в отраслевой } \\
\text { занятости, \% }\end{array}$ & $\begin{array}{l}\text { Удельный вес работников организаций отрасли субъекта } \\
\text { Российской Федерации в общей численности работников } \\
\text { организаций отрасли в России, } 2018, \%\end{array}$ & $I E S_{i j}=\frac{E_{i j}}{\sum_{i=1}^{m} E_{i j}}$ \\
\hline 1.2 .2 & $\begin{array}{l}\text { Доля отрасли } \\
\text { в региональной } \\
\text { занятости, \% }\end{array}$ & $\begin{array}{l}\text { Удельный вес работников организаций отрасли в общей } \\
\text { численности работников организаций в субъекте } \\
\text { Российской Федерации, 2018, \% }\end{array}$ & $R E S_{i j}=\frac{E_{i j}}{T E_{i}}$ \\
\hline 1.2 .3 & $\begin{array}{l}\text { Заработная плата, } \\
\text { тыс. руб. }\end{array}$ & $\begin{array}{l}\text { Среднемесячная начисленная заработная плата работников } \\
\text { организаций отрасли в субъекте Российской Федерации, } \\
2018 \text {, тыс. руб. }\end{array}$ & $W_{i j}=\frac{P_{i j}}{12 \cdot E_{i j}} \cdot 1000$ \\
\hline
\end{tabular}


(продолжение)

\begin{tabular}{|c|c|c|c|c|}
\hline № $п / п$ & $\begin{array}{l}\text { Краткое } \\
\text { наименование } \\
\text { показателя }\end{array}$ & $\begin{array}{l}\text { Полное } \\
\text { наименование } \\
\text { показателя }\end{array}$ & Формула расчета & Обозначения \\
\hline \multicolumn{5}{|c|}{ 2. Показатели региональных профилей } \\
\hline 2.1.1 & Доля занятых, \% & $\begin{array}{l}\text { Удельный вес работников организаций отраслей } \\
\text { специализации в общей численности работников } \\
\text { организаций в субъекте Российской Федерации, 2018, \% }\end{array}$ & $S E E S_{i}=\frac{\sum_{k=1}^{z} E_{i k}}{T E_{i}}$ & \multirow{3}{*}{$\begin{array}{c}i \text { - порядковый номер региона } \\
k \text { - порядковый номер отрасли } \\
\quad \text { специализации } \\
z \text { - общее число отраслей } \\
\quad \text { специализации региона } \\
P \text { - фонд оплаты труда } \\
E \text { - общая численность занятых }\end{array}$} \\
\hline 2.1 .2 & Прирост занятых, \% & $\begin{array}{l}\text { Прирост численности работников организаций отраслей } \\
\text { специализации в субъекте Российской Федерации за год, } \\
2018 \text { к 2017, \% }\end{array}$ & $S E E G_{i}=\frac{\sum_{k=1}^{z} E_{k}^{2018}}{\sum_{k=1}^{z} E_{k}^{2017}} \cdot 100 \%$ & \\
\hline 2.1.3 & $\begin{array}{l}\text { Заработная плата, } \\
\text { тыс. руб. }\end{array}$ & $\begin{array}{l}\text { Среднемесячная начисленная заработная плата работников } \\
\text { организаций отраслей специализации в субъекте } \\
\text { Российской Федерации, 2018, тыс. руб. }\end{array}$ & $S E W_{i}=\frac{\sum_{k=1}^{z} P_{i k}}{12 \cdot \sum_{k=1}^{z} E_{i k}} \cdot 1000$ & \\
\hline
\end{tabular}


(продолжение)

\begin{tabular}{|c|c|c|c|c|}
\hline № $п / п$ & $\begin{array}{l}\text { Краткое } \\
\text { наименование } \\
\text { показателя }\end{array}$ & $\begin{array}{l}\text { Полное } \\
\text { наименование } \\
\text { показателя }\end{array}$ & Формула расчета & Обозначения \\
\hline \multicolumn{5}{|c|}{ 3. Показатели рейтинга отраслей специализации субъектов Российской Федерации } \\
\hline \multicolumn{5}{|c|}{ 3.1. Значимость для региона } \\
\hline 3.1.1 & $\begin{array}{l}\text { Доля отрасли } \\
\text { в занятости } \\
\text { региона, \% }\end{array}$ & $\begin{array}{l}\text { Удельный вес работников организаций отрасли в общей } \\
\text { численности работников организаций в субъекте } \\
\text { Российской Федерации, 2018, \% }\end{array}$ & $R E S_{i j}=\frac{E_{i j}}{T E_{i}}$ & $\begin{array}{ll}i & - \text { порядковый номер региона } \\
j & - \text { порядковый номер отрасли } \\
E & - \text { численность занятых } \\
V & - \text { объем отгрузки }\end{array}$ \\
\hline 3.1 .2 & $\begin{array}{l}\text { Доля отрасли } \\
\text { в отгрузке } \\
\text { региона, \% }\end{array}$ & $\begin{array}{l}\text { Удельный вес отрасли в общем объеме отгруженных } \\
\text { товаров, выполненных работ и услуг (без НДС и акцизов) } \\
\text { в субъекте Российской Федерации, 2018, \% }\end{array}$ & $R V S_{i j}=\frac{V_{i j}}{T V_{i}}$ & $\begin{array}{l}I \quad \text { - объем инвестиций } \\
T E \text { - общая численность занятых } \\
T V \text { - общий объем отгрузки } \\
T I \text { - общий объем инвестиций }\end{array}$ \\
\hline 3.1.3 & $\begin{array}{l}\text { Доля отрасли } \\
\text { в инвестициях } \\
\text { региона, \% }\end{array}$ & $\begin{array}{l}\text { Удельный вес отрасли в общем объеме инвестиций } \\
\text { в основной капитал в субъекте Российской Федерации, } \\
2018, \%\end{array}$ & $R I S_{i j}=\frac{I_{i j}}{T I_{i}}$ & \\
\hline
\end{tabular}


(продолжение)

\begin{tabular}{|c|c|c|c|c|}
\hline № $\Pi / \Pi$ & $\begin{array}{l}\text { Краткое } \\
\text { наименование } \\
\text { показателя }\end{array}$ & $\begin{array}{l}\text { Полное } \\
\text { наименование } \\
\text { показателя }\end{array}$ & Формула расчета & Обозначения \\
\hline \multicolumn{5}{|c|}{ 3.2. Значимость для России } \\
\hline 3.2.1 & $\begin{array}{l}\text { Доля региона } \\
\text { в отраслевой } \\
\text { занятости, \% }\end{array}$ & $\begin{array}{l}\text { Удельный вес работников организаций отрасли субъекта } \\
\text { Российской Федерации в общей численности работников } \\
\text { организаций отрасли в России, 2018, \% }\end{array}$ & $I E S_{i j}=\frac{E_{i j}}{\sum_{i=1}^{m} E_{i j}}$ & \\
\hline 3.2.2 & $\begin{array}{l}\text { Доля региона } \\
\text { в отраслевой } \\
\text { отгрузке, \% }\end{array}$ & $\begin{array}{l}\text { Удельный вес субъекта Российской Федерации в общем } \\
\text { объеме отгруженных товаров, выполненных работ и услуг } \\
\text { (без НДС и акцизов) в отрасли в России, 2018, \% }\end{array}$ & $I V S_{i j}=\frac{V_{i j}}{\sum_{i=1}^{m} V_{i j}}$ & \\
\hline 3.2.3 & $\begin{array}{l}\text { Доля региона } \\
\text { в отраслевых } \\
\text { инвестициях, \% }\end{array}$ & $\begin{array}{l}\text { Удельный вес субъекта Российской Федерации в общем } \\
\text { объеме инвестиций в основной капитал в отрасли в России, } \\
2018, \%\end{array}$ & $I I S_{i j}=\frac{I_{i j}}{\sum_{i=1}^{m} I_{i j}}$ & \\
\hline
\end{tabular}


(окончание)

\begin{tabular}{|c|c|c|c|c|}
\hline № $п / п$ & $\begin{array}{l}\text { Краткое } \\
\text { наименование } \\
\text { показателя }\end{array}$ & $\begin{array}{l}\text { Полное } \\
\text { наименование } \\
\text { показателя }\end{array}$ & Формула расчета & Обозначения \\
\hline \multicolumn{5}{|c|}{ 3.3. Предпринимательская активность } \\
\hline 3.3.1 & $\begin{array}{l}\text { Доля МсП } \\
\text { в отрасли, \% }\end{array}$ & $\begin{array}{l}\text { Удельный вес микро-, малых и средних предприятий } \\
\text { в общем числе организаций отрасли в субъекте Российской } \\
\text { Федерации, 2018, \% }\end{array}$ & $S M E_{i j}=\frac{N u m b \_S M E_{i j}}{\text { Total_org }{ }_{i j}}$ & $\begin{array}{c}\text { Numb_SME } \\
\text { - число организаций } \\
\text { Мсп } \\
\text { New_org } \quad-4 \text { чсло новых } \\
\\
\text { организаций }\end{array}$ \\
\hline 3.3.2 & $\begin{array}{l}\text { Доля новых } \\
\text { организаций } \\
\text { в отрасли, \% }\end{array}$ & $\begin{array}{l}\text { Удельный вес организаций, созданных за период с начала } \\
2017 \text { г. по конец } 2018 \text { г., в общем числе организаций отрасли } \\
\text { в субъекте Российской Федерации, 2018, \% }\end{array}$ & $I R_{i j}=\frac{N e w \_o r g_{i j}}{T o t a l \_o r g_{i j}}$ & $\begin{array}{r}\text { Total_org } \\
\quad \text { общее число } \\
\text { организаций }\end{array}$ \\
\hline
\end{tabular}




\section{Приложение 2. Перечень торгуемых отраслей и относящихся к ним видов экономической деятельности}

\begin{tabular}{|c|c|c|c|}
\hline $\begin{array}{l}\text { Наименование } \\
\text { отрасли }\end{array}$ & $\begin{array}{l}\text { Наименование } \\
\text { отрасли (англ.) }\end{array}$ & $\begin{array}{l}\text { Код } \\
\text { ОКВЭД2 }\end{array}$ & Наименование вида экономической деятельности \\
\hline Авиастроение и космос & $\begin{array}{l}\text { Aerospace Vehicles } \\
\text { and Defence }\end{array}$ & 30.30 & Производство летательных аппаратов, включая космические, и соответствующего оборудования \\
\hline \multirow[t]{8}{*}{ Автомобилестроение } & \multirow[t]{8}{*}{ Automotive } & 24.53 & Литье легких металлов \\
\hline & & 24.54 & Литье прочих цветных металлов \\
\hline & & 28.13 & Производство прочих насосов и компрессоров \\
\hline & & 29.10 & Производство автотранспортных средств \\
\hline & & 29.20 & Производство кузовов для автотранспортных средств; производство прицепов и полуприцепов \\
\hline & & 29.31 & Производство электрического и электронного оборудования для автотранспортных средств \\
\hline & & 29.32 & Производство прочих комплектующих и принадлежностей для автотранспортных средств \\
\hline & & 30.40 & Производство военных боевых машин \\
\hline \multirow[t]{2}{*}{ Бытовая техника } & \multirow[t]{2}{*}{ Appliances } & 27.51 & Производство бытовых электрических приборов \\
\hline & & 27.52 & Производство бытовых неэлектрических приборов \\
\hline \multirow{7}{*}{$\begin{array}{l}\text { Вторичные } \\
\text { металлические изделия }\end{array}$} & \multirow{7}{*}{$\begin{array}{l}\text { Downstream Metal } \\
\text { Products }\end{array}$} & 25.29 & Производство прочих металлических цистерн, резервуаров и емкостей \\
\hline & & 25.40 & Производство оружия и боеприпасов \\
\hline & & 25.71 & Производство ножевых изделий и столовых приборов \\
\hline & & 25.72 & Производство замков и петель \\
\hline & & 25.91 & Производство металлических бочек и аналогичных емкостей \\
\hline & & 25.92 & Производство тары из легких металлов \\
\hline & & 25.99 & Производство прочих готовых металлических изделий, не включенных в другие группировки \\
\hline
\end{tabular}


(продолжение)

\begin{tabular}{|c|c|c|c|}
\hline $\begin{array}{l}\text { Наименование } \\
\text { отрасли }\end{array}$ & $\begin{array}{l}\text { Наименование } \\
\text { отрасли (англ.) }\end{array}$ & $\begin{array}{l}\text { Код } \\
\text { ОКВЭД2 }\end{array}$ & Наименование вида экономической деятельности \\
\hline \multirow[t]{21}{*}{ Деловые и ИТ-услуги } & \multirow[t]{21}{*}{ Business Services } & 49.32 & Деятельность такси \\
\hline & & 62.01 & Разработка компьютерного программного обеспечения \\
\hline & & 62.02 & Деятельность консультативная и работы в области компьютерных технологий \\
\hline & & 62.03 & Деятельность по управлению компьютерным оборудованием \\
\hline & & 62.09 & $\begin{array}{l}\text { Деятельность, связанная с использованием вычислительной техники и информационных } \\
\text { технологий, прочая }\end{array}$ \\
\hline & & 63.11 & $\begin{array}{l}\text { Деятельность по обработке данных, предоставление услуг по размещению информации } \\
\text { и связанная с этим деятельность }\end{array}$ \\
\hline & & 64.20 & Деятельность холдинговых компаний \\
\hline & & 70.10 & Деятельность головных офисов \\
\hline & & 70.22 & Консультирование по вопросам коммерческой деятельности и управления \\
\hline & & 71.11 & Деятельность в области архитектуры \\
\hline & & 71.12 & $\begin{array}{l}\text { Деятельность в области инженерных изысканий, инженерно-технического проектирования, } \\
\text { управления проектами строительства, выполнения строительного контроля и авторского надзора, } \\
\text { предоставление технических консультаций в этих областях }\end{array}$ \\
\hline & & 71.20 & Технические испытания, исследования, анализ и сертификация \\
\hline & & 74.30 & Деятельность по письменному и устному переводу \\
\hline & & 74.90 & $\begin{array}{l}\text { Деятельность профессиональная, научная и техническая прочая, не включенная в другие } \\
\text { группировки }\end{array}$ \\
\hline & & 77.12 & Аренда и лизинг грузовых транспортных средств \\
\hline & & 77.40 & Аренда интеллектуальной собственности и подобной продукции, кроме авторских прав \\
\hline & & 78.10 & Деятельность агентств по подбору персонала \\
\hline & & 78.30 & Деятельность по подбору персонала прочая \\
\hline & & 81.10 & Деятельность по комплексному обслуживанию помещений \\
\hline & & 82.20 & Деятельность центров обработки телефонных вызовов \\
\hline & & 82.30 & Деятельность по организации конференций и выставок \\
\hline
\end{tabular}


(продолжение)

\begin{tabular}{|c|c|c|c|}
\hline $\begin{array}{l}\text { Наименование } \\
\text { отрасли }\end{array}$ & $\begin{array}{l}\text { Наименование } \\
\text { отрасли (англ.) }\end{array}$ & $\begin{array}{l}\text { Код } \\
\text { ОКВЭД2 }\end{array}$ & Наименование вида экономической деятельности \\
\hline \multirow{3}{*}{$\begin{array}{l}\text { Деятельность в области } \\
\text { связи }\end{array}$} & \multirow{3}{*}{$\begin{array}{l}\text { Communications } \\
\text { Equipment } \\
\text { and Services }\end{array}$} & 61.20 & Деятельность в области связи на базе беспроводных технологий \\
\hline & & 61.30 & Деятельность в области спутниковой связи \\
\hline & & 61.90 & Деятельность в области телекоммуникаций прочая \\
\hline \multirow{3}{*}{$\begin{array}{l}\text { Добыча металлических } \\
\text { руд }\end{array}$} & \multirow[t]{3}{*}{ Metal Mining } & 07.10 & Добыча и обогащение железных руд \\
\hline & & 07.21 & Добыча урановой и ториевой руд \\
\hline & & 07.29 & Добыча руд прочих цветных металлов \\
\hline \multirow{6}{*}{$\begin{array}{l}\text { Добыча неметаллических } \\
\text { руд }\end{array}$} & \multirow[t]{6}{*}{ Non-metal Mining } & 08.11 & Добыча декоративного и строительного камня, известняка, гипса, мела и сланцев \\
\hline & & 08.12 & Разработка гравийных и песчаных карьеров, добыча глины и каолина \\
\hline & & 08.91 & $\begin{array}{l}\text { Добыча минерального сырья для химической промышленности и производства минеральных } \\
\text { удобрений }\end{array}$ \\
\hline & & 08.92 & Добыча и агломерация торфа \\
\hline & & 08.93 & Добыча соли \\
\hline & & 08.99 & Добыча прочих полезных ископаемых, не включенных в другие группировки \\
\hline \multirow[t]{3}{*}{ Добыча угля } & \multirow[t]{3}{*}{ Coal Mining } & 05.10 & Добыча и обогащение угля и антрацита \\
\hline & & 05.20 & Добыча и обогащение бурого угля (лигнита) \\
\hline & & 09.90 & Предоставление услуг в других областях добычи полезных ископаемых \\
\hline \multirow{7}{*}{$\begin{array}{l}\text { Животноводство } \\
\text { и смешанное сельское } \\
\text { хозяйство }\end{array}$} & \multirow{7}{*}{$\begin{array}{l}\text { Livestock and Mixed } \\
\text { Farming } 20\end{array}$} & 01.41 & Разведение молочного крупного рогатого скота, производство сырого молока \\
\hline & & 01.42 & Разведение прочих пород крупного рогатого скота и буйволов, производство спермы \\
\hline & & 01.43 & Разведение лошадей и прочих животных семейства лошадиных отряда непарнокопытных \\
\hline & & 01.44 & Разведение верблюдов и прочих животных семейства верблюжьих \\
\hline & & 01.45 & Разведение овец и коз \\
\hline & & 01.46 & Разведение свиней \\
\hline & & 01.47 & Разведение сельскохозяйственной птицы \\
\hline
\end{tabular}

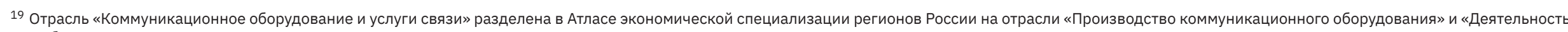
в области связи».

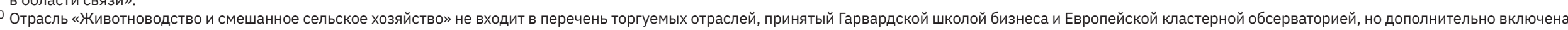
в состав торгуемого сектора в Атласе экономической специализации регионов России. 
(продолжение)

\begin{tabular}{|c|c|c|c|}
\hline $\begin{array}{l}\text { Наименование } \\
\text { отрасли }\end{array}$ & $\begin{array}{l}\text { Наименование } \\
\text { отрасли (англ.) }\end{array}$ & $\begin{array}{l}\text { Код } \\
\text { ОКВЭд2 }\end{array}$ & Наименование вида экономической деятельности \\
\hline & & 01.49 & Разведение прочих животных \\
\hline & & 01.50 & Смешанное сельское хозяйство \\
\hline Звукозапись & $\begin{array}{l}\text { Music and Sound } \\
\text { Recording }\end{array}$ & 59.20 & Деятельность в области звукозаписи и издания музыкальных произведений \\
\hline \multirow{13}{*}{$\begin{array}{l}\text { Издательское дело, } \\
\text { дизайн и маркетинг }\end{array}$} & \multirow{13}{*}{$\begin{array}{l}\text { Marketing, Design, } \\
\text { and Publishing }\end{array}$} & 58.11 & Издание книг \\
\hline & & 58.12 & Издание адресных справочников и списков адресатов \\
\hline & & 58.14 & Издание журналов и периодических изданий \\
\hline & & 58.19 & Виды издательской деятельности прочие \\
\hline & & 63.12 & Деятельность web-порталов \\
\hline & & 63.91 & Деятельность информационных агентств \\
\hline & & 63.99 & Деятельность информационных служб прочая, не включенная в другие группировки \\
\hline & & 70.21 & Деятельность в сфере связей с общественностью \\
\hline & & 73.11 & Деятельность рекламных агентств \\
\hline & & 73.12 & Представление в средствах массовой информации \\
\hline & & 73.20 & Исследование конъюнктуры рынка и изучение общественного мнения \\
\hline & & 74.10 & Деятельность специализированная в области дизайна \\
\hline & & 91.01 & Деятельность библиотек и архивов \\
\hline \multirow[t]{6}{*}{ Изделия из дерева } & \multirow[t]{6}{*}{ Wood Products } & 16.10 & Распиловка и строгание древесины \\
\hline & & 16.21 & Производство шпона, фанеры, деревянных плит и панелей \\
\hline & & 16.22 & Производство сборных паркетных покрытий \\
\hline & & 16.23 & Производство прочих деревянных строительных конструкций и столярных изделий \\
\hline & & 16.24 & Производство деревянной тары \\
\hline & & 16.29 & $\begin{array}{l}\text { Производство прочих деревянных изделий; производство изделий из пробки, соломки } \\
\text { и материалов для плетения }\end{array}$ \\
\hline
\end{tabular}


(продолжение)

\begin{tabular}{|c|c|c|c|}
\hline $\begin{array}{l}\text { Наименование } \\
\text { отрасли }\end{array}$ & $\begin{array}{l}\text { Наименование } \\
\text { отрасли (англ.) }\end{array}$ & $\begin{array}{l}\text { Код } \\
\text { ОКВЭД2 }\end{array}$ & Наименование вида экономической деятельности \\
\hline \multirow[t]{4}{*}{ Киноиндустрия } & \multirow{4}{*}{$\begin{array}{l}\text { Video Production } \\
\text { and Distribution }\end{array}$} & 18.20 & Копирование записанных носителей информации \\
\hline & & 59.11 & Производство кинофильмов, видеофильмов и телевизионных программ \\
\hline & & 59.12 & $\begin{array}{l}\text { Деятельность монтажно-компоновочная в области производства кинофильмов, видеофильмов } \\
\text { и телевизионных программ }\end{array}$ \\
\hline & & 59.13 & Деятельность по распространению кинофильмов, видеофильмов и телевизионных программ \\
\hline Кожаные изделия & $\begin{array}{l}\text { Leather and Related } \\
\text { Products }\end{array}$ & 15.12 & $\begin{array}{l}\text { Производство чемоданов, дамских сумок и аналогичных изделий из кожи и других материалов; } \\
\text { производство шорно-седельных и других изделий из кожи }\end{array}$ \\
\hline \multirow[t]{4}{*}{ Культура } & \multirow[t]{4}{*}{ Performing Arts } & 90.01 & Деятельность в области исполнительских искусств \\
\hline & & 90.02 & Деятельность вспомогательная, связанная с исполнительскими искусствами \\
\hline & & 90.03 & Деятельность в области художественного творчества \\
\hline & & 90.04 & Деятельность учреждений культуры и искусства \\
\hline \multirow[t]{4}{*}{ Лесная промышленность } & \multirow[t]{4}{*}{ Forestry } & 02.10 & Лесоводство и прочая лесохозяйственная деятельность \\
\hline & & 02.20 & Лесозаготовки \\
\hline & & 02.30 & $\begin{array}{l}\text { Сбор и заготовка пищевых лесных ресурсов, недревесных лесных ресурсов и лекарственных } \\
\text { растений }\end{array}$ \\
\hline & & 02.40 & Предоставление услуг в области лесоводства и лесозаготовок \\
\hline \multirow[t]{4}{*}{ Мебель } & \multirow[t]{4}{*}{ Furniture } & 31.01 & Производство мебели для офисов и предприятий торговли \\
\hline & & 31.02 & Производство кухонной мебели \\
\hline & & 31.03 & Производство матрасов \\
\hline & & 31.09 & Производство прочей мебели \\
\hline \multirow[t]{4}{*}{ Медицинские услуги } & \multirow[t]{4}{*}{ Medical Services ${ }^{21}$} & 86.10 & Деятельность больничных организаций \\
\hline & & 86.21 & Общая врачебная практика \\
\hline & & 86.22 & Специальная врачебная практика \\
\hline & & 86.23 & Стоматологическая практика \\
\hline
\end{tabular}

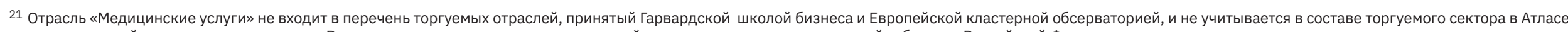
экономической специализации регионов России, но включается в перечень отраслей при определении специализаций субъектов Российской Федерации. 
(продолжение)

\begin{tabular}{|c|c|c|c|}
\hline $\begin{array}{l}\text { Наименование } \\
\text { отрасли }\end{array}$ & $\begin{array}{l}\text { Наименование } \\
\text { отрасли (англ.) }\end{array}$ & $\begin{array}{l}\text { Код } \\
\text { ОКВЭД2 }\end{array}$ & Наименование вида экономической деятельности \\
\hline \multirow[t]{2}{*}{ Медоборудование } & \multirow[t]{2}{*}{ Medical Devices } & 26.60 & $\begin{array}{l}\text { Производство облучающего и электротерапевтического оборудования, применяемого } \\
\text { в медицинских целях }\end{array}$ \\
\hline & & 32.50 & Производство медицинских инструментов и оборудования \\
\hline \multirow{15}{*}{$\begin{array}{l}\text { Металлообрабатывающая } \\
\text { промышленность }\end{array}$} & \multirow{15}{*}{$\begin{array}{l}\text { Upstream Metal } \\
\text { Manufacturing }\end{array}$} & 24.10 & Производство чугуна, стали и ферросплавов \\
\hline & & 24.31 & Производство стальных прутков и сплошных профилей методом холодного волочения \\
\hline & & 24.32 & Производство холоднотянутого штрипса \\
\hline & & 24.33 & Производство профилей с помощью холодной штамповки или гибки \\
\hline & & 24.34 & Производство проволоки методом холодного волочения \\
\hline & & 24.41 & Производство драгоценных металлов \\
\hline & & 24.42 & Производство алюминия \\
\hline & & 24.43 & Производство свинца, цинка и олова \\
\hline & & 24.44 & Производство меди \\
\hline & & 24.45 & Производство прочих цветных металлов \\
\hline & & 24.46 & Производство ядерного топлива \\
\hline & & 24.51 & Литье чугуна \\
\hline & & 24.52 & Литье стали \\
\hline & & 25.50 & $\begin{array}{l}\text { Ковка, прессование, штамповка и профилирование, изготовление изделий методом порошковой } \\
\text { металлургии }\end{array}$ \\
\hline & & 25.93 & Производство изделий из проволоки, цепей и пружин \\
\hline \multirow{6}{*}{$\begin{array}{l}\text { Микроэлектроника } \\
\text { и приборостроение }\end{array}$} & \multirow{6}{*}{$\begin{array}{l}\text { Information } \\
\text { Technology } \\
\text { and Analytical } \\
\text { Instruments }\end{array}$} & 26.11 & Производство элементов электронной аппаратуры \\
\hline & & 26.12 & Производство электронных печатных плат \\
\hline & & 26.20 & Производство компьютеров и периферийного оборудования \\
\hline & & 26.40 & Производство бытовой электроники \\
\hline & & 26.51 & Производство инструментов и приборов для измерения, тестирования и навигации \\
\hline & & 26.52 & Производство часов \\
\hline
\end{tabular}


(продолжение)

\begin{tabular}{|c|c|c|c|}
\hline $\begin{array}{l}\text { Наименование } \\
\text { отрасли }\end{array}$ & $\begin{array}{l}\text { Наименование } \\
\text { отрасли (англ.) }\end{array}$ & $\begin{array}{l}\text { Код } \\
\text { ОКВЭД2 }\end{array}$ & Наименование вида экономической деятельности \\
\hline & & 26.70 & Производство оптических приборов, фото- и кинооборудования \\
\hline & & 26.80 & Производство незаписанных магнитных и оптических технических носителей информации \\
\hline & & 58.21 & Издание компьютерных игр \\
\hline & & 58.29 & Издание прочих программных продуктов \\
\hline \multirow[t]{3}{*}{ Мясная продукция } & \multirow[t]{3}{*}{ Livestock Processing } & 10.11 & Переработка и консервирование мяса \\
\hline & & 10.12 & Производство и консервирование мяса птицы \\
\hline & & 10.13 & Производство продукции из мяса убойных животных и мяса птицы \\
\hline \multirow[t]{3}{*}{ Наука } & \multirow{3}{*}{$\begin{array}{l}\text { Education } \\
\text { and Knowledge } \\
\text { Creation }^{22}\end{array}$} & 72.11 & Научные исследования и разработки в области биотехнологии \\
\hline & & 72.19 & Научные исследования и разработки в области естественных и технических наук прочие \\
\hline & & 72.20 & Научные исследования и разработки в области общественных и гуманитарных наук \\
\hline \multirow[t]{7}{*}{ Образование } & \multirow{7}{*}{$\begin{array}{l}\text { Education } \\
\text { and Knowledge } \\
\text { Creation }^{22}\end{array}$} & 85.21 & Образование профессиональное среднее \\
\hline & & 85.22 & Образование высшее \\
\hline & & 85.23 & Подготовка кадров высшей квалификации \\
\hline & & 85.41 .2 & Образование в области культуры \\
\hline & & 85.41 .9 & Образование дополнительное детей и взрослых прочее, не включенное в другие группировки \\
\hline & & 85.42 .9 & $\begin{array}{l}\text { Деятельность по дополнительному профессиональному образованию прочая, не включенная } \\
\text { в другие группировки }\end{array}$ \\
\hline & & 94.12 & Деятельность профессиональных членских организаций \\
\hline \multirow[t]{2}{*}{ Обувь } & \multirow[t]{2}{*}{ Footwear } & 15.11 & Дубление и выделка кожи, выделка и крашение меха \\
\hline & & 15.20 & Производство обуви \\
\hline \multirow{3}{*}{$\begin{array}{l}\text { Огнеупорные материалы } \\
\text { и резиновые изделия }\end{array}$} & \multirow{3}{*}{$\begin{array}{l}\text { Vulcanized and Fired } \\
\text { Materials }\end{array}$} & 22.11 & Производство резиновых шин, покрышек и камер; восстановление резиновых шин и покрышек \\
\hline & & 22.19 & Производство прочих резиновых изделий \\
\hline & & 23.11 & Производство листового стекла \\
\hline
\end{tabular}

\footnotetext{
22 Отрасль «Образование и наука» разделена в Атласе экономической специализации регионов России на отрасли «Образование» и «Наука».
} 
(продолжение)

\begin{tabular}{|c|c|c|c|}
\hline $\begin{array}{l}\text { Наименование } \\
\text { отрасли }\end{array}$ & $\begin{array}{l}\text { Наименование } \\
\text { отрасли (англ.) }\end{array}$ & $\begin{array}{l}\text { Код } \\
\text { ОКВЭД2 }\end{array}$ & Наименование вида экономической деятельности \\
\hline & & 23.12 & Формирование и обработка листового стекла \\
\hline & & 23.13 & Производство полых стеклянных изделий \\
\hline & & 23.19 & Производство и обработка прочих стеклянных изделий, включая технические изделия из стекла \\
\hline & & 23.20 & Производство огнеупорных изделий \\
\hline & & 23.31 & Производство керамических плит и плиток \\
\hline & & 23.32 & Производство кирпича, черепицы и прочих строительных изделий из обожженной глины \\
\hline & & 23.41 & Производство хозяйственных и декоративных керамических изделий \\
\hline & & 23.43 & Производство керамических изоляторов и изолирующей арматуры \\
\hline & & 23.44 & Производство прочих технических керамических изделий \\
\hline & & 23.49 & Производство прочих керамических изделий \\
\hline \multirow[t]{6}{*}{ Одежда } & \multirow[t]{6}{*}{ Apparel } & 14.11 & Производство одежды из кожи \\
\hline & & 14.12 & Производство спецодежды \\
\hline & & 14.13 & Производство прочей верхней одежды \\
\hline & & 14.14 & Производство нательного белья \\
\hline & & 14.19 & Производство прочей одежды и аксессуаров одежды \\
\hline & & 14.20 & Производство меховых изделий \\
\hline \multirow[t]{5}{*}{$\begin{array}{l}\text { Оптовая торговля } \\
\text { и электронная коммерция }\end{array}$} & \multirow{5}{*}{$\begin{array}{l}\text { Distribution } \\
\text { and Electronic } \\
\text { Commerce }\end{array}$} & 46.11 & $\begin{array}{l}\text { Деятельность агентов по оптовой торговле сельскохозяйственным сырьем, живыми животными, } \\
\text { текстильным сырьем и полуфабрикатами }\end{array}$ \\
\hline & & 46.12 & $\begin{array}{l}\text { Деятельность агентов по оптовой торговле топливом, рудами, металлами и химическими } \\
\text { веществами }\end{array}$ \\
\hline & & 46.13 & Деятельность агентов по оптовой торговле лесоматериалами и строительными материалами \\
\hline & & 46.14 & $\begin{array}{l}\text { Деятельность агентов по оптовой торговле машинами, промышленным оборудованием, судами } \\
\text { и летательными аппаратами }\end{array}$ \\
\hline & & 46.15 & $\begin{array}{l}\text { Деятельность агентов по оптовой торговле мебелью, бытовыми товарами, скобяными, ножевыми } \\
\text { и прочими металлическими изделиями }\end{array}$ \\
\hline
\end{tabular}


(продолжение)

Наименование отрасли

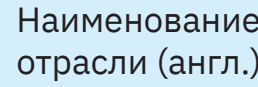

\section{Код ОКВЭД2}

46.16

46.17

46.18

46.19

46.21

46.22

46.23

46.24

46.31

46.32

46.34

46.35

46.38

46.41

46.42

46.43

46.44

46.45

46.46

46.47

46.48

46.49

\section{Наименование вида экономической деятельности}

Деятельность агентов по оптовой торговле текстильными изделиями, одеждой, обувью, изделиями из кожи и меха

Деятельность агентов по оптовой торговле пищевыми продуктами, напитками и табачными изделиями

Деятельность агентов, специализирующихся на оптовой торговле прочими отдельными видами товаров

Деятельность агентов по оптовой торговле универсальным ассортиментом товаров

Торговля оптовая зерном, необработанным табаком, семенами и кормами для сельскохозяйственных животных

Торговля оптовая цветами и растениями

Торговля оптовая живыми животными

Торговля оптовая шкурами и кожей

Торговля оптовая фруктами и овощами

Торговля оптовая мясом и мясными продуктами

Торговля оптовая напитками

Торговля оптовая табачными изделиями

Торговля оптовая прочими пищевыми продуктами, включая рыбу, ракообразных и моллюсков

Торговля оптовая текстильными изделиями

Торговля оптовая одеждой и обувью

Торговля оптовая бытовыми электротоварами

Торговля оптовая изделиями из керамики и стекла и чистящими средствами

Торговля оптовая парфюмерными и косметическими товарами

Торговля оптовая фармацевтической продукцией

Торговля оптовая мебелью, коврами и осветительным оборудованием

Торговля оптовая часами и ювелирными изделиями

Торговля оптовая прочими бытовыми товарами 
(продолжение)

Наименование отрасли

\section{Наименование отрасли (англ.)

Код
ОКВЭД2

46.51

\section{Наименование вида экономической деятельности}

Торговля оптовая компьютерами, периферийными устройствами к компьютерам и программным обеспечением

46.52 Торговля оптовая электронным и телекоммуникационным оборудованием и его запасными частями

46.61 Торговля оптовая машинами, оборудованием и инструментами для сельского хозяйства

46.62 Торговля оптовая станками

46.63 Торговля оптовая машинами и оборудованием для добычи полезных ископаемых и строительства

46.64 Торговля оптовая машинами и оборудованием для текстильного, швейного и трикотажного производств

Торговля оптовая офисной мебелью

46.66 Торговля оптовая прочей офисной техникой и оборудованием

46.69 Торговля оптовая прочими машинами и оборудованием

46.71 Торговля оптовая твердым, жидким и газообразным топливом и подобными продуктами

46.72 Торговля оптовая металлами и металлическими рудами

46.76 Торговля оптовая прочими промежуточными продуктами

47.91 Торговля розничная по почте или по информационно-коммуникационной сети Интернет

52.10 Деятельность по складированию и хранению

77.31 Аренда и лизинг сельскохозяйственных машин и оборудования

77.32 Аренда и лизинг строительных машин и оборудования

77.33 Аренда и лизинг офисных машин и оборудования, включая вычислительную технику

77.34 Аренда и лизинг водных транспортных средств и оборудования

77.35 Аренда и лизинг воздушных судов и авиационного оборудования

77.39 Аренда и лизинг прочих видов транспорта, оборудования и материальных средств, не включенных в другие группировки

82.92 Деятельность по упаковыванию товаров 
(продолжение)

\begin{tabular}{|c|c|c|c|}
\hline $\begin{array}{l}\text { Наименование } \\
\text { отрасли }\end{array}$ & $\begin{array}{l}\text { Наименование } \\
\text { отрасли (англ.) }\end{array}$ & $\begin{array}{l}\text { Код } \\
\text { ОКВЭД2 }\end{array}$ & Наименование вида экономической деятельности \\
\hline \multirow[t]{8}{*}{$\begin{array}{l}\text { Офисное оборудование } \\
\text { и товары для досуга }\end{array}$} & \multirow[t]{8}{*}{$\begin{array}{l}\text { Recreational and Small } \\
\text { Electric Goods }\end{array}$} & 28.23 & $\begin{array}{l}\text { Производство офисной техники и оборудования (кроме компьютеров и периферийного } \\
\text { оборудования) }\end{array}$ \\
\hline & & 30.91 & Производство мотоциклов \\
\hline & & 30.92 & Производство велосипедов и инвалидных колясок \\
\hline & & 32.20 & Производство музыкальных инструментов \\
\hline & & 32.30 & Производство спортивных товаров \\
\hline & & 32.40 & Производство игр и игрушек \\
\hline & & 32.91 & Производство метел и щеток \\
\hline & & 32.99 & Производство прочих готовых изделий, не включенных в другие группировки \\
\hline \multirow{4}{*}{$\begin{array}{l}\text { Очистка и распределение } \\
\text { воды, обработка отходов }\end{array}$} & \multirow[t]{4}{*}{ Environmental Services } & 36.00 & Забор, очистка и распределение воды \\
\hline & & 38.12 & Сбор опасных отходов \\
\hline & & 38.22 & Обработка и утилизация опасных отходов \\
\hline & & 38.32 & Утилизация отсортированных материалов \\
\hline \multirow{9}{*}{$\begin{array}{l}\text { Первичные } \\
\text { металлические изделия }\end{array}$} & \multirow{9}{*}{$\begin{array}{l}\text { Metalworking } \\
\text { Technology }\end{array}$} & 23.91 & Производство абразивных изделий \\
\hline & & 25.11 & Производство строительных металлических конструкций, изделий и их частей \\
\hline & & 25.12 & Производство металлических дверей и окон \\
\hline & & 25.61 & Обработка металлов и нанесение покрытий на металлы \\
\hline & & 25.62 & Обработка металлических изделий механическая \\
\hline & & 25.73 & Производство инструмента \\
\hline & & 25.94 & Производство крепежных изделий \\
\hline & & 28.41 & Производство металлообрабатывающего оборудования \\
\hline & & 28.91 & Производство машин и оборудования для металлургии \\
\hline \multirow[t]{3}{*}{ Пластмассовые изделия } & \multirow[t]{3}{*}{ Plastics } & 20.16 & Производство пластмасс и синтетических смол в первичных формах \\
\hline & & 22.21 & Производство пластмассовых плит, полос, труб и профилей \\
\hline & & 22.22 & Производство пластмассовых изделий для упаковывания товаров \\
\hline
\end{tabular}


(продолжение)

\begin{tabular}{|c|c|c|c|}
\hline $\begin{array}{l}\text { Наименование } \\
\text { отрасли }\end{array}$ & $\begin{array}{l}\text { Наименование } \\
\text { отрасли (англ.) }\end{array}$ & $\begin{array}{l}\text { Код } \\
\text { ОКВЭД2 }\end{array}$ & Наименование вида экономической деятельности \\
\hline & & 22.23 & Производство пластмассовых изделий, используемых в строительстве \\
\hline & & 22.29 & Производство прочих пластмассовых изделий \\
\hline & & 28.96 & Производство машин и оборудования для переработки пластмасс и резины \\
\hline \multirow[t]{4}{*}{ Полиграфия и печать } & \multirow{4}{*}{ Printing Services } & 18.11 & Печатание газет \\
\hline & & 18.12 & Прочие виды полиграфической деятельности \\
\hline & & 18.13 & Изготовление печатных форм и подготовительная деятельность \\
\hline & & 18.14 & Деятельность брошюровочно-переплетная и отделочная и сопутствующие услуги \\
\hline \multirow[t]{16}{*}{ Продукты питания } & \multirow{16}{*}{$\begin{array}{l}\text { Food Processing } \\
\text { and Manufacturing }\end{array}$} & 10.31 & Переработка и консервирование картофеля \\
\hline & & 10.32 & Производство соковой продукции из фруктов и овощей \\
\hline & & 10.39 & Прочие виды переработки и консервирования фруктов и овощей \\
\hline & & 10.41 & Производство масел и жиров \\
\hline & & 10.42 & Производство маргариновой продукции \\
\hline & & 10.51 & Производство молока (кроме сырого) и молочной продукции \\
\hline & & 10.52 & Производство мороженого \\
\hline & & 10.61 & Производство продуктов мукомольной и крупяной промышленности \\
\hline & & 10.62 & Производство крахмала и крахмалосодержащих продуктов \\
\hline & & 10.72 & $\begin{array}{l}\text { Производство сухарей, печенья и прочих сухарных хлебобулочных изделий, производство } \\
\text { мучных кондитерских изделий, тортов, пирожных, пирогов и бисквитов, предназначенных } \\
\text { для длительного хранения }\end{array}$ \\
\hline & & 10.73 & Производство макаронных изделий кускуса и аналогичных мучных изделий \\
\hline & & 10.81 & Производство сахара \\
\hline & & 10.82 & Производство какао, шоколада и сахаристых кондитерских изделий \\
\hline & & 10.83 & Производство чая и кофе \\
\hline & & 10.84 & Производство приправ и пряностей \\
\hline & & 10.85 & Производство готовых пищевых продуктов и блюд \\
\hline
\end{tabular}


(продолжение)

\begin{tabular}{|c|c|c|c|}
\hline $\begin{array}{l}\text { Наименование } \\
\text { отрасли }\end{array}$ & $\begin{array}{l}\text { Наименование } \\
\text { отрасли (англ.) }\end{array}$ & $\begin{array}{l}\text { Код } \\
\text { ОКВЭД2 }\end{array}$ & Наименование вида экономической деятельности \\
\hline & & 10.86 & Производство детского питания и диетических пищевых продуктов \\
\hline & & 10.89 & Производство прочих пищевых продуктов, не включенных в другие группировки \\
\hline & & 10.91 & Производство готовых кормов для животных, содержащихся на фермах \\
\hline & & 10.92 & Производство готовых кормов для домашних животных \\
\hline & & 11.01 & Перегонка, очистка и смешивание спиртов \\
\hline & & 11.02 & Производство вина из винограда \\
\hline & & 11.03 & Производство сидра и прочих плодовых вин \\
\hline & & 11.04 & Производство прочих недистиллированных напитков из сброженных материалов \\
\hline & & 11.05 & Производство пива \\
\hline & & 11.06 & Производство солода \\
\hline & & 11.07 & $\begin{array}{l}\text { Производство безалкогольных напитков; производство минеральных вод и прочих питьевых вод } \\
\text { в бутылках }\end{array}$ \\
\hline \multirow{2}{*}{$\begin{array}{l}\text { Производство и передача } \\
\text { электроэнергии }\end{array}$} & \multirow{2}{*}{$\begin{array}{l}\text { Electric Power } \\
\text { Generation } \\
\text { and Transmission }\end{array}$} & 35.11 & Производство электроэнергии \\
\hline & & 35.12 & Передача электроэнергии и технологическое присоединение к распределительным электросетям \\
\hline \multirow{6}{*}{$\begin{array}{l}\text { Производство } \\
\text { и транспортировка } \\
\text { нефти и газа }\end{array}$} & \multirow{6}{*}{$\begin{array}{l}\text { Oil and Gas Production } \\
\text { and Transportation }\end{array}$} & 06.10 & Добыча сырой нефти и нефтяного (попутного) газа \\
\hline & & 06.20 & Добыча природного газа и газового конденсата \\
\hline & & 09.10 & Предоставление услуг в области добычи нефти и природного газа \\
\hline & & 19.10 & Производство кокса \\
\hline & & 19.20 & Производство нефтепродуктов \\
\hline & & 49.50 & Деятельность трубопроводного транспорта \\
\hline $\begin{array}{l}\text { Производство } \\
\text { коммуникационного } \\
\text { оборудования }\end{array}$ & $\begin{array}{l}\text { Communications } \\
\text { Equipment } \\
\text { and Services } \\
\text { 23 }\end{array}$ & 26.30 & Производство коммуникационного оборудования \\
\hline
\end{tabular}

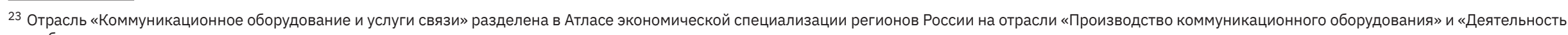
в области связи». 
(продолжение)

\begin{tabular}{|c|c|c|c|}
\hline $\begin{array}{l}\text { Наименование } \\
\text { отрасли }\end{array}$ & $\begin{array}{l}\text { Наименование } \\
\text { отрасли (англ.) }\end{array}$ & $\begin{array}{l}\text { Код } \\
\text { ОКВЭд2 }\end{array}$ & Наименование вида экономической деятельности \\
\hline \multirow[t]{17}{*}{ Растениеводство } & \multirow[t]{17}{*}{ Plant Growing ${ }^{24}$} & 01.11 & Выращивание зерновых (кроме риса), зернобобовых культур и семян масличных культур \\
\hline & & 01.12 & Выращивание риса \\
\hline & & 01.13 & Выращивание овощей, бахчевых, корнеплодных и клубнеплодных культур, грибов и трюфелей \\
\hline & & 01.14 & Выращивание сахарного тростника \\
\hline & & 01.15 & Выращивание табака и махорки \\
\hline & & 01.16 & Выращивание волокнистых прядильных культур \\
\hline & & 01.19 & Выращивание прочих однолетних культур \\
\hline & & 01.21 & Выращивание винограда \\
\hline & & 01.22 & Выращивание тропических и субтропических культур \\
\hline & & 01.23 & Выращивание цитрусовых культур \\
\hline & & 01.24 & Выращивание семечковых и косточковых культур \\
\hline & & 01.25 & Выращивание прочих плодовых деревьев, кустарников и орехов \\
\hline & & 01.26 & Выращивание плодов масличных культур \\
\hline & & 01.27 & Выращивание культур для производства напитков \\
\hline & & 01.28 & Выращивание специй, пряно-ароматических, эфиромасличных и лекарственных культур \\
\hline & & 01.29 & Выращивание прочих многолетних культур \\
\hline & & 01.30 & Выращивание рассады \\
\hline \multirow{3}{*}{$\begin{array}{l}\text { Рыболовство } \\
\text { и производство } \\
\text { рыбопродуктов }\end{array}$} & \multirow{3}{*}{$\begin{array}{l}\text { Fishing and Fishing } \\
\text { Products }\end{array}$} & 03.11 & Рыболовство морское \\
\hline & & 03.12 & Рыболовство пресноводное \\
\hline & & 10.20 & Переработка и консервирование рыбы, ракообразных и моллюсков \\
\hline \multirow{3}{*}{$\begin{array}{l}\text { Сельскохозяйственные } \\
\text { услуги и производство } \\
\text { удобрений }\end{array}$} & \multirow{3}{*}{$\begin{array}{l}\text { Agricultural Inputs } \\
\text { and Services }\end{array}$} & 01.61 & Предоставление услуг в области растениеводства \\
\hline & & 01.62 & Предоставление услуг в области животноводства \\
\hline & & 01.63 & Деятельность сельскохозяйственная после сбора урожая \\
\hline
\end{tabular}

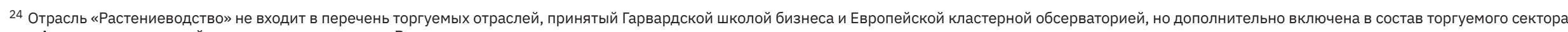
в Атласе экономической специализации регионов России. 
(продолжение)

\begin{tabular}{|c|c|c|c|}
\hline \multirow[t]{3}{*}{$\begin{array}{l}\text { Наименование } \\
\text { отрасли }\end{array}$} & $\begin{array}{l}\text { Наименование } \\
\text { отрасли (англ.) }\end{array}$ & $\begin{array}{l}\text { Код } \\
\text { ОКВЭД2 }\end{array}$ & Наименование вида экономической деятельности \\
\hline & & 01.64 & Обработка семян для посадки \\
\hline & & 20.15 & Производство удобрений и азотных соединений \\
\hline \multirow[t]{5}{*}{ Страхование } & \multirow[t]{5}{*}{ Insurance Services } & 65.11 & Страхование жизни \\
\hline & & 65.12 & Страхование, кроме страхования жизни \\
\hline & & 65.20 & Перестрахование \\
\hline & & 66.21 & Оценка рисков и ущерба \\
\hline & & 66.29 & Деятельность вспомогательная прочая в сфере страхования и пенсионного обеспечения \\
\hline \multirow{15}{*}{$\begin{array}{l}\text { Строительство и } \\
\text { строительные материалы }\end{array}$} & \multirow{15}{*}{$\begin{array}{l}\text { Construction Products } \\
\text { and Services }\end{array}$} & 23.14 & Производство стекловолокна \\
\hline & & 23.51 & Производство цемента \\
\hline & & 23.52 & Производство извести и гипса \\
\hline & & 23.61 & Производство изделий из бетона для использования в строительстве \\
\hline & & 23.62 & Производство гипсовых изделий для использования в строительстве \\
\hline & & 23.64 & Производство сухих бетонных смесей \\
\hline & & 23.65 & Производство изделий из асбестоцемента и волокнистого цемента \\
\hline & & 23.70 & Резка, обработка и отделка камня \\
\hline & & 23.99 & $\begin{array}{l}\text { Производство прочей неметаллической минеральной продукции, не включенной в другие } \\
\text { группировки }\end{array}$ \\
\hline & & 24.20 & Производство стальных труб, полых профилей и фитингов \\
\hline & & 25.30 & Производство паровых котлов, кроме котлов центрального отопления \\
\hline & & 35.30 & Производство, передача и распределение пара и горячей воды; кондиционирование воздуха \\
\hline & & 42.12 & Строительство железных дорог и метро \\
\hline & & 42.22 & Строительство коммунальных объектов для обеспечения электроэнергией и телекоммуникациями \\
\hline & & 42.91 & Строительство водных сооружений \\
\hline
\end{tabular}


(продолжение)

\begin{tabular}{|c|c|c|c|}
\hline $\begin{array}{l}\text { Наименование } \\
\text { отрасли }\end{array}$ & $\begin{array}{l}\text { Наименование } \\
\text { отрасли (англ.) }\end{array}$ & $\begin{array}{l}\text { Код } \\
\text { ОКВЭД2 }\end{array}$ & Наименование вида экономической деятельности \\
\hline \multirow{9}{*}{$\begin{array}{l}\text { Судостроение и водный } \\
\text { транспорт }\end{array}$} & \multirow[t]{9}{*}{ Water Transportation } & 30.11 & Строительство кораблей, судов и плавучих конструкций \\
\hline & & 30.12 & Строительство прогулочных и спортивных судов \\
\hline & & 33.15 & Ремонт и техническое обслуживание судов и лодок \\
\hline & & 38.31 & Демонтаж техники, не подлежащей восстановлению \\
\hline & & 50.10 & Деятельность морского пассажирского транспорта \\
\hline & & 50.20 & Деятельность морского грузового транспорта \\
\hline & & 50.30 & Деятельность внутреннего водного пассажирского транспорта \\
\hline & & 50.40 & Деятельность внутреннего водного грузового транспорта \\
\hline & & 52.22 & Деятельность вспомогательная, связанная с водным транспортом \\
\hline Табачные изделия & Tobacco & 12.00 & Производство табачных изделий \\
\hline \multirow{13}{*}{$\begin{array}{l}\text { Текстильное } \\
\text { производство }\end{array}$} & \multirow[t]{13}{*}{ Textile Manufacturing } & 13.10 & Подготовка и прядение текстильных волокон \\
\hline & & 13.20 & Производство текстильных тканей \\
\hline & & 13.30 & Отделка тканей и текстильных изделий \\
\hline & & 13.91 & Производство трикотажного и вязаного полотна \\
\hline & & 13.92 & Производство готовых текстильных изделий, кроме одежды \\
\hline & & 13.93 & Производство ковров и ковровых изделий \\
\hline & & 13.94 & Производство канатов, веревок, шпагата и сетей \\
\hline & & 13.95 & Производство нетканых текстильных материалов и изделий из них, кроме одежды \\
\hline & & 13.96 & Производство прочих технических и промышленных текстильных изделий \\
\hline & & 13.99 & Производство прочих текстильных изделий, не включенных в другие группировки \\
\hline & & 14.31 & Производство вязаных и трикотажных чулочно-носочных изделий \\
\hline & & 14.39 & Производство прочих вязаных и трикотажных изделий \\
\hline & & 20.60 & Производство химических волокон \\
\hline
\end{tabular}


(продолжение)

\begin{tabular}{|c|c|c|c|}
\hline $\begin{array}{l}\text { Наименование } \\
\text { отрасли }\end{array}$ & $\begin{array}{l}\text { Наименование } \\
\text { отрасли (англ.) }\end{array}$ & $\begin{array}{l}\text { Код } \\
\text { ОКВЭД2 }\end{array}$ & Наименование вида экономической деятельности \\
\hline \multirow[t]{10}{*}{ Транспорт и логистика } & \multirow{10}{*}{$\begin{array}{l}\text { Transportation } \\
\text { and Logistics }\end{array}$} & 33.16 & Ремонт и техническое обслуживание летательных аппаратов, включая космические \\
\hline & & 49.39 & $\begin{array}{l}\text { Деятельность прочего сухопутного пассажирского транспорта, не включенная в другие } \\
\text { группировки }\end{array}$ \\
\hline & & 49.41 & Деятельность автомобильного грузового транспорта \\
\hline & & 51.10 & Деятельность пассажирского воздушного транспорта \\
\hline & & 51.21 & Деятельность грузового воздушного транспорта \\
\hline & & 51.22 & Деятельность космического транспорта \\
\hline & & 52.21 & Деятельность вспомогательная, связанная с сухопутным транспортом \\
\hline & & 52.23 & Деятельность вспомогательная, связанная с воздушным и космическим транспортом \\
\hline & & 52.24 & Транспортная обработка грузов \\
\hline & & 52.29 & Деятельность вспомогательная прочая, связанная с перевозками \\
\hline \multirow[t]{12}{*}{ Туризм } & \multirow[t]{12}{*}{ Hospitality and Tourism } & 01.70 & Охота, отлов и отстрел диких животных, включая предоставление услуг в этих областях \\
\hline & & 55.10 & Деятельность гостиниц и прочих мест для временного проживания \\
\hline & & 55.20 & Деятельность по предоставлению мест для краткосрочного проживания \\
\hline & & 55.30 & $\begin{array}{l}\text { Деятельность по предоставлению мест для временного проживания в кемпингах, } \\
\text { жилых автофургонах и туристических автоприцепах }\end{array}$ \\
\hline & & 55.90 & Деятельность по предоставлению прочих мест для временного проживания \\
\hline & & 77.21 & Прокат и аренда товаров для отдыха и спортивных товаров \\
\hline & & 79.11 & Деятельность туристических агентств \\
\hline & & 79.12 & Деятельность туроператоров \\
\hline & & 79.90 & Услуги по бронированию прочие и сопутствующая деятельность \\
\hline & & 91.02 & Деятельность музеев \\
\hline & & 91.03 & Деятельность по охране исторических мест и зданий, памятников культуры \\
\hline & & 91.04 & $\begin{array}{l}\text { Деятельность ботанических садов, зоопарков, государственных природных заповедников } \\
\text { и национальных парков }\end{array}$ \\
\hline
\end{tabular}


(продолжение)

Наименование отрасли

отрасли

Тяжелое машиностроение

\begin{tabular}{|c|c|c|}
\hline $\begin{array}{l}\text { Наименование } \\
\text { отрасли (англ.) }\end{array}$ & $\begin{array}{l}\text { Код } \\
\text { ОКВЭД2 }\end{array}$ & Наименование вида экономической деятельности \\
\hline & 92.11 & Деятельность казино \\
\hline & 92.12 & Деятельность залов игровых автоматов \\
\hline & 92.13 & Деятельность по организации заключения пари \\
\hline & 93.11 & Деятельность спортивных объектов \\
\hline & 93.12 & Деятельность спортивных клубов \\
\hline & 93.19 & Деятельность в области спорта прочая \\
\hline & 93.21 & Деятельность парков культуры и отдыха и тематических парков \\
\hline & 93.29 & Деятельность зрелищно-развлекательная прочая \\
\hline \multirow{14}{*}{$\begin{array}{l}\text { Production Technology } \\
\text { and Heavy Machinery }\end{array}$} & 25.21 & Производство радиаторов и котлов центрального отопления \\
\hline & 28.11 & $\begin{array}{l}\text { Производство двигателей и турбин, кроме авиационных, автомобильных и мотоциклетных } \\
\text { двигателей }\end{array}$ \\
\hline & 28.12 & Производство гидравлического и пневматического силового оборудования \\
\hline & 28.14 & Производство прочих кранов и клапанов \\
\hline & 28.15 & Производство подшипников, зубчатых передач, элементов механических передач и приводов \\
\hline & 28.21 & Производство печей, термокамер и печных горелок \\
\hline & 28.22 & Производство подъемно-транспортного оборудования \\
\hline & 28.24 & Производство ручных инструментов с механизированным приводом \\
\hline & 28.25 & Производство промышленного холодильного и вентиляционного оборудования \\
\hline & 28.29 & $\begin{array}{l}\text { Производство прочих машин и оборудования общего назначения, не включенного в другие } \\
\text { группировки }\end{array}$ \\
\hline & 28.30 & Производство машин и оборудования для сельского и лесного хозяйства \\
\hline & 28.49 & Производство прочих станков \\
\hline & 28.92 & Производство машин и оборудования для добычи полезных ископаемых и строительства \\
\hline & 28.93 & $\begin{array}{l}\text { Производство машин и оборудования для производства пищевых продуктов, напитков и табачных } \\
\text { изделий }\end{array}$ \\
\hline
\end{tabular}


(продолжение)

\begin{tabular}{|c|c|c|c|}
\hline $\begin{array}{l}\text { Наименование } \\
\text { отрасли }\end{array}$ & $\begin{array}{l}\text { Наименование } \\
\text { отрасли (англ.) }\end{array}$ & $\begin{array}{l}\text { Код } \\
\text { ОКВЭД2 }\end{array}$ & Наименование вида экономической деятельности \\
\hline & & 28.94 & $\begin{array}{l}\text { Производство машин и оборудования для изготовления текстильных, швейных, меховых } \\
\text { и кожаных изделий }\end{array}$ \\
\hline & & 28.95 & Производство машин и оборудования для изготовления бумаги и картона \\
\hline & & 28.99 & $\begin{array}{l}\text { Производство прочих машин и оборудования специального назначения, не включенных } \\
\text { в другие группировки }\end{array}$ \\
\hline & & 30.20 & Производство железнодорожных локомотивов и подвижного состава \\
\hline & & 30.99 & $\begin{array}{l}\text { Производство прочих транспортных средств и оборудования, не включенных в другие } \\
\text { группировки }\end{array}$ \\
\hline \multirow{2}{*}{$\begin{array}{l}\text { Фармацевтическая } \\
\text { продукция }\end{array}$} & \multirow[t]{2}{*}{ Biopharmaceuticals } & 21.10 & Производство фармацевтических субстанций \\
\hline & & 21.20 & Производство лекарственных препаратов и материалов, применяемых в медицинских целях \\
\hline \multirow[t]{9}{*}{ Финансовые услуги } & \multirow[t]{9}{*}{ Financial Services } & 64.11 & Деятельность Центрального банка Российской Федерации (Банка России) \\
\hline & & 64.30 & Деятельность инвестиционных фондов и аналогичных финансовых организаций \\
\hline & & 64.91 & Деятельность по финансовой аренде (лизингу/сублизингу) \\
\hline & & 64.92 & Предоставление займов и прочих видов кредита \\
\hline & & 64.99 & $\begin{array}{l}\text { Предоставление прочих финансовых услуг, кроме услуг по страхованию и пенсионному } \\
\text { обеспечению, не включенных в другие группировки }\end{array}$ \\
\hline & & 66.11 & Управление финансовыми рынками \\
\hline & & 66.12 & Деятельность брокерская по сделкам с ценными бумагами и товарами \\
\hline & & 66.19 & $\begin{array}{l}\text { Деятельность вспомогательная прочая в сфере финансовых услуг, кроме страхования } \\
\text { и пенсионного обеспечения }\end{array}$ \\
\hline & & 66.30 & Деятельность по управлению фондами \\
\hline \multirow[t]{5}{*}{ Химические вещества } & \multirow{5}{*}{$\begin{array}{l}\text { Upstream Chemical } \\
\text { Products }\end{array}$} & 20.11 & Производство промышленных газов \\
\hline & & 20.13 & Производство прочих основных неорганических химических веществ \\
\hline & & 20.14 & Производство прочих основных органических химических веществ \\
\hline & & 20.17 & Производство синтетического каучука в первичных формах \\
\hline & & 20.20 & Производство пестицидов и прочих агрохимических продуктов \\
\hline
\end{tabular}


(продолжение)

\begin{tabular}{|c|c|c|c|}
\hline $\begin{array}{l}\text { Наименование } \\
\text { отрасли }\end{array}$ & $\begin{array}{l}\text { Наименование } \\
\text { отрасли (англ.) }\end{array}$ & $\begin{array}{l}\text { Код } \\
\text { ОКВЭД2 }\end{array}$ & Наименование вида экономической деятельности \\
\hline \multirow[t]{8}{*}{ Химические продукты } & \multirow{8}{*}{$\begin{array}{l}\text { Downstream Chemical } \\
\text { Products }\end{array}$} & 20.12 & Производство красителей и пигментов \\
\hline & & 20.30 & $\begin{array}{l}\text { Производство красок, лаков и аналогичных материалов для нанесения покрытий, } \\
\text { полиграфических красок и мастик }\end{array}$ \\
\hline & & 20.41 & Производство мыла и моющих, чистящих и полирующих средств \\
\hline & & 20.42 & Производство парфюмерных и косметических средств \\
\hline & & 20.51 & Производство взрывчатых веществ \\
\hline & & 20.52 & Производство клеев \\
\hline & & 20.53 & Производство эфирных масел \\
\hline & & 20.59 & Производство прочих химических продуктов, не включенных в другие группировки \\
\hline \multirow{7}{*}{$\begin{array}{l}\text { Целлюлозно-бумажные } \\
\text { изделия }\end{array}$} & \multirow[t]{7}{*}{ Paper and Packaging } & 17.11 & Производство целлюлозы и древесной массы \\
\hline & & 17.12 & Производство бумаги и картона \\
\hline & & 17.21 & Производство гофрированной бумаги и картона, бумажной и картонной тары \\
\hline & & 17.22 & $\begin{array}{l}\text { Производство бумажных изделий хозяйственно-бытового и санитарно-гигиенического } \\
\text { назначения }\end{array}$ \\
\hline & & 17.23 & Производство бумажных канцелярских принадлежностей \\
\hline & & 17.24 & Производство обоев \\
\hline & & 17.29 & Производство прочих изделий из бумаги и картона \\
\hline \multirow{8}{*}{$\begin{array}{l}\text { Электрооборудование } \\
\text { и осветительные приборы }\end{array}$} & \multirow{8}{*}{$\begin{array}{l}\text { Lighting and Electrical } \\
\text { Equipment }\end{array}$} & 27.11 & Производство электродвигателей, электрогенераторов и трансформаторов \\
\hline & & 27.12 & Производство электрической распределительной и регулирующей аппаратуры \\
\hline & & 27.20 & Производство электрических аккумуляторов и аккумуляторных батарей \\
\hline & & 27.31 & Производство волоконо-оптических кабелей \\
\hline & & 27.32 & Производство прочих проводов и кабелей для электронного и электрического оборудования \\
\hline & & 27.33 & Производство электроустановочных изделий \\
\hline & & 27.40 & Производство электрических ламп и осветительного оборудования \\
\hline & & 27.90 & Производство прочего электрического оборудования \\
\hline
\end{tabular}


(окончание)

\begin{tabular}{|c|c|c|c|}
\hline $\begin{array}{l}\text { Наименование } \\
\text { отрасли }\end{array}$ & $\begin{array}{l}\text { Наименование } \\
\text { отрасли (англ.) }\end{array}$ & $\begin{array}{l}\text { Код } \\
\text { ОКВЭд2 }\end{array}$ & Наименование вида экономической деятельности \\
\hline \multirow{3}{*}{ Ювелирные изделия } & \multirow{3}{*}{$\begin{array}{l}\text { Jewellery and Precious } \\
\text { Metals }\end{array}$} & 32.11 & Чеканка монет \\
\hline & & 32.12 & Производство ювелирных изделий и аналогичных изделий \\
\hline & & 32.13 & Производство бижутерии и подобных товаров \\
\hline
\end{tabular}

Источник: составлено ИсиЭз ниу ВшЭ no [Ketels, Protsiv, 2014]. 


\section{Атлас экономической специализации регионов России}

Редактор М. Ю. Соколова Арт-директор О. В. Васильев

Дизайнеры Г. В. Подзолкова, А. В. Стахнова

Компьютерный макет В. В. Пучков 
Подписано в печать 15.03.2021.

Формат $60 \times 90^{1} / 8$. Бумага мелованная.

Печ. л. 33.0. Тираж 150 экз. Заказ № 0174/21.

Национальный исследовательский университет

«Высшая школа экономики»

Отпечатано в 000 «Верже-РА»

129323, Москва, Сельскохозяйственная ул., 43/1

Тел.: +7 (495) 727-00-08

По вопросам приобретения книги обращаться

в Институт статистических исследований и экономики знаний НИУ ВШЭ:

101000, Москва, Мясницкая ул., 20

Тел.: + 7 (495) 621-28-73

issek.hse.ru

issek@hse.ru 